\author{
UNIVERSIDADE DE SÃO PAULO \\ FACULDADE DE FILOSOFIA, LETRAS E CIÊNCIAS HUMANAS \\ DEPARTAMENTO DE GEOGRAFIA \\ PROGRAMA DE PÓS-GRADUAÇÃO EM GEOGRAFIA
}

\title{
Água e Metrópole: Limites e Expectativas do Tempo
}

\author{
Maurício Waldman
}

Tese apresentada ao Programa de PósGraduação em Geografia, do Departamento de Geografia da Faculdade de Filosofia, Letras e Ciências Humanas da Universidade de São Paulo, para obtenção do título de Doutor em Geografia.

Orientador: Prof. Dr. Ariovaldo Umbelino de Oliveira 


\section{DEDI CATÓRI A}

Em memória de Luís Alberto Goulart de Oliveira (1950-1999), operário ambientalista, membro da oposição metalúrgica da Baixada Santista, diretor do sindicato da sua categoria e indomável combatente pelos direitos do homem. 


\section{AGRADECI MENTOS}

Obra pretensamente solitária, um doutorado se constrói com cumplicidades e parcerias.

Neste sentido, seria indispensável agradecer:

Ao meu orientador, o professor Ariovaldo Umbelino de Oliveira, com quem compartilho o ideal de uma geografia combatente, de massas, justa e democrática;

À Bia Costa, pela cumplicidade permanente, fruto do amor profundo;

Ao amigo Dan Moche Scheneider, pelas discussões estimulantes que temos travado ao longo de muitos anos;

Para Rosana Núbia Sorbille, pela amizade, cativada por aspirações comuns e conversas ritmadas pelo sacolejar do trem;

Para Marina Duran, pela identificação da garra brasileira que habita em todos nós, mesmo que não percebamos;

Para a historiadora Marina Veiga Scalabrini, do Acervo Histórico de Ribeirão Pires, pela disposição em contribuir para com esta pesquisa;

Ao CNPq - Conselho Nacional De Desenvolvimento Científico e Tecnológico, pelo inestimável auxílio financeiro que possibilitou a elaboração desta tese de doutorado;

Para todos os meus alunos, especialmente dos cursos de capacitação em recursos hídricos do Sub-Comitê Billings-Tamanduateí, pela vontade e pela determinação de lutar pela preservação das águas doces.

São Paulo, 21 de Dezembro de 2005. 


\section{RESUMO}

Água e Metrópole, Limites e Expectativas do Tempo, é uma tese que analisa a dificuldade crescente das grandes metrópoles serem atendidas nas suas demandas por água. Esclarecendo a respeito da questão central deste trabalho, a hipótese básica é de que esta demanda não poderá ser satisfeita a não ser que se implantem mudanças radicais nas mais diversas escalas da vida humana.

Neste sentido, este texto dedica grande atenção para a modalidade linear e progressiva da temporalidade que caracteriza a modernidade. Foi com base neste ordenamento do tempo que o mercado conquistou sua hegemonia na sociedade, entendimento que também permite compreender a forma como a relação com o meio ambiente passou a ser construída no pensamento ocidental.

Com efeito, o debate relacionando água e metrópole não pode se isentar da articulação que estas duas temáticas sustentam com a questão socioambiental. As cidades correspondem ao principal ambiente de vida da humanidade nos dias atuais, assim como o espaço por excelência a partir do qual emana a ordenação temporal que caracteriza a modernidade.

Ademais, é também no ambiente urbano, máxima expressão da hegemonia de um tempo subsidiado pelo mercado, que a exclusão social predomina, configurando um quadro marcado por todo tipo de contradições e dentre estas, a que tem se materializado pela sede. Nesta perspectiva, paralelamente ao levantamento das diferentes interfaces suscitadas pela questão dos recursos hídricos, enfoca a região metropolitana de São Paulo e do grande $A B C$, casos entendidos como emblemáticos para a compreensão desta problemática.

Por fim, esta tese enseja a discussão de diversas contradições que perpassam pela sociedade contemporânea, tais como os limites institucionais frente à questão ambiental, a dimensão da expansão urbana e sua associação com a questão social e da utilização dos recursos hídricos, todas de fundamental importância para que se possa pensar num novo tempo, móvel para a construção de um novo espaço de vida, socialmente justo e ecologicamente responsável. 


\section{ABSTRACT}

Water and Metropolis, Limits and Expectations of the Time, is a thesis that analyzes the increasing difficulty of the great metropolises to be taken care of its demands for water. The central discussion of this work, its hypothesis, is that this demand could not be satisfied unless radical changes in the most diverse scales of the human being life are implanted.

Therefore, this text dedicates great attention for the linear and gradual modality of the temporality that characterizes modernity. It was based in this order of the time that the market conquered its hegemony in the society, this study also point to understand how the occidental thinking constructs its relation with the environment.

The debate relating water and metropolis cannot be exempt of the articulation that these two thematic support with the ambiental and social discussion. The cities correspond to the main environment of life of the humanity in the current days, as well as the space par excellence from which emanate the secular ordinance that characterizes modernity.

Moreover, is also in the urban environment, maximum expression of the hegemony of a time subsidized by market, that the social exclusion predominates, configuring a picture marked for all type of contradictions and among these, the water scarcity. In this perspective, parallel to the survey of the different interfaces excited for the question of the hidrics resources, this research focus the region metropolitan of São Paulo and the Grande ABC, both understood as emblematic for the understanding of this problematic.

Finally, this thesis intends the quarrel of diverse and typical contradictions that the society contemporary, such as the institutional limits to the environmental questions, the dimension of the urban expansion and its association with the social matter and the use of the hidric resources. All these matters are fundamental for thinking a new time, capable to construct a new space of life, socially just and too with environmentalist responsible. 


\title{
PALAVRAS-CHAVE
}

\author{
Meio ambiente \\ Recursos hídricos \\ Metrópole \\ Tempo \\ Espaço.
}

\section{KEY WORDS}

\author{
Environment \\ Hidric resources \\ Metropolis \\ Time \\ Space.
}




\section{SUMÁRIO}

ÍNDICE DE TABELAS

ÍNDICE DE GRÁFICOS

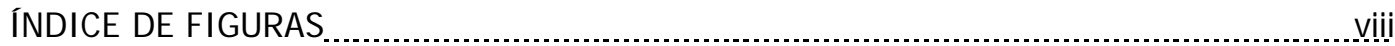




\section{Í NDI CE DE TABELAS}

1 - As Maiores Cidades do Mundo 2000 - 2015 129

2 - Consumo Médio Residencial de Água por Atividade Doméstica

3 - Balanço Energético das Atividades Humanas ...................................................... 194

4 - As Multinacionais da Água

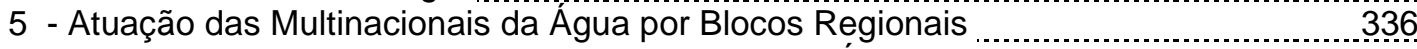

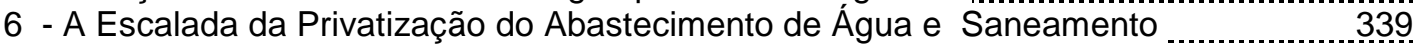

7 - Disponibilidade Hídrica Social no Brasil $\ldots \ldots \ldots \ldots \ldots$

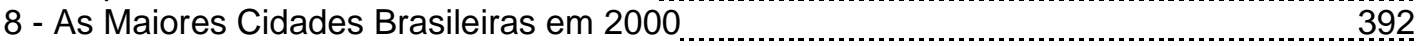

9 - População das Regiões Metropolitanas do Brasil em 2000 396

10 - População Dos Municípios da RMSP em $2000 \ldots 408$

11 - Sistemas Fornecedores de Água para a RMSP

12 - Coleta e Tratamento de Esgotos na RMSP

13 - Municípios do Grande ABC Paulista

14 - IDH dos Municípios do ABC Paulista

\section{Í NDI CE DE GRÁFICOS}

GRÁFICO 1 - Atividades nos cinco estágios de ciclo de vida de um produto.........................

GRÁFICO 2 - Países Potencialmente Provedores de Água Doce

GRÁFICO 3 - Parâmetros para Água Potável Regulamentados nos EUAA a partir $1920 \quad 385$

GRÁFICO 4 - Consumo e Produção de Eletricidade pela Light .......................................

\section{ÍNDICE DE FIGURAS}

FIGURA 1 - A Metrópole Paulista em 2004

FIGURA 2 - Qual é o Clima?

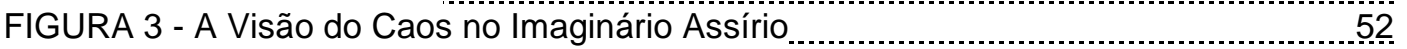

FIGURA 4 - O templo-montanha de Angkor-Wat

FIGURA 5 - A Pedra do Sol

FIGURAS 6a, 6b, 6c e 6d - As Torres Imaginárias da Modernidade

FIGURA 7 - As Torres Reais da Modernidade $\ldots$

FIGURA 8 - Composição ferroviária relegada ao abandono

FIGURA 9 - Um Oceano de Casas

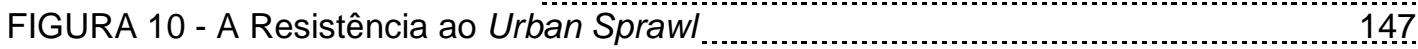

FIGURA 11 - A Galáxia de Luz da Tecnosfera

FIGURA 12 - Vista da Terra tendo foco central no continente africano

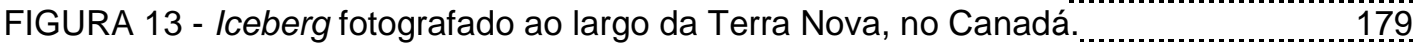

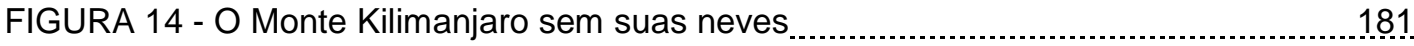

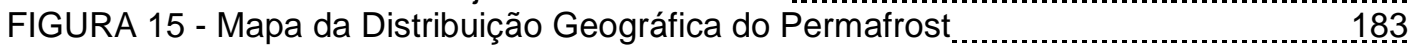

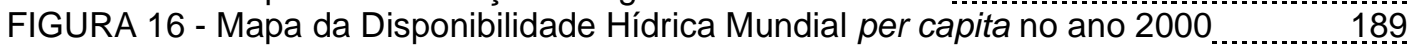

FIGURA 17 - Mapa da Disponibilidade Hídrica Mundial per capita no ano 2025 ....................

FIGURA 18 - Mapa da Disponibilidade Física e Econômica da Água no ano 2025 ...........191

FIGURA 19 - A energia e o imaginário do alumínio ........................................................

FIGURA 20 - Parque eólico em funcionamento no trecho britânico do Mar do Norte .......214

FIGURA 21 - Descarte de Lixo Domiciliar nos EUA

FIGURA 22 - De onde veio este pneu? 
FIGURA 23 - Esquema da Tríade Temática: Uma proposição gráfica

FIGURA 24 - Depósito de pneus usados nos EUA

FIGURA 25 - O Fantasma da Incineração, Mito ou Realidade?

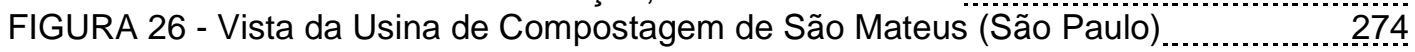

FIGURA 27 - Coletor de pilhas usadas em Madri

FIGURA 28 - O Aterro Bandeirantes (São Paulo)

FIGURA 29 - Mapa de Israel, Cisjordânia e Faixa de Gaza

FIGURA 30 - Geografia do Conflito $\ldots$

FIGURA 31 - Meandros do Rio Jordão

FIGURA 32 - Poço de água em Natwarghad

FIGURA 33 - Mapa do Sistema Grande Rio Feito pelo Homem

FIGURA 34 - Mapa do Lago Texcoco Antes da Conquista Espanhola $\ldots \ldots \ldots$

FIGURA 35 - Vista de Netzahualcoyotl

FIGURA 36 - Trecho gretado do antigo lago Texcoco hoje

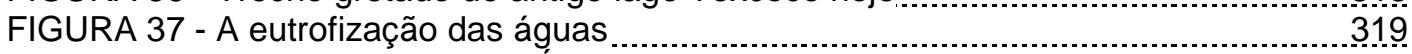

FIGURA 38 - Cena da "Guerra da Água" em Cochabamba, Bolívia, no ano 2000. ............. 342

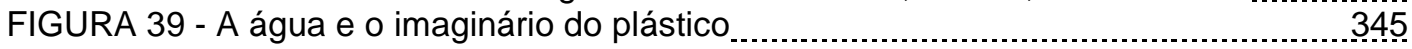

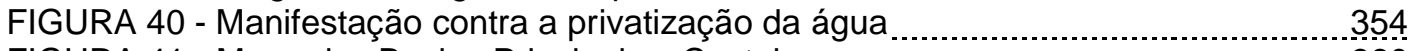

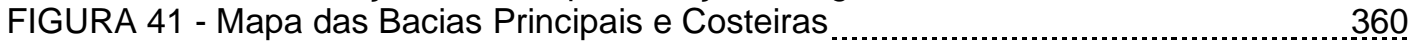

FIGURA 42 - Mapa das Bacias Hidrográficas Brasileiras e sua Subdivisão

FIGURA 43 - Vista do rio Branco

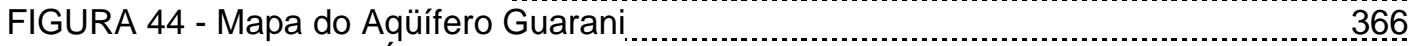

FIGURA 45 - Mapa das Áreas de Afloramento e de Confinamento do Aqǘfero Guarani 368

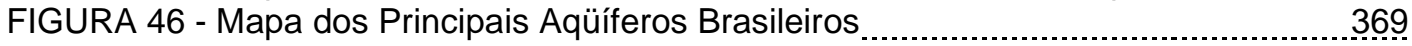

FIGURA 47 - Mapa das Bacias Demográficas e Distribuição da População ………….... 372

FIGURA 48 - Mapa da Expansão do Acesso aos Serviços de Água, 1980-2000 …...................

FIGURA 49 - Mapa da Expansão do Acesso aos Serviços de Esgoto, 1980-2000 .................

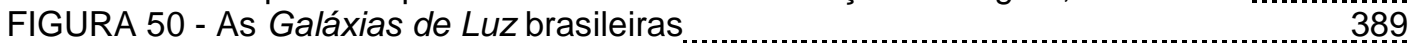

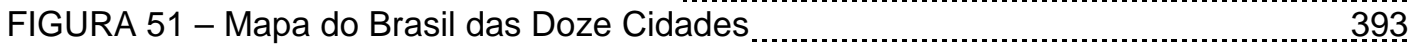

FIGURA 52 - MAPA das 26 Regiões Metropolitanas do Brasil

FIGURA 53 - Foto de satélite de Fortaleza

FIGURA 54 - Mapa das Densidades demográficas do Estado de São Paulo em 1996 ....404

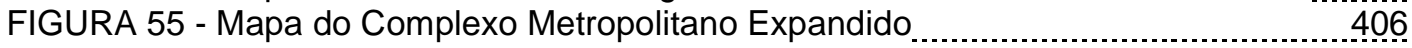

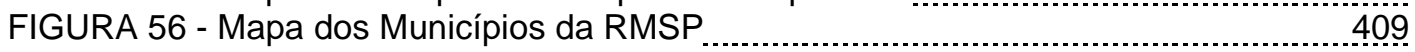

FIGURA 57 - Mapa da Bacia Hidrográfica do Alto Tietê.

FIGURA 58 - Sistemas de Fornecimento de Água da RMSP

FIGURA 59 - Adutora do Sistema Rio Claro

FIGURA 60 - A RMSP e os Reservatórios da Billings e Guarapiranga

FIGURA 61 - Mapa do Sistema Produtor do Alto Tietê

FIGURA 62 - Vista da região a jusante da Represa Taiaçupeba

FIGURA 63 - Vista das obras de ampliação da Represa Taiaçupeba pela SABESP $\quad 421$

FIGURA 64 - Trecho do Canal Taiaçupeba-Jundiaí interligando estes dois reservatórios 422 ?

FIGURA 65 - Vista da Talha de escoamento da Represa Jundiaí ........................................

FIGURA 66 - Vista do Reservatório de Ponte Nova

FIGURA 67 - Vista panorâmica da Represa Ponte Nova

FIGURA 68 - Vista da pista de monitoramento da Barragem Ponte Nova

FIGURA 69 - Vertedouro da Represa Ponte Nova

FIGURA 70 - Vista das Comportas da Estação Elevatória de Ponte Nova ……………..............

FIGURA 71 - Casa das Máquinas da Estação Elevatória de Ponte Nova

FIGURA 72 - Marcas comerciais de água mineral da RMSP

FIGURA 73 - Esquema da Colina e do Promontório

FIGURA 74 - Esquema do Binômio São Paulo-Santos e o "Bolsão" do

Caaguaçu-São Bernardo ........................................................................... 449

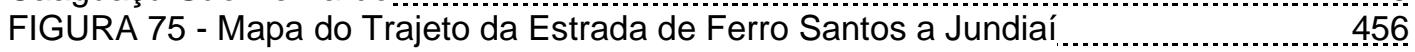

FIGURA 76 - Placa de identificação de vagão da E.F.S.J.

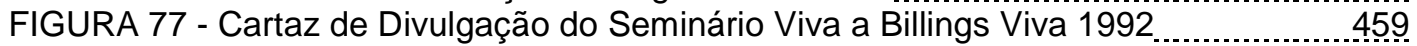

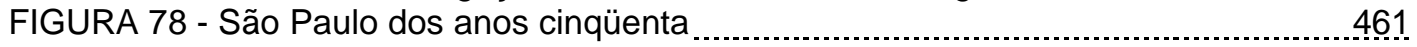

FIGURA 79 - Sr Mário, trabalhador do granito

FIGURA 80 - Mapa das sub-regiões da Região Metropolitana de São Paulo ............................

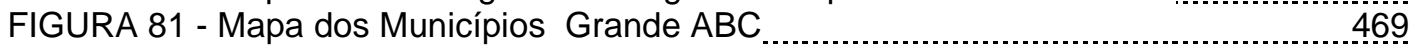


FIGURA 82 - A RMSP e a Billings

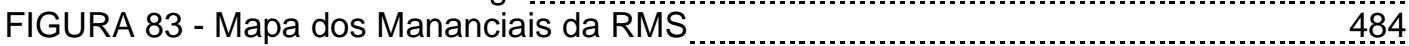

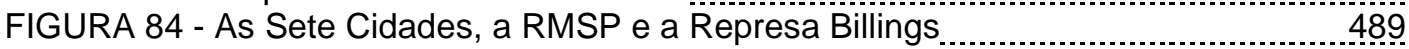

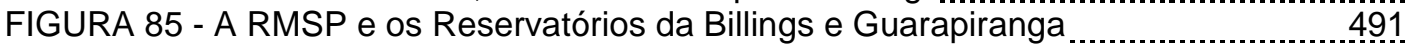

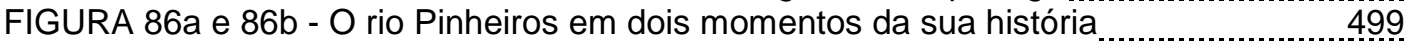

FIGURA 87 - Objetos hidrotécnicos da capital e imediações ..........................................

FIGURA 88 - Mapa dos Rios Formadores da Represa Billings ....................................

FIGURA 89 - Mapa da Bacia da Billings: Sub-regiões, Sub-bacias

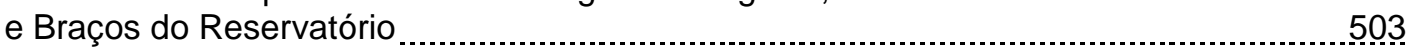

FIGURA 90 - Mapa da Represa Billings e Limites Municipais

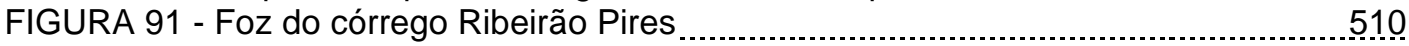

FIGURA 92 - Croqui referente às soluções propostas para o Sistema Billings $\quad 514$

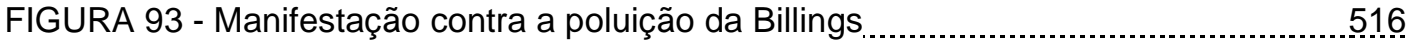

FIGURA 94 - Croqui do Sistema Cantareira e do Sistema Tietê-Billings

FIGURA 95 - Situação de Risco nos Mananciais do ABC

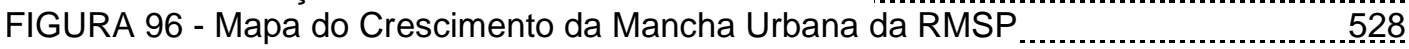

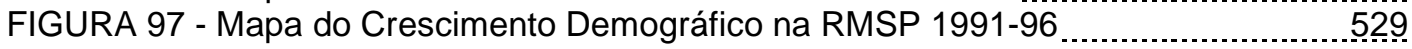

FIGURA 98 - Mapa da Bacia da Billings: Evolução da Cobertura Florestal 1989-1999 _... 531

FIGURA 99 - Mapa da Bacia da Billings: Cobertura Florestal em 1999 _.......................

FIGURA 100 - Mapa da Bacia da Billings: Unidades de Conservação

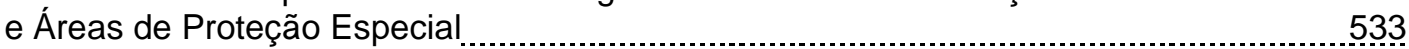

FIGURA 101 - Mapa da Bacia da Billings: Uso do Solo em 1989

FIGURA 102 - Mapa da Bacia da Billings: Uso do Solo em 1999

FIGURA 103 - Mapa da Bacia da Billings: Evolução da Urbanização 1989-1999 _............

FIGURA 104 - Mapa da Bacia da Billings: Atividade Mineraria $\ldots \ldots \ldots \ldots . . .537$

FIGURA 105 - Porto de areia abandonado em Ribeirão Pires............................................ 538

FIGURA 106 - Mapa do Trajeto do Rodoanel na RMSP

FIGURA 107 - Mapa do Trajeto do Rodoanel na Bacia Billings

FIGURA 108 - Mapa da Bacia da Billings: Disposição Irregular de Efluentes ....................542

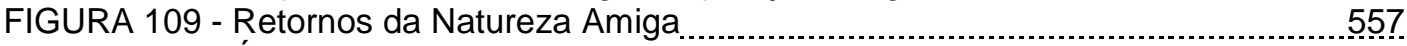

FIGURA 110 - Águas que fluem hoje

FIGURA 111 - A RMSP e Ribeirão Pires

FIGURA 112 - Pichação em Ribeirão Pires.

FIGURA 113 - A Reprodução da Mitologia Bandeirante

FIGURA 114 - Vista da Capela de Nossa Senhora do Pilar

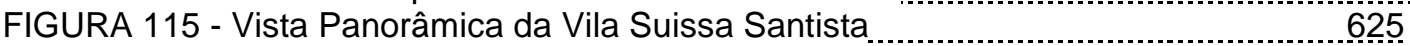

FIGURA 116 - Estação ferroviária de Ribeirão Pires

FIGURA 117 - Três Tipos de Pavimento à Mostra

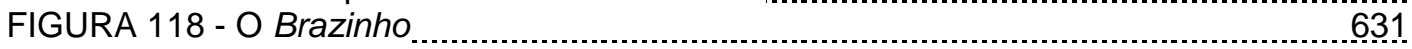

FIGURA 119 - Mapa das Bacias Hidrográficas Ribeirão Pires $\quad 637$

FIGURA 120 - Mapa do potencial de Águas Subterrâneas em Ribeirão Pires _............... 634

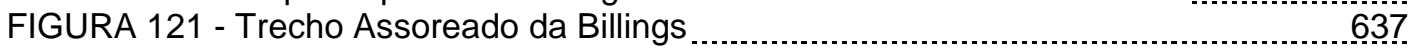

FIGURA 122: Proibido Pescar e Nadar

FIGURA 123 - Ramal do Sistema Rio Claro 


\section{ÍNDICE}

I NTRODUÇÃO

PARTE I

ESPAÇO, GEOGRAFI A E MEI O AMBI ENTE 8

CAPÍTULO 1

PRESSUPOSTOS, OPÇÕES E METAMORFOSES

1.1. O Matrimônio Sagrado do Tempo com o Espaço

1.2. Geografia, Crise Ambiental e Sociedade $\ldots \ldots$

CAPÍ TULO 2 - CI RCUI TOS, TENSÕES E AMPLITUDES

2.1. Espaço, Sustentabilidade e os

Desafios da Natureza Hostil

29

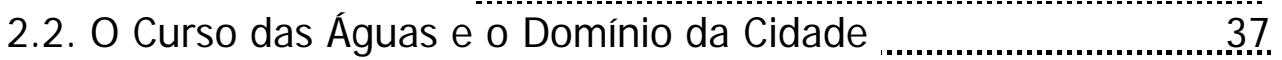

\section{PARTE II}

MEI O URBANO, QUESTÃO AMBI ENTAL E MODERNI DADE

CAPÍ TULO 3 - TEMPO, MODERNI DADE E NATUREZA

3.1. Repensando a Ecologia a partir do Oikos ...................................................

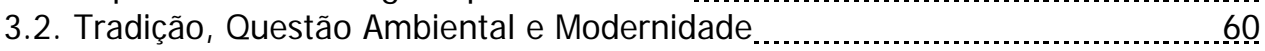

3.3. A Imperiosidade da Discussão do Tempo

3.4. A Modernidade e a Morte do Mundo Tradicional Europeu

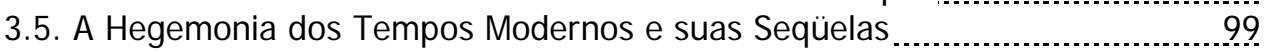

CAPÍ TULO 4 - URBANI ZAÇÃO, TECNOSFERA E OS LI MITES DO TEMPO

4.1. Progressividade, Modernidade e o Contexto da Cidade ................................

4.2. Rede Urbana Mundial: Cenários e Desafios $\ldots 127$

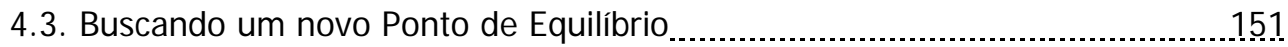

\section{PARTE III}

SOCI EDADE, ÁGUA E MEI O AMBI ENTE

\section{CAPÍ TULO 5 - ÁGUA: UM RECURSO ESTRATÉGICO}

5.1. A Água e sua Importância para as Sociedades Humanas $\quad 159$

5.2. As Águas Doces no Planeta Terra

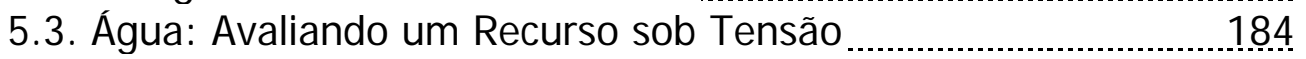

\section{CAPÍTULO 6 - ÁGUA: UM RECURSO I NDI SPENSÁVEL}

6.1. Água e Energia

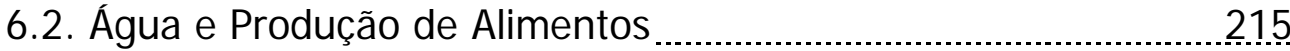

6.3. Água e Industrialização

\section{CAPÍTULO 7 - RECURSOS HÍ DRI COS E RESÍ DUOS SÓLI DOS}

7.1. Resíduos Sólidos: Um Problema Crescente _......................... 234

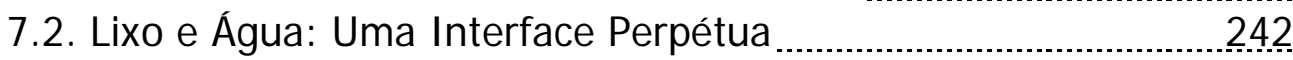

7.3. Classificação e Destinação dos Resíduos Sólidos .......................... 252

7.4. Repensando os Resíduos Sólidos Domiciliares …........................... 262

7.5. Recursos Hídricos, Fração Orgânica e Reciclagem __.................. 
7.6. Recursos Hídricos, Fração Inorgânica e Reciclagem _............. 279

CAPÍ TULO 8 - A GEOGRAFI A DA SEDE

8.1. Água: Natureza, Sociedade e Escassez _.............................. 287

8.2. A Exaustão dos Recursos Hídricos ……………......................... 306

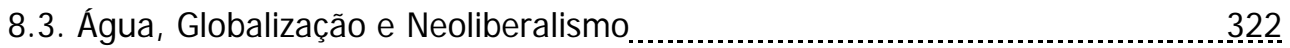

8.4. Água: Um Direito a ser Assegurado .................................................327.

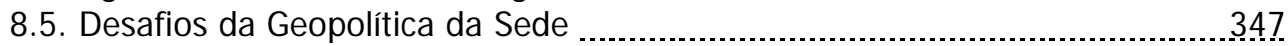

\section{PARTE IV}

GRANDE ABC, RECURSOS HÍ DRI COS E A METRÓPOLE PAULI STA

CAPÍ TULO 9 - RECURSOS HÍ DRI COS E QUESTÃO URBANA NO BRASI L

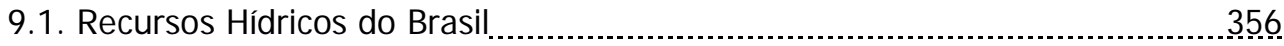

9.2. Sede no País das Muitas Águas

CAPí TULO 10 - A METRÓPOLE PAULISTA E A QUESTÃo DOS MANANCI AIS

10.1. A Grande São Paulo no Contexto da Escassez de Água ..............................403.

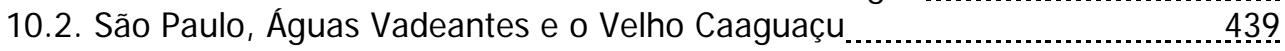

\section{CAPÍ TULO 11 - O GRANDE ABC E A QUESTÃO DOS MANANCI AIS}

11.1. O Grande ABC no Contexto da RMSP

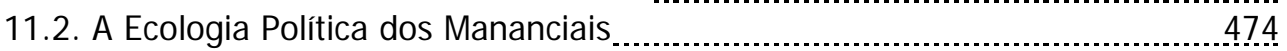

CAPÍ TULO 12 - METRÓPOLE, RECURSOS HÍDRI COS E LI MITES DO ESPAÇO

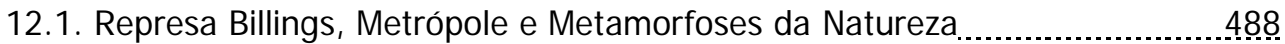

12.2. Os Mananciais Frente à "Não-Política" de Águas Doces ...................................

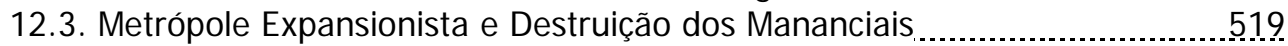

PARTE V - EM BUSCA DE UM FI NAL TRANSI TÓRI O $\ldots \ldots \ldots \ldots \ldots$

Repensando um Trajeto

A Encruzilhada dos Tempos Modernos $\ldots$

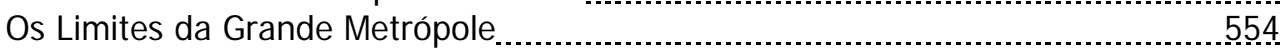

Pensando o Curso das Águas

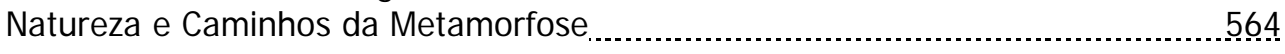

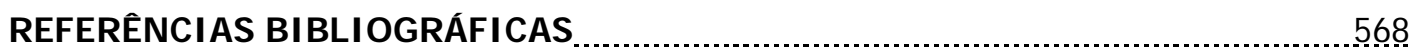

ANEXO

Ribeirão Pires: A Reprodução da Metrópole

APÊNDI CES

Apêndice 1: Lei no 898, de 18 de Dezembro de 1975

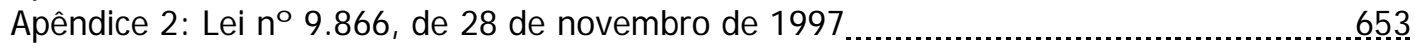




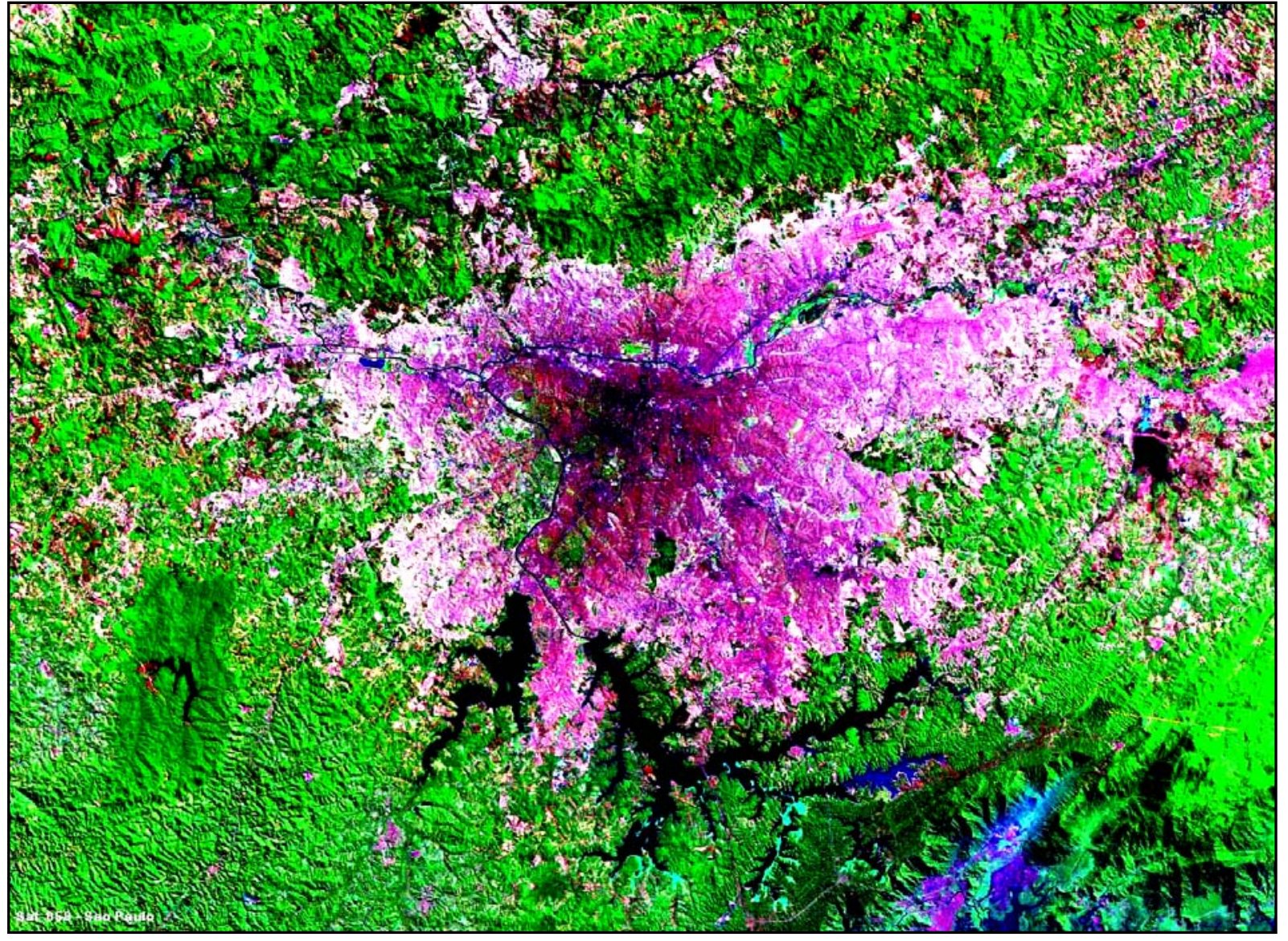

FIGURA 1 - A Metrópole Paulista em 2004

(Fonte: <http://www.brazilbrazil.com/s/sat_058.jpg>, acesso em 03-11-2005) 


\section{NTRODUÇÃO}




\section{NTRODUÇÃO}

Água e Metrópole: Limites e Expectativas do Tempo é um trabalho versando sobre a dificuldade crescente das grandes metrópoles serem atendidas nas suas demandas por água. E, esclarecendo de vez a respeito da questão central deste trabalho, o texto que se prolonga desta página em diante trabalha com uma hipótese básica: a de que não será possível satisfazer esta necessidade a não ser que se implantem mudanças radicais nas mais diversas escalas da vida humana.

Ainda que essa assertiva reporte a um amplo e complexo rol de temáticas, elegemos como eixo organizador da análise dois arranjos espaciais básicos, intimamente articulados entre si: a Região Metropolitana de São Paulo (RMSP) e o Grande ABC, a mais importante das sub-regiões da RMSP após a capital. Em seu interior, Ribeirão Pires, integrando o grupo de sete municípios que formam a subregião, foi o espaço mais recentemente abordado pelo pesquisador, uma vivência que permitiu certificarem muitas das hipóteses trabalhadas nesta tese quanto aos dois outros arranjos espaciais citados anteriormente.

Quanto ao tema deste trabalho, tanto a RMSP quanto o Grande $A B C$ expressam uma problemática hídrica que de modo emblemático prognosticam as mais duras conclusões. Na voz do povo, repete-se que é muito difícil encarar a realidade de frente. Mas quando ela é encarada, não restam muitas opções. Uma delas é conformar-se com ela e não reagir. A outra, é indignar-se e procurar resposta ao que nos incomoda. A escolha que motivou esta pesquisa foi a segunda, e com esta responsabilidade é que se construiu essa análise.

Como sentenciou Max Weber, no plano das opções que o pesquisador realiza no campo da ciência, inexiste objetividade despida de subjetividade. Do ponto de vista dos reflexionamentos emocionais, o Grande $A B C$ reporta a um histórico de vida relativamente longo para o proponente deste trabalho. Meu pai, Wolf Waldman, um comerciante de origem judaico-polonesa que perambulou durante muitos e muitos anos pelas cidades da sub-região, fazia suas caminhadas quase sempre contando com minha companhia. 
Foi assim que tomei contato com São Caetano do Sul, Santo André, São Bernardo do Campo, Diadema, Mauá e Ribeirão Pires, cidades do ABC que aprendi a reconhecer, acompanhando a conversa dos adultos, como se fossem uma só. As recordações destas andanças são muito vívidas. Aprendi a reconhecer os marcos característicos da paisagem do Grande $A B C$ e a desfrutar do que este encantador recanto da metrópole pode oferecer.

Nessa época, não se falava nem em greve e muito menos em mobilização da sociedade. E, com o golpe militar de 1964, quem conhecia algo a respeito destes temas refugiou-se no silêncio. Mas, dificilmente uma região com a vitalidade do Grande $A B C$ poderia ser silenciada e assim, este espaço se reapresentou na minha vida através das mobilizações ambientalistas.

A partir dos anos setenta, muitos segmentos da opinião pública passaram a evidenciar crescente inconformismo com a degradação da represa Billings e dos seus mananciais. Este temário, dantes restrito ao movimento ecologista, afirmouse nas décadas seguintes tanto na consciência social quanto no plano das necessidades objetivas de água por parte da metrópole em expansão.

Capitaneada pela cidade de São Paulo, uma urbe que, dizia-se nos tempos de antanho, "não poderia parar de crescer", a região metropolitana expandiu-se acirrando no seu interior toda sorte de antagonismos sociais. Simultaneamente, motivada pelo seu dinamismo descontrolado, neste processo a metrópole inevitavelmente confrontou-se com os ciclos mais essenciais da natureza, afetando inclusive os que permitem aos humanos desfrutar a mais vital de todas as substâncias, relacionada diretamente com a vida: a água.

Deste modo, na esteira das mobilizações ecologistas e da ascensão do Partido dos Trabalhadores (PT) terminei exercendo, entre 1991 e 1992, o cargo de Secretário do Meio Ambiente da Prefeitura Municipal de São Bernardo do Campo (PMSBC). Postado no comando institucional numa relevante administração do Grande $A B C$, as dinâmicas sócio-espaciais que se desenhavam na vida de cidade se explicitavam de modo irretorquível. Ademais, dado ser impossível dissociar esse dinamismo de quaisquer outras cidades do ABC e destas, da RMSP, o 
próprio cotidiano de trabalho se encarregava de destacar os dilemas da subregião, assim como os da metrópole paulista como um todo.

Mantendo nos anos seguintes toda sua atualidade e potencialidade em termos dos desafios colocados para a questão do acesso à água, foi possível, entre 2002/2005, conferir esta problemática durante as pesquisas e o trabalho de campo visando esta tese de doutorado, desenvolvido em paralelo com a participação em projetos de educação ambiental voltados para o $A B C$ paulista financiados pelo Fundo Estadual de Recursos Hídricos (FEHIDRO), e, ao exercício do magistério em nível superior e desenvolvimento de cursos de capacitação de professores da rede municipal de Ribeirão Pires.

Deste modo, a partir de 2001, quando já participava oficialmente do programa de pós-graduação em geografia humana da FFLCH-USP, e secundado por um processo de especulações pertinentes às preocupações que foram expostas, lentamente foi se sedimentando na proposta do trabalho de doutorado a incorporação da temática da questão do abastecimento de água nas grandes cidades brasileiras, envolvendo a RMSP e o ABC paulista, assim como, é claro, a experiência vivida na cidade de Ribeirão Pires, formando uma massa de informações cruciais para esta tese.

Deve ser ressalvado que ao estar centrado na questão do meio urbano e dos recursos hídricos, o temário proposto por Água e Metrópole: Limites e Expectativas do Tempo articula-se com outras problemáticas de importância fundamental para o futuro da RMSP, dentre estas, as da matriz energética e as relacionadas com a questão do uso e ocupação do solo urbano. Assim sendo, esta tese de doutorado inclui temáticas que se estendem da poluição da água por cargas difusas, passando pela destinação dos resíduos sólidos e, numa outra ponta deste espectro, com os problemas associados como a ocupação dos mananciais.

Quanto ao Grande ABC em si mesmo, trata-se de um espaço extremamente dinâmico, concentrando formidável parque industrial e um pujante setor de serviços. Portanto, não é de se admirar que sua história tenha sido atravessada pelas mais turbulentas performances demográficas, com impactos evidentes nos 
mananciais da represa Billings. Numa perspectiva ambiental, o $A B C$ é uma área de grande importância para os ciclos hidrológicos da RMSP, corporificados na Billings, nas suas matas remanescentes e no seu rico potencial de águas subterrâneas.

Deste modo, o $A B C$ no seu conjunto sugere enorme potencialidade em termos de animar expectativas voltadas para a compreensão da realidade materializada na RMSP, contribuindo tanto como dado adicional dirigido para a formulação de várias outras pistas de análise, quanto para certificar uma visão crítica desta mesma realidade.

Neste início do Século XXI, bem mais do que nas décadas anteriores, a questão do acesso à água potável e a necessidade de uma política urbana empenhada em contribuir de fato com a superação das contradições surgidas de um processo de acumulação de capital que, em linhas gerais, tem mantido sua tendência em criar, e explicitamente recriar sempre de modo cada vez mais ampliado e contraditório desigualdades mais e mais profundas, atualizam de modo radical esta discussão.

Acelerado por um dinamismo temporal que vincula as problemáticas regionais ao seu espelho global e vice-versa, as questões a serem debatidas nesta tese, Água e Metrópole: Limites e Expectativas do Tempo, constituem um convite para serem trilhados os mais diversos caminhos e travessias. No entanto, todos conduzirão a um mesmo destino: a necessidade de dar conta de problemas prementes, somente passíveis de resolução através de novos paradigmas, habitados a decifrar as contradições que se expressam no tempo e no espaço.

Com estas diretrizes à disposição, organizei a exposição numa seqüência composta por cinco partes, divididas em capítulos e subcapítulos, nos quais o aprofundamento dos temas arrasta consigo as discussões anteriores, ao mesmo tempo em que as retoma e amplia.

- Na primeira parte da tese, Espaço, Geografia e Meio Ambiente, discrimino as principais linhas teóricas que sustentam a tese, assim como os principais eixos da discussão. 
- Na segunda, Meio Urbano, Questão Ambiental e Modernidade, os vínculos mantidos pela questão ambiental na modernidade com a ordenação social do tempo e do espaço, indissociáveis do desenho do meio urbano, estão colocadas de modo sucinto, apontando para uma crítica da sociedade ocidental e da sua forma de relacionamento com o meio ambiente.

- A terceira parte, Sociedade, Água e Meio Ambiente, a exemplo das anteriores mantém-se rigidamente focada geografia humana, detendose especialmente nos aspectos contraditórios das relações sócioespaciais, ao mesmo tempo em que se relata detalhadamente as mais diferentes perspectivas envolvidas na questão dos recursos hídricos.

- Na quarta parte, Grande $A B C$, Recursos Hídricos e a Metrópole Paulista, faço primeiramente um balanço dos recursos hídricos no Brasil e uma avaliação das suas dinâmicas urbanas gerais, para posteriormente situar a problemática da RMSP e do Grande ABC frente a um dinamismo sócio-espacial no qual a hegemonia da temporalidade moderna é um dado essencial para sua compreensão.

- Por último, na quinta parte, Em Busca de um Final Transitório, procuro, destacando os limites da institucionalidade, enfatizar a necessidade de superação das contradições que vedam aos humanos a realização da sua humanidade, que como será visto, não pode para tanto dispensar desta expectativa a naturalidade perpassa e envolve a consecução da própria vida. 


\section{PARTE I}

\section{Espaço, Geografi a e Mei o AMBi ente}




\section{CAPÍTULO 1}

\section{PRESSUPOSTOS, OPÇÕES E METAMORFOSES}

\subsection{O MATRI MÔNI O SAgRAdo do TeMPo COM O EsPaço}

Este estudo localiza-se no campo do conhecimento geográfico. Portanto, nada mais compreensível que o conceito de espaço e seus desdobramentos constituam um foco obrigatório de análise e fonte de subsídios para substantivar esta pesquisa.

Importa deixar claro que o enfoque da geografia é específico, diferindo das demais especialidades. Como se verá adiante, para os geógrafos o espaço não se confunde com os espaços físico, social ou econômico, tratados pela física, pela sociologia e pela economia. Por outro lado, nada disto depõe contrariamente quanto a geografia fazer uso do conceito de espaço das outras disciplinas (Cf SILVA, 1978:81/82).

Uma vez esclarecida esta vocação pelo espaço, não haveria como marginalizar sua contrapartida, isto é, o tempo. Saliente-se que a dimensão espacial somente é devidamente apreendida, tanto na sua qualificação concreta quanto na imaginária, na hipótese de, na sua intelecção, ser afiançado o vínculo mantido com a dimensão temporal.

As esferas do espaço e do tempo configuram, vis-à-vis, "realidades indissociáveis, em qualquer plano, escala ou sistema de relações" (ANDRADE, 1971:93). Envolvendo-se mutuamente em termos de coexistência, permanência e transitoriedade, o binômio espaço-tempo consubstancia um indispensável plano de entendimento da realidade, daí decorrendo a importância dessa discussão para a geografia (Cf OLIVEIRA, 1982c).

Para a geografia, a interligação entre as dimensões temporal e espacial, objetivamente presentes no dinamismo de todas as formas conhecidas de 
organização do homem em sociedade, e, portanto, em nível do imaginário e da sua concretude, permitiria identificar as metamorfoses que marcam a transformação do espaço. A interdependência entre os dois fatores, absolutamente nítida, transparece em todo seu fulgor na análise da paisagem elaborada pelo geógrafo Olivier DOLLFUS:

A fisionomia da Terra está em perpétua transformação. Toda paisagem que reflete uma porção do espaço ostenta as marcas de um passado mais ou menos remoto, apagado ou modificado de maneira desigual, mas sempre presente. É um palimpsesto onde a análise das sucessivas heranças permite que se rastreiem as evoluções. O espaço geográfico se acha impregnado de história (1972:11).

Em especial, tal debate é meritório devido seu entrelaçamento com o conceito de formação sócio-espacial ou abreviadamente, espacial. Esta formulação, consensada ao longo de muitas circunlocuções travadas no seio da geografia, filia-se a um escopo teórico de orientação marxista, embasando-se fortemente nos conceitos de formação social e de modo de produção. Estes paradigmas foram intensamente discutidos por diversas das ciências sociais nos anos setenta e oitenta do século passado, período no qual vários círculos acadêmicos da geografia também manifestaram interesse pelo tema.

Todavia, seria cabível preliminarmente ponderar que antes da discussão que resultou no conceito de formação espacial, disciplinas como a sociologia e a antropologia desenvolveram estudos que exaltavam o papel do espaço quanto à trajetória assumida pelas comunidades humanas. Em comum, tais análises contestavam a noção de que o tempo se prontificasse enquanto referência par excellence para o estudo da realidade social, assim como que a dimensão espacial constituísse mero "receptáculo" das relações sociais, um palco neutro das ações humanas.

Essa orientação esteve presente na obra de sociólogos como Émile Durkheim, cujas investigações identificaram a correspondência entre as representações do espaço e sua respectiva origem social; de Maurice Halbwachs, na sua ênfase da importância do espaço para a memória coletiva; e de Georg 
Simmel, que avaliou a proeminência de um centro espacial para um Kirchenstaat Estado eclesiástico - caso do Tibet, cuja capital, Lhasa, tinha na sua posição central o Potala, um vistoso convento que era a sede do governo e para o qual convergiam todas as estradas do país (CUVILLIER, 1975:138/161; ver também BETTANINI, 1982:81/110).

Quanto à antropologia, não seria difícil discernir uma forte preocupação com o espaço. Ela encontra justificativa no fato do mundo tradicional trabalhar a todo instante com uma articulação orgânica entre espaço social e sistemas míticos, nos quais um entrosamento com os ciclos e dados naturais é indissociável da sua reprodução social. Assim, as pesquisas de Carlos SERRANO (1983), Marc AUGÉ (1985) e Claude TARDITS (1985), voltadas respectivamente para o reino do Ngoyo na área cultural Bakongo ${ }^{1}$, para a África Ocidental e o reino Bamoun ${ }^{2}$, reportaram direta ou indiretamente ao espaço.

Outras elaborações, aninhadas, por exemplo, na seara da filosofia, também poderiam ser arroladas, desvendando ângulos de grande validade para a questão do espaço (ANDRADE, 1971). Entretanto, as iniciativas encabeçadas por várias das ciências humanas não necessariamente identificaram a espacialidade inerente a qualquer formação social. Basicamente, em razão de que ao se eximirem de articular conceitualmente uma totalidade sócio-espacial, seus dinamismos internos e, em especial, suas contradições no plano do espaço-tempo, tais esforços foram insuficientes para consolidar uma teorização abrangente, operacional de espaço.

Atente-se para a sugestão do geógrafo Ruy MOREIRA, presente no excerto abaixo transcrito:

O estudo mais e mais preciso do conceito e articulação de formação econômico-social e de modo de produção, a par do estudo minucioso da economia política, das instituições e da ideologia, sem o qual não se pode mergulhar fundo na compreensão de uma formação econômico-social, e a convergência de tudo isso ao estudo do conceito, forma e processos da formação espacial, eis o que nos parece que é necessário para um bom trabalho de construção teórica do espaço (1982a:63).

\footnotetext{
${ }^{1}$ Os Bakongo formam uma etnia habitante das duas margens do Zaire, especialmente na costa e adjacências da foz deste rio, compreendendo territórios de Angola, Republica Democrática do Congo e República do Congo.

${ }^{2}$ Reino tradicional africano localizado em partes do atual Camerun.
} 
Recorde-se que o conceito de modo de produção, não se confunde com o de modo de produção de bens materiais. Este último subentende uma expressão descritiva, referindo-se apenas à estrutura econômica da sociedade. Respaldar uma análise com base no modelo do modo de produção implica na adoção de uma formulação abrangendo a totalidade social, tanto a estrutura econômica da sociedade quanto todos os outros níveis sociais, o jurídico-político e o ideológico (GEBRAN, 1978:14), arrazoado que credenciaria essa formulação para o estudo teórico do espaço.

É importante anotar que o debate responsável pelos novos conceitos que passaram a transitar a partir dos anos 80 no pensamento geográfico esteve perpassado pela verve questionadora da geografia crítica, uma das correntes que medraram no interior do movimento de renovação de geografia. Constituindo um momento no qual o marxismo ganha notoriedade no interior das especulações geográficas, a geografia crítica promoveu reavaliações cujo denominador comum endossavam uma visão crítica da realidade.

A receptividade encontrada pelo marxismo no pensamento geográfico foi catalisada, no caso brasileiro, por um contexto no qual o país ensaiava seus primeiros passos na direção da redemocratização. Nessa perspectiva, caberia à geografia ao incorporar o marxismo no seu plano de análise, dar conta de uma contribuição eminentemente geográfica - isto é, espacial - de compreensão do movimento contraditório da sociedade (MORAES, 1981: 112 et seq).

Neste sentido, cabe ponderar que embora a geografia crítica tenha sido granjeada com adjetivações como geografia marxista, radical, ou, de relevância social, muito do seu desenvolvimento teórico inspirou-se numa efervescência intelectual externa ao antigo mundo socialista, cuja produção geográfica obedecia a outros ditames e diretrizes. É sabido que na ex-URSS e em muitos outros países do Leste europeu, a geografia se resumia a um inventariamento dos recursos naturais, abordados numa ótica economicista ou então, vinculada à geofísica e demais ciências naturais. Apenas excepcionalmente, nos países anteriormente governados por regimes marxistas, se encontra uma geografia humana inspirada 
no chamado socialismo científico (Ver a respeito MONTEIRO, 1980:138/139; e CHRISTOFOLETTI, 1985:26/29).

Seria também obrigatório lembrar a pluralidade de concepções que se abrigam no pensamento marxista. De fato, a geografia crítica diz respeito, além de Marx e Engels, a uma variada gama de pensadores. Na lista de autores de referência, figuram, entre muitos outros nomes, os de Leon Trotsky, Antonio Gramsci, Karl Wittfogel, Rosa Luxemburgo, Giorgy Luckács, Mao Tse Tung e Lênin, defendendo posições teóricas que não necessariamente coincidiam e pelo contrário, estiveram marcadas por discordâncias profundas.

Nesta seqüência, seria mister registrar que a incorporação do marxismo no pensamento geográfico não esteve isenta de obstáculos conceituais e metodológicos. O principal deles é que o marxismo, em igual medida com o conjunto das escolas filosóficas e dos sistemas de pensamento do mundo ocidental anteriores ao Século XX, manteve-se sob o domínio do tempo. Na lógica marxista, as dinâmicas e categorias temporais constituem o essencial de sua argumentação. Teriam assegurado Karl MARX e seu parceiro Friedrich ENGELS em A Ideologia Alemã: "a única ciência que conhecemos é a ciência da história"3 (1977:23). Exatamente por esta razão, conforme sublinhou o geógrafo norteamericano Edward SOJA, o surgimento de um forte materialismo histórico não foi correspondido por um igualmente robusto materialismo geográfico (Cf 1986:04; ver também QUAINI, 1979:34/47).

Essa lacuna do pensamento marxista quanto ao espaço mobilizou segmentos da geografia identificados com esta filosofia na senda de não só resgatar o espaço quanto de espacializar conceitos marxistas temporalizantes, dentre estes, o de modo de produção (Vide BERNARDES, 2001). Tal releitura impunha-se por si mesma, pois o conceito de modo de produção do ponto de vista epistemológico, incorpora o tempo e não o espaço como primado de interpretação da realidade. 0

\footnotetext{
${ }^{3}$ Observa o geógrafo José Willian VESENTINI: "Essa frase, juntamente com algumas outras, foi riscada pelos autores, que inicialmente pretenderam publicar o manuscrito, mas desistiram após algumas dificuldades e, segundo argumentaram posteriormente, porque essas idéias serviram somente como amadurecimento intelectual" (1989:44). Entretanto, independentemente dessa sentença ter constituído um exercício intelectual ou não, o caráter eminentemente temporal das argumentações marxistas e marxianas é inquestionável.
} 
resultado destes esforços levou, muito sinteticamente, ao entendimento de que modo de produção e formação social, conceitos marxistas fortemente enraizados na tradição temporalizante ocidental, poderiam ser desdobrados numa tradução espacial.

Nos termos pelos quais pretendo desenvolver esta avaliação, essas aferições constituem um indicativo básico para incorporar as contribuições de Milton Santos, "uma das mais amplas e substantivas empreendidas pela geografia crítica" (MORAES, 1981:123). O vulto, vigor e a pertinência da produção deste estudioso da problemática do espaço, profundamente identificada com uma leitura questionadora da realidade, conquistou projeção principalmente a partir da década de oitenta, configurando um acervo teórico dotado de capilaridade na escala nacional e internacional (Ver MAMIGONIAN, 1996:201/205). Motivo de orgulho para todos os brasileiros, Milton Santos foi o primeiro geógrafo do Terceiro Mundo - e único até o presente momento - a ser laureado com o Prêmio Vautrin Lud, considerado o Nobel da Geografia (1994).

Tal teorização, possuindo nota predominante no conceito de espaço produzido, espaço habitado, espaço artificial ou simplesmente natureza segunda, constitui uma contribuição de grande quilate para a geografia, considerada parte inseparável do patrimônio conceitual da disciplina. O espaço, dantes divorciado do tempo, reencontra nessa ótica a condição necessária para sua completude. As sociedades agem sobre o espaço e, mais precisamente, produzem determinado espaço enquanto expressão do seu dinamismo histórico-social. Desse modo, o espaço, espaço-paisagem testemunha um modo de produção nestas suas manifestações concretas, o testemunho de um momento do mundo (SANTOS, 1978a:138).

Ao mesmo tempo, uma terminologia específica, como fixos, fluxos, objetos espaciais, sistemas técnicos, processos de espacialização e divisão espacial do trabalho, conquistaram popularidade nas análises costuradas pela geografia em temas como a organização territorial, exclusão espacial e a questão urbana. Este rol de conceituações está embasado pela poderosa aliança formada pelo binômio espaço-tempo, uma parceria onipresente nas especulações de Milton Santos. 
Como explícito em uma venerável sentença desse notável geógrafo brasileiro, uma vez sendo verdadeiro que o tempo se transforma em espaço, seria igualmente correto pensar que o espaço também se transforma em tempo (SANTOS, 1978a:105).

Claramente, estes enfoques explicitam a incorporação da preocupação como o espaço em processos dantes entendidos como eminentemente temporais. Nesta ordem de argumentação, os imperativos do espaço para o conceito de formação social poderiam ser explicitados por algumas premissas básicas, dentre as quais:

1. Analisar como o tempo se transforma em espaço e como o tempo passado e o tempo presente têm, cada qual, um papel específico no funcionamento do espaço atual (SANTOS, 1978a:105).

2. Interpretar o espaço, na acepção deste constituir um fator, um fato e uma instância social (idem, 1978a:130).

3. Compreender o papel pertinente às rugosidades, formas espaciais criadas pela ação do homem, cuja inércia espacial condiciona novas localizações (idem, 1978a:138).

4. Entender que as formas espaciais são duráveis, não se desfazendo e influenciando a organização do espaço mesmo com o fim dos processos que Ihes deram origem. Elas são factíveis de serem revivificadas pelo movimento social (idem, 1978a:149).

5. A relação entre o homem e a natureza é uma relação que produz espaço, onde a natureza transformada, socializada, é um arranjo espacial, uma natureza segunda. Em suma, o espaço é uma herança dinâmica, no qual temos uma acumulação desigual de tempos (idem, 1978a:201 e 209). 
Tais deduções prestam-se sumamente para a avaliação do papel das "rugosidades". A noção de rugosidade é uma das que no cenário analítico montado por Milton Santos congraçam mutação e estabilidade, tempo e espaço, história e geografia. Estas constituiriam "o espaço construído, o tempo histórico que se transformou em paisagem, incorporado ao espaço" (SANTOS, 1978a:138). Assim, o espaço, longe de configurar-se enquanto elemento estático é ele mesmo agente de transformação, continuidade ou de revivescência. Desta reflexão intuise que as rugosidades:

Criam imposições sobre a ação presente da sociedade; são uma 'inércia dinâmica' - tempo incorporado na paisagem - e duram mais que o processo que as criou. São assim uma herança espacial que influi no presente. Por esta razão, o espaço é também uma instância, no sentido de ser uma estrutura fixa e, como tal, uma determinação que atua no movimento da totalidade social. As formas espaciais são resultados de processos passados, mas são também condições para processos futuros. As velhas formas são continuamente revivificadas pela produção presente, que as articula em sua lógica (MORAES, 1981:123/124).

Deste ponto de vista, contribuem em igual medida para a organização do espaço os condicionamentos oriundos das heranças espaciais do passado. Não raro, objetos e formas espaciais pretéritas, tais como monólitos, sistemas de irrigação, vias de comunicação, aglomerados de aldeias, fortificações, edificações, assim como arranjos e objetos espaciais de todo tipo, constituem a base fixa para a rearticulação ou continuidade de determinado dinamismo espacial, mantendo ou gerando novos fluxos no espaço geográfico. Caberia, deste modo então, compreender como este movimento se efetiva.

Em coerência com esta linha de raciocínio, dificilmente um modo de produção faz tabula rasa das condições espaciais pré-existentes. Comumente, a nova organização social do espaço que sucede à anterior incorpora as antigas rugosidades ressemantizando-as, isto é, decretando um novo regime de significados para as marcas e objetos espaciais herdados do passado. Por isso mesmo, é necessário repetir que as rugosidades, "são o espaço construído, o 
tempo histórico que se transformou em paisagem, incorporado ao espaço" (SANTOS, 1978a:138).

Dado subjacente a esta argüição, as formações sociais, ao tecerem forte relação de correspondência com o espaço com o qual interagem, não poderiam ser desvencilhadas in abstracto deste substrato, que alicerça sua personalidade social, cultural e histórica. Embalados nessa dedução, tem-se que nenhuma sociedade poderia ser plenamente compreendida sem levar o espaço em consideração. Propugnar formações sociais privadas de um "piso espacial" configuraria, em todas as letras, um equívoco. Ademais, pensar um modo de produção apenas pelo prisma do tempo, a-espacialmente, seria pensar um tempo abstrato, o qual pode sinonimizar diferentes formações sociais. Do mesmo modo, o espaço, sem a dimensão tempo, torna-se um espaço congelado (SANTOS, 1978a:199 e MOREIRA,1982a:62).

No que evidencia a procedência desse ajuizado, o conceito de formação espacial é fundamental para revelar a "fisionomia concreta" das sociedades. Nesta perspectiva, poder-se-ia inventariar diversos problemas decorrentes da noção de tempo abstrato constatados nos estudos das formações histórico-sociais. Exemplificando, foi em face de erros derivados da não-espacialização da história é que foi conferida à formação social feudal, um fenômeno geograficamente restrito a uma porção do continente europeu, uma universalidade que não teve, determinando, por exemplo, fortes controvérsias sobre o modo de produção asiático (MOREIRA, 1982a:62; Ver também SOFRI, 1977, BARTRA, 1978, CARDOSO, 1990a e 1990b).

Outro grande atrativo do pensamento de Milton Santos reside na sua arguta visualização dos reflexos e desdobramentos decorrentes da ordenação temporal da modernidade para a organização do espaço, cuja feição mais representativa está expressa na geografia urbana. A urbanização, um fenômeno recente, crescente e aparente numa escala planetária, constitui tema subjacente a todos debates que pontuam a sociedade contemporânea. Entre 1800 e 1950, a população mundial multiplicou-se 2,5 vezes; porém, a população urbana multiplicou-se por 20 vezes nesse mesmo período histórico (SANTOS, 1981:3/4). 
Particularmente, a maximização da grande metrópole, a tecnosfera (referindo-se ao espaço artificial que inclui tanto a cidade moderna quanto o meio rural a ela submetido), quanto a psicoesfera (o reino das expectativas que norteia o espaço concreto e que a ele se antecipa), prontificam-se enquanto ferramentas conceituais de primeira ordem. Assumindo hodiernamente a feição de um meio técnico-científico-informacional, a tecnosfera tem por papel mais proeminente subsidiar os fluxos do sistema, cuja velocidade impõe um cunho de transitoriedade cada vez mais flagrante ao espaço habitado (passim SANTOS, 1998).

Como não poderia deixar de ser, esta dinâmica transmuta-se nas metamorfoses dos modelados e no direcionamento dos fluxos espaciais, cuja intempestividade corresponde a um esperado seguimento da ação humana no meio natural. Por isso mesmo,

O problema do espaço ganha, nos dias de hoje, uma dimensão que ele não havia obtido jamais antes. Em todos os tempos, a problemática da base territorial da vida humana sempre preocupou a sociedade. Mas, nesta fase atual da história tais preocupações redobraram, porque os problemas também se acumularam (SANTOS, 1998:17/18).

Este é o mote por excelência para a compreensão da crise socioambiental do mundo moderno. Exacerbado por uma ordenação do tempo que se confunde com a apropriação privada da natureza, eclodiu um cenário de distúrbios em cujo centro estão as próteses urbanas e a repercussão dos seus ciclos artificiais de vida. A agudização das contradições entre cultura e natureza no mundo moderno constitui um epifenômeno indissociável da torção do espaço-tempo, e isto, de um modo como nunca foi observado na história.

No que é característico da vida social moderna, os distúrbios presenciados na atualidade são eminentemente laicos. Ao contrário do passado, não existe lugar para propiciações mágicas ou explicações de índole cosmológica, pois os transtornos derivam exclusivamente do saber institucionalizado. Portanto, os riscos ecológicos se tornaram na modernidade virtualmente secularizados, disto diferindo de todas as derrocadas ambientais que historicamente ocorreram no mundo tradicional. Basicamente, uma faceta fundamental da crise socioambiental 
da modernidade se relaciona diretamente com o conteúdo de artificialidade da sociedade moderna e com os procedimentos da civilização científica (BETTANINI, 1982:71/72).

$\mathrm{Na}$ seqüência destas considerações, uma outra ordem de motivações quanto à obra de Milton Santos justifica-se pela nossa preocupação em discutir a questão ambiental. Esta, pensada nos limites deste texto enquanto um nexo de desequilíbrios advindos diretamente de uma organização social do tempo e de uma crise espacial a ela relacionada, encontraria uma vez mais referendamento na obra deste geógrafo:

O exame do que significa em nossos dias o espaço habitado, deixa entrever claramente que atingimos uma situação limite, além da qual o processo destrutivo da espécie humana pode tornar-se irreversível (...) Senhor do mundo, patrão da Natureza, o homem se utiliza do saber científico e das invenções tecnológicas sem aquele senso de medida que caracterizará as suas primeiras relações com o entorno natural. O resultado, estamos vendo, é dramático (SANTOS, 1988:44).

Seria cabível asseverar que em resposta às possíveis críticas eventualmente esboçadas quanto à "ausência de preocupações ambientalistas" na obra de Milton Santos (quando não de óbices que o autor esposaria quanto à temática em si mesma e aos seus expoentes políticos e sociais), esta análise se fixa sobremaneira na abrangência que o método desenvolvido por este geógrafo promove para a compreensão da questão ambiental.

Neste, como em qualquer outro caso, apenas poder-se-ia facultar veracidade a um veredicto na hipótese dos seus pressupostos estarem apoiados na verificação de constituírem um autêntico critério de verdade, que diga respeito à sua competência enquanto instrumental de análise, e de resto, ao paramento de que a toda teoria verdadeira deve corresponder uma eficácia operatória real.

Finalmente, os argumentos de Milton SANTOS, contribuindo para realçar os vínculos inquebrantáveis existentes entre uma humanidade socialmente organizada e o espaço por ela habitado, destacam a geografia no centro de um debate crucial: Nas condições atuais do mundo, ainda mais que na era 
precedente, o espaço está destinado a desempenhar um papel importante na escravidão ou na libertação do homem (1978a:218).

A aspiração é que os capítulos seguintes possam, em coerência aos ajuizados de uma avaliação espaço-temporal e com a preocupação de explicitar as implicações dos desequilíbrios ambientais, contribuir para esclarecer e inspirar formas de resistência e de luta por um outro espaço de vida, socialmente justo e ecologicamente responsável.

\subsection{Geografi A, Crise Ambi ental e Sociedade}

Diz o senso comum que as situações de crise são pródigas em propiciar releituras e recomendações. Julgando com isenção, dificilmente poder-se-ia proferir qualquer objeção a esse enunciado. Sabe-se intuitivamente que o desnudamento em toda sua crueza das contradições, colocando a prova posturas estabilizadas, vivenciadas como "naturais", podem consumar a inauguração de um possível point of no return.

Nada como o relampaguear que prenuncia a crise para iluminar a necessidade de revisão de condutas. Afinal, uma vez diante da aspereza do real, como the negar jurisprudência para rever procedimentos? É exatamente a consciência da falibilidade que justifica, dialeticamente, a superação das desventuras, a criação de novos entendimentos, a abertura de novos caminhos e a afirmação de novos pactos. Nesta visada, as crises incluem tanto a possibilidade de estagnação quanto de superação. O sucesso - ou insucesso - simplesmente advém do que se aprende dessa vivência.

Seria o caso de se anunciar, diante da gravidade dos problemas ambientais, que a humanidade vive um momento que solicita mudança de paradigma? Quero crer que sim. Mas, antes de tudo há a necessidade de se certificar que essa transformação diz respeito a concepções inseridas historicamente, refletindo determinados consensos. Tais consensos - que não são eternos - se dissolvem ou 
são revistos mediante a apresentação de novos problemas, que não encontrando resposta através do paradigma anterior, são gradativamente substituídos por outros, afeitos à nova circunstância histórica (passim PRICE, 1976).

Numa única palavra, a elaboração de um paradigma exclui a intervenção voluntarista e firma-se no terreno das práticas sociais concretas. O progresso do conhecimento teórico, "incluindo as formas mais elevadas da atividade científica, aparecem vinculadas com as necessidades práticas dos homens" (VAZQUEZ, 1980:245). Portanto, não é uma teoria nova que reformula ordenação dos fatos, "mas é a nova ordenação dos fatos que encerra ela mesma uma nova escala de valores e obriga a construção de uma nova teoria" (SANTOS, 1978a:157).

No que constitui um exercício enriquecedor, construir um paradigma admite a importação de contribuições de diferentes áreas do conhecimento. Paradigmas exclusivos, particulares, de uma única ciência isoladamente, é uma proposta fora de cogitação. A noção de paradigma

...não pode ser derivada da história particular de uma ciência ou de uma descoberta feliz de um cientista caprichoso e genial. A noção de paradigma pertence à história e se impõe ao mesmo tempo em que os movimentos históricos de fundo (SANTOS, 1978a:160).

Nesse sentido, a conjuntura vivida pela humanidade nos dias atuais estimularia um contexto ímpar. A crise socioambiental da modernidade, evidenciando a problemática da continuidade da vida, coloca radicalmente esta questão, obrigando a todos meditar sobre a possibilidade de um quadro de colapso anunciado para ocorrer nessa mesma geração. "A história humana, tão cheia de promessas e esperanças, chegaria por si própria para nos fazer merecer outro futuro. Um futuro diferente daquele que nos parece esperar nos próximos anos" (BOOKCHIN, 1989:45).

Diante de um emaranhado de problemas caracterizados por uma incisividade ecológica nunca vista, procuro respostas para as essas aflições nos templos do conhecimento. E, ao adotar tal atitude, não há como se deixar enganar sequer por um instante: apenas a história é quem pode instruir sobre o significado das coisas 
(SANTOS, 1998:15). Ter-se-ia então pleno direito de indagar: No que os saberes institucionalizados poderão contribuir para pensar um novo espaço de vida? Poderão fornecer programas de cunho decisório? Afinal, o que existe de efetivo nos santos tabernáculos?

É nessa ótica que a geografia se torna um caminho privilegiado. Avaliar o extraordinário acúmulo de discussão amealhado pela disciplina no tocante à inserção da temática ambiental junto ao seu campo de conhecimento certamente revelaria insuficiências, mas também muitas potencialidades que magnetizam estes dois pólos entre si. Ciência que pode orgulhosamente exibir na sua hagiografia nomes como de Bernard Varenius, que no alvorecer do século XVII elaborou um requintado compêndio no qual esquadrinhava o cabedal de potencialidades da disciplina frente ao mundo natural ${ }^{4}$, de fato a ela o olhar obrigatoriamente se dirige na busca de conforto e de esperança.

Palmilhando esse cenário, não há como deixar de indexar a geografia como um dos raros campos do conhecimento que nutriram apaixonada cumplicidade com a questão ambiental. Tanto assim, que várias pesquisas comprovam uma associação sedimentada na consciência social, pela qual o meio ambiente seria uma prerrogativa do trabalho dos biólogos e geógrafos (Ver ALBERTO, 2002). E sendo objetivo: esta citação não encontraria qualquer dificuldade para ser chancelada. A biologia e a geografia, estando centradas respectivamente no estudo das formas de vida e na inter-relação homem-natureza, personificam em si mesmas uma mediação axiomática com o meio ambiente.

Com base nesse dado objetivo, a percepção dos elos da geografia e da biologia com a questão ambiental, legitimada pelo próprio modus operandi das duas disciplinas, desponta assim de modo tão flagrante no imaginário das pessoas que ambas terminam inclusive identificadas com este propósito de modo quase que exclusivo (ALBERTO, 2002). No caso da biologia, pode-se respaldar essa consideração por intermédio de um rompante de Samuel Murgel BRANCO, pelo qual:

\footnotetext{
${ }^{4}$ Trata-se de Geografia Generalis, obra escrita quando este genial geógrafo somava apenas 28 anos de idade. Impressionando gigantes como Newton e Kant, é considerada seminal para os primeiros passos do conhecimento geográfico (Ver a respeito, ETGES, 2000).
} 
A relação da questão ambiental com a biologia num contexto interdisciplinar é inegável. Mais do que isso: é fundamental, no sentido de que a biologia é, por definição, a ciência que trata da vida em seu amplo sentido, enquanto a preocupação com o meio ambiente diz respeito, objetivamente, à prevenção contra a extinção da vida em geral e, em particular, da vida humana (2001:9).

Quanto à geografia, as relações mantidas pelo homem em sociedade com o meio natural este sempre estiveram fortemente presentes no seu foco de análise. O afazer geográfico, explicitando a interconexão entre o homem e o mundo natural, tradicionalmente descortinou pareceres que indubitavelmente não foram registrados por nenhuma outra disciplina (Vide MORAES, 2002:92/93). Por exemplo, o geógrafo alemão Friedrich RATZEL discernia um forte liame entre as condições naturais e o homem, patente na classificação que propôs quanto aos campos de pesquisa da disciplina: geografia física, biogeografia e antropogeografia (passim, 1990). De resto, a rubrica "ambientalismo" à qual se recorre para distinguir a teorização desse geógrafo constituiria signo adicional revelador dessa propensão (Vide MORAES, 1981: 60 e 1990:9).

A escola francesa de Paul Vidal de la Blache repete a centralidade desse primado geográfico. No seu legado, o objeto da geografia seria a relação homemnatureza avaliada na perspectiva da paisagem. Na sua construção teórica, o homem, entendido enquanto potente agente de transformação do espaço, estaria granjeado da credencial de fator geográfico de primeira ordem. Na fisionomia do planeta, o homem se impõe direta ou indiretamente, por sua presença, por suas obras ou pelas conseqüências das suas obras. A visão lablachiana, apesar de classificar a geografia como uma ciência natural, Ihe reservava, em razão do antropismo, uma vocação substantiva em prol da inter-relação entre o homem e o ambiente natural (Ver BLACHE, 1985:37).

Como de resto está delineado em muitas outras elaborações, seria praticamente inconcebível imaginar uma análise geográfica na qual o espaço deixasse de evocar a atuação humana no meio natural. A este respeito, pode-se resgatar um desabafo do geógrafo francês Pierre GEORGE, que diagnosticava com certa indignação: "Que sentido se poderia atribuir a um estudo sintético de 
paisagem natural a não ser definir as condições oferecidas à vida e à ação humana pelas ações recíprocas dos fatores físicos?" (1972:15).

Contudo, a despeito da geografia enfocar a relação homem-natureza, nada do que foi colocado implicaria na inexistência de insuficiências conceituais quanto à questão do meio ambiente. O crescimento da consciência ambiental (Fig. 2), tonificado pelas profanações que vitimaram o meio natural, lancetado por todo o tipo de violências e intrusões, não permitiria aceitar como satisfatório meramente enfocar a inter-relação homem-natureza. Mais do que pautar este pressuposto, o que está intrinsecamente colocado pela crise ecológica é a criação de um saber ambiental decidido a decifrar essa problemática, conferindo a este conhecimento o papel de provedor de proposições, alternativas e respostas (passim, LEFF, 2004).

Nesta perspectiva, o fato da inter-relação homem-natureza constituir elemento permanente na historiografia geográfica, não obrigatoriamente tornou a questão ambiental um tema de proa no seu horizonte de análises. E contrariando a interpretação apressada de alguns, tal lacuna não resultou de uma motivação de ordem exclusivamente cronológica, centrada no "ineditismo" dos problemas ecológicos. Na realidade, o conjunto de prédicas inseridas pela questão ambiental, questionando valores, condutas e procedimentos que dinamizaram o mundo contemporâneo, dificilmente the granjearia adesões. Tampouco, qualquer facilidade para ser aceita. A questão do meio ambiente, tanto para as vertentes conservadoras quanto para as progressistas, ofereceu dificuldades em diversos sentidos para ser assimilada (Ver GUIMARÃES, 1991, CAPRA, 1991, GONÇALVES, 2001 e PIVOTTO, 2005).

Certo é que não estou, nessa discussão, respaldando fabulações da questão ambiental, evocando um naturalismo idealista desvinculado do homem enquanto entidade histórica e social. Acima de tudo porque o espaço geográfico que diviso diante dos olhos resultou de uma intensa agregação de trabalho humano. Ecossistemas isentos de alterações provocadas pelo homem simplesmente não existem (QUAINI, 1979:49). Minha certificação suprema é o espaço, noção que colocada num plano humanista e vinculada aos processos sociais, simultaneamente atesta tanto a historicidade da natureza quanto a naturalidade da 
história. Logo, este texto não se resumiria a singelamente "levar em consideração" os ciclos naturais e seus reflexos para a vida humana. Bem mais

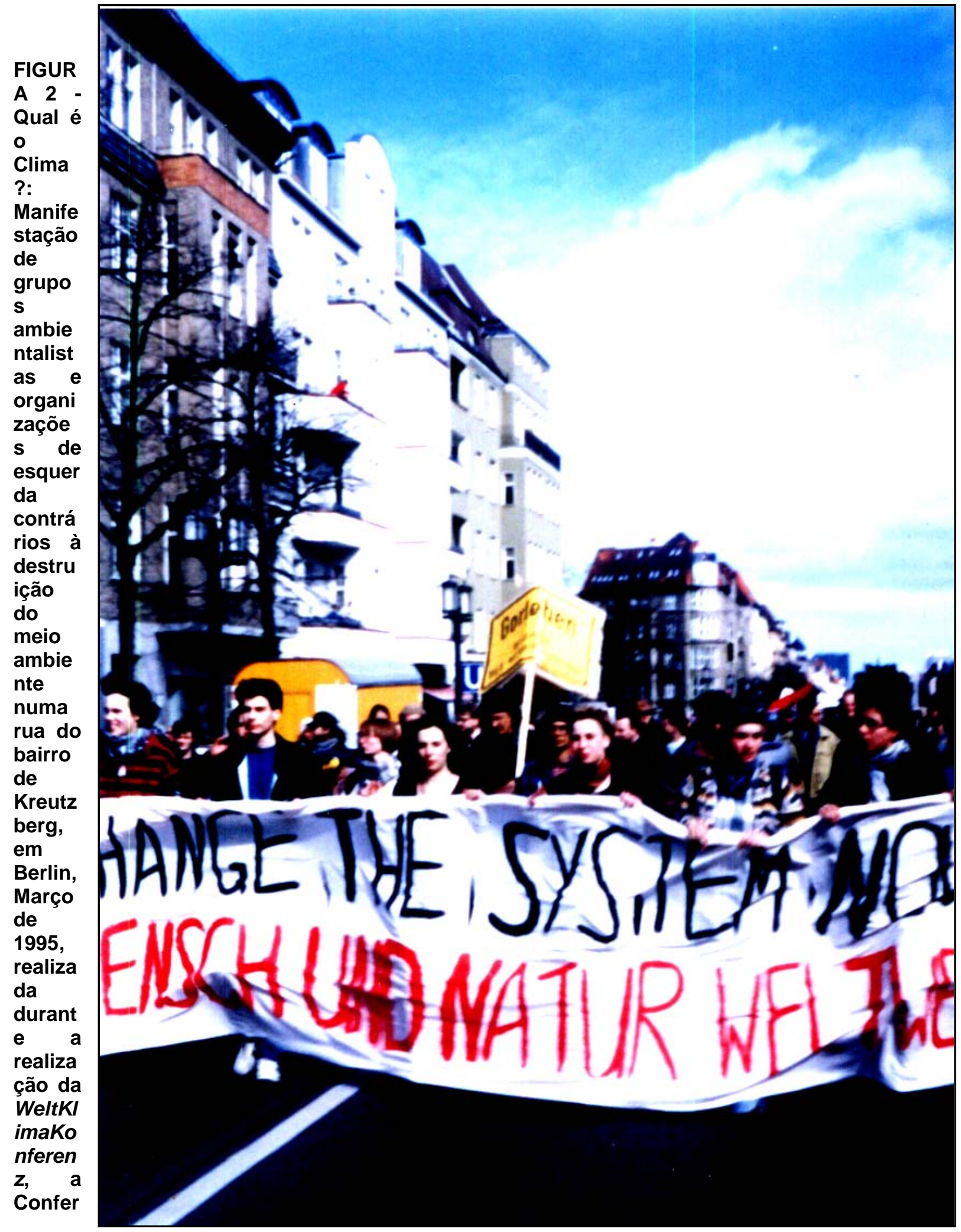


ência Mundial do Clima da ONU (Foto: Maurício Waldman). 
do que discutir o equilíbrio ecológico, o que está priorizado nesta discussão é a sustentabilidade do espaço artificial criado pelo homem.

Para a geografia, tendo adiante de si um quadro ambiental no qual o fator determinante não é uma lei abstrata natural, mas acima de tudo um universo calcado por relações sociais, pensar o nexo axiomático homem-natureza frente aos desequilíbrios ecológicos derivados do modo de ser da modernidade implicaria em optar por uma abrangência mais precisa, extensa e problematizadora. Nesta acepção, simplesmente pautar a inter-relação homemnatureza, além de insuficiente, seria abdicar da pretensão de encontrar respostas para a questão ambiental. Importa sobremaneira acentuar o caráter central do como a inter-relação homem-natureza se concretiza, no que ela implica e em qual medida deve-se alterá-la para assegurar o futuro da sociedade humana. O que a questão ambiental ensina são os limites da natureza num determinado contexto sócio-histórico. Em resumo, para cada situação vários usos da natureza são possíveis, mas não qualquer uso (GONÇALVES, 1988:14, grifo nosso).

Deste modo, a conexão da produção do espaço com os processos sociais, que se desenvolvem sob o signo da contradição entre os homens, impõem para a análise ambiental uma interface inegável com as determinações sociais. Decididamente, as lutas sociais do século XIX, sob a égide do capitalismo ascendente, permitiram descortinar a existência de grupos com interesses opostos no seio da mesma sociedade. Os conflitos interclassistas, fossem estes vistos como "motores da história" (Marx e Engels), ou como "problemáticas para a ordem estabelecida" (Augusto Comte), passaram de um modo ou de outro a reclamar as atenções dos cientistas sociais. Nos estudos geográficos, os velhos adágios que facilitavam o ocultamento ou mesmo a naturalização dos antagonismos sociais, cederam diante das evidências que se acumularam quanto ao caráter contraditório que perpassa pela construção do espaço, inferência para cuja detecção o conceito de formação social demonstrou notável maestria (MAMIGONIAN, 1996 e 1997).

Todavia, a contestação ao saber geográfico tradicional enfrentou resistências incrustadas no cerne da disciplina. Recorde-se que a geografia tradicional, cuja ascensão ocorreu na fase triunfal da burguesia, assumiu um pendor manipulatório 
que suplantou em muito suas potencialidades científicas. Freqüentemente, a geografia terminou arregimentada como uma arma ideológica a serviço das classes dominantes ou então, acoplada à engrenagem da máquina de propaganda dos governos. Com este leitmotiv em pauta, dificilmente estranhar-se-ia o empenho da geografia pelo mascaramento das contradições na análise do espaço, colocando-a a serviço do exercício do poder, da condução da guerra e da organização do Estado, acumulando enfoques anódinos para assim proteger a ordem que a sustentava (LACOSTE, 1977, SANTOS, 1978a:78/80, QUAINI, 1979:11/14, e GONÇALVES, 2001).

Estes posicionamentos repercutem diretamente quando o tema em debate é o ambiental. Pode-se perceber que embora a crise ecológica tenha se alçado, dada a sua gravidade, a um assunto do cotidiano, o relacionamento entre meio ambiente e organização social continuou obscuro na literatura escolar, nos meios de comunicação e na fala institucional em geral. Paralelamente à abordagem dos problemas ecológicos (de resto inevitável frente à escalada da devastação), o esforço em indiferenciar os atores sociais relacionados com a crise ambiental mascarando a compreensão do problema - se evidencia em si mesma. Na galeria dos responsáveis anônimos pela destruição do meio ambiente podemos discernir "o homem", "a ganância", "o egoísmo", "a atividade industrial" e até mesmo um "instinto predatório", este último teologicamente inscrito por algumas opiniões como inerente à humanidade (WALDMAN e GARCIA, 1991a e 1991b).

Tal argumentação, dado constituir uma peça com perfil nitidamente ideológico, não visa compreender a questão ambiental nem mais, nem melhor. Ademais, esta prerrogativa não estaria colocada à disposição desta linha de interpretação. Visto encampar um argumento mistificador, essa interpretação não expressa propriamente uma teoria, mas sim seu oposto. Como toda obstrução do entendimento do real, sua pretensão é antes a construção de um retrato invertido, através do qual, as coisas passam a receber um significado que efetivamente não possuem, confundindo, e não esclarecendo relativamente ao universo que nos cerca (Ver CUVILLIER, 1975:19/30, SANTOS, 1978a:157 e ALTHUSSER, 1980:69/104). 
Repetida sistematicamente no âmbito pedagógico, pela comunicação de massa, por órgãos institucionais e empresariais, esta peça mistificadora da degradação ambiental lançou fortes raízes na compreensão do cidadão comum quanto à crise ambiental. Neste consenso fabricado, a crise ecológica, ao estar endossando um conceito de humanidade socialmente genérica enquanto elemento explicativo geral, faz com que o status quo fique isento de qualquer associação com o problema. Ela também se presta a instrumentalizar as ações em favor da conservação da natureza. Dado que nessa interpretação estaríamos diante de uma problemática de cunho geral e universal, nada impediria que as próprias grandes empresas, um dos mais poderosos agentes da devastação ambiental, possam encabeçar as próprias campanhas de defesa do meio ambiente.

Exatamente por essa razão, um comentário do geógrafo Carlos Walter Porto Gonçalves apontava nos anos oitenta para o nódulo central dessa questão. De acordo com sua ponderação, seria preciso:

Ir além daquela formulação tão em voga nos movimentos ecológicos de que os homens estão destruindo a natureza. Se um trabalhador opera uma serra elétrica que derruba milhares de árvores em algumas horas, não se pode responsabilizá-lo por esse ato sem que enfoquemos as relações sociais sob as quais vive (GONÇALVES, 1982:223, grifo nosso).

Contudo, é claro que em si mesma que a análise da sociedade, mesmo sendo crucial para a discussão do meio ambiente, não esgota a compreensão da crise ecológica. Dada sua complexidade, nos problemas ambientais se entrecruzam, paralelamente à problemática da sociedade, aspectos relacionados com conhecimentos técnico-científicos, normas estéticas, valores culturais, sensos políticos e padrões econômicos. Essas derivações, ainda que dinamizadas por arrazoados diferenciados entre si e mesmo não sendo dicotômicas entre si, reclamam todo cuidado para com os múltiplos aspectos levantados, sendo indistintamente centrais para esta discussão.

Claro também é que nas próprias formulações marxistas "sempre se fala primeiramente da relação do homem trabalhando socialmente a natureza e 
somente depois da relação dos homens entre si" (WITTFOGEL, 1992:80). Dito de outra forma: a oposição entre o homem e o meio natural detém precedência. Não seria assim qualquer despropósito reclamar a proeminência desta formulação numa época em que se assiste, de um modo jamais visto, uma acelerada desaparição das grandes emanações da naturalidade.

Ao mesmo tempo, nada disso contradiz uma premissa essencial da história dos humanos que é a força do dinamismo social e sua capacidade de imprimir mudanças no mundo real. É esta a força habilitada a mudar o rumo dos acontecimentos e inaugurar novos caminhos:

Fluindo na direção da morte, a vida do homem arrastaria, consigo, inevitavelmente, todas as coisas humanas para a ruína e a destruição, se não fosse a faculdade humana de interrompê-las e iniciar algo novo, faculdade inerente à ação como perene advertência de que os homens, embora devam morrer, não nascem para morrer, mas para começar (Hanna Arendt, citada in DIÓGENES, 1992:8).

Nesta argumentação, deve-se recordar que o aprendizado que frutificou do relacionamento objetivo com o mundo real contribuiu no passado para a gestação das mais edificantes experiências encetadas pelo rico histórico de resistência dos povos e das lutas das classes oprimidas. Hoje, a revisão das certezas que encantam o imaginário dos grupos, povos e civilizações pode, desse modo, fortalecer uma visão crítica, endossando experimentos que clamam por ação e emoção.

Preciosos como a naturalidade que se esvai e se despede deste mundo a passos de gigante, são esses atos que poderão - quem sabe - alavancar precauções, paliativos e medidas agilizados somente a título excepcional pela ordem dominante.

É assim que esta época, na qual sua rudeza é tão prenhe de vicissitudes quanto de novos projetos, pode prenunciar um momento novo, inaugurando um período de possibilidades sem precedentes, um tempo novo, correspondido por um novo espaço. 
Tarefa que continua requerendo a necessária e bem-vinda participação da geografia, uma dádiva que este texto pretende, nas limitações e alcances colocados pelo tema adotado, modestamente contribuir. 


\section{CAPÍTULO 2}

\section{CIRCUITOS, TENSÕES E AMPLITUDES}

\subsection{EspaÇo, Sustentabi li dade e os Desafi os da Natureza Hosti l}

Entender a relação entre o homem e a natureza pressupõe a compreensão de um leque significativo de interconexões, nas quais se interpenetram estruturas sociais, políticas e econômicas. Sobretudo, subentende que a produção do espaço pelo homem em sociedade implica simultaneamente num relacionamento específico com o meio natural, marco da identidade social, cultural, histórica e geográfica dos humanos.

A relação com o meio natural está indelevelmente retratada na "arena territorial" esculpida por cada formação sócio-espacial. As sociedades humanas, na sua permanente predisposição em modelar o meio natural se assenhorearam dos circuitos físicos e biológicos dos ecossistemas, exibindo na paisagem criada diferentes "metabolismos" representativos do seu engajamento com a artificialização da natureza.

Sobejamente, este ato consciente levado a cabo visando a edificação do artifício seria, por definição, um predicado solene do Homo faber. Tal peculiaridade constitui seu mais resoluto monopólio, marco divisório essencial na diferenciação frente aos demais seres vivos:

O animal apenas utiliza a natureza, nela produzindo modificações somente por sua presença; o homem a submete, colocando-a a serviço de seus fins determinados, imprimindo-Ihe as modificações que julga necessárias, isto é, domina a natureza. E esta é a diferença essencial e decisiva entre o homem e os demais animais (ENGELS, 1979:223).

A intervenção das sociedades junto aos fluxos e ciclos do meio natural, na dependência dos desígnios sociais em voga, articula um relacionamento com as 
forças da natureza, conotado pela criação de arranjos espaciais aquinhoados com uma maior ou menor perdurabilidade, um desdobramento direto dos seus “compromissos ambientais" (QUAINI, 1979:141/142). Para utilizar uma expressão muito em voga nos dias de hoje, no transcorrer da história as sociedades colocaram a prova graus variáveis de "sustentabilidade ecológica", determinando processos que levaram à continuidade ou desaparecimento das culturas e das civilizações.

Implicitamente, essa evidência repudia a possibilidade de sociedades cotejadas por uma "simbiose com a natureza". Tal suposição, alicerçada a partir de uma quimérica noção "equilíbrio", tem sido consistentemente rejeitada com base nos mais diversos argumentos científicos. Adverte o físico llya PRIGOGINE, "um sistema em equilíbrio não tem, e nem pode ter história: apenas pode persistir no seu estado, no qual as flutuações são nulas" (1991:42). De resto, esta aspiração sequer encontra respaldo em provas arqueológicas ou de qualquer outro tipo.

$\mathrm{Na}$ realidade, o entorno natural foi transformado desde a entrada em cena dos primeiros humanos, que encetaram, premeditadamente ou não, mudanças no ambiente terrestre. Certamente, a fisionomia de muitos espaços catalogados como pertencentes ao "reino natural", seria irreconhecível na ausência do trabalho acumulado por sucessivas comunidades humanas. Um convincente memorial de pistas e documentos respaldam o julgamento pelo qual as paisagens usualmente definidas por biogeógrafos como "naturais" correspondem, na realidade, a espaços extensivamente manipulados pelos homens, nos quais o papel das populações tradicionais foi categórico (DIEGUES, 1994 e CARVALHO, 2000).

Este diagnóstico dos espaços tradicionais como sendo "naturais" decorreu das veleidades da idiossincrasia ocidental, que posicionou como válida apenas a sua modalidade de transformação do meio natural. Conseqüentemente, foi recusada legitimidade para quaisquer acepções de ocupação do espaço pautadas por sociedades externas à Europa. O pensamento ocidental, operando uma noção de natureza em estado puro e sugerindo o congelamento de dada situação ecológica, declinou de analisar as paisagens artificializadas pelos povos não- 
ocidentais com base nos anseios inerentes ao modo de ser dessas populações. Coerentemente, legendou como "naturais" vastas superfícies constitutivas dos espaços tradicionais. Em todos os continentes (inclusive o europeu), territórios inteiros, supostamente devotados para um não-uso, foram considerados "vazios" e, portanto, parte da natureza.

Porém, sendo esta uma conclusão carente de veracidade, pode-se, outrossim, asseverar que a naturalidade foi alvo de intensa e contínua artificialização pelo conjunto das sociedades humanas, cada uma das quais imprimiu sua feição ao espaço. Os humanos, interagindo com o meio natural impulsionados por diferentes contextos histórico-sociais, sempre tiveram no espaço o suporte privilegiado das suas expectativas, diferindo caso a caso consoante o curso da sua história. Independentemente da essencialidade de um pivot propriamente biológico para a definição de natureza, é na esfera decisiva da história que o meio natural se afirma diante dos humanos (Ver entre outros CARVALHO, 1991 e DIEGUES, 1994).

Acumulando sucessivas decantações de tempos pretéritos, o espaço geográfico evoca uma metamorfose incessante, uma mutação reveladora dos contratos assumidos com o dinamismo sócio-espacial. A espacialidade constitui, portanto, o espelhamento concreto da transformação do meio natural, estando umbilicalmente atada às demandas das sociedades. Recorrendo ao axioma do filósofo grego Heráclito de Éfeso, pelo qual não se atravessa um mesmo rio por duas vezes ${ }^{5}$, o espaço, usufruindo a potencialidade de adquirir novas feições, tem na sua plasticidade um celebrado eixo de teorizações da geografia. A natureza, sendo passível de ajustes e metamorfoses, arranjos e reacomodações, apropriações e releituras, justifica sua conceituação enquanto uma entidade socialmente construída, culturalmente vivenciada, historicamente configurada e espacialmente explicitada.

Assim, uma vez que o espaço habitado materializa um dinamismo apoiado no binômio espaço-tempo e corporifica concomitantemente uma ordenação social dos ciclos de matéria e energia, seria incongruente desconectar as crises espaciais 
dos desequilíbrios ambientais que pari passu contracenam com ela. Na reflexão do geógrafo Antonio Carlos Robert MORAES, "o ambiental não se homogeneíza num só alvo de ação, antes se difunde como faceta inerente a todo ato de produzir espaço" (2002:30). Neste prisma, natureza e espaço não intercambiam somente um pleito de cumplicidade. Bem mais do que isso convivem na condição de sinônimos (SANTOS, 1978a:201). Portanto, fenômenos como a fome, abundância, secas, epidemias, bonança, a derrocada ou continuidade das civilizações, constituem injunções focadas no que habita seu cerne: as relações mantidas entre o homem e o meio natural.

Coincidindo com transtornos ambientais, a hecatombe das civilizações assombrou a consciência social em todas as épocas e em todos os continentes. $\mathrm{Na}$ grande maioria das sociedades tradicionais, a ruptura da unidade - isto é, da espacialidade - traduzia-se pela imagem do caos, da desordem, de crises espaciais e ecológicas que punham a perder os fluxos socialmente apropriados de matéria e energia. A contraposição entre o cosmo (território habitado) e o caos (território estranho ou desconhecido), um arquétipo peculiar ao mundo da tradição (BETTANINI, 1982:86/88), tinha na ruptura do espaço um momento marcado pelo triunfo da desordem. Era o fim do mundo, tão visceralmente pressagiado nas invectivas dos profetas, dos magos e dos sacerdotes.

Distintamente, os impérios baseados na formação social asiática travavam uma guerra sem quartel contra a "abominação do caos" e as "forças do abismo". No antigo oriente, somente um criativo gerenciamento das potencialidades naturais, apoiado numa base técnica que primava pela rusticidade, poderia conter o esgarçamento do arranjo espacial. Daí a administração dos recursos naturais numa linha de perdurabilidade, a reposição da fertilidade do solo e os equilíbrios hidrotécnicos pautados pelo monitoramento dos canais de irrigação constituírem alvo prioritário do Estado oriental. Bem mais do que um "compromisso ambiental" ou uma idílica "preocupação ecológica", o zelo das realezas asiáticas pela integridade do espaço tinha por pressuposto que bons ou maus governos seriam revelados pelas colheitas, cujo desempenho, matricial para as "tempestades do

\footnotetext{
${ }^{5}$ Tal juízo não é privativo deste filósofo, pois para o conjunto dos seus predecessores pré-
} 
céu oriental", confirmariam ou não o benefício do mandato celestial outorgado à monarquia então reinante (MARX, 1976:22).

Deste modo, em termos mais amplos vigora o auspício de que uma civilização se esgota quando não mais consegue viabilizar o "retrato ecológico" com o qual está identificada. Por conseguinte, a superação de um sistema social remete diretamente ao esgotamento das possibilidades de reprodução de um tempo social, de um arranjo territorial e pela exaustão de um balanço energético. Uma vez inviabilizado o controle dos fluxos de energia pelo sistema dominante, isto necessariamente conduz à "extinção ou superação do modo de produção existente" (GUGLIELMO, 1991:68).

Neste quesito, a discrepância identificada entre as sociedades de outrora e a sociedade moderna é patente. Outrora a construção do espaço prescrevia uma presença constante da naturalidade. As grandes marcas ou obras sociais que demarcavam a implantação do artifício (tais como canais, estradas ou diques), demandavam por conteúdos de naturalidade, permitindo a vazão dos fluxos do ambiente ou então, sua contenção dentro de limites de certo modo fluídos, que oscilavam ao sabor dos humores ecológicos. Deste modo, as estradas acompanhavam as nervuras da topografia; os canais de irrigação tinham por eixo o curso de um grande rio; os diques valorizavam os desníveis naturais do relevo; os reservatórios eram erguidos pressupondo a oscilação do débito fluvial e da pluviometria e assim por diante.

Mesmo os mais ousados objetos espaciais implantados pelas civilizações do passado constituíam próteses assentadas num tecido natural, sendo que tais adições não necessariamente conflitavam com os fluxos da natureza. Fosse atuando nas franjas de um ecossistema (pela caça, pesca, coleta), ou ainda, através da socialização dos grandes ciclos presentes no ambiente natural (caso, por exemplo, do controle despótico da água pelos impérios asiáticos), o processo de territorialização detinha-se junto às manifestações maiores das dinâmicas têmporo-espaciais da natureza, acentuando um "colorido ecológico" hoje festejado pelos movimentos em defesa da natureza.

socráticos, a mudança é vista como incessante e universal (COLLINSON, 2004: 22). 
De um modo ou de outro, a instauração do artifício nas sociedades de outrora requisitava algum tipo de colóquio com o meio natural, engendrando uma naturalidade da metamorfose indissociável dos arranjos espaciais da antiguidade. Este precatório fazia com que o epílogo das civilizações tradicionais não necessariamente induzisse uma esterilização dos fluxos do meio natural. Pelo contrário, muitos casos evidenciam que a Zusammenbruch der Zivilisation (derrocada das civilizações), podia resenhar um prólogo descrevendo um momento ambiental inédito, através do qual a reorganização do espaço apelava para o aproveitamento de outros níveis ecológicos, assumidos agora enquanto um novo patamar de vida (Vide DIAMOND, 2005).

Contudo, este contexto se altera severamente no mundo contemporâneo. A expansão da sociedade moderna, tendo por base o capitalismo e a instauração de paradigmas que acirraram a oposição entre o homem e o meio natural, materializou um quadro sem paralelo de desequilíbrios. O triunfo da civilização ocidental, perpassado pela visão de que a economia seria o pressuposto para a "libertação do homem da natureza", emergiu acompanhado de distúrbios socioambientais simplesmente impensáveis mesmo em tempos recentes. O resultado foi a aparição de um quadro perturbador, no qual "as condições ambientais são ultrajadas, com agravos à saúde física e mental das populações. Deixamos de entrever a natureza amiga e criamos a natureza hostil" (SANTOS, 1988:43).

A eclosão deste cenário, tendo por fulcro extensivo desfile de distúrbios resultantes do relacionamento institucionalizado pelo ocidente para com a natureza, destaca a questão ambiental numa condição de primazia junto à totalidade dos campos de conhecimento, incluindo-se nestes, os círculos de conhecimento alheios a uma apreciação técnica ou científica. Este seria o caso da teologia, que passou a delegar ao meio ambiente um investimento ponderável em termos de especulações. Decididamente, a questão ambiental, tornando-se indissociável da bagagem conceitual do mundo contemporâneo, trouxe toda sorte de desafios, em particular pelo caráter premente que caracteriza várias das suas 
manifestações. É o que deixa transparecer o duro comentário de Murray BOOKCHIN:

A civilização, tal como hoje a conhecemos, com sua história e mitologia próprias, é ainda mais muda que a própria natureza que pretende interpretar, é ainda mais cega e elementar que as forças que ela pretende controlar. Esta civilização vive na oposição permanente com tudo que a rodeia a até consigo própria. As suas cidades anormais e desventradas, as suas terras mortas, seu ar envenenado, o seu espírito mercantil e estreito são o repertório cotidiano da sua imoralidade e da sua indiferença (1989: 45).

Para a geografia, a proeminência dessa composição incentivou, acelerou ou colocou em questão certas tendências endógenas da disciplina. Embora as interrelações entre natureza e sociedade sempre estivessem presentes no seu foco de análise - na verdade uma vocação cultivada desde os tempos clássicos da disciplina - este filão não foi, todavia, contemplado com as atenções que o público não-acadêmico no geral credencia para o saber geográfico. Abrigando tendências díspares quanto à questão ambiental, faria sentido relatar, por exemplo, que enquanto geógrafos brasileiros da área física se enveredavam ativamente nas discussões sobre meio ambiente, a geografia humana manteve-se curiosamente ausente desse debate, no qual discípulos oriundos da sociologia e da economia, dentre muitas outras disciplinas correlatas, se embrenharam de modo destacado (Ver a respeito, MAMIGONIAN, 1982 e 1997:1/2, assim como COIMBRA, 2002:279 e 284).

Porém, a emergência da crise socioambiental batendo à porta do mundo moderno, alterou drasticamente este modus vivendi. As performances da natureza hostil, as dificuldades encontradas para a viabilização do way of life da sociedade moderna e a necessidade de reavaliação do paradigma ocidental da relação homem-natureza, dentre outras asserções, ditaram vários desafios para a geografia. Inevitável enfatizar, a crise ambiental advoga uma outra roupagem para a crise espacial da modernidade, perpassada por curtos-circuitos que nada mais reproduzem do que as dessimetrias implantadas na relação entre os humanos e a natureza (passim SANTOS, 1978a e 1988). Estes espasmos do sistema de 
engenharia que anima o espaço da modernidade reflexionam a progressiva inoperância do modelo civilizatório em vigor, qual seja, sua insustentabilidade.

Neste sentido, uma ponderação amplificada pela crise do meio ambiente diria respeito ao tempo nos seus inelutáveis compromissos com o espaço. $\mathrm{Na}$ análise da questão ambiental, hoje vista como empapada por um sedutor geographic flavour, um fator crucial é que a sociedade ocidental constituiu a primeira formação social junto a qual a dimensão tempo foi alçada à hegemonia. Tal desenlace se confunde com os enunciados que nortearam a economia de mercado desde seu surgimento. No capitalismo, o fruir do tempo social, cujo encorpamento materializou-se primeiramente na Europa, obteve nota substantiva numa sobreposição desarmoniosa com o tempo da natureza, dos homens e os regramentos da temporalidade que vicejavam nas sociedades tradicionais, indistintamente percebidos enquanto obstáculos para a implantação dos ritmos e seqüências da temporalidade moderna.

A ordenação do tempo da modernidade sustenta uma contradição com o meio natural cujo pressuposto imanente é o desencaixe do tempo para com o espaço (passim GIDDENS, 1991). Uma vez auferindo autonomia e postado à testa dos processos sociais, políticos e econômicos este tempo imediatamente subordinou o espaço sob seu tacão, tanto o natural quanto aquele resultante da sua hegemonia. No que tange a artificialidade, a reconstrução permanente do espaço no mundo contemporâneo é uma das suas marcas mais notórias, expressando um dinamismo autofágico do sistema agilizado com base num desequilíbrio ecológico estrutural, circunstância indispensável para que esta acepção do tempo perpetue seu império sobre a humanidade.

Dada a relação de similaridade que articula a temporalidade moderna com a degradação da natureza e a imposição da sua freqüência temporal para vasta maioria dos humanos, é possível, a partir desta correlação, firmar o caráter igualmente correlato da torção do espaço-tempo social com a de dois outros estratos, quais sejam, o da natureza e dos humanos si mesmos. Nos bastidores desta torção generalizada, encontra abrigo seguro aquele desencaixe, desconexão, descolamento, desacoplamento, desajuste do entre o tempo e o 
espaço, vital para se compreender o esgarçamento dos equilíbrios sociais, naturais e individuais.

Ora, tais considerações trazem a baila um questionamento essencial, direcionado a respeito da forma de como conviria à geografia pensar a dimensão tempo. Recordando que na ótica que norteou a elaboração do conceito de formação espacial a transformação do tempo em espaço assume importância capital, faria sentido revisitar tal discernimento metodológico na memorável tecedura traçada pelo saudoso geógrafo Armando Corrêa da SILVA:

Desse modo, a principal categoria do pensamento geográfico é o espaço e similarmente, por exemplo, ao tempo para a história. Contudo, o tempo interessa ao geógrafo, não tanto como seqüência cronológica e significativa de eventos, mas do ponto de vista de como o espaço natural e o ocupado pelo homem estão organizados e estruturados em cada momento. Do ponto de vista do pesquisador, podem interessar, em particular, os momentos - da história natural e da história humana - por assim dizer, críticos, de organização espontânea ou racional do espaço (1978:82, grifo nosso).

Nesta ordem de preocupações, caberia à geografia responder a três interrogações básicas. A primeira delas refere-se à origem da crise espacial da modernidade. Uma segunda, diria respeito ao seu dimensionamento nas diversas escalas nas quais se explicita. Por último, teríamos uma outra indagação eivada por um senso propositivo, nem que unicamente para delinear as limitações colocadas pelo modelo civilizatório que comanda a humanidade. Para estas três especulações, o conceito de formação sócio-espacial, ao lidar com as dimensões do tempo e do espaço, desponta enquanto uma versátil ferramenta de análise, mais ainda quando estamos às voltas com uma contribuição eminentemente geográfica para este debate (MAMIGONIAN, 1996 e 1997).

O momento atual sugere a elaboração de um novo modo de relação com 0 meio natural, que repense o tempo, o espaço e a natureza na perspectiva de uma humanidade socialmente organizada e solidariamente comprometida. Sugere enfim um novo espaço de vida, cuja edificação transmuta-se mais e mais 
enquanto uma prioridade inquestionável para os humanos, quer disto tenham ciência ou não.

A formulação de um cenário alternativo deve caminhar na direção exatamente oposta à temporalidade moderna, contrapondo a artificialidade com o reforço da conservação da natureza, através da qual a historicidade da natureza tenha sua correspondência numa naturalidade da história.

A cientista política Lorraine ELLIOTT advertiu no final do século passado, $O$ século XXI pode transfigurar-se numa espécie de ponto de não retorno ambiental. Portanto, devemos neste momento encetar opções corretas (1998:253).

$\mathrm{E}$, que a análise que se está processando possa contribuir para alargar a consciência da gravidade do momento que se vive, com a finalidade única de superá-lo e promover uma nova perspectiva de futuro.

\subsection{O CuRso das Águas e o Domí nI O da CI dADE}

Uma observação da qual não poderia furtar-me é o fato da tese que pretendo desenvolver operar com dois marcos cuja inserção no mundo atual impõe definições de cunho radical. Um desses corresponde à cidade, espaço no qual nidificou e se agigantou a civilização ocidental. O outro seria a água, o mais indispensável de todos os recursos oferecidos pela natureza.

Trabalhando com essas duas polaridades, dificilmente poderia escapar da certificação de um acidentado itinerário de questionamentos e investigações. Isto porque os dois temários - a água e a cidade - têm por pano-de-fundo expressivos desequilíbrios ecológicos, que antecipados em muitas projeções futuristas, se consubstanciam como os mais corrosivos de toda a história humana, açulados por um ordenamento social do tempo despido de qualquer outra meta que não a afirmação da sua materialidade.

O acirramento das contradições entre a vida urbana e a utilização dos recursos hídricos, hoje dispostos numa franca rota de colisão, constitui o item mais 
conflitivo da cornucópia de desprazeres, embaraços e inquietações gestados pela crise ambiental da modernidade. Não existiria, desse modo, nenhuma questão que dissesse respeito a uma parcela tão expressiva da humanidade e que simultaneamente estivesse associada a uma substância tão imprescindível para a vida.

Porém, é necessário recordar que as palavras água e cidade, em razão da densa conotação simbólica que perpassa por ambas, sugerem sentimentos que se descolam da gravidade com que foram revestidos pelo mundo moderno. Raros seriam os termos que podem suscitar imagens de plenitude, resgatar emoções ou ensejar motivações existenciais tão envolventes quanto estes. Isto significa que no âmago sensível dos humanos habitam outras aspirações, cujas implicações procurar-se-á apurar por intermédio deste trabalho.

Reservando um primeiro momento para discorrer sobre a água, assinale-se que ao líquido foram imputados os mais sedutores dos simbolismos. Nas sociedades tradicionais, é visível a atenção recebida pela água no imaginário religioso e nas concepções que regravam sua injunção no pensamento das sociedades. O antropólogo romeno Mircea Eliade, baseado em diversos estudos comparativos das culturas do passado, propôs atribuir à água, em razão de um entendimento comum a todos os povos, a coexistência com uma simbologia universal. Esta seria a tradição das águas primordiais, constatada em grande número de variantes nas cosmogonias arcaicas e primitivas (Vide ELIADE, 2000:5).

Nestas concepções, a água, ao afirmar-se como origem do mundo habitado e enquanto argumento fundante das manifestações da vida, jamais é considerada uma substância inerte. Pelo contrário, as águas são sempre germinativas, encerrando em sua unidade não fragmentada as virtudes de todas as formas existentes. Simbolizando a totalidade das virtualidades, a água constitui a substância primordial da qual nascem todas as formas e para a qual estas retornam, por regressão ou cataclismo Tal percepção cósmica do líquido animou as noções de antanho sobre a geografia terrestre, marcando presença nas 
representações cartográficas, na cosmografia e em muitos outros produtos culturais (Ver ELIADE, 2000:3/5 e também SILVA, 1998:19/25).

Por exemplo, nas representações do mundo elaboradas pelos mesopotâmios, as terras emersas estão cercadas por um rio de águas salgadas, o Oceanus. Na imago mundi fornecida pela llíada e a Odisséia de Homero, o mundo conhecido da época, abarcando a bacia do Mediterrâneo, também era circundado por uma massa oceânica única. Tal concepção reaparece na proposta de Hecateu (circa 157 a.C.), para a qual a Terra seria um disco flutuante cercado por um oceano sem fim. Por sua vez reencontra-se essa visão no pensamento hebraico. Em Bereshit, o livro massorético da criação (também conhecido como Gênesis), o surgimento do mundo ocorre através da diferenciação das águas eternas que preenchem o universo ${ }^{6}$, incluindo os céus, que para os antigos hebreus (assim modo para muitos outros povos do antigo Oriente), não era composto de ar, mas sim de água ${ }^{7}$.

Quanto aos rios, escoando o fluxo de uma substância eivada de significados cósmicos, igualmente foram ofertados de atribuições simbólicas. Exemplificando, o antigo rio Meandro, situado na Ásia Menor (hoje rio Menderes, na Turquia), miticamente identificado como descendente de Oceanus e de Thetys, era considerado uma dádiva sagrada para os gregos jônicos. As crenças de Mileto, cidade situada na sua foz, informavam que usufruir ritualmente das suas águas poderia garantir a vida eterna. Além do honrado líquido que escoava pelo seu leito, as próprias sinuosidades deste rio (origem da terminologia meandros, intensamente utilizada pelos hidrólogos e geomorfólogos), foram sacralizadas. Suas curvas graciosas, vadeando de um lado para outro, talhando vales e dando forma à bacia hidrográfica, eram consideradas símbolos da benevolência fluvial, sendo igualmente veneradas pelos frígios da Anatólia (Cf SILVA, 1998:22).

\footnotetext{
${ }^{6}$ No primeiro versículo da gesta de origem, o Yom Echad (dia primeiro ou mais corretamente, dia um), podemos conferir baseados na tradução do poeta Haroldo de CAMPOS: 1. Nocomeçar Deus criando: o fogoágua e a terra; 2. Eaterra era lodo torvo, Eatreva sobre orostodoabismo, EosoproDeus revoa sobre orostodágua (1984).

7 Significativamente a palavra hebraica para céu, Shamaim, é uma combinação de Shem e Maim, isto é, Deus e Água.
} 
Esse apanhado de liturgias louvando a essencialidade de um cosmos aquático, reflete a importância das águas para os processos vitais de continuidade da vida, uma consideração, aliás, amplamente respaldada em dados objetivos. A água perfaz nove décimos do volume total do corpo humano e cerca de dois terços de seu peso médio. Um ser humano pode deixar de comer por algumas semanas. Mas, não consegue passar mais do que dez dias sem beber (RUTKOWSKI, 1999b:5). A perpetuação da espécie humana na Terra, indissoluvelmente vinculada à presença da água, justifica o papel central que desempenha nas manifestações culturais e religiosas da maioria dos humanos.

Quanto à cidade, seria obrigatório sublinhar as conotações fervorosas despertadas pelo conceito no ideário cultural dos povos. Prova disso é a profusão de alegorias urbanas impregnadas de sentidos utópicos, metafísicos ou inscritos na ordem do maravilhoso. No exame de Yi Fu TUAN, a cidade transcende as incertezas da vida; ela reflete a precisão, a ordem e a predição dos céus (1980:174). De um modo geral, a cidade transparece como sinônimo da aglutinação consagradora, antípoda da solidão que arrebata a alma do homem. Não por acaso, conforme subscritou Pierre DEFFONTAINES, a busca de companhia e de contato social constitui reconhecido fator para o surgimento dos aglomerados urbanos (Vide 2004:131/133).

Contudo, a cidade não é simplesmente um lugar onde as pessoas se concentram na busca de convívio com outros humanos. Na história da humanidade, a cidade foi o espaço que esplendidamente propiciou o despertar dos instintos criativos e a circulação do conhecimento. Nela, como fruto do intercâmbio e do crescimento das idéias, a civilização se desenvolveu e se fortaleceu. Coerentemente, em muitas das línguas semíticas difundidas na orla do Fértil Crescente - área em que se acredita ter o urbanismo encontrado sua primeira arena geográfica e histórica - a palavra cidade compartilha raízes etimológicas com a noção de despertar, tomar consciência do mundo ${ }^{8}$.

Deste modo, longe de constituir coincidência, a antropologia elegeu a vida urbana como um dos traços mais típicos que singularizam a ocorrência de um

\footnotetext{
${ }^{8}$ Trata-se de raiz semítica que é origem da palavra hebraica ir, cidade.
} 
padrão civilizatório. Aliás, a própria palavra civilização decorre do latim civitas, isto é, cidade.

Naturalmente não teria cabimento fazer uso destas pontuações para consagrar a cidade enquanto espaço isento de conflitos, a começar pelos sociais. Uma coisa seria constatar a existência de imagens culturais sobre a cidade, que refletem determinados consensos relacionados às suas atribuições e significados simbólicos gerais. Outra coisa, seria esquecer sua sintaxe histórica. Não haveria como negar, as cidades, mesmo nos seus estágios históricos mais recuados, foi conflagrada por todo tipo de antagonismos e lutas entre grupos.

Nesta linha de raciocínio, é interessante assinalar a centralidade da noção de conflito para pensar o surgimento da cidade no tempo e no espaço. Na ótica do processo de diferenciação social, a filiação da cidade com as mudanças ocorridas na economia agrícola comunal, natural ou auto-suficiente seria patente. Foi apenas com a produção de um excedente alimentar que a cidade passou a dispor de condições materiais para alicerçar sua existência. Secundada pela criação de instituições sociais que asseguraram a transferência do mais-produto do trabalho agrícola para os grupos dominantes, ficou aberto o caminho para o surgimento da vida urbana (Vide MAMIGONIAN, 1982:204/205 e SINGER, 2002:7/12).

Neste sentido, a origem da cidade se confunde com a eclosão da sociedade de classes, uma interrelação tão enfática que não permite marginalizá-la em qualquer que seja o ângulo de análise. A expressão região, como assinalou o geógrafo francês Etienne Juillard, provém do latim régis, significando área de dominação de uma realeza. Portanto um território que possui por centro uma cidade, que coleta impostos e tributos (MAMIGONIAN, 1982:205). As concentrações urbanas, onde quer que tenham sido fundadas, nasceram sob o signo das contradições sociais. Quase sempre apresentando uma configuração social de mote biestratificado, como tal ela é encontrada numa pujante sucessão de materiais. Exemplificando, nos escritos de PLATÃO a cidade não era uma, mas pelo menos duas, ferrenhas inimigas uma da outra: a dos pobres e a dos ricos 
(422e, 1990:166/167, grifo nosso). Assim, dificilmente a cidade poderia ser visualizada como uma entidade monolítica (Cf SANTOS, 2003:172).

Nesta correlação de forças, a cidade é por definição um espaço gerenciado pelas classes dominantes de uma dada sociedade. A identificação da governança com a cidade é nítida já nos anais militares dos impérios da antiguidade. Toda vez que um conquistador quer jactar-se das suas conquistas, suas crônicas relatam saques das cidades conquistadas e a humilhação das suas elites. Conquistar um país é queimar as cidades adversárias, ocupá-las e guarnecê-las com uma milícia leal ao novo governante. A cidade é sumamente a sede do poder. Tal nuança justificaria longa série de étimos associados ao fenômeno urbano e seu universo de valores. Ora, burguês deriva do germânico burg, isto é, cidade; os adjetivos polido, o verbo polir, assim como as palavras política e polícia, derivam do grego polis, identicamente significando cidade (BRETON, 1990:13).

Assim, como se pode perceber, seria absurdo identificar no nascedouro das cidades as sementes da harmonia ou do equilíbrio. Todavia, este inconformismo se acentuaria ainda mais para o caso das aglomerações modernas. $\mathrm{Na}$ modernidade, a cidade está dilacerada por clivagens sociais, culturais, políticas e econômicas, contradições que repercutem diretamente no espaço articulado. A cidade, que tão esperançosamente surgiu na história como anteparo para o florescimento das manifestações da arte, da ciência e do espírito, tornou-se sobremaneira o espaço no qual viceja seu antônimo, qual seja, a incivilidade. Suprema manifestação da artificialidade da metamorfose, o meio urbano parece agora determinado a destruir as próprias pré-condições responsáveis pela sua manutenção: "A humanidade move-se, lenta e segura, para um fenômeno de vampirização do espaço. A grande cidade é o centro que engole e drena os inumeráveis fluxos de circulação" (BETTANINI, 1982: 34).

Nesta seqüência, dificilmente encontrar-se-ia exposição tão flagrante da fragilidade da sociedade ocidental quanto as que se divisam nas interfaces que articulam o funcionamento do meio urbano com a utilização dos recursos hídricos. Na modernidade o papel da água, em si mesmo de importância capital para a humanidade, longe de perder sua importância foi exacerbado ainda mais. A água, 
apresentando-se enquanto elemento básico para as atividades humanas, constitui substância verdadeiramente imprescindível, nuança particularmente notada no meio urbano:

A cultura urbano-industrial, entendendo aquelas como recurso inesgotável, gera demandas hídricas de crescimento exponencial, obrigando a uma procura contínua por fontes hídricas, além de promover a urbanização dos corpos d'água criando novos desenhos hidrográficos interdependentes, que se sobrepõem na mesma paisagem. Qualquer função urbana residencial, comercial ou industrial - depende prioritariamente da existência da água para atender às suas necessidades, tanto pela utilização direta, como dessedentação, quanto indireta, como a produção de energia hidráulica (RUTKOWSKI, 1999b:16).

A tempestuosa aparição da sociedade ocidental provocou um desequilíbrio estrutural na utilização dos recursos naturais, dentre estes, os que se referem às águas. Embora o debate relacionado com a água esteja atualmente estampado em todos os jornais, praticamente ninguém na escala de poucas décadas atrás anteviu a enormidade da crise que hoje se avizinha no mundo. A modernidade, vivenciando uma situação caracterizada por uma demanda hídrica em descompasso crescente com a possibilidade de ser atendida, presencia a ameaça da generalização da sede.

Tal situação, característica desta época, habilitou a popularização de um termo originalmente esboçado enquanto jargão específico de um cabedal técnico: stress hídrico, conceito pioneiramente lançado em 1989 pela hidróloga sueca Malin Falkenmark. Singularmente, o conceito de stress hídrico é bastante apropriado para explicitar a equação pela qual os recursos hídricos, em face do comprometimento da capacidade de reciclagem e de diluição dos poluentes pelo meio natural, foram colocados a uma distância cada vez maior da satisfação das necessidades dos humanos. Dado emblemático, a terminologia é proveniente de stress, palavra inglesa que significa pressão, esforço ou tensão, sendo neste exato sentido assumida no âmbito das geociências e disciplinas afins (OLIVEIRA, 1995). 
Neste sentido, um deferimento importante atenderia pela distinção feita pelos especialistas entre termos água e recurso hídrico. O primeiro refere-se ao elemento natural em si mesmo, desvinculado de qualquer uso ou utilização. Por sua vez, recurso hídrico seria a consideração da água como um bem utilizado pelas sociedades humanas, passível de tal finalidade. A noção de recurso hídrico não abarca a totalidade das águas presentes na Terra, pois estas não necessariamente apresentam algum tipo de viabilidade econômica ou social (Cf REBOUÇAS, 2002a:1).

Neste contexto, seria inevitável recordar que o Brasil concentra o maior quinhão hídrico do Planeta, calculado em $12 \%$ de toda água doce de superfície (REBOUÇAS, 2002a:29). O fato reunir gigantesco volume de água doce atribui ao Brasil, paralelamente ao importante papel na discussão internacional sobre o futuro dos recursos hídricos mundiais (MARTINS, 2003), a necessidade de um posicionamento muito sério quanto à existência de regiões com carência de acesso à água doce. Esta perspectiva por si só denuncia a proeminência do enfoque social, exaltando a associação da utilização dos recursos naturais com o universo das contradições que opõem os humanos entre si.

Deste modo, sendo a geografia humana o vértice da discussão que se está pautando, mais do que propriamente uma análise sobre a água, este material versa sobre a problemática dos recursos hídricos. Em suma, mesmo que neste texto os aspectos gerais relativos à água sejam obviamente fundamentais, o que se está discutindo é basicamente a repercussão dessa questão para as comunidades humanas. Tratando-se de um debate que emerge subsidiado pela deterioração dos corpos aquáticos por conta da impetuosidade de um modelo civilizatório, será no terreno das inferências sociais que esta problemática encontrará - ou não - equacionamento habilitado a garantir a presença humana no Planeta.

Finalmente, com base no que foi exposto poderia relacionar aspectos diretamente envolvidos com as motivações que norteiam a elaboração deste material, atuando como linhas de procedimento analítico e de pesquisa. Neste caminho repudio com veemência a empáfia narcísica. Criticada pelo geógrafo 
Armen MAMIGONIAN, esta seduz muitos intelectuais, que construindo elaborações singelamente calcadas no "ineditismo", no mais das vezes apenas recaem numa "especialização" cuja única função seria manter a invisibilidade dos problemas socioambientais (1996:205).

As fontes, próceres e cenários já foram anunciados, e a pretensão agora não poderia ser outra que não a de agregar com este estudo mais uma contribuição para o desenvolvimento da geografia. Restaria agora evidenciar o que me proponho a desenvolver.

Deste modo, seriam pontos obrigatoriamente indexados às preocupações dessa tese:

1. Avaliação detalhada da questão dos recursos hídricos: A água constitui suprimento prioritário na pauta dos recursos ambientais básicos do mundo moderno, particularmente para a grande cidade. Diversas análises apontam para uma situação de stress hídrico para esta década, acentuando-se nas seguintes. Este contexto irá alavancar um comércio de água doce em diversas escalas e envolvendo complexo conjunto de variáveis. O conhecimento dos dados físicos, da distribuição natural, das estratégias e da logística da apropriação desses recursos, propiciando maior nitidez dos contornos dessa problemática, desponta deste modo como uma linha obrigatória de investigação. No interior desta diretriz o papel desempenhado pelo modelo de desenvolvimento existente, assim como das expectativas civilizatórias frente ao meio natural - para as quais os ordenamentos sociais do espaço e do tempo são fundamentais - acompanharão o rumo geral dessa discussão.

2. Avaliação dos aspectos geopolíticos pertinentes à questão dos recursos hídricos: O recrudescimento da escassez da água por conta do aumento da demanda, da degradação ambiental e da utilização perdulária do recurso, juntamente com a nova configuração urbana mundial, opondo as metrópoles do Norte, consumidoras por excelência de recursos hídricos, às metrópoles do Sul, também às voltas com o problema de abastecimento de água potável, articulam 
objetivamente a questão dos recursos hídricos com a estrutura de poder em seus inevitáveis rebatimentos nos planos internacional, nacional e local. As contradições advindas desse cenário são merecedoras de uma atenção privilegiada, e, portanto, ocuparão espaço generoso nessa análise.

3. Avaliação do stress hídrico nas regiões metropolitanas: A compreensão da questão dos recursos hídricos nas diferentes interfaces incorporadas por essa discussão, referenda-se pelo vínculo mantido especialmente com a questão urbana, incluindo, por exemplo, a interconexão das temáticas dos recursos hídricos com a dos resíduos sólidos e da matriz energética. O fato do Brasil potencialmente despontar como um possível provedor mundial de água doce, ao mesmo tempo em que reúne diversas regiões metropolitanas nas quais o abastecimento de água potável tem se mostrado notoriamente problemático, é seguramente uma das grandes contradições a serem tratadas neste trabalho. Tal é o contexto vivenciado pela Região Metropolitana da Grande São Paulo (RMSP), assim como pelo Grande $A B C$ e a cidade de Ribeirão Pires, referências geográficas de peso nesta análise.

4. Analisar as políticas de abastecimento hídrico e seus vínculos com a questão energética: A despeito de pressupor uma utilização consuntiva dos recursos hídricos, não necessariamente o histórico da energia no Brasil tem se compatibilizado com as necessidades do abastecimento público de água potável. Esta ausência de articulação de políticas de gerenciamento dos recursos hídricos tem suscitado a degradação dos reservatórios, prejudicando o abastecimento a partir dos mananciais próximos das cidades e induzindo a contribuição de outras áreas mais distantes. É assim que, por exemplo, o Sistema Cantareira, que abastece atualmente grande parte da capital paulista, foi implantado para suprir a demanda comprometida pela poluição do reservatório Billings, em grande parte catalisada por uma estratégia de favorecimento dos interesses constituídos em função da geração de energia. 
5. Compreender as potencialidades e os limites da atuação institucional frente à questão ambiental: Não haveria como dispensar do corpo desta análise questões relacionadas com a institucionalidade, até porque esta se vincula diretamente com a organização do espaço, e, por conseguinte, com a gestão dos recursos hídricos. Entretanto, a atuação do Estado diante da questão ambiental materializa uma situação paradoxal: parte de sua engrenagem refere-se a canais institucionais de defesa ambiental, enquanto que outra parte, atua como um agente direto de devastação do meio ambiente (Cf MORAES, 2002:57). Além disso, mesmo quando se corporificam medidas em favor da conservação da natureza (principalmente na forma de políticas de planejamento e de ordenamento territorial), a limitação que estas demonstram diante do dinamismo espacial hegemônico é manifesta. Portanto, este contexto sugere a necessidade de alertar para a fragilidade das concepções que intuem as ordenações legais como dotadas da mágica capacidade de regrar a apropriação do espaço urbano. Nesta abordagem, a pressuposição é que o escopo jurídico estará continuadamente fadado ao insucesso na eventualidade de insistir em ocultar, negar ou secundarizar uma leitura precisa das contradições sociais existentes, especialmente as que se associam com as grandes massas de excluídos. Coerentemente, mais do que preocupados em analisar decretos e outras arquiteturas jurídicas, os processos reais de espacialização, passíveis de explicitar os limites das práticas e dos discursos políticos é que serão valorizados enquanto instâncias que asseguram a compreensão do dinamismo real da formação espacial.

6. Reforçar o nexo que envolve justiça social e a questão do meio ambiente: Praticamente complementando o item anterior, explicitar a limitação das práticas institucionais desdobra-se, na filosofia que norteia este texto, em apontar para outros paradigmas, extrapolando os marcos colocados por elas. Apenas nesta perspectiva é que a construção de uma legislação ambiental poderá, por exemplo, se capacitar enquanto instrumento real de defesa do meio ambiente. Certamente, este poderá ser o grande convite que a questão ambiental estará pautando de 
agora em diante neste texto, incitando todos a pensar outros modos de relação com o meio natural e de organização da sociedade, simultaneamente justa e ecologicamente responsável. 
PARTE I I

Mei o URBAno, Questão Ambi ental e Moderni dade 


\section{CAPÍTULO 3}

\section{TEMPO, MODERNI DADE E NATUREZA}

\subsection{RePEnSANDO A ECOLOgI A A PARTIR dO OIKOS}

Certamente, em função dos marcos que estão esboçados para este trabalho, a primeira preocupação seria alinhavar algumas diretrizes relacionadas com a conceituação de ecologia. A partir deste ponto, tendo por foco nodal a modernidade, a discussão será retomada mais adiante na direção das relações que conjugam questão ambiental e tempo social, assim como nas implicações que este debate oferece para o conceito de meio urbano e tecnosfera.

Evidentemente, um objetivo implícito seria delinear a contribuição do enfoque geográfico nos termos de um melhor entendimento da problemática ambiental. Esta preocupação poderia ser respaldada, dentre muitos outros pronunciamentos, pelo proferido pela geógrafa portuguesa Alzira Filipe ALBERTO. Na sua opinião, a geografia é uma disciplina que subentende um projeto ambientalista, uma vez que, ao longo da sua história, "sempre se tem preocupado com as relações homem/meio" (2002).

Neste particular, assinale-se que a contemporaneidade do debate relacionado ao meio ambiente imprime a esta discussão um cunho bastante instigante. Basta recordar que unicamente a partir das três últimas décadas do século XX é que a defesa da natureza, envolvendo diversos segmentos sociais e de opinião, passou a inspirar crescentes manifestações em nível internacional. Tal mobilização, se posicionando em favor de uma relação equilibrada com o meio natural, corporificou-se através de reivindicações impensáveis mesmo em épocas historicamente recentes. 
Embora a questão ambiental estivesse potencialmente colocada desde a aurora do homem na Terra, esta apenas eclodiu em toda sua magnitude no século XX. Ressalva inerente a uma avaliação com o perfil da que está sendo desenvolvida, inexiste história humana descolada de uma intervenção transformadora do meio natural. Cada uma das formações sócio-espaciais estabelecidas ao longo da história constituiu expressão de uma forma específica de apropriação da natureza. Tal apropriação, numa assertiva que há muito se tornou senso comum para o conjunto das ciências sociais, "é uma condição necessária do intercâmbio material entre o homem e a natureza; é a condição natural eterna da vida humana" (MARX, 1975b:208).

Assim, já em longínquo passado detectam-se registros evidenciando conexão entre meio ambiente e dinamismos sociais. Além disso, na medida em que avançam as pesquisas arqueológicas, recua cada vez mais no tempo a constatação da presença do homem na Terra, e paralelamente, as provas de sua intervenção na natureza. Esta provocou profundas alterações na paisagem natural e a extinção de inúmeras espécies animais e vegetais. Os vestígios coletados pelos arqueólogos confirmam que as sociedades do passado, contestando uma difusa concepção de "paraíso perdido", chegaram a engendrar severas crises ambientais.

Os desequilíbrios ambientais que tiveram por palco a antiguidade resultaram dos mecanismos sociais, espaciais, culturais e temporais que animavam as sociedades do passado. O declínio das civilizações antigas muito raramente decorreu exclusivamente da erupção de desastres ou cataclismos naturais. $\mathrm{Na}$ pena do geógrafo Jared DIAMOND,

Os povos do passado não eram maus administradores ignorantes que merecessem ser exterminados ou espoliados, nem ambientalistas conscientes que resolviam problemas que não podemos resolver hoje em dia (...) Tendiam ao sucesso ou ao fracasso, dependendo de circunstâncias similares àquelas que atualmente nos fazem tender ao sucesso ou ao fracasso (2005:25). 
Seguramente, débâcles de cunho socioambiental contribuíram para que civilizações como as da Núbia, do Ghana e do Zimbábue na África, do antigo império Maia na Meso-América e da ilha da Páscoa na Oceania, dentre tantos outros exemplos, entrassem em decadência e finalmente sucumbissem. O vínculo existente entre a derrocada das civilizações da antiguidade e o acirramento do relacionamento com o meio natural pode ser rastreado através de uma profusa coletânea de mitos e relatos, nos quais os desequilíbrios ecológicos transparecem de modo indiscutível. Via de regra, estes sobrevém em decorrência da sobrecarga de tributos e do uso indevido dos recursos naturais, gerando as mais assombrosas prefigurações junto à consciência social (Fig. 3).

No caso romano, a crise do império incluiu um recorte ambiental registrado pelas fontes da época. Roma, a odiada capital de um império que se arrogava a assumir o controle total da bacia do Mediterrâneo (o mare nostrum), era o destino final do fluxo de imensas riquezas, que transformavam esta cidade num verdadeiro "ralo do mundo". Eis como Aelius Aristides, documentalista grego do século I d.C., expressou esse gigantesco movimento de recursos, fruto do saque sistemático das províncias:

De todas as partes da terra e dos mares afluem para vosso país produtos de todas as estações e de todos os países, os dos rios e dos lagos, e tudo que pode conceber a indústria dos gregos e dos bárbaros... Há tantos navios de carga aportando no cais do Tibre que Roma de certa forma é o mercado universal do mundo. Os frutos da Índia e da Arábia..., os tecidos da Babilônia, as jóias da Barbárie mais longínqua chegam a Roma em grande quantidade e com muita facilidade (citado in CLÉVENOT: 1979).

Entretanto, raramente as transformações ambientais da antiguidade, realizadas no transcorrer de prolongados lapsos de tempo, colocaram em perigo os ciclos ou os equilíbrios maiores da biosfera. Muito menos ameaçaram, como nos dias de hoje, a perpetuação geral da vida no Planeta. Este seria o caso da ilha da Páscoa, um excelente exemplo tanto das limitações das visões romanceadas sobre as sociedades do passado quanto da especificidade da crise ambiental nas sociedades pré-modernas. Páscoa constitui o rasgo de terra habitada mais isolado do mundo, uma pequena ilha da Polinésia oriental $\left(163,6 \mathrm{~km}^{2}\right)$, distante 3.700 
quilômetros do litoral sul-americano e outros dois mil a leste das ilhas Pitcairn, um ponto também remoto do Pacífico.

Um detalhe importante é que esse espaço insular abrigou uma civilização que ao contrário das demais - e semelhantemente à ocidental - não tinha para onde ir. Os proeminentes despojos desta civilização isolada, as estátuas gigantescas conhecidas como moai, constituem testemunhas mudas de um passado encerrado de modo radical. Tais monumentos, pontos terminais e próteses silenciosas de um sistema que soçobrou de modo inapelável, deixaram de ser compreendidos pela própria população remanescente. Na ilha da Páscoa,

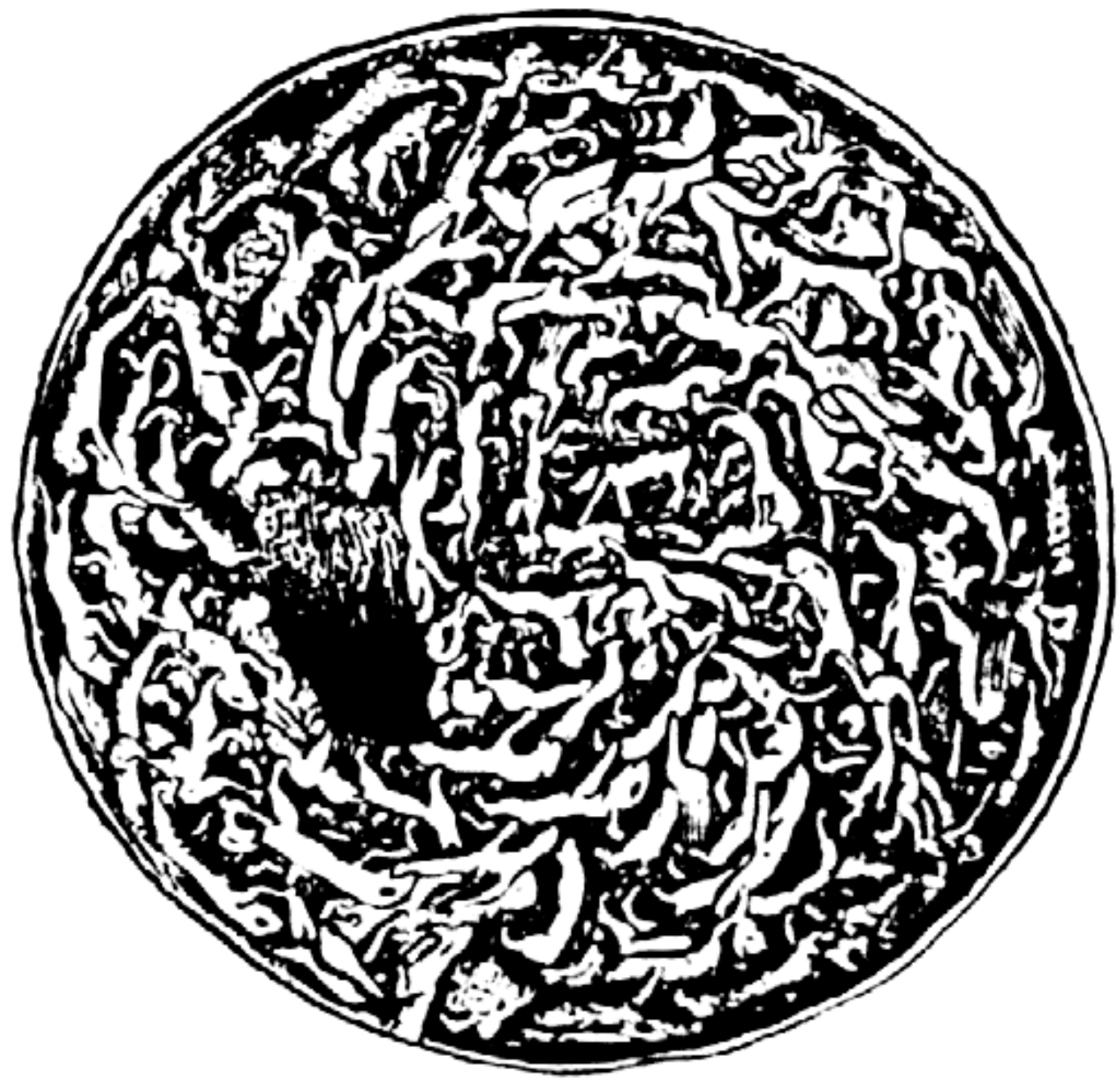


FIGURA 3 - A Visão do Caos no Imaginário Assírio: O mundo antigo foi assoberbado por suas próprias contradições, que no plano imaginário engendravam as mais tenebrosas visões de desordem, todas com íntimas vinculações com a desarticulação da ordem ambiental existente. A desordem associa-se quase sempre à noção de um fim do mundo, e não meramente sua desarticulação conjuntural. Uma exemplificação de ordem imagética é a cataclísmica visão acima reproduzida, originaria da antiga assíria. Ela traduz por si mesma os aterradores sentimentos envolvidos com a noção de desordem no mundo antigo. As forças do abismo engolem num remoinho - que é uma espiral ao contrário - todas as formas de vida, tragadas irremediavelmente para o nada (Fonte: Charles James Ball, Light from the East, London: Eyre as Spottis, 1899, The Jewish Encyclopedia, página 144, Verbete Abyss). 
em vista do implacável esgotamento dos recursos naturais, a derrocada da formação espacial não encontrou nenhum outro patamar ecológico, daí seu inglório crepúsculo (Vide PONTING, 1995:19/29 e DIAMOND, 2005:105/152).

Mas este cenário drástico de desarticulação ambiental constituiu uma notória exceção no mundo pré-moderno. Em contraste com a modernidade, jamais no passado o "ambiente de risco" da humanidade ameaçou a existência do conjunto dos humanos e das formas de vida na sua totalidade, contextualização à qual poderíamos agregar ao caso de Páscoa. As crises ambientais que precederam a que se instalou no mundo contemporâneo, além de restritas a espaços isolados, apresentavam efeitos na escala do tempo que nem de longe seriam equiparáveis com os pautados pela civilização ocidental. As repercussões dos desequilíbrios ecológicos foram indubitavelmente menos intensas e inclusive, não necessariamente declinaram no epílogo de processos sócio-espaciais. Pelo contrário, a estes muitas vezes se apresentava a oportunidade de continuidade.

Um bom exemplo estaria substantivado na crise do Velho Império Maia, decorrente do esgotamento dos frágeis solos dos altiplanos da costa do Pacífico da América Central. Ponderando a respeito, o geógrafo Olivier DOLLFUS, assinala que essa civilização baseava-se no setor agrícola,

...na cultura do milho praticada em clareiras abertas na floresta. $O$ abandono desse meio talvez tenha sido provocado pelo esgotamento dos solos: este por sua vez, teria sido uma conseqüência da rotação demasiadamente rápida das culturas motivada pelo crescimento da população (1972:31/32).

Porém, isto não significou um ponto final para esta civilização. Audaciosamente, os maias deslocaram sua arena territorial para $400 \mathrm{~km}$ ao norte, no seio da Península do Yukatán, espaço no qual sua cultura ganhou novo alento e se manteve até a conquista espanhola.

Ademais, as áreas esgotadas não estavam fadadas à esterilidade perpétua. Os espaços territorializados pelas sociedades antigas, mesmo quando exauridos por práticas agrícolas inadequadas, pastoreio intensivo, desmatamento e outras mazelas ambientais, terminaram, em muitos casos, retomados pelos ciclos 
dinâmicos do meio natural, que "renaturalizaram" áreas dantes humanizadas. Novamente lançando mão para o caso dos maias, atente-se que:

Certas regiões, atualmente abandonadas pelos homens e que aparentam jamais terem sido povoadas, são na realidade setores transformados $\mathrm{e}$ empobrecidos por uma ação humana inconscientemente devastadora. A floresta que se estende ao Sul do Yucatán, na proximidade da fronteira guatemalteca, é quase desabitada. Ora, essa mesma região foi um dos focos da civilização maia, há uma dezena de séculos (DOLLFUS, 1972:32).

Deste modo, os dinamismos da natureza, ao resgatarem áreas ecologicamente dilapidadas pelos humanos agilizavam um autêntico movimento de "retorno da natureza". Por isso os sítios de "cidades desaparecidas" como Wagadu (Mauritânia), Nínive (Iraque), Palenque (México) ou de majestosos complexos templários como os de Borobudur (Indonésia) e de Angkor-Wat (Camboja), foram retomados respectivamente pela savana, pelo deserto e pela floresta equatorial (Fig. 4). Contrariamente ao vaticínio que hoje assombra a consciência da humanidade, o homem no passado teve oportunidade de usufruir recursos novamente colocados pela natureza à sua disposição.

Embora obviamente não esgotando a complexidade do relacionamento construído pelas sociedades de outrora com o meio natural, os exemplos citados evidenciam que a problemática ambiental das sociedades do passado difere em muito da que enfrentamos nos dias de hoje. Indiscutivelmente, nas sociedades "pré-capitalistas" o quadro posterior ao kaput ambiental constratava totalmente do que está prognosticado pelas seqüelas da ação humana e pelos resíduos gerados pela modernidade. Isto, fundamentalmente em razão dos padrões civilizatórios de antanho assumirem formas próprias de perceber e de se relacionar com o meio natural.

O vasto conjunto de sociedades que terminaram categorizadas como pertencentes ao "mundo tradicional", mesmo se diferenciando entre si, resguardavam relativamente ao meio natural um complexo código de conduta que não admitia sua redução à condição de mero elemento à disposição da vontade humana. Discorreu a respeito Juan Martinez ALIER: 
Até a grande experiência colonial que se inicia algo antes de 1492 e vai até a industrialização maciça da Europa, a relação com o meio ambiente não foi pensada como dominação ou transformação da natureza, senão como intercâmbio com forças naturais freqüentemente sacralizadas em mitos ou cosmologias religiosas (1992:49).

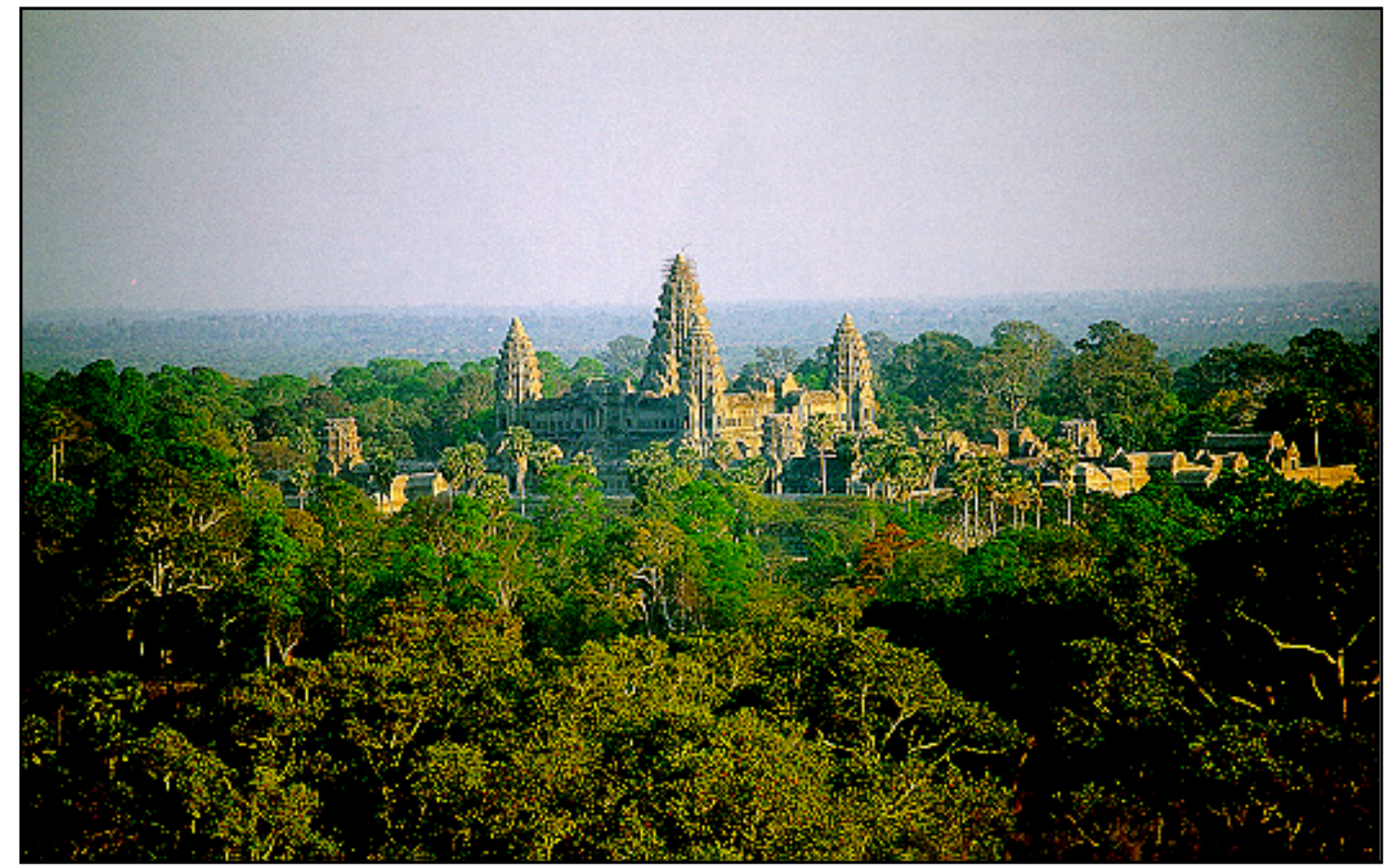

FIGURA 4 - O templo-montanha de Angkor-Wat: envolvido pela floresta equatorial do Camboja, suas torres alteiam-se, no entanto, ao tecido vegetal circundante (Foto Unesco, 2000, <http://whc.unesco.org levents/angkor1.jpg>, acesso em 10-11-2005). 
Exatamente por esta razão que fica fragilizada a argumentação de que os processos de degradação ambiental do passado poderiam ser sinonimizados com os que se verificam no presente. Outra nuança é que a despeito do problema da exploração dos recursos naturais estar objetivamente colocado para a sociedade moderna desde pelo menos o Renascimento, somente nas últimas décadas é que este transpareceu na plenitude das suas implicações, caracterizando o que passou a ser denominado como crise ambiental. Neste sentido, não haveria como deixar de registrar que o mundo ocidental radicalizou uma oposição para com o mundo natural que parece ser, sobremodo, uma das suas características inquestionáveis (Ver GIDDENS, 1991).

Com toda certeza este cenário enraíza-se nas profundas mudanças inauguradas pela modernidade no relacionamento com o meio natural, e isto, de uma forma que não têm precedentes. Diferentemente da pré-modernidade, os desequilíbrios ambientais que caracterizam o mundo atual reportam a um cabedal de ameaças com feições assombrosamente alarmantes, inserindo perigos latentes quaisquer que sejam os ângulos com que se analise essa questão. Tudo isto faz com que a crise do meio ambiente conquiste caráter emergencial, um temário literalmente colocado na ordem do dia. Desta inferência decorre que a palavra "ecologia" tenha conquistado apelo universal exclusivamente a partir do início dos anos setenta (passim ELLIOTT, 1998).

Definitivamente, não existe problemática tão contemporânea, ou em outras palavras, tão filha de nossa época quanto a ambiental. A questão ambiental constitui acima de tudo uma marca registrada do século XX e de nenhum outro. Tendo por pano-de-fundo este cenário é que a palavra ecologia se tornou corrente para o grande público, trafegando por todos os meios sociais. Difundida especialmente pelo movimento ambientalista, a ecologia conquistou os jornais, as revistas, a televisão, o sistema escolar, e os órgãos administrativos e governamentais em todos os níveis (Vide GUIMARÃES, 1991:103). 
Isto aconteceu de um modo tão marcante, que a expressão passou a estar relacionada com os mais diversos aspectos da vida cotidiana. Assim sendo, as pessoas passaram a falar de um estilo de vida ecológico; em uma atuação ecológica; em maneiras ecologicamente corretas de ser e de viver; em defesa da natureza; em produtos verdes; em uma política ambiental e uma série imensa de outros posicionamentos "ecológicos". O conceito de ecologia, que anteriormente habitava apenas o mundo científico e a militância ambientalista, tornou-se inseparável do cabedal de expressões utilizadas cotidianamente pela quase totalidade dos cidadãos.

Uma vez triunfante na consciência da sociedade, dado que a terminologia encontrou aplicação para toda sorte de situações e contextos, ainda assim restaria indagar: decididamente, o que é ecologia? E o conceito com o qual mantém relação de sinonímia, a crise ambiental, do que exatamente se trata? Certamente, pode-se reportar a toda sorte de manuais e alfarrábios para responder esta pergunta. Pode-se igualmente buscar auxílio na profusão de textos que nas quatro últimas décadas se voltaram para discutir esta temática.

Todavia, a proposta aqui, seria avaliar os sentidos prístinos da palavra ecologia. Pelo sim, pelo não, a enxurrada de significados pertinentes aos termos, quaisquer que sejam, constituem uma decantação das mais diversas compreensões, cujo piso conceitual provém da sua inauguração no tempo e no espaço. Deste modo, discutir uma terminologia implica em descortinar posicionamentos, frente aos quais, contrapondo-nos ou não a eles, tais se prontificam enquanto uma rota de compreensão que além de desvendar as diferentes conceituações que se sedimentaram com base na acepção original, permitem resgatar significados que, a despeito de estarem borrados ou esmaecidos pelo tempo, possibilitam aguçar a compreensão do seu significado atual.

Por conseguinte, pode-se iniciar a resposta explorando o significado etimológico da terminologia ecologia, acompanhada da contextualização históricosocial da qual é proveniente. Antes, não haveria como não consignar a importância da etimologia enquanto ferramenta de análise, procedente do fato de 
que os códigos lingüísticos atuam no sentido de normatizar direta ou indiretamente vasto conjunto de padrões cognitivos. Conseqüentemente, estes não podem ser destituídos da condição de indicadores do modo como determinada sociedade conquista sua materialidade (Ver SOUZA, 1991). Como sentenciou em certa ocasião o antropólogo norte-americano Edward HALL, "A própria percepção que o homem tem do mundo em torno de si, é programada pela língua que fala" (1981:13/14).

Certamente a definição clássica de ecologia é por demais conhecida. Formatada no âmbito das ciências naturais pelo biólogo e filósofo alemão Ernst Heinrich Haeckel, o termo aparece pela primeira vez em 1866 numa nota de pé de página do seu Generelle Morphologie der Organismen, em substituição a biologia, cujo alcance foi considerado, na opinião deste pensador, indevidamente restritivo (ACOT, 1990:27). Ecologia é costumeiramente definida como estudo da casa. Não por outra razão senão pelo fato de que de um modo etimologicamente literal, o termo decorre do grego oikos-logos, onde oikos reportaria a vivenda, casa ou aposento e logos, por sua vez, corresponderia a estudo, tratado ou entendimento. Além desta conceituação, teríamos estudo do habitat, muito corriqueira junto aos materiais com perfil biológico.

Vale lembrar que a compreensão do termo ecologia passou a auferir, até por conta do dinamismo semântico que passou a rondá-lo, de sentidos edificados consoante toda sorte de interpelações romanceadas, nas quais a nota predominante são acepções de cunho naturalizante. Em face do entendimento usual de ecologia, fica-se de um modo ou de outro diante de um universo conceitual socialmente amorfo, destituído de contradições. Sua meta suprema seria a perpetuação do "equilíbrio" e da "harmonia", locuções que se prestariam em muitas ocasiões para uma utilização mistificadora - para não dizer ideológica da relação das sociedades com o meio natural. Nesta senda, as determinações sociais que perpassam pela questão ambiental são eliminadas, penalizando também a identificação do caráter contraditório que norteia a relação entre o homem e a natureza (Ver a respeito, MORAES, 2002:53). 
No entanto, seria possível abstrair da definição clássica muitas outras interpretações, até porque a palavra grega oikos sugere uma ordem de enunciados largamente insuspeitos. Observe-se, antes de tudo, que além de "casa" relacionam-se ao termo oikos profícua oferta de entendimentos, dentre estes: oikeiotês: relação, aparentado, amizade; oikeiow: habitar, coabitar, reconciliar-se, estar familiarizado e finalmente oikoumene: terra habitada, mundo conhecido e civilizado. Quanto a esse último significado, originalmente dizendo respeito às terras conhecidas pelo mundo greco-romano, posteriormente agregou o sentido de uma humanidade que se reconhece enquanto unidade, habitando um espaço unificado e convivendo uma mesma historicidade, isto é, uma ampliação do oikos.

Assim, indo diretamente ao ponto, a primeira pontuação a respeito de ecologia, reclamaria avaliar sua fundamentação não só nas raízes gregas da palavra, proveniente do grego oikos-logos, como igualmente sua ambientação histórico-social. Isto porque a recorrente definição estudo da casa, além de não esgotar a problemática ambiental, habilita, mais do que um entendimento real, uma diversidade de entraves para sua intelecção (a este respeito, vide GEORGE, 1997 e BAITELLO JÚNIOR, 2005:52/53).

É válido ressalvar que oikos na descrição de Homero, tal como este nos apresenta o conceito na llíada e na Odisséia e consonantemente com a consciência social do período arcaico grego, corresponderia a uma unidade autosuficiente de produção e consumo, da qual dependia a sobrevivência do grupo, subentendendo uma determinada organização social, política e econômica, substantivada numa determinada porção do espaço (Vide FLORENZANO, 1982:14/23).

Sumamente, o oikos direciona para uma inflexão cultural e histórica. Seu pressuposto é um grupo socialmente organizado, econômicamente credenciado e por fim, politicamente estruturado. Significativamente, o radical indo-europeu weik, do qual oikos é derivado, indica uma unidade social imediatamente superior à residência do chefe de família. Portanto, a terminologia suscitaria uma dimensão biocenótica em geral contida nas acepções modernas do vocábulo. 
Coincidentemente, os biocenóticos hoje de bom grado definem a ecologia como uma "ciência das comunidades" (ACOT, 1990:27).

Nos textos de Homero, o oikos está associado ao comando de um chefe guerreiro, que encabeça a família e amplo rol de agregados. Não era estranho ao oikos o exercício da guerra. O oikos encetava razzias contra as comunidades vizinhas, acompanhadas de saques e de pilhagens, com o que se desfaz qualquer visão idílica relativamente a esta organização social. Em coerência com o que foi colocado, uma primeira pontuação sinalizaria que se todo oikos na Grécia antiga constituía uma casa, nem toda casa necessariamente constituiria um oikos.

Um segundo detalhamento é que oikos, dizendo respeito a produção e consumo, implicaria na impossibilidade de se separar o conceito de ecologia do conceito de economia. Não por acaso, ecologia e economia compartilham sua origem no mesmo termo: oikos. Se ecologia significa estudo da casa, a palavra economia é por sua vez derivada de oikos-nomos, isto é, ordem ou organização da casa. Deste modo, quando se discute a questão ambiental divorciada da questão econômica, comete-se um duplo equívoco. Isto porque tanto uma economia que honre sua origem etimológica deve se assumir enquanto uma economia ecológica, assim como uma ecologia coerente também deve se prontificar enquanto uma ecologia econômica (Ver RAFFESTIN, 1993:24 e passim LEFF, 2004).

Um terceiro aspecto (e nisto, aproximo-me ainda mais do enfoque que desejo discutir), é que o oikos, independentemente da aura de romantismo que perpassa pelo conceito, inseria relações decididamente desiguais no seu interior. Poucos recordam este aspecto, o oikos era regrado pelo trabalho escravo e perpassado por clivagens de poder de todo tipo. Por este motivo, o oikos na Grécia antiga desintegrou-se por conta das acirradas contradições sociais que nasceram e proliferavam em seu interior. Sua desagregação constituiu uma das origens da polis, a cidade-estado grega, uma nova articulação espacial cujo surgimento se justificou prioritariamente por conta dos antagonismos políticos gerados pelo sistema escravista, contradições estas gerenciadas de modo ampliado nas novas aglomerações urbanas. 
Neste sentido, as avaliações preocupadas com os problemas ecológicos não podem dispensar os liames que pavimentam sua conexão com questões de índole cultural, social, políticas e econômicas. Tanto no passado do homem quanto nos dias atuais, a questão ambiental relaciona-se sumamente com um sistema de poder, não podendo ser aquilatada na ausência deste referencial. Inegavelmente, a ecologia é um dado inerente a todas as formas de dominação.

Estivesse este pressuposto descompassado da realidade, as classes dominantes não se empenhariam no controle estratégico das fontes de recursos naturais e energéticos, para que deste modo submeter "os de baixo" à sua dependência. Outrossim, a apropriação da natureza igualmente demarca um domínio ecológico das classes dominadas (Cf GUGLIELMO, 1991:67).

Por conseguinte, oikos não se restringiria de modo algum a aspectos "ecológicos", ponto de partida para várias interpretações ambientalistas. Pelo contrário, fica-se propenso a entender que o que está em discussão é uma temática muito mais ampla do que o "estudo da casa", tal como estaria singelamente sugerido por uma leitura superficial do conceito.

Claro é que uma preocupação tão sugestiva como esta, requereria, visando melhor elucidação, a agregação de outros enunciados e de vários outros parâmetros. Sugestão que acatada, semeia os parágrafos que seguem.

\subsection{TRAdI ÇÃo, QUeStÃo AmBi ental e MOderni dade}

Pensar a respeito de um temário que incorpora a ecologia enquanto um dos seus sustentáculos conceituais suscitaria, por definição, uma avaliação sobre as relações existentes entre modernidade e a questão ambiental. Constituindo uma noção que pressupõe estar a relação entre o homem e o meio natural perpassada

pelas mais diversas contradições, nada mais correto do que se avaliar um momento da história humana no qual estas atingiram as raias do paroxismo. 
Recorde-se que além das proporções alcançadas pela crise do meio ambiente na modernidade, esta guarda especificidades extremamente bem demarcadas no espaço e no tempo, daí a necessidade de se delinear os motes da modernidade frente a este tema. Deixar de levar em consideração este aspecto, além de implicar no comprometimento do nexo que se pretende imprimir a esta tese, acarretaria uma compreensão desestoricizada da questão ambiental, o que não seria de forma a intenção deste trabalho.

Com base nesta preocupação, o primeiro ponto a ser pautado remeteria às radicais distinções que ratificam um contexto cujos pressupostos geográficos, culturais, históricos, sociais, políticos e econômicos são em tudo dessemelhantes dos que vigoraram no antigo mundo tradicional. Neste sentido, recorrendo a um parecer cunhado pelo sociólogo britânico Anthony GIDDENS, a modernidade pode ser definida como uma sociedade promotora de um enquadramento simultaneamente técnico e unificador, via de regra grafada como ocidental, respaldando um conjunto de modos de vida que teriam desvencilhado a humanidade de todos os tipos tradicionais de ordem social, e isto, de uma maneira que não têm precedentes (passim, 1991).

Ao mundo ocidental caberia, em função das prerrogativas que endossou, a transposição das suas perspectivas civilizatórias para o conjunto do Planeta, inaugurando uma Gessellschaft construída a seu gosto e colocada sob seu comando. Saliente-se que não seria fortuita a opção por este termo. No pensamento alemão, Gesellschaft (sociedade) está em oposição a Gemeinschaft (comunidade), uma antinomia que no memorável parecer do cientista social novicentista Ferdinand Tönies transpareceria como a seguir reproduzido:

...Gemeinschaft representava o passado, a aldeia, a família, o calor. Tinha motivação afetiva, era orgânica, lidava com relações locais e com interação. As normas e o controle davam-se através da união, do hábito, do costume e da religião. Seu círculo abrangia família, aldeia e cidade. Já Gesellschaft era a frieza, o egoísmo, fruto da calculista modernidade. Sua motivação era objetiva, era mecânica, observava relações supralocais e complexas. As normas e o controle davam-se através de convenção, lei e opinião pública. Seu círculo abrangia metrópole, nação, Estado e Mundo (RECUERO, 2001). 
Nesta perspectiva, o mundo tradicional estaria inteiramente apartado da turbulenta, agitada e frenética sociedade ocidental. $E$ de fato, procede em muito a constatação da existência de um dinamismo "mais lento" para as sociedades tradicionais, justificado pela presença de desígnios sociais que tipificam modos de vida e de percepção da realidade sem qualquer relação com os que triunfaram no ocidente. Afirmação que dificilmente encontraria opositores, o homem imerso na esfera da tradição era regido por um dinamismo social no qual a exigência de ordem ou de conformidade prevalecia sobre a exigência de mudança (BALANDIER, 1976a:235).

Estas sociedades, consideradas "frias" ao gosto de uma definição elaborada pelo antropólogo francês Claude LÉVI-STRAUSS (1970), contextualizariam, pois, modos de vida nos quais embora não se pudesse encontrar a noção de um "equilíbrio absoluto", nelas a história se "aquecia" unicamente em lapsos mais prolongados de tempo. O mundo da tradição seria, portanto, radicalmente distinto das "sociedades quentes", no caso, as pertencentes ao mundo ocidental. Evidentemente, uma argumentação implícita neste raciocínio subentende o mundo inaugurado pela modernidade enquanto um "divisor de águas" dos processos sociais colocados à prova pela humanidade. Demarcando dois universos inteiramente opostos entre si, o moderno terminaria nesta acepção por se especificar enquanto um marco que dispensaria à tradição tudo o que está em desajuste com seus predicados, pressupostos e interesses (Cf GIDDENS, 1991:14 et seq).

No que tange ao cerne dessa discussão, outro desdobramento deste recorte distinguindo modernidade e tradição enquanto dois pólos distintos, evidencia-se quando se depara com a avaliação dos modelos adotados pela humanidade na relação com o meio natural. Analisando as diferentes modalidades resultantes da determinada predisposição do homem em territorializar o meio natural, pode-se discernir junto ao mundo moderno dinâmicas opostas às que imperaram nas sociedades tradicionais, inferência esta passível de ser identificada tanto na concretude quanto no imaginário do mundo ocidental. 
Obviamente, retomando uma sugestão comentada parágrafos antes, seria cabível recordar que o mundo tradicional, não obstante seus vínculos notórios com o meio natural, nunca esteve facultado a esposar a aura de uma "idade de ouro perdida". Tal visão se ajustaria à postura de avaliar as sociedades tradicionais como estáveis, isentas de contradições ou de conflitos, e por extensão, não propensas a mudanças e transformações. Este horizonte idealizado poderia filiarse a um modelo de interpretação de sociedade calcado no funcionalismo, formatando uma perspectiva marcada pela compreensão naturalista e harmônica de sociedade, sendo sua pedra de toque o conceito de totalidade social e cultural integrada.

Contrariando visões inspiradas neste arrazoado, hoje em dia já se admite que populações "primitivas" como os caçadores-coletores, engendraram profundas transformações ambientais, afetando os ecossistemas dos mais diversos modos. Por exemplo, parece certo que amplas extensões de paisagens consideradas "naturais" resultaram da caça pelo fogo. Entre outros casos, tal prática explicaria a origem das vastas porções das savanas africanas e dos cerrados sul-americanos com precisão muito maior do que as influências edáficas ou de ordem climática (Ver RIZZINI, 1979:102 e também COUTINHO, 1977). Além disso, as mudanças provocadas pelo homem neste cenário natural, assim como em muitos outros, teriam o privilégio da senioridade. Ainda quanto aos espaços savaneiros, o geógrafo britânico David H. HARRIS lembra que "a ocupação do meio ambiente da savana, na África e na Ásia, remonta ao aparecimento do gênero Homo, há mais de um milhão de anos atrás" (1982:181).

As migrações humanas deixaram atrás de si um rastro de destruição e mudanças ambientais, diretamente relacionadas com a implantação de novos assentamentos. Na ilha de Malta, no Mediterrâneo, o elefante-anão, autêntica relíquia zoológica, foi liquidado logo nas primeiras vagas de ocupação humana. $\mathrm{Na}$ Nova Zelândia, os maoris extinguiram o moa, uma magnífica ave da Oceania, muito antes dos europeus. Durante o Paleolítico, a presença humana na América do Norte havia eliminado por volta de 10.000 a.C. 
...grandes animais como o mamute, o cavalo, o camelo, a preguiça gigante, o tigre de dentes de sabre, e leões e cães selvagens, além de muitas aves, que foram totalmente dizimados e extintos do continente americano (PASCHOAL, 1978:7).

Nenhum espaço permaneceu incólume com a aparição dos humanos. Foi o que ocorreu em Madagascar, a grande ilha africana ocupada pelas vagas de malaios apenas em tempos históricos. Destino semelhante acometeu a Ilha Maurício e as Kerguelen, situadas no Índico, abordadas pelos navegantes europeus durante o processo da expansão marítima e comercial, assim como as ilhas Orkneys, Shetlands e Faröe, arquipélagos alcançados pela expansão viking ${ }^{9}$ a partir da Escandinávia (DIAMOND, 2005:219/258). No povoamento do continente americano, os homens e mulheres que cruzaram o estreito de Bering 14.000 anos atrás vindos da Ásia ${ }^{10}$, foram cúmplices da extinção de grande quantidade de exemplares da fauna em seu trajeto rumo ao sul (TAKS e FOLADORI, 2002).

A adoção da agricultura, ao promover o surgimento de campos de cultivo, que sumamente constituem "ecossistemas simplificados", derivou em alterações mais drásticas ainda. O chamado Fértil Crescente (o Vale do Nilo, da Mesopotâmia e áreas circunvizinhas), um dos berços da agricultura, "foi outrora vegetado com florestas de cedro e savanas ricas de fauna e flores" (PASCHOAL, 1978:07). No caso do Egito Faraônico, uma ação humana bem documentada permite avaliar a magnitude da transformação da paisagem pelos agricultores antigos (VERCOUTTER, 1974:17). Na calha do rio Nilo, a planície atual estendese sobre o que foi outrora um terreno desértico. Desapareceram densas concentrações de palmares, quase verdadeiras florestas de palmeiras. Além do recuo do deserto, os pântanos, juntamente com sua fauna e flora, foram

\footnotetext{
${ }^{9}$ Os vikings não constituíam uma etnia, mas sim um conjunto de povos germânicos estabelecidos na Europa setentrional. O termo parece derivar do germânico antigo vikingar: saqueadores.

${ }^{10} \mathrm{O}$ início do povoamento da América tem sido reavaliado mediante a descoberta de novos jazigos arqueológicos. Se contada exclusivamente pelos registros fósseis da chamada 'paleontologia física', o Homo sapiens teria povoado o continente por volta de 14 mil anos atrás. Mas pela antropologia molecular, baseada no estudo do DNA de populações modernas, a data recua alguns milhares de anos. Evidências genéticas apontam para uma colonização superior a 14 mil anos, segundo estudos apresentados no $51^{\circ}$ Congresso Brasileiro de Genética (Manchetes Socioambientais, edição de 12-09-2005).
} 
praticamente extintos. Antigamente, no limiar dos aluviões anuais, "os confins do deserto eram charcos cobertos de grandes juncos ondulantes, povoados por milhares de espécies de aves e por numerosa fauna de pequenos carnívoros" (SAUNERON, 1970:51).

Estas alterações não se restringiram unicamente à paisagem, refletindo também em importantes modificações hidrológicas, climáticas e da fauna, muitas vezes de modo irreversível. A atividade dos agricultores tradicionais, ao implicar na seleção empírica do germoplasma, foi origem dos modernos exemplares de plantas como o milho, arroz, feijão, batata, batata doce, mandioca, trigo, cevada, centeio, inhame, amendoim e sorgo. Estas espécies, fruto do labor humano, terminaram "naturalizadas" no transcorrer da história e percebidas como provenientes do meio natural.

O mesmo ocorreu quanto à domesticação dos animais, em vários casos introduzidos pelo homem em ambientes que Ihes eram originalmente estranhos. Os esforços estiveram concentrados na seleção de um pequeno número de animais, que foram a seguir privilegiados como elementos de base pelas economias antigas. Estes seriam, de acordo com o geógrafo Roland BRETON: a cabra e o carneiro no Crescente Fértil, o asno no Egito, o boi e o pato no sul da Europa, o boi zebu e talvez a galinha e o porco na Índia, o búfalo aquático no Sudeste Asiático, o iaque no Tibet, o camelo da Tartária na Ásia Central, o dromedário nos desertos da Arábia, o cavalo nas estepes da Eurásia, a rena na Tundra, o peru na América do Norte e finalmente, a cobaia, a Ihama e a alpaca na América do Sul (1990:47).

Os efeitos ecológicos das atividades humanas desenvolvidas no mundo tradicional, grande maioria das quais não-premeditados, chamou a atenção de diversos estudiosos, que registraram as seqüelas deixadas pelas sociedades prémodernas. Eis como o olhar de Friedrich ENGELS captou este acontecimento:

Os homens que na Mesopotâmia, na Grécia, na Ásia Menor e noutras partes destruíram os bosques para obter terra arável, não podiam imaginar que dessa forma, estavam dando origem à atual desolação dessas terras ao despojá-las de seus bosques, isto é, dos centros de captação e acumulação de umidade. Os italianos dos Alpes, quando devastaram, na 
sua vertente Sul, os bosques de pinheiros, tão cuidadosamente conservados na vertente Norte, nem sequer suspeitavam que, dessa maneira, estavam arrancando, em seu território, as raízes da economia das granjas leiteiras; e menos ainda suspeitavam que assim estavam eliminando a água das vertentes da montanha, durante a maior parte do ano e que, na época das chuvas, seriam derramadas furiosas torrentes sobre as planícies (1979:224).

Em decorrência, poder-se-ia rascunhar um ponderável elenco de alterações promovidas pelo homem tradicional a partir de atividades consideradas "ambientalmente brandas", implicando na eliminação ou rarefação de centenas de espécies. Houve uma época em que os uros ${ }^{11}$ eram vistos pelas florestas da Gália e da Bélgica; em que manadas de camelos atravessavam o vale do Mississipi; em que os leões se aqueciam ao Sol da Macedônia, Numídia, Pérsia, da Lacedemônia e do Bokhara; em que os rinocerontes e os crocodilos se refestelavam no delta do rio Nilo; em que os lobos caçavam nos campos da Nortúmbia, do Danelaw e da Cornualha; em que os mares nórdicos pululavam de leões marinhos; em que os rinocerontes chafurdavam nos rios da Borgonha. Afinal, onde foram parar estes admiráveis espécimes da fauna terrestre?

Assim, as sociedades não-ocidentais imprimiram sua marca no meio natural e isto, de forma não necessariamente superficial. No que importa ao núcleo dessa discussão, o imaginário de um "paraíso ecológico", mantendo estreita relação com o simbolismo da "idade de ouro", cultuando sociedades supostamente caracterizadas por um entrosamento absoluto com o meio ambiente, constituiria simplesmente uma peça de ficção. Como recorda Juan Martinez ALIER, nenhuma civilização foi ecologicamente inocente (1992:49).

Entretanto, outro é o parecer que povoa o imaginário social. Tais saudosos "Jardins do Éden", tragados pela expansão do mundo ocidental, revestir-se-iam de expectativas e de valores a serem resgatados de um tempo simultaneamente idílico e nostálgico. No limite, estas sedutoras imagens pressupõem que do passado poderia advir a solução para as angústias do presente. Porém, entenda-

\footnotetext{
${ }^{11}$ Os uros são relatados por várias fontes romanas e em algumas narrativas celtas. Elas se referem a um tipo de bovídeo gigantesco, que vivia profusamente na Europa Ocidental ainda nos tempos de Júlio César. As imagens mais conhecidas dos uros estão retratadas no complexo de Lascaux, França.
} 
se que uma coisa seria sustentar a inexistência de contradições entre o homem e a natureza nas sociedades de outrora; uma outra, entender que o mundo tradicional comprometia em menor escala os recursos naturais; e uma outra coisa ainda, entender como possível transpor este modelo para o mundo atual. De qualquer modo, reservo-me a sumarizar que independentemente das suas implicações, estas três posturas não deixam de frisar que objetivamente o objeto de discussão é a crise ambiental da modernidade, e não do mundo tradicional.

Nesta seqüência, é a discussão da relação mantida pela modernidade com o meio natural que se reveste de caráter central. É exclusivamente da compreensão deste locus espacial e temporal que se torna possível compreender a eclosão da crise ambiental no seu sentido mais pungente e por conseqüência, as alternativas de enfrentamento do problema e a possibilidade da humanidade manter uma relação minimamente equilibrada com o meio ambiente. Por isso mesmo, ao constituir um desafio novo, seria descabido entender o tradicional enquanto modelo capacitado a solucionar o que não é tradicional, mesmo porque a crise ambiental, tal como hoje é compreendida, não estava colocada neste cenário. Concretamente, o fato é que uma sociedade ecológica está por ser instaurada, e não restaurada.

Nesta ótica, pode-se identificar vários epifenômenos pertinentes à modernidade, que atuaram de modo a internamente ordenar a sociedade e externamente, a impor da sua vontade a outros povos e regiões, desdobrando-se em comprometimentos ambientais de todo tipo. É neste sentido que se torna possível, com base em diversas avaliações disponíveis para consultas, juntamente com comentários oriundos de diversas outras fontes (Vide entre outros VESENTINI, 1989:20 e CAPRA, 1991), enumerar alguns imperativos pertinentes ao surgimento do mundo moderno e à sua consolidação enquanto uma altissonante weltanschaung. Estes seriam:

1. O Estado como organização política por excelência; Constituindo um pressuposto para qualquer sociedade civilizada, evidentemente o aparelho de Estado é aquele concebido a partir das condições históricas do mundo ocidental, 
sendo as demais formações estatais desqualificadas enquanto formas aceitáveis de organização e de exercício do poder. Nesta perspectiva, os chamados "Estados Despóticos do Oriente", categoria que englobaria amplo leque de formações estatais extra-européias, estariam, como na célebre avaliação de Montesquieu presente no O Espírito das Leis, caracterizados pela ausência de regras e do senso de justiça. No aguçado juízo de Roger BARTRA, estes seriam administrados por soberanos governando segundo sua vontade e seus caprichos, cujo poder, estaria respaldado pela escravidão generalizada do reino (1978:11/42).

2. Noção de trabalho exaustivo e produtivo; Significaria, no caso, o trabalho voltado para a produção de mercadorias, dentro da lógica de acumulação do capital. Nesta lógica, apenas um tipo de trabalho, o voltado para a produção de valores de troca, seria considerado válido e produtivo. Desta noção decorreu, por exemplo, a idéia de que as populações tradicionais seriam preguiçosas e que a organização econômica "pré-capitalista" seria arcaica e atrasada, dentre outros motivos, evidentemente por sua resoluta oposição pelo acúmulo de bens e revolucionamento das relações de produção.

Esta revolução na ótica pela qual a esfera do econômico passou a ser exercitada embalou toda sorte de pontuações referentes aos novos tempos inaugurados pela economia de mercado. Nesta linha de argumentação, a diferença entre o mundo moderno e tradicional teria numa radical alteração das perspectivas existenciais dos humanos uma das suas notas mais marcantes. A economia, partindo de sistemas preocupados com uma talvez singela e prosaica satisfação limitada, atendendo desejos e expectativas de comunidades fechadas e autárquicas, passou, desde então, a empenhar-se na construção de um estado de insatisfação ilimitada, ampliado incessantemente de modo a abarcar o conjunto do Planeta.

Comparando as economias antigas com seu novel contraponto moderno, assim julgou o pensador Karl MARX: 
A antiga concepção segundo a qual o homem sempre aparece (por mais estreitamente religiosa, nacional ou política que seja a apreciação) como o objetivo da produção, parece muito mais elevada do que a do mundo moderno, na qual a produção é o objetivo do homem, e a riqueza, o objetivo da produção (...). Por isto, de certo modo, o mundo aparentemente infantil dos antigos mostra-se superior: e é assim, pois, na medida em que buscarmos contornos fechados, forma e limitação estabelecida. Os antigos proporcionavam satisfação limitada, enquanto o mundo moderno deixa-nos insatisfeitos ou, quando parece satisfeito consigo mesmo, é vulgar e mesquinho (1975a:80/81).

É com base nesta transformação que o mundo tangível dos humanos tornase, antes de uma fonte de abundância, em um manancial de escassez. Nada doravante será como antes, pois a escala da insatisfação, contrariamente à da satisfação, se estende na escala do infinito.

3. A ciência vista como um conhecimento voltado para o domínio e o controle da natureza; Tal conceituação ganha crescente influência paralelamente à importância cada vez maior da economia de mercado. Seus pressupostos destacam o homem - e apenas o gênero homem - como um ser predestinado ao domínio de todos os demais seres vivos e o conjunto do meio natural. Reflete uma negação e/ou desqualificação da natureza que ganhou corpo nos séculos XVI e XVII com os novos métodos empíricos de investigação desenvolvidos no interior da chamada revolução mecanicista, que revolucionou a concepção até então em vigor no referente à relação com o meio natural.

A partir da revolução mecanicista, a ciência passa a alinhavar uma nova inteligibilidade, baseada no desenvolvimento da física, das experiências laboratoriais e numa verdadeira matematização do olhar. Nesta nova perspectiva, o objetivo do cientista é a descrição racional de todos os fenômenos naturais de acordo com leis matematizáveis, um quadro analítico que se tornou o paradigma dominante do conhecimento científico, influenciando todos os ramos da chamada ciência moderna (Ver CARVALHO, 1991:46/47).

Dado inseparável desta ótica é que a investigação científica, tendo por meta finalidades predominantemente utilitárias, é reinventada de modo a distinguir-se radicalmente da postura que caracterizou as culturas antigas frente à natureza. 
Por isso mesmo, respaldando ansiedades desde logo manifestadas pela nascente civilização ocidental relativamente ao relacionamento com o ambiente natural, o filósofo Francis Bacon defendeu este novo método de investigação em termos que seriam não só apaixonados, mas com freqüência, francamente rancorosos. A natureza, na sua opinião,

...tinha que ser acossada em seus descaminhos, obrigada a servir e escravizada. Devia ser reduzida à obediência e o objetivo do cientista seria extrair da natureza, sob tortura, todos os seus segredos (CAPRA, 1991:51/52).

Definitivamente, com a modernidade a natureza deixou de ser um modelo para tornar-se alvo de uma conquista, uma atitude que redundaria nas mais drásticas conseqüências.

4. Concepção de natureza como um mero recurso voltado para manter e expandir incessantemente o progresso e o desenvolvimento econômico; Nesta acepção, está implícita uma leitura ocidental do antropocentrismo, sugerindo não uma interlocução, mas sim a submissão da natureza a um homem concretamente identificado com os proprietários dos meios de produção, com os cidadãos ou mais exatamente, com a nova classe burguesa. Por conseguinte, não seria demasiado ressalvar a forte presença de um ideário patriarcal, valorizando-se implicitamente o gênero masculino comparativamente ao feminino, tanto em nível do imaginário quanto no da concretude social.

llustrando esta linha de pensamento, pode-se novamente recorrer ao pensamento de Francis Bacon. As imagens violentas utilizadas por este pensador inglês quanto ao relacionamento a ser mantido com a natureza provavelmente foram inspiradas nos julgamentos das bruxas, tal como eram freqüentemente realizados na sua época. A influência exercida por esta atmosfera persecutória na linha de investigação elaborada por este filósofo teria sido cabal. Dentre outros fatores, Francis Bacon estaria 
...intimamente familiarizado com tais denúncias e libelos e, como a natureza era comumente vista como fêmea, não deve causar surpresa o fato dele transferir as metáforas usadas no tribunal para os seus escritos científicos. De fato, sua idéia da natureza como uma mulher cujos segredos têm que ser arrancados mediante tortura, com a ajuda de instrumentos mecânicos, sugere fortemente a tortura generalizada de mulheres nos julgamentos de bruxas do começo do século XVII. A obra de Bacon representa, pois, notável exemplo da influência das atitudes patriarcais sobre o pensamento científico (CAPRA, 1991:52).

Essa visão antropocêntrica, triunfante na Inglaterra do século XVIII, subentendia que a autoridade humana sobre o mundo natural era soberanamente ilimitada. O filósofo francês René Descartes conceituou esta separação entre o homem e a natureza de modo extremo, pregando que os animais não seriam dotados de alma e que Deus seria totalmente transcendente, externo à criação (Cf DIEGUES, 1994:36/37). No seu pensamento, o homem, manifestação única da racionalidade, deteria prevalescência inconteste sobre todos os seres vivos, abrindo caminho, por exemplo, para que fossem abandonados quaisquer pruridos no tratamento dispensado aos animais.

$\mathrm{Na}$ esteira desse arcabouço conceitual, deixando de encontrar amparo junto aos sistemas morais e religiosos, a natureza perdia inexoravelmente sua grandeza. Na aurora e na juventude da humanidade, o mundo animal fora visto como seu parceiro a toda prova. Recorde-se que a própria palavra animal originase de anima, significando alma em latim, sentido que obviamente se enraíza num antigo entendimento tradicional dos viventes não-humanos. Todavia, tudo isto deixa de ter qualquer sentido diante do antropocentrismo ocidental, para o qual a esfera do natural cede, de um modo como jamais ocorrera no passado, suas prerrogativas para beneplácitos meramente utilitaristas.

5. Eclosão, no plano do imaginário, da aspiração de um domínio simbólico da história, transformando o progresso e o mercado enquanto fatores eternos, imutáveis e vistos inclusive como indissociáveis da "natureza humana"; Subjacente e simultaneamente à consolidação do capitalismo, verificou-se, no interior do pensamento ocidental, uma tendência em compreender a economia de 
mercado como referência máxima de compreensão da realidade, inseparável do próprio conceito de humanidade.

Assim, a economia de mercado atuaria como linha divisória na diferenciação do homem das demais espécies, cuja índole, incorporaria uma tendência natural inata para negociar, de trocar uma coisa por outra. Tal "impulso trocativo", entendido como uma característica-chave para explicar a evolução da humanidade, seria, no entendimento de Adam Smith pai da economia liberal, próprio exclusivamente da humanidade. Eis como este economista ilustrou este raciocínio no seu clássico $A$ Riqueza das Nações:

Ninguém nunca viu dois cães procederem a uma troca eqüitativa e deliberada de ossos, nunca se viu um animal tentando dizer a outro, através de gestos e gritos naturais, que uma coisa é ou não sua, ou que pretende trocar uma coisa pela outra (SMITH, 1979:13).

Tais imperativos fundamentaram uma desqualificação universal das sociedades não européias. A economia de mercado e os seus valores constituíram máximos parâmetros para o julgamento das demais formações sociais, independentemente do fato dessas não postularem o mercado como referência para sua organização social, política, econômica. Largamente utilizados para alicerçar a dominação européia sobre os demais povos, estes conceitos conquistaram obviedade no pensamento europeu, tornando-se inseparáveis da idiossincrasia ocidental, perpassando, em termos do imaginário do outro, como um dado óbvio.

Por conseguinte, aos "atrasados", percebidos como vegetando em meio a uma desavergonhada estupidez, foi-Ihes granjeada toda sorte de estigmas e sinais denunciadores de sua abjeta condição de inferioridade:

...não acreditando em Deus, não tendo alma, não tendo acesso à linguagem, sendo assustadoramente feio e alimentando-se como um animal, o selvagem é apreendido nos modos de um bestiário. E esse discurso da alteridade, que recorre constantemente à metáfora zoológica, abre o grande leque de ausências: sem moral, sem religião, sem lei, sem escrita, sem Estado, sem consciência, sem razão, sem objetivo, sem arte, sem passado, sem futuro (LAPLANTINE, 1988:41). 
Para piorar, a estes malfadados primitivos estava reservado o supremo pecado de serem economicamente subalternos. As populações que viviam sob regimes sociais estranhos à economia de mercado, julgamento que recai de modo particularmente duro sobre os "primitivos", estariam prisioneiras da carência, da adversidade, do domínio da brutalidade das forças da natureza e das suas intempéries, uma situação infeliz da qual certamente seriam resgatados pelo congraçamento com o triunfo do novo estilo de vida, impregnado pelos ideais de progresso e de desenvolvimento. Evidentemente, a resistência destas populações em adotar os novos modelos impostos pelos europeus foi codificada intempestivamente como uma manifestação de contrariedade ao progresso e à civilização, e deste modo, sujeita a sansões e outras medidas corretivas.

O atrasado seria, portanto, inapelavelmente um "inferior", alguém que não se ajusta ou optou por não se ajustar ao que é considerado avançado. Dele, simplesmente nada seria possível esperar. Na nova linha do tempo elaborada com base num sentido progressivo da história, é postulada uma seqüência na qual os primitivos (do latim primi, ou seja "primeiros"), os aborígines (isto é "originários"), silvícolas ("habitantes da selva"), ou então os naturvölker ${ }^{12}$ (ao pé da letra, "povos da natureza"), são deslocados para um remoto princípio da história, uma noite dos tempos habitada por todos aqueles que não foram agraciados pela reelaboração do tempo-espaço promovida pela Europa. É neste sentido que o outro, no Ocidente, mais que um espaço diverso, habita uma época diferente.

Destes paradigmas poucos atores do mundo ocidental conseguiram desvencilhar-se. Cumpre ressaltar que estes parâmetros, ao tipificarem o pensamento ocidental, relacionam-se não só com os expoentes diretamente relacionados com a reprodução histórica deste padrão civilizatório, vale dizer, com a classe proprietária dos meios de produção, quanto também poderiam ser estendidos para linhas de pensamento que se posicionaram a partir de um ponto de vista em tese crítico ou antagônico a ele. Dentre estas linhas, as que fundamentam muitos primados marxistas mereceriam menção obrigatória. Vale

\footnotetext{
12 Expressão cunhada pela etnologia alemã, não se confunde com Urmensch, homem primitivo. Atente-se que para geógrafos como Friedrich RATZEL, a denominação naturvölk não indicava povos vivendo relação íntima com a natureza, mas antes, sob o império desta (1990:72).
} 
lembrar, o fato de os genitores do materialismo histórico terem desenvolvido uma poderosa teorização crítica do capitalismo, não pode subentender uma ruptura completa com a visão de ambos sobre o mundo extra-europeu, e muito menos a respeito das matrizes civilizatórias das quais eram provenientes.

Não por outra razão, senão pelo fato de que tanto Karl Marx quanto Friedrich Engels não estavam, e nem sequer poderiam deixar de estar, alheios às concepções da sua época e do seu mundo. Foi em função de uma atmosfera desenvolvimentista, reforçada pensamento iluminista do século XVIII e empapada pela ideologia do progresso, que Karl Marx e Friedrich Engels foram categóricos, por exemplo, na defesa de uma necessidade histórica de um máximo desenvolvimento das forças produtivas, desenvolvimento este, visto como uma alavanca para um progresso da história. Certamente contagiados pelo autêntico triunfalismo que caracterizou a expansão do industrialismo, elementos economicistas, produtivistas e eurocêntricos não deixaram de impregnar a produção teórica e as avaliações de Marx e Engels.

Detalhando melhor, pode-se destacar a soberba predisposição dessa vertente filosófica em considerar o avanço das forças produtivas como epítome da transformação do meio ambiente pela ação triunfante do homem, corporificando desse modo sua marca no meio natural ${ }^{13}$. Promovida pelo capitalismo, tal tendência auguraria uma festejada "vitória sobre as forças da natureza". Na esteira dessa, teríamos, fazendo jus ao desfecho inevitável do "progresso da história", a instauração final da esperada sociedade socialista (VESENTINI, 1989:48/50, MORIN e KERN, 2003:79, COLLINSON, 2004:190/196).

Subliminarmente aos conceitos de "progresso" e de "desenvolvimento das forças produtivas", basilares na lógica marxista, se instala a categorização como "atrasado" de tudo que seria considerado incompatível com as exigências estruturais da modernidade. Daí que Marx e Engels, mesmo esboçando modelos preocupados com as especificidades das formações sociais "pré-capitalistas",

\footnotetext{
${ }^{13}$ Lembre-se que a adoção do conceito de Produtvekraefte (forças produtivas), em oposição a Produtiveenergien, (energias produtivas), um dos debates apócrifos da parceria Marx-Engels, teve enormes repercussões para o marxismo, impedindo, por exemplo, o avanço na direção de uma visão "histórico-energética", que poderia ter se estabelecido antes ou por si mesma (ALIER, 1992:48, Ver também Karl WITTFOGEL, 1992).
} 
jamais tenham deixado de homenagear o ocidente como parâmetro do desenvolvimento geral da humanidade, uma meta obrigatoriamente pavimentada por uma visão unitária do devir histórico. Assim, ao desqualificarem o mundo nãoocidental, coerentemente se posicionaram favoravelmente à dominação colonialista, entendida como "suporte da civilização" (Ver BALANDIER, 1969:12/13 e SOFRI, 1977:30).

Dentre diversas exemplificações disponíveis, é possível recorrer às que seguem, reveladoras da índole com que o marxismo avaliava o mundo "précapitalista". Karl MARX, no seu comentário sobre a dominação britânica na Índia avaliava que esta teria dois papéis a desempenhar naquele país: um "primeiramente destrutivo", através do aniquilamento da velha sociedade asiática, e um outro posterior, de "caráter regenerador", através do lançamento dos fundamentos materiais da sociedade ocidental na Ásia (1976:27, grifo nosso). Marx também demonstrava grande indisposição para com a religião indiana, em face dos seus adeptos desenvolverem "um degradante culto à natureza, prostrando-se aos pés de Hanuman, a macaca, e de Sabala, a vaca" (idem, 1976:25).

Deve ser reconhecido que Marx e Engels, assim como Émile Durkheim e outros mestres fundadores das ciências sociais (com a notável exceção de Max Weber) observavam a era moderna como uma época turbulenta, permeada por contradições e prenhe de quimeras de todo o tipo. Porém, acreditavam que nesse período da história - e muito mais do que em qualquer outro - residiriam possibilidades benéficas, trazendo em seu bojo uma sociedade de tipo novo, capacitada a dar conta das vicissitudes colocadas pela própria modernidade e superando suas seqüelas negativas. O marxismo entendia a luta de classes como uma fonte de dissidências fundamentais na ordem capitalista. Entretanto, simultaneamente vislumbrava a partir dele a emergência de um sistema social mais humano (Cf GIDDENS, 1991:17).

A linha clássica de argumentação do materialismo histórico, exaltando a fé no progresso e no desenvolvimento das forças produtivas, termina basicamente por identificar como o grande e quase único problema a questão da apropriação 
privada e da irracionalidade burguesa na condução do mecanismo da economia. Deste modo, Marx e Engels, jamais questionam o paradigma central, ou seja, a crença no progresso e no desenvolvimento incessante. No interior do pensamento marxista, como no da ordem imaginária moderna, a produção de riquezas não possui limites.

Deste modo, a própria crítica elaborada por Karl Marx ao capitalismo,

...não é uma crítica ao desenvolvimento das forças produtivas. Marx é estritamente falando, um clássico da modernidade, tal como Adam Smith, David Ricardo e Stuart Mill, para assinalar alguns poucos dos que seriam conhecidos como economistas (GONÇALVES, 2001:34).

Assim sendo, a racionalidade científica que estaria caracterizando a futura sociedade socialista, viria obviamente prosseguir com esse progresso, sem os nefastos desequilíbrios próprios da produção capitalista, derivados da anarquia de mercado e da ausência de planejamento (VESENTINI, 1989:49).

Por conseguinte, é bastante significativo o repertório dos que hoje esposam o ponto de vista pelo qual o socialismo, tal como foi efetivamente aplicado em muitos países, teve basicamente os mesmos propósitos que o capitalismo em relação ao meio natural, dispondo, para se assegurar de uma "vitória" sobre as forças da natureza, de concepções e de um aparato técnico e científico pelo mínimo a ele assemelhado. O fato é que se está diante de dois sistemas que se explicitaram, de modo exemplar, enquanto sociedades consagradas ao trabalho, sociedades tributárias do econômico, voltadas para a produção, entendendo o espaço público como uma esfera de interesse do governo e do Estado, assentadas com base no primado do racional, ou no que interessaria mais diretamente, na oposição ao natural (Ver a respeito DIÓGENES, 1992).

É neste sentido que a questão ambiental suscita um debate que se coloca qualitativamente adiante da mera discussão referente a "sistemas econômicos". $\mathrm{Na}$ realidade, o ponto nodal desta discussão é a crítica dirigida a um padrão civilizatório, cujas duas ramificações seriam justamente o capitalismo e o socialismo. Por esta razão, trabalhar com uma visão desmistificadora dos seus 
enunciados, demanda não só o estudo dos seus epifenômenos, mas principalmente dos primados mais abrangentes que lhes garantiram sustentação.

É justamente por intermédio desta via que a questão da ordenação social do tempo e da organização do espaço tornam-se relevantes a toda prova, esclarecendo o conteúdo de novidade que o mundo moderno historicamente inaugura, inclusive na comparação com a sociedade medieval européia que o precedeu.

\subsection{A I MPERI OSI DADE DA DISCUSSÃO DO TEMPO}

Até o presente momento, a análise sumarizou as implicações dos relacionamentos mantidos pelas sociedades tradicional e moderna no que tange ao meio natural. Contudo, sublinhar a descontinuidade demarcada pela modernidade requer abordar, daqui por diante, as mudanças que o mundo contemporâneo instaurou no relacionamento mantido com a natureza assim como a forma estabelecida para apreendê-la.

A este respeito o termo "ecologia" está impregnado - como já foi visto - de modernidade. Em conformidade com esta linha de interpretação, em nada as crises ambientais de outrora poderiam justificar qualquer identidade com o que se observa no mundo atual. Uma coisa é entender que o homem do passado não dispunha da "sensibilidade ambiental" muitas vezes apaixonadamente apregoada

pelo imaginário ecologista. Outra coisa completamente diferente é com isso pretender igualá-lo ao mundo ocidental.

Nada mais falso e improcedente. Hoje, destrói-se o ambiente natural numa escala e velocidade nunca vistas anteriormente e, para completar, numa ferocidade jamais registrada nas sociedades do passado. A este respeito, um incisivo relatório divulgado pela ONG Worl Wildlife Fundation (WWF) em Outubro de 2004 informa: 
A cada 13 minutos uma espécie de animal desaparece no mundo. As populações de animais terrestres, de água doce e marinha tiveram uma redução de $40 \%$ no período de 1970 a 2000. A redução da fauna é causada, de acordo com o relatório Planeta Vivo 2004, pela crescente demanda por alimentos, fibras, energia e água, assim como pelos métodos não sustentáveis de produção. O relatório mediu também a taxa de uso dos recursos naturais do Planeta. A conclusão foi que a população mundial consome cerca de $20 \%$ a mais de recursos do que a Terra é capaz de repor. Desde 1961 a pressão humana sobre fontes de recursos naturais aumentou, em média, 160\% (citado in Manchetes Socioambientais, edição de 22-10-2004).

Conseqüentemente, um quadro dantesco de desequilíbrios ambientais assedia o homem contemporâneo. Trata-se de problemas que por sua intratabilidade são repassados, na premeditada busca de um "estado de desatenção civil", para um temerário segundo plano (GIDDENS, 1991:130). O mundo moderno observa-se diante de um sentimento de angústia, prisioneiro das ansiedades engendradas pelo próprio modelo civilizatório que propõe. Deve-se a Sigmund Freud a célebre sentença mal-estar da cultura, título do conhecido ensaio no qual o famoso pensador, alarmado com as implicações da civilização moderna advertia sobre as possibilidades de destruição total conferidas pelo processo de racionalidade na técnica e na ciência à violência humana.

Sem titubear, Sigmund Freud delineava do modo que segue a respeito das conseqüências da propensão da razão ocidental em negar, ignorar ou desqualificar os tentames sensíveis nos quais os humanos se embeberam de afirmação existencial durante a maior parte de sua história:

Os homens alcançaram um domínio tal sobre as forças da natureza que se Ihes tornou difícil hoje em dia servir-se delas para se exterminarem até o último. Eles sabem disto, e daí provém uma boa parte da inquietação atual, de seu mal-estar e de sua angústia. É de se esperar que o outro dos dois poderes celestes, o Eros eterno faça um esforço em afirmar-se na luta contra seu adversário, o Thanatos, também eterno. Mas quem é que poderá prever o resultado e o desfecho? (citado in LEÃO, 1992:225).

Objetivamente gerados pela ação de sistemas de conhecimento criados pelo ocidente, corporificou-se um "ambiente de risco" originário de uma perturbadora pauta de agressões à natureza, quase sempre sem solução a vista (passim 
ELLIOTT, 1998). Nada pior para embalar os pesadelos do homem contemporâneo. Uma contabilidade assustadora de desequilíbrios estendeu-se planetariamente, tendo por pano-de-fundo a possibilidade de elevação do nível dos oceanos, da destruição da atmosfera terrestre, da contaminação do solo e o desaparecimento da maior parte das espécies animais e vegetais. No que ninguém poucas décadas atrás ousou profetizar, mesmo os abundantes (e vitais), recursos hídricos da Terra também terminaram por ingressar nos prognósticos sombrios das substâncias colocadas cada vez mais à distância da satisfação das necessidades humanas.

Este momento da civilização humana evidenciaria um mundo vitimado por sua própria racionalização e despaganização do cosmos. Levado a defrontar-se com perigos laicos gerados pela dessacralização de valores, crenças e posturas que durante a maior parte da história da humanidade, a weltanschaung da modernidade repudia as antigas contribuições do mundo tradicional enquanto suporte ontológico e de percepção do real. Fato que se impõe por si mesmo, a modalidade contemporânea de crise ambiental estaria enraizada nesta nova correlação metafísica que, reinando de modo absoluto, pode de fato vaticinar e conduzir a sociedade humana global para um malfadado império da desordem sem fim.

Vivendo no centro de uma crise ambiental sem precedentes, o conjunto dos humanos possui motivos de sobra para repensar esta questão de modo a visualizar possibilidades para sua superação. Neste sentido, as construções sociais do espaço e do tempo, ao serem reveladoras do caráter dos modelos de relacionamento com o meio natural, constituem, mais do que quaisquer outros, aspectos indispensáveis para o entendimento dos mecanismos de perpetuação e reprodução dos sistemas de engenharia (passim SANTOS, 1978a e 1988), criados

pelos humanos. Para determinada organização do espaço, se tem um determinado tempo social para mantê-la e vice-versa.

Não seria demasiado enfatizar, entre tempo e espaço se estabelece uma indissociabilidade permanente. Para o geógrafo Ariovaldo Umbelino de OLIVEIRA, o espaço e o tempo, "tomados em sua indissolúvel unidade, caracterizam a 
plenitude de existência do mundo material sob aspectos que se completam reciprocamente" (1982c:109). Cabe assinalar, este relacionamento entre estas duas dimensões exclui uma mera interação mecânica. O traço geral do espaço e do tempo, no matrimônio que sacramenta a atração eterna que os mantém imantados, "consiste no fato de que neles estão unidos os momentos da mutação e da estabilidade" (OLIVEIRA, 1982c:97).

Esta discussão reclama a agregação de comentários indispensáveis relacionados com a questão da temporalidade. Aparte contextos em que tempo e temporalidade convivem em condição de sinonímia, em outros, estas terminologias remetem a dois conceitos diferentes: enquanto que tempo implica em um entendimento de uma acepção social mais geral, temporalidade diria respeito à forma como diferentes apreensões da fruição do tempo se desenvolve no interior do espaço de uma determinada sociedade. Advertia a este respeito o geógrafo Milton SANTOS:

...O território é na verdade uma superposição de sistemas de engenharia diferentemente datados, e usados, hoje, segundo tempos diversos. As diversas estradas, ruas, logradouros, não são percorridos por todos. Os ritmos de cada qual - empresas ou pessoas - não são os mesmos. Talvez fosse mais correto utilizar aqui a expressão temporalidade em vez da palavra tempo (1998:45/46).

Seja como for, com base neste marco inicial a modernidade acataria uma norma comum ao passado da humanidade, visto que sumamente, não há qualquer sistema social que prescinda de uma forma de percepção e de organização do tempo. Convém assinalar que o significado forja o tempo na realidade simbólica da cultura e da história, e, portanto, esta dimensão não pode ser definida enquanto uma simplória sucessão de eventos (Cf LEFF, 2004:338). Deste modo, no tocante ao tempo social, tal noção constitui um dos traços identitários marcantes da personalidade histórica das civilizações. Recorrendo às palavras do historiador judeu russo Aaron Y. GOUREVITCH, as representações do tempo: 
...são componentes essenciais da consciência social, cuja estrutura, reflete os ritmos e as cadências que marcam a evolução da sociedade e da cultura (...) sendo que cada civilização percebe o tempo através de sistemas que lhe são próprios. Estes se formam durante a atividade prática dos homens, à base de sua própria experiência e da tradição herdada das gerações anteriores. A cada etapa do desenvolvimento da produção, da evolução da economia e do homem com relação ao meio natural, correspondem maneiras particulares de viver o mundo (1975:263).

Uma vez definido um percurso analítico no qual o espaço e o tempo constituem seu cerne, se torna factível, daqui por diante, avaliar a asserção do mundo moderno resultar do predomínio de um padrão temporal específico. A modernidade capitalista, tal como as demais formações sócio-espaciais da história, deve seu dinamismo a uma leitura particular da fruição do tempo, que a magnetizou e direcionou na escalada rumo à hegemonia planetária. Nesta perspectiva, caberia evidenciar seus traços específicos e sua dinâmica, de forma a resguardar a historicidade que lhe é inerente.

Por contraste, recorde-se primeiramente que no mundo tradicional, de um modo quase geral, os ritmos sociais estavam articulados com visões cíclicas e não-lineares do tempo. Nas sociedades sob a tutela da tradição, tal acepção do tempo era modelada pelos grandes ciclos naturais e astronômicos, como as fases da Lua, das estrelas ou da Terra em rotação e revolução. Mas, de acordo com o geógrafo sino-americano Yi-Fu-TUAN, a ordenação da vida social através de fases naturais foi gradativamente escamoteada, e assim:

O homem moderno reconhece estas fases recorrentes, mas para ele, pouco mais são do que ondas na direção da corrente do tempo. O tempo, para ele, tem direção e a mudança, é progressiva. Acredita-se que a visão escatológica do cristianismo promoveu o sentido de mudança progressiva. Entretanto, o sentido do tempo do homem medieval, refletindo o seu cosmo vertical e rotatório, era essencialmente cíclico. Foi somente no século XVIII que o conceito linear e direcional do tempo tornou-se importante (1980:170).

$\mathrm{Na}$ pré-modernidade, o tempo não se desenrolava de maneira linear do passado para o futuro. $O$ universo de valores do mundo da tradição, a partir dessa recusa ontológica, excluía qualquer subordinação do fruir da temporalidade a uma 
lógica que matematizasse seu encadeamento, abstraísse sua organicidade com o meio natural ou a separasse dos códigos rituais e simbólicos. Nas sociedades tradicionais o tempo ora é imóvel, ora é cíclico:

Aquilo que já foi, retorna a intervalos determinados. Esta concepção do tempo, que se encontra também muito mais tarde, numa forma renovada e em sistemas muito mais evoluídos, está em grande parte ligada ao fato de que o homem não se desligou da natureza, e sua consciência se subordinou às transformações periódicas das estações do ano e dos ciclos de produção que lhe são adaptados (GOUREVITCH, 1975:265/266).

$\mathrm{Na}$ antiguidade, a interpretação do mundo natural e do mundo social, regrado pela noção da circularidade do tempo ${ }^{14}$, sustentava-se num paradigma no qual este se renovava continuamente, justificando elaborações como a crença no eterno retorno (Vide ELIADE, 1978). O tempo cíclico estava presidido em nível do imaginário por divindades poderosas, que amparavam sua aparição e continuidade. Sua intelecção apelava para um universo mágico e simbólico, revelando uma idiossincrasia alicerçada em uma trajetória histórica e social específica.

Conclui-se então que o conceito de tempo cíclico, predominante nas sociedades primitivas e nas civilizações antigas, bem como em certos povos europeus ${ }^{15}$ era:

...produzido por um outro estilo de vida, por uma concepção particular do mundo, por um tipo preponderante de sociedade. As concepções de tempo nesta ou naquela sociedade ou região cultural, refletem a cadência da evolução social. O predomínio, na consciência social, do tempo cíclico sobre o tempo linear, é condicionado pela relação específica entre os

\footnotetext{
${ }^{14}$ A disscussão sobre o tempo cíclico é de grande complexidade, ultrapassando os limites deste texto. Vale assinalar que a conceituação é objeto de controvérsias, em especial quanto à tendência em entendê-la como universal ao conjunto das civilizações não-européias. No caso africano, Sulayman S. NYANG sugere, por exemplo, uma outra interpretação, propondo uma acepção tridimensional pela qual o tempo seria simultaneamente passado, presente e futuro, repudiando as interpretações unilinear, tipicamente ocidental, e a ascética, do Oriente (1983:32). É possível, entretanto, destacar traços de união dos tempos sociais das populações tradicionais, fundamentados na perdurabilidade a na afinidade para com aspectos qualitativos, sensíveis da realidade.

${ }^{15}$ Convém observar, o pensamento grego não omitia a concepção de tempo cíclico (Ver a respeito, LLOYD, 1975).
} 
elementos dinâmicos e os elementos estáticos no processo histórico (GOUREVITCH, 1975:283).

Considere-se que estes enunciados não são redutíveis a elementos abstratos. Antes, estão impregnados por determinações concretas. A acepção do tempo cíclico, prescrevendo uma lógica na qual o passado, o presente e o futuro se entrelaçam numa única expressão temporal, pavimentava o substrato de uma identidade duradoura das relações sociais. O tempo circular, detendo um caráter reversível, declinava numa segurança ontológica imiscuída nas práticas rotinizadas pela tradição, constituindo a mola mestra propulsora da temporalidade (GIDDENS, 1991:107). Tal postura frente ao tempo, presente nas cosmogonias relativas ao tempo nas sociedades antigas (BANU, 1969 e ELIADE, 1978), integrava uma prefiguração imaginária maior, na qual um tempo cósmico, articulado com os fluxos maiores do meio natural, formava uma identidade inquebrantável do espaço-tempo social com o natural, do espaço habitado com o cosmos no sentido mais amplo (Vide Fig. 5).

Ora, a modernidade altera radicalmente este quadro de organização do tempo. Na lógica de reprodução do capitalismo:

...as máquinas só são produtivas, ou seja, só funcionam como capital em movimento. Os trabalhadores só produzem no processo de trabalho. As matérias primas são riquezas que por si só podem ser destruídas. $E$, portanto da essência do processo de produção material que as relações sejam um fluxo contínuo (SEABRA, 1987:148, grifo nosso).

Neste sentido, a organização do tempo no capitalismo advoga uma ordenação linear e progressiva da temporalidade, que esteve - como ainda está diretamente articulada com o tempo da produção, da circulação, do consumo e da realização da mais valia (passim SANTOS, 1988). Naturalmente, este entendimento moderno da temporalidade não surgiu de uma hora para outra. Antes, ele resultou das expectativas do nascente sistema capitalista, com as quais se entrelaçaram um longo, lento e cumulativo conjunto de especulações intelectuais. 
$\mathrm{E}$, no que há de singular, nada semelhante à temporalidade moderna pode ser localizada no passado do homem. A temporalidade inaugurada pela economia de mercado é alheia aos ciclos presentes no espaço natural, que outrora foram referência determinante para a organização do próprio tempo social. Uma vez extintos os laços que sempre haviam conectado de forma inquebrantável o

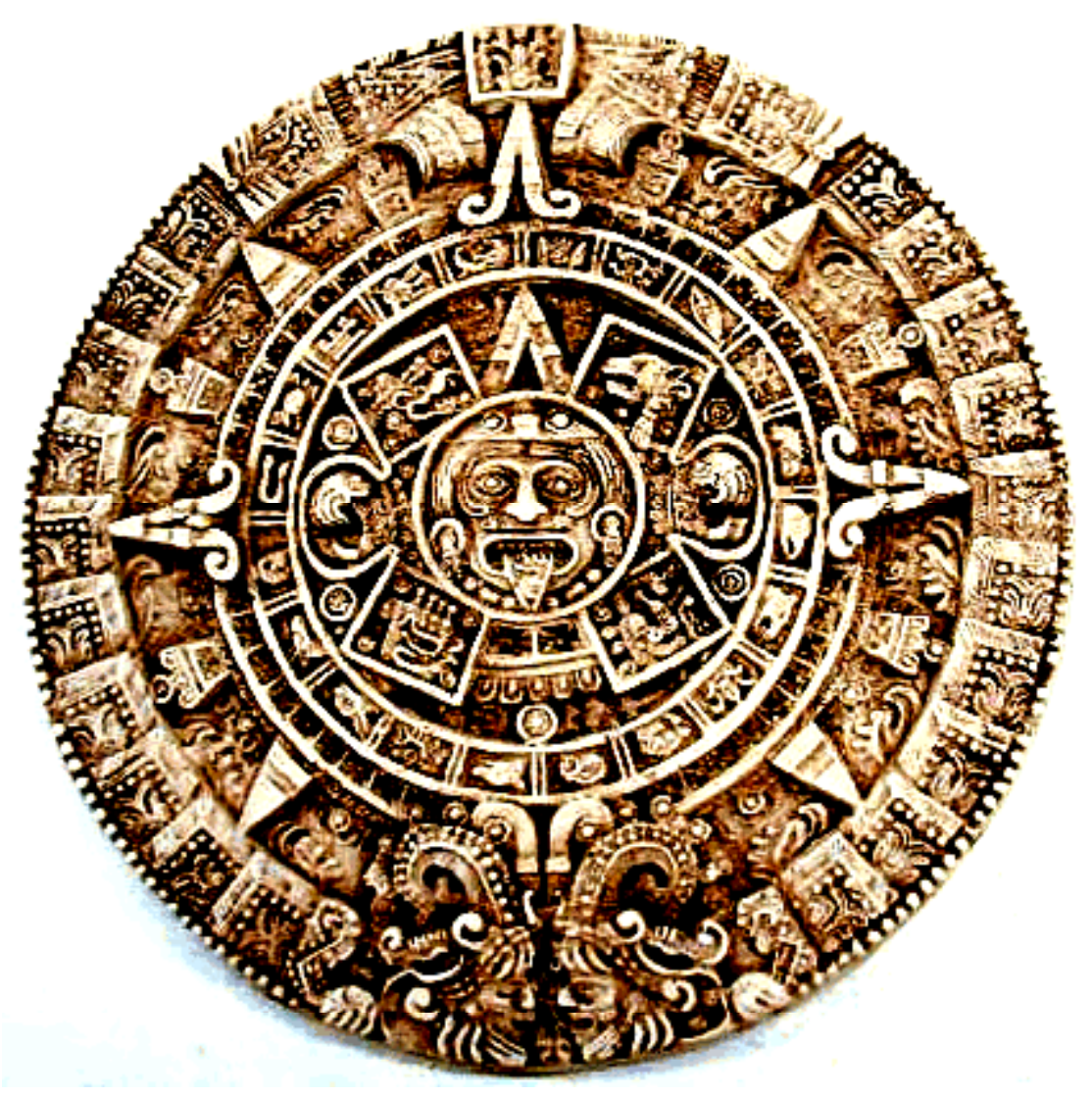

FIGURA 5 - A Pedra do Sol: A temporalidade tradicional denuncia a existência de um padrão cognitivo de cunho espacializante, em cujo interior estavam alojadas as acepções sociais do tempo. Dada a cumplicidade das sociedades antigas para com o meio natural, era inevitável que este estivesse qualificado tanto nos circuitos do espaço habitado quanto no ritmado do tempo social. A Natureza, constituindo critério de delimitação e de enquadramento do espaço articulado, era também o marco maior da temporalidade. Estas ponderações se explicitam na Pedra do Sol, também denominada "Calendário Asteca". A escultura foi descoberta em 1760 na Cidade do México, uma das muitas peças soterradas pela conquista espanhola. Sua nota característica é o disco 
solar central, apresentando as quatro direções fundamentais e os signos dos vinte dias do mês asteca, todos identificados com seres ou elementos da natureza, circundada por duas serpentes de fogo (Fonte: <http://www.earthfiles.com/Images/news/A/AztecCalendar2.gif>, acesso em 19-08-2005). 
o espaço e o tempo, sobreveio então uma hegemonia inconteste do tempo. $\mathrm{Na}$ modernidade - e apenas com ela - é que o espaço passa a ser verdadeiramente o resultado de uma produção, emanação direta do tempo, seu resultado objetivo, concreto e material.

A irmandade imemorial que sempre havia governado as relações do espaço com o tempo foi rompida, sobrevindo mecanismos que alargaram cada vez mais a distância entre estas duas esferas, daí a menção obrigatória ao que terminou categorizado como desencaixe do tempo para com o espaço (GIDDENS, 1991:25/27). É deste modo que o ordenamento da temporalidade edificado com a modernidade termina por se responsabilizar, no final das contas, pelos mecanismos catalisadores da desordem ambiental. Contrastando com todas as demais acepções do tempo a ele anteriores, este fato impõe a necessidade de discutirmos o tempo linear e progressivo.

Presente direta ou indiretamente em todas as manifestações do mundo contemporâneo, tanto nas concretas quanto nas imaginárias, uma linha de investigação preocupada com sua decifração pautaria de modo obrigatório debruçar sobre suas origens e seus desdobramentos.

\subsection{A Moderni dade e a Morte do Mundo Tradi ci onal EuropeU}

Em conformidade com o que foi colocado, a investigação do tempo social remete ao modelo de mundo que tipifica este ou aquele momento histórico, sua especificidade geográfica, suas expectativas sociais e todos os demais desdobramentos a ele pertinentes.

Nesta linha de análise, a plena compreensão da instauração do tempo linear e progressivo não poderia se circunscrever à modernidade. Resultando de um processo que se estendeu ao longo de muitos séculos, esta análise requer que seja passado a limpo o continuum que serviu de nascedouro para o nascente sistema capitalista, qual seja, a Europa medieval. 
Por esta via, o primeiro aspecto digno de nota é o fato da temporalidade moderna nascer do interior de uma formação social, o feudalismo, que de forma semelhante às demais sociedades pré-modernas, tinha na perdurabilidade, na multiplicidade e numa afinidade sensível para com a fruição do tempo, uma das suas marcas mais proeminentes. No feudalismo, a temporalidade estava em consonância com um mundo agropastoril, autárquico, auto-suficiente e produtor de valores-de-uso, no qual o mercado estava muito distante de configurar uma instituição central (Vide POLANYI, 2000:76/88).

Embora muitas análises notifiquem que o mundo feudal não era regrado por uma economia propriamente "natural", isto é, na qual as transações monetárias e o comércio fossem inexistentes, ressalve-se, de outra parte, que o mercado detinha expressão meramente local, desprovido da auto-regulação assumida posteriormente no capitalismo (passim POLANYI, 2000). Quanto ao intercâmbio com países estrangeiros, ocorrendo de modo esporádico e voltado para o consumo suntuoso das elites, este não desempenha qualquer papel determinante nos fins e nos métodos de produção, detendo escasso poder de influência em uma sociedade orientada pelo costume e pela tradição (Cf SWEEZY, 1977:22/23).

O localismo de poder era regra geral. A ordem social correspondente a este estado de coisas, formada por camponeses, guerreiros e sacerdotes, primava por uma "lentidão" condicionada pela sazonalidade da própria organização agrária existente. O universo medieval era ainda perpassado pela religiosidade, que expressava, de modo bastante eficiente, a acomodação com este estado geral de coisas. Em suma, a partir dos escombros do Império Romano, o feudalismo estabelece o tempo eclesiástico ou da Igreja.

Por toda a Idade Média, e semelhantemente ao mundo tradicional em geral, o tempo, dado seu imbricamento com o meio natural, encaixava-se com o espaço. Essa determinação era reforçada em nível do imaginário por representações simbólicas que preconizavam e reforçavam o isolamento do pequeno mundo povoado em grande parte por agricultores, cujo cotidiano apenas excepcionalmente era alterado pelas tempestades da política ${ }^{16}$. Nesta sociedade,

\footnotetext{
${ }^{16}$ Note-se que em russo, a palavra mir significa simultaneamente aldeia, paz e mundo.
} 
o desconhecido, o estranho, o alienígena enfim, era por motivos óbvios repudiado por ser um elemento potencialmente perturbador de um universo avesso a novidades, aferrado à repetição dos trabalhos, dos ritmos e das técnicas recebidos de forma hereditária, produzindo os mesmos produtos e freqüentemente entregando parte da produção à mesma família dominante, que se perpetuava no poder quase sem rupturas.

A territorialidade eminentemente local do feudalismo sugeria que a alteridade também estivesse concatenada nos planos concreto e imaginário a uma contextualização espacial. Não fosse deste modo, dificilmente esta poderia estar vinculada à produção de um discurso que justamente se preocupava em assinalar sua existência através de linhas divisórias voltadas a circunscrevê-la de modo espacial. Os alienígenas, de modo comum ao conjunto do pensamento tradicional, habitavam os bordos do espaço, situam-se depois dos limites do mundo conhecido, vivendo para além das fronteiras reconhecidas. Quando muito, estes habitavam na melhor das hipóteses os "poros" da sociedade existente, manifestando-se enquanto uma organização de alógenos que coabitava de modo estanque um espaço social e politicamente referendado por elementos sociais com os quais não comungavam anseios de qualquer índole.

Esta prefiguração é patente na relação com "o outro" medieval que era, por excelência, o judeu. Os preconceitos contrários a esta minoria, centrados na alegoria do Ahasverus (o judeu errante), tinha por sustentação uma argumentação de fundo teológico-religioso voltada contrariamente a uma minoria étnica que, face aos critérios feudais, constituía um grupo desterritorializado. O Ahasverus respondia por um imaginário através do qual o judeu era integrado pela rejeição, engendrado como marginal e diferenciado para que não deixasse de existir (PINSKY, 1981:11). Por conseguinte, este antagonismo, mais do que por critérios de ordem religiosa, estava articulado com a atividade que lhes fora reservada pelo próprio sistema feudal: a de responsáveis pela restrita circulação monetária admissível numa economia autárquica, atividade esta que também estava em contradição latente com os mecanismos maiores de reprodução social e econômica do feudalismo. 
Em suma, o feudalismo materializa uma sociedade voltada para si mesma, mostrando-se enormemente desinteressada pela ampliação dos contatos e das comunicações. Na escala do continente, a indisposição em ultrapassar os limites conhecidos abrigou-se em um imaginário impeditivo da ultrapassagem das suas fronteiras. Por todo o período medieval, grassavam crenças pelas quais as regiões equatoriais seriam, por exemplo, inabitáveis devido ao calor escaldante. Não fosse suficiente, existia o temor de monstros e criaturas malignas habitando nichos mal conhecidos das terras emersas e dos oceanos (tais como silfos, elfos, vampiros, bruxas, dragões, serpentes marinhas, basiliscos, harpias e salamandras). Este sentimento estava associado a uma visão demonizante das paragens limítrofes à Europa, possível pátria de populações temidas e estigmatizadas (muçulmanos, lotófagos, antropófagos, pagãos e semi-humanos em geral).

Além destas, crenças como as da terra quadrada, findando após a ultrapassagem da última vaga do oceano, num abismo sem fim, literalmente aprisionaram os europeus durante séculos em seu compartimento continental. Neste quesito recorde-se que a imagem de um mundo quadrado, comum a diversas civilizações pré-modernas, não poderia ser preconceituosamente indicativa de "sinal de atraso" do homem tradicional. A noção da "Terra chata" e/ou "quadrada", era alimentada pelo enraizamento do homem tradicional no seu espaço vivido, que lhe fornecia uma base objetiva para este tipo de compreensão. A humanidade, durante a maior parte da história, habitou compartimentos territoriais dos quais raramente se distanciava. A "quadratura do mundo" refletia tão somente uma observação - aliás, fenomenologicamente correta - que assumia o compartimento territorial como observatório da trajetória do Sol:

...A direção da marcha aparente do Sol no firmamento, permitiu ao homem considerar um primeiro eixo estável, com um ponto fixo correspondendo ao lado em que o Sol aparece no horizonte, e outro lado em que ele desaparece. A partir deste eixo Leste-Oeste, não foi difícil estabelecer outro no sentido Norte-Sul (OLIVEIRA, 1978:36).

Portanto, contrariando um julgamento eivado de objeções preconceituosas, Cristóvão Colombo, por exemplo, em sua jornada inicial de "descoberta" da 
América, não lutou propriamente contra a "ignorância" de sua tripulação, temerosa de deparar-se com um abismo no final do horizonte. Principalmente, ele contestou uma concepção tradicional de espaço que acudia no âmago dos corações e das mentes de seus marinheiros, que repetida de geração em geração e empiricamente observada no dia-a-dia, conquistara foros de verdade indiscutível.

Numa das variadas confirmações de que a visão geral do mundo transcende a realidade objetiva, isoladamente ou em conjunto, tais elementos imaginários constituíram fatores determinantes para o enclausuramento dos europeus, reforçando o sentido autárquico do sistema feudal. Os aterrorizantes sentimentos que inundavam a imaginação européia são representativos do quanto o imaginário termina pautando as relações dos humanos com o espaço habitado. Como argumentou o geógrafo norte-americano David LOWENTHAL:

As esperanças e o medo da mente humana freqüentemente animam as percepções de senso comum. A localização suposta e os aspectos do paraíso estimularam muitos cartógrafos medievais, muitas expedições de exploração procuraram alusivos Eldorados (1985:119).

Deste modo, mesmo quando o homem medieval encetava formidáveis caminhadas para fora de seu compartimento continental era em função de referências maravilhosas que impregnavam seu espírito. Por exemplo, viajantes isolados partiram em busca de impérios fabulosos, como o legendário reino de Prestes João, um mirabolante governo cristão instalado em algum nebuloso rincão da Etiópia ou das Índias. Muitas crônicas descreviam este reino mítico repleto de riquezas infinitas. Ameaçado pelos irascíveis muçulmanos e por pagãos convictos, este país, farol da mensagem do espírito santo num espaço sufocado pelas forças do mal, estaria aguardando por um auspicioso contato com a cristandade. Esta notícia, espalhando-se pela Europa ao longo do século XII, inundou os mapas da época, seduzindo aventureiros a assumirem as mais desatinadas peripécias. Nos albores do século $X V I$, este reino persistia em aparecer nos mapas confeccionados por Diogo Homem, Abraham Ortelius e muitos outros cartógrafos, 
demonstrando a força das configurações imaginárias na percepção do espaço, assim como o animus que as mobilizava (Cf NEBENZAHL, 2004:9 e 52).

Todavia, a partir da Baixa Idade Média, o imaginário espacial do mundo tradicional europeu termina profundamente convulsionado por uma outra ordem de considerações. Estas acabam expulsando os temores relacionados com seres desconhecidos e aos espaços interditos aos ocidentais. Os antigos móveis da percepção do espaço decididamente formavam uma dimensão despida de quaisquer analogias com o novo universo de valores eivado pela racionalidade, típico dos novos relacionamentos engendrados pela economia de mercado. Os ensejos que passariam a alimentar as aventuras dos viajantes europeus seriam outros, totalmente diferentes dos anteriores. Lenta, mas inexoravelmente uma outra ordem das coisas vai sendo instaurada, desintegrando a antiga sociedade e todos os elementos que a compunham e Ihe ofereciam afago e segurança.

O fortalecimento do comércio no interior do espaço europeu originou, ao longo das florescentes rotas comerciais de Flandres, Borgonha e Norte da França, um desenvolvimento urbano que credencia as cidades como uma articulação espacial passível de desagregar o feudalismo. As concentrações urbanas passaram a ser o cenário no qual se abrigou e fortaleceu um novo ator social, a burguesia. Sintomaticamente, a classe burguesa deve sua identidade ao burg, isto é, à cidade, tal como este espaço é conhecido em muitas das línguas germânicas. Os objetivos desta nova categoria social para com o tempo diferiam consideravelmente de tudo aquilo que até então havia sido formulado ao longo da história.

A classe burguesa, construindo uma compreensão de mundo adequada aos seus interesses, foi, passo a passo, elaborando sua própria concepção da temporalidade. Além das óbvias pré-condições materiais, o tempo social da modernidade firmou-se com base em elaborações filosóficas e científicas, vale dizer, na formação de um imaginário, primeiramente evidenciado nas obras dos pensadores da Renascença. Neste período, 
meio de experimentos, configurante de uma atitude mais tarde denominada científica (SEVCENKO, 1984:11).

O objetivo deste desenvolvimento científico e tecnológico era o domínio do meio natural, garantindo a exploração de todo os recursos possíveis em proveito do tempo de mercado. Definindo uma visão de mundo sem paralelo na história humana, este imaginário inseriu um alcance insuspeito mesmo para seus mais entusiasmados próceres, arautos e apologistas. A ciência, objetivando a dominação da natureza, passou a concebê-la como em contradição com pressupostos ditos racionais. Este posicionamento, tendo por pretensão uma descrição matemática da realidade, induziu a preocupação com as propriedades quantificáveis da matéria. Conseqüentemente, as experiências decorrentes da sensibilidade estética e ética, valores, qualidade e sentimentos, motivos e intenções, não redutíveis a este paradigma, foram por definição expulsas do domínio do discurso científico e prontamente excluídas do campo das especulações consideradas como imbuídas de seriedade (CAPRA, 1991:51).

Coerentemente, o conhecimento científico moderno abandonou as dimensões qualitativas nas quais a consciência social dos humanos trafegou durante a maior parte da sua história. A ciência foi inteiramente laicizada e expurgada das considerações de ordem cósmica que haviam influenciado seus fundamentos até um passado não muito distante. Paralelamente, a compatibilidade entre ciência e técnica de um lado, e a arte e a vida, do outro, patentes, por exemplo, na etimologia da palavra tecnologia (do grego teckne, arte) desapareceu, criando um fosso que se aprofundou cada vez mais, repercutindo inconteste até a atualidade.

Fato pouco sublinhado, o fenômeno renascentista prenunciava a moderna sociedade capitalista. Neste sentido, como assinalou Pascal ACOT, este período materializa muito mais uma transição que propriamente um renascimento (1990:13). Nesta transição, o cosmos por inteiro foi geometrizado. Formulado matematicamente, neste paradigma a natureza deixou de possuir qualquer outro interesse que não a sua transformação em um recurso para o sistema de produção de mercadorias. As cosmogonias antigas, caracterizadas por uma 
proximidade com a natureza e os seus ciclos acabaram definitivamente abandonadas. Foram substituídas por uma nova mitologia em cujo centro estava uma versão do antropocentrismo negadora da natureza e dos vínculos dos humanos com o cosmos. Esta nova relação com o meio natural foi destacada em verso pelo poeta inglês John Donne. No século XVII este homem das letras premonitoriamente assim a descreveu: "Nós esporeamos, freamos as estrelas em seu curso. Elas se dispõem diversamente para aceitar nosso comportamento" (in ACOT, 1990:131).

Este antropocentrismo, diverso dos anteriores por justamente ignorar as pulsões e os ritmos da natureza, justificou acelerada depleção dos recursos naturais. Como se viu, é indiscutível que o conjunto das populações tradicionais, ao estabelecerem formas geralmente mais brandas na relação com o ambiente, preservaram, conscientemente ou não, os recursos naturais. Ironicamente, poderse-ia ressaltar, foi esta estratégia que assegurou, na escala do Planeta, a prodigalidade de bens naturais incorporados pela expansão do mundo contemporâneo, propiciando ao ocidente a possibilidade de posteriormente dilapidá-los sem piedade.

Nesta consideração poder-se-ia recordar o destino das florestas. Transformadas em fonte de matéria prima essencial para a influente indústria naval e como matriz energética para a produção do ferro, foram abatidas com uma voracidade nunca dantes registrada na história humana. Paradoxalmente, foi devido aos elevados índices de desmatamento que já no início do século XIV surgiram os primeiros decretos visando controlar o desflorestamento. A estes se agregaram mais adiante, amplas e minuciosas legislações versando sobre o tema, caso do célebre decreto do ministro Jean-Baptiste Colbert, Das Águas e das Florestas (1669). Recorde-se, no entanto, que tal normatização não incluía "compromissos ecológicos" de qualquer tipo. Seu objetivo prioritário era garantir as bases ambientais de reprodução do nascente sistema capitalista e não a defesa do meio natural. De resto, nada disso foi suficiente para impedir a escalada da destruição do meio ambiente, que avançou na Europa e no restante do mundo. 
A erosão ambiental ganhou velocidade conjuntamente com uma erosão cultural, consubstanciada na unificação, ou melhor, homogeneização, lingüística, religiosa e nacional, indiscernível do processo de centralização monárquica que alicerçou o predomínio da nova classe burguesa. Nada disto ocorrera antes, e certamente, sem o concurso da nova interpretação social do tempo, tal não teria sido possível. Inspirando um cabedal de conceitos científicos estreantes, a nova acepção da temporalidade foi rapidamente implantada, animando a expansão colonial e rompendo ou submetendo ao cadenciamento da produção os diferentes tempos eleitos como objeto de domesticação: o dos humanos, o da natureza e o das formações histórico-sociais do mundo extra-europeu. Em resumo, a legitimação global do processo de expansão do ocidente reportou a esta interpretação da fruição do de tempo social.

A criação de um novo imaginário histórico-cultural dito "nacional", foi uma petulante peça cultural associada a esta preocupação. Sua predisposição foi, por definição, escorraçar e sobrepujar tudo o que não fosse branco, ocidental e burguês. Neste imaginário, a burguesia reinventou a totalidade da história humana, criou personagens novos, privilegiou os detalhes que melhor se ajustavam ao padrão proposto e ao mesmo tempo desqualificou ou negou o que não the interessava. Atuando como pólo organizador, o imaginário ocidental gestou novos modelos identitários, inspirados no geral, na ressemantização da herança lingüística e de alguns "ancestrais míticos", hipotéticos povos fundadores das diversas nacionalidades.

Por isso mesmo, uma mitologia nacional passou a "provar" que bretões, provençais, alsacianos, borgonheses e normandos, seriam franceses (isto é, seriam descendentes dos francos), e que bávaros, renanos, turíngios, pomeranos, silesianos e prussianos, seriam todos, sem exceção, alemães (ou seja, descendentes dos alamanos). Melhor ainda, esta pretensiosa mitologia prescrevia que cada um dos novos agrupamentos nacionais, em geral um conjunto dispare de dialetos, de tradições locais e de particularismos, sempre teriam formado a França ou a Alemanha, afirmações que de um ponto de vista geográfico, histórico e antropológico soariam como grosseiras, simplistas e insolentes. O mesmo 
sucedeu por toda a Europa, na qual cedo ou tarde a totalidade das populações viu-se subitamente investida do privilégio de pertencer a esta ou aquela "nacionalidade".

Nos novos modelos de identidade nacional, a antiga Gália, povoada de celtas e adornada por menhires, tornou-se uma evocação romântica do "passado do povo francês". A Dácia inspirou poetas e historiadores nacionalistas da Romênia na defesa de uma "ilha latina" contra o desprezado mundo eslavo e húngaro circundante. A Germânia, miticamente coberta de névoa e por florestas de carvalho, terminou transformada no "território ancestral" do moderno Estado alemão. A antiga Panônia e seus cavaleiros ugrianos egressos das estepes da Ásia, tornou-se o território mítico do moderno Estado magiar. A Roma Republicana, seus ícones e legendas teriam na Itália hodierna a herdeira das suas antigas glórias. Quanto à velha Hélade, mesmo dividida em poleis dilaceradas por guerras intestinas entre si e que nunca desfrutaram de qualquer afinidade política, encontraria, apesar de tudo, sua aclamada reencarnação no prosaico Estado nacional grego moderno.

Sem que a afirmação sugira qualquer exagero, tal processo redundou na criação de entidades étnicas e nacionais dantes virtualmente inexistentes. Para tanto, apelou-se para uma jurisprudência respaldada em um estatuto de desnaturalização, aplicado com denodado afinco junto a vastos contingentes populacionais. Tal processo, tipificado em diversas situações durante a criação dos chamados Estados "nacionais" europeus, ao voltar-se para a lapidação das novas identidades nacionais, sugeria necessariamente a remodelagem dos marcos étnicos anteriores.

Entre outros exemplos, o rompante Criamos a Itália, resta-nos criar os italianos, como se sabe, uma argüição textual do primeiro-ministro Cavour ao rei Vittorio Emanuele nos momentos finais da unificação de uma península supostamente habitada por um único povo, escancara inequivocamente este fato. A este propósito importaria comentar que ainda hoje a Itália presencia a militância de particularismos regionais, inconformados, com a redução dos seus linguajares (como o napolitano, vêneto, sardo e o siciliano) à condição de "dialetos" do 
italiano, o que do ponto de vista lingüístico simplesmente não teria qualquer cabimento. Isto nada mais denuncia do que as dificuldades de construção de uma identidade italiana, assim como de diversas outras "nacionalidades", aceitas pelo senso comum como realidades culturais dadas e raramente sujeitas a uma avaliação crítica ${ }^{17}$.

Em resumo, em qual momento se poderia negar que a imaginação deixou de confirmar um cenário mítico de um momento para outro travestido de verdades? $\mathrm{Na}$ origem, este fenômeno de modelagem das nacionalidades possuiu relação siamesa com a formação dos mercados nacionais, com a criação das moedas únicas e com o fortalecimento do absolutismo real. Foram decretadas línguas nacionais (ou melhor, de Estado ou oficiais), geralmente com base em um linguajar com maior proeminência literária (caso do toscano, na Itália), política (o falar da corte, na França) ou comercial (o holandês, nos Países Baixos). A imposição de um código lingüístico unificado em nível de cada "nação", normatizou direta ou indiretamente um conjunto de padrões de compreensão da realidade, pois programando os eventos de maneira completamente diferente, estas línguas criaram mundos sensoriais dantes difusos ou inexistentes.

Este processo caminhou na contra-mão de uma heterogeneidade que sempre, como no conjunto da pré-modernidade, havia caracterizado a totalidade do continente. Tradicionalmente, a Europa esteve retalhada numa imensa Babel, aglutinando uma miríade de idiomas por sua vez fracionados em um número incontável de dialetos. No mundo medieval, a possível influência unificadora do papado não conseguiu consolidar-se frente à fragmentação objetiva do poder. Mesmo a liturgia da Igreja, vertida em latim, era um falar estrangeiro para a maioria da população. O feudalismo se nutria ao mesmo tempo em que reforçava relações de cunho local/patrimonial que eram sua essência indiscutível. O espaço europeu estava decomposto em unidades autárquicas e auto-suficientes, cuja fragmentação era reforçada por uma dependência do meio natural.

Secundando tal segmentação, povos e etnias se interpenetravam uns relativamente aos demais, com papéis sociais engastados com recortes e

\footnotetext{
${ }^{17}$ Por ocasião da unificação italiana (1870), apenas 3\% da população se expressava no idioma
} 
qualificações étnicas. Exemplificando, em regiões como a Curlândia e a Livônia, no Báltico Oriental, a Ordem dos Cavaleiros Teutônicos, uma classe senhorial de ascendência germânica, polarizava com uma massa camponesa de origem estoniana ou leto-lituana. Por toda a Rutênia, os latifundiários, denominados localmente de pans, eram poloneses e não ucranianos. Em muitas partes da GrãBretanha, os daneses, um antigo grupo viking que havia migrado da Escandinávia e se instalado em posições fortificadas na "nova pátria", exerciam seu poder sobre um campesinato de origem celta ou anglo-saxônica. Por toda a Europa, as cidades, quando de caráter mercantil, reuniam fervilhantes colônias de alógenos, particularmente de judeus, armênios e outros grupos cosmopolitas.

Assim, nada mais estranho ao mundo feudal do que a homogeneização aplicada pela nova classe dominante burguesa no espaço europeu. Muito antes de inaugurar o massacre das populações indígenas, de escravizar milhões de africanos e de submeter os povos da Ásia e Oceania ao seu tacão, a criação das novas identidades nacionais européias (por sinal das quais muitas seriam dificilmente identificáveis no tecido étnico europeu apenas alguns séculos antes), ensejou um genocídio físico e cultural de proporções até então desconhecidas, atingindo centenas de grupos juntamente com os seus falares, seus gostos, suas festividades, suas aptidões e suas relações sócio-ambientais, que em quase todos os casos desapareceram para sempre.

A aguda percepção deste processo está contemplada nas indignadas palavras com que o geógrafo Carlos Walter Porto GONÇALVES registra esta tendência:

Geralmente fala-se muito que os europeus destruíram as civilizações dos Maias e Astecas, quando da conquista da América, mas nos esquecemos que eles primeiro eliminaram os diferentes dentro da própria Europa. Onde estão os godos, visigodos e celtas, por exemplo? No próprio continente europeu, quem não era hegemônico, quem não era dominante, também foi destruído (1992:6). 
Por conseguinte, e ao contrário do pensado por muitos, o fortalecimento das monarquias nacionais européias não se especificou unicamente na discriminação contra os judeus, muçulmanos ou ciganos, mas também contra todos os que fossem diferentes no próprio âmbito europeu. E aí, estavam incluídos os etnicamente assemelhados. Milhares de comunidades camponesas, seus hábitos, suas tradições seculares e suas leituras da temporalidade, foram destroçadas para que pudesse vingar o tempo progressivo e o novo arranjo territorial que prontamente o acompanhava alguns passos atrás.

A brutalidade destas "campanhas de homogeneização" pode ser aquilatada em função do universo da temporalidade tradicional no qual os camponeses europeus estavam imersos. Na Europa Feudal, o tempo linear era objetivamente ignorado pela população camponesa. O campesinato medieval estava em larga medida apegado a noções mágicas derivadas de um estilo de vida regrado pela sazonalidade das estações e dos ciclos agrícolas, o que justifica a popularidade das antigas práticas pagãs, criminalizadas como "bruxaria" pelas autoridades eclesiásticas. Durante a Idade Média, o cristianismo "não conseguiu superar o apego característico da consciência arcaica do arquétipo mítico, a atitude ritual e mágica diante da realidade e em particular, do fluir do tempo" (GOUREVITCH, 1975: 275).

Isto posto, foi posteriormente a uma imensa operação de "purificação étnica" realizada em solo europeu que as potências colonialistas lançaram-se à imposição de seu sangrento domínio no além-mar, com resultados que, aliás, rivalizaram com estrondoso sucesso frente aos seus primeiros - e nefandos - experimentos de aniquilação (Vide CROSBY, 2000:71/98). A formação do Estado espanhol ilustra as linhas gerais desse processo. Primeiramente foi selada a unificação monárquica, pela união dos Reinos de Castela e Aragão (1479). Sucede-se rapidamente a ofensiva contra o último reduto muçulmano na Península Ibérica, o Reino de Granada e a expulsão dos judeus espanhóis. Após esta purificação étnica, inicia-se então, a partir da "descoberta" da América, o genocídio do negro e do indígena americano. A interconexão entre estes acontecimentos transparece mesmo em nível cronológico: a destruição do reino mouro de Granada, o 
banimento dos judeus e a viagem de Cristóvão Colombo (considerada como marco da opressão do negro e do indígena) são eventos que ocorreram num mesmo - e fatídico - ano: 1492.

Este mosaico de medidas foi referendado por um imaginário específico da inculturação européia que passou a impregnar a totalidade do mundo ocidental. Ao contrário das configurações do passado, este imaginário de tipo novo não incluiu as emanações ou fluxos naturais. Tratava-se de uma percepção divorciada da natureza, esboçando uma compreensão totalmente artificial e geometrizada, expressão da matematização do tempo e de sua autonomia frente a quaisquer outros fluxos temporais. Este "arquétipo" exaltou traços meliorativos como o reto, o puro, o limpo, o alto, o superior, racional e o não-sexual. Excluiu o curvo, o impuro, o sujo, o baixo, o inferior, o prazer e o espontâneo. Nele, o processo de significação se ensaiou antes mesmo da constituição dos signos.

Tal construção imaginária teve nítidos reflexos na compreensão do espaço e do tempo. Na Idade Média, como se pode presumir, o imaginário espacial estava eivado de conotações hoje entendidas como arcaicas ou ingênuas. Explicitariam esta interpretação fabulosa do espaço do período medieval: a explicação ptolomaica do universo, com uma Terra plana ocupando seu centro; Jerusalém como o omphalos ${ }^{18}$ do mundo habitado e em decorrência disto, do universo; o registro, nos mapas medievais, de toda sorte de bestas e animais fantásticos, procedentes de uma biologia maravilhosa; o domínio de concepções mágicas relativas aos ventos, às marés, grutas, vulcões, bosques, terremotos e tufões; crença de que o espaço habitado coexistiria com o Jardim do Éden, Trapalanda e a Ilha das Sete Cidades, países supostamente reais, esboçados a esmo nas cartas geográficas anteriores às navegações européias (Vide SCHEINES, 1991: 13).

Contudo, o imaginário que surge com a modernidade borrou completamente seu precedente feudal. Constituindo uma representação matematizada e laicizada da realidade, esse imaginário moderno expulsou da consciência social aquelas

\footnotetext{
${ }^{18}$ Omphalos significa umbigo em grego, sendo metaforicamente utilizado para referir-se ao centro do universo. $\mathrm{Na}$ antiga Grécia era toponímicamente identificado com o Oráculo de Delfos (Ver PLATÃO, 427a, 1990:175).
} 
representações típicas da iconografia religiosa européia pré-moderna, tais como o paraíso terrestre, a arca de Noé e a torre de Babel, que haviam sido costumeiras nos mapas medievais nos séculos anteriores. Desapareceram também diversos continentes insólitos, tais como Thule e Atlântis. Criaturas fantásticas, integrantes de uma "zoologia maravilhosa", tais como sátiros, serpentes marinhas, grifos, basiliscos, a ave roc, as harpias, o odradec, os unicórnios, as salamandras e os antílopes de seis patas foram empurrados para uma reserva imaginária do natural, pois eram incompatíveis com um espaço cada vez mais geometrizado.

Tais símbolos, seres e territórios, em alguns casos acompanhados dos povos e das populações que haviam constituído seus interlocutores concretos, migraram penosamente para o domínio das lendas, do folclore popular ou então para a esfera do irracional. Desta derradeira fortaleza, estes excluídos, agora metamorfoseados em criaturas monstruosas, lançaram-se, vez por outra, em investidas no espaço do sono e dos sonhos, gerando pesadelos e sobressaltos. No plano concreto, este processo terá seu rebatimento, fora dos limites europeus, repetido pela desterritorialização dos não-ocidentais e conseqüentemente, pela releitura de seus espaços, rotulados ao capricho dos novos dominadores europeus (Vide TUAN, 1980:47/51 e passim NEBENZAHL, 2004).

Nada melhor espelha tais injunções imaginárias do que a toponímia que passou a impregnar a cartografia desenvolvida no ocidente ${ }^{19}$. Para o caso da Europa recorreu-se a uma simbologia cujas origens perdiam-se em meio à antiguidade clássica. Nos mitos gregos, Europa correspondia a uma amante de Zeus, vista como relacionada com a civilização minóica, e, não sem razão incorporada com uma referência central para a identidade ocidental pela renascença. Mas no exercício destas fantasmagorias, os novos senhores do mundo se viram diante de certas dificuldades na tarefa de inventarem a si

\footnotetext{
${ }^{19}$ A Cartografia espelha as prefigurações espaciais de uma dada cultura ou civilização. Os mapas, ao resultarem de uma seleção de dados implementada em atendimento ao que é considerado relevante para um imaginário espacial, guardam forte identidade com dados históricos e culturais (RAFFESTIN, 1993:145). A Cartografia faz uso, consciente ou não, de um aparato simbólico cujas significações decorrem das expectativas espaciais pertinentes a um determinado padrão civilizatório e sendo assim, seu papel extrapola a mera aferição objetiva do espaço (passim NEBENZAHL, 2004).
} 
próprios. Na cortante ponderação do geógrafo Rogério HAESBAERT, seria importante lembrar que

...a Europa nunca existiu de fato. Nem mesmo a geografia tradicional conseguiu resolver o dilema de definir a Europa como algo mais do que uma grande península ou 'um simples promontório da Ásia', como disse Paul Valéry (1997:30).

Todavia, se existiram objeções para mapear as identidades que vão sendo construídas no plano imaginário, estas foram inexistentes quando o que estava em pauta eram as necessidades práticas do mundo da economia e do poder. A cartografia européia, esboçada com base em um sistema que repudiava os fluxos da natureza, outorga substancia social às novas prefigurações racionalizantes, excluindo um conjunto de elementos míticos que deixaram de possuir sentido com o avanço da modernidade. O eurocentrismo, acompanhado da racionalização do espaço, passou a imperar nas representações cartográficas. A Europa passou a ser representada na parte superior dos mapas, posição antes ocupada pela Ásia (caso do Mapa de Roda medieval ou Orbis Terrarum). Jerusalém, que era costumeiramente destacada no centro do mundo, perdeu esta localização com a descoberta da rotundidade da Terra.

As representações cartográficas passaram a ser como reflexo da matematização do tempo, rigorosamente esquadrinhadas por uma rede de coordenadas geográficas. Ocupando o lugar dos antigos conceitos, estas noções asseguravam a hegemonia da interpretação progressiva do tempo social. Tudo isto para garantir "segurança e exatidão das viagens marítimas e sucesso dos negócios dos mercadores europeus" (SEVCENKO, 1984:11). Expressão do domínio espacial crescente do capitalismo, as grandes viagens transoceânicas, como a Viagem de Colombo (1492), a chegada de Vasco da Gama nas Índias (1502) e a circunavegação do globo por Fernão de Magalhães e Sebastião Del Cano (1519/1522), não poderiam ser indissociáveis dos avanços da geometria, da 
física, da matemática e da astronomia, assim como das novas metodologias de confecção de mapas criadas pelo cartógrafo flamengo Gerhard Kremer²0.

No plano epistemológico, a mundialização da formação social capitalista foi legitimada por enfoques que traduziam as injunções do novo ritmo temporal linear e progressivo, mesmo porque, ontologicamente, este tempo social arrogava-se a uma universalidade. O Ocidente passou a ser apresentado como o único a possuir história efetiva, eivada de significados progressivos, desenvolvimentistas e eurocêntricos. Os demais povos, os ditos "atrasados" - expressão esta de nítida conotação temporal - passaram a ocupar posições cronologicamente subalternas ou então, deixaram simplesmente de possuir história. Em resumo, o atrasado é acima de tudo definido pelo que não é. Daí decorre a conhecida declinação desqualificante, presente inclusive no jargão acadêmico de muitos segmentos das ciências sociais, pelo qual as sociedades primitivas são caracterizadas por uma ótica da negatividade, costumeiramente rotuladas como sem Estado, sem classes sociais e sem propriedade privada.

No plano geográfico-espacial, este tempo, primordialmente restrito a pequenos bolsões da Europa Ocidental, passou a comandar os ritmos de uma produção material cujo cenário tangível confundiu-se com o mundo inteiro. Coerentemente, esta regulação social do tempo opõe-se explicitamente ao particularismo e por extensão, à heterogeneidade, manifestada na presença simultânea de diferentes regulações sociais do tempo-espaço. Ao contrário das acepções perduráveis dos antigos tempos sociais, a concepção que surgiu na Europa Ocidental não era espacialmente circunscrita, e sua propensão era o domínio do horizonte: "Às caravelas e a imprensa, se junta a pólvora, atrás de cujo poder de morte, a noção de obstáculo desaparece" (BETTANINI, 1982: 24).

Esta profunda alteração dos padrões sensíveis que no passado caracterizaram as sociedades humanas em geral e que hoje demarcam a maior encruzilhada de que a humanidade jamais teve notícia, atenderam a uma estratégia deliberada de colocar povos e regiões a serviço da acumulação de capital, sempre encabeçada pelo tempo linear e progressivo. Em função desta

\footnotetext{
${ }^{20}$ Também conhecido na forma latinizada de Gerhard Mercator (1512-1594), este geógrafo criou
} 
necessidade, foram profanados e mortificados todos os espaços, criados ou reelaborados outros signos, símbolos e estigmas, cruciais para a organização do tempo social, do espaço habitado e da requalificação de seus habitantes humanos e não-humanos.

Seqüelas que apenas um detalhamento mais preciso do tempo da modernidade poderia explicitar.

\subsection{A Hegemonia dos Tempos Modernos e suas Seqüelas}

Dificilmente seria possível identificar mudanças em qualquer âmbito desobrigando-se da salutar atribuição de anotar a substituição dos símbolos e das manifestações do poder constituído à medida que este muda de mãos ao longo do tempo histórico. Tal pretensão seria enfim indispensável, em vista dos próprios detentores do poder jamais se eximirem de demonstrar quem, no final das contas, detém as rédeas do domínio da sociedade.

Nessa pauta de considerações, os ícones que expressam o controle material do fruir do tempo ocupam destaque obrigatório. Qual observador das sociedades poderia ser descuidado a ponto de não perceber a importância deste fato, que se manifesta em sociedades tão díspares quanto as responsáveis pela construção do conjunto megalítico do Stonehange, as estabelecidas com base no controle dos eventos sociais pelas realezas tradicionais da África Negra e no férreo exercício da instauração dos calendários nas sociedades teocráticas por parte dos imperadores orientais?

Exatamente movidos por este intuito é que se poderia primeiramente, a guisa de comentar a erupção da nova ordenação social do tempo, deter-se em apreender o simbolismo político, histórico, geográfico e cultural dos marcadores da marcha do tempo impostos sob signo do capitalismo, vale dizer, os relógios implantados nas cidades européias no transcorrer da gradativa hegemonia da 
nova temporalidade estabelecida com base na economia de mercado, assim como nos demais epifenômenos deles decorrentes.

É preciso recordar primeiramente que longe de constituir uma coincidência, a ascensão da burguesia como nova classe dominante e a implantação de relógios mecânicos nos torreões das prefeituras municipais européias foram fatos correlatos e mutuamente dependentes entre si. Esses relógios, requintados e esplendidamente instalados, para além de um marco artístico ou estético na paisagem urbana, eram o símbolo da supremacia de uma temporalidade, linear e progressiva, que constituiu a suprema materialização de um processo histórico que expurgou conotações plásticas, sensíveis, pulsantes e qualitativas da fruição do tempo, que tinham comandado os humanos no período medieval.

Neste particular, uma pista denunciadora das inquietações temporais dos antigos, fornecendo amplo cabedal de informações, pode ser encontrada na história da relojoaria. Os gnomons (ou relógios de Sol), as clepsidras (ou relógios de água) e as ampulhetas (ou relógios de areia), juntamente com uma série de habilidosos dispositivos mecânicos, foram construídos com base em princípios cosmológicos avessos à noção moderna de uma temporalidade abstrata, transcorrendo a despeito do espaço. No que era representativo das prefigurações temporais da antiguidade, o relógio solar do mundo greco-romano "raramente indicava, por meio de números, as linhas das horas, mas quase invariavelmente, as linhas do Equador e dos Trópicos estavam ali adequadamente inscritas" (PRICE, 1976:61).

Quanto aos relógios da antiguidade, embora em vários casos tecnicamente muito consistentes e intuindo conceitos mecânicos bastante avançados, como o de simulacra e de automata (respectivamente dispositivos que retratam e que se movem por si mesmos), as acepções quantitativas do tempo raramente estavam espelhadas nestes engenhos. Ao invés disto, os relógios mecânicos da Europa pré-moderna amiúde conotavam preocupações de índole completamente diferente. O mais complexo destes relógios, o construído por Giovanni de Dondi, em Pádua, no ano de 1264, continha sete mostradores, "cada um deles exibindo 
um planeta e apresentando toda sorte de dados astronômicos e, mais um modesto mostrador extra, que marca o tempo" (PRICE, 1976: 41, grifo nosso).

Vale a pena refletir que, alicerçado num vínculo de tempo e lugar, no qual as ocorrências naturais regulares desempenhavam importante papel, o mundo tradicional fundamentalmente se reconhecia em razão de um espaço-tempo, e não de um tempo-espaço. Contrariamente à modernidade, a tradição conferiu o espaço como a suprema medida do tempo, paradigma plenamente constatado numa vasta gama de manifestações da cultura espiritual dos antigos. Não é a toa que mesmo nas chamadas línguas "modernas", caso do alemão, do inglês, do castelhano e muitas outras do tronco indo-europeu, percebe-se esta tendência pela persistência, na nomenclatura dos dias da semana, dos nomes de astros e planetas, adotados como marcadores espaciais para a fruição do tempo. Seguramente, muito mais que regido por um tempo próprio, o homem do passado sentia-se em comunhão com toda sorte inferências cósmicas, que os "relógios" da antiguidade e outras formas de controle da fruição do tempo procuravam atestar.

Em nada disto diferia a velha ordem feudal. Cabe aquilatar, no medievo o tempo estava sacralizado, ordenado mediante um calendário povoado por santos, procissões, peregrinações, cultos e festividades religiosas dos mais diferentes matizes. O transcorrer do dia, era normatizado pelos ofícios religiosos, por preces obrigatórias e por toda sorte de rituais. O tempo não possuía aquele valor que mais tarde se tornaria sua característica inseparável. O homem medieval vivenciava o tempo como o tempo da vida dos homens, e não como algo exterior a ele. O badalar dos sinos, representação máxima de um tempo eclesiástico, não era sentido como uma entidade neutra, mas antes, como uma materialidade, conectada com as práticas do cotidiano. Esta regulação social do tempo era ainda influenciada pelo predomínio dos ciclos agrícolas como principal meio de subsistência, cuja sazonalidade foi, em maior ou menor grau, assumida pelo tempo da Igreja.

Entretanto, sob o carrilhão dos torreões municipais, o ciclo de produção do artesão deixou de ser determinado pela alternância das estações ou pelas oscilações climáticas. 
Se o agricultor estava diretamente envolvido no ciclo natural e não podia livrar-se dele a não ser com dificuldade e incompletamente, o artesão da cidade estava ligado à natureza por relações mais complexas a contraditórias. Havia criado entre ela e ele um ambiente artificial constituído por seus diversos instrumentos de trabalho e por todas as espécies de dispositivos a mecanismos que mediatizavam suas relações com o ambiente natural (GOUREVITCH, 1975:279).

Crescentemente, o homem percebia-se como criador autônomo de seu próprio mundo artificial, distinto da natureza:

A atividade dos vendedores exige que as distâncias entre os pontos comerciais sejam vencidas rapidamente. Os empresários se preocupam em produzir o mais possível numa unidade de tempo determinada e de aumentar o tempo de trabalho; os pequenos artesãos a os operários têm interesse em que as horas de trabalho sejam medidas com precisão. $O$ tempo, ou mais precisamente a hora se torna a medida do trabalho. Ele adquire grande valor, transformando-se em fator essencial da produção (GOUREVITCH, 1975:280, grifo nosso).

Se a temporalidade eclesiástica podia mostrar-se displicente quanto aos aspectos quantitativos do tempo, evidentemente tal não poderia ocorrer com o tempo social de mercado. Assinalar a passagem do tempo através da posição do Sol no horizonte, pela passagem dos equinócios e dos solstícios, pela sucessão das dinastias, pela implantação dos pontificados, pela celebração das festividades religiosas, pela passagem dos cometas e das estrelas cadentes ou pelo calendário agrícola, deixou de fazer sentido em um sistema no qual a própria hora transformou-se em uma mercadoria.

Esta inferência foi registrada pelo inventor norte-americano Benjamin Franklin no aforismo que se tornou a grande referência simbólica do mundo moderno: Tempo é Dinheiro. O tempo linear, ao se infiltrar em domínios tão diferenciados quanto as relações de trabalho, o convívio social e o lazer, tem justamente nesta frase, uma reconhecida máxima da modernidade. Ela explicita o consenso social do mundo moderno pelo qual uma eficaz administração do tempo, sob o signo da velocidade, da rapidez e do revolucionamento permanente da produção e do conhecimento tecno-científico, constitui a base que habilita aos homens a geração de riquezas. Uma pregação constante, por vezes apaixonada, em prol de um 
trabalho físico ou mental incessante, coberta de objeções éticas e morais quanto ao ócio e a sensualidade, ao sono e as conversas ociosas, tornaram a perda de tempo no primeiro e principal de todos os pecados (WEBER, 1967:112).

Esse tempo impessoal, cujo caráter sobrenatural liga-se a sua essência nãonatural, foi gradativamente imposto ao conjunto da sociedade, internalizado pelos seus atores sociais e posteriormente colocado como regente da totalidade do mundo conhecido. No Renascimento, com a criação dos relógios de bolso, foi dado o primeiro passo para tornar corporal o ritmo social hegemônico. Mais tarde, com os relógios de pulso, desdobramento dos de bolso, este ritmo fica permanentemente à vista dos seus portadores, uma garantia da sincronia dos dinamismos corporais com as demandas temporais solicitadas pelo sistema.

Embora em princípio esta obsessão com as finalidades práticas do uso do tempo não estivesse necessariamente vinculada com uma precisão de ordem técnica, ela não tardou em tornar-se uma referência inquestionável, impondo-se virtualmente a todos os membros da população. A difusão do relógio mecânico, um fenômeno que data dos finais do século XVIII, foi de significação-chave para universalizar um tempo vazio, separado do espaço, quantificado de maneira a permitir a designação precisa de zonas do dia, como por exemplo, a jornada de trabalho (GIDDENS, 1991:26).

A socialização do aparato biológico, constituindo uma fisiotécnica, perpassada por relações desiguais e hierárquicas, passa a comportar a explicitação de uma instrumentalização das diferenças dos corpos preocupada com seu disciplinamento para levar a cabo os intuitos da nova temporalidade triunfante (VIDART, 1996). No caso da classe trabalhadora, essa domesticação incluiu processos particularmente mortificadores, brutais e violentos. Por exemplo, no Século XVI, a população rural inglesa, expropriada e expulsa de suas terras e, em seguida, compelida à vagabundagem, "foi enquadrada na disciplina exigida pelo trabalho assalariado por meio de um grotesco terrorismo legalizado que empregava o acoite, o ferro em brasa e a tortura" (MARX, 1975b:854).

A vigilância patronal que se estabeleceu sobre o tempo de trabalho foi desde o princípio objeto de escrupuloso controle. Seu exercício corporificou um confisco 
da temporalidade humana paginado através de um dos mais opressivos capítulos da exploração do homem pelo homem jamais registrados na história. Na ausência dessa premissa, o industrialismo, alicerçado sobre um terreno crivado de crimes contra o campesinato, ambientado em saques, roubos, encarceramentos, profanações e reformatórios, incluindo práticas genocidas, trabalho infantil, migrações forçadas e usurpação de direitos das populações tradicionais, nunca teria obtido o menor sucesso.

No detalhamento cada vez mais preciso da apropriação do tempo alheio, o taylorismo ${ }^{21}$, edificado como doutrina disciplinar do trabalho seriado nos Estados Unidos a partir do princípio do século $\mathrm{XX}$, prontificou-se como um paradigma máximo da temporalidade capitalista. Empenhado numa guerra aberta e declarada contra as leituras do tempo discrepantes das que endossava, o taylorismo impôs uma standartização forçada, quebrando e usurpando as formas tradicionais de organização do trabalho. Sob sua chancela, nunca mais a rotina das oficinas foi a mesma:

...os capatazes impuseram a nova modalidade de trabalho repetitivo e designaram tarefas segundo ordens patronais. Os cronômetros se instalaram sobre os ombros dos operários qualificados para descobrir seus tempos e movimentos. Com estes índices, logo se elaboraram tábuas de produção sujeitas a ritmos muito mais intensos. Através do roubo do saber artesanal, o taylorismo transferiu, em bloco, o conhecimento das operações e os projetos à gerência (KATZ, 1995:14, grifo nosso).

Nesta sina, o tempo social, acompanhando o frenético ritmo de desenvolvimento das forças produtivas, distanciou-se das inferências provenientes da natureza, sobrepondo-se a elas. O relógio atômico do Século XX constituiria o símbolo quase paradigmático deste tempo. Ele assinala a passagem dos segundos, minutos, horas, dias, meses e anos, ativado por uma central própria de energia, sinal de que o tempo social baniu o tempo da natureza. O novo tempo inaugurado pelo mercado criou um mundo à sua própria imagem, no qual o início e o final do dia deixaram de ser governados, como sempre o fora no passado do

21 Neologismo referente a Frederick Winslow Taylor (1856-1915), considerado "pai da produtividade", autor de The Principles of Scientific Management (1911). 
homem, pelo movimento do Sol, da Lua ou das estrelas. Este é agora demarcado pelo transcorrer da jornada de trabalho, independentemente do período do ano ou das condições meteorológicas.

O tempo linear e progressivo, emanação de forças sociais que subentendem os humanos e a natureza como elementos à disposição do progresso e do desenvolvimento, excluiu todas as acepções sensíveis porventura assimiláveis ao intelecto humano. As presentes em solo europeu num primeiro momento. As do restante do mundo, no seguinte. A dimensão cósmica que sempre havia habitado o tempo e o espaço, entrelaçando a ambos e os unindo simultaneamente aos humanos, foi abolida e substituída por uma outra, de cunho eminentemente prático e quantitativo, descolando o tempo do espaço. A ruptura desta parceria com o espaço representou a possibilidade do tempo substantivar-se em uma cronologia temporal alheia a qualquer outra determinação, e nesta, um certo sentido de velocidade que passou a ser a marca característica da modernidade (GREGOTTI, 1975:77).

Estendido retilineamente, o tempo, diferentemente das concepções de outrora, deixou de possuir uma "respiração", de ser uma entidade viva e pulsante. Em franca oposição a um modelo cíclico que foi, dentro de determinados limites, o grande paradigma temporal das civilizações de outrora, o tempo linear projeta a história continuamente para frente. Preconizando uma ênfase evolutiva estranha a qualquer outro padrão civilizatório do passado, esse tempo necessariamente entra em contradição com modos de vida regrados pela estabilidade, pela repetição, pelo convívio com as energias sutis do corpo, do território e do cosmos.

Outra conseqüência (visto que as dinâmicas temporais predominam sobre quaisquer outras), é que o espaço, desencaixado do tempo e a ele subordinado, também perdeu sua significação sensível. O homem da modernidade, contrariamente aos seus ancestrais, é sumamente um ser que trafega junto aos fluxos do tempo, que subordina seu cotidiano em meio a um espaço crescentemente indiferenciado. Caracterizado por fluxos de produção avessos ao tempo-espaço natural, o tempo linear e progressivo termina por adiantar-se ao próprio espaço construído, que constitui seu reflexo direto. 
Esta prevalescência ontológica do tempo está muito longe de constituir uma afirmação meramente conceitual. Pelo contrário, ela se expressa no mundo material, com variados reflexos no universo vocabular do homem moderno, conotando formas específicas de apreensão do espaço. No dia-a-dia, o homem contemporâneo apela constantemente, quase sem perceber, para expressões de cunho temporal quando se defronta com a necessidade de mensurar ou de qualificar distâncias. Por exemplo, ele refere-se à "horas de viagem", "minutos de trajeto", "tempo de percurso" para assinalar distâncias entre pontos no espaço geográfico. Mesmo quando a referência é o espaço sideral, esta tendência manifesta-se pela utilização de marcadores como o "ano-luz", cuja conotação temporal é por si mesma evidente.

Ao contrário das culturas tradicionais, nas quais o passado era honrado e os símbolos valorizados por conterem a experiência de gerações, na modernidade este parâmetro temporal deixa de contribuir para com que é definido como "segurança ontológica". Nesta ótica, o que é considerado pretérito passa a ser totalmente abstraído de sentidos significativos por um mundo no qual o próprio presente tornou-se um instante fugidio, um lapso que vai do passado para o futuro e transforma rapidamente o futuro em passado (GOUREVITCH, 1975:282).

$\mathrm{O}$ antes e o depois se tornaram marcos de uma marcha processual na qual o futuro, assim que é capturado pelo presente, é rapidamente erodido e transformado em um aluvião composto de partículas cuja inteligibilidade, uma vez desfeito o sentido organizador do presente, desaparece. Com isso, a própria memória do passado também é eliminada. Os eventos, sucedendo-se rapidamente, são metamorfoseados em simulacros, encarcerados em um caleidoscópio que virtualiza seu sentido, fluindo por breves momentos perdidos na voragem de um tempo dominador e inflexível. Sinteticamente, a modernidade é um modo de vida em que tudo se torna prontamente parte do passado.

Desta forma, o tempo, não mais vivenciado como o tempo de cada coisa, mas sim, como um ritmo ao qual todo homem deve se submeter, é unificado em uma escala cada vez mais ampla. O sistema de redes ferroviárias construídas na Europa ao longo do século XIX, concorre para sua padronização em nível do 
Estado-nação, pela implantação das horas oficiais e logo em seguida, na sincronização dos continentes, através da criação do sistema internacional dos fusos horários. Os trilhos, estabelecendo uma comunicação regional, nacional e posteriormente internacional, expandem ao longo de milhares de quilômetros um tempo único, tornado padrão para todos os demais tempos.

Esta sincronização é sucedida pela exatidão. A temporalidade moderna encontra sua explicitação mais acabada no relógio digital. Ao contrário dos relógios oriundos do Renascimento, que ainda resguardavam reminiscências do extinto tempo cíclico, com mostradores e ponteiros dando voltas ao redor de um eixo, esta última manifestação da circularidade do tempo é secundada pelo cristal líquido dos relógios digitalizados. O tempo passa a cristalizar-se, desintegrando-se molecularmente para ressurgir com base em um novo impulso elétrico. Graças ao quartzo, mesmo as frações de segundo são poupadas do desperdício.

Nos locais de trabalho, nos meios de comunicação e ao longo das vias expressas das urbes modernas, os relógios digitais lembram incessantemente que sua onipresença é sinal de que os humanos, paradoxalmente, deixaram de possuir qualquer tempo. Anteriormente múltiplo, permeável e qualitativo, o tempo carrega agora consigo a marca inelutável da opressão. Ele é inerente a um sistema de produção de mercadorias sob cujo tacão é mister que o trabalho se efetue ordenadamente, com vistas a um fim (MARX, 1978:17).

Este processo encontra seu grande paradigma na moderna linha de montagem. Ela foi primeiramente concebida nos matadouros nos finais do século XIX (Vide KATZ, 1995:15), e aplicada na indústria automobilística por um entrepreneur, o famoso Henry Ford, que coerentemente era um relojoeiro de origem $^{22}$. A Era Industrial somente pode ser explicada por uma máquina-chave que não é a máquina a vapor, mas sim, o relógio. O contrário seria fetichizar a

\footnotetext{
22 Henry Ford (1863-1947), também chegou a esta concepção com o concurso das idéias de Frederick W. Taylor, de Henry Fayol, tido como o tutor da estrutura por funções, autor de General Principles of Management (1916) e do sociólogo alemão Max Weber (1864-1920), cujas teorias a respeito do modelo burocrático foram fundamentais para a moderna teoria da organização. Caberia uma advertência aos que sinonimizam o fordismo, assim entendido como o modelo implantado por Henry Ford nas suas indústrias, ao sistema capitalista. Muitos autores recordam a similaridade entre os seus métodos e os que foram implantados na década de 30 na antiga URSS sob a égide
} 
máquina. Isto porque a máquina não existe sozinha, mas sim, como representação concreta de uma organização do tempo à qual está ajustada, a cuja lógica acata e obedece. Seria cabível comentar, a lógica da fabricação inequivocamente antecede ao sistema do que é fabricado (VIDART, 1996). Assim sendo, as engrenagens constituem antes a materialização de uma concepção de tempo do que origem da sua manifestação.

O severo reducionismo do tempo linear e progressivo, ao encarcerar esta esfera sensível em prol de compromissos sem rosto, que são sua tradução sociológica, redundou em um mundo universalmente povoado por estranhos (Vide GIDDENS, 1991:84). Submerso pelo narcisismo, o atomizado homem contemporâneo está obcecado por dúvidas, angústias, perturbações e distúrbios toda vez que o reflexo do outro o alcança. Acostumados com a vida de cada um por si, tornou-se difícil para o homem contemporâneo, "compreender que para a maior parte da história do homem, todos os homens viviam uma vida, por necessidade, envolvida com o bem estar dos seus semelhantes" (MC LUHAN e FIORE, 1971:24).

Sob o impulso catalizador da progressividade, os homens foram induzidos a uma volubilidade pela qual, os relacionamentos, tal como as coisas, foram se tornando cada vez mais transitórios, efêmeros. Consolidou-se o que tem sido classificado como Era da Transitoriedade (passim, TOFLER, 1973). Enfraquecidos os laços que atavam um humano aos demais, o mundo moderno substantivou-se a partir de uma ruptura radical com a antiga vida pública, que deixou de atuar como fator de interação (BETTANINI, 1982:130/131). Com isto, aquele equilíbrio no final das contas tão necessário para a estabilidade emocional do homem, também deixou de existir. Multidões de pessoas estão agora preocupadas, mais do que nunca, apenas com as histórias de suas próprias vidas e com as suas emoções particulares (SENNETT, 1993:17).

Anteriormente à eclosão do tempo linear e progressivo, o entrelaçamento da vida comunitária com seu espaço de vida constituía um embasamento prioritário para os velhos modos de produção, articulando-se com a personalidade cultural 
dos grupos e o funcionamento dos arranjos espaciais. As antigas formações sócioespaciais prescreviam enquanto códice magno para suas opções civilizatórias, diretivas de perdurabilidade, sustentabilidade e estabilidade, observáveis nos relacionamentos mantidos com a natureza como nos que regravam a vida social. Desta máxima raramente o conjunto da pré-modernidade raramente se afastou.

Contudo, tal normatização, básica no passado para uma apreensão qualitativa do cosmos e do homem foi preterida e abandonada pela adoção das novas premissas reducionistas e quantitativas, afeitas à implantação da temporalidade moderna. A sociedade contemporânea perdeu de vista que, na história, ao lado da evolução, o elemento estável desempenhou papel fundamental (GOUREVITCH, 1975:283).

Neste novo ditame, produzir é melhor do que viver; consumir, melhor do que perpetuar; mudar, preferível a permanecer; e quem sabe, como destacou o cineasta David Cronemberg na sua película Videodrome (1982), virtualizar muito melhor do que existir.

Frente à tamanha e tão detalhada elaboração implicando numa supremacia temporalmente totalizante, surgiria a tentação de indagar sobre os rebatimentos espaciais desta postura. Afinal, o que poderia se equiparar em termos de ineditismo frente a ela?

É exatamente este caráter nunca visto que incita a refletir um pouco mais aprofundadamente sobre este tema, ampliando o nosso próprio potencial de respostas e de perspectivas.

Stakhanovismo - foram extensivamente classificadas como uma espécie de fordismo socialista. 


\section{CAPÍTULO 4}

\section{URBANI ZAÇÃO, TECNOSFERA E OS LI MI TES DO TEMPO}

\subsection{Progressi vi dade, Moderni dade e o Contexto da Cidade}

Refletir a respeito da temporalidade moderna em momento algum poderia se desvencilhar do mapeamento dos indicadores concretos e abstratos que motivaram o mundo europeu a encerrar de modo tão abrupto os modos tradicionais de relação com o universo. Foi observado, à medida que se impunham os parâmetros cultivados pelo pensamento renascentista, o mundo medieval europeu era sacudido nos seus alicerces e substituído por um novo sistema de valores, que desmantelava sem piedade as antigas verdades.

Inequivocamente, surgiria a predisposição em definir a nova situação criada pelos tempos modernos como uma inversão profunda da existência social dos humanos, ao menos no tocante ao depoimento da sua forma imemorial de compreensão e de interação com o universo. O triunfo da razão enquanto alicerce do entendimento da realidade inseriu problemáticas inéditas, perceptíveis até os dias atuais. Meditando a respeito, a socióloga Glória Maria dos Santos DIÓGENES recorda que tal racionalização do mundo estaria

...carregada daquela angústia mítica radicalizada travestida de controle, de certeza, de onipotência, de exatidão, da verdade, do não-medo. O homem seria o mentor do progresso, o construtor de sua história, o transformador da natureza, e com isso, mudaria a feição do mundo e a de si próprio. Progresso vem significar domínio, em relações reconhecidamente assimétricas, onde se justifica em seu nome a morte das 'culturas atrasadas', de povos que entravam o desenvolvimento, das tradições que insistem em manter crenças fora dessa 'nova' ordem universal (1992:3).

Constituindo seu sucedâneo obrigatório, o cadenciamento do tempo proposto pela modernidade, em face da nítida precedência conquistada na nova ordem das 
coisas, reclamaria sobremaneira o essencial das nossas atenções. Prisioneira de um tempo subtraído do corpo vivo de uma história dantes plena de significados, a humanidade terminou assombrada pelo espectro de um tempo exclusivista e absoluto:

Dissemos que a cidade havia se tornado senhora de seu próprio tempo; quer dizer que este fugira ao controle da Igreja. Mas também é verdade que precisamente na cidade o homem deixa de ser senhor do tempo, pois este, tendo futuramente a possibilidade de fluir independentemente dos homens e dos eventos, estabelece a sua tirania, à qual os homens são obrigados a se sujeitar (GOUREVITCH, 1975: 282).

Visto que as dinâmicas temporais predominam sobre quaisquer outras, uma conseqüência inevitável foi que o espaço, uma vez desencaixado do tempo, terminasse despossuído de sua significação sensível. O homem da modernidade é sumamente um ser que trafega junto aos fluxos do tempo, que subordinam seu cotidiano em meio a um espaço crescentemente indiferenciado. Na modernidade, como destacou Anthony GIDDENS, "a coordenação através do tempo, é a base para o controle do espaço" (1991:26).

Numa assertiva que constitui desdobramento direto do que se tem discutido, no passado, a produção do espaço era um evento condicionado por impulsos temporais encadeados ao próprio espaço, e este, por sua vez, era uma précondição para a reprodução de determinado tempo social. Mas com o surgimento da economia de mercado, é o tempo que está no comando processual de todos os dinamismos, consideração que reportaria ao sentido de velocidade que em particular, tipifica este novo momento da história da humanidade.

Por conseguinte, não surpreende que na modernidade, ao contrário das sociedades tradicionais, nas quais o passado era honrado e os símbolos valorizados por conterem a experiência de gerações, o passado tenha deixado de constituir um referencial existencial. Encarnando um tempo descompassado das demais dinâmicas e via de regra, adiantado a elas, a espacialidade do tempo linear ganha uma conotação de transitoriedade que é, tão somente, a manifestação de uma temporalidade que rege soberanamente a edificação das 
marcas espaciais de um modelado eminentemente artificial. Não por outra razão senão pelo fato de que na modernidade, nada é permanente.

A velocidade dos fluxos, materializada numa espacialização incontida e irrefreável dos tempos modernos, é uma característica observável a todo o momento na paisagem urbana contemporânea ${ }^{23}$. O espaço, estando premido por um tempo preocupado com a vazão incontrolável do seu dinamismo, é levado a uma transmutação constante. Disto decorre a constante reespacialização do espaço urbano, agregando elementos novos que vão sendo constantemente incorporados à paisagem criada na substituição dos antigos, descartados sem demora. Caracterizado por fluxos de produção avessos ao espaço-tempo natural, o tempo linear e progressivo termina por adiantar-se ao próprio espaço artificial ou espaço-prótese, que é seu reflexo direto.

Por esta razão, os sistemas voltados para a fruição do tempo são constantemente esgotados e substituídos por outros mais novos e mais velozes ainda. No caso da malha viária, é isto que leva, por exemplo, ao asfaltamento das estradas de terra e à duplicação das já asfaltadas ${ }^{24}$. No meio urbano, tal variável orienta a construção de corredores de alta velocidade, implantação ou expansão dos sistemas de metrô e surgimento de serviços de comunicação aérea (helicópteros executivos). Idêntica expressão desses fluxos, os sistemas de comunicação que rasgaram o leito submarino e desafiaram longos braços de mar, unindo a Grã-Bretanha ao continente europeu e unificando as ilhas do arquipélago nipônico, antecipam o dia em que o mundo inteiro poderá estar cortado por escoadouros do tempo linear.

$\mathrm{Na}$ medida em que se decantam os fluidos do tempo, forma-se um cenário artificial composto por plásticos, aço, vidro, alumínio, concreto e asfalto, materiais que se confundem com a própria vida moderna. Os obstáculos a artificialização incessante do ambiente são canalizados ou retificados (rios, córregos e arroios), drenados (pântanos e alagadiços), aplainados (morros, colinas e matacões) ou

\footnotetext{
${ }^{23}$ Este frenesi está admiravelmente captado na película Koyaanisqatsi (1983), dirigida por Geofrey Reggio.

${ }^{24}$ Note-se também a força locacional das marcas espaciais pretéritas promovendo a reapropriação das rugosidades presentes no espaço habitado.
} 
aterrados (reentrâncias da topografia). As cidades, nascendo no entrecruzamento destes fluxos ou nos pontos nos quais momentaneamente são interrompidos ou se detêm, formam concreções, nódulos, terminais e pontos fixos, espaços que concentram um quantum maior de conteúdos de tempo, uma contigüidade que se expressa simultaneamente nos aspectos concretos e simbólicos dos humanos.

Contudo, a expansão da artificialidade não está qualificada unicamente pela alteração da natureza primeira ou das suas reminiscências. Vivências oriundas de uma acumulação passada de tempos terminam igualmente recompostas, refeitas e recombinadas, pois na artificialidade moderna, tudo é transitório. Esta transmutação do espaço é inerente ao predomínio do tempo linear e progressivo, que vai corroendo inexoravelmente os sinais do passado. Deste modo, o arquiteto Luís SAIA, recorda que no caso do primeiro assentamento urbano de São Paulo, utilizando paredes de taipa de pilão, dele nada restou nas reconstruções urbanas posteriores, que apagaram todas as suas marcas (1978, ver também CARLOS, 2001:33).

Daí decorre a dificuldade de se vislumbrar a história que se descortina diante dos próprios olhos: "Quem desembarca em São Paulo reconhece a história dos objetos presentes, mas não a história da cidade" (SANTOS, 1988:68, 1998:138). Neste caminho perpassado por (des)entendimentos, a cidade, obra humana lato sensu, não impõe sua presença apenas pela acumulação de tempos. A perda dos referenciais urbanos, respaldando um espaço amnésico e um tempo efêmero, constituem produto da rapidez com que a morfologia se transforma, redefinindo a prática socioespacial e fazendo a todos mergulhar, queira-se ou não, na vertigem do vácuo (CARLOS, 2001:348).

Outro dado, é que, independentemente das metamorfoses da paisagem urbana tidas como "espontâneas", estas também podem resultar de um planejamento premeditado. Neste caso, elas geralmente ocorrem sob o signo da prepotência dos planejadores, podendo remeter, como no caso da célebre intervenção promovida na Paris do século XIX pelo Barão Eugène Haussmann, a uma verdadeira tabula rasa. Visando implantar vias rápidas de circulação, racionalizar a ocupação do espaço urbano, segregar espacialmente as classes 
sociais e inclusive, controlar a turbulência do proletariado, Eugène Haussmann (le artisté démoliseur), não hesitou em desmantelar severamente o traçado urbano anterior, considerado inadequado para as exigências da "vida urbana moderna".

Certifique-se, porém que a cidade moderna, planejada ou não, oriunda de tempos passados ou construída de alto a baixo pelos influxos da economia moderna, prima de um modo ou de outro pela artificialidade. Este é o seu mandato e a sua essência mais íntima. Não existe cidade alheia ao tempo mundializado ou à sua mais costumeira manifestação, que é o mercado. Conseqüentemente, de uma forma ou de outra, o meio urbano é cada vez mais um meio artificial, fabricado com restos de uma natureza primitiva crescentemente encobertos pelas obras dos homens (SANTOS, 1988:42).

Vale asseverar, na modernidade a inércia espacial, ou seja, a tendência do espaço motivar revivificações e retomadas do tempo social, constitui basicamente um desdobramento tendencial da instalação do tempo no espaço e não, como nas sociedades tradicionais, uma irradiação do tempo a partir das marcas espaciais pré-existentes. Particularmente, o modelado urbano reflete um torvelinho do tempo, sugando recursos e trabalho humano, fazendo cristalizar próteses urbanas, nódulos de tempo nos quais o espaço é articulado para responder às suas demandas. É do tempo e do seu dinamismo - concreto e simbólico - que se pode compreender a difusão e supremacia da vida urbana, indiscernível do padrão temporal com o qual se confunde.

A cidade, articulação espacial na qual primeiramente acomodou-se o tempo linear, foi o eixo por excelência de sua difusão, daí a urbanização enquanto um fenômeno típico da modernidade. Funcionando como um foco de irradiação de dinâmicas temporais colocadas permanentemente à sua frente em razão do dinamismo irrefreável do próprio tempo, as cidades atraíram recursos materiais e humanos numa razão diretamente proporcional à ampliação da influência do campo de força do tempo. O ritmo temporal iniciado a partir de alguns rincões isolados da Europa Ocidental, ganhou não só conotação planetária como também, manifestou firme determinação em colocar a maior parcela da humanidade sob seu controle direto. O meio urbano, constituindo o âmago da ordem econômica, 
social e geopolítica existente, transformou o Planeta inteiro numa espécie hinterland, num entorno da rede mundial de cidades (Ver BOYDEN e CELECIA, 1981).

Obviamente, ao formar um modelado artificial, o espaço urbano não pode subentender os humanos enquanto um mero elo de uma "cadeia ecológica". Afinal, estou referindo-me a um espaço construído, e não aos que foram presenteados com adereços de naturalidade. De um ponto de vista ambiental, as relações que os homens sustentam com a natureza num meio urbano alteraram enormemente o ritmo e o funcionamento dos ecossistemas, diferindo do que se encontra nas inter-relações dos fatores fisiográficos. Estes passaram a variar de acordo com uma estratificação social e dificilmente tendem à perdurabilidade, podendo ser mais bem definidos como antagônicos e de ruptura dos equilíbrios (SOBRAL et AMARAL e SILVA, 1989:75, SEABRA, 1991).

Suprema materialização do que se define como distanciamento do tempo social para com os ritmos e cadências do tempo-espaço natural, a cidade, enquanto um sistema de engenharia (SANTOS, 1978a e 1988), expressa uma construção do espaço que sendo incessante, requisita um imenso volume de recursos naturais, indispensáveis para o abastecimento e funcionamento dos seus ciclos artificiais de vida. Embora dependente de uma vasta periferia de ecossistemas, a grande cidade moderna, ao mesmo tempo em que traga recursos do entorno natural, não retribui senão enquanto um foco de permanente e sistemática agressão à natureza, tendência esta indissociável pelo próprio volume de recursos que incessantemente é instada a açambarcar.

As cidades, como insiste o ecólogo Genebaldo Freire DIAS, "são pontos emanadores de indução de alterações ambientais globais" (2002b:15). Tal observação é confirmada pela grande influência das cidades sobre o consumo de matérias primas. Uma avaliação presente em um estudo elaborado pela prestigiosa organização ambientalista WorldWatch Institute, assegura que "as cidades ocupam cerca de $2 \%$ da superfície terrestre, mas contribuem para o consumo de $76 \%$ da madeira industrializada e 60\% da água doce" (JOHN, 2000). $\mathrm{Na}$ mesma linha de raciocínio, um levantamento sintético aponta que o meio 
urbano absorve cerca de $75 \%$ dos recursos naturais planetários (Vide DIAS, 2002b:15).

Um outro tipo de avaliação quantitativa se insere no conceito de ecological footprint (literalmente "pegada ecológica"), correspondendo à área equivalente de terra produtiva e ecossistemas aquáticos necessários para gerar bens requeridos por determinado padrão social e cultural e para assimilar os resíduos decorrentes das demandas de uma dada população, sob um determinado estilo de vida. Com base neste parâmetro, observa-se que as cidades são sustentadas à custa da apropriação dos recursos de áreas muitas vezes superiores à sua área urbana, determinando um "déficit ecológico" (Cf DIAS, 2002b:31 e 185/194 e ISA, 2004: 42 e 360).

De acordo com o especialista suíço em planificação ambiental Mathis WACKERNAGEL, as 29 maiores cidades européias requisitam, para o atendimento das suas necessidades, áreas entre 565 a 1130 vezes maiores do que aquelas que em tese estão ocupando (1998:2/3). Outro bom exemplo é o alerta de que uma cidade como Londres, na Inglaterra, requer uma área 58 vezes maior do que a que ocupa para obter alimentos e madeira para sustento de seus habitantes. Neste raciocínio perturbador, caso o padrão das metrópoles afluentes fosse estendido ao resto das populações urbanas do mundo, seriam necessários três planetas Terra para sustentar todos os terráqueos (JOHN, 2000).

Não existiria, portanto, qualquer exagero em afirmar que as cidades "sugam" recursos numa escala territorial gigantesca. Esta "vampirização" do espaço-tempo natural gera zonas devastadas que se ampliam cada vez mais, pois as cidades, necessitam cobrir distâncias extraordinárias para a captação dos recursos necessários à sua existência e para o depósito de seus resíduos sólidos e líquidos (VIOLA e LEIS, 1991:33). Pressionadas por suas demandas crescentes e sob o risco de morrerem asfixiadas sob o acúmulo de dejetos, as metrópoles modernas geram impactos que se estendem numa escala extremamente vasta do tempoespaço. As cidades impactam a totalidade da biosfera, pois articuladas entre si através de circuitos que associam uma concreção urbana à outra, necessariamente transformam o mundo inteiro no vertedouro dos seus fluxos. 
Contudo, nada disso caracterizou as sociedades de outrora. Dado que as antigas formações sócio-espaciais não dissociavam, temporal e espacialmente, o campo da cidade, a rede urbana confundia-se com os terminais dos fluxos, mesclando-se à rede de tributação e às necessidades de sua preservação. Cidades maiores ou menores traduziam fluxos maiores ou menores de tributos, não correspondendo, portanto, a eventuais progressos de uma autêntica economia urbana. Todavia, com o advento da modernidade o meio rural, inversamente do passado, mais do que uma inferência para a ruralização da cidade é ele mesmo um meio crescentemente urbanizado, reprodutor das prefigurações simbólicas e da própria espacialidade urbana (MARX, 1975a: 75).

Dada a dependência do meio rural para com as dinâmicas têmporo-espaciais cujo suporte é a cidade e seu aparato fabril, não há como este se manter indiferente às solicitações da urbanização, que impõe assim uma "industrialização" da agricultura (SINGER, 2002:25/26). Para fornecer recursos à cidade - e fazê-lo rapidamente - o campo foi levado a uma padronização da produção, de elevado custo energético e dispendiosa em recursos. A agropecuária moderna, com base em agrotóxicos, maquinário agrícola, fertilizantes artificiais e na simplificação biótica, ocasiona erosão, adelgaçamento e compactação do solo agrícola, além de perdas de biodiversidade. Objetivamente, as problemáticas ambientais localizadas no campo não podem ser dissociadas das influências urbanas, que se tornam deste modo o centro de qualquer discussão ambiental desenvolvida nos termos da modernidade.

Saliente-se que este conjunto de problemáticas não se restringe aos impactos disseminados no entorno urbano ou alhures. Além de influenciar ampla periferia geográfica, ressalve-se que o meio urbano impacta antes de tudo a si mesmo, daí a necessidade de rediscuti-lo criticamente. Basicamente, os transtornos presentes nos seus ciclos artificiais de vida fundamentam-se na extrema velocidade dos inputs e outputs que percorrem este imponente sistema artificial, configurando o que muito apropriadamente podemos considerar como curtos-circuitos (passim SANTOS, 1978a e 1988). 
Exemplificando, a alteração dos equilíbrios naturais, vários deles possivelmente irreversíveis, possibilitaram o surgimento, em meio ao contexto urbano, de uma metereologia artificial ${ }^{25}$. Estes novos dinamismos climáticos, inaugurados pela urbe moderna, estão consignados nas ilhas de calor, inversões térmicas, nos bolsões de gases tóxicos e na chuva ácida, um ambiente condizente com a artificialidade do tempo social que o engendrou. Tais ciclos dinâmicos artificiais, se notabilizam pela nocividade e pelo seu caráter destrutivo. A concentração industrial e a impermeabilização do solo pelas construções e o capeamento asfáltico, propiciariam, por exemplo, a aparição de disritmias pluviométricas acompanhadas de fortes inundações. A presença de abundante material particulado em suspensão na atmosfera acelera o processo de condensação, com conseqüente ocorrência de pancadas de chuvas, que desabam em curto espaço de tempo, caracterizadas por fortes intensidades pluviométricas (Vide CASSETI, 1991:118).

Com a blindagem do espaço, os rios, privados dos seus meandros por obras de retificação ou ainda envelopados, são transformados em escoadouros de um sistema de drenagem artificial, que potencializa o débito fluvial original, tornando inevitáveis os efeitos do seu transbordamento. As chuvas tornam-se torrenciais, escoando pelos sulcos do traçado urbano (suas ruas e sarjetas), acumulando-se nos espaços antigamente ocupados por lagos, pelas várzeas inundáveis, fundos de vale e em terrenos que dantes admitiam a absorção da água. Nestas ocasiões, os rios, os córregos e os arroios desprezam as formas artificiais que procuram encarcerá-los e transbordam violentamente, provocando inundações catastróficas, rotineiras na pauta dos serviços noticiosos em todo o mundo, escorraçando intempestivamente as obras humanas que encontram no seu caminho ${ }^{26}$.

Do mesmo modo que muitos outros problemas de gestão do meio ambiente urbano, as enchentes terminam instrumentalizadas com base em soluções que agudizam ainda mais o problema. Isto em razão de que as respostas institucionais a estas calamidades correm no sentido de reforçar as superfícies pavimentadas, via implantação de coletores e sistemas de drenagem, obras que por motivos

\footnotetext{
${ }^{25}$ A respeito da temática do clima artificial, ver TARIFA e AZEVEDO, 2001.
} 
óbvios, atraem as atenções das grandes empreiteiras. Em nome do solucionamento do problema, as inundações são transferidas para locais mais distantes, o que além de não resolver a questão, acentuam o problema ao agregarem ainda mais água ao volume que não encontra infiltração no solo (BRAZIL/CANADA, 1991).

Estas ponderações tornam o espaço urbano de grande significação para o futuro da maioria dos humanos. Particularmente, pelo fato deste espaço ser o fulcro de uma torção do tempo-espaço na qual as dinâmicas temporais são predominantes. Defrontados com um estranho mundo novo regido por um tempo inexorável, os humanos - ou ao menos uma parcela destes - não deixam de ser assaltados pela perplexidade ante uma dominação que se imiscui por todos os poros da sociedade moderna, e ao materializar-se desta forma, difunde sua crise pela totalidade social que compõe a modernidade.

Por conseguinte, dada a crescente urbanização do espaço no qual o essencial da vida moderna está centrado, avançam numa mesma direção ritmos e seqüências regidos cada vez mais pelo artifício e menos pela natureza (BALANDIER, 1988:146). O mundo moderno, aprofundando visceralmente todas as contradições possíveis com a natureza, com "os outros" e com o próprio homem, parece deslumbrado em clonar sem descanso o cenário artificial emoldurado por metrópoles resplandecentes, encimadas por esguias e reluzentes torres que despontam como seu traço mais característico. Estes pináculos da modernidade, primeiramente antevistos nos rascunhos imaginários das artes para depois serem materializados junto ao real, constituem o ícone confesso da metrópole, introjetando suas expectativas, devaneios e contradições (Fig. 6 e 7).

Não restam, na modernidade, quaisquer vestígios dos antigos deuses ou forças cósmicas. O espaço foi esterilizado para que pudesse servir de matériaprima para a irrefreável propensão do tempo linear em engendrar, a partir de suas entranhas, o mundo da mercadoria. Não é demais lembrar que mercado e espaço são sinônimos, pois um não se entende sem o outro (SANTOS, 1993b:99). Tal epítome se estruturou a partir das ações convergentes do mercadeio, da

\footnotetext{
${ }^{26}$ Quanto ao fenômeno das enchentes na Grande São Paulo, Ver CUSTÓDIO, 2001.
} 
intervenção do aparato de poder e da divisão espacial do trabalho, reforçando uma hierarquia dos lugares, criando novas centralidades e periferializando pessoas e espaços. Nesse contexto, a cidade torna-se a condição geral da produção, formando uma cadeia que integra, além da mão de obra, os processos produtivos, centros de intercâmbio, serviços e, como não poderia deixar de ser, o mercado (CARLOS, 2001:14).

Dificilmente existiriam dúvidas de que a cidade se reproduz enquanto garantia de reprodução da própria artificialidade enquanto mercadoria. Nessa interpretação, o meio urbano, enquanto o grande ambiente de risco da modernidade, constituiria resultado direto da propensão de um tempo social em concentrar geograficamente aqueles elementos, tais como homens, máquinas, matérias primas e matrizes energéticas que são a garantia de sua reprodução material e subsídio último de sua materialidade. A cidade é, pois a máxima explicitação de um contexto que assinala o predomínio do tempo sobre o espaço, do interesse particular sobre o coletivo, do que é mundial sobre o que é local.

Complementando este convulsivo quadro da artificialidade, irrompem, no interior da espacialidade urbana, uma outra ordem de "disritmias", sociais no caso, cuja razão de ser repete a constância do padrão temporal que subordinou todos os demais tempos ao seu comando único. Expressão de um mundo construído sob a resoluta determinação de unificar - mas não de unir - seu resultado inevitável foi, em razão da mundialização do tempo linear estar acompanhada da integração desigual dos humanos na fruição temporal 


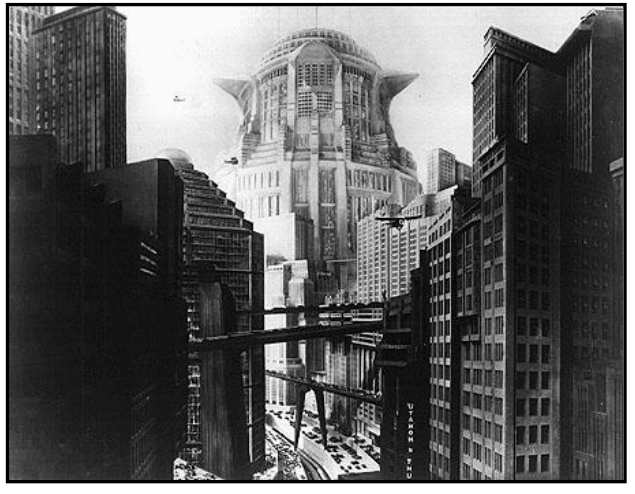

6a. A grande cidade em Metropolis

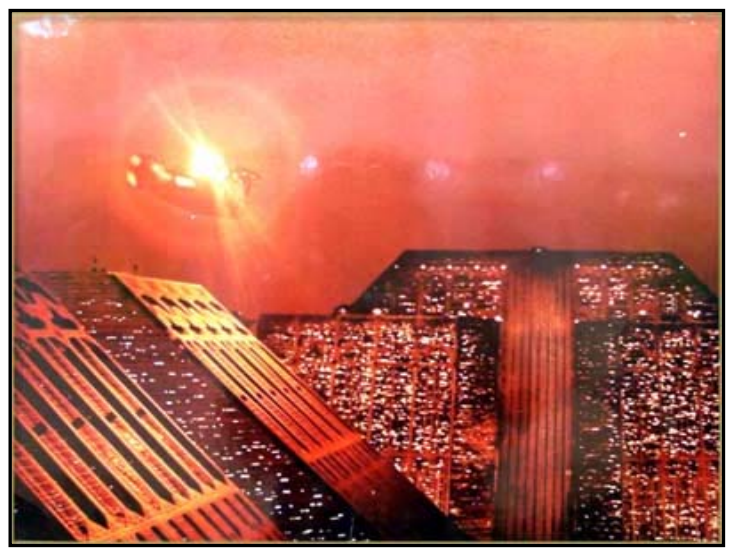

6b. A grande cidade em Blade Runner

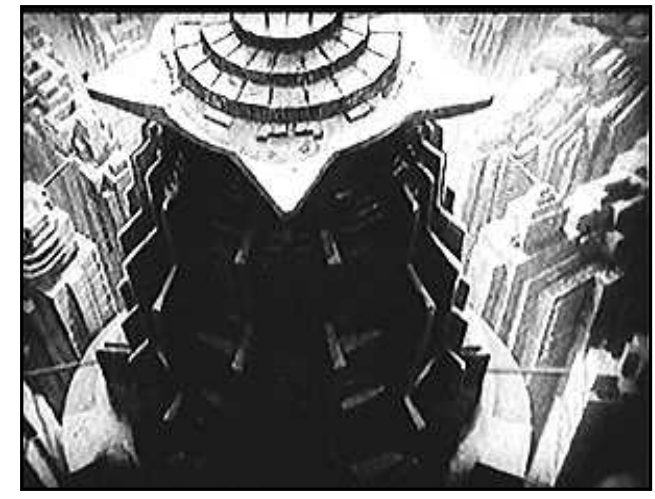

6c. A Torre Central em Metropolis

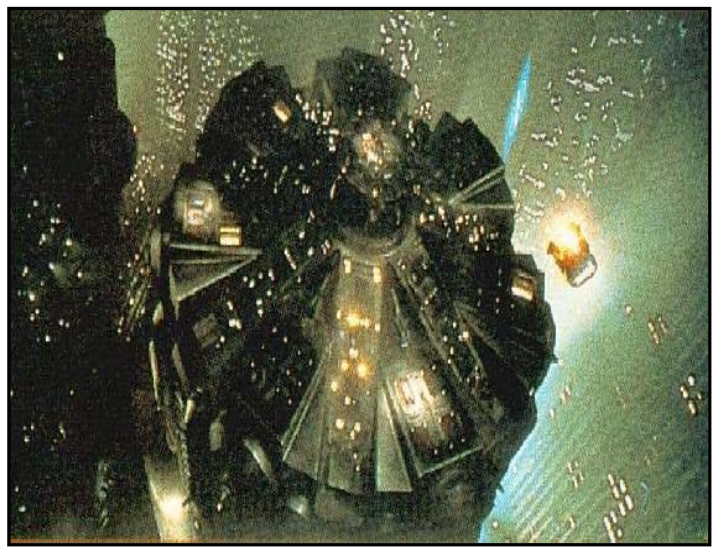

6d. A Torre Central em Blade Runner

FIGURAS 6a, 6b, 6c e 6d - As Torres Imaginárias da Modernidade: Duas das melhores películas futuristas que explicitamente abordam o tema das metrópoles e das torres, a saber, Metropolis (1927) e Blade Runner (1982), incorporam temáticas e conteúdos imagéticos bastante similares. Paralelamente à uma idêntica indagação existencial - "O Que é o Homem?" - as duas produções compartilham vários outros elementos comuns. Há, por exemplo, uma forte presença da água nas duas criações. As águas inundam Metropolis e a chuva é permanente em Blade Runner. No dois casos temos a presença de seres artificialmente combinados, com uma mulher híbrida no centro do conflito (respectivamente Maria e Rachel). As duas cidades (6a e 6b) são governadas por capitalistas poderosos, que controlam as urbes do alto das suas grandes torres (6c e 6d). As duas cidades estão caracterizadas por rígidas clivagens sócio-espaciais, os dominantes habitando as partes mais altas e os dominados, as partes baixas ou seus subterrâneos. É interessante notar que neste imaginário cinematográfico, implicitamente endossando uma linha de reformismo político, as torres, a despeito das contradições que suscitam e promovem, são poupadas e a ordem existente não sofre maiores abalos. (Fonte: 6a: <http://jahsonic.com/Metropolis.jpg>; 6b, 6c e 6d: <http://www3.sympatico.cal philippe.lemieux2/index.html>, acesso em 26-08-2005) 


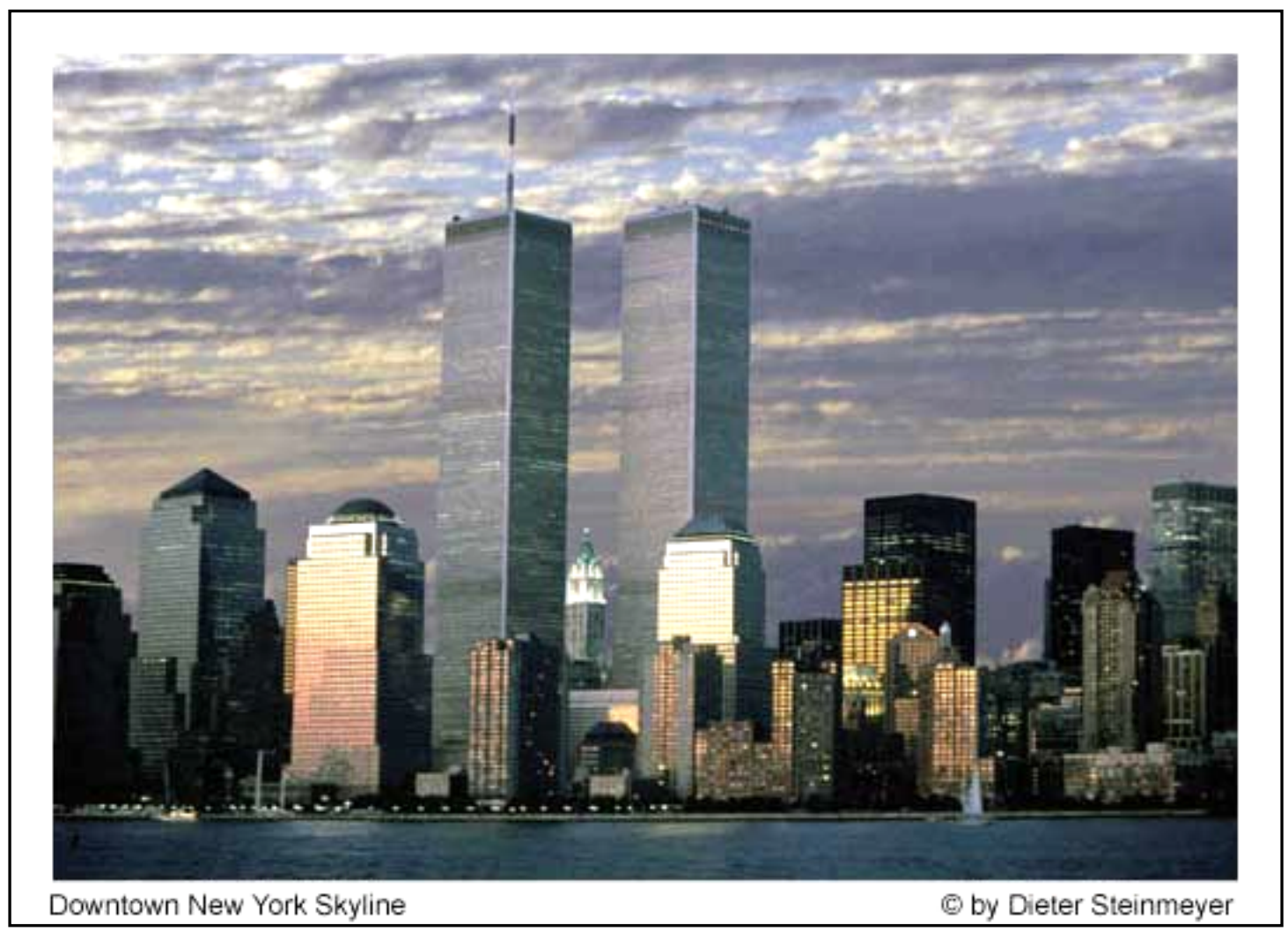

FIGURA 7 As Torres

Reais da Modernidad e: Nova York e as torres gêmeas do WTC, enquanto existiam (Fonte: <http://www .ridgewood cameraclub. org/WTC_Tr ibute.htm>, acesso em 24-08-2005). 
dominante, a formação de um imenso conjunto de excluídos (Vide SANTOS, 1998:35).

Este processo foi sustentado pela desapropriação dos meios de produção cuja posse geralmente repousava, nas sociedades de outrora, nas mãos daqueles que os utilizavam. O capitalismo, ao apropriar-se dos pré-requisitos de reprodução da vida material e de subsistência, ou seja, da possibilidade dos homens comandarem seu próprio tempo, engendrou o "trabalho livre e assalariado", um eufemismo para mascarar a submissão dos humanos ao capital ${ }^{27}$.

Convém destacar que o caráter excludente do tempo linear se justifica, para além de substantivar-se enquanto instrumento de domínio político, de subordinação econômica e social, de domesticação psíquica e corporal, pelo fato da modernidade imprimir um cunho de mercadoria à sua temporalidade. Como argumenta Anthony GIDDENS reportando ao historiador e filósofo alemão Georg Simmel, o dinheiro constituiria, na perspectiva da análise que aqui está se endossando, um mecanismo de desencaixe, um meio de distanciamento no tempo-espaço, pois possibilita a realização de transações entre agentes amplamente separados no tempo e no espaço (1991:32). Assim pode-se contextualmente retroagir a máxima de Benjamim Franklin, afiançando que dinheiro também pode ser tempo. Detendo a posse do capital, a burguesia dispõe da última palavra na ordenação do tempo, permitindo-lhe coordenar o dinamismo social e tutelá-lo sob seu tacão.

Previsivelmente, seria demasiado simplória a pretensão em isentar a ação dessas forças em marcha da irrupção de contradições. Na medida em que o industrialismo se propaga vitoriosamente pelo mundo, o operariado industrial, tal como a burguesia uma das "classes puras" da sociedade capitalista (Vide LUKÁCS, 1981:31), estréia sua aparição no cenário social ${ }^{28}$. Aos trabalhadores

\footnotetext{
${ }^{27}$ Karl Marx distingue claramente a forma-dinheiro da forma-capital: "a circulação de mercadorias é o ponto de partida do capital. A produção de mercadorias e o comércio, forma desenvolvida da circulação de mercadorias, constituem as condições históricas quer dão origem ao capital. $O$ comércio e o mercado mundiais inauguram no século XVI a moderna história do capital" (MARX, 1975b:165). Neste texto, o termo dinheiro está sinonimizado ao de capital.

${ }^{28}$ A noção de "classe pura" expressa uma polaridade social do capitalismo possuindo caráter histórico. Portanto, pode suscitar reavaliações concatenadas com mudanças estruturais operadas no plano do capitalismo mundial.
} 
industriais é imposto - não sem que estes deixem de retrucar com denodadas provas de resistência - o papel de acatar os ritmos e freqüências da produção fabril. Paralelamente é engendrado um outro contingente populacional, apenas sazonalmente inserido nas atividades produtivas. Denominado exército industrial de reserva, este se apresenta como um stock de força de trabalho que extrapola em muito as necessidades de exploração do capital, configurando em toda a sua crueza um verdadeiro reservatório de tempo à disposição do sistema. Tal "subproletariado" tem na desocupação um dos móveis que sustentam as taxas de lucro, revigorando com sua paralisia forçada o poderio do próprio sistema que o oprime (VIANA, 1982:126/127 e SINGER, 2002:60).

Esta lógica de exploração está sincronizada com os intuitos que o tempo linear aspira relativamente ao espaço. $\mathrm{Na}$ equação que promoveu o adensamento de uma grande massa de protagonistas colocados numa situação de subalternidade frente à temporalidade moderna, pode-se identificar vários elos comuns. Quase sempre, os excluídos são humanos procedentes do meio rural, pertencendo a uma variada gama de grupos, em geral não-brancos, nãoocidentais e evidentemente, não-burgueses. Eles formam um caudal de novos estranhos que tomou o rumo das cidades embalado pelo sonho do progresso, do consumo, do desenvolvimento e porque não, do ingresso na modernidade. Mas, estes homens e mulheres descobrem rapidamente que nas cidades, não há espaço para eles. Coerentemente, na ótica da organização do espaço hegemônica, tais parcelas da humanidade, uma vez desapropriadas de seu tempo, não tem como escapar da sina de serem obrigatoriamente desespacializadas.

Estes segmentos de excluídos são os eternos consumidores de uma cidade imaginária, emblemática por não existir de fato para eles, perversa por ser apropriada por poucos, por alguns. Estes forasteiros do tempo hegemônico, marginalizados e punidos por, após terem sido privados do seu tempo, não terem sido integrados pelo próprio sistema que os espoliou, fundam geralmente nas imediações da pujante, poderosa e portentosa arquitetura dos que, direta ou indiretamente, monitoram o fruir do tempo linear, uma outra cidade, um outro 
espaço, negado e não-reconhecido pela cidade formal. Ao menos no sentido convencional, é preciso reconhecer que para as massas pobres, não há rede urbana (SANTOS, 1981:151).

$\mathrm{Na}$ realidade, este espaço "informal", que tipifica a periferia das metrópoles do Terceiro Mundo ${ }^{29}$, materializa a forma como um contingente expressivo dos novos metropolitas solucionou a questão da moradia. Desassistidos pelos programas oficiais de moradia e subestimados enquanto prioridade pelos gestores do planejamento urbano, estes setores resolvem do seu próprio modo as agruras das "não-políticas" de habitação. Assim na RMSP, um texto pioneiro datado dos finais dos anos setenta identificava os loteamentos periféricos e a produção maciça de casa própria através da autoconstrução enquanto estratégias visando solucionar uma demanda objetivamente ignorada pela cidade formal (Cf OLIVEIRA, 1982b).

É deste modo que o território dos excluídos, a cidade operária, o espaço dos trabalhadores, repudiado enquanto expressão malévola de um suposto "caos urbano", se ergue, recusando-se a ser privado da sua humanidade. Embora evidente, não seria demasiado repetir que esta concepção de "caos urbano" possui claros compromissos ideológicos. Intensamente utilizada pela mídia e presente em muitas análises, esta noção observa o ilógico no lógico, terminando por respaldar manipulações tecnocráticas que subentendem os problemas urbanos como "expressões desviantes", dados conjunturais e não estruturais, passíveis, portanto de serem solucionados por intermédio de políticas de ajustes e de correções (OLIVEIRA, 1982b:142/143; SANTOS, 1993b:105/107).

Desta maneira, perpassada por contradições, por conflitos e desequilíbrios, a cidade moderna, bastião do tempo, prótese dos fluxos e concreção da exclusão,

\footnotetext{
${ }^{29}$ Os debates relacionados com a terminologia Terceiro Mundo inspiraram décadas atrás muitos pronunciamentos na geografia (Cf LACOSTE, 1980). A partir dos anos noventa, alterações promovidas pela internacionalização do fluxo de capitais, integração das economias nacionais, deslocamento dos centros de poder e a dissolução do Segundo Mundo (Leste Europeu), suscitaram novos modelos teóricos, fazendo jus à Nova Ordem Mundial (Ver Magnoli, 1993:17/18 e 61/62; HAESBAERT, 1997). Neste texto, o termo está despido das pretensões de postular um bloco monolítico ou expressar uma linha de atuação política (o terceiromundismo). Antes, identifica espaços que na hierarquia espacial implantada com base na distribuição desigualitária dos fluxos formata zonas opacas, discrepantes das zonas luminosas, ou ainda, espaços do mandar e espaço do fazer (Cf SANTOS, 1988:50/53, 1993b:51 e 1998:106/108 e 114/116).
} 
conquista contornos e atributos não previstos por um imaginário preocupado com a justificação ideológica da modernidade enquanto uma contraposição ao atraso, à barbárie, à imutabilidade e à estagnação. Aparentemente alheios ao fato de que a desordem é apenas a ordem do possível, já que nada é desordenado, a "cidade informal" termina corriqueiramente categorizada pelos administradores e planejadores urbanos como áreas de crescimento dito desordenado (SANTOS, 1988:66).

Entretanto, é óbvio que tais espaços constituem dado indissociável do padrão temporal vigente, em cuja lógica de reprodução se abrigam. Tal espacialidade mantém, na realidade, uma articulação desigual e combinada como o tempo social dominante, no qual o desequilíbrio e a desarmonia são as notas predominantes. Através desta lógica funcional, compreende-se o surgimento destas áreas junto à maioria das urbes da modernidade. De forma quase imprevisível, tais espaços brotam literalmente do dia para a noite, ou melhor, da noite para o dia. Esta aparição quase mágica reflete-se na própria terminologia, como a palavra callampas (cogumelos), usual em muitos países na América Latina.

Espalhando-se sem critério pelas nervuras da topografia e artificializando a seu modo a natureza primeira, este espaço é construído pelos principais arquitetos do Terceiro Mundo: as famílias pobres que constroem sua própria casa (SALAS, 1987:16). Utilizando os mais inusitados e bizarros materiais, como restos de demolições, sucata, lataria e pedaços de madeira, sua natureza precária é evidente no termo bidonville (cidade de lata), comum nos países francófonos. Estas favelas, enfim, formam uma caricatura da cidade imaginária, uma rugosidade que prolifera em terrenos pouco propícios à edificação.

Ressalvou Milton Santos, os nichos ocupados por estes humanos desigualmente integrados ao tempo linear caracterizam-se pela inadaptação do habitat ao sítio. Estes são freqüentemente de caráter clandestino, o que remete à definição de que a cidade informal comumente está implantada junto a áreas de risco e outros espaços desprezados pela cidade formal. Neste caso pode-se enumerar regiões de declive acentuado ou afloramentos rochosos como os cerros de Caracas e os morros do Rio de Janeiro; depósitos de lixo urbano em Lima e em 
Manila; terrenos pantanosos na Ásia das monções, caso de Kolkata (ex-Calcutá, Índia) e da Cidade Ho Chi Min (ex-Saigon, na República do Vietnam); ou a orla insalubre dos rios, estuários e braços de mar, exemplificados em Salvador, Hong Kong e Pnom Pehn (Cf SANTOS, 1981:179).

O crescimento destes núcleos é incentivado por um processo perverso de especulação imobiliária que reserva sempre as áreas mais desfavoráveis para a população de baixa renda. No Brasil, por exemplo, não há dúvida de que são sempre as baixadas sujeitas a toda sorte de inundações, ou as encostas, onde a planta bidimensional esconde as medidas e a situação do lote na realidade, as primeiras áreas colocadas à venda (OLIVEIRA, 1982b:113; PELOGGIA, 1998:59/70). Fato comum às grandes concentrações urbanas do hemisfério sul, este processo de ocupação atira-se ainda sobre as áreas de preservação ambiental e mananciais de água potável.

Embora situados à margem dos planejamentos oficiais, a porcentagem de humanos que habitam estes espaços é significativa em meio a todas as grandes concentrações urbanas do Terceiro Mundo. No início do milênio, a mídia começou a popularizar a expressão mega-favelas, referindo-se ao surgimento das primeiras "cidades informais" reunindo concentrações milionárias de seres humanos. Este seria o caso de Dharavi, favela situada em Mumbai (ex-Bombaim, Índia), considerada a maior da Ásia, reunindo um milhão de habitantes e, de acordo com algumas previsões, apenas a primeira conta de um colar cosmopolita de cidades informais milionárias.

Este quadro sintético de crises que está se expondo nos seus incontroláveis rebatimentos sócio-espaciais (tanto no natural quanto no artificial), é indiscutivelmente o mais preocupante retrato da modernidade, resultante de uma temporalidade que abdicou do espaço como seu espelho estável. Esta crise tornase ainda mais acirrada por não ser existir outro patamar espacial exeqüível que possa dar conta das contradições geradas por este processo. Pelo menos por enquanto, a colonização em massa do espaço sideral habita exclusivamente as projeções futuristas, e neste conjunto, apenas as mais entusiasmadas. 
Restaria assim, pensar respostas centradas nos espaços realmente habitados, ao alcance imediato das expectativas e da ação concreta. Certo é que nada pode ser colocado de taxativo na história dos homens, mesmo quando o panorama que se vive é este colocado pelo mundo contemporâneo.

Pensar as contradições que assoberbam a modernidade deve, acima de tudo, ser um convite para amealharmos modelos e conceitos que nos auxiliem a compreender a crise.

E isto para que a profundidade desta crise venha a constituir um convite para que numa mesma direção, seja possível aprofundar a compreensão e a magnitude das medidas que poderão - ou não - contê-la e ultrapassá-la.

\subsection{Rede Urbana Mundial: Cenários e Desafios}

Foi delineado de um modo relativamente sumário algumas das manifestações plenamente visíveis para qualquer observador equipado com a preocupação em decodificar geograficamente a paisagem ofertada pela modernidade, e isto, especialmente nas suas acepções urbanas. Numa paisagem dominada por fluxos, a existência de estacas concretas é fundamental. A geografia dos fluxos não pode desprezar a geografia dos fixos (SANTOS, 1999:202).

Nesta seqüência, pode-se considerar que o tempo linear, ao formar uma rede de pontos fixos interconectados em um tecido ou malha de amplitude planetária, implementou um processo de urbanização com características inteiramente diversas das do passado, daí a emergência em trazer a baila seus condicionantes e desdobramentos que se mesclam ao seu dinamismo.

Deslocando a atenção para este ângulo, a compreensão da escala da rede urbana do mundo atual, e ademais, dos impactos a ela relacionados, reclamaria discernir cinco fatos estruturais básicos, a saber: 
1. Em primeiro lugar, estariam os aspectos quantitativos da urbanização mundial; A medida em que as vagas do tempo alcançavam o meio rural, este "liberava" enormes contingentes populacionais, alimentando as cidades através de migrações gigantescas, as maiores da história. Em 1973, alertava o historiador britânico Arnold TOYNBEE que os camponeses vivendo "em comunidades aldeãs, no estilo da Idade Neolítica, ainda constituíam a maioria da geração humana então viva" (...), porém estes, "estavam rapidamente escoando do campo para as favelas que envolviam as cidades" (1979:717).

Deste modo, um cenário delineado em 1984 durante o Colóquio A Cidade, Hoje e Amanhã, organizado pela Organização das Nações Unidas para a Educação, a Ciência e Cultura (UNESCO), antecipava que no início do Século XXI o meio urbano estaria reunindo pela primeira vez na história a maior parte da humanidade sob o seu domínio direto: não menos que 52\% dos humanos, inferência confirmada por relatório elaborado em 1997 pelo The World Resources Institute juntamente com a UNEP (United Nations Environment Programme), UNDP (United Nations Development Programme) e Banco Mundial (World Bank).

O ineditismo desta cifra é flagrante quando se sabe que, tomando o Planeta como um todo, "a população considerada urbana representava apenas 1,7\% do total nos inícios do século XIX; em 1950, tal percentual era de 21\%, percentagem que passa para $25 \%$ em 1960, 37,4\% em 1970 e cerca de $41,5 \%$ em 1980" (SANTOS, 1988:41). Outro dado, discutido na Conferência da ONU HABITAT $\|^{30}$, prevê que as cidades aglutinarão em 2025 uma porcentagem orçada em 60,1\% da humanidade (1996:3). Não poderia, pois, existir divergência quanto ao fato de que este processo evidencia a urbanização enquanto um fenômeno espacial, temporal e sociologicamente global, e por isso mesmo um fato central para qualquer prognóstico referente ao futuro da humanidade.

2. Em segundo lugar, cumpriria avaliar os aspectos qualitativos desta urbanização; No passado, mesmo as cidades que abrigaram a nascente classe

\footnotetext{
${ }^{30}$ Esta conferência mundial foi convocada pela ONU para discutir a urbanização mundial. Tratou-se da segunda e última reunião de cúpula internacional sobre o tema realizada pela ONU no $\|^{\circ}$ milênio (a primeira ocorreu em Vancouver, no Canadá, em 1976).
} 
mercantil européia eram pequenas e ainda não haviam perdido seu vínculo com o meio rural. Contudo, a partir do Século XVIII, a população urbanizada tendeu a concentrar-se em urbes cada vez maiores, primeiramente nas metrópoles e posteriormente, nas megalópoles, as maiores manchas urbanas de todos os tempos. A grande cidade, mais do que qualquer outra obra confeccionada pelo engenho humano tornou-se o ícone por excelência da sociedade contemporânea (LEFF, 2004:288). As urbes que hoje ponteiam pela superfície do Planeta formam um conjunto de fundamental importância do ponto de vista demográfico, e ao que tudo indica, mais ainda o serão em futuro próximo (Vide Tabela 1).

Agregue-se a este comentário a singularidade da urbanização ter se difundido mundialmente. A expansão urbana aos tempos do industrialismo primordial tinha fortalecido suas raízes particularmente nos países ocidentais. Contudo, este processo transbordou seus limites geográficos originais, que basicamente acatavam as fronteiras européias. Atualmente, das 21 maiores

TABELA 1

\section{AS MAIORES CIDADES DO MUNDO 2000 - 2015}

Colocação - Cidade - País

1. Tóquio, Japão

2. Mumbai, Índia

3. São Paulo, Brasil

4.Shangai, China

5. Nova York, EUA

6. Cidade do México, México

7. Pequim, China

8. Djakarta, Indonésia

9. Lagos, Nigéria

10.Los Angeles, EUA

11.Kolkata, Índia
2000

27,9

18,1

17,8

17,2

16,6

16,4

14,2

14,1

13,5

13,1

12,7
2015

Colocação em 2015

28,7

1

27,4

20,8

23,4

17,6

18,8

19,4

21,2

24,4

14,3

17,6
2

6

4

11

10

8

5

3

17

12 
12.Tianjin, China

13.Seúl, Coréia do Sul

14.Carachi, Paquistão

15.Delhi, Índia

16.Buenos Aires, Argentina

17.Manila, Filipinas

18.Cairo, Egito

19.Osaka, Japão

20.Rio de Janeiro, Brasil

21.Daca, Bangladesh
12,4

12,3

12,1

11,7

11,4

10,8

10,7

10,6

10,2

10,2
17,0

13,1

20,6

17,6

12,4

14,7

14,5

10,6

11,6

19,0
14

18

7

13

19

15

16

23

21

9

Fonte: World Prospects: The 1994 Revision (1995), United Nations Department for Economic and Social Information and Policy Analysis Population Division (cifras em milhões de habitantes) 
cidades do mundo, treze são asiáticas ${ }^{31}$ (incluindo Tóquio, Osaka e Seul), quatro são latino-americanas (Cidade do México, São Paulo, Rio de Janeiro e Buenos Aires), duas são africanas (Lagos e Cairo) e duas, são norte-americanas (Nova York e Los Angeles). É interessante assinalar que a Europa, justamente o berço da cidade moderna, não abriga nenhuma das 21 maiores cidades do mundo em 2000.

Para uma melhor apreciação deste tema, deve-se frisar que do ponto de vista geográfico a urbanização passou a localizar-se, a partir dos meados do século $X X$, na periferia do mundo capitalista. Sinal claro de que algo grandiosamente diferente passou a interferir nos destinos da maior parte da humanidade, as cidades européias e norte-americanas, dantes capitaneando o processo urbano mundial, perderam crescentemente sua importância populacional frente às novas cidades da periferia do sistema. Ainda que as cifras referentes às aglomerações dos países periféricos sejam consideradas espantosas aos olhos de muitos setores de opinião, saliente-se que estas não constituem novidade em qualquer sentido.

Recorrendo novamente aos dados do Colóquio A Cidade, Hoje e Amanhã, estes esclareciam que por volta do ano 2.000 , quando metade dos seis bilhões de humanos estaria concentrada nas áreas urbanas, dois bilhões residiriam em metrópoles dos países periféricos e um bilhão, nas dos países centrais. Subscrevia igualmente que, das 60 cidades com mais de cinco milhões de habitantes, 47 estariam situadas no Terceiro Mundo. Esta parte do globo concentraria também 12 das 15 megalópoles (Vide UNESCO, 1984:24).

\footnotetext{
${ }^{31} \mathrm{Na}$ perspectiva da economia urbana mundial, a urbanização asiática reclamaria certa atenção. Particularmente na Ásia Oriental, estão sendo erguidos os maiores conjuntos de torres, irrompendo em cidades como Bangcoc, Seul, Taipé, Cingapura, Kuala Lampur e Djakarta. Estes novos e orgulhosos skyscrapers (arranha-céus) do Oriente não desafiam apenas os ventos ou a instabilidade geológica de vários dos sítios nos quais foram construídos; para seus habitantes, constituem ícones de um capitalismo regional determinado a assumir uma "fisionomia oriental", desenhando uma leitura própria da modernidade ocidental. Neste conjunto, repetindo a contradição Norte/Sul, encontramos metrópoles afluentes (Tóquio, Osaka, Hong Kong e Seul) e periféricas (Manila, Bangcoc, Djakarta e Mumbai). Mas simultaneamente este conjunto assegura-se de uma identidade própria. Mantendo intenso intercâmbio entre si, essas cidades constituem as estacas do espaço regionalizado Leste Asiático. O crescimento das trocas econômicas regionais constitui um dos seus fundamentos. Fluxos migratórios internos, assim como uma nascente "personalidade cultural" (baseada, por exemplo, na radiodifusão de uma "música popular asiática" transmitida de Tóquio a Kuala Lampur, passando por Hong-Kong, Taipé, Seul e Manila), contribui para um
} 
Em larga medida, tais prognósticos demonstraram sua veracidade, relegando a hegemonia anteriormente detida pelas cidades dos países centrais a um episódio perdido nas páginas da história. Para o ano 2015, prevê-se que apenas duas metrópoles setentrionais - Tóquio e Nova York - constarão do ranking das quinze maiores cidades do mundo. Também está previsto para 2015 que das 27 maiores metrópoles, somente cinco estariam localizadas no Norte: Nova York, Los Angeles, Tóquio, Osaka e Paris, esta última, ocupando uma singela $22^{a}$ posição (passim HABITAT II, 1996).

Porém, em 1950 sete das 15 maiores aglomerações situavam-se nos países desenvolvidos, proporção que diminuiu drasticamente para 3 no ano 2000. Nesta relação das grandes cidades do Planeta, Londres, que sempre liderou internacionalmente o mundo urbano, estará ausente. E o que falar então de São Petersburgo e de Viena, que em 1900 constavam do ranking das dez maiores cidades?

Em 2015, estima-se que a $3^{a}$ maior urbe do planeta será Lagos, na Nigéria, com 22,5 milhões de habitantes. Só perderá para Mumbai, que concentrará 27,4 milhões de pessoas. Além de Mumbai e Lagos, um exaustivo catálogo de metrópoles periféricas poderia ser alinhavado. Dentre estas seria obrigatório registrar: Xangai, que terá então 23,4 milhões; Djakarta, na Indonésia, com 21,2 milhões; São Paulo, 20,8 milhões; Carachi, no Paquistão terá 20,6; Pequim, 19,4; Daca, capital do miserável Bangladesh, 19 milhões e a Cidade do México, 18,8 milhões de habitantes.

Tais números, quase impensáveis em função do recorte social que marca estas concentrações urbanas, são nesta ótica estarrecedores em si mesmos, justificando presságios sombrios. Em 1985, numa das audiências públicas da CMMDA preparatórias do Relatório Brundtland realizadas na cidade de São Paulo, foram coletados veredictos dos participantes. Um destes vaticinava o seguinte cenário: 
As cidades do Terceiro Mundo serão cada vez mais centros de competição acirrada por um pedaço de terra onde se possa construir um abrigo, por um quarto para alugar, por um leito de hospital, por um lugar numa escola ou num ônibus, sobretudo por uma vaga nos poucos empregos estáveis adequadamente remunerados, e mesmo pelo espaço numa praça ou calçada onde se possa expor e vender mercadorias, atividade de que dependem tantas famílias (1988:266).

Estas considerações se impõem em qualquer discussão sobre o meio urbano do mundo contemporâneo, sinalizando para a precariedade de se trabalhar com um conceito de metrópole calcado na experiência das sociedades do Norte. A metrópole que se apresenta com força cada vez mais intensa é não-branca, nãoocidental e para completar, periférica. É este o meio urbano que deve absorver com toda paixão possível as atenções dos que se dedicam ao estudo da questão urbana em nível mundial.

3. Em Terceiro, as cidades no mundo atual mantêm intenso intercâmbio entre si, reconhecidamente dessimétrico em toda a sua extensão; A malha urbana mundial reflete uma estrutura social, política e econômica, cujas contradições, articuladas nas mais diversas escalas, materializam-se, é óbvio, globalmente, mas de modo desigual, variando de um contexto a outro. Não existe um global indistinto, mas um global que se especifica desigualmente, daí a necessidade de se pensar a especificidade dos diferentes espaços urbanos do mundo atual.

Por conseguinte, ao menos parcialmente a explicação relativa ao funcionamento das metrópoles do Sul reportaria ao relacionamento mantido com as metrópoles do Norte (SANTOS, 1982:17/18). Desempenhando um papel subordinado, as metrópoles da periferia materializam uma geografia urbana própria, compartilhando características comuns em todo 0 mundo subdesenvolvido, expressão da sua integração desigual no mundo global:

Não se trata aqui de negar o caráter global do estudo do espaço, já o mostramos em outro lugar: mas de distinguir, num nível inferior de generalidade, o espaço dos países desenvolvidos e o espaço dos países subdesenvolvidos (SANTOS: 1978b:103). 
Sintetizando o que foi colocado, comentar de modo genérico a respeito de uma crise urbana "mundial", não faria qualquer sentido. O relacionamento mantido entre as cidades está consubstanciado por relações marcadamente desiguais, que por sua vez respaldam sua interação na rede urbana mundial. Ao mesmo tempo, esta configuração urbana global articula as cidades em um conjunto hierarquicamente diferenciado, demograficamente polarizado e desigualmente integrado na economia urbana mundial.

Reproduzindo uma lógica inerente à reprodução do capitalismo, o relacionamento entre as metrópoles que formam essa rede está perpassado, de alto a baixo, por relações dessimétricas, transformando as megalópoles dos países do Sul em pontos de apoio de uma vasta rede planetária, por intermédio da qual os fluxos econômicos transitam continuamente da periferia na direção do centro do sistema. Isto ocorre porque embora uma lógica funcional articule as metrópoles do Norte e do Sul numa mesma rede urbana mundial, esta é de fato hegemonizada de fato pelas metrópoles dos países do centro (passim SANTOS, 1988, Ver também SINGER, 2002:71/72).

Nesta interpretação, categorizar as metrópoles do Terceiro Mundo como "inviáveis" constituiria uma afirmação carente de qualquer estatuto científico. Nada mais incorreto do que este imprudente julgamento. Quem colocaria em dúvida que são as "metrópoles afluentes" do Norte que constituem, em razão do seu estilo de vida individualista, perdulário e consumista, o verdadeiro epicentro da crise urbana e ambiental da modernidade? Poder-se-ia considerar "viáveis" as grandes cidades dos países centrais caracterizadas pelo seu estilo de vida opulento e esbanjador? E qual seria a base de sua viabilidade, se elas tenderão a funcionar cada vez mais apelando para recursos obtidos à custa da espoliação de outras áreas, no mais das vezes procedentes dos países do Sul?

Neste sentido, a crise urbana dos países do Sul conquista caráter estrutural, sendo dificilmente solucionável nos marcos do relacionamento Norte/Sul atualmente existente, apontando necessariamente para uma revisão do modelo de civilização que atualmente comanda a humanidade. 
O fato de que os recursos naturais planetários existentes são insuficientes para universalizar o modelo urbano hegemônico assim como o processo de globalização que o sustenta é um dos pontos de contato que entrelaçam explosivamente a crise urbana com a crise socioambiental da modernidade.

A civilização urbana, tal como esta se configurou nos países do Norte, embora básica para se compreender o fenômeno da globalização, revela que paradoxalmente a globalização não dispõe de espaço para ser global.

Daí a importância de se discutir não só o tempo, mas numa mesma magnitude, o espaço, e particularmente o urbano.

4. Em quarto, as metrópoles desempenham papel de liderança no comando das redes urbanas, eventualmente alterando sua forma, porém mantendo seus vetores dominantes; No encalço das transformações ocorridas nas últimas décadas do século $X X$, as regiões metropolitanas, núcleo que encabeça os circuitos que magnetizam a espacialidade urbana, alteraram vários dos seus dinamismos sócio-espaciais. A partir dos anos setenta do século passado uma constelação de mudanças inéditas modificou as determinações até então válidas para a organização do espaço, apontando novos desenhos para as regiões metropolitanas.

Basicamente, este quadro associou-se à imposição de novos padrões de acumulação de capital inspirados no processo de globalização da economia. Tais transformações filiam-se sob diversos ângulos a uma releitura das relações com o tempo e o espaço, associadas com marcantes inovações tecnológicas, passíveis de serem agrupadas em algumas linhas básicas (tais como a microeletrônica, robótica e biotecnologia), assim como com uma "repactuação" firmada com o objetivo de estipular novas regras entre os indivíduos e o mundo da economia. Deve-se acentuar que estes dois processos (os tecnológicos e os sócioeconômicos), não são estanques, relacionando-se e interagindo entre si, fortalecendo a impregnação do meio social com os valores transmitidos pela globalização. 
Nesta ampla redefinição que transcorre nos dias atuais, tem-se um movimento contingente, sujeito a marchas e contra-marchas e que se apresenta sob diversas formas, mas que tem deixado sua marca indelével na sociedade global. O seu grande motor é a competitividade, eleita enquanto paradigma central para a organização da economia e da sociedade, tornando-se o eixo que orienta o movimento da globalização. Numa definição certeira, seu anseio máximo é a busca da velocidade absoluta (SANTOS, 1997:8). Disseminada com o auxílio de um discurso floreado no qual despontam sentenciamentos como "luta contra privilégios corporativos", "desregulamentação das relações de trabalho" e "mercado como princípio regulador total", estes termos transparecem como verdadeiras pedras de toque que impulsionam o nexo assumido por grande parte da economia mundial.

A implementação destas teses pelo mundo capitalista foi favorecida por um panorama geopolítico no qual o Leste Europeu - seu grande oponente durante mais de setenta anos - deixou de existir como contraponto ideológico, político, social e econômico, ao mesmo tempo em que as forças sociais que se the opõem encontram grandes dificuldades para formatar um conjunto articulado de idéias que barrem efetivamente sua afirmação (Ver a respeito, MAGNOLI, 1993:46/62, OLIC, 1993:81/83 e HAESBAERT, 1997). O capitalismo dispõe, neste momento histórico, de condições mais do que favoráveis para impor e exacerbar seu código de gerenciamento do tempo até suas últimas conseqüências, abrindo mão de qualquer veleidade e aplicando sem restrições a sistemática do mercado total.

Tais diretrizes destronaram conceitos consagrados no bojo da antiga civilização industrial e urbana, abrindo caminho para que postulados "clássicos" (caso do exército industrial de reserva e da mobilidade dos trabalhadores), passassem a serem refeitos mediante uma ótica inteiramente nova. Com a admissão das novas tecnologias, a força de trabalho, que no início do capitalismo tinha importância fundamental, passa a contar cada vez menos. Dito de outra forma, os aumentos de produtividade passam a se ocorrer ao mesmo tempo em que a participação do trabalho torna-se menos expressiva no interior dos 
processos produtivos. Trata-se do que é alcunhado no jargão economicista como jobless growth, isto é, crescimento sem emprego.

Este balanço propicia uma potencialização da exclusão social, que se expande como nunca. Tal como está ressalvado na candente elaboração da geógrafa Maria de Fátima Almeida MARTINS, o avanço técnico logrado sob o capitalismo a partir dos finais do século XX, encerraria:

...não mais a virtualidade da emancipação do homem em relação ao dispêndio intenso de trabalho vivo, uma vez que isso já se constitui em fato histórico concreto. Mas, se as forças sociais despertadas pelo capital engendram um mundo onde a natureza bruta já não mais se põe como ameaça à reprodução social, o horizonte do não-trabalho posto por esta forma de sociedade não anuncia nada de emancipatório, haja vista que a possibilidade do não trabalho se transforma, desgraçadamente, em desemprego, ou em trabalho precário, o que, não sem alguma razão, tem alimentado algumas das interpretações que ultimamente vêm ganhando expressão na explicação do mundo atual (1998:56).

Fazendo uma reedição de comentário registrado nos parágrafos anteriores, tem-se que se no passado os grupos "liberados" do meio rural foram, após serem subtraídos da sua temporalidade, conduzidos para os grandes centros urbanos para proceder seu ingresso na produção fabril e imersos na sua temporalidade, as declinações contemporâneas da modernidade sugerem uma indução bem mais perversa. Uma conduta peculiar à economia globalizada tem sido a de excluir parcelas expressivas da população para fora das suas relações de produção específicas, promovendo a ampliação do número de pessoas não incorporadas diretamente às relações especificamente capitalistas de produção. São os protoproletários, os excluídos, sobrantes que não mais cabem no conceito de exército industrial de reserva (MARTINS, 1998:56, grifo nosso; ver também KURZ, 1992:192/197 e SANTOS, 2003:16/17).

Tal "reengenharia" vincula-se organicamente com a lógica interna encontrada no cadenciamento da fruição linear e progressiva do tempo. Nesta estratégia, se inscrevem as tecnologias aplicadas no domínio da produção, das comunicações e dos serviços, introjetadas sob a égide do jobless growth. Neste caso se inscreveriam, por exemplo, os sistemas de transmissão instantânea, ditos on line 
ou tempo real. Típicos do cotidiano moderno, modelos informacionais como os caixas 24 horas e o comércio eletrônico, além de eliminarem postos de trabalho, implicam numa releitura da relação com o espaço, ensejando uma percepção que contraria seu sentido imemorial, desfigura sua majestade e promove sua virtualização crescente. Dado inquestionável, os objetos geográficos são, a cada dia que passa, mais carregados de informação (SANTOS, 1998:140).

No que tange à organização territorial urbana, a formação de estruturas organizadas em redes horizontais, nas quais o fenômeno da polarização de certo modo se dilui para dar lugar a um conjunto de fixos funcionalmente articulados e integrados entre si com base em fluxos rápidos e ágeis, implicou na reconfiguração do tecido urbano, agraciado com dispositivos de um meio técnicoinformacional. Este direcionamento tende a formar uma única bacia de empregos, de residência e de atividades, uma logística que alimenta forte relacionamento com o mercado em todos os seus níveis. É preciso dizer que se está claramente diante de um outro avatar da metrópole moderna, cujo desempenho econômico e social se faz em estreito intercâmbio entre núcleos que mantém entre si trocas permanentes, impregnados da temporalidade de mercado e dos seus conteúdos.

Ora, este cenário difere substancialmente da antiga metrópole industrial. O grande centro urbano criado a partir do triunfo da maquinofatura foi substituído por pólos de serviços que agregam tecnologias de ponta, requisitando padrões específicos de intercâmbio social e de trabalho. Esta realidade induz processos organizacionais que primam por uma menor verticalidade e por segmentação menos rígida. Passa a ocorrer, conforme está pontuado no texto da geógrafa Rosa MOURA,

"uma refuncionalização dos espaços metropolitanos, recolocando-os como pólos modificados, que se tornam cada vez mais seletivos para a alocação de atividades e população. As funções de comando e gestão, que passam a caracterizar as metrópoles, altamente tecnificadas, dispensam trabalhadores, particularmente os menos qualificados" (2003:8).

Por isso mesmo, mais do que uma alegoria, o termo "desindustrialização" não deixa de fazer algum sentido no plano concreto. Efetivamente o coração das 
metrópoles "perdeu" indústrias, e não em pequena quantidade. Galpões em ruínas, chaminés que não soltam mais nenhuma fumaça, armazéns destelhados que se transformam em habitação de pombos, ramais ferroviários tomados pelo mato, pátios abandonados, muros e portais desmantelados, construções abandonadas com vidros quebrados, containers pichados, vagões relegados à ferrugem e silos que contemplam o vazio são algumas das "miragens" da desolação e da decadência dos bairros industriais dos velhos centros industriais, comuns a muitas metrópoles do mundo de hoje (Fig. 8).

A conseqüência esperada deste rol de transformações foi a diminuição das taxas de crescimento demográfico, especialmente no núcleo das grandes manchas urbanas. Tendo por base esta constatação do "esvaziamento" da grande cidade, passaram a medrar algumas fabulações. Sub-repticiamente, algumas vozes ficaram tentadas a insinuar que as metrópoles estariam perdendo sua capacidade de liderar vastas redes urbanas. Existiria nesta sugestão um raciocínio subliminar pelo qual população é poder, e assim, a "estagnação" ou o "retrocesso" demográfico dos grandes centros urbanos constituiria sinal de fragilidade das metrópoles na hierarquia de comando da rede, um quadro acirrado pela própria desindustrialização, que objetivamente a promoveu.

Contudo, trabalhando mais detalhadamente esta exposição, pode-se perceber que a realidade não estaria em concordância com esta interpretação. Mais corretamente, as metrópoles estariam implementando uma reengenharia das relações de poder econômico, político e social que sustenta sua posição de 


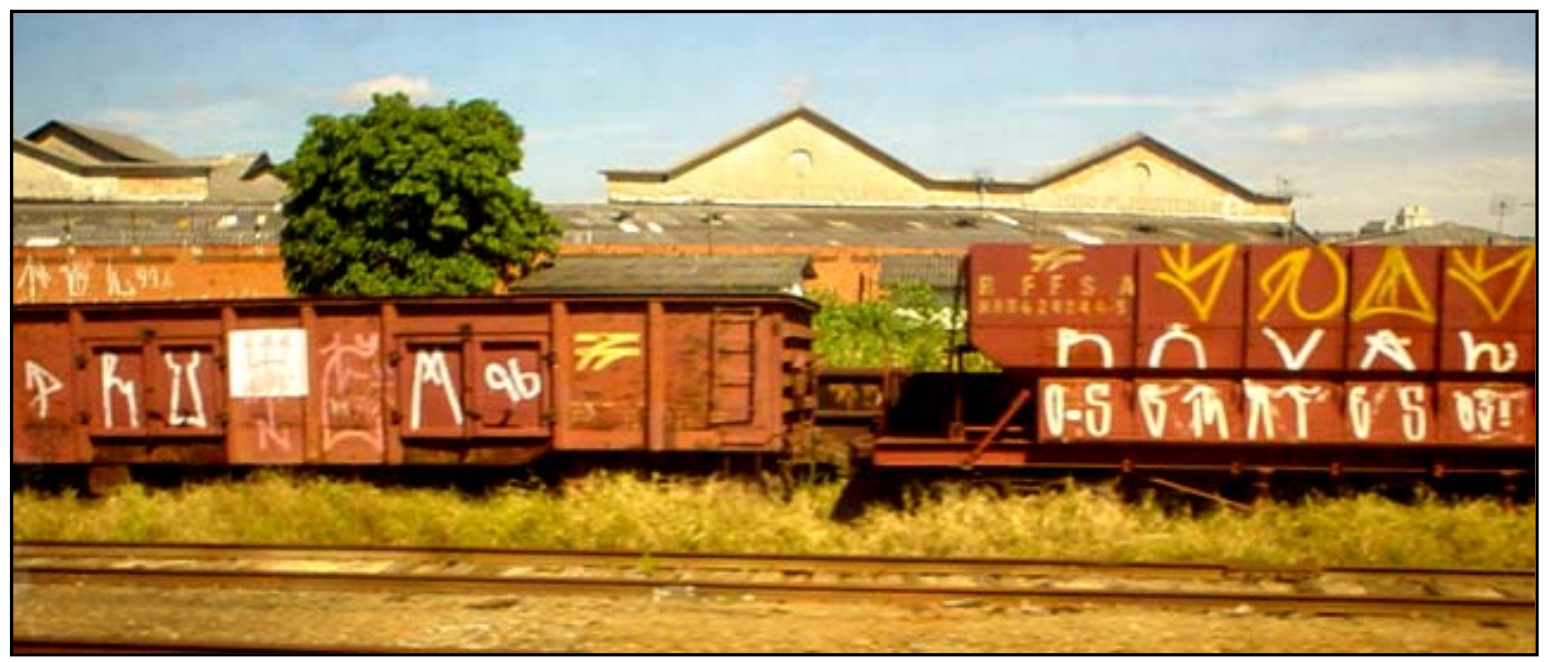

FIGURA 8 - Composição ferroviária relegada ao abandono: Em toda a extensão do trajeto dos trilhos da atual CPTM (Companhia Paulista de Transportes Metropolitanos, ex-Estrada de Ferro de Santos a Jundiaí), pode-se notar, como neste trecho situado no Grande ABC Paulista entre as estações de Capuava e Mauá, vagões de carga que serviam as indústrias localizadas ao longo da estrada de ferro. Parte significativa dessas instalações, como as do fundo da foto, foi desativada. Os vagões paralisados atestam esta situação (Foto: Maurício Waldman, Fevereiro de 2004). 
mando com o concurso de outros pontos de apoio. Tratar-se-ia de uma reacomodação dos elementos que articulam o espaço urbano não para alterar esta hegemonia, mas perpetuá-la e assim, buscando sua confirmação e não sua negação. Exemplificando, uma abordagem relacionada com a metrópole paulista evidencia que os novos objetos urbanos introduzidos nesse espaço desencadearam uma onda de valorização imobiliária, induzindo

...um deslocamento de atividades subsidiárias e de ocupações menos solváveis para áreas mais distantes, porém conectadas ao núcleo central. Assim, grandes metrópoles e mesmo suas áreas metropolitanas podem crescer menos, porém expandem-se. Mas também se expandem as metrópoles de menor porte, estendendo suas áreas periféricas e incorporando novos municípios ao núcleo metropolitano, que se tornam similares às suas próprias centralidades intra-urbanas (MOURA, 2003:8, grifo nosso).

Seguindo os passos desta interpretação, o que temos não seria propriamente uma desindustrialização, mas sim uma desconcentração industrial, que ao procurar pelo entorno das metrópoles e tendo neste espaço sua realocação preferencial, confirma em inúmeros exemplos uma desconcentração centralizada. Muito mais do que mero recurso semântico, a terminologia esclarece que este movimento ocorre mantendo o antigo núcleo enquanto pólo ao redor do qual se reorganizam as atividades econômicas, cabendo a ele neste processo a gestão de fluxos caracterizados por uma utilização intensa e maciça de ciência e tecnologia. Disto resultam não apenas as crescentes exigências concernentes à especialização do trabalhador, mas igualmente uma perda efetiva de participação do trabalho vivo nos processos produtivos, realimentando o processo de "esvaziamento" da urbe e de exclusão social (Cf MARTINS, 1998:56).

Deste modo, caberia assinalar que a idéia de "desmetropolização" requer alguns cuidados. Alicerçado numa releitura das formas de reprodução da formação social capitalista, na realidade o dinamismo metropolitano apenas tem reafirmado uma tendência de expansão da grande cidade. Neste sentido, o papel das metrópoles na liderança das redes urbanas é mantido e inclusive reforçado. Recorrendo ao comentário de Milton Santos dirigido ao questionamento da 
aderência desse conceito a dinâmicas sócio-espaciais como a brasileira, fenômenos aparentemente contraditórios como metropolização e desmetropolização seriam na verdade complementares, e o que assistimos seria muito mais verdadeiramente o reforço da metropolização juntamente com uma espécie de desmetropolização (SANTOS, 1993b:286, grifo nosso; Ver também SANTOS, 2003).

Acatando a linha desta argumentação, é antes a natureza do desafio urbano metropolitano que se alterou, mas não a sua proeminência enquanto "nó górdio" da modernidade. A metrópole mantém-se, para todos os efeitos, enquanto arena privilegiada para o futuro da humanidade, instigando não só a luta por uma outra temporalidade, como também por uma outra espacialidade.

5. Em quinto lugar, a despeito da percepção das áreas pobres das metrópoles enquanto espaço instigador de impactos ambientais, não há como analisar os desequilíbrios ambientais urbanos desconsiderando uma visão crítica dirigida no sentido exatamente oposto, qual seja, polemizando o estilo de vida urbano afluente, tutelado por um sistema reprodutor de desigualdades; Podemos facilmente localizar na iconografia e na literatura divulgadas pelos meios de comunicação, assim como pelas instituições que se voltam para a difusão de um saber sistematizado, farta informação revelando um quadro de agravos socioambientais que conotam os espaços ocupados pela população pobre das grandes cidades.

$\mathrm{Na}$ verdade, desde os primórdios da urbanização moderna são abundantes os relatos detalhando condições de vida adversas em todos os campos da expressão cultural e do conhecimento humano. Por exemplo, na literatura podemos mencionar a obra do escritor britânico Charles Dickens (1812-1870), um libelo carregado de denúncias explicitando o deteriorado ambiente de vida e de trabalho imposto ao operariado. Seria também possível detectar evidências apontando para o desequilíbrio ambiental em A Situação da Classe Trabalhadora na Inglaterra, um texto de autoria de Friedrich Engels. Nesta obra, aparece um cáustico relato centrado na condição operária num momento em que se 
presenciavam as dores do parto do industrialismo, no qual o barulho, a água infectada e as casas insalubres estão descritos em todas as suas cores.

Estes problemas, que ninguém hoje obstaria em classificar como ambientais, evidenciam que o silêncio histórico que pesou sobre a questão ecológica encontra sua justificativa no fato dos trabalhadores terem sido por muito tempo as vítimas exclusivas da degradação ambiental. Apenas a partir do momento em que a destruição do meio ambiente atingiu a pequena-burguesia e ameaça os setores dominantes, colocando-se numa ordem de grandeza impeditiva do ocultamento da discussão, é que a questão ambiental ganhou espaço nos meios de comunicação, promovendo inclusive, dada a sua popularidade, o surgimento de uma coleção de debates e de produtos culturais dedicados ao assunto (Cf GONÇALVES, 1982:222).

Assim, é possível identificar um itinerário que transitou da não visibilidade da questão ambiental ${ }^{32}$ alcançando na outra ponta seu entendimento enquanto situação condizente com as más condições de vida ou a condição de exclusão. Todavia esta constatação, em que pese a existência de um conteúdo de verdade, não permite descuidos quanto às generalizações e certos lugares comuns que povoam avaliações sobre a questão ambiental. Uma destas refere-se à associação mecânica entre pobreza e destruição da natureza. Esta sinonímia seria falsa por englobar contextos cuja análise requisitam óticas específicas de análise.

É necessário recordar que na visão dominante, tudo o que não integra o regime de afluência é considerado "pobre", independentemente da sua relação funcional com a economia de mercado. Este recorte, que reduz a compreensão do mundo a um prisma composto por oposições binárias radicais, inevitavelmente gera equívocos para a compreensão da equação que articula as sociedades

\footnotetext{
${ }^{32}$ Embora esporadicamente, considere-se que a percepção dos riscos ambientais, que costuma ser exclusivamente identificada ao mundo contemporâneo, pode ser apontada nos séculos passados. No Brasil, os protestos visionários de Frei Vicente Salvador (1564-c. 1636) condenando o mau uso da terra e a eloqüente representação de José Bonifácio em prol da conservação dos recursos naturais (1823), explicitam uma tradição esquecida de crítica ambiental digna de todo interesse social e acadêmico (Ver a respeito, PÁDUA, 2002 e MARCONDES, 2005).
} 
humanas e o meio ambiente. Seria, neste caso, interessante analisar a passagem reproduzida a seguir:

Enquanto populações ribeirinhas e migrantes podem ser igualmente qualificadas como populações 'pobres', elas apresentam diferentes culturas ecológicas e produzem diferentes impactos ambientais, desafiando, deste modo, o consenso expresso no Relatório Brundtland, na Eco 92 e em publicações oficiais, de que pobreza e degradação ambiental estejam necessária e intimamente relacionadas (LIMA e POZZOBON, 2000).

Desta forma, além da pobreza não estar necessariamente colada à noção de desequilíbrio ecológico, existiria também o perigo desta ser entendida não como resultado, mas sim enquanto condição para o surgimento dos problemas ambientais, ou seja, ser sua causa. Tal argumento surge de um modo ou de outro em diversas publicações, dentre estas o Relatório Brundtland. Considerado uma das matrizes das teses do "desenvolvimento sustentável", pode-se conferir no corpo deste documento o que segue:

A própria pobreza polui o meio ambiente, criando outro tipo de desgaste ambiental. Para sobreviver, os pobres e os famintos muitas vezes destroem seu próprio meio ambiente: derrubam florestas, permitem o pastoreio intensivo excessivo, exaurem as terras marginais e ocorrem em número cada vez maior para as cidades já congestionadas (CMMAD, 1988:30, grifo nosso).

Aparentemente, no Relatório Brundtland, como em muitos outros materiais, as pessoas pobres são movidas por atos de pura vontade, independentemente dos contextos e das relações sociais, ignorando assim os soberbos e clamorosos apelos em defesa da natureza. Entretanto, na ausência desta compreensão, as respostas que se prontificariam a solucionar o problema poderiam ser encontradas nas políticas econômicas. Na seqüência desta formulação, e até por uma questão de coerência, a pobreza, sendo-lhe imputada o papel de degradação ambiental, teria no seu contrário, a riqueza, um pressuposto para alcançar o tão almejado equilíbrio com a natureza.

Nesse mesmo relatório também está escrito: 
A pobreza reduz a capacidade das pessoas para usar os recursos de modo sustentável, levando-as a exercer pressão sobre o meio ambiente. A maioria dos pobres absolutos vive nos países em desenvolvimento (...) Uma condição necessária, mas não suficiente, para a eliminação da pobreza absoluta é o aumento relativamente rápido das rendas per capita do Terceiro Mundo. Portanto, é essencial inverter as atuais tendências de estagnação do crescimento (CMMAD, 1988:53, grifo nosso).

Levando-se em conta esta perspectiva, os problemas sociais e econômicos seriam corrigidos pelo desenvolvimento, preferencialmente carregado de sustentabilidade. Deste modo, a sociedade padeceria não propriamente da lógica inerente à sua arquitetura social e econômica, mas antes, das falhas em gerenciála de modo competente, plenamente solucionável mediante a aplicação de um programa de ajustes e correções (Ver a respeito, SANTOS, 1991 e 1992).

Fórmulas como estas constituem um atalho para anistiar um sistema reprodutor de desigualdades, justificando assim sua continuidade. A fragilidade desta argumentação é subentender que o problema reside na esfera da produção, quando na realidade a grande questão do mundo contemporâneo é a distribuição do produto social. Aliás, ressalve-se que nunca existiu um período da história humana no qual a produção de bens tenha alcançado níveis tão impressionantes quanto os atuais.

Justamente este enfoque, assumindo a questão da apropriação da riqueza e o seu vínculo com a questão ambiental é que constitui o ponto de partida para desconstrução da percepção da exclusão como geradora de desequilíbrio ambiental. De antemão, deve ser avaliado que seria a afluência, tal como esta foi estipulada pelo mundo ocidental, o dado básico para se compreender a problemática ambiental urbana. E este esclarecimento pode ser deduzido a partir da análise da ocupação do espaço da cidade moderna e dos estilos de vida associados à sua reprodução. Assim, a proposição seria dar continuidade ao desenvolvimento deste tema retomando a discussão da dinâmica vivenciada pelas metrópoles a partir dos finais do século passado.

Foi comentado, desde os anos setenta tem-se conhecimento do que terminou definido como sinais de "estagnação" das áreas centrais das grandes metrópoles. Primeiramente nos países centrais, este contexto foi acompanhado por um 
ponderável deslocamento demográfico procurando pela periferia das grandes metrópoles, dinamismo espacial cuja lógica expressaria uma suburbanização (SANTOS, 1981:3 et seq). Uma das nações nas quais primeiramente detectou-se esta inclinação foi o Reino Unido. Neste país, a redistribuição demográfica caminhou par a par com a redução populacional nos principais centros urbanos e paralelamente, pelo que foi propagandeado como "revitalização de pequenas cidades rurais" (Vide HABITAT II, 1996:3).

Obviamente, seria insuficiente esgotar esta discussão nos termos de um "deslocamento populacional". É necessário também indagar quais grupos sociais, no final das contas, mudaram sua residência para o entorno das grandes metrópoles. Neste particular, as análises sinalizam que as migrações intraurbanas foram encetadas em especial pelas classes médias e pelos segmentos sociais mais bem aquinhoados, instigados tanto pela fuga da "violência urbana" quanto pela reconquista da "qualidade de vida perdida". Esta transferência foi também motivada pela sedução do discurso do "contato com a natureza" e do "acesso ao verde", justificando novas experiências urbanísticas.

Nos EUA, o gigantesco movimento migratório das classes médias urbanas para a periferia das grandes cidades, conhecido pela rubrica urban sprawl (difusão ou esparramamento urbano), integrou milhões de estadunidenses em formas eminentemente horizontais de uso e ocupação do solo, baseadas em unidades residenciais familiares aglutinadas em um tecido urbano de cunho condominial. Este modelo, conhecido como suburb, constitui contraponto à visão tradicional da "floresta de edifícios". Para além de materializar um primado habitacional, este modelo está subsidiado por um estilo de vida, caracterizado por elevados índices de consumo energético e de matérias primas. A expansão desta modalidade de uso do solo formou formidáveis cinturões nos arredores dos grandes complexos metropolitanos, sendo o "oceano de casas" sua representação visível mais conhecida (Fig. 9).

Reconhecidamente, tal dinamismo urbano promoveu a multiplicação dos impactos provocados no meio ambiente. Primeiramente por ampliar consideravelmente a superfície ocupada pelas cidades. As estatísticas indicam 
que em 1950 os aproximadamente 70 milhões de estadunidenses que viviam em áreas urbanizadas ocupavam 13 mil milhas quadradas de território $(33.700$ km²). No entanto, em 1990, quando a população urbana dos Estados Unidos dobrou, alcançando a marca de 140 milhões de estadunidenses, ao mesmo tempo a superfície ocupada pelas cidades multiplicou-se por cinco, cobrindo 60 mil milhas quadradas (155.400 km²), transformando os sistemas de vias expressas em meras avenidas unificando uma área conurbada à vizinha (MITCHELL, 2001:55).

Por sinal, este processo não tem dado mostras de arrefecimento. Acredita-se que em 2025 a população estadunidense agregará mais 63 milhões de novos habitantes, provocando uma demanda de mais de 30 milhões de novas residências, agravando os impactos desta suburbanização desenfreada. A expansão dos suburbs tem absorvido uma superfície de 1,2 milhão de acres (ou seja, cerca de $4.860 \mathrm{~km}^{2}$ ) de solo por ano. Na voz de todos os especialistas no tema, o urban sprawl tem atuado como fator de comprometimento da preservação

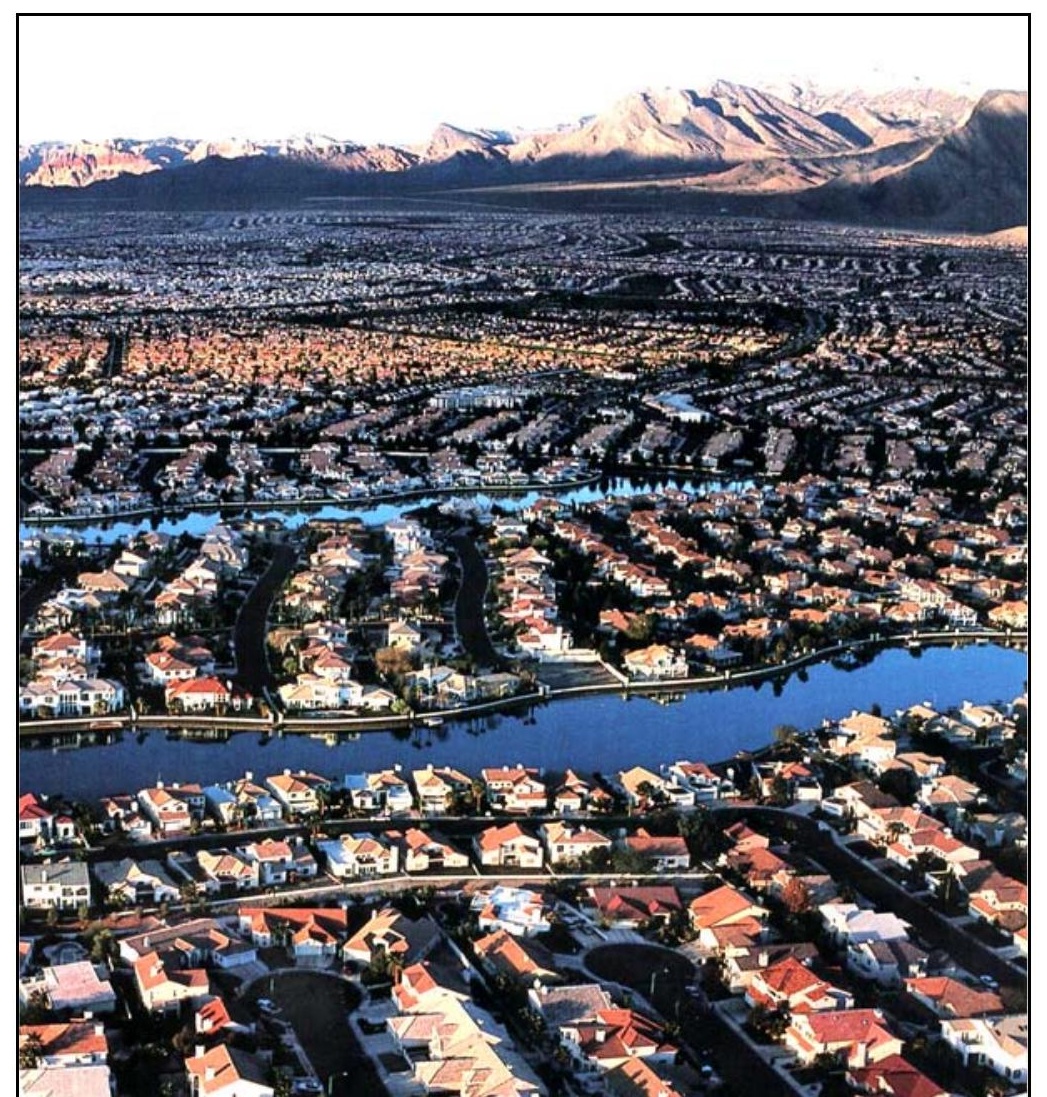


FIGURA 9 - Um Oceano de Casas: Foto de um suburb localizado em Las Vegas (Arizona), uma das áreas metropolitanas de maior crescimento nos EUA. Os lagos artificiais deste condomínio são sustentados pela importação de água de outras áreas e de lençóis subterrâneos, sobejamente porque a região é desértica, na qual, em princípio, o líquido é escasso (Foto de Sarah Leen, National Geography, Julho de 2001, in MITCHEL, 2001:58/59). 
das florestas, da vida selvagem e provocando perda de solo agrícola. Esta cifra, somada à requisição de áreas já antropizadas, alcançaria então a espantosa superfície de 2 milhões de acres (isto é, o equivalente a $8.093 \mathrm{~km}^{2}$ ), a cada ano que passa (MITCHELL, 2001:58).

Em segundo lugar, o modelo suburb incorpora impactos relacionados com a infra-estrutura e equipamentos necessários para sustentar este modo de habitar. Dentre estes estão os associados ao transporte individual, opção por excelência (e única) para os deslocamentos diários dos habitantes destes condomínios. Em geral, cada família moradora de um suburb possui mais de dois automóveis, realizando uma média de dez viagens de carro diariamente. O excesso de veículos gera congestionamentos que aprisionam estas famílias no trânsito mais de 500 horas por ano, ocasionando perdas anuais de US\$ 72 bilhões em combustível (dados de 2001). Isto contribui para explicar o elevado consumo de gasolina dos Estados Unidos, da ordem de 459 galões habitante/ano (cada galão norte-americano equivale a 3,78 litros), índice considerado o maior do mundo ${ }^{33}$.

Muito embora a propalada "selva de pedra" formada pela aglomeração de edifícios não seja propriamente um paraíso ecológico, é evidente que o suburb norte-americano, desmentindo o consenso fabricado pelas imobiliárias, distanciase ainda mais desta referência. Nos níveis concreto e imaginário, este modelo individualista de vida exige para sua sustentação muito mais recursos, intensificando a pressão sobre o meio natural. Nestes espaços horizontais, as "elites do tempo" usufruem benesses que poucas décadas atrás eram oferecidas pelos arranha-céus de alto padrão das metrópoles. Sintomaticamente, o urban sprawl tem provocado estragos de tal monta que se tornou alvo preferencial dos ecologistas radicais norte-americanos, numa escala que se estende de pichações a incêndios premeditados de residências colocadas à venda (vide Fig. 10).

33 Comparemos este índice com outros países centrais: Canadá, 303 galões habitante/ano; Alemanha, 140; Japão, 113; Rússia, 55 (Dados do US Energy Information Administration, WorldWatch Institute e BP Amoco statistical review of World Energy 2000, in National Geographic, março 2001). Evidentemente os níveis de consumo energético seriam outros caso a organização do espaço possibilitasse o transporte coletivo. 
O suburb, após consolidar sua posição no imaginário de afluência dos Estados Unidos, passou a ser adotado pelos setores de alta renda em todo o mundo. Além dos países da Europa Ocidental, as elites dos países periféricos,

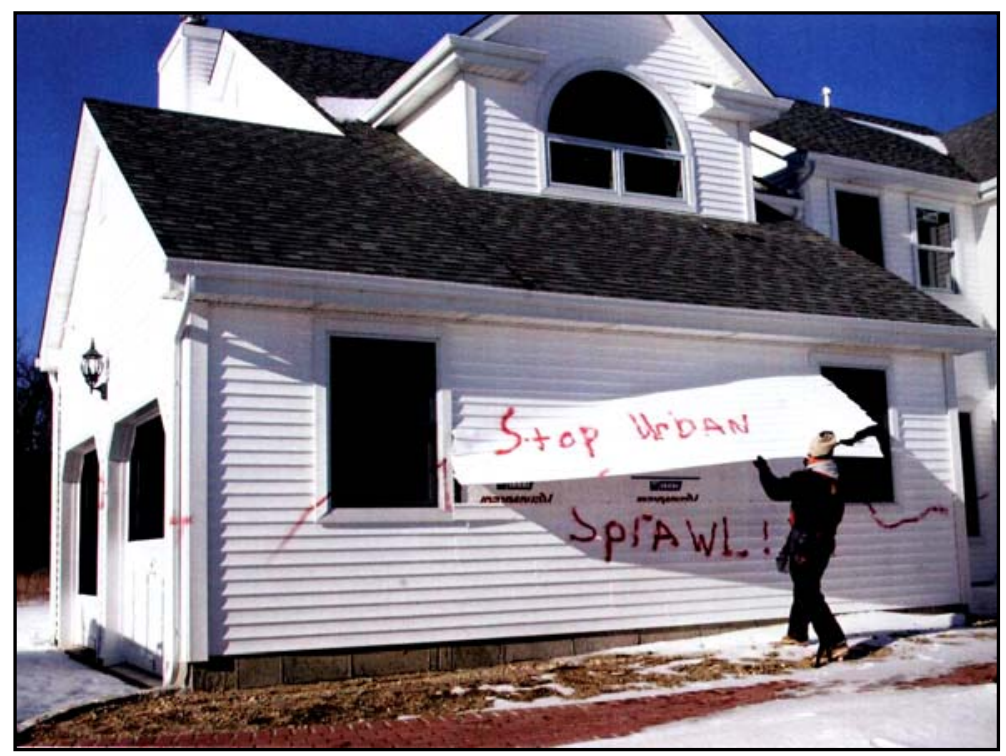

FIGURA 10 - A Resistência ao Urban Sprawl: Ambientalistas radicais da Frente de Libertação da Terra picharam esta casa em um condomínio de Long Island, New York, e queimaram diversas outras. "A Terra não está morrendo, está sendo assassinada", proclamou um comunicado do grupo, "e aqueles que a estão matando, possuem nomes e endereços" (Foto de Sarah Leen, National Geography, Julho de 2001, pp. 71 in MITCHEL, 2001:71). 
por conta tanto de um "efeito imitação" quanto pela busca de um "refúgio tranqüilo"34 da temporalidade que os granjeia à condição de comando da sociedade, passaram a construir versões locais destes suburbs ${ }^{35}$, implantando ilhas de "padrão californiano" muitas vezes cercadas por bairros pobres ou favelas. Implantados em sociedades crivadas por desigualdades de todo tipo, estes "bolsões de opulência" recorrem a todo tipo de tecnologia de segurança para fazer frente à vaga dos excluídos, subliminarmente inscrita num amendontrador "arrastão urbano".

Por sinal, estes temores não encontraram guarida apenas na psicose das elites metropolitas dos países sulistas. Após a II ${ }^{a}$ Guerra Mundial, a prosperidade renovada dos países ricos inverteu a tradicional corrente migratória que escoava dos países "velhos" na direção dos países "novos". Passando a desdenhar funções tidas como schwartz arbeit ("trabalho negro", tarefas consideradas sujas, servis, indignas e/ou degradantes), as sociedades do Norte recepcionaram maciços contingentes populacionais do Terceiro Mundo para o desempenho destas ocupações, motivando um trânsito que recorreu tanto para as vias legais quanto às clandestinas.

Quanto às migrações não-documentadas, estas, organizadas pelas redes de snakeheads (isto é, cabeças de cobra, como são conhecidos os contrabandeadores de pessoas), transformaram-se em num verdadeiro rodamoinho demográfico. Dado seu caráter ilegal, o envolvimento do crime organizado com o lucrativo tráfico de gente (mulheres, crianças e trabalhadores), caso da Yasuka japonesa, das Triads chinesas e da Máfia italiana, tem se tornado uma praxe rotineira nos noticiosos policiais globais. Apesar de alvo de rancorosas recriminações por parte de políticos conservadores em todo o mundo, estas altercações demográficas, ao acatarem necessidades objetivas de acumulação do capital, dificilmente deixarão de existir. Justamente neste sentido é que a contra face da colonização seria a colorização da Europa (SANTOS, 1988:41).

${ }^{34}$ Com efeito, este é um slogan repetido no marketing voltado para a comercialização dos condomínios fechados.

${ }_{35}$ Um destes suburbs, revestido dos ouropéis de um ícone imobiliário, atende pelo "modelo Alfaville", implantado em Barueri, na RMSP. 
Sobretudo, é este imperativo que torna compreensível a insistência com que o bloqueio da linha fronteiriça Norte/Sul esteja sendo colocado à prova incessantemente, perpretado por pessoas que burlando barreiras dispostas em terra, mar e ar, reclamam inserção nos espaços afluentes. Há quem considere esta massa de desvalidos como o cerne de um "arrastão planetário", cenário que ensejaria redobrada vigilância das entradas e saídas dos espaços centrais. No entanto, a movimentação destes "sobrantes", apesar de contidos, detidos, expulsos ou mesmo mortos, é simplesmente incontrolável. Ela resulta das précondições objetivas que tem restringido cada vez mais o espaço de parcelas consideráveis dos humanos.

Esses alienígenas de tipo novo, honorabilizados com uma série de adjetivações tornadas universais pela mídia (outsiders, foreign people, ausländer, disabled persons, clandestinos, boat people, etc), integram um deslocamento que se acentua em escala e impacto, nutrido pela própria lógica do intercâmbio mundial os expele para fora do sistema. Conforme as forças da globalização se tornam mais penetrantes e a fricção da distância separando as nações torna-se mais e mais erodida, este movimento se acentua cronicamente numa mesma escala, realimentando este processo (Vide HUGO, 1998:11). Nas grandes cidades de todo o mundo, a presença destes grupos afirma-se cada vez mais. Repudiados socialmente, marginalizados economicamente, banidos politicamente e culturalmente exorcizados, estes alógenos se organizam em bolsões carregados de tensão étnica, explodindo com o estranhamento que thes é devotado pela sociedade incluída.

Este estado de insolvência do sistema contraria profecias, como as alentadas pelos economistas clássicos, pelas quais o capitalismo difundiria em todas as camadas da sociedade uma abundância generalizada (SMITH, 1979:11). Na nova ordem mundial,

...a pobreza dissemina-se por toda a superfície do globo, avançando sobre as fronteiras do Primeiro Mundo e instalando-se no coração dos Estados Unidos e da Europa ocidental. No mundo todo, microespaços de prosperidade convivem com cinturões envolventes de pobreza e desemprego. Vastas regiões da África subsaariana, América Latina e Ásia 
meridional conhecem as tragédias associadas à miséria absoluta (MAGNOLI, 1993:62).

Por tudo isso, a urbanização moderna não só representa um modelo de civilização como igualmente um modo de relacionamento com o meio ambiente que atravessa uma crise estrutural profunda, e exatamente por esta razão solicita revisão urgente. Tendo por cenário esta realidade crivada por contradições, todos seriam tentados a entender que não haveria como alimentar expectativas alvissareiras para os dilemas urbanos da modernidade. Decididamente, as cidades estão doentes mais do que em qualquer outra época da história do ser humano (DIAS, 2002b: 35).

No entanto, "o sentido da cidade enquanto obra da civilização - que não se reduz à sua construção física - diz respeito à construção da humanidade do homem" (CARLOS, 2004:29). É necessário recordar que desde sua origem, a noção de pertencer à cidade, a uma coletividade organizada que reúne um conjunto de cidadãos, esteve, como ponderou o geógrafo Roland Breton, ligada semanticamente à idéia de refinamento. É o que se pode apreender quando se toma conhecimento de que as palavras civilização e cidadania originaram-se, da mesma forma que o advérbio civilmente, o adjetivo civil e o conceito de civilidade, do latim civitas, isto é, cidade. De uma outra raiz latina, urbs, também significando cidade, seriam provenientes os adjetivos urbano e o substantivo urbanidade (BRETON, 1990:13).

Seria oportuno comentar, a questão percepção do meio ambiente enquanto móvel das atitudes que se adota junto à natureza conquistou desde os anos oitenta o merecido reconhecimento que the cabe nas ciências sociais e no que interessa diretamente a este trabalho, no pensamento geográfico (Ver GONÇALVES, 1982 e 1990; MOREIRA, 1982b). Caberia, pois certificar uma percepção ambiental tendo por meta o meio urbano, e com base nesta preocupação, pensar um projeto político de tipo novo, destacando a cidade enquanto um espaço habilitado a assegurar a inclusão da maioria dos humanos e não sua exclusão. 
Tendo em mente a sentença pela qual a crise ambiental da humanidade ou será resolvida no meio urbano ou terá nas cidades seu epitáfio, o resgate do sentido original da palavra cidade sinaliza para a necessidade de repensar os valores que têm legitimado sua existência na perspectiva de uma sociedade justa e ecologicamente responsável.

Exatamente por esta razão é que se pode neste momento finalizar este caudal de comentários e explicações apontando para alguns dos entendimentos propostos por um oikos-logos ampliado, uma outra oikoumene, alternativa à da modernidade excludente.

\subsection{BUSCANDO UM NOVO PONTO DE EQUI LÍBRIO}

Conforme se ressaltou, a partir da modernidade a interferência do homem no ambiente acentuou-se, gerando intensa artificialização do espaço habitado. A fruição linear e progressiva do tempo suscitou a irrupção de um espaço regrado por circuitos eminentemente artificiais, no qual pespontam objetos técnicos e demais eminências de uma artificialidade avassaladora.

A paisagem cultural substituiu a paisagem natural e os artefatos assumiram sobre a superfície terrestre um status cada vez mais altivo. Este espaço-prótese, dominado pela presença de objetos idealizados pelos humanos e articulados entre si através de sistemas, corresponde a um compartimento artificial engendrado pela Gesellschaft humana e submetido unicamente ao seu comando. A tecnosfera (ou seja, uma esfera técnica), forma o resultado final deste processo.

A tecnosfera, configurando um meio técnico-científico-informacional, é sumamente a espacialidade da modernidade. Ela reúne a cidade, as imensas parcelas tecnificadas do meio rural, assim como seus predicativos técnicos, estruturais e sistêmicos. Seu funcionamento solicita a agregação incessante de conteúdos de tempo, garantindo fluidez e velocidade cada vez maiores ao 
conjunto do sistema, uma aceleração que constitui sua essência mais marcante e inescapável (SANTOS, 1998:31/33, 44/45, 127/128 e 139/140).

Verdadeiramente, a tecnosfera é um espaço no qual a atuação da espécie humana é tão incisiva e sua influência de tal envergadura que se tornou inevitável conceituá-la enquanto elemento operacional distinto. Daí o consenso em perfilar a tecnosfera como uma sexta camada, usufruindo estatuto similar à litosfera, hidrosfera, criosfera, atmosfera e a biosfera. As denominações utilizadas ao gosto deste ou daquele autor, termos como esfera artificial, humana, da inteligência, camada técnica ou noosfera ${ }^{36}$, em nada se omitem de decalcar este sentido ou de esclarecer o quanto esta construção constitui um crédito do engenho humano (passim SANTOS, 1988, 1998 e REBOUÇAS, 2002a:5).

Reconhecidamente, a tecnosfera perde inteligibilidade no caso de ser dissociada do entendimento do meio urbano enquanto seu núcleo ativante. As cidades, materializando o cerne da ordem econômica, social e política existente, transformaram a totalidade do Planeta em um espaço subordinado aos seus dinamismos de reprodução. Em face desta inferência, rede urbana mundial e tecnosfera mantém íntima relação entre si, potencializada pela organicidade que solda estas instâncias uma com a outra. Tal interação, legitimada por fixos e fluxos das mais diversas consistências, engendra a mais singular das materialidades do mundo moderno (Fig. 11).

Portanto, não seria de estranhar que justamente em nível das dinâmicas substantivadas na tecnosfera vislumbra-se o retrato mais fiel da torção do espaçotempo da modernidade. Concretamente, as problemáticas decorrentes da tecnosfera são de tal modo presentes, que torna obrigatório pautar este compartimento em qualquer debate imbuído de contemporaneidade. Não existe a menor possibilidade de se pensar a crise socioambiental do mundo atual menosprezando sua influência e o caráter decisivo que desempenha para a existência da totalidade dos humanos.

${ }^{36}$ Termo cunhado por Teilhard de Chardin (1881-1955), definindo o mundo do espírito e do pensamento humano, um lençol habitado por inteligências livres, tendo por meta a ascensão da consciência. 
Contudo, a complexidade deste fenômeno não se esgota na eventualidade de se ater exclusivamente às nuanças concretas da tecnosfera. Pelo contrário, compreendê-la significa amplificar a percepção não só para as instâncias visíveis quanto também para as invisíveis que regem sua sustentação. As prefigurações imaginárias, substantivadas em sistemas sêmicos, arquétipos culturais e códigos topológicos, revelam uma força insubstituível na objetivação do espaço, cabendoIhes, justificadamente, papel influente nas motivações que moldam e remodelam incessantemente o espaço habitado pelo homem.

Os modelos espaciais imaginários, resultando de processos históricos e sociais, articulam-se com o funcionamento do arranjo espacial, gerando uma comunicação que assegura a ligação entre os objetivos intencionais e sua materialização. Assim, produzir uma representação do espaço já seria uma apropriação, uma empresa e um controle. Mesmo se isso permanece nos limites de um conhecimento, qualquer projeto expresso por uma representação revela a

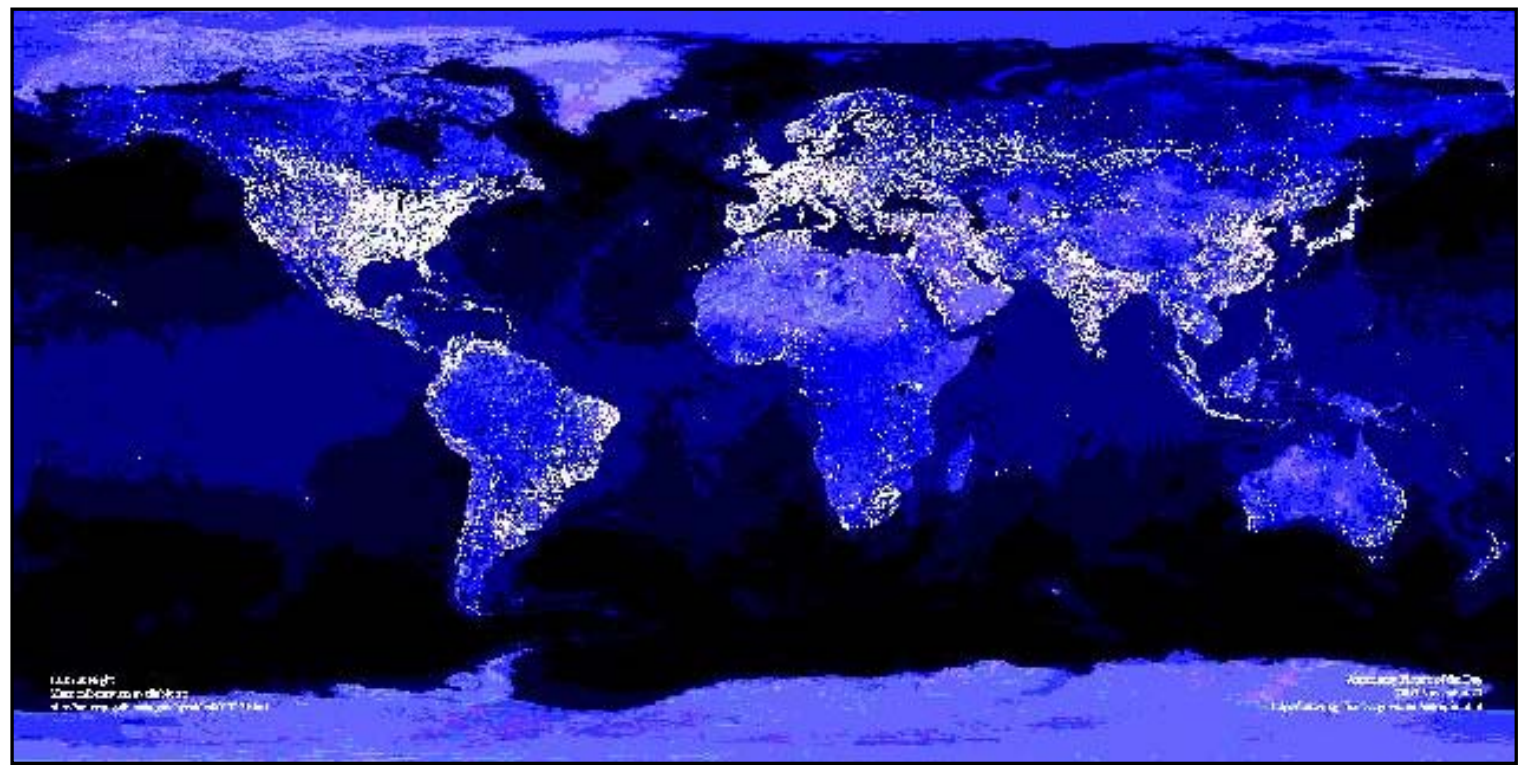


FIGURA 11 - A Galáxia de Luz da Tecnosfera: Montagem fotográfica da madrugada terrestre de 27 de Novembro de 2000, evidenciando galáxias de luzes formadas a partir das aglomerações urbanas e outros objetos espaciais luminosos. (Fonte: Astronomy picture of the day, Nasa, <antwrp.gsfc.nasa.gov/apod/astropix.html>, acesso em 12-01-2005) 
imagem desejada de um território, de um local de relações, passível de ser, cedo ou tarde, materializado no próprio espaço (RAFFESTIN,1993:144).

A este respeito, também poder-se-ia recorrer à fala do geógrafo francês Paul CLAVAL, para o qual:

O espaço é um dos apoios privilegiados da atividade simbólica. Ele é percebido e valorizado de forma diversa pelos que o habilitam e lhe dão valor; à extensão que ocupam, percorrem e utilizam superpõe em seu espírito, aquela que conhecem, amam e que é para eles signo de segurança, motivo de orgulho ou fonte de apego. O espaço vive assim sob a forma de imagens mentais; elas são tão importantes para compreender a configuração de grupos e forças que trabalham quanto às realidades reais do território que ocupam (1979:20/21).

Por tudo isso interessaria emendar que o pensamento de Milton Santos, ao propor uma noção de totalidade social incluindo simultaneamente a esfera do concreto e a do ideal, subentendia possivelmente a existência de uma tecnosfera conectada a uma psicoesfera. Neste quesito, uma ponderação pertinente reportaria à noção de concrescência, elaborada pelo filósofo britânico Alfred North Whitehead. Este conceito, proposto enquanto uma evolução criadora do processo de concreção, conjumina, na adição simultânea dos aspectos físicos e dos espirituais, indissoluvelmente irmanados e ativos entre si, seu nexo epistemológico fundante (Vide Diccionario de Filosofia, Nicola Abbagnano, 1991:210).

Assim a tecnosfera e a psicosfera, longe de serem discrepantes, formam um binômio inextricável, repleto de interações e correspondências de todo o tipo. Neste intercâmbio, a psicoesfera, reunindo as crenças, desejos, paixões, vontades e hábitos que inspiram a prática concreta, as relações interpessoais, os comportamentos filosóficos e a comunhão com o universo, é confidente das expectativas sociais que antecedem, apóiam e sustentam no plano imaginário, a futura materialidade do meio técnico-científico (Cf SANTOS, 1993b:50/51, 1998:32 e 1999:203/204).

A importância da psicoesfera se torna patente por especificar, contrariamente ao postulado pelas teceduras vulgares do materialismo, que a consciência detém um papel de magno desempenho nos processos de espacialização. Ela se 
manifesta quando se percebe que o espaço se reproduz sufragado por pressupostos imaginários, capacidados a antecipar as expectativas colocadas pela territorialização. No caso do Brasil,

...como tecnosfera, o meio técnico-científico se dá como um fenômeno contínuo na maior parte do Sudeste e do Sul, desbordando para grande parte do Mato Grosso do Sul. Como psicoesfera, ele é o domínio do país inteiro (SANTOS, 1998:32/33).

Por esta via de entendimento, mais do que prisioneiro de uma lógica que o comanda, os humanos podem, a partir do que venha a residir como expectativa de futuro em nível do imaginário, devassar um outro porvir, absolutamente diverso do que se descortinaria diante deles. Esta inferência se ancora no predicado pelo qual as informações não criam idéias, mas pelo contrário, são as idéias que criam as informações. A psicoesfera, correspondendo a um dado empírico, mas não material, está definitivamente incorporada ao reino da liberdade (SANTOS, 1998:84).

Com este dado em mãos, pode-se advertir que a fragilidade da oikoumene existente, do seu frenesi incontido que nada mais evidencia do que as pulsões da sua crise, não está credendiada a arrastar de modo irreversível a humanidade consigo no torvelinho do tempo que ela mesmo engendrou. Afinal, neste momento da história é a própria sociedade ocidental, diferentemente dos tempos em que avançava sem reconhecer qualquer obstáculo à sua expansão, que admite a existência de desequilíbrios. Tal postura é perceptível nos discursos que colocam em questão os parâmetros nos quais o ocidente se amparou durante séculos, ao mesmo tempo em que propõem alternativas para sua continuidade.

O famoso informe elaborado em 1968 pelo Clube de Roma, significativamente publicado sob o título Limites do Crescimento (documento também conhecido como Relatório Meadows), constitui um ótimo exemplo do que foi exposto. Este material materializou pela primeira vez um discurso de caráter científico assumindo abertamente a existência de limites para o desenvolvimento, advertindo para a impossibilidade deste manter ilimitadamente sua expansão. Daí 
a preocupação em ao menos mascarar as limitações objetivas que se colocavam crescentemente à forma de reprodução da sociedade moderna, dentre estas obviamente aquelas com base na relação mantida com a natureza (GONÇALVES, 2001:8).

É igualmente interessante notar que logo nos parágrafos iniciais de Limites do Crescimento, o espaço-tempo está referendado como padrão de referência para a vida humana, um argumento imanente que percorre o corpo da publicação num variado rol de temas, tais como a questão do crescimento exponencial, demoras naturais nos processos ecológicos, o estado de equilíbrio global, etc. Nesta ordem de considerações, estaria a ecologia, entendida como obstáculo às estratégias de desnaturalização e inserindo uma discussão com conteúdos temporais, capacitada a assumir o papel, como definiu Georges BALANDIER (1988:195), de uma ciência do tempo? Poder-se-ia pensar a ecologia enquanto eixo motivador da rediscussão do espaço de vida dos homens e sua reavaliação em termos de um conceito humanista, não-excludente?

Acredito que a resposta poderá ser dada não por meio de conceitos abstratos, mas sim por uma prática real preocupada com um novo projeto de oikoumene. Este seria um excelente momento para recordar - dado que se está referindo à crise de uma ordenação social do tempo advinda do Renascimento e que terminou por engolfar o planeta inteiro sob sua hegemonia - que seu calcanhar de Aquiles é justamente a aceleração. Tanto esta observação corresponde, que os humanos desigualmente integrados à modernidade cedo descobriram nas greves e nas operações-tartaruga modalidades eficazes de colocar em cheque a fruição do tempo hegemônico. Resumidamente: a força dos fracos é o seu ritmo lento (SANTOS, 1993a e 1998:81/86).

Neste sentido, talvez os mais autênticos senhores do tempo não sejam aqueles que habitam as orgulhosas torres das próteses do tempo. Contrariamente ao que muitos arautos da velocidade imaginam, pode-se entender que nos "espaços opacos" das urbes modernas, espaços ocupados pela informalidade e pelo alheamento não-premeditado ao que postulado como moderno, é que a 
compreensão do processo - e por extensão a resposta a ele - pode ser encontrada:

A força é dos 'lentos' e não dos que detêm a velocidade elogiada por um Virílio em delírio na esteira de um Valéry sonhador. Quem na cidade tem mobilidade - e pode percorrê-la e esquadrinhá-la - acaba por ver pouco da Cidade e do Mundo. Sua comunhão com as imagens, freqüentemente préfabricadas, é a sua perdição. Seu conforto, que não desejam perder, vem exatamente do convívio com essas imagens. Os homens 'lentos', por seu turno, para quem estas imagens são miragens, não podem, por muito tempo, estar em fase com este imaginário perverso e acabam descobrindo as fabulações (SANTOS, 1998:84).

Trata-se, pois, da possibilidade de uma nova temporalidade, heterogênea, preocupada em unir e não simplesmente unificar, capacitada a resgatar os sentidos de humanidade e de naturalidade para que estes possam então ser materializados no espaço habitado.

Possibilidades que acima de tudo residem na esperança, esperança que se confunde com a resistência, resistência cujo sentido último será dado pela história concreta dos homens dispostos a resgatarem seu próprio destino.

Desafio que se coloca a todos, em todos os espaços e todos os tempos! 
PARTE I I I

SOCI EDADE, ÁGUA E MEIO AMBI ENTE 


\section{CAPÍTULO 5}

\section{ÁGUA: UM RECURSO ESTRATÉGI CO}

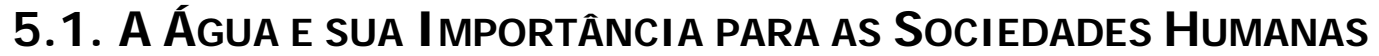

Como se sabe, a água é um recurso natural essencial. Isto, em razão de constituir um componente bioquímico indispensável para a totalidade dos seres vivos, incluindo-se nesta acepção o conjunto da raça humana. A água é, por definição, o ambiente de vida para inumeráveis espécies animais e vegetais. Organismos muito simples podem sobreviver sem ar. Todavia, nenhum deles consegue sobreviver sem água (RUTKOWSKI, 1999b:5).

Os vínculos que relacionam a água com as manifestações de vida são de tal modo evidentes, que tornam obrigatória a recordação desta associação qualquer que seja o estudo ou a avaliação técnica versando sobre a importância do recurso. Importa consignar, especialidades relacionadas diretamente com o domínio das águas, como seria possível citar, a hidrologia e a limnologia, de forma alguma se omitem em recomendar este vínculo. Pelo contrário, estas se dispõem em frisar, a todo o instante, tal relacionamento.

Neste sentido, a limnologia, ao dedicar-se ao estudo interdisciplinar dos meios aquáticos, manifesta uma preocupação irrevogável com os aspectos que interagem com o conjunto dos seres vivos. Quanto à hidrologia, mesmo dando especial atenção à água em termos da sua ocorrência, circulação e distribuição, suas propriedades físicas e químicas, está igualmente voltada para a relação mantida com o ambiente natural e com as formas de vida, categoria que obviamente inclui os seres humanos (Cf CHORLEY e HAGGETT, 1975:104).

A água esteve presente em todas as etapas do surgimento e posterior expansão da espécie humana no nosso Planeta. Na ausência deste líquido vital, o surgimento das poderosas civilizações do passado, fortemente identificadas com a 
presença das águas doces, seria impensável. Recorda Fernando de AVILAPIRES, dentre os fatores ecológicos que influenciaram na seleção de locais para o estabelecimento dos primeiros núcleos de povoamento, um dos mais importantes foi reconhecidamente a ocorrência de água potável (1983:47). De fato, a espacialidade tradicional foi claramente marcada pela necessidade de acesso aos veios de água. Exemplificando, na África, registros históricos referentes ao intercâmbio comercial transaariano dão conta de que as grandes rotas de comércio acatavam premissas bastante claras, obedecendo a roteiros muito bem definidos nos quais a reserva de água era a consideração primordial (Vide JONES, 1966:222/223).

Assim, não admira que no longínquo passado a proeminência desta substância já estivesse consolidada. Fato incontestável, as regiões agraciadas com a presença de água, caso típico dos grandes vales fluviais (rios Nilo, Hindus, Ganges, Amarelo, Mekong, Niger, Zambeze, Tigre e Eufrates) e de áreas lacustres intensamente irrigadas (caso do Vale do México e da bacia do lago Tonle Sap, na Indochina) marcaram de modo indelével a vida e a organização social, política e econômica dos povos que os ocuparam. Como ponderou o geógrafo e antropólogo italiano Eugenio TURRI, isto o demonstra a história dos grandes rios, de diversas formas e em épocas diferentes (1983:4). De outra parte, sistemas de oásis como os do Sinkiang-Dzungária, do Kara-Kum e o colar de afloramentos saarianos, também foram fundamentais para a criação de colônias agrícolas e entrepostos comerciais, espaços nos quais a vida regurgitava contrastando com a opacidade que lustra os desertos (MAULL, 1959:64/65).

Nas civilizações erguidas com base nessas ocorrências naturais de água (por sinal consistindo, do ponto de vista histórico, os primeiros arranjos espaciais de vulto), é possível identificar um embrião de estratégias de gerenciamento dos recursos hídricos. Esta constatação é particularmente verdadeira para as sociedades ditas "hidráulicas" ou "de regadio", regidas pela formação social asiática, despótica, tributária ou oriental. No mundo "asiático" - ou como diziam Karl Marx e Friedrich Engels, na "Velha Ásia" - a administração dos recursos 
naturais, sobejamente dos hídricos, constituía uma prioridade indiscutível (Vide BANU, 1969, SOFRI, 1977, BARTRA, 1978 e MAMIGONIAN, 1997).

Nestas sociedades, a prosperidade, ao decorrer diretamente da irrigação, configurava a água e a rede de canais construídos para drená-la enquanto elemento-chave indissociável da perpetuação do espaço articulado. Este seria o caso do Sri Lanka, país no qual 850 anos atrás, a água já era objeto de uma meticulosa regulamentação. Esta previa não somente as modalidades de sua distribuição,

...como também determinava as responsabilidades quanto à conservação dos reservatórios e canais de irrigação. Até se tornarem obsoletas com o advento da economia monetarista, essas disposições foram aplicadas através de um sistema de cooperação mútua. A tradição persiste em muitas aldeias isoladas (GURUGE, 1985: 30).

Esta "hidrofilia" das antigas sociedades baseadas na agricultura irrigada dizia respeito a necessidades absolutamente objetivas. Como analisou Karl MARX,

...essa fertilização artificial do solo, dependendo de um governo central e caindo em decadência desde que a irrigação ou a drenagem fosse negligenciada, explica o seguinte tato, que de outro modo pareceria estranho: territórios inteiros, outrora admiravelmente cultivados, como Palmyra, Petra, as ruínas do Yêmen, vastas províncias do Egito, da Pérsia e do Indostão, encontram-se hoje estéreis e desérticos. Assim como explica porque uma única guerra devastadora pôde despovoar o país durante séculos e privá-lo de toda a sua civilização (1976:22).

Exatamente esta fatalidade destruiu para sempre a posperidade da antiga Felix Arábia (atual Yêmen), após a ruptura do açude que represava a torrente do Adhanat, por um terremoto em 542 d.C. Esta barragem coletava as precipitações pluviais de uma vasta região, cujas águas, eram então cuidadosamente conduzidas para os campos irrigados por intermédio de uma intrincada rede de canais. Objeto artificial imprescindível para a manutenção do sistema de irrigação que transformou a Arábia Meridional em um jardim de especiarias ao longo de um milênio e meio, o rompimento do dique foi golpe decisivo para destruir para sempre o arranjo espacial formado pelos chamados "Reinos do Incenso": Sabá 
(ou Sheba), Hadramaut e Qataban. Estes principados, afamados na Antiguidade Oriental pela produção de aromas e essências aromáticas de toda ordem, como oloés, mirra e evidentemente o incenso, descreveram desde então uma irrefreável trajetória de decadência, sendo enfim sepultados nas areias e no esquecimento.

Tal como no passado, em nível mundial, a agricultura é de longe, na atualidade, além da atividade mais suscetível à escassez de água, o mais importante usuário de recursos hídricos. Esta atividade consome entre 65\% e 70\% do total, porcentagem considerável na comparação com os $24 \%$ requisitados pela indústria, e mais ainda, quando o termo da comparação é o uso residencial. As atividades domésticas, alvo freqüente das campanhas de economia de água, respondem por $8 \%$ a $10 \%$ do consumo total, sendo seguramente o menos expressivo dos usos (Vide Tabela 2). A agricultura tem sido responsável por notável utilização consuntiva dos recursos hídricos, inclusive por conta da necessidade premente de expansão da oferta de alimentos, alicerçada especialmente na irrigação. Nesta perspectiva, assinale-se que nos países em desenvolvimento o percentual utilizado pela agropecuária pode ser até mais alto, chegando a alcançar 80\% (Ver entre outros RODRIGUES, 1998:25).

É fácil compreender a magnitude do consumo de recursos hídricos pelas atividades rurais. Não por outro motivo senão pelo fato da água ser insubstituível nos processos biológicos. Sua importância é evidente quando se lembra que a água pode representar até $90 \%$ da composição dos vegetais. A disponibilidade inadequada do recurso em períodos como o do crescimento das plantas, pode comprometer lavouras inteiras e gerar crises de fome em larga escala. Em vastas porções do meio rural em todo o mundo, a ausência de chuva é interpretada como um capricho cruel da natureza, preconizando toda sorte de ansiedades e momentos tormentosos, um verdadeiro fantasma que amedronta o camponês até os recônditos da sua alma.

No referente à pecuária, a importância da água não é menor. Poucas imagens se tornaram tão familiares quanto às de rebanhos calmamente se deleitando na beira de um afloramento aquático qualquer. O líquido é vital para a dessedentação dos animais, para a produção de ração, para o funcionamento dos 
matadouros e posteriormente, para o processamento da carne pela indústria alimentícia. Além disso, ressalve-se que a ração animal incorpora água não só para ser produzida como também solicita determinado teor de umidade para configurar-se eficazmente enquanto forragem.

Contabilizando o volume total de água solicitado pelos rebanhos, chegamos a um enorme input hídrico, fato raramente conhecido pelo cidadão comum. Os índices de consumo de água pelos rebanhos, variam, como seria de se esperar, em virtude das condições ambientais, dos métodos de criação e das suas finalidades. Mas de qualquer modo, o volume consumido jamais pode ser considerado desprezível. Uma avaliação elaborada com base em dados provenientes do semi-árido nordestino nos indicaria, apenas no referente às

TABELA 2

CONSUMO MÉDIO RESIDENCIAL DE ÁGUA POR ATIVIDADE DOMÉSTICA

ATIVIDADES DOMÉSTICAS (UNIDADE)

Banho de ducha

Banho de banheira

Máquina de lavar louça

Máquina de lavar roupa
DEMANDAS DE ÁGUA (LITROS)

$$
\begin{array}{lll}
40 & - & 80 \\
150 & -200 \\
5 & - & 15 \\
80 & - & 120
\end{array}
$$

(Fonte: Armand, 1998, L'eau en danger, Collection Les Essentiels, Milan/Paris) 
quantidades voltadas para a dessedentação dos animais, os seguintes valores: 53 litros diários para o gado bovino; 41 para cavalos e jumentos; 6 para os suínos, cabras e ovelhas; 0,2 para galinhas (REBOUÇAS, 2004:49).

Coerentemente, dada a importância da água para a criação dos animais, não admira que nas regiões áridas e semi-áridas do planeta, nas quais a escassez do líquido é notória, os pastores nômades tenham desenvolvido agudo senso de reconhecimento do recurso no ambiente natural, prospectando poços de água e explorando os veios que afloram superficialmente - como no caso dos poços e dos oásis que irrompem através dos desertos - nos quais é possível repousar, desfrutar de sombra, obter alimento e matar a sede do gado.

Ao menos em tese, o consumo agropecuário de água se manterá majoritário em termos do consumo global. O crescimento das áreas de lavoura irrigada e das pastagens conquistadas ao meio natural permanecerá, ao que tudo indica, responsável pela maior parcela da utilização dos recursos hídricos nos próximos 25 anos. O grande leitmotiv é que a água nunca pode estar ausente nas atividades rurais. A título de exemplo, deve-se atentar que "para se produzir uma tonelada de grãos são necessárias mil toneladas de água, e para uma tonelada de arroz, duas mil toneladas de água" (SALATI, LEMOS e SALATI, 2002:49).

Outra certeza é que a industrialização está cada vez mais se destacando no consumo de água. Analisando esta questão, registra o conhecido ambientalista norte-americano Lester BROWN:

As mil toneladas de água utilizadas na Índia para produzir uma tonelada de trigo, valendo talvez US\$200, podem também ser utilizadas para incrementar facilmente a produção industrial em US\$10 mil, ou seja, 50 vezes mais. Essa relação ajuda a explicar por que, no Oeste americano, a venda de direitos de água de irrigação para os centros urbanos pelos fazendeiros é uma ocorrência quase diária (2001).

Porém nada nestes dados obsta as considerações primordiais relacionadas com a alimentação. Afinal, ninguém pode comer vidro, papel, plástico, aço ou alumínio. Nesta linha de raciocínio, a ampliação da produção agrícola seria, em princípio, indissociável de um consumo hídrico que é sua condição sine qua non, 
inerente ao seu próprio dinamismo. E, tal assertiva é particularmente correta quando o assunto em pauta é a irrigação, prática que tem respondido pelos aumentos de produtividade da agricultura registrados em quase todo o mundo. Mesmo que as terras irrigadas representem neste exato momento apenas um sexto de toda a área agrícola, recorde-se que estas são, na contra-mão, fornecedoras de mais de um terço da produção global de alimentos (Cf VILLIERS, 2002:199).

Dada a associação entre população humana e alimentação, a expansão demográfica constitui um outro motivo freqüentemente apontado para explicar a ampliação do consumo de água. Atualmente, a humanidade soma 6,2 bilhões de indivíduos. Acredita-se que este total passará para 7 bilhões em 2010, 8,5 bilhões em 2025 e presumivelmente alcançando a cifra de 10,5 bilhões em 2050 (Ver a respeito $N Y T, 2000: 482)$. A população humana cresce à razão de 90 milhões de indivíduos por ano. Isto equivaleria, com base em dados demográficos do ano 2005, à população de um país como o México a cada doze meses, ou a três Marrocos, seis Repúblicas Malgaches ou ainda a oito nações do porte da Grécia, no mesmo período de tempo (Ver entre outros BROWN, 2001).

No entanto, é necessário ressalvar, de uma vez por todas que o crescimento populacional não constitui, em si mesmo, um elemento motivador da ampliação das áreas voltadas para a produção de alimentos e tampouco, da ampliação do consumo de recursos hídricos. Na realidade,

...todo modo histórico de produção tem suas leis próprias de população, validas dentro de limites históricos. Uma lei abstrata de população só existe para plantas e animais, e apenas na medida em que esteja excluída a ação humana (MARX, 1975b:733).

Muito mais do que a "expansão demográfica" pesa a persistência, entre vários arrazoados, de diversas inferências econômicas consorciadas em nível da atividade agropastoril com modelos do uso do solo e dos recursos naturais, assim como suas indiscutíveis interfaces sociais e políticas. Estas por sua vez estão vinculadas com formas perdulárias de utilização dos recursos hídricos, 
hegemônicas enquanto opção preferencial para a produção de alimentos em muitos cenários geográficos do mundo.

Em suma, são os fatos influentes da arquitetura social, bem mais do que as considerações demográficas, que têm respaldado os prognósticos crescentemente preocupantes quanto à disponibilidade de água doce. Nesta acepção, o crescimento populacional per se não constitui a razão para a aceleração do consumo de água. Sequer de outros epifenômenos correlatos à expansão de modelos agrícolas que tem sido alvo de toda sorte de questionamentos socioambientais. Dentre estes poderíamos mencionar o alastramento de campos antropogênicos voltados para a produção de carne, especialmente da bovina, e de culturas comerciais como a da soja, ambas afetando diretamente espaços florestados e aqueles que, de uma forma ou de outra, terminaram incorporados à categoria de "ambientes naturais" 37 .

Em síntese, a grandiosidade da expansão demográfica, que em algumas análises seria agravada pelo seu próprio caráter exponencial, não evidenciaria uma problemática hidrológica singelamente vinculada com o crescimento populacional, ainda que este último tenha se explicitado de um modo historicamente sem precedentes. Como se verá adiante, muito mais do que na demografia, a explicação para o crescente problema do acesso aos recursos hídricos reside numa ordem de motivações muito mais complexa. Esta recusaria um frágil, porém atraente, entendimento superficial da realidade.

Em suma, o que está no centro desta problemática é um modelo de desenvolvimento gerador da crise socioambiental em nível mais amplo e da penúria hídrica no seu sentido mais particular. Ainda que a distribuição natural dos recursos hídricos e sua administração seja por definição objeto de interesse de toda pesquisa voltada para a questão dos recursos hídricos, a temática ora apresentada reclamaria prestigiosa atenção para o universo das influências

\footnotetext{
${ }^{37}$ Em Maio de 2005, dados divulgados pelo INPE relevaram que no Brasil a área desmatada entre Agosto de 2004 e Agosto de 2005 alcançou a assombrosa cifra de $26.130 \mathrm{~km}^{2}$ (quase uma Alagoas), o segundo maior número desde 1988, quando o monitoramento começou a ser feito. Quase metade da devastação $\left(12.586 \mathrm{~km}^{2}\right)$ ocorreu em Mato Grosso. Em grande parte a devastação foi motivada pela expansão da pecuária, do cultivo da soja e da exploração madeireira (Manchetes Socioambientais, edição de 19-05-2005).
} 
sociais. Na ausência deste enfoque, declinações contábeis poderiam arvorar-se em ciência social e a perspectiva endossada neste trabalho deixaria de fazer qualquer sentido.

Esclareço que mesmo com o registro destes reparos, tal questão, por demais complexa para ser esgotada neste momento, estará freqüentando os pronunciamentos desta explanação nos mais diversos ângulos e perspectivas. $O$ tema que será objeto de análise nos próximos parágrafos, referente à presença da água no espaço geográfico terrestre e suas possíveis atribuições concernentes às demandas dos humanos, consistirá em mais uma das propícias ocasiões que se terá pela frente para exercitar esta discussão neste trabalho.

\subsection{As Águas doces no Planeta Terra}

A água é a substância mais abundante na superfície do mundo. Visível por todo o Planeta, a conhecida sentença A Terra é Azul, proferida pelo famoso astronauta soviético Yuri Gagarin ao entrar em órbita terrestre em 12 de Abril de 1961, reflete em grande parte este fato objetivo. Tal percepção do astro, um corpo celeste azul e branco contrastando com a escuridão infinita do cosmos (Fig. 12), constituiu experimento contundente e singular, mudando desde então o relacionamento do homem com o seu ambiente em geral e com a água em particular (REBOUÇAS, BRAGA e TUNDISI, 2002:III).

O surgimento do estoque natural de água existente no Planeta, calculado em 1.386.000.000 de $\mathrm{km}^{3}$, ocorreu na escala do tempo geológico, somando dezenas de milhões de anos. Este volume é geralmente tomado como referência básica para pensar a questão dos recursos hídricos no nosso Planeta, manifestando-se basicamente na forma de um balanço em circulação que tem permanecido constante na passagem dos tempos históricos (NEGRET, 1982:35). Este montante foi formado desde as convulsões mais críticas da Era Pré-cambriana, concomitantemente com resfriamento da crosta, a eclosão de chuvas torrenciais, 
formação dos reservatórios aquáticos e com o concurso, em menor escala, de vários outros fenômenos.

Dentre estes, pode-se citar para o caso dos jazimentos subterrâneos as águas de origem juvenil, isto é, geradas pelos processos magmáticos da Terra e estimadas em aproximadamente $300 \mathrm{~m}^{3}$ por ano (Cf REBOUÇAS, 2002b:127). Quanto ao volume composto pelas águas superficiais, tem ocorrido de modo imemorial o ingresso de nacos alienígenas do líquido através dos chamados cometas de água, que trazem consigo, desde os confins do universo, uma ninfa azul encapsulada. Entendimento postulado por diversas vozes da física e do meio astronômico, tais corpos celestes seriam responsáveis pela incorporação, pelo 


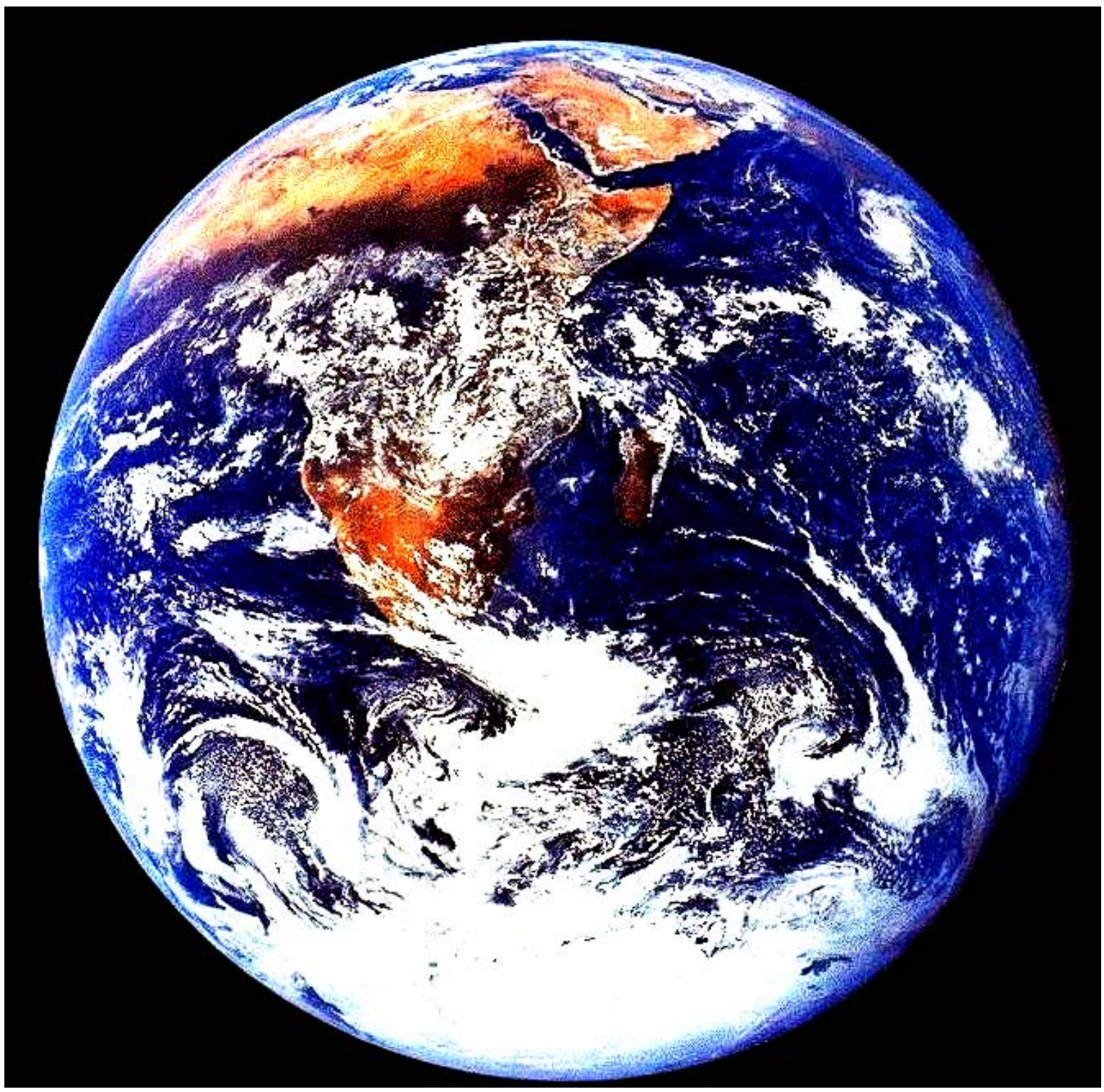

FIGURA 12 - Vista da Terra tendo foco central no continente africano

(Fonte: <http://www.globalgeografia.com/satellitelafrica.jpg>, acesso em 10-02-2005) 
Planeta, de cerca de três trilhões de toneladas de água extraterrestre a cada dez mil anos (Ver a respeito GARCIA e DARQUE, 2004:13).

Mais notável, contudo, foram as modificações ocorridas na forma de distribuição espacial, isto é, a presença em corpos líquidos como rios e lagos, aqüíferos, geleiras, oceanos e mares ${ }^{38}$, em alguns casos de magnitude considerável. Foi o que ocorreu durante os períodos glaciais. Com o avanço das geleiras a fisionomia da água, e do próprio planeta Terra, foram profundamente transformadas, promovendo em igual medida amplo rol de alterações ambientais. As marchas e contra-marchas das glaciações inscreveram no seu devido tempo, mudanças radicais na distribuição desta substância ao longo do nosso Planeta (Ver a respeito POPP, 1983:97/98, SHIKLOMANOV, 1999 e REBOUÇAS, 2002a:6/8).

Porém, independentemente das alterações na sua distribuição, a persistência de mecanismos naturais de renovação das águas constituiu dado inerente à circulação do líquido no nosso Planeta. Assim sendo, o estoque hídrico terrestre tem sido constantemente reciclado por intermédio do ciclo hidrológico - ou, da água - fundamental para a vida e sua manutenção. É em decorrência das águas serem constantemente depuradas que as demandas do conjunto dos ecossistemas e dos seres vivos têm sido satisfeitas. Isto, sem contar a participação junto às vitais dinâmicas climáticas e geofísicas gerais da Terra, todas estreitamente vinculadas a este ciclo.

A importância em explicitar um quadro geral da distribuição da água reporta ao fato da totalidade da substância ao longo da Terra formar, do ponto de vista geofísico, uma única entidade. Recorde-se que nos movimentos da atmosfera, aos quais a água se associa de modo inquebrantável, não se pode isolar nenhuma parte, pois cada uma delas age sobre sua vizinha (BLACHE, 1985:38, grifo nosso). Dado que a água disponível no planeta integra um mesmo ciclo

\footnotetext{
${ }^{38}$ Dado que os mares constituem comumente parcelas dos oceanos, note-se que muitos lagos salgados, como no caso do Mar Morto (no Oriente Médio) e do Mar de Aral (no Turquestão), recebem esta denominação impropriamente. Ressalvem-se as justificativas decorrentes dos contextos histórico-culturais. Por exemplo, o Mar Morto foi assim denominado por constituir a única grande extensão de águas salgadas conhecida no passado por parte das tribos hebraicas que
} 
hidrológico, temos uma seqüência de fenômenos pelos quais a água transita por diferentes estados físicos (liquido, sólido e gasoso), ao mesmo tempo em que percorre os diversos reservatórios naturais existentes no Planeta. Assim, a água salgada, por exemplo, torna-se um dado momento doce e esta, por sua vez, retorna à sua condição salina anterior (NEGRET, 1982:34).

Neste contexto, como em muitos outros, pode-se perceber a estreita correlação existente na natureza entre a água e a energia. A movimentação da água se acha duplamente relacionada à energia disponível. Em primeiro lugar porque a evaporação depende do fornecimento de energia à água. Em segundo, em face da manutenção da umidade do ar depender da temperatura, isto é, da energia contida na atmosfera. Ocorrendo perda desta energia (resfriamento), o vapor retorna ao estado líquido. Atesta Samuel Murgel BRANCO (1993:27/29), o ciclo da água está intimamente ligado ao ciclo energético, isto é, com a difusão na Terra da energia proveniente do Sol.

O calor do Sol aquece a superfície das águas - dos oceanos, dos lagos, dos rios, das geleiras ou do próprio solo úmido - produzindo sua evaporação, ou seja, o enriquecimento do ar em vapor. Quando o ar absorve a máxima quantidade de vapor que é capaz de reter, ele fica saturado. Uma vez sucedendo este fenômeno, o excesso de vapor que não pode ser absorvido condensa-se. Retornando ao estado líquido, sucedem as chuvas e diversos outros hidrometeoros, dentre os quais pode-se mencionar o orvalho, nevadas, geadas, garoas e nevoeiros. Como é possível inferir, além da energia radiante do sol, a força da gravidade contribui poderosamente para a efetivação deste ciclo.

A hidrosfera (do grego, "esfera de água") é a denominação dada ao conjunto dos corpos líquidos da Terra. Esta corresponde, ao lado da atmosfera ("esfera de ar"), da litosfera ("esfera de pedra") e da biosfera ("esfera de vida"), a um dos quatro grandes compartimentos naturais reconhecidos pela geografia física. Quanto a tecnosfera ("esfera técnica") ou antroposfera ("esfera humana"), este compartimento materializa, em conformidade com o que foi discutido, o espaço artificial construído pelo homem. Atualmente sua influência sobre os ciclos 
naturais terrestres é de tal monta que torna essencial o conhecimento deste sistema de engenharia para o futuro das massas líquidas e da natureza em geral.

No planeta, a presença da hidrosfera é clara e inequívoca. Citando exclusivamente as superfícies ocupadas por oceanos e mares, ressalve-se que estas se referem a $71 \%$ da superfície do Planeta, ou seja, 3/4 do total (361 milhões de $\mathrm{km}^{2}$ ). Quanto às terras emersas (continentes e ilhas), estas ocupam somente os $29 \%$ restantes, ou seja, aproximadamente 1/4 da superfície total (149 milhões de $\mathrm{km}^{2}$ ). Em síntese, na ponta do lápis a Terra seria muito mais um Planeta Água do que Terra.

Todavia, apenas uma fração diminuta da massa líquida existente é apropriada para o consumo humano. Isto porque a água destinada ao consumo residencial, industrial, agrícola e pecuário deve ser doce (Freshwater). A água doce, tanto a presente na superfície do planeta (Blue Water Flow), quanto no subsolo (Gray Water Flow) ou no próprio organismo dos seres vivos (Green Water Flow), não pode, a despeito de qualquer sinonímia, ser classificada em função da quantidade de sais nela dissolvidos. Isto porque a referência de salinidade não são os sais, mas sim, o teor de STD: Sólidos Totais Dissolvidos.

Neste particular, o critério mundial de classificação das águas considera como doce apenas a água que apresenta STD inferior a $1.000 \mathrm{mg} / \mathrm{l}$, presente, por exemplo, no corpo líquido dos rios, lagos e depósitos subterrâneos da Terra. Por sua vez, as águas classificadas como salobras, encontradas no subsolo e na faixa de transição entre os oceanos e os estuários dos rios, possuem STD entre $1.000 \mathrm{e}$ $10.000 \mathrm{mg} / \mathrm{l}$. Finalmente, as que apresentam índice superior a $10.000 \mathrm{mg} / \mathrm{l}$, correspondem às águas salgadas, sempre associadas aos mares e oceanos (Ver a respeito REBOUÇAS, 2002a:1).

Outra sinonímia recorrente, gerando freqüentes mal-entendidos, é aquela que reporta à identificação da água doce como necessariamente potável. Nada mais incorreto. As águas entendidas como potáveis correspondem às soluções aquosas adequadas para ingestão humana, preparo dos alimentos, assim como para a limpeza dos utensílios domésticos. Coerentemente, devem apresentar baixa 
presença de sólidos em suspensão, e ademais, estarem isentas de microorganismos patogênicos e de substâncias orgânicas dissolvidas. Portanto, convém distinguir água doce de água potável, pois se toda água potável constitui uma água doce, o contrário não seria obrigatoriamente verdadeiro (Ver entre outros CAMARGO e PEREIRA, 2003:49).

Outra consideração a ser registrada quanto a potabilidade está relacionada com o surgimento da química moderna e a constituição dos modernos sistemas urbanos de abastecimento. A partir deste momento, adotou-se a convenção de que a água potável é - ou deveria ser - líquida na temperatura ambiente, pura, insípida, inodora e incolor. Tais pré-requisitos limnológicos (isto é, relacionados às condições físicas, químicas, meteorológicas e biológicas da água) e organolépticos (ou seja, capazes impressionar os sentidos humanos), mesmo integrando o senso comum do homem da atualidade e repetidos ad nauseam a todo o momento, divergem, contudo em várias nuanças das características da água no seu soberbo estado natural.

Sumamente porque a água na natureza não é "pura". Mesmo a água da chuva, que passou por um processo natural de purificação, contém partículas de outras substâncias incorporadas durante a precipitação, decorrente do contato com o ar, poluído pelo homem ou não. O mesmo poderia ser dito das águas de um regato tranqüilo, ou de um lago soberanamente integrado à paisagem natural dos arredores. Não fosse esta a condição deste líquido fenomenal, jamais a água poderia ser alcunhada como "solvente universal". A suposta água "pura, insípida, inodora e incolor", simplesmente não existe no meio natural. Tal definição é, acima de tudo, própria de um manual de química, não fazendo qualquer sentido junto ao leque das substâncias naturais existentes no nosso planeta.

Sinteticamente, a água na natureza é uma "solução diluída de elementos dissolvidos na superfície da Terra, ou precipitados do ar" (VILLIERS, 2002:157). Outro aspecto, é que a água quimicamente pura pode não ser boa para inúmeros usos. Como já pensavam os antigos, a água para ser adequada à vida deve usufruir a qualidade de ser germinativa, ita est, ser capaz de abrigar o surgimento de seres vivos, sugerindo uma distância pelo mínimo cautelosa do critério de 
"pureza". Finalmente, é a presença de gases e também de sais e outros compostos, que tornam a água "apta a sustentar a vida aquática: os peixes e outros seres não poderiam viver em água pura" (BRANCO, 1993:40).

Coerentemente, a água considerada potável possui, sim, os mais diversos gostos e sabores. A água existente na natureza "é sempre uma mistura de quase todos os elementos encontrados na superfície do globo terrestre" (BRANCO, 1993:22). Assim, o líquido caracteriza-se por apresentar uma série infinitamente variável de soluções aquosas formadas por diferentes substâncias ou compostos químicos. Aliás, sendo por excelência o solvente universal, dificilmente a água poderia ser "insípida". De resto, a água potável deve possuir substâncias que "Ihe dêem o gosto característico e um mínimo de salinidade compatível com a composição de nossas células. A água fervida torna-se insípida exatamente por perder gases, como o gás carbônico, durante o aquecimento" (BRANCO, 1993:40).

Um exemplo concreto da inveracidade da insipidez enquanto característica positivamente aceita residiria no fato de se presenciar nos dias de hoje uma enorme ofensiva comercial tendo por base as águas minerais. E estas, por definição, constituem águas nobres cujo diferencial é justamente o seu sabor peculiar. Poderia esta situação sugerir uma realidade pela qual os humanos poderão ser transformados em sommeliers da água? Dada a popularidade conquistada pelas águas minerais, dificilmente esta indagação poderia compor uma resposta negativa. Claramente, a água com gosto chegou para ficar. A tendência hoje seria considerá-la como as melhores safras dos tintos e brancos de Baco (CARLONI, 2003).

Uma vez esclarecido nosso ajuizado referente ao critério mundial de água doce (qual seja, a classificação englobando águas cuja concentração de STD é inferior a $1.000 \mathrm{mg} / \mathrm{l})$, restaria identificar sua manifestação no Planeta. Neste sentido, a única conclusão possível é que esta constitui fração mínima dos recursos hídricos mundiais. E ademais, dificilmente este veredicto, sentenciando as águas doces à condição de exigüidade, comportaria qualquer tipo de revisão. Indo diretamente ao ponto, a descoberta de concentrações de água doce em 
regiões distantes ou em ambientes nos quais sua presença é incomum, mesmo ampliando os prognósticos referentes ao estoque hídrico global, ainda assim não alteraria em absolutamente nada o radical julgamento referente à difusão restrita destas águas.

Neste pormenor, seria cabível registrar manifestações incomuns. Dentre estas a ocorrência de depósitos de água doce nas profundezas do subsolo marinho, formando reservatórios que tem sido explotados, embora em pequena escala, mediante diversas inovações tecnológicas (Vide LQES, 2003). Ocasionalmente, podemos encontrar mar adentro fontes borbulhantes, uma singularidade providencial para os ilhéus que pioneiramente povoaram a ilha Henderson, na Oceania (Vide DIAMOND, 2005:157).

Além destes depósitos, expedições encetadas desde os anos 50 pela antiga União Soviética evidenciaram a existência de corpos líquidos gigantescos, nunca dantes imaginados, tais como os lagos sub-glaciais da Antártida. Na última década do século $\mathrm{XX}$, diversas pesquisas comprovaram a existência sob a capa de gelo da calota polar antártica de não menos que 76 lagos sub-glaciais, uma descoberta inusitada sob qualquer ponto de vista.

Destes ambientes, o destaque cabe ao lago Vostok, cuja existência foi confirmada em 1996 por glaciólogos russos e britânicos. O Vostok ("oriente", em russo), o maior de todos os lagos sub-glaciais, está situado numa região inóspita do continente gelado (por sinal considerada recordista mundial em baixas temperaturas), configurando-se como uma descoberta que tem justificadamente catalisado a atenção dos geógrafos, biólogos, físicos e muitos outros especialistas. Algumas avaliações indicam que o Vostok está pelo mínimo a três e possivelmente trinta milhões de anos, sem qualquer contato com os demais ecossistemas do planeta.

O Vostok mede $240 \mathrm{~km}$ de comprimento e $50 \mathrm{~km}$ de largura, possuindo $14.300 \mathrm{~km}^{2}$, uma área equivalente ao Lago Ontário, um dos Grandes Lagos americanos. Porém, é muito mais profundo. Enquanto o Ontário possui no máximo $244 \mathrm{~m}$ de profundidade, o Vostok alcança $1.000 \mathrm{~m}$ em alguns pontos. A água do Vostok permanece líquida devido à pressão do gelo (equivalente a 350 
atmosferas) e também pela atividade de uma fonte geotérmica no fundo do lago. Selado pela calota antártida numa espessura variando entre 3.700 e 4.100 m, este lago é o mais importante ambiente aquático isolado da Terra (Vide KAPITSA, A. P., RIDLEY, J.K., ROBIN, G.Q., SIEGERT, M.J. e ZOTIKOV, A., 1996).

No entanto, descobertas como esta, surpreendentes nos mais diversos sentidos, em nada desmerecem o sentenciamento primordial quanto à exigüidade das águas doces no nosso planeta. Em resumo: as águas doces totalizam somente $2,5 \%$ do montante hídrico total existente. De pronto, este dado remete diretamente a um outro, referente aos demais $97,5 \%$ das águas mundiais. Esta porcentagem, representando o maior de todos os reservatórios da hidrosfera, é a formada pela massa líquida dos oceanos, mares e lagos salgados. Apesar de representar um volume gigantesco, esta proporção é evidentemente imprópria para o consumo.

Neste particular, a proposta de dessalinização da água dos corpos líquidos salinos (no caso incluindo, além da água do mar, a potabilização das águas salobras subterrâneas e das águas municipais recicladas), exeqüível de ser obtida através de processos como a destilação e a osmose reversa, tem sido postulada com certa freqüência. No final das contas, a massa líquida dos oceanos, em vista de somente $3,5 \%$ da sua composição ser constituída por sólidos em dissolução, poderia ser rubricada como uma espécie de "água doce disfarçada", sugerindo grande potencialidade de conversão a uma condição de potabilidade.

A dessalinização tem, deste modo e não sem razão, magnetizado a imaginação de muitos setores de opinião. O impacto desta tecnologia no imaginário é patente: inexistem cenários futuristas dispensando turbinas eólicas, seres clonados, antenas parabólicas, cidades artificialmente climatizadas e naturalmente, imensas usinas de dessalinização. Nesta linha de argumentação, a questão da escassez dos recursos hídricos deixaria virtualmente de pertencer à pauta de preocupações da humanidade.

Contudo a popularidade desta proposta deve ser convenientemente contrastada com alguns comentários elucidadores. O primeiro deles seria endereçado às objeções decorrentes do mau entendimento da própria 
terminologia. Corroborado por inúmeros pareceres, o termo dessalinização, recordava o biólogo Samuel Murgel BRANCO, seria tecnicamente contestável, justificando sua substituição por dessalgamento (1993:61). A alegação, longe de constituir mero preciosismo de linguagem, é que os processos de dessalinização não se destinam a remover toda a salinidade marinha. Antes, tais processos se prestam apenas a retirar o excesso de sais da água, tornando-a potável. Respaldando esta colocação está o fato da água doce não ser, como se viu, destituída de sólidos dissolvidos, seja qual for sua emanação no meio natural.

Essa provocação de Samuel Murgel Branco sugere uma outra consideração, a de que não necessariamente necessita-se de "águas sem sal" para as atividades que asseguram a sobrevivência. Deve-se, pois levar em consideração que as águas grafadas como de "qualidade inferior", categoria que incluiria águas como as salobras, as servidas ou com níveis de STD não obrigatoriamente condizentes como o padrão das supostas "águas puras", estarem habilitadas a atender diversas necessidades humanas. Este conjunto pode se prestar, mediante inclusive a utilização de processos de dessalinização em menor escala, para diferenciada gama de demandas, uma compreensão inexistente em passado recente, visto que se estipulava apenas as "águas com grau elevado de pureza" como apropriadas para o atendimento das necessidades humanas.

Aparte estes apontamentos, seria cabível ainda enumerar algumas considerações no tocante à dessalinização no seu sentido clássico, isto é, aquela que assume os oceanos e mares como sua "matéria prima". Existiriam, neste sentido, três grandes obstáculos. O primeiro seria o custo econômico da dessalinização. Caro por excelência, este processo está situado fora do alcance da maioria da população da Terra. Um segundo obstáculo residiria no fato de que tanto a destilação quanto a osmose reversa serem notórias devoradoras de energia $^{39}$. Fundamentalmente derivada da queima de combustíveis fósseis,

\footnotetext{
39 "Os dois recursos, solo e água, que como acabamos de ver são objeto de relações de poder e estão no centro de estratégias múltiplas, estão integrados em técnicas que evoluem constantemente. As técnicas de utilização do solo e da água não param de ser aperfeiçoadas, para obter plantas e animais alimentares ou não. Porém, essas técnicas são consumidoras, num nível cada vez mais elevado, de recursos não renováveis e, em particular, de energia" (RAFFESTIN, 1993:232).
} 
particularmente o petróleo e o carvão (e dos dois, especialmente o primeiro), tecnologicamente este processo tem por pressuposto inconfesso farto suprimento de combustíveis fósseis (Ver BARLOW e CLARKE, 2003:157).

Em função do que foi exposto, temos que a implantação de usinas de dessalinização não seria tão fácil quanto algumas expectativas pressupõem. Nesta perspectiva, não admira que a maioria das usinas de dessalinização se concentrem nos países do Oriente Médio. Neste recanto do mundo situam-se países que além de contarem com polpudas receitas do petróleo, dispõem de fartas jazidas de hidrocarbonetos à disposição. Das 7.500 usinas de destilação em operação no mundo, dois terços delas situam-se nesta região, particularmente na Arábia Saudita, país que concentra $26 \%$ deste total, correspondendo ao maior usuário de água dessalinizada do mundo (Cf VILLIERS, 2002:392).

Existiriam ainda, em terceiro lugar, seqüelas de ordem ambiental. Ressalvese que a dessalinização, para cada volume de água do mar processado, produz apenas 1/3 deste mesmo volume em água doce, sendo os 2/3 restantes compostos por uma salmoura altamente concentrada, que escoada em temperaturas elevadas para as águas dos oceanos, constitui uma fonte preocupante de poluição marinha. Por fim, constituindo objeção bem mais séria que a precedente, o processo de potabilização adiciona à atmosfera GEE, gases que provocam efeito estufa (um dos principais inimigos dos suprimentos de água doce do mundo), dentre os quais podemos listar o gás carbônico $\left(\mathrm{CO}^{2}\right)$, o metano $\left(\mathrm{CH}^{4}\right)$ e o óxido nitroso $\left(\mathrm{N}^{2} \mathrm{O}\right)$. Por isso mesmo, esta alternativa defronta-se com diversas inadequações do ponto de vista ambiental.

Assim sendo, conclui-se que as atenções devem concentrar-se nos 2,5\% correspondentes às águas doces. Mas, os problemas persistem quando se recorda a questão do acesso humano a estas águas. Para começar, seria bom frisar que $68,9 \%$ das águas doces estão aprisionadas nas neves eternas das regiões montanhosas (como no caso dos Andes, Cáucaso, Atlas, Alpes, Himalaia, Rochosas, etc), em geleiras (na Rússia, Canadá, Noruega, Finlândia, Islândia, Áustria, Alasca, Patagônia, Groenlândia, etc) ou nas calotas polares. Nestas, 
reinam de modo inconteste os inlandsis, vastas e compactas geleiras que agasalham quase totalmente a topografia da Groenlândia e da Antártida. Quanto ao continente gelado, assinale-se que, no seu quase solene isolamento, este armazena cerca $90 \%$ do gelo do mundo.

Ocupando cerca de $10 \%$ da superfície total da Terra, as regiões cobertas por água em estado sólido (isto é, gelo) constituem o mais importante estoque de água doce do mundo. Sua importância para o equilíbrio climático terrestre é simplesmente fundamental. No Brasil, os avanços e os recuos da massa de ar polar antártica condicionam diretamente as dinâmicas atmosféricas, a começar pela pluviometria, de vastas porções do país. Estas considerações têm inspirado argumentações defendendo a existência de um quinto compartimento natural, a saber, a "esfera de gelo e das neves", em princípio batizada como criosfera. Entendida enquanto elemento operacional distinto, a criosfera passaria a usufruir, de um ponto de vista conceitual, um status compatível com sua importância objetiva para os destinos do Planeta (Ver a respeito REBOUÇAS, 2002a:4).

Mas, estando ou não dispostos a concordar com tal proposição, tornou-se de qualquer modo inevitável que a criosfera passasse a ser percebida como um possível manancial ${ }^{40}$ para satisfazer um mundo sedento. Afinal, se existem registros históricos de mineração de gelo alpino no império romano, porque então se eximir de repetir este feito notável com o concurso de máquinas e meios tecnológicos mais avançados? Por isso a apresentação de sugestões de "garimpar água" da criosfera, suscitando cenários que a subentendem enquanto uma reserva destinada à prospecção de imensos blocos de gelo, rebocados através de cabos de aço pelos oceanos do mundo para aplacar a sede dos homens.

No entanto, aparentemente uma proposta interessante, minerar os estoques de água congelada para obter água doce suscitaria pelo mínimo algumas ressalvas. O procedimento oferece dificuldades de toda ordem, a começar pela

\footnotetext{
${ }^{40}$ Neste parágrafo e em outros pontos do texto, "manancial" refere-se a uma definição genérica, definindo "qualquer corpo d'água, superficial ou subterrâneo, utilizado para abastecimento humano, industrial, animal ou para irrigação", tal como discriminado no Vocabulário de Meio Ambiente, Feema, 1991 (Vide CEPAM-FPFL, 1991). As implicações conceituais mais profundas desta terminologia serão retomadas adiante, particularmente no item 4.2.4 do Cap. IV.
} 
alteração da estabilidade das geleiras. A retirada de imensas camadas de gelo contribuiria inevitavelmente para a aceleração do aquecimento global, fenômeno que tem sido apontado como responsável por mudanças climáticas em todo o Planeta. Desde 1986 os glaciólogos têm registrado a multiplicação dos icebergs nos oceanos (Fig. 13) assim como a aparição de icebergs gigantes, de proporções inusitadas, que se destacam especialmente da Antártida. Sua gênese tem sido relacionada com o derretimento das calotas, apontada por diversos estudos como causa direta da elevação do nível dos mares em nível mundial. Além disso, visto que estas reservas hídricas localizam-se em áreas de difícil acesso, o custo econômico da empreitada seria elevado e para completar, estando demasiado distantes dos centros consumidores, o frete requereria um custo adicional.

Existem obviamente grandes massas de gelo concentradas nas regiões montanhosas de todo o mundo, em alguns casos situadas bem próximo dos seus prováveis consumidores. Neste particular, não há como não listar países que, como a Áustria e a Noruega, ao disporem de amplas reservas de água na forma de gelo, estariam predestinados ao papel de mineradores de gelo. A água potável obtida através da empreitada poderia então alcançar os centros urbanos por meio de sistemas de aquedutos, relegando a escassez do líquido a uma mera declamação infundada de um ambientalismo precipitado. Nesta acepção, a realidade transformou em um dado concreto o que um dia foi classificado como engenharia visionária: hoje, um aqueduto de alta tecnologia transporta água dos Alpes para Viena, existindo planos para construir outros corredores de aquedutos conduzindo, através da projetada Rede de Água Européia, os recursos destas montanhas para a Espanha, Grécia e quiçá alhures.

Como seria de se esperar, a proposta de exploração das geleiras alpinas tem perturbado, com toda razão, mais de um segmento de opinião pública 


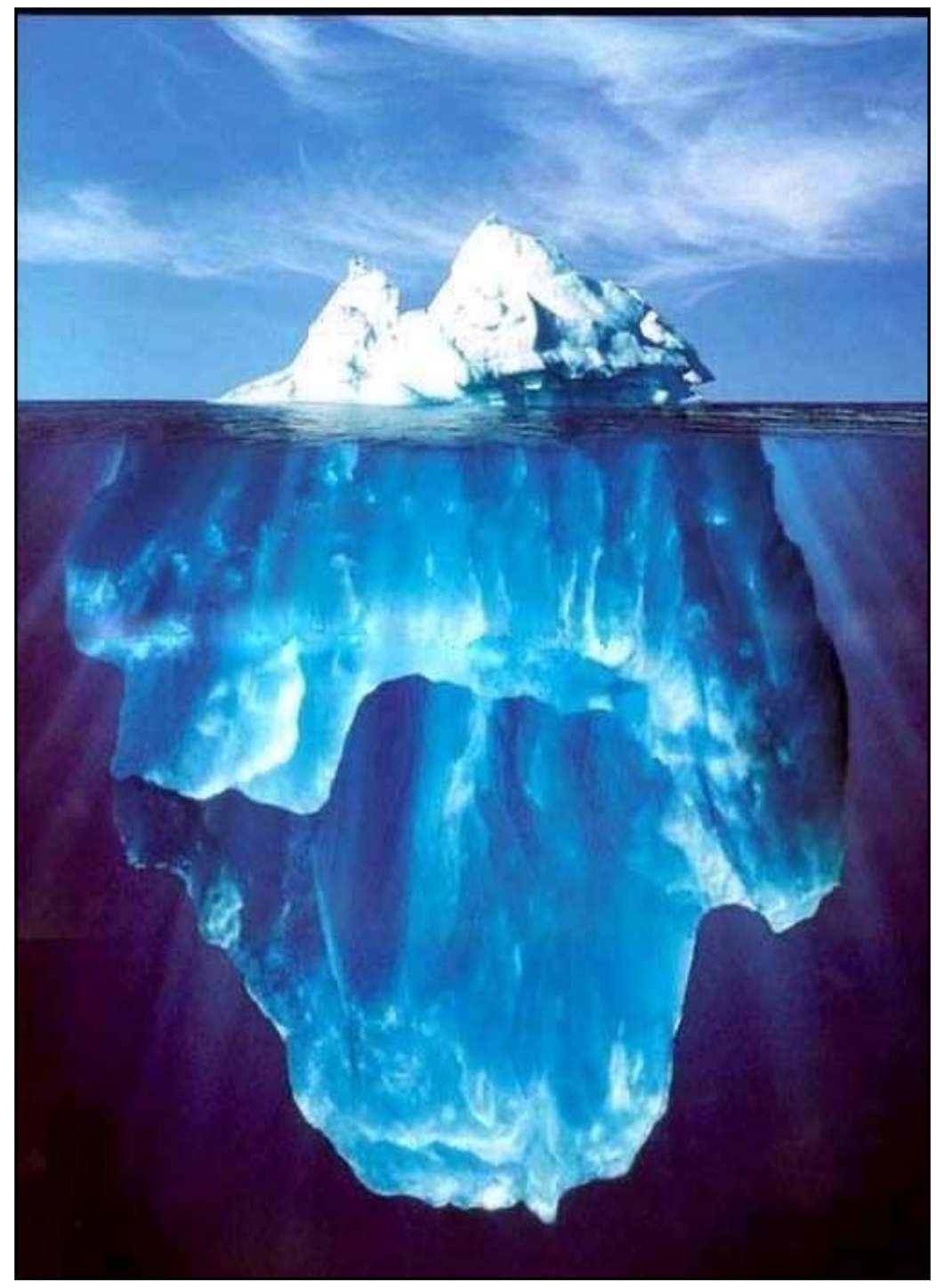

FIGURA 13 - Iceberg fotografado ao largo da Terra Nova, no Canadá. (Fonte: <http://www.canofenley.com/images/lceberg. jpg>, Ralph A Clevenger/Corbis, acesso em 23-06-2005) 
européia. Na própria Áustria, tal projeto causa temores justificados. Seguidamente, os ecologistas locais têm advertido sobre os danos que as exportações em grande volume poderão ocasionar ao sensível ecossistema das altas montanhas (Vide BARLOW e CLARKE, 2003:158). Em nível mais amplo, recorde-se que a mineração do gelo, ao contribuir com a aceleração do efeito estufa, poderá catalisar a falência da prospecção glacial por contribuir ela mesma para com a desaparição das próprias geleiras.

Longe de constituir qualquer alarme falso, o desnudamento total das neves do monte Kilimandjaro, na Tanzânia, conforme testemunho fotográfico datado de 2005 divulgado na mídia mundial (Vide Fig. 14), ilustra de modo eloqüente a ameaça real associada com a exploração dos glaciares do mundo. Assim, oferecendo obstáculos de monta, dentre estes os de mote ambiental, a obtenção de água doce das reservas congeladas tem sido preterida em favor de alternativas consideradas mais atraentes.

Uma destas estaria direcionada para a exploração dos depósitos subterrâneos ou, de água fóssil, como também estes reservatórios são categorizados pelos hidrólogos. Evitando entendimentos errôneos, que fique claro que as águas subterrâneas não existem independentemente do ciclo natural da água. Em sentido estrito, isto significa que a água dita "fóssil", contida em reservatórios subterrâneos, não constitui uma água estancada ou, "que não esteja submetida a um processo de renovação. Simplesmente isto quer dizer que sua renovação é extremamente lenta" (MARGAT e SAAD, 1985:15). Em função deste mecanismo natural, as águas subterrâneas devem ser objeto de exploração criteriosa, cercada de todas as cautelas técnicas possíveis (REBOUÇAS, 2002b:139/142 e passim, 2004).

No afã de retirar a água escondida nos veios da Terra, estima-se que cerca de 250 milhões de poços foram colocados em operação no mundo, dos quais possivelmente $10 \%$ no Brasil (REBOUÇAS, 2004:45). A intensidade das perfurações justifica-se pelos números estonteantes das águas subterrâneas. De fato, tais estoques, alojando $29,9 \%$ da água doce do mundo, concentrados notadamente nos aqüíferos, são simplesmente colossais. Apesar disto, a 
exploração deste suprimento implica em investimentos em termos de estudos geotécnicos preliminares, gastos com perfuração e outras providências. 


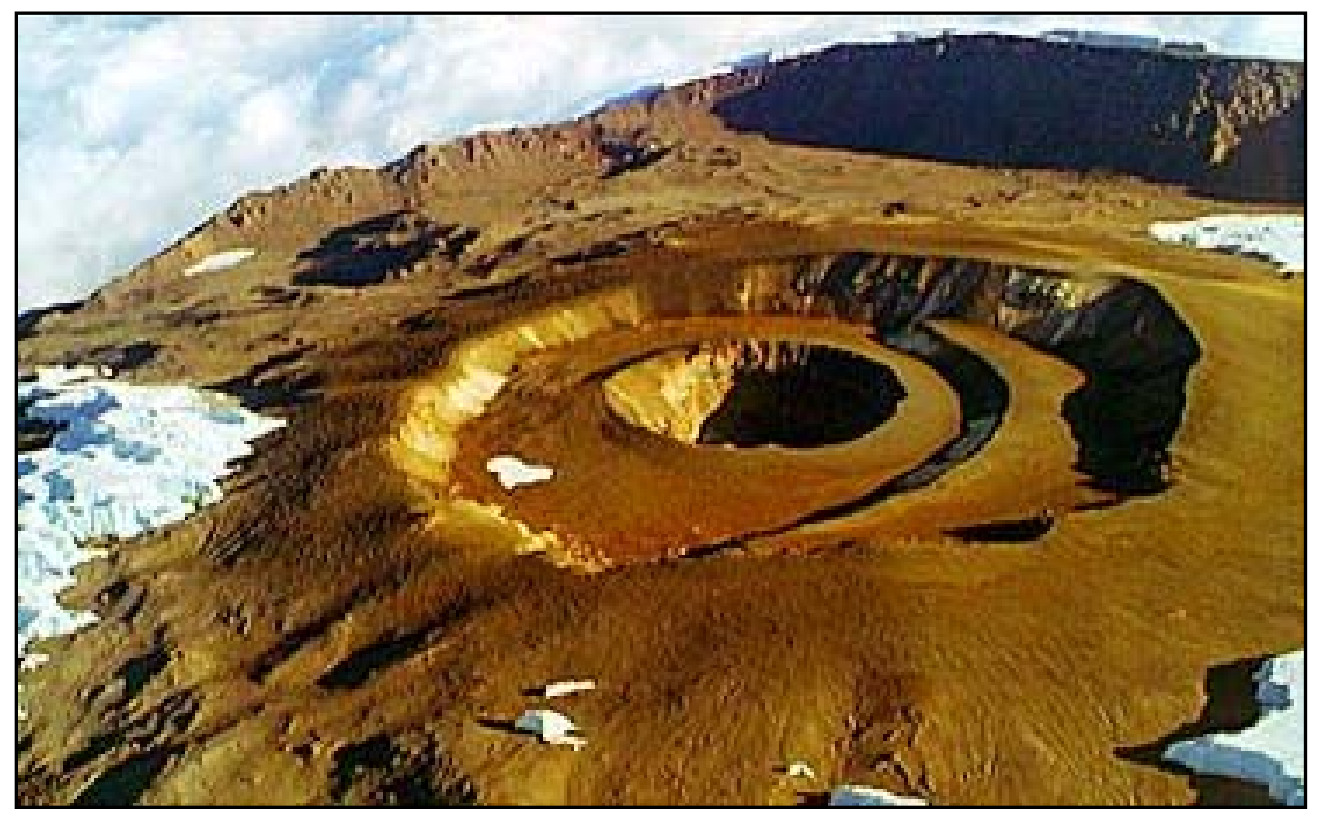

FIGURA 14 - O Monte Kilimanjaro sem suas neves: O Monte Kilimanjaro está localizado no norte da Tanzânia, bem próximo da fronteira com o Quênia. Com 5.895 metros de altitude, o Kilimanjaro ergue-se em meio à savana e constitui o ponto mais alto de África. $O$ nome deste antigo vulcão, deriva de Kilima Njaro, "montanha brilhante" na língua Swahili, pois seu cume, coberto de "neves eternas", podia ser avistado de uma distância considerável. Esta montanha inspirou um conto do escritor norte-americano Ernest Hemingway, o clássico The Snows of Kilimandjaro ("As Neves do Kilimanjaro"), do qual Hollywood produziu em 1952 uma versão cinematográfica. No entanto, em 2005 o mundo tomou conhecimento de que a cratera do Kilimanjaro, após inúmeros vaticínios, estava finalmente despida de neves "eternas", sinal evidente de que o efeito estufa iniciou sua trajetória determinada de desmantelar os grandes e magníficos monumentos da natureza (Fonte: <http://www.schaetze-der-welt.de/denkmaeler/73/aufmacher.jpg>, acesso em 23-06-2005). 
Outros cuidados relacionam-se com a recarga natural dos reservatórios subterrâneos, que pode reivindicar dezenas, centenas ou mesmo milhares de anos. Conseqüentemente, o pressuposto para a exploração dos aqüíferos solicita contrapartidas zelando pela preservação da qualidade das águas, sugerindo, visando impedir a contaminação dos corpos líquidos subterrâneos, regras rigorosas quanto ao uso e ocupação do solo na superfície. Infelizmente, a adoção de normas visando proteger estes reservatórios não tem progredido na velocidade desejada (SAMPAT, 2000). Desta forma, mesmo reunindo enorme volume, pensar este estoque como alternativa capacitada a satisfazer a demanda de água doce reclama eficientes estratégias de gerenciamento, sugerindo descartar qualquer otimismo fácil quanto à sua exploração.

Por fim, outros 0,9\% corresponderiam às águas estocadas no solo, isto é, na parte mais superficial da litosfera, em contato praticamente direto com as dinâmicas atmosféricas e com a biosfera em geral. A umidade que impregna os solos, terras úmidas como os pântanos e alagadiços em geral (Okavango, Sundarbans, Bar-el-Ghazal, Pripet, etc) ou então, os volumes concentrados no permafrost, constituiriam exemplos deste reservatório de águas doces. Neste grupo, as terras úmidas são aquelas áreas nas quais o lençol d'água se encontra na superfície da terra durante a maior parte do ano (ANDERSON et alli, 1979:56). Quanto ao permafrost, este último corresponderia a um tipo de solo congelado encontrado nas regiões circumpolares (caso do Norte da Sibéria, da Lapônia, Canadá Setentrional e Alasca) e áreas caracterizadas por elevada altitude, incluindo cadeias montanhosas e os altos planaltos, como o Tibet (Vide Fig. 15).

Neste caso, como nos anteriores, as dificuldades não são poucas. Além de gerar fortes impactos ambientais, são óbvios os empecilhos para obter água nestes ambientes. No caso do permafrost a retirada de água teria os mesmos inconvenientes da exploração das geleiras, com a agravante de impactar um ecossistema muito suscetível frente a intervenções antropogênicas. Quanto ao caso específico das terras úmidas, recorde-se que estes espaços naturais se configuram como sistemas naturais de filtragem e absorção das águas doces, áreas de armazenamento, criadouros biológicos e habitat de considerável número 
de espécies da vida selvagem. Ademais, estes ambientes já foram intensamente drenados no decorrer da historia humana, visando a expansão dos pastos, terras cultivadas ou áreas para habitação humana.

\section{Distribution of Perm afrost}

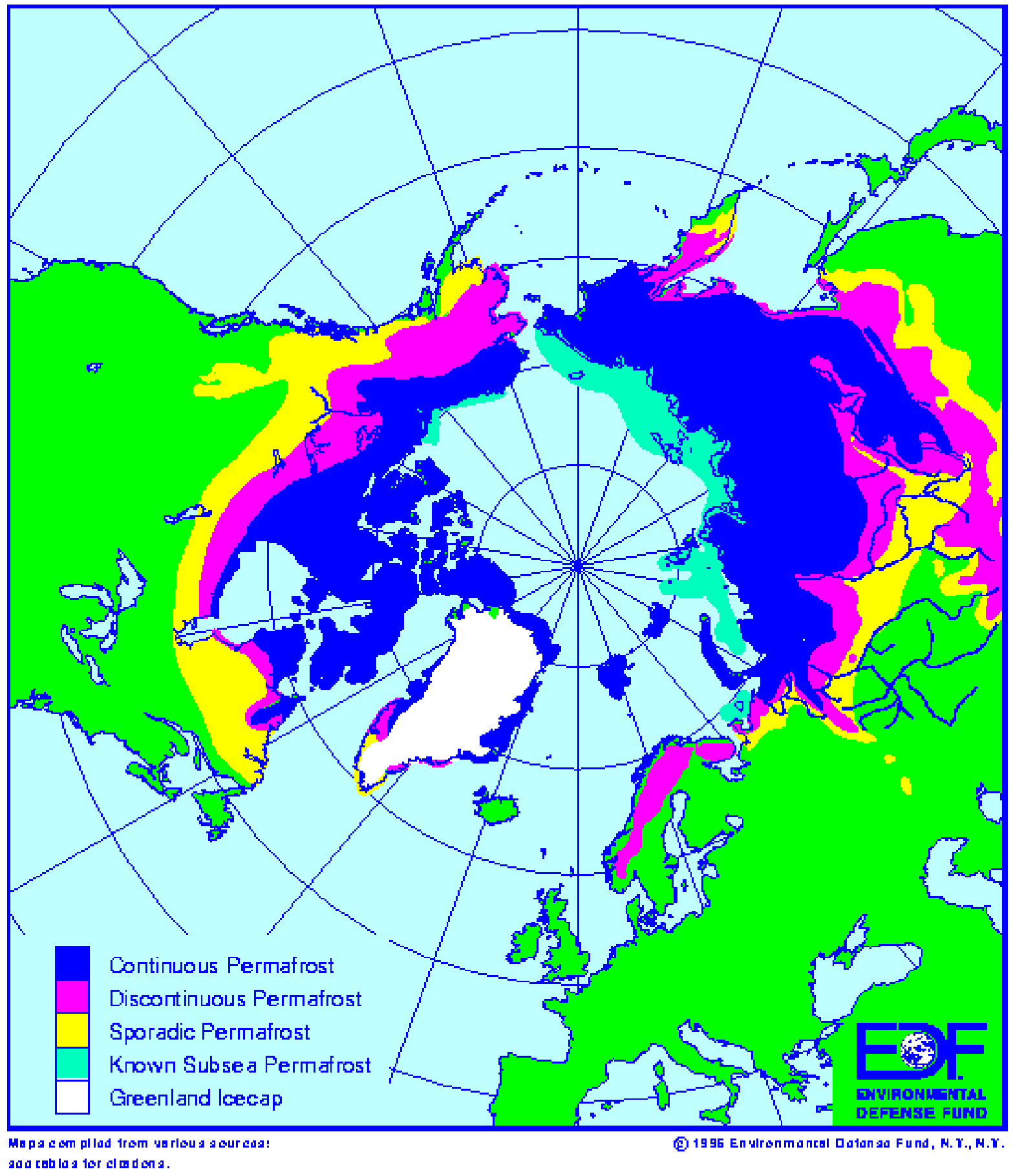


FIGURA 15 - Mapa da Distribuição Geográfica do Permafrost

(Fonte: <http://www.dpc.dk/Res\&Log/Links/Graphics/Permafrost.gif>, escala aproximada 1:24.000.000, acesso: 13-04-2005) 
Em resumo, a água doce em estado livre na natureza, presente em corpos d'água como rios, lagos e oásis, ao alcance imediato da satisfação das necessidades humanas, perfaz uma ínfima porcentagem das águas mundiais. Apenas 0,3\% dos 2,5\%. Esta porcentagem representaria $200.000 \mathrm{~km}^{3}$, isto é, somente $0,014 \%$ das águas do mundo. É deste reduzido estoque de águas doces - também denominadas superficiais ou então, azuis - que depende a continuidade da existência humana e da maior parte das formas de vida. Justifica-se assim uma atenção redobrada quanto ao gerenciamento deste suprimento.

\section{3. Água: Avali ando um Recurso sob Tensão}

Como foi possível inferir, embora em contínua reciclagem pela natureza, as águas doces constituem um recurso finito em termos da sua disponibilidade para o homem. Com base nos ciclos naturais, as águas doces superficiais armazenadas nos rios e nos lagos sempre foram eficientemente depuradas, contando-se dentre os mecanismos naturais de limpeza das águas, a sedimentação, aeração, diluição e os processos bacterianos. Contudo,

...o aumento da população e a acelerada industrialização superaram as propriedades naturais de reciclagem dos cursos d'água, o que resultou em uma brutal poluição e uma crescente ameaça tanto à saúde humana como ao abastecimento de água em geral (VILLIERS, 2002:143).

Portanto, é uma conjuntura dramática que induziria a todos indagar a respeito da quantidade de água solicitada pelos seres humanos. Quanta água, no final das contas, é reclamada para a sobrevivência? Qual seria o mínimo necessário para tal? A partir de que momento poder-se-ia então considerar uma situação de stress hídrico?

Respostas é que não faltam. Há quem proponha o índice de 25 litros diários enquanto volume de água voltado simplesmente para a subsistência (BARLOW e 
CLARKE, 2003:285). Ampliando este dado, várias agências internacionais propõem que 50 litros por pessoa por dia seriam suficientes para cobrir as necessidades humanas básicas de água para consumo, limpeza, higiene e culinária (Vide CMB, 2000). Todavia, na hipótese do indivíduo usufruir esgotamento sanitário, a realidade tem demonstrado a impossibilidade de pensarmos uma taxa de consumo inferior a 100 litros/pessoa/dia (Cf REBOUÇAS, 2004:59).

Recorde-se que as quantidades consideradas vitais variam de acordo com padrões climáticos, sociais e culturais em geral. Por esta exata razão, pode-se encontrar um profícuo conjunto de dados e estatísticas a respeito deste assunto. Todavia, existe certo consenso em considerar que o volume de 100 litros per capita/dia, correspondendo a $36,5 \mathrm{~m}^{3}$ por ano, poderia ser alçado à condição de valor mínimo para o consumo pessoal (SELBOURNE, 2002:45). Contudo, esta discussão fica acirrada quando se visualiza o conceito numa ótica mais ampla, abarcando os volumes destinados para a indústria, agricultura e geração de energia, atividades que não poderiam, é óbvio, serem desvinculadas do modo de ser da sociedade atual. Não é a toa que se poderia listar várias divergências, tanto no sentido quantitativo quanto no qualitativo, relativamente à compreensão do mínimo de água doce necessário para perpetuar a vida dos humanos.

Caso se queira levar em conta os pareceres propostos em 1989 pela hidróloga Malin Falkenmark, a oferta de recursos hídricos satisfatórios para o atendimento das necessidades humanas (incluindo nesta contabilidade as requisições da agricultura, da indústria e da produção energética), não poderia ser inferior ao patamar de $1.700 \mathrm{~m}$ 3/pessoa/ano. Esta referência, também conhecida como Índice de Stress Hídrico (WSI, abreviatura técnica de Water Stress Index) ou Indicador de Falkenmark, indicaria um estado de alerta, identificado toda vez em que este índice encontra dificuldades em ser disponibilizado. Paralelamente, patamares inferiores a $1.000 \mathrm{~m}^{3} / \mathrm{hab} / \mathrm{ano}$ demarcariam para a pesquisadora sueca a condição de escassez de água (Chronic Water Scarcity), e abaixo de 500 m³/hab/ano, um estado de penúria hídrica absoluta (Absolute Water Scarcity), situações ainda mais problemáticas quanto ao abastecimento de água. 
Deve-se ressalvar que a noção de stress hídrico, tal como delimitada por Malin Falkenmark, convive com variados graus de concordância e antagonismo com outras formulações. De um ponto de vista quantitativo, é extremamente difícil, por exemplo, adotar um padrão que contemple a heterogeneidade de situações vivenciadas pela humanidade. No que parece constituir uma crítica procedente, os indicadores propostos por Falkenmark parecem ignorar, por exemplo, a existência de regiões que convivem relativamente bem com a escassez ou penúria de recursos hídricos, tais como o sul da Espanha e muitas regiões do Levante (SHUVAL, 1998). Sem desconsiderar o arrojo indiscutível da cientista sueca em lançar o conceito de stress hídrico, este tem sido intensamente debatido e sua sustentação teórica questionada das mais diversas formas, inclusive no tocante à especificidade política, social e geográfica (Ver a respeito SHUVAL, 1998, OHLSSON, 1998 e 1999, GRANAHAN, 2002 e RIJSBERMAN, 2004). Assim, não há rigorosamente ninguém que proclame como definitivo o Indicador de Falkenmark (Cf GRANAHAN, 2002:20).

Outrossim, o Indicador de Falkenmark, sob o qual pesa o justificado veredicto de refletir o modo de vida das sociedades afluentes (mas não do conjunto da humanidade), tem convivido com a apresentação de outras indicações quantitativas. Embora o índice de $1.700 \mathrm{~m} 3 /$ pessoa/ano seja fundamental para a avaliação de um vulto considerável de casos, um conjunto significativo de pesquisadores, dentre estes participantes de órgãos como Banco Mundial, departamentos da ONU, assessorias técnicas especializadas e ONG relacionadas com os recursos hídricos, tem proposto o patamar de $1.000 \mathrm{~m}^{3} /$ pessoa/ano enquanto parâmetro mais universal para demarcar a condição de stress hídrico. Quanto à escassez de água, esta se configuraria nas situações nas quais a oferta é inferior a $500 \mathrm{~m} 3 / \mathrm{hab} / \mathrm{ano}$. Não diferentemente, seria desta forma que muitos pesquisadores brasileiros tem pautado esta questão do ponto de vista técnico e conceitual (Ver REBOUÇAS, 2002a:19 e 2004:68/69).

No entanto, note-se que critérios quantitativos, quaisquer que sejam - e desde que pensados unicamente enquanto médias matemáticas - estão incapacitados de esgotar as problemáticas sociais, políticas e econômicas que 
rondam a questão dos recursos hídricos. Tanto procede esta objeção, que seria possível identificar propostas que trabalham com índices ainda menores do que $1.000 \mathrm{~m}^{3} /$ pessoa/ano. Por exemplo, o engenheiro ambiental israelense Hillel SHUVAL (1998), tem proposto uma média de consumo de $125 \mathrm{~m}^{3} /$ pessoa/ano para os habitantes das áreas urbanas dos países áridos do Oriente Médio, o Minimum Water Requirement (MWR). Isto com base na renomada experiência da gestão israelense dos recursos hídricos, como se sabe, uma nação reconhecidamente competente na administração das águas doces (REBOUÇAS, 2004:71 e 136).

Afora padrões numéricos, há com certeza um cabedal expressivo de objeções quanto ao uso exclusivo de médias matemáticas na avaliação da disponibilidade dos recursos hídricos. Estas poderiam incluir as seguintes limitações: as médias anuais, particularmente as de índole nacional, ocultam profundas situações de escassez em escalas menores, regionais e urbanas, ambas extremamente significativas; os indicadores quantitativos não identificam o peso das obras de infra-estrutura quanto às modificações que provocam na disponibilidade de água; por fim, a adoção de limiares técnicos não reflete as importantes variações existentes na demanda de água decorrentes do estilo de vida, do clima e do contexto histórico (passim RIJSBERMAN, 2004).

Por isso mesmo, a propensão quantitativa existente no Indicador de Falkenmark, terminou reavaliada e enriquecida por outras contribuições, dentre as quais caberia menção obrigatória para o Índice de Stress Hídrico Social (Social Water Stress Index), proposto por outro cientista sueco, o especialista em ecopolítica Leif Ohlsson. Tomando por base a dificuldade de acesso aos recursos hídricos e relacionando-o com o Índice de Desenvolvimento Humano (IDH), proposto pela ONU, o trabalho de Leif Ohlsson reclama nossas atenções para o entrelaçamento da condição de exclusão social com a da situação de indigência hidrológica, contexto que caracteriza vastos segmentos populacionais, inclusive em países considerados ricos em água doce. Portanto, sua contribuição, ao incluir um componente social muitas vezes secundarizado em avaliações que utilizam 
exclusivamente métodos quantitativos, é absolutamente pertinente e imprescindível (Ver a respeito OHLSSON, 1998 e 1999).

Isto posto, saliente-se que não haveria como dispensar os dois recortes em discussão, quais sejam, os de mote quantitativo e os fundamentados em critérios qualitativos. A adoção de um parâmetro numérico para um tema tão objetivo quanto a disponibilidade hídrica é em si mesmo indispensável. Este contribui para identificar (mesmo que cercado de ressalvas), questões associadas com a oferta de água para o atendimento das necessidades humanas elementares de saúde, higiene e bem-estar. Simultaneamente, o necessário aporte dos cenários sociais, políticos e econômicos, faria pleno sentido ao enriquecer esta avaliação com os aspectos contraditórios que perpassam em muitos espaços da sociedade contemporânea. Em particular, estes interessariam para a análise da escassez urbana de água, um problema que acomete muitas metrópoles da periferia e dentre estas, diversas aglomerações brasileiras.

A dramaticidade desta questão é óbvia quando se sabe que, segundo estimativas da ONU, cerca de $30 \%$ da população mundial, afetando especialmente os setores excluídos, já vive a situação de stress hídrico. Pensando um referencial com base em 50 litros diários per capita (em linhas gerais a quantidade consumida por uma cabeça de gado bovino unicamente para dessedentação), um bilhão de pessoas vive, nos dias de hoje, com uma oferta menor do que esta. Em 2025, cerca de 3,5 bilhões de pessoas estarão habitando áreas com carência de água, conjunto no qual o destaque caberia aos países pobres. Em 2050, novamente adotando como referência o padrão de 50 litros diários, poderão ser 4,2 bilhões de pessoas para as quais não será possível sequer garantir este volume (Vide CMB, 2000).

Outro fator inquietante adicional são as projeções que indicam para 2025 uma situação de stress hídrico para muitos dos países centrais, consumidores por excelência de água. Em mais de uma acareação, repete-se que o consumo destes países é muitas vezes superior ao dos países pobres. Uma criança nascida num país rico utilizaria, por exemplo, cerca de 30 a 50 vezes mais água do que uma de 
um país pobre ${ }^{41}$. A demanda das nações ricas, detentoras de um padrão de consumo de água muito mais elevado do que o dos países do Terceiro Mundo permite projetar um cenário perpassado por conflitos e toda sorte de pendências políticas centradas na questão da água.

Uma observação bastante instigante é a demarcada por meio da comparação dos dados da disponibilidade per capita de água doce no ano $2000 \mathrm{e}$ 2025 , isto é, avaliações centradas exclusivamente em dados físicos e quantitativos (Vide Fig. 16 e 17), com aqueles perpassados pelo crivo da dimensão social e econômica projetados para o ano 2025 (Fig. 18). Como é possível conferir, muitos dos países periféricos que despontam com excedente hídrico físico em 2000, estarão vivenciando uma situação de escassez econômica de água em 2025. Por outro lado os países do norte, grande parte dos quais não são de modo algum agraciados com recursos hídricos, estarão pelo contrário - e a

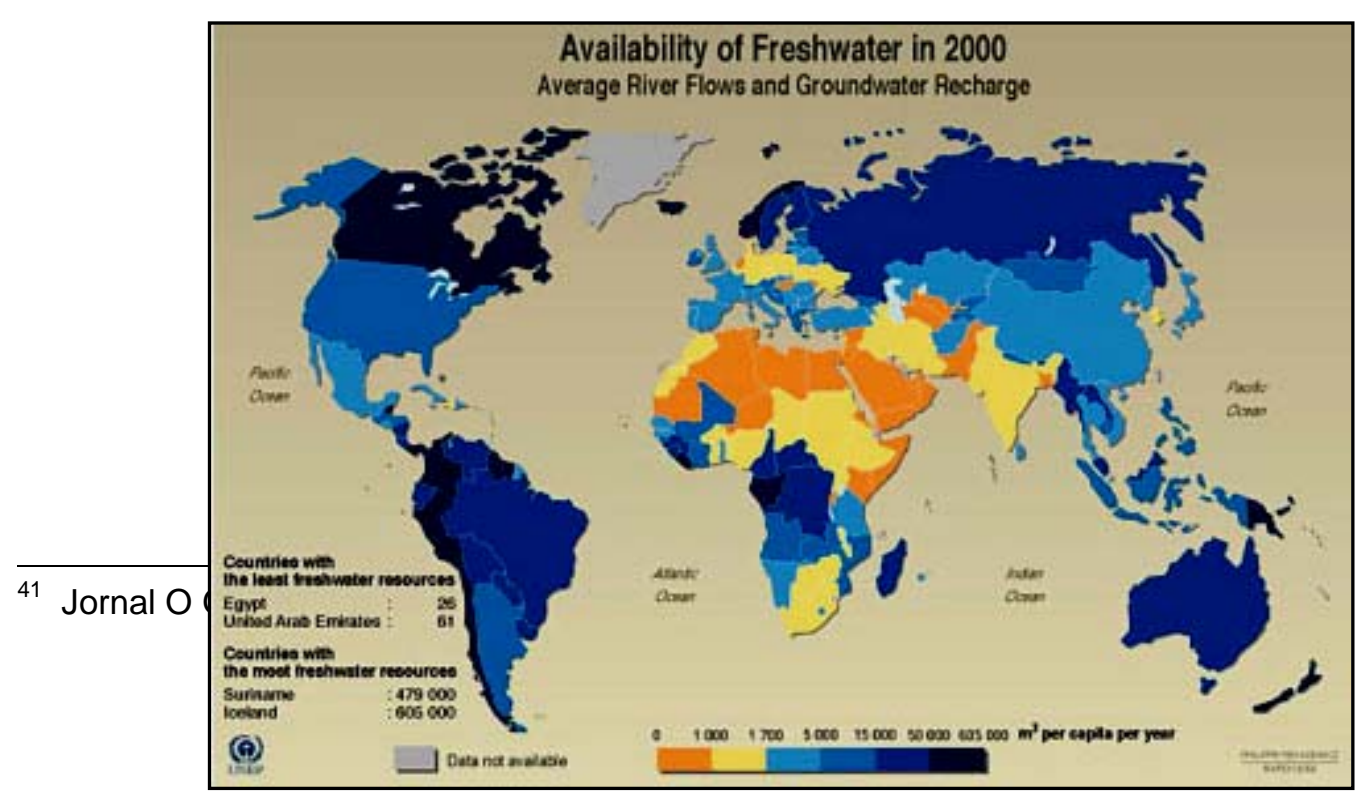


FIGURA 16 - Mapa da Disponibilidade Hídrica Mundial per capita no ano 2000 ( $\mathrm{m}^{3} / \mathrm{hab} / \mathrm{ano}$ ) (Fonte: <http://www.worldwatercouncil.org/ press_fr/cartes/freshwateravailability.jpg>, escala aproximada 1:197.600.000, in RIJSBERMAN, 2004, acesso: 13-05-2005) 


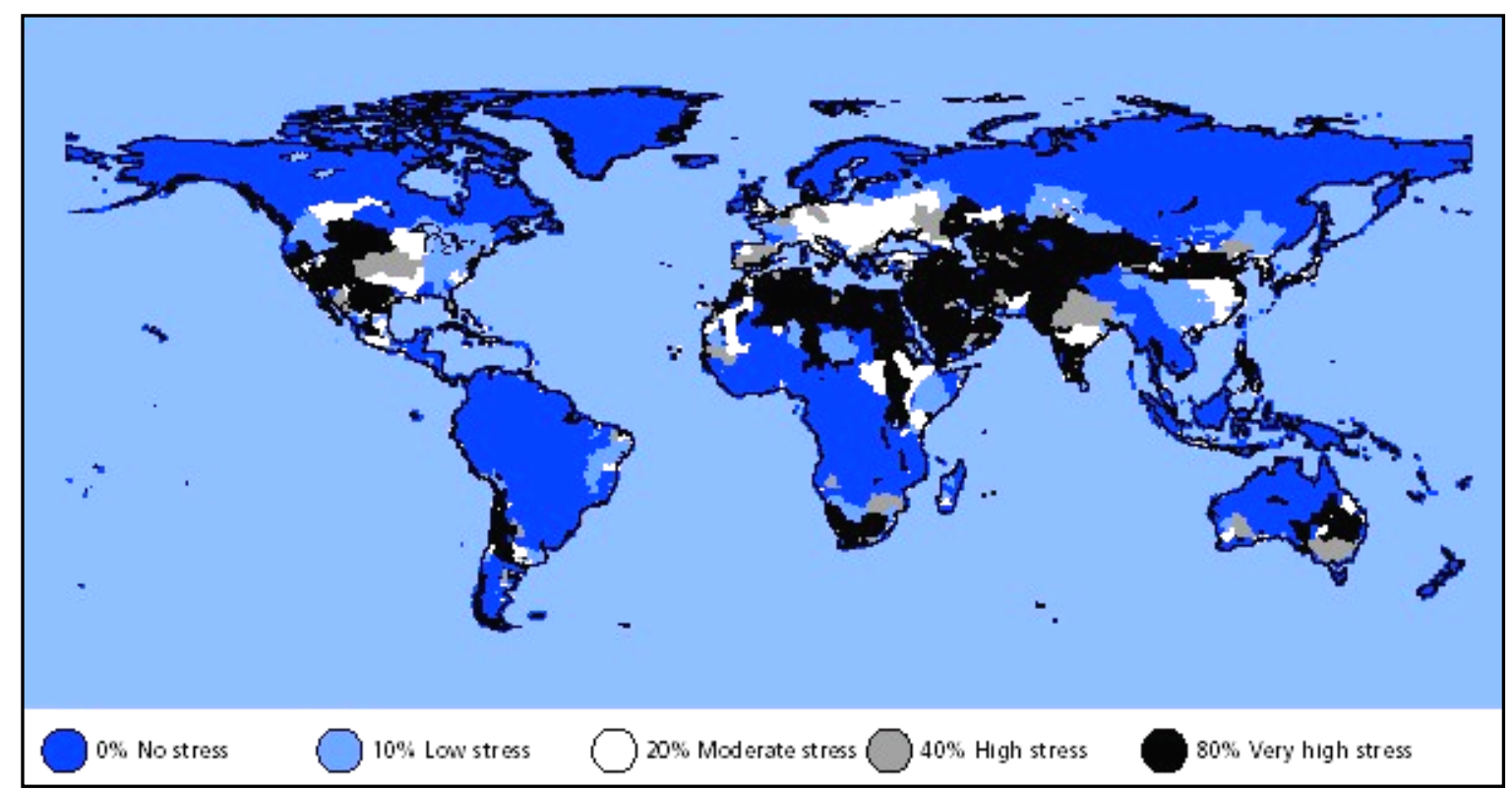

FIGURA 17 - Mapa da Disponibilidade Hídrica Mundial per capita no ano 2025 (m³/hab/ano) (Fonte: <http://www.worldwatercouncil.org/press_fr/cartes/waterstress.jpg> escala aproximada 1:242.600.000, acesso: 09-03-2005) 


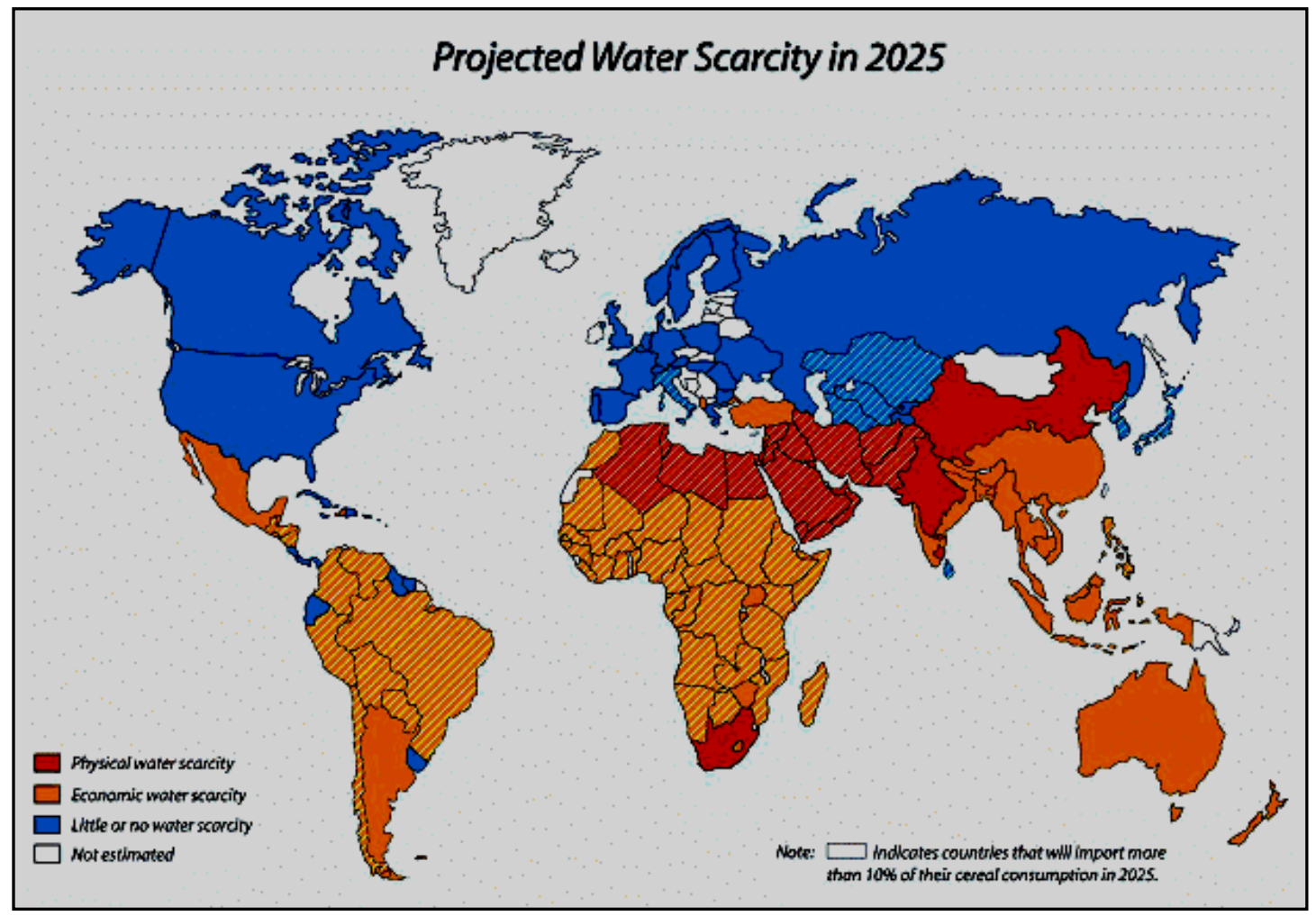

FIGURA 18 - Mapa da Disponibilidade Física e Econômica da Água no ano 2025 (Projeção) (Fonte: <http://www.cropscience.org.aulicsc2004/plenary/1/1994 rijsbermanf-3.gif>, escala aproximada 1:197.600.000, in RIJSBERMAN, 2004, acesso: 22-02-2005) 
despeito do possível acentuamento físico da escassez física de recursos hídricos desfrutando de acesso à água doce (Ver a respeito RIJSBERMAN, 2004).

Estes dados em si mesmos constituiriam claro indicativo de uma crise (em curso ou potencial) quanto ao abastecimento de água potável, com notórias repercussões para o conjunto da população mundial, agraciada ou não de acesso ao líquido. Inserindo toda sorte de conflitos potenciais, a questão dos recursos hídricos transparece como o mais fundamental problema a ser enfrentado pela humanidade em futuro próximo. Por isso mesmo julgar a respeito de uma problemática mundial de água configuraria muito mais do que mera especulação (VILLIERS, 2002:56).

A preocupação com a preservação do líquido passou a se difundir por tudo o mundo, motivando a adoção do dia 22 de Março como Dia Mundial da Água, efeméride estipulada pela ONU - Organização das Nações Unidas - em 1992. Entretanto, até que ponto a questão da escassez, agora transformada em evento comemorativo global, atinge de fato os habitantes do nosso Planeta? E, de que modo as atividades humanas estão implicadas nesta ordem de considerações?

Alinhavar argumentos para responder estas indagações é um convite dirigido a todos para a elaboração de uma resposta detalhada. Exatamente este será o objetivo dos próximos capítulos. 


\section{CAPÍ TULO 6}

\section{ÁGUA: RECURSO I NDI SPENSÁVEL}

\section{1. Água e Energia}

A energia é um aspecto sumamente vinculado à vida moderna, nas suas mais diferentes implicações. É impossível conceber, nos marcos da modernidade, um conglomerado urbano ou uma instalação industrial de porte dispensando uma conexão funcional com um provimento fluente de energia. Por conseguinte, 0 consumo de energia (ou melhor, conversão da energia, terminologia considerada mais adequada do ponto de vista técnico) cresceu exponencialmente com o advento do mundo ocidental. Sem dúvida alguma, em nenhum outro momento da história humana a demanda pela energia alcançou índices tão pronunciados.

Este crescimento se especificou particularmente na produção de bens, na prestação de serviços e no conjunto dos processos de reprodução social e cultural que caracteriza a vida dos humanos na modernidade. Tal evidência está claramente consignada no quadro seguinte (Tabela 3), que explicita os diferentes patamares de utilização da energia ao longo da história humana. A dependência da sociedade contemporânea quanto à energia empresta a esta discussão um cunho de certa dramaticidade. Isto porque o mundo moderno, para produzir os insumos tornados social e historicamente necessários para seu modo de vida, reclama vasta quantidade de energia.

Exemplificando, para produzir vidro, papel, plástico, aço e alumínio, materiais que praticamente simbolizam a vida moderna, são requeridos enormes inputs energéticos. Para obter uma única tonelada de vidro precisamos de 150 quilowatt por hora (kWh). O papel incorpora $600 \mathrm{kWh}$ para cada tonelada produzida. Quanto ao plástico, este solicita $1.140 \mathrm{kWh}$ por tonelada. Por sua vez, uma tonelada de 
aço corresponde a um consumo de $5.750 \mathrm{kWh}$. Finalmente, uma tonelada de alumínio não pode ser produzida com menos de 17.600 kWh.

TABELA 3

\section{BALANÇO ENERGÉTICO DAS ATIVIDADES HUMANAS}

(em milhares de calorias diárias)

Alimentação $\begin{array}{cccc}\text { Trabalho } & \text { Indústria e } \\ \text { doméstico e } & \text { Agricultura } & \text { Transporte } & \text { Total } \\ \text { serviços }\left(^{*}\right) & & \end{array}$

$\begin{array}{cccccc}\begin{array}{c}\text { Homem do } \\ \text { Paleolítico }\end{array} & 2 & & & & 2 \\ \begin{array}{c}\text { Caçador-coletor } \\ \text { Agricultor Neolítico }\end{array} & 3 & 2 & 4 & & 5 \\ \begin{array}{c}\text { Agricultor } \\ \text { Desenvolvido }\end{array} & 6 & 4 & 7 & 1 & 12 \\ \text { Homem Industrial } & 7 & 32 & 24 & 14 & 77 \\ \text { Homem Tecnológico } & 10 & 66 & 91 & 63 & 230\end{array}$

(Fonte: Wolfgang Sassin, revista O Correio da UNESCO, Setembro de 1981, página 11)

(*) No setor de serviços incluem-se o trabalho de escritório, comércio, ensino etc. 
A magnitude destes números é evidente quando se compara o custo energético do vidro com os demais materiais listados. Recorde-se que o vidro, apesar de constituir o produto menos exigente em eletricidade da listagem, tratase de um material cujo input energético já é elevado pelo simples motivo de resultar da fusão de matérias primas inorgânicas, dentre as quais, um papel fundamental caberia à areia ${ }^{42}$. Não por acaso, o Líbano, país que corresponde aproximadamente à antiga Fenícia, foi intensamente desmatado muitos séculos atrás inclusive por conta das exigências da indústria vidreira ${ }^{43}$.

O caso mais dramático é sem dúvida alguma referente ao alumínio. Este metal, mais do que qualquer outro se tornou representativo do estilo de vida da modernidade. Ele está fortemente presente na construção civil, na indústria aeronáutica, na indústria de peças e implementos mecânicos, nos objetos de uso diário, nas embalagens e na exploração do cosmos. O sucesso do alumínio é por demais evidente. Sua onipresença é perceptível não só num ostensivo conjunto de bens e na própria paisagem criada, quanto nas formas de consumo simbólico associadas às suas características estéticas e físicas, que se manifestam nos detalhamentos que recordam sua existência através da textura e da cor, ou mesmo, do brilho (Fig. 19).

Tal predileção pelo alumínio, em vista da sua prospecção e beneficiamento desdobrar-se em impactos de todo o tipo no meio ambiente, suscita notórias interfaces direcionadas com a questão ambiental. Obviamente, é possível assinalar que os processos de beneficiamento dos metais são, no geral, lesivos para o meio ambiente. Por exemplo, os rejeitos e efluentes ${ }^{44}$ da mineração do ferro, representam quase metade da tonelagem do minério retirado das

\footnotetext{
${ }^{42}$ Assinale-se que não existe propriamente vidro, mas sim, vidros, cada um dos quais resultante de uma combinação notoriamente específica de componentes minerais. De um modo ou de outro, esta afirmação também poderia ser estendida aos papéis, plásticos e diferentes ligas de metais.

${ }^{43} \mathrm{O}$ antigo Líbano era coberto por densa vegetação, inclusive por florestas inteiras de cedro, objeto de encantamento dos cronistas da Bíblia e de todos os povos do antigo Levante. Apesar da bandeira deste país exibir um exemplar desta árvore em seu campo central, o cedro foi praticamente extinto. O cedro está atualmente reduzido a alguns exemplares protegidos por lei. A eliminação da cobertura vegetal do Líbano é um dos exemplos de como as chamadas tecnologias "pouco exigentes" interferem de modo cumulativo e irreversível no meio ambiente.
} 
montanhas. Contudo, esta proporção é significativamente mais alta no caso da bauxita, minério responsável pela quase totalidade de produção do alumínio

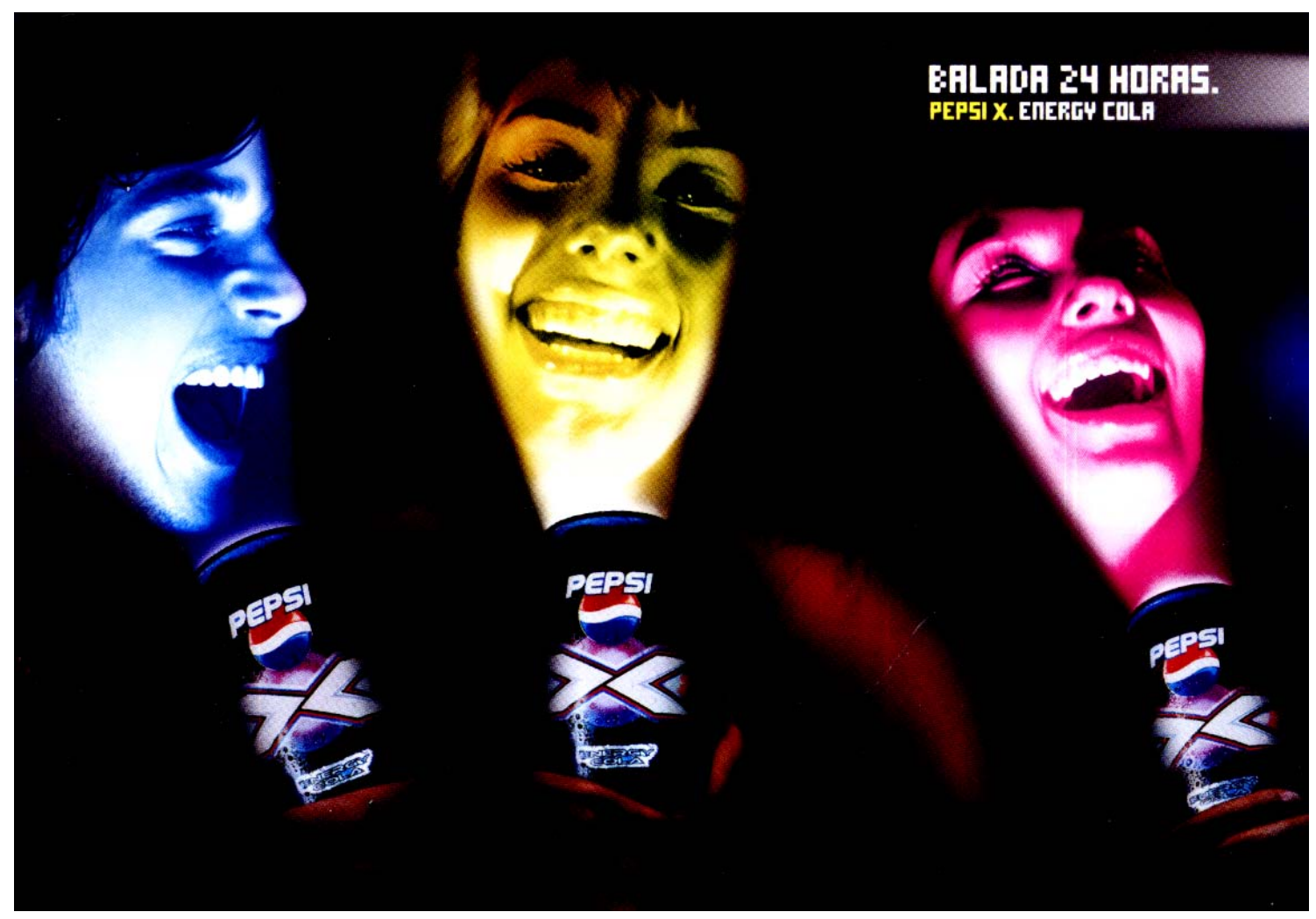

FIGURA 19 - A energia e o imaginário do alumínio: Postal de propaganda de bebida gaseificada distribuído em 2004 nos circuitos de bares e restaurantes da cidade de São Paulo vinculando a lata de alumínio e o dinamismo de 24 horas da vida moderna com a dessedentação.

\footnotetext{
44 "Efluente: Qualquer tipo de água ou líquido, que flui de um sistema de coleta, como tubulações, canais, reservatórios, elevatórios ou de um sistema de tratamento ou disposição final, com estações de tratamento e corpos de água" (Glossário Ambiental).
} 
primário. Praticamente três quartos da bauxita removida constituem rejeitos. Importa registrar que a elevada carga de revolvimento do solo decorre do teor médio relativamente baixo de metal presente na terra vermelha - como também é conhecida a bauxita - oscilando em torno de 25\% (Ver a respeito, GEORGE, 1980:112, SEVÁ, 1997:16 e CALDERONI, 2003:180).

Além dos impactos ocasionados por sua explotação implicar no revolvimento de portentosas camadas de solo e poluição do ambiente com uma nefasta carga de detritos resultantes do beneficiamento nas usinas metalúrgicas, o alumínio também é, por definição, um produto eletro-intensivo. Os dados expostos esclarecem que a produção deste metal consome $17.600 \mathrm{kWh} /$ tonelada. Uma contabilidade simples nos revela, portanto, que o material utiliza cerca de 120 vezes mais energia que o vidro, 25 vezes mais que o papel, 15 vezes o plástico e aproximadamente três vezes mais do que o aço. Outro cálculo indica que uma latinha de alumínio incorpora energia suficiente para manter uma lâmpada de 100 Watts acesa durante aproximadamente 3:30 horas ou manter a televisão ligada por pouco mais de 3 horas $^{45}$.

Fato plenamente observável, a identificação deste metal como o modo de ser da modernidade difundiu extensivamente sua utilização em todo o cotidiano e através dos mais diversos campos da atividade industrial e produtiva. Nesta linha de argumentação, na contabilidade ambiental do alumínio devem ser incorporados os prejuízos ambientais decorrentes da implantação e manutenção de centrais de eletricidade cuja energia está destinada para trazê-lo ao mundo. Por isso mesmo, entre outras razões, o alumínio é responsável por fração ponderável do consumo energético. No Brasil, as empresas encarregadas da sua produção se apropriam de aproximadamente $10 \%$ da hidroeletricidade gerada no território nacional (CEMPRE, Cempre Informa).

O vulto da participação do alumínio no consumo energético, também deve ser avaliado com base no fato de que os setores industriais responsáveis por sua produção são igualmente agraciados com tarifas significativamente mais baixas do que as pagas pelo cidadão comum. $\mathrm{O}$ apoio das administrações federais tem sido

\footnotetext{
${ }^{45}$ Informação divulgada no site da ALCOA Alumínio S.A (acesso: 22-03-2005).
} 
explícito quando se sabe que desde o início das operações da Usina Hidrelétrica (UHE) de Tucuruí em 1984, as Centrais Elétricas do Norte do Brasil S.A. (ELETRONORTE) tem fornecido a energia a preços subsidiados para as indústrias de alumínio do Pará e do Maranhão (SANTOS FILHO, 1999:134), prática que, aliás, prossegue até os dias de hoje. Comparativamente aos consumidores residenciais, a Companhia Alumínio Brasileiro S.A. (ALBRÁS, instalada no Pará), cujas instalações produzem alumínio para exportação, paga pela energia fornecida apenas $10 \%$ do total pago pelas residências. Um dos cálculos disponíveis avalia que cerca de 250 milhões de dólares são desta forma repassados a cada ano para as indústrias exportadoras de alumínio, significando um claro subsídio em prol do consumo deste metal por parte das afluentes economias centrais ${ }^{46}$.

Estes dados são em si mesmo reveladores dos pressupostos que regem a matriz energética nacional. Pensando-se que poucos anos atrás a nação foi sacudida com o fantasma do chamado "apagão", fica evidente a necessidade de antes de serem estabelecidas "regras para a contenção do desperdício" e ou mesmo de "racionamento", de se rever as prioridades do uso da energia produzida no território nacional. Ao Brasil, constituindo uma nação com destacada posição na geração da hidroeletricidade e que agrega a esta condição a de ser grande produtor e exportador de alumínio, está concretamente colocada na ordem do dia repensar o gerenciamento da sua matriz energética.

Por outro lado, é evidente que mensurar os índices de consumo energético dos materiais utilizados pelo mundo moderno, por mais preocupantes que estes sejam, não esgota a discussão relativa à energia em seu sentido mais amplo. Além dos aspectos mencionados, seria cabível destacar aqueles que se prontificam a uma articulação com a questão dos recursos hídricos. Basicamente em razão da geração de energia sempre implicar em algum tipo de vínculo como os recursos hídricos. Exatamente por esta razão, algumas ponderações constituem pauta obrigatória desta discussão.

46 Informação obtida no site do Movimento dos Atingidos por Barragens: $<$ http://www.mabnacional.org.br/>, (acesso: 19-06-2005). 
Antes de tudo, é válido lembrar que a água está presente em praticamente todas as formas hoje existentes de conversão da energia. Esta locução se expressa de modo explícito para o caso da hidroeletricidade; noutros processos, como a biomassa, energia termonuclear e termoelétrica, a água também sustenta uma parceira com a produção energética. Ademais, muitos impactos ambientais com origem na matriz energética terminam atingindo, de um modo ou de outro, os corpos aquáticos.

Exemplificando, mesmo as usinas maremotoras, funcionando com base no aproveitamento energético do deslocamento das marés ${ }^{47}$ e normalmente percebidas como isentas de comprometimentos ambientais, apresentam seqüelas para o meio ambiente. Embora diversos estudos evidenciem serem específicos os impactos das usinas maremotoras (diferindo de um ponto para outro, na dependência direta das características geográficas de cada área), e da energia maremotriz não resultar na emissão de gases responsáveis pelo aquecimento global e tampouco em deposições ácidas, o bloqueio do fluxo da maré, represado numa baía, estuário ou qualquer outra reentrância do litoral por essas instalações, pode resultar em alterações negativas para os ecossistemas fluviais e marinhos. De resto, a intervenção na linha da costa pode ser prejudicial para a navegação, pesca e a recreação.

\footnotetext{
${ }^{47}$ Esta fonte de energia interessa principalmente para as regiões com grande diferença entre as marés alta e baixa, podendo ser explorada através das usinas maremotoras, instalações que convertem a energia das marés em energia elétrica. Elas funcionam de modo semelhante às hidrelétricas, dispondo de turbinas movimentadas pela água do mar represada. Este represamento é obtido pela construção de barragens em recortes apropriados do litoral, amplos e profundos. Quando ocorre a maré alta, estes trechos do litoral são ocupados pela água do mar e antes que a água do mar recue, as comportas são fechadas, represendo as águas. Posteriormente, este volume é gradativamente liberado de modo a acionar turbinas geradoras de eletricidade. A construção de usinas maremotoras solicita a existência de diversas pré-condições, tais como a ocorrência de marés altas e condições geográficas apropriadas. Embora a energia maremotriz seja uma das grandes fontes renováveis de energia do mundo, ela concentra-se em alguns poucos locais, como o Canal da Mancha, o Mar da Irlanda, Mar de Barentz e Mar Branco. O uso da energia das marés pode diminuir a necessidade da emergia nuclear, com seus riscos associados à radiação. O imenso potencial energético das marés é ainda pouco utilizado na escala mundial. Uma das mais conhecidas experiências de aproveitamento da energia maremotora é a estação maremotriz do Rance, situada na península da Bretanha, na França. Concebida para ser a primeira de uma série de estações maremotrizes, o programa de construção de estações maremotoras da França foi paralisado, suplantado pela expansão da construção de usinas nucleares nos anos sessenta.
} 
A articulação entre as questões dos recursos hídricos e da matriz energética se repete no caso das novas tecnologias de geração de energia. Este seria o caso das células de combustível. Esta tecnologia, proposta pela primeira vez em 1839, adota por insumo energético a própria água. No século XIX, a descoberta da possibilidade de utilizar o líquido para fornecer à humanidade toda a energia de que necessitava estimulou o fervor visionário de muitos pensadores, cientistas e escritores. Escreveu Júlio Verne na sua obra $A$ Ilha Misteriosa (1874): "A água será um dia um combustível. O hidrogênio e o oxigênio que a constituem, utilizados separadamente oferecerão uma fonte de calor e de luz inexauríveis".

Nas células de combustível, a energia é obtida pela separação dos átomos de hidrogênio e de oxigênio presentes no líquido, gerando através de transformação exotérmica, calor e energia elétrica. Este processo, além de não produzir qualquer tipo de poluição, tem por efluente apenas água despida de resíduos. Entretando, exatamente o fato de propor a utilização energética de um recurso difuso (a água) e de não propiciar controle (pois a energia é gerada no local do consumo), é que impediu o aprofundamento das pesquisas. Num mundo cuja economia foi construída com base em combustíveis fósseis e com o intento declarado de dominar a vida dos humanos, é fácil adivinhar os motivos que engavetaram os estudos para viabilizar as células de combustível como opção viável. Hoje, aguardando aprimoramentos técnicos, a tecnologia tem despertado renovado interesse, recolocando na ordem do dia a interrelação entre a energia e a água.

De qualquer modo, tudo isto torna patente que os recursos hídricos não podem ser - sob qualquer ponto de vista - dissociados dos debates relacionados com a questão da matriz energética. A produção de energia, de um modo ou de outro, sempre possui a água como pressuposto. Neste sentido, um avantajado escopo de argumentações pavimenta a advertência no sentido de jamais se desvincular a discussão relacionada com os recursos hídricos das condizentes com a matriz energética. Gerar e disponibilizar energia implica, quando o assunto em pauta é a sociedade moderna, em uma demanda ampliada de recursos 
hídricos, o que por sua vez também se relaciona com diversificados impactos socioambientais.

E, dificilmente poder-se-ia minimizar esta preocupação quando a modalidade de geração de energia é a hidroeletricidade. Constituindo uma forma de geração de energia na qual a associação com os recursos hídricos apresenta-se de modo indiscutível, a importância da hidroeletricidade no universo das opções energéticas disponíveis no Brasil é manifesta. O país ocupa atualmente a terceira posição no ranking mundial em capacidade instalada de geração hidrelétrica, superado apenas pelos Estados Unidos e Canadá. Na escala dos dez maiores produtores mundiais, o Brasil constitui, juntamente com a Índia e a República Popular da China, um dos três únicos grandes geradores de hidroeletricidade situados fora do contexto dos países centrais ou das nações tradicionalmente industrializadas.

Este fato contribui para justificar a expressiva participação da hidroeletricidade no conjunto da produção elétrica nacional. Nas últimas décadas a hidroeletricidade tem respondido, pelo mínimo, por 90\% do volume total gerado, cabendo a produção da fração restante ao labor das usinas termoelétricas e nucleares. No Brasil, a construção de hidrelétricas tem impregnado profundamente o imaginário referendado na modernidade e decerto, a proliferação de barragens erguidas desde primórdios do século passado em todo o território nacional certamente corroboraria este julgamento.

Esta proeminência do primado energético na construção das represas tem sido, aliás, origem de um dos problemas mais sérios vivenciados pela população urbana do país. Observe-se que em linhas gerais, os interesses mobilizados pela geração de energia com base nos recursos hídricos armazenados nos reservatórios, respaldados solidamente no poder econômico e político, tenderam a se afirmar frente aos voltados para o abastecimento de água potável para a população.

Deste modo, embora as represas possibilitem dupla finalidade (gerar energia e fornecer água potável), foi a produção de energia que geralmente terminou priorizada de fato, submetendo os demais usos dos recursos hídricos às suas prioridades e expectativas. Nesta perspectiva, numa flagrante inversão dos termos 
pelos quais a água se prontifica enquanto elemento reprodutor da vida, a água represada termina transformada em mera energia potencial a disposição da movimentação das turbinas, inexistindo cuidados visando garantir a qualidade do líquido.

Paralelamente a estas colocações, pode-se registrar uma outra ordem de problemas, pois de acordo com um ponto de vista ambiental, as hidrelétricas, geralmente apontadas como uma forma ambientalmente adequada (ou até mesmo "limpa"), de geração de energia, não escapariam, a bem da verdade, de diversos outros questionamentos, atendendo inclusive a problemáticas conceituais. Recorde-se que embora constitua uma locução constantemente repetida, dificilmente se poderia apontar uma forma verdadeiramente limpa de geração de energia. Neste particular, existiriam, no máximo, apenas fontes de energia menos sujas, mas não fontes verdadeiramente limpas, parecer que também incluiria as consideradas alternativas.

Precisando melhor o comentário anterior, no geral as formas alternativas, consideradas "limpas", possuem como denominador comum o fato de serem renováveis e serem bastante adaptadas ao meio natural. No entanto, isto não quer dizer ausência de impactos. As energias renováveis também apresentam impactos ao meio ambiente e ao bem-estar humanos. Elas ocasionam desde ferimentos decorrentes de quedas de telhados durante a manutenção térmica solar e o inconveniente brilho do sol nas superfícies de vidro, até as agressões em termos de poluição sonora gerados pelas modernas turbinas movidas a vento, podendo incomodar a população vizinha.

Certificando o comentado nos parágrafos anteriores, pode-se agregar que a suposta característica "menos impactante" da energia hidrelétrica constitui um discurso que freqüentemente descarta uma série de agressões socioambientais, a começar pelas que atingem as populações deslocadas pela construção de barragens. Praxe repetida em múltiplos cenários, as obras hidrelétricas, tanto no passado quanto na atualidade, suscitam alterações radicais de ordem econômica, social, política e cultural. Não há como negar, a implantação de usinas hidrelétricas, especialmente os chamados mega-projetos hidrelétricos, tem 
perturbado o sistema de vida de significativos grupos populacionais em todo o mundo. Oneradas diretamente pelo impacto da construção dos reservatórios, as populações deslocadas terminam, quando muito, reassentadas ou indenizadas apenas quando se mobilizam com este fim.

Outro aspecto é que dentre os segmentos atingidos pela construção dos reservatórios das represas, um contingente muito elevado é formado por povos indígenas, minorias étnicas e populações tradicionais como camponeses, ribeirinhos e grupos extrativistas em geral (CMB, 2000). Estruturadas perifericamente ao modo hegemônico de territorialização, tais populações têm sua vida social alicerçada numa dependência para com o meio ambiente, fator que as tornam particularmente sensíveis aos impactos provocados pela construção de grandes barragens (Vide SANTOS e ANDRADE, 1988).

De resto, como estes grupos estão, em maior ou menor grau, desigualmente integrados às sociedades em cujo seio vivem, esta situação é origem de diversas dessimetrias no relacionamento com os Estados Nacionais, a começar pela fragilidade política destas populações frente aos órgãos governamentais em todos os níveis e naturalmente, às construtoras. Por isso mesmo, tais grupos sofreram um nível desproporcionalmente alto de deslocamentos, ocasionando impactos variadamente negativos sobre seus meios de subsistência, sua cultura e existência espiritual (CMB, 2000). Não sem razão, estes segmentos sociais terminaram por serem transformados em intérpretes incontestes das mobilizações ambientalistas contrárias à construção dos reservatórios.

Não fosse suficiente a construção de usinas hidrelétricas também potencializa desequilíbrios ecológicos dos mais diversos gêneros, no geral pouco conhecidos pela opinião pública. Notadamente, um destes nos remeteria às emissões de GEE (Gases de Efeito Estufa), decorrentes do enchimento dos reservatórios das hidrelétricas construídas em áreas de floresta densa. Com o afogamento e posterior apodrecimento da massa vegetal, gera-se metano (conhecido como "gás dos pântanos") e dióxido de carbono, ambos em grande quantidade. Os gases oriundos dos reservatórios contribuem diretamente, lado a 
lado com a queima de combustíveis fósseis, das emissões provenientes dos resíduos sólidos e do esterco dos rebanhos, para com o aquecimento global.

Claro é que a formação dos lagos artificiais das hidrelétricas pode, independentemente das alterações ecológicas que acompanham seu surgimento, corresponder a um padrão de fornecimento de energia sugerindo que os custos ambientais relacionados com a construção de barragens estariam ao menos justificados por uma retribuição eficiente quanto ao fornecimento de energia para a sociedade mais ampla. Nesta linha de interpretação seria o caso de se mencionar a UHE de Paulo Afonso I-IV, responsável, por exemplo, pela geração de 3.984 MW com base numa área alagada de 1.600 hectares (ha). Matematicamente, Paulo Afonso gera $2.490 \mathrm{~kW}$ por ha alagado, índice considerado elevado na comparação com muitas outras hidrelétricas. No sistema hidrelétrico brasileiro, em termos da capacidade instalada, Itaipu gera $93 \mathrm{~kW} / \mathrm{ha}$ alagado; o sistema Billings, 69, $7^{48}$; Jupiá, 42; São Simão, 41; patamares considerados tecnicamente bons ou aceitáveis. Entretanto, numa outra ponta a usina de Sobradinho gera $1.050 \mathrm{MW}$ tendo por contrapartida um reservatório com área de 421.400 ha, configurando um índice de apenas dois kW por hectare alagado.

São considerações deste tipo que induzem muitos especialistas a recomendarem,

...como menos prejudiciais do ponto de vista ecológico-sanitário, represas que se caracterizem por um máximo volume de água represada, com mínima superfície de inundação ou, expresso de outra maneira, máxima capacidade geradora por área inundada (BRANCO, 2002:239, grifo nosso).

A despeito da sabedoria desta máxima, não necessariamente os órgãos estatais de planejamento atendem ao primado da utilização eficiente dos recursos naturais. Pelo contrário, são inúmeros os exemplos de hidrelétricas construídas ignorando quaisquer arrazoados da boa engenharia e infelizmente, respondendo por perturbações socioambientais de todo o tipo.

\footnotetext{
${ }^{48}$ Valor obtido com base em informação prestada pelo gestor ambiental da EMAE, Edson Fernando Escames, em 07-12-2005.
} 
Um caso notório que instrumentalizou a água enquanto item a serviço do desequilíbrio ambiental foi o da UHE de Balbina, construída no final dos anos 80 no estado do Amazonas. Esta obra é considerada um dos piores desastres ambientais de todos os tempos. O lago da hidrelétrica, cuja área equivale à metade do Distrito Federal, afogou vasta extensão florestal, destruiu diversos sítios arqueológicos e inundou parte da reserva indígena Waimiri-Atroari. A Hidrelétrica de Balbina libera três milhões de toneladas de $\mathrm{CO}^{2}$ por ano, o mais importante gás de efeito estufa. E o fará durante 20 anos, enquanto que uma termoelétrica a gás libera em média 0,35 milhão de toneladas por ano (Vide NOVAES, 2000). E, tais custos não se justificariam nem mesmo por benefícios em termos de abastecimento energético: Balbina gera apenas um quilowatt por hectare alagado. Sua contribuição energética é insuficiente para abastecer Manaus, capital do Amazonas, que em tese estaria atendendo.

Um outro aspecto importante nesta discussão, é que a proliferação indiscriminada de barragens é em si mesma, um elemento determinante da diminuição da oferta dos recursos hídricos, em razão da elevação das taxas de evaporação e destruição dos sistemas naturais provedores de água doce. Tal fenômeno atinge proporções verdadeiramente dantescas na República Popular da China. Além de encaminhar a construção da maior hidrelétrica do mundo, a das Três Gargantas ${ }^{49}$, recorde-se que a China reúne $46 \%$ das barragens no mundo (CMB, 2000). A magnitude dos projetos chineses de construção de barragens é incontestável:

Em 1900, não havia no mundo barragens mais altas do que 15 metros. Por volta de 1950, havia 5.270, duas delas na China. Trinta anos depois havia 36.562, das quais não menos de 18.820 na China (VILLIERS, 2002:179).

Outras seqüelas derivadas do gigantismo desmesurado e inconseqüente dos planejadores do setor elétrico implicam, de uma maneira ou de outra, na concentração de um recurso que anteriormente estava parcimoniosamente

${ }^{49}$ Em razão da experiência acumulada pela engenharia nacional na construção de grandes barragens, a empresa brasileira FURNAS Centrais Elétricas S.A. participa deste empreendimento. 
distribuído pela natureza. Existe farta documentação evidenciando que muitos dos mega-projetos hidrelétricos, incensados pela propaganda oficial, interferem cedo ou tarde nos ciclos hidrológicos dos rios, alterando suas características, sua velocidade e a vazão das suas águas. Há também uma contabilidade ambientalmente negativa configurada no desmatamento ou inutilização de terras agrícolas pela construção das linhas de transmissão; perda de acervos históricos, culturais, paisagísticos e de biodiversidade; maximização da concentração de sedimentos; e para completar, alterações nos micro-climas locais.

Paralelamente, as barragens hidrelétricas são responsáveis pela destruição dos equilíbrios naturais responsáveis pela manutenção dos recursos hídricos, afetando diversas formas de vida dos cursos dos rios, e de modo bastante direto, a ictiofauna e as populações ribeirinhas dela dependentes. Conseqüentemente, devido ao grande número de problemas gerados pelas diversas obras hidrelétricas, as populações atingidas em todo o mundo têm se organizado na defesa dos seus interesses. Recorde-se que o Brasil contabiliza no ano de 2005, mais de 2.000 barragens construídas em seu território, responsáveis pelo alagamento de uma área de 34 mil km² (a título de comparação o estado de Alagoas tem $29.107 \mathrm{~km}^{2}$ ) e pelo deslocamento de mais de um milhão de pessoas. E, apesar do gigantismo destes números, nada disto parece sensibilizar os órgãos governamentais responsáveis pela implantação de novas barragens ${ }^{50}$.

Por isso mesmo, a resistência à construção de hidrelétricas terminou justificando a formação do Movimento dos Atingidos por Barragens (MAB), movimento social considerado, ao lado do seu congênere indiano, como um dos mais vigorosos de todo o mundo. Recorde-se que mesmo em determinados países centrais, como seria o caso dos Estados Unidos, a consciência dos danos provocados pelo barramento indiscriminado dos rios suscitou mobilizações inéditas solicitando a desativação estas obras, consideradas contrárias aos interesses vitais da população ${ }^{51}$.

\footnotetext{
50 Informações divulgadas em 17/06/2005 pelo Movimento dos Atingidos por Barragens davam conta de que até 2008, outras 100.000 pessoas seriam deslocadas no Brasil pela construção de represas (nota divulgada no site do MAB).

${ }^{51}$ Notar que esta tendência deve ser observada com cautela. Muitos setores do ambientalismo sugerem que o lobby da indústria nuclear poderia ser um beneficiário direto da eliminação das
} 
Neste país, a era da edificação de represas parece ter virtualmente cessado de existir. Um dos líderes mundiais na construção de represas, "os Estados Unidos, hoje lideram sua derrubada. O país está desativando mais do que construindo a cada ano, e já removeu pelo menos 465 delas, conforme um estudo da American Rivers, Friends of the Earth, e Trout Unlimited. A França e outros países estão seguindo o mesmo caminho" (RUNYAN, 2001:31). Apresentadas no século passado como marco do "desenvolvimento econômico" e da "vitória do homem sobre a natureza", as barragens, construções reconhecidamente emblemáticas da ascendência dos humanos sobre o meio natural, ingressaram no novo milênio marcadas por estigmas e pela indignação pelos problemas que tem provocado.

Porém, não se pode esquecer que este tipo de planta energética não constitui o único vetor de destruição e comprometimento das águas doces. Contradizendo difuso senso comum, um poderoso agente de danos dos corpos aquáticos está substanciado nas termoelétricas. Em muitos segmentos sociais, está bastante sedimentado o julgamento de que estas centrais energéticas, tendo por base a produção de energia a partir da queima de combustíveis fósseis, dispensariam a utilização de água para o seu funcionamento. Este pressuposto transitou com muita tranqüilidade nas polêmicas relacionadas com o "apagão" durante o ano de 2001, quando então, uma forte corrente de opinião advogava a implantação das termoelétricas enquanto alternativa válida às hidrelétricas visto serem entendidas como pouco ou nada dependentes da vazão dos rios e da pluviometria.

Mas, a despeito do mencionado senso comum pelo qual as hidrelétricas são consideradas consumidoras por excelência de água, e as termoelétricas, pelo contrário, poupadoras de recursos hídricos, cumpre salientar que as termoelétricas também se destacam enquanto vorazes devoradoras de recursos hídricos. Fato largamente desconhecido pela opinião pública, as termoelétricas requisitam água em diversas etapas da sua operação. Dentre estas, podemos citar a geração de vapor, refrigeração e manutenção do sistema, e isto, numa proporção 
considerável. Não é de se admirar, portanto, que as termoelétricas ocupem posição privilegiada na relação dos grandes consumidores de água em diversos países do mundo, incluindo nesta observação diversos países do Norte às voltas com o problema do stress hídrico. Faria sentido, portanto, analisar a partir de um registro recente e fidedigno (LANNA, 2002:543), alguns dados que ilustram estas afirmações:

- O consumo de água pelas termoelétricas constitui nos Estados Unidos, a segunda maior atividade de consumo de água (726 m³/hab/ano), perdendo por pouco apenas para a irrigação, a primeira colocada (774). Tais dados são por sua vez significativamente superiores aos relativos ao abastecimento urbano (218) e do consumo da própria indústria (128). Ressalve-se, no caso, que este é o último item da pauta de consumo do país mais industrializado do planeta.

- Além dos Estados Unidos, muitos outros países seriam exemplos da enorme demanda hídrica das termoelétricas. Na República Federal da Alemanha, as termoelétricas lideram o consumo de água (534 $\mathrm{m}^{3} / \mathrm{hab} / \mathrm{ano}$ ), índice muito acima do consumo urbano (79) e industrial (30);

- Da mesma forma, na França as termoelétricas também detêm a liderança (395), relegando o abastecimento urbano a um modesto segundo lugar (108), seguido pela irrigação (87) e pela utilização industrial (79). O mesmo se repete monotonamente em muitos outros casos (Vide LANNA, idem).

Além de utilizarem recursos hídricos em larga escala, há também que serem considerados os impactos indiretos das termoelétricas nos corpos d'água, como 
os relacionados com as deposições ácidas. Esclareça-se que deposição úmida refere-se às chuvas, ao nevoeiro ou neve ácidas. Por sua vez, a deposição seca refere-se aos gases e partículas ácidas. Fato pouco conhecido, quase metade da acidificação da atmosfera decorre da deposição seca, não necessariamente tendo por veículo as precipitações pluviométricas.

Em muitas regiões industrializadas as deposições ácidas secas, e não os nevoeiros, chuvas e neves ácidas (todos pertencentes à categoria das deposições úmidas), correspondem ao "carro-chefe" da acidificação do meio ambiente. Deste modo, a famosa chuva ácida constitui um dos casos relatados das deposições ácidas, e não necessariamente a mais freqüente. Assinale-se também que no seu stricto sensu, toda chuva é pelo menos fracamente ácida, pela ação da combinação com o dióxido de carbono do ar (Ver a respeito LEWGOY, 1986:58/59). Obviamente, em nada isto se compara com a acidificação promovida pela revolução industrial, de resto responsável pelo surgimento das deposições secas.

Deste modo, tanto as chuvas quanto os ventos constituem veículos da acidificação do meio ambiente, difundindo gases e partículas ácidas sobre edificações, carros, residências, vegetação e corpos aquáticos em geral. Suas conseqüências para a saúde humana e o meio ambiente são tremendas. Os danos para a economia também são notórios e indiscutíveis. Embora os depósitos ácidos possam ser lavados pelas chuvas e tempestades, as águas resultantes do contato com substâncias acidificantes terminam por transferir o problema para outras áreas ainda mais distantes.

Nesta linha de argumentação, uma vez que as centrais termoelétricas utilizam combustíveis fósseis na produção de eletricidade, estas instalações terminam responsáveis pela emissão de enorme quantidade de enxofre e de óxidos de nitrogênio, ambos fundamentais para a formação de ácidos na atmosfera. Deste modo, as termoelétricas constituiriam foco potencial da acidificação dos recursos hídricos, e em razão das dinâmicas atmosféricas, seu mapa de riscos indexaria mesmo os corpos d'água situados a uma distância considerável destas. Os vínculos existentes entre as termoelétricas e a ocorrência 
da deposição ácida na massa líquida dos rios, lagos e mares, permitindo, num segundo momento, a infiltração e contaminação dos reservatórios subterrâneos, constitui, pois um fato grave que reclama claro posicionamento por parte da sociedade.

Deve-se ainda registrar dentre as implicações negativas das termoelétricas para a preservação das águas doces, as decorrentes da mineração do carvão e da prospecção dos hidrocarbonetos, matérias primas energéticas mais comumente utilizadas por estas instalações. Por exemplo, a indústria petrolífera lança mão do método de injetar água nos poços, pressionando os lençóis de petróleo visando maximizar a produção, procedimento que além de retirar água do ciclo hidrológico, promove sua contaminação. Quanto às minas de carvão, estas retiram enormes volumes de águas subterrâneas altamente salinas dos veios carboníferos, indiscriminadamente lançados no meio ambiente. Posteriormente, tanto o beneficiamento do petróleo, quanto do minério de carvão reclamam outro quinhão de impactos nos recursos hídricos.

Deste modo, direta ou indiretamente o funcionamento e a expansão das termoelétricas repercute diretamente na qualidade das águas doces, configurando-se enquanto importante fator gerador da sua escassez. Por isso mesmo, é possível considerar que os recursos hídricos estarão muito mais protegidos com o concurso da revisão da matriz energética do que simplesmente substituindo hidrelétricas por termoelétricas. Neste sentido, deveríamos agregar na discussão que conjuga os recursos hídricos e a matriz energética, a reflexão sobre os impactos provocados pelas formas através das quais a energia é consumida, que se tornam, sem que disto o cidadão comum se dê conta, em instrumentos da malversação dos recursos hídricos.

Confira-se, por exemplo, a questão referente às pilhas comuns. Esse produto, contendo metais pesados como o cádmio, chumbo e mercúrio na sua composição, pode lesionar o meio ambiente. Portanto, as pilhas tem sido alvo de orientações minuciosas em muitos países quanto ao seu descarte final. Porém, procedimentos legais reclamam fiscalização para serem consolidados. No caso do Brasil, a Resolução $n^{\circ} 257$ do Conselho Nacional de Meio Ambiente (CONAMA), 
tecnicamente em vigor desde 30-06-1999, prescreve a proibição do lançamento de pilhas e baterias in natura a céu aberto tanto em áreas urbanas quanto rurais; proíbe seu despejo em corpos aquáticos e áreas sujeitas a inundação; interdita sua queima em ambiente aberto assim como em instalações inadequadas; de resto, obriga as empresas a criarem serviços de reutilização, reciclagem ou de destinação final adequada para este resíduo. Entretanto, estas diretivas legais tem sido ignoradas, permitindo a liberação de quantidade ponderável de substâncias tóxicas no meio ambiente.

Outro caso paradigmático poderia ser endereçado às lâmpadas fluorescentes. Fato bastante conhecido, as lâmpadas fluorescentes são mais econômicas do que as incandescentes, reduzindo entre 70 a $80 \%$ a demanda por energia. Tal peculiaridade tem sido frisada enquanto estratégia adotada pelo comércio para incentivar as vendas do produto em nome do uso racional de energia. Por esta razão, esse produto conquistou no ano de 2001 uma enorme reputação diante da ameaça do "apagão", gerando uma demanda tão alta que naquele momento, esta teve que ser atendida inclusive apelando para a importação. Afinal, economizar energia seria pelo mínimo uma forma de preservar um fornecimento ameaçado de interrupção.

No entanto, aspecto raramente recordado é que cada lâmpada fluorescente contém em média 15 miligramas de mercúrio metálico, um notório metal pesado. Em si mesma, esta quantidade é desprezível. Porém, multiplicada por milhões de unidades, torna-se um perigo real. Liberado na forma de vapor toda vez que o invólucro da lâmpada é rompido, o mercúrio possui ação tóxica e afeta o sistema nervoso. A falta de critérios na quebra das lâmpadas fluorescentes certamente constitui uma das mais nocivas agressões ao meio ambiente e à saúde pública.

Não por acaso, a legislação norte-americana classifica as lâmpadas fluorescentes como um resíduo perigoso, estando, pois sujeitas a uma legislação especial. Na Alemanha, as leis determinam que estas lâmpadas precisam ser moídas, embaladas, enterradas e lacradas para sempre em minas abandonadas. Muitos outros países europeus repetem esta preocupação por intermédio de recomendações específicas, severas e contundentes. Nas grandes cidades 
européias, faz parte do cenário urbano observar o trabalho de pequenos veículos e de profissionais especializados retirando de tempos em tempos lâmpadas fluorescentes dispostas em espaços demarcados das calçadas para encaminhálas rumo a um confinamento em local seguro.

O Brasil, embora descartando entre 100 e 150 milhões de lâmpadas fluorescentes, não possui nenhuma legislação proibindo a disposição destas lâmpadas no lixo domiciliar, inerte, hospitalar ou industrial. Para exemplificar a respeito da gravidade desta situação, pode-se anotar que na cidade de São Paulo, o consumo anual oscila entre 8 e 10 milhões de lâmpadas fluorescentes por ano, um total que corresponderia à assombrosa soma de 31.950 lâmpadas por dia útil (Cf Dossier Limpurb - A Questão das Lâmpadas Fluorescentes, 2000). Em si mesmos, estes números sugeririam a implantação imediata de um serviço de coleta específica e destinação adequada para as lâmpadas fluorescentes.

No que importa diretamente ao nosso tema central, esta discussão é inerente às características do próprio produto. Conforme assinalado, uma vez rompidas, tais lâmpadas liberam mercúrio metálico e, o destino desta substância nociva será, cedo ou tarde, um corpo aquático, muitas vezes um rio ou reservatório destinado a fornecer água "potável". A volumosa e quase inacreditável quantidade de lâmpadas descartadas torna-se assim, mais uma nefasta contribuição para o comprometimento do rico acervo hidrológico nacional.

Caberia, pois indagar: ao se utilizar lâmpadas fluorescentes sem o amparo de medidas ambientalmente corretas de disposição final dos resíduos, estar-se-ia, no final das contas economizando o que, água ou energia? Ou estaríamos, na realidade, desperdiçando ambos?

Em resumo, propor uma política de uso inteligente de toda gota de água disponível se conjugaria não só com medidas - conforme sublinhado pelo jargão técnico - de conservação de energia conjuminadas com estratégias de eficiência energética, mas igualmente com a revisão do modelo de geração, distribuição e acesso aos recursos energéticos. Sem estas ferramentas conceituais qualquer proposição de economia de água e de uma utilização racional dos recursos 
hídricos na sua interface com a questão energética perderia sua eficácia operacional na defesa da sociedade e do meio ambiente.

Isto posto, a diminuição do impacto sobre os recursos hídricos tendo por base uma revisão da matriz energética sugeriria várias medidas, insistentemente colocadas já há muitos anos (Cf SEVÁ, 1990:19), mas nem por isso menos atuais. Tais seriam:

- Maximização do aproveitamento das reservas energéticas disponíveis;

- Endurecimento da legislação relacionada com o consumo energético dos equipamentos domésticos e industriais;

- Implantação e expansão de programas de conservação de energia nas residências, indústrias e em todos os campos da atividade econômica;

- Revisão do modelo industrial, cessando os privilégios que sustentam a industrialização de produtos eletrointensivos, como seria o caso, em particular, do alumínio;

- Implantação de programas de educação ambiental e de projetos de Coleta Seletiva de Lixo (CSL), preferencialmente os primeiros antecedendo a implantação dos segundos;

- Redução e controle da poluição ambiental, com o estabelecimento de normas adequadas para a disposição final de resíduos que, como no caso das lâmpadas fluorescentes, possam comprometer o meio ambiente e os recursos hídricos;

- Opção preferencial pela construção de micro-barragens, desativandose os programas de construção de mega-barragens. A hidroenergia das pequenas barragens é menos dispendiosa do que 0 
aproveitamento energético do vento, do sol, da geotermia e das marés;

- Adoção, incentivo e investimento nas pesquisas de fontes menos poluidoras e alternativas de energia, como as células de combustível, do gradiente térmico oceânico, das marés, da maremotora, da energia solar, da biomassa e da eólica (Fig. 20).

Quanto à energia solar e a biomassa, é digno de nota o potencial brasileiro quanto a estas duas fontes de energia, maximizado pela articulação que de um ponto de vista natural, as irmana de modo irrepreensível. O Brasil é a maior "nação solar" do Planeta. Seu território recebe por dia o equivalente à energia gerada por 320.000 hidrelétricas de Itaipu. Simultaneamente, nenhuma outra nação detém tanta água doce, a contrapartida indispensável para a formação dos hidratos de carbono. A biomassa é fruto justamente do encontro do sol com a água. Estas duas potencialidades poderiam sustentar um novo modelo energético para o país, renovável e sob controle nacional, garantindo sua autonomia energética (Cf VASCONCELOS e VIDAL, 2001:11 e 20; quanto ao álcool carburante, ver ANDRADE, 1994).

Repensar a utilização de energia também significa utilizar tecnologias apropriadas para as finalidades desejadas. Por exemplo, deve-se favorecer a implantação de sistemas de aquecimento doméstico preferencialmente com base na energia solar, que além de ambientalmente menos impactante, possui um custo ambiental muito menor. O Brasil, segundo consta, é o único país do mundo que universalizou o chuveiro elétrico. E, toda vez que um deles é instalado, isto acarreta investimentos de US\$8.000. A substituição do sistema de aquecimento utilizando energia elétrica poderia redundar em formidável economia energética e, além disso, em enorme diminuição dos impactos ambientais (Cf DIAS, 2003:529).

Assim, arrematando esta discussão, caberia observar que uma sociedade preocupada com a garantia do acesso universal à água por parte da atual geração assim como das próximas, deve também ser uma sociedade voltada para a 
conservação de energia e otimização dos processos de produção e consumo energético. Nada do que foi exposto poderá alcançar sucesso sem a necessária revisão crítica dos padrões de consumo vigentes e do estilo de vida contemporâneo, calcado no modelo das sociedades afluentes do Norte, manifestadamente perdulário e em contradição com o meio ambiente.

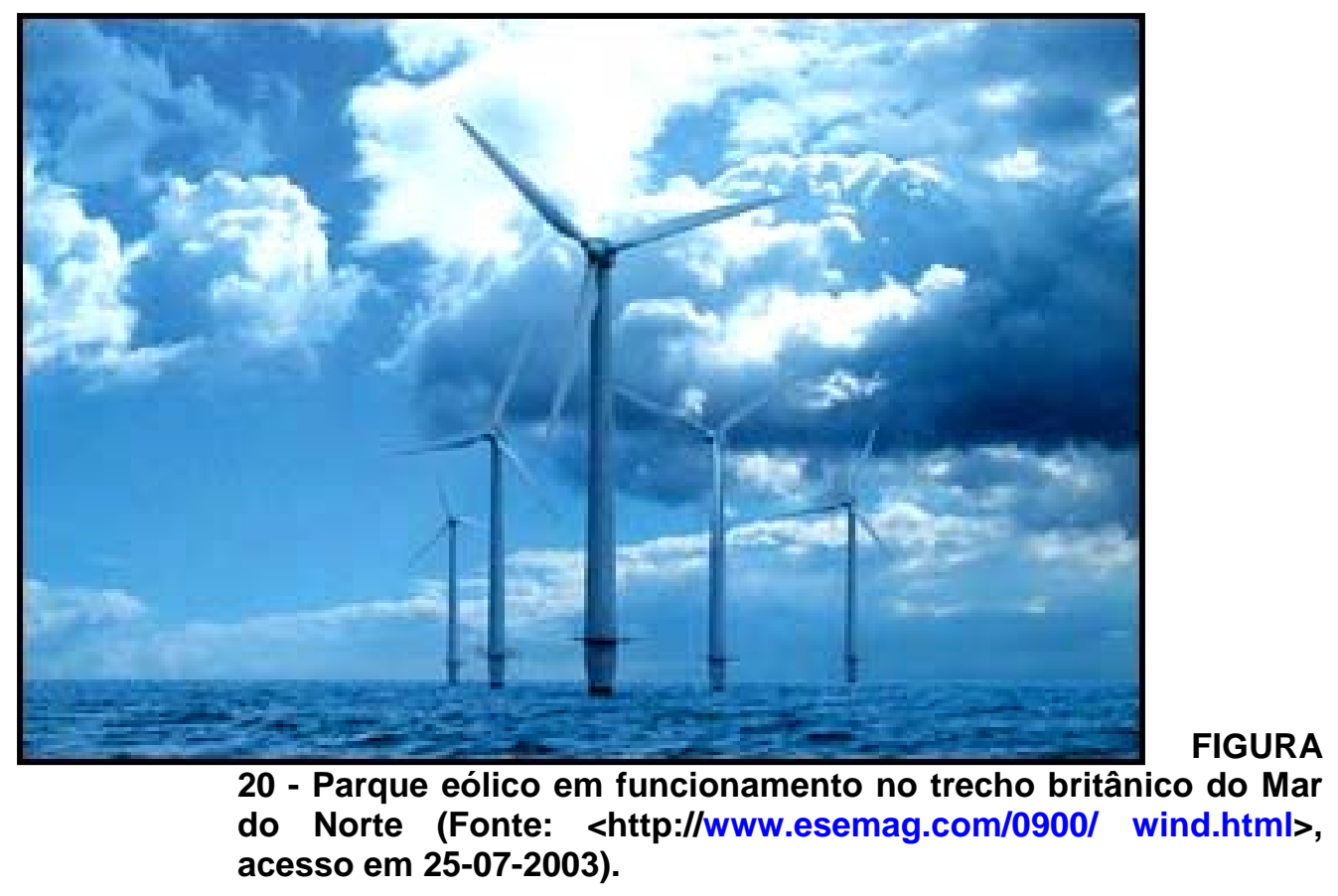


$\mathrm{E}$, mais do que uma crítica enragé, qualquer avaliação permitiria até mesmo adjetivar como iníquo o quadro mundial de consumo de energia. A nação líder do mundo afluente, os Estados Unidos, reunindo somente 5\% da população do mundo, consumia em 1988 quase 30\% da produção total de energia do mundo. Ao mesmo tempo, a África, cuja população é cerca de três vezes a dos EUA, consumia apenas $3 \%$ da energia mundial ${ }^{52}$. Repetir este modelo, ostensivamente marcado pela desigualdade, seguramente implica em ampliar de modo inaceitável uma escala de constrangimentos ambientais em nível planetário.

Nos primórdios dos anos 80 do século passado o físico alemão Wolfgang SASSIN ponderava, em texto disponibilizado pela UNESCO, que a solução do problema energético estava se tornando cada vez mais uma corrida contra o tempo (1981:12). É necessário pensar que a crise energética associa-se à crise dos recursos hídricos, disto decorrendo a impossibilidade dissociar a questão da água da questão da energia.

Por isso mesmo, a questão dos recursos hídricos constitui um caminho privilegiado para repensar os próprios desafios colocados pela questão da energia, compatibilizando duas problemáticas que podem, em uníssono, constituir uma solução.

\section{2. Água e Produção de Alimentos}

Como se sabe, o consumo de água no mundo moderno expandiu-se de modo incessante. Paralelamente, esta demanda tem sido confrontada com uma exigüidade cada vez maior do recurso. Uma vez que, a rigor, inexiste qualquer possibilidade de ampliação do estoque natural das águas doces a disposição dos humanos, a necessidade de se repensar a utilização dos recursos hídricos se

52 US Energy Information Administration, WorldWatch Institute e BP Amoco statistical review of World Energy (dados de 1998), in revista National Geography, Março de 2001, pp. x/xi. 
impõe por si mesma. Certamente esta ponderação poderia com muita tranqüilidade ser dirigida à produção de alimentos. Afinal, em conformidade com o que já foi exposto, a agropecuária é responsável pela "parte do leão" da utilização dos recursos hídricos mundiais, em média $70 \%$ do total (Vide REBOUÇAS, 2004:9).

Deixar de enfocar o papel da produção de alimentos, prejudicaria não só a compreensão do problema dos recursos hídricos, como principalmente a sua resolução, que se impõe como pauta prioritária para o conjunto da humanidade já para os próximos anos. Nesta ordem de considerações, sinaliza um relatório da ONU:

...À medida que aumenta a população e crescem as economias, a água vai convertendo-se em um recurso mais escasso e valioso. Em muitos países, a competição entre a agricultura, a indústria e os núcleos urbanos pelos recursos hídricos já está limitando as iniciativas de desenvolvimento (FAO, 1996).

Em particular, a agricultura irrigada, em função da sua notável expansão taxa de expansão e pela importância crescente que desempenha na oferta de alimentos, ocupa um papel central na discussão sobre as águas doces. Entre 1800 e os dias atuais, a superfície irrigada no mundo cresceu cerca de trinta vezes. Compreensivelmente, uma tendência no sentido de relacionar a escassez de água no mundo como decorrente pura e simplesmente da irrigação é bastante sedutora, exercendo atração irresistível em muitas avaliações. Mas, a bem da verdade, relacionar mecanicamente escassez dos recursos hídricos com a agricultura irrigada poderia incluir julgamentos precipitados, como o equívoco de outra locução comentada neste texto vinculando o problema de acesso às águas doces com o mero crescimento populacional.

Talvez o primeiro aspecto a ser problematizado seria não propriamente a irrigação, mas sim a forma perdulária com que esta prática tem sido levada adiante no mundo. Um detalhe que chama a atenção de qualquer pesquisador é a onipresença de métodos considerados como de baixa eficiência, amplamente 
utilizados inclusive em países caracterizados pelo stress e pela escassez de água. Uma "ilha de excelência" neste quesito, o Estado de Israel e seus avançados métodos de irrigação por gotejamento monitorados em tempo real por sistemas computadorizados antes constituem uma exceção confirmando uma regra geral.

Na prática imperam sistemas arcaicos operando com base em elevado nível de perdas, evaporação e infiltração descontrolada. Dentre as técnicas consideradas perdulárias em recursos hídricos poder-se-ia citar a irrigação por superfície, os sistemas autopropelidos e os de pivô central. Esta é a norma na América Latina e nos continentes africano e asiático. No caso brasileiro, relativamente aos desperdícios ocorridos na agricultura,

...deve-se considerar que sobre cerca de 93\% dos quase três milhões de hectares irrigados no Brasil, ainda se utilizam métodos de irrigação menos eficientes do mundo, tais como o espalhamento superficial (56\%), pivô central (19\%) e aspersão convencional (18\%) (REBOUÇAS, 2004:43).

Matematicamente, o que transparece com clareza é que algo de verdadeiro existe na colocação de vários técnicos da área dos recursos hídricos pela qual não ocorreria propriamente uma "crise de água", mas sim uma "crise de gerenciamento da água". Julgamento repetido em muitos seminários e simpósios é evidente que caso fosse poupada apenas $10 \%$ da água utilizada na agricultura, então a escassez de água potável no mundo contemporâneo cessaria virtualmente de existir. No entanto, tal tentadora equação é incompleta na hipótese de se recordar que o dinamismo social não é redutível à contabilidade. Caso assim o fosse, não existiria fome no Brasil e tampouco problemas com acesso à terra e de moradia, pois não existe carência de alimentos, sequer de solo agrícola ou de terrenos nas cidades. Aliás, em face dos estoques hídricos do país, também não haveria sede.

Por esta exata razão, importa aos preocupados com a questão dos recursos hídricos, conhecer os dados culturais, políticos, sociais, econômicos, técnicos e ambientais que entrelaçam a temática dos recursos hídricos com os da produção de alimentos, preferencialmente compreendidos numa ótica não fragmentada e voltada para o relacionamento que os fenômenos do mundo social sustentam 
entre si. Este quadro mais detalhado pode contribuir na identificação dos motes que condicionam uma disputa cada vez mais embrutecida pela posse das águas azuis. Conforme já foi diagnosticado, em futuro próximo, "os usuários de água para fins doméstico e industrial vão competir cada vez mais com a agricultura irrigada, principalmente em algumas regiões da Ásia e da África" (SALATI, LEMOS e SALATI, 2002:49).

Esta problemática conquista complexidade quando se sabe que a expansão da agropecuária, geralmente afetando ambientes que dantes constituíam reservas de umidade, contribui para reforçar fenômenos como os da aridez e da escassez crescente dos próprios recursos hídricos, por conta de mudanças climáticas que atingem especialmente os países pobres. E, são justamente estes os que tem despontado nas estatísticas como importadores líquidos de cereais, em sua maior parte proveniente dos países afluentes do primeiro mundo. Nesta perspectiva, o que se tem à frente é um quadro degradado das condições ambientais articulado com os mais espicaçados conflitos e contradições sociais, políticas e econômicas.

A este respeito, salienta a australiana Lorraine ELLIOTT, especialista em eco-política:

\begin{abstract}
Estas nações, as quais são comumente tidas como as mais afetadas pelos impactos das mudanças climáticas, como as mudanças de temperatura, pela elevação do nível dos oceanos, pelas alterações nas zonas agrícolas, pelo possível incremento acelerado das condições metereológicas, pelas variações dos estoques de águas e dos suprimentos pluviométricos, constituem as nações mais pobres do mundo, cujos ecossistemas já estão degradados e cujas economias e infra-estruturas são menos flexíveis e menos adaptadas face à degradação ambiental (1998:227).
\end{abstract}

Dado que a agropecuária responde por fração significativa do consumo mundial de água, uma questão fundamental (apesar de freqüentemente esquecida), é o instigante exercício de se avaliar o custo hídrico dos alimentos. Apenas satisfazendo esta preocupação é que se poder tomar conhecimento da complexidade e a dimensão de que se reveste o problema. Até porque, no tocante à reprodução da vida humana, a água é consumida muito mais através da alimentação do que pelo simplório ato da dessedentação. 
Na seqüência desta explanação, seria, pois condizente recordar a avaliação do engenheiro Antonio Eduardo L. LANNA ressalvando que um $\mathrm{m}^{3}$ de água potável seria suficiente para suprir a necessidade biológica de dessedentação anual de um indivíduo e que outros $100 \mathrm{~m}^{3}$ anuais em média dariam conta dos propósitos domésticos (2002:534). Uma vez mais, deve-se recordar que a porcentagem apropriada para o uso residencial do conjunto das águas do planeta não passa, em média, dos 10\% do montante total consumido.

Exatamente por conta do que foi exposto, esta aferição impõe conclusivamente que não será fechando as torneiras no âmbito doméstico que a crise dos recursos hídricos encontrará solução. Por extensão, deve-se centrar a atenção nos segmentos que reclamam para si, na escala do planeta, o essencial das águas doces. Com base neste exercício, poder-se-á localizar os nexos que habilitariam a realização de uma avaliação crítica dos relacionamentos mantidos entre a agropecuária e a questão dos recursos hídricos. Neste particular, seria preciso deter-se, numa primeira abordagem, no consumo de água pela agropecuária.

Quanto à agricultura, uma vasta literatura confirma a grande proporção de água tradicionalmente solicitada pelo meio rural. Exemplificando, a produção de um quilo de trigo reclama o suprimento de 900 litros de água. Para produzir um quilo de milho, são necessários 1.400 litros. Um quilo de arroz implica em 1.910 litros. Um quilo de carne de frango solicita 3.500 litros. Por fim, a carne bovina pressupõe na melhor das hipóteses vultosos 16.193 litros para cada quilo produzido, quantidade requerida tomando por base uma pecuária altamente eficiente quanto ao consumo de água (Ver SHUVAL, 1998). A criação de bovinos pode ainda alcançar a fabulosa quantia de 100.000 litros de água para cada quilo no caso da criação extensiva operando com escasso nível agro-técnico (Vide PIMENTEL, 1997 e também ARMAND, 1998).

Procurando assimilar o significado destes dados, recorde-se que os 100.000 litros de água requisitados para produzir um quilo de carne bovina equivalem a 
cem caixas d'água domésticas ${ }^{53}$, o que de pronto já significa muita água. Ora, lembrando que uma caixa d'água doméstica acumula um $\mathrm{m}^{3}$ de água (isto é, mil litros do líquido), isto significa que a produção de cada quilo de carne equivaleria ao volume de $100 \mathrm{~m}^{3}$ d'água, dado perturbador quando se sabe que a falta de água assola milhões de pessoas que dispõem no dia a dia bem menos do que uma fração deste volume. Uma outra forma de contabilizar este montante é recordar que esta quantidade de água é suficiente para uma pessoa tomar banho de ducha durante quatro anos e oito meses e banho de imersão durante um ano e sete meses. Por conseguinte, poupa-se mais água deixando de comer meio quilo de carne do que se isentando de tomar banho durante um ano inteiro.

A repercussão da pecuária bovina possui desdobramentos para a própria saúde humana. Estudos desenvolvidos nas últimas décadas têm demonstrado que o mundo ocidental se alimenta com uma dieta excessiva de proteína, gordura saturada com colesterol, pesticidas e muito pouca fibra. Este tipo de dieta, cujo esteio é em larga medida o consumo de carne bovina, está ocasionando enormes custos médicos e de saúde, matando as pessoas e destruindo o ambiente. Este padrão alimentar, identificado com as sociedades urbanas e ricas do hemisfério norte, é responsável pelo desaparecimento das pequenas propriedades e do avanço do latifúndio e da agricultura industrializada, nunca beneficiando o trabalhador rural.

Além disso, entre outros impactos sócio-ambientais, a produção de carne, ao ter por pressuposto a criação de animais, também implica na produção de dejetos. A criação confinada em cocheiras geralmente abarrotadas transforma as modernas instalações de criação de animais em verdadeiras "cidades sem esgoto", com uma geração de estrume em tal proporção que se torna difícil dispensá-lo com segurança. O esterco é um produto orgânico altamente poluente, podendo gerar a morte dos rios em razão da DBO (Demanda Bioquímica de Oxigênio). A produção de carne suína insere, neste particular, aspectos bastante preocupantes. Isto porque um litro diário de dejetos de porco polui tanto quanto a mesma quantidade de dejetos de cem pessoas.

\footnotetext{
${ }^{53} \mathrm{O}$ comércio de materiais de construção também disponibiliza modelos que armazenam 500 litros
} 
Neste sentido, e tomando por base o município de Concórdia, situado em Santa Catarina, temos que as suas 250.000 cabeças de gado suíno produzem tanta poluição orgânica quanto uma cidade com 25.000.000 habitantes. Nesta mesma linha de argumentação, a região do Oeste catarinense, abrangendo uma área de $30.000 \mathrm{~km}^{2}$ e formada por 60 municípios, ao concentrar um plantel de 3.000.000 de porcos, impactaria o meio natural no tocante aos dejetos, tanto quanto uma concentração de 300.000.000 de pessoas (Cf TELLES, 2002:327). Este total corresponderia a mais do que o dobro do total de habitantes do populoso Bangladesh em $2005^{54}$.

Existem também várias outras implicações relacionadas, por exemplo, com a disponibilização do produto para o consumidor final. No caso da carne, o processamento nos matadouros e frigoríficos tem por condição necessária um volumoso consumo de água. Na preparação da carne de aves são necessários 25 litros por quilo e no caso dos suínos, 1.200 litros por quilo. No caso dos frangos, as indústrias brasileiras já trabalham com metas otimizadas, mas que ainda sim são altas: nada menos do que 14 quilos de água para cada quilo de frango (SILVA e SIMÕES, 2002:357). Quanto aos bovinos, estes consomem 2.500 litros por cada rês abatida (BRANCO, 2002:228). Além dos custos hídricos na lavagem e processamento das carcaças, os rejeitos aquosos, caracterizados por elevada DBO, presença de sólidos suspensos e materiais graxos, constituem outra evidente fonte de preocupações.

Outro dado, é que lado a lado com a agropecuária, a aqüicultura igualmente se destaca enquanto atividade consumidora de água. A aqüicultura é um termo relativamente amplo, podendo ser entendido como o cultivo de animais ou vegetais que requisitam ambientes aquáticos para seu desenvolvimento. A atividade engloba cultivo de peixes, répteis, ostras, mexilhões, algas, abalones, ouriços do mar, anfíbios, lagostins e camarões, esta última criação conhecida como carcinocultura (Cf BORGHETTI e OSTRENSKY, 2002:459). Deste modo, a

\footnotetext{
de água, isto é, $0,5 \mathrm{~m}^{3}$.

54 De acordo com várias estimativas, a população do Bangladesh alcançou em Julho de 2005, 144.319.628 habitantes.
} 
terminologia piscicultura, comumente utilizada como sinônimo da aqüicultura, se restringiria à criação em ambiente confinado dos peixes, que, aliás, geralmente correspondem à maior parte das espécies cultivadas.

Como seria cabível registrar neste momento, o consumo de recursos hídricos solicitado pela agricultura e pecuária poderá entrar em futuro próximo em contradição com as demandas da aqüicultura. Diante da destruição dos meios aquáticos que tradicionalmente tem fornecido a proteína dos peixes e de outros animais marinhos e fluviais à população humana, a produção aqüícola tende a se tornar um forte concorrente na disputa pelas águas azuis disponíveis. Outro impacto é a introdução de espécies estrangeiras, que escapando das fazendas de aqüicultura e dos pesqueiros recreativos invadem os ambientes nativos, eliminando ou provocando a retração de muitas espécies. Este seria o caso da tilápia ( $T$. melanopleura), peixe africano introduzido no Brasil e que tende a dominar os ambientes nos quais é introduzido.

A dimensão da aqüicultura pode ser mais bem avaliada na eventualidade de se frisar que já na atualidade, um em cada três peixes degustados pela população mundial é proveniente de fazendas de piscicultura. No setor, ocupa posição de destaque a República Popular da China, país em que uma plêiade de instalações de aqüicultura responde por cerca de $90 \%$ da produção aqüícola mundial. $\mathrm{Na}$ escala do Planeta, o crescimento da aqüicultura tem promovido a desaparição de mangues, alagadiços e pântanos ${ }^{55}$, que cedem espaço para os criadouros de peixes e camarões. A criação confinada uma vez mais reforça a tendência em encarcerar a água em sistemas produtivos fechados, tornada inevitável pela destruição deste recurso no meio natural livre (Vide também CMMAD, 1988:151/152).

Deve-se também atentar para os dados relativos a vários outros impactos provocados pela produção de alimentos nos recursos hídricos. A seguir, estão arrolados alguns deles:

${ }^{55}$ Outro caso bastante conhecido é o da piscicultura israelense, que surgiu ao custo da destruição dos pântanos do Hule, situados no norte deste país. 
- No Brasil, apenas quanto ao item dessedentação, os rebanhos são responsáveis por $5 \%$ da água consumida no país, sendo que deste total, o gado bovino absorve cerca de $93 \%$, dos quais a região CentroOeste é responsável pela terça parte deste consumo (TUCCI, HESPANHOL e NETTO, 2001:60);

- Conforme foi colocado, a produção de carne, ao relacionar-se diretamente com a criação de animais, significa também produzir dejetos. Os restos orgânicos dos rebanhos, além de contaminarem em larga escala os recursos hídricos, igualmente contribuem, tal como no caso das hidrelétricas, para com o aquecimento global, dado que emitem metano, um dos principais GEE;

- Um aspecto importante do consumo de água reside no quesito produção de bebidas e de refrigerantes. Contando com uma legislação corporativista a seu favor, os fabricantes oferecem bebidas engarrafadas a um preço mais baixo do que a água mineral ou mesmo do que o leite. Com base nesta lógica perversa, cada mexicano consumia, nos anos noventa, em média uma quantidade três vezes maior de refrigerantes do que de leite, apesar deste último ser mais barato e nutritivo (DELPEUCH, 1990:109);

- Outro aspecto, também negligenciado nas discussões de alimentos, é o custo energético que envolve a produção e a distribuição dos alimentos. Este percentual energético tem crescido por conta da refrigeração e refeições de consumo rápido, tais como pratos congelados e legumes pré-cozidos;

- Na seqüência ao item anterior, na contabilidade da energia deve ser incorporado o input energético das embalagens, cuja difusão caminha paralelamente ao fortalecimento do modo ocidental de vida. Recorde- 
se que enquanto que nos Estados Unidos a indústria processa de 70 a $90 \%$ dos alimentos, esta porcentagem cai para $70 \%$ no caso da Europa e para um percentual entre 10 e 30\% para os países subdesenvolvidos, obviamente implicando em diferentes perfis energéticos no tocante à comercialização dos alimentos (Ver DELPEUCH, 1990).

- Nesta perspectiva, embora a energia elétrica empregada na agricultura represente apenas $2 \%$ do total em um país como a França, a atividade alimentar como um todo, desde a fabricação de adubos até o consumidor final, utiliza entre 16 e $17 \%$ do total da energia consumida no país. Não há, de fato, como se desvencilhar da questão da alimentação dos aspectos pertinentes à água e à energia (Ver a respeito DELPEUCH, 1990:43);

- A importância dada pelos ocidentais ao consumo de carne e de vegetais cultivados fora da estação é outra influência palpável na elevação do input energético dos alimentos. De resto, os alimentos "viajam" cada vez mais nos países afluentes: cerca de $2.100 \mathrm{~km}$ em média nos Estados Unidos (Cf SILVA, 2003);

Ademais, articulando os aspectos mencionados com a questão do comportamento alimentar, não haveria como deixar de pensar na repercussão ambiental promovida pela alimentação. Visando ilustrar este ponto, nada melhor do que as clarividentes palavras do geógrafo Josué de CASTRO, que no seu célebre "Geografia da Fome", assim discorreu sobre o assunto:

Nenhum fenômeno se presta mais para ponto de referência no estudo ecológico destas correlações entre os grupos humanos e os quadros regionais que eles ocupam, do que o fenômeno da alimentação - o estudo dos recursos naturais que o meio fornece para subsistência das populações locais e o estudo dos processos através dos quais essas 
populações se organizam para satisfazer as suas necessidades fundamentais em alimentos (1965:15).

Poder-se-ia então ressalvar na contabilidade relacionada com os impactos provocados nos recursos hídricos os derivados das opções culturais. Estas incorporam considerável importância, e não podem, de forma alguma, serem negligenciadas. Basta lembrar que a pauta alimentar é um dado cultural que se materializa com base em gostos e sabores socialmente determinados, e por este motivo, condiciona concretamente o perfil do consumo de água. Não por outra razão, senão pelo fato de que toda e qualquer pauta alimentar necessariamente implica em um input hídrico igualmente específico.

Desta forma, temos que o consumo de água via alimentos irá variar enormemente em função do universo cultural, pois deste decorre a pauta alimentar das sociedades humanas. Exemplificando, enquanto que nos Estados Unidos a produção da "dieta californiana" típica reclama 2.200 m³/per capita/ano (dos quais 64 \% são encaminhados para a produção de carne), na Tunísia, nação norte-africana, metade deste volume, ou seja, $1.100 \mathrm{~m}^{3} / \mathrm{per}$ capita/ano (dos quais apenas $27 \%$ estão voltados para a produção de carne), são suficientes para alimentar satisfatoriamente os habitantes deste país (Vide FAO, 1996).

Seria interessante recordar que o fortalecimento do modelo ocidental de alimentação, ao qual igualmente está associado um padrão de afluência social, é normalmente acompanhado de uma demanda adicional de água. Recorda a respeito o ambientalista Lester BROWN,

...à medida que as pessoas ascendem na cadeia alimentícia e passam a
consumir mais carne bovina, suína, aves, ovos e laticínios, consomem
mais grãos" (2001). Uma dieta americana rica em produtos pecuários
requer 800 quilos de grãos por pessoa por ano, enquanto as dietas na
Índia, dominadas por uma alimentação básica de amidos como arroz,
caracteristicamente necessitam apenas de 200 quilos. O consumo quatro
vezes maior de grãos por pessoa significa igual crescimento no consumo
de água (2001).

Face ao exposto, é necessário repensar não apenas a questão da dieta ocidental, fortemente apoiada no consumo de proteína de origem animal, como 
também nas tensões ambientais provocadas por este modelo, ainda mais que este se mantém solenemente alheio com os impactos inerentes a sua forma de relação com a natureza ${ }^{56}$.

Todavia, saliente-se que apesar dos problemas gerados, o que se pode perceber é a difusão ampliada deste padrão. O consumo de carne bovina tem sido respaldado através das redes de lanchonetes fast food, cujas metas mercadológicas tem sido marcadamente voltadas para a difusão do hambúrguer ${ }^{57}$, dos refrigerantes e da batata frita. Configurando pela primeira vez na história um sistema dedicado a oferecer lanches rápidos em escala planetária, estas redes difundem hábitos de consumo que corroem padrões culinários locais, sem serem, do ponto de vista qualitativo, necessariamente melhores do que estes últimos.

Questões como estas conquistam caráter geopolítico quando se passa a perceber a íntima articulação entre a questão alimentar e a influência exercida pelo colonialismo. Assinale-se que em muitos contextos, a pauta alimentar reproduz os padrões impostos pelos colonizadores estrangeiros, articulando inserções sociais e políticas. Os aspectos históricos exercem, nesta contextualização, um papel importante nas opções culinárias de povos, grupos e pessoas. Estes contribuem, por exemplo, para compreender a razão do porque da Somália, parte qual constituiu uma ex-possessão italiana que jamais se destacou na produção de trigo, ser um país vorazmente consumidor de espaguete e o porque do Brasil, uma ex-colônia portuguesa, importar azeite de oliva e milhares de toneladas de azeitonas sem na contrapartida posicionar-se como um cultivador de porte da oliveira.

É o que pode ser constatado no meio urbano de muitas nações do Terceiro Mundo. As urbes da periferia, sendo fortemente influenciadas pelos padrões culturais das ex-metrópoles e constituindo por excelência o espaço das elites

\footnotetext{
${ }^{56}$ Neste particular, o meio rural tradicional de muitas regiões do mundo encontrou soluções ambientalmente mais eficientes do que as adotadas pelo padrão moderno de agro-pecuária. $\mathrm{Na}$ Índia, por exemplo, existiam prescrições contrárias ao descarte do esterco bovino em corpos líquidos. A utilização dos dejetos como fonte de energia atenuava o problema da contaminação do ambiente e na seqüência, evitava a transformação das florestas em lenha.

${ }^{57}$ Assinale-se que em alguns países, as "multinacionais do sanduíche" tiveram que adaptar seus produtos em função de restrições religiosas locais. No caso da Índia, substituindo a carne bovina pela de porco.
} 
dominantes, caracteriza-se por uma pauta alimentar absolutamente diversa do camponês do interior, que ainda atém-se aos padrões culinários tradicionais, enraizados na realidade local e que são no geral, ambientalmente mais sadios e eficazes. Tomando como exemplo a cidade de Dakar, capital do Senegal, um cidadão desta urbe, sendo influenciado profundamente pela cultura da França, exmetrópole, consome em média $10 \mathrm{~kg}$ de milho miúdo, $77 \mathrm{~kg}$ de arroz e de $33 \mathrm{~kg}$ de trigo. Enquanto isso, seu conterrâneo do meio rural requisita respectivamente 158 kg, $19 \mathrm{~kg}$ e $2 \mathrm{~kg}$ dos mesmos produtos (DELPEUCH, 1990:63).

Necessário recordar, esta ocidentalização (e uniformização) do padrão alimentar contou, para além da influência cultural das ex-metrópoles, com a estratégia do "auxílio alimentar" encaminhado para regiões do Terceiro Mundo. Basicamente de origem norte-americana, a doação de alimentos, na realidade um procedimento preocupado em reforçar a demanda por produtos importados (Vide DELPEUCH, 1990), terminou alterando a pauta nutricional tradicional das nações agraciadas com este auxílio.

Inevitável comentar, através da oferta de alimentos gratuitos ou oferecidos politicamente a baixo custo, esta estratégia implantou novos hábitos alimentares nos países pobres, criando mercados consumidores dantes inexistentes. Uma vez mais reportando ao exemplo de Dakar, metrópole senegalesa na qual a baguete fabricada com farinha de tribo tornou-se um verdadeiro ícone culinário, o painço, o sorgo e o milho, cereais tradicionais da região da Senegâmbia, passaram a representar menos de $10 \%$ do consumo local da cidade, e isto em oposição à tendência local de consumo destes alimentos (DELPEUCH, 1990:99).

Nos últimos anos, muita tinta tem sido gasta na crítica ao modo como o mundo ocidental tem se alimentado e ainda recentemente, a imprensa tem sido inundada com artigos referindo-se ao paradoxal avanço da obesidade em um mundo faminto. Uma vez que discutir alimentação reporta a discutir água, e, dada a magnitude do consumo dos recursos hídricos na produção de alimentos, vale a pena, por fim, frisar que mais do que fechar a torneira é necessário repensar o padrão de alimentação adotado, assim com as suas formas de produção e de distribuição dos alimentos. 
Inexistindo uma estratégia preocupada com o correto equacionamento da questão dos recursos hídricos e da alimentação, dificilmente se poderá pensar no êxito de uma política preocupada com a preservação das águas doces. Como está implícito nas considerações tecidas por este texto, a técnica, modalidades do uso do solo e a indelével pressão do poder econômico imprimem sua marca na questão da alimentação e dos recursos hídricos.

No entanto, uma mudança de perspectivas sugere que ao lado das variáveis citadas, que se faça sentir a necessidade uma nova forma de se saborear a água, de senti-la através dos alimentos. Sem essa preocupação, poder-se-ia até atenuar problemas no curto e no médio prazo. Mas com certeza eles continuarão sem solução no longo prazo.

E, a perdurabilidade dos recursos hídricos constituiria cabalmente o cerne de uma conduta preocupada com a disponibilidade das águas doces para as sociedades humanas. Razão adicional para se repensar a relação existente entre a água e os alimentos.

\section{3. ÁGUA E I NDUSTRI ALI ZAÇÃo}

Dado que a competição pelo acesso às águas doces disponíveis tem se recrudescido cada vez mais e sabendo-se que algo entre $24 \%$ dos recursos hídricos são destinados para a atividade industrial, importa tomar conhecimento dos diversos perfis de demanda do líquido por parte deste segmento das atividades humanas. A preocupação justifica-se porque mesmo sendo o consumo industrial menor que o da agropecuária, desde o início da revolução industrial a solicitação de água pelas fábricas tem aumentado de modo incessante.

A este respeito, recorde-se de que não há qualquer atividade industrial que prescinda da água. Ela é fundamental para o funcionamento dos sistemas de refrigeração, lavagem de tanques e caldeiras, cocção e hidratação. Qualquer produto oriundo das indústrias pressupõe um input hídrico para ser elaborado ou 
processado. Mas, tal como acontece com a produção agropecuária, a importância dos recursos hídricos na produção industrial impregnou muito pouco o imaginário social. Daí a sugestão de amealhar alguns comentários visando ilustrar este aspecto.

Neste sentido, os dados relacionados com a atividade industrial quase sempre revelam elevada proporção de dependência para com os recursos hídricos. Basta tomar ciência dos dados arrolados a seguir: a fabricação de cerveja consome de 4 a 7 litros de água para produzir 1 litro da bebida, rapidamente consumida numa festa ou restaurante; para produzir $1 \mathrm{~kg}$ de açúcar, são consumidos 100 litros; no caso da gasolina, 1 litro do combustível exige, em geral, um volume de 10 litros de água; no caso do papel, $1 \mathrm{~kg}$ do material implica na solicitação de 250 litros de água (Ver entre outros, ARMAND, 1998).

O biólogo e engenheiro Samuel Murgel Branco expõe por sua vez outros dados, igualmente reveladores do papel fundamental que a água ocupa nas atividades industriais: os alimentos em conserva requisitariam de 7 a $35 \mathrm{~m}^{3}$ de água para cada tonelada produzida; numa refinaria de petróleo, são gastos 18 litros do líquido para cada litro de petróleo processado; na fabricação de fibras sintéticas, são consumidas entre 375 e $835 \mathrm{~m}^{3}$ por tonelada; no tocante à borracha sintética, esta requisita de 83 a $2.800 \mathrm{~m}^{3}$ por tonelada; finalmente, nas lavanderias, são utilizados de 20 a $50 \mathrm{~m}^{3}$ de água para cada tonelada de roupa lavada (BRANCO, 2002:228).

A metalurgia, entendida pelo senso comum como basicamente uma atividade consumidora de energia, é também uma voraz consumidora de água. Assinalam os engenheiros Gil Anderi da Silva e Reinaldo Augusto Gomes Simões, que o trabalho de extração dos metais dos seus minérios, ricos em óxidos e carbonatos, implica num elevado consumo de água. Tal atividade solicita, por exemplo, no caso do aço, uma faixa de 100 a $500 \mathrm{~m}^{3}$ por tonelada. Nas coquerias, a água utilizada para resfriamento do coque e dos gases é da ordem de 170 a 580 litros para cada tonelada de carvão processada. A recuperação dos gases voláteis consome outros 75 a 95 litros (SILVA e SIMÕES, 2002:361). Existiria também uma menção obrigatória envolvendo o consumo de água pela produção do alumínio. 
Este material solicita para a sua fabricação um ponderável input hídrico: 100.000 litros para cada quilo produzido (Vide ARMAND, 1998).

Grande parte dos bens manufaturados da modernidade caracteriza-se pelo intenso consumo de água. Acredita-se que sejam necessários 400.000 litros de água para produzir um único automóvel (Vide BARLOW e CLARKE, 2003:9). Mesmo computando exclusivamente as etapas finais da montagem dos veículos, em razão da indústria automobilística operar com um amplo leque de materiais já processados (portanto materializando input hídrico pretérito), estas também consomem muita água. Deste modo, descontado a água já incorporada nos metais, vidros, plásticos e pneus e borrachas de vedação, um automóvel médio reclama um custo hídrico de aproximadamente 700 litros de água por unidade produzida. Por esta exata razão, a fábrica da Fiat localizada na cidade de Betim (MG) apesar dos avanços técnicos incorporados ao processo produtivo, consome mensalmente tanta água quanto uma cidade de 60.000 habitantes (FREITAS, 1998).

Destas ressalvas não escaparia a chamada indústria de alta tecnologia, incensada por muitas correntes de opinião, inclusive as "preocupadas com o meio ambiente", como sendo uma "indústria limpa". Contrariamente ao imaginado, este setor da economia moderna utiliza grandiosos volumes de água doce ionizada para produzir seus produtos, e por esta razão, requisita incessantemente novas fontes do líquido. Esta indústria tem por legado uma impressionante carga de poluição dos recursos hídricos. Atualmente, o Vale do Silício, na Califórnia, tem mais locais de assentamento de resíduos tóxicos registrados pela Agência de Proteção Ambiental dos Estados Unidos (EPA, Environment Protection Agency), do que qualquer outra área daquele país. Este levantamento indica nada menos do que 150 locais de contaminação dos lençóis freáticos. As empresas de alta tecnologia seriam responsáveis ainda, por $50 \%$ da contaminação da água subterrânea de Phoenix (Arizona) e dos seus arredores, comprometendo o próprio abastecimento da população urbana (Vide BARLOW e CLARKE, 2003:9).

Não fossem suficientes, aos dados do consumo industrial devemos acrescentar os relativos à poluição das águas de superfície. Em grande número 
das regiões industrializadas do mundo, os rios que percorrem os centros urbanos funcionam como lixeira das indústrias. Normalmente, os efluentes, isto é, a carga líquida poluída lançada pelos estabelecimentos industriais, alcança as águas dos rios, lagos e dos oceanos sem qualquer tratamento prévio, prejudicando o abastecimento humano e destruindo o ambiente natural nas mais diversas escalas. Por isso mesmo, a industrialização tem sido apontada como um dos principais motivos da escassez de água em muitas regiões do mundo.

Recorde-se que os impactos provocados pela indústria não se restringem àqueles que acometem diretamente os corpos de água doce, podendo incluir os relacionados com o cultivo de matérias-primas. Centrando atenção na indústria do papel, este material tem utilizado como fonte de celulose a madeira produzida por florestas homogêneas de eucalipto, cultivadas em muitas regiões dantes cobertas por matas nativas. Além de afetar todas as formas de vida locais, a silvicultura do eucalipto é extremamente exigente em água, implicando em drástico rebaixamento dos lençóis freáticos.

Por isso mesmo, associações camponesas em todo o mundo têm resistido à expansão deste cultivo. Num episódio histórico, datado de agosto de 1983, milhares de fazendeiros do estado indiano de Karnataka, revoltados com os impactos do plantio homogêneo do eucalipto, "marcharam em massa para o viveiro florestal e arrancaram milhões de mudas de eucalipto, colocando em seu lugar sementes de tamarindo e de manga" (SHIVA e BANDYOPADHYAY, 1991:65).

Contemporaneamente, a implantação de novos pólos industriais em espaços periféricos localizados no Brasil, México, China, Índia e África do Sul, além da expansão dos já existentes, poderá indiscutivelmente acirrar uma disputa pelos estoques disponíveis das águas azuis. Esta inferência é comprovada por estudos indicando que o setor industrial, muitas vezes avançando sem o amparo de qualquer cautela ambiental, tem se apropriado dos corpos aquáticos tradicionalmente destinados aos cultivos. Evidência que ninguém contesta, a agricultura, ao constituir uma atividade - na comparação com a indústria - cuja 
produção incorpora menor valor agregado, tem recuado em muitos países diante da voracidade das indústrias na apropriação dos recursos hídricos.

Pelo visto, tensões hídricas são inerentes à tendência de expansão da indústria. Alavancada pela lógica de um sistema que alicerça sua hegemonia, a produção industrial confronta-se com os ditames da reprodução biológica dos humanos. Repetindo o que colocamos alguns parágrafos atrás, não é possível alimentar-se de metais, plásticos e de outros materiais manufaturados. Dado que as indústrias, persistindo a atual tendência de crescimento, reclamarão, antes de 2025, a duplicação de seu quantum no consumo total (BARLOW e CLARKE, 2003:8), um cenário povoado de prognósticos sombrios poderia ser mapeado por qualquer observador mais arguto. Não seria improcedente recordar os violentos distúrbios ocorridos em 1993 em Delhi (Índia), provocados pela precariedade do abastecimento. Em Daca, no Bangladesh, a população sublevou-se em 1999 contra as autoridades, indignada com a falta de água para beber ${ }^{58}$. Estes enfrentamentos falam por si mesmos quanto aos limites da economia quando esta se defronta com necessidades humanas básicas: água para dessedentação e água para alimentação.

Em síntese, mesmo sabendo-se que o mundo moderno seria impensável sem a industrialização e a sua capacidade inata em multiplicar bens, há também que ser lavrado o comentário de que estes processos se dão em um mundo no qual a escassez de água já é uma realidade, tendendo, inequivocamente, a agravarem-se cada vez mais. Claro está que os processos industriais, ao menos da forma como foram concebidos e desenvolvidos, não poderão ser mantidos. Será necessário não só atenuar impactos, mas também repensar os modelos tecnológicos hídrico-intensivos, apontando para uma nova forma de relacionamento com o ambiente natural.

Neste sentido, a indústria poderia oferecer contribuições positivas, adotando, por exemplo, práticas conservacionistas na utilização de águas de qualidade inferior. Ao lado de medidas tipo end-of-pipe, como estações de tratamento de água que despejam águas sem resíduos aos rios (PEREIRA, 2002:99), a 
reciclagem da água habilita uma redução de consumo num promissor porcentual de $50 \%$ ou mais, com a vantagem adicional de diminuir a poluição resultante (SELBORNE, 2002:36). Estes avanços são patentes na experiência do parque industrial da Alemanha Ocidental. Neste país, a reciclagem da água industrial (iniciada nos anos setenta), não obstante a expansão da produção, permitiu manter um consumo praticamente idêntico dos recursos hídricos durante mais de vinte anos (Vide BARLOW e CLARKE, 2003:278).

Recorde-se que, conforme sugerido nos parágrafos anteriores, os processos de transformação industrial não necessariamente exigem recursos hídricos com grau de pureza elevado. Podemos resgatar o conceito formulado pelo Conselho Econômico e Social das Nações Unidas, pelo qual, "a não ser que exista grande disponibilidade, nenhuma água de boa qualidade deve ser utilizada para usos que toleram águas de qualidade inferior" (citado in REBOUÇAS, 2004:31). De resto, deve-se lembrar que a redução do consumo de água bruta pode recorrer à substituição das tecnologias tradicionais, dentre estas, a substituição da água nos processos de resfriamento pelo ar e outras que minimizam de modo extraordinário a utilização de recursos hídricos (Ver a respeito, SILVA e SIMÕES, 2002, 351/353).

No entanto, apesar da existência de modelos tecnicamente exeqüíveis, viáveis e eficientes na otimização e minimização da utilização dos recursos hídricos, estes, contrariando o otimismo de determinados setores, não tem sido incorporados pelo setor industrial na velocidade desejada. Conduta aparentemente contraditória em um mundo às portas de uma crise hídrica sem precedentes, esta insere, certamente, uma lógica sistêmica que a justifica. Seria ocasião para indagar as razões do porque, no final das contas, embora concretamente exeqüíveis, as "eco-técnicas" não serem adotadas, e quando muito, serem recordadas exclusivamente quando não existe nenhuma outra solução disponível.

Exatamente neste momento, seria obrigatório recordar que nenhuma qualificação técnica é, em si mesma, consagradora da sua aceitação ou de sua

\footnotetext{
${ }^{58}$ Paradoxalmente, o Bangladesh integra um seleto grupo de países considerados ricos em água
} 
difusão social. Nunca, em nenhum lugar e em época alguma, virtudes abstratas conseguiram se impor ignorando os mecanismos sociais existentes. Portanto, propor uma qualificação imanente para a técnica seria, pelo mínimo, incorrer nos riscos inerentes a um "idealismo" absolutamente despropositado. Deste modo, ressalve-se que qualquer tecnologia inédita, aparte sua viabilidade técnica e operacional, reclama ambientação histórica, social e política que habilite sua materialização junto a concretude social e ao mundo econômico real. Que fique sublinhado: na ausência destes pressuposto nenhuma nova criação do espírito humano encontra sua devida materialidade.

Tais considerações, no tocante ao uso dos recursos hídricos pela indústria moderna, são particularmente verdadeiras quando recuperamos uma questão que tem perpassado ao longo de todo este texto, remetendo à forma de reprodução do sistema. Os primados que governam os mecanismos centrais do moderno sistema de engenharia, em conformidade com o que foi exaustivamente explanado, têm por substrato a velocidade, a transitoriedade e o tempo do capital, inferências que condicionam diretamente suas formas de reprodução material. Com base nesta aferição, estará o setor industrial fadado a se tornar não um fator de prosperidade e de bem estar para o homem em sociedade, mas sim, em um elemento desestabilizador da sociedade humana?

Tal indagação, que pode ser endereçada a qualquer outro setor de intervenção do homem no meio natural, não poderia deixar de estar emaranhada com os ditames civilizatórios no seio da qual a industrialização encontrou abrigo e sustentação. Motivo adicional para registrarmos nos próximos capítulos e parágrafos, antecipando qualquer conclusão precipitada, alguns lineamentos básicos de compreensão da problemática apontada ao longo do capítulo que ora estamos finalizando.

doce. 


\section{CAPÍTULO 7}

\section{RECURSOS HÍ DRI COS E RESÍ DUOS SÓLI DOS}

\subsection{Resíduos Sólidos: Um Problema Crescente}

Contrariamente à água, substância apreendida de modo culturalmente positivo pelo conjunto da humanidade, poucas palavras evocam significados e sentimentos tão negativos quanto o termo lixo. Fato notório, lixo reportaria, junto ao imaginário social, a toda sorte de substâncias sujas, inúteis, contaminadas ou repugnantes. Uma vez incomodando, oferecendo desconforto estético e perigos latentes ou imediatos às coletividades humanas, o lixo deveria, por definição, permanecer longe do convívio das pessoas.

Não por acaso, a presença de lixo amontoado nas calçadas ou nas áreas que carecem de coleta adequada é interpretado como sinal de exclusão social, abandono ou de depreciação imobiliária. Nos lugares nos quais o lixo é depositado de modo irregular, ou seja, em espaços coloquialmente definidos pelo cidadão comum como "lixões", são comuns os deslizamentos, as enchentes, os odores pestilentos, os focos de doenças e a presença de animais estigmatizados, como seria o caso dos urubus e das ratazanas ${ }^{59}$. Lixo tornou-se sinônimo de coisa imprestável, fadada a ser eliminada do modo mais rápido possível.

Lado a lado com as objeções que povoam o imaginário social, os enormes volumes de materiais descartados que dia-a-dia entopem as lixeiras e contaminam o meio ambiente, transformaram a questão dos resíduos em um problema de primeira grandeza em praticamente todos os países do mundo (POSTIGLIONE,

\footnotetext{
${ }^{59}$ Notadamente, fatores de ordem cultural interferem na maledicência ou aversão devotada a estes animais. Os pombos, por exemplo, convivem nos lixões com os ratos, e as garças, com os urubus. No entanto, o pombo está vinculado pelo cristianismo ao espírito santo e a garça, é percebida
} 
1992). As montanhas diárias de resíduos constituem problema presente numa escala verdadeiramente planetária, incluindo uma gama de espaços que se estenderia desde as grandes cidades até os assentamentos indígenas e de outras populações tradicionais. Não constituísse esta sentença uma realidade, ao menos as paragens mais ermas do Planeta estariam a salvo do lixo.

Porém, mesmo no ponto culminante da Terra, o pico do Everest (Nepal/Tibet) desde a base até o cume, calcula-se que existam cerca de 500 toneladas de tubos de oxigênio, latas de alimentos em conserva, ferramentas, plásticos, cordas, etc. No caso do Arquipélago das Pitcairn, um remoto grupo de ilhas situado na Oceania e distante por completo de qualquer rota de navegação ${ }^{60}$, um pesquisador britânico, lá desembarcando para coletar e pesquisar insetos, ficou indignado com a quantidade de lixo encontrada. Em uma carta escrita para uma Organização Não-Governamental (ONG), o cientista registrou volumoso achado de 953 objetos de vários tipos, incluindo 171 garrafas de vidro, 25 calçados, duas cabeças de boneca e uma bombinha de asma.

No total, atualmente o mundo gera dois milhões de toneladas de resíduos sólidos domiciliares por dia. Com base neste dado, chega-se ao portentoso resultado de 730 milhões de toneladas por ano. Jamais na história da humanidade descartou-se tamanho volume de materiais e substâncias. As proporções assumidas no mundo moderno pelo problema dos resíduos gerados pela produção e o consumo são tais, que geógrafos como Jean Gotman não titubearam em referir-se à época atual não como uma "Idade do Aço", "do Petróleo", "da Energia Nuclear" ou "da Conquista da Lua", mas sim, como a Era do Lixo e do Refugo (Vide QUAINI, 1979:142).

Como seria possível antecipar, a geração de lixo é absolutamente desigual, variando de acordo com os indicadores sociais e econômicos. Neste sentido, a

como uma "ave elegante". Assim, pombos e garças, a despeito de idênticos no convívio com a sujeira com outras espécies, terminam positivamente qualificados.

60 Situado a meio caminho entre a Nova Zelândia e a América do Sul, este arquipélago se enquadraria no que é geograficamente definido como finisterra (BRETON, 1990:33/34). Estas ilhas isoladas foram ocupadas entre os séculos IX-XV d.C. pelos polinésios, cuja colonização soçobrou em virtude de desastres ambientais (DIAMOND, 2005:153/170). Em 1790, quando lá aportaram os amotinados do Bounty na sua fuga da justiça naval britânica, a ilha estava completamente desabitada. 
contribuição de algumas nações na produção mundial de resíduos, particularmente as pertencentes ao grupo dos países centrais, é notória. Por exemplo, os Estados Unidos são responsáveis por 230 milhões de toneladas ao ano, representando $31 \%$ do total de resíduos domiciliares gerados no mundo (Fig. 21). Este volume, somado com a contribuição do Canadá e dos países

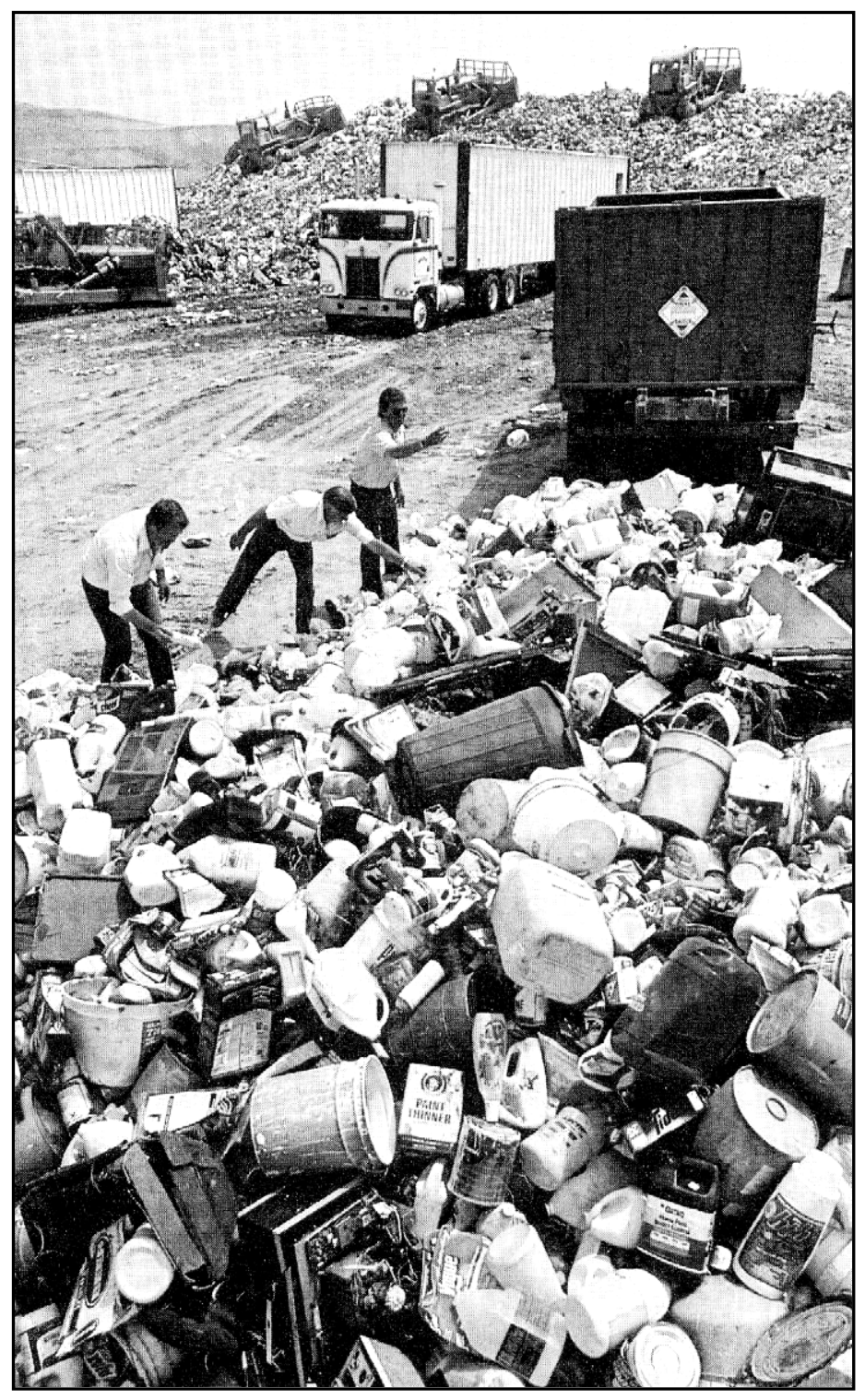


FIGURA 21 - Descarte de Lixo Domiciliar nos EUA

(Foto: POSTIGLIONE, 1992:19) 
Europa ocidental representa o fabuloso percentual de $56 \%$ do lixo mundial (Cf GRIMBERG, 2002).

Conclusão inevitável, nos países do hemisfério norte a média de geração de resíduos por habitante é bastante superior a dos países do Sul. No Canadá a média é de 1,9 $\mathrm{kg}$ por pessoa/dia e nos Estados Unidos, $1,5 \mathrm{~kg} / \mathrm{pessoa} / \mathrm{dia}$. Ao mesmo tempo, no Brasil, este volume se reduz para $0,7 \mathrm{~kg} / \mathrm{pessoa} / \mathrm{dia}$, e na Índia, para 0,4 kg/pessoa/dia. Em meio aos segmentos sociais mais pobres, com poder aquisitivo muito reduzido, este índice pode baixar para $0,3 \mathrm{~kg} / \mathrm{pessoa} / \mathrm{dia}$ ou até menos. Em geral, nos países pouco industrializados, a média oscila entre 0,4 e 0,9 kg/dia por habitante (Dados da Organização Mundial da Saúde, 1995, citados in GRIMBERG, 2002; a respeito das características dos RSD no Brasil e no exterior, vide FIALHO, 1998:59/63).

Outra observação pertinente é que a geração de lixo apresenta um vínculo explícito com o modo ocidental de vida. A forma de reprodução deste padrão civilizatório, ao caracterizar-se pela incessante requisição dos recursos naturais, é, em si mesma, em um fator que outorga a todos os componentes do sistema, mesmo que de modo desigual, uma parcela de responsabilidade pela geração de lixo. Assim, embora os resíduos sejam majoritariamente gerados por um reduzido conjunto de nações ricas, afluentes e perdulárias, a questão da destinação dos resíduos também conquistou gravidade na periferia do mundo capitalista, especialmente nas suas áreas metropolitanas. Neste particular, assinale-se que na América Latina mais de 100 milhões de toneladas de resíduos domiciliares são produzidos anualmente, correspondendo a cerca de $13 \%$ do total mundial (Cf GRIMBERG, 2002).

A escalada do descarte de resíduos assumiu tal proporção, que nas décadas finais do século $X X$ o mundo assistiu ao surgimento de um tipo inédito de transporte internacional: o envio de lixo dos países centrais para áreas situadas no Terceiro Mundo (CMMAD, 1988:253/254). O assunto, dada sua manifesta notoriedade, tornou necessária uma legislação internacional voltada para a questão da disposição de lixo em locais diferentes daqueles nos quais foram gerados. 
Daí o surgimento da Convenção da Basiléia (1989), preocupada em regulamentar a movimentação de lixo e inclusive, seu tráfico intercontinental. Até junho de 2002, 151 países haviam ratificado a convenção. Entretanto, ainda que seis dos países pertencentes ao G7 (o bloco das nações mais industrializadas do planeta), tivessem ratificado este tratado, os EUA, o maior gerador de resíduos do mundo, ainda em 2005 não se recusavam a endossar o documento. No que evidencia as limitações objetivas dessa convenção, embora muitos países tenham firmado a Convenção de Basiléia, isto não significa que estejam se empenhando em efetivamente brecar o tráfico ilegal de lixo. Em 2004, mais de $50 \%$ do total de resíduos perigosos produzidos no primeiro mundo foram exportados para os países periféricos (VEIGA, 2004:73).

$\mathrm{Na}$ realidade, a simples existência da Convenção de Basiléia, embora definindo um referencial para discutir o problema, obviamente não o solucionou. Existem brechas que permitem justificativas para o trânsito de resíduos, até mesmo a título de prover a indústria de reciclagem de matéria prima. Exemplificando, o Brasil é signatário da convenção, ratificada desde 16/06/1992. Todavia, isto não impediu o país de tornar-se alvo da polêmica importação de pneus usados. As previsões para 2005 estimam que serão importados 11 milhões de unidades $^{61}$. Acredita-se que em 2006 a questão irá se acirrar tanto no Brasil como em nível mundial. Neste ano, a Europa proibirá o descarte de pneus em aterros e o continente terá 80 milhões de pneus usados/ano para descartar em outros lugares (Fig. 22). Além disso, países como a China, adotaram uma política de permissionamento pago pelo ingresso de resíduos recicláveis do Primeiro Mundo, uma montanha de cerca de 11.000 .000 de toneladas em 1997, volumes que não cessam de crescer (Vide DIAMOND, 2005:443).

Agravando este problema, os resíduos, do ponto de vista histórico, além de terem se expandido em termos de volume, passaram a incorporar um número crescente de materiais novos, que foram somando-se ao montante de substâncias

\footnotetext{
${ }^{61}$ Embora não constitua resíduo perigoso, os pneus causam diversos estorvos ambientais. Por isso, esta controvertida questão tem gerado inconformismo por parte de vários setores da população e do movimento ambientalista (Ver a respeito, ABES INFORMA, maio/junho de 2004, página 5)
} 
descartadas. Na medida em que os resíduos foram aumentando sua quantidade e também se diversificava a natureza da sua composição, as soluções para o problema também conquistaram maior complexidade. Neste sentido, em nada adiantaria advogar em favor da tese de que o lixo constituiria um antigo e persistente problema para as comunidades humanas. Apesar de correto, este argumento perde sua força quando recordamos que na civilização moderna,

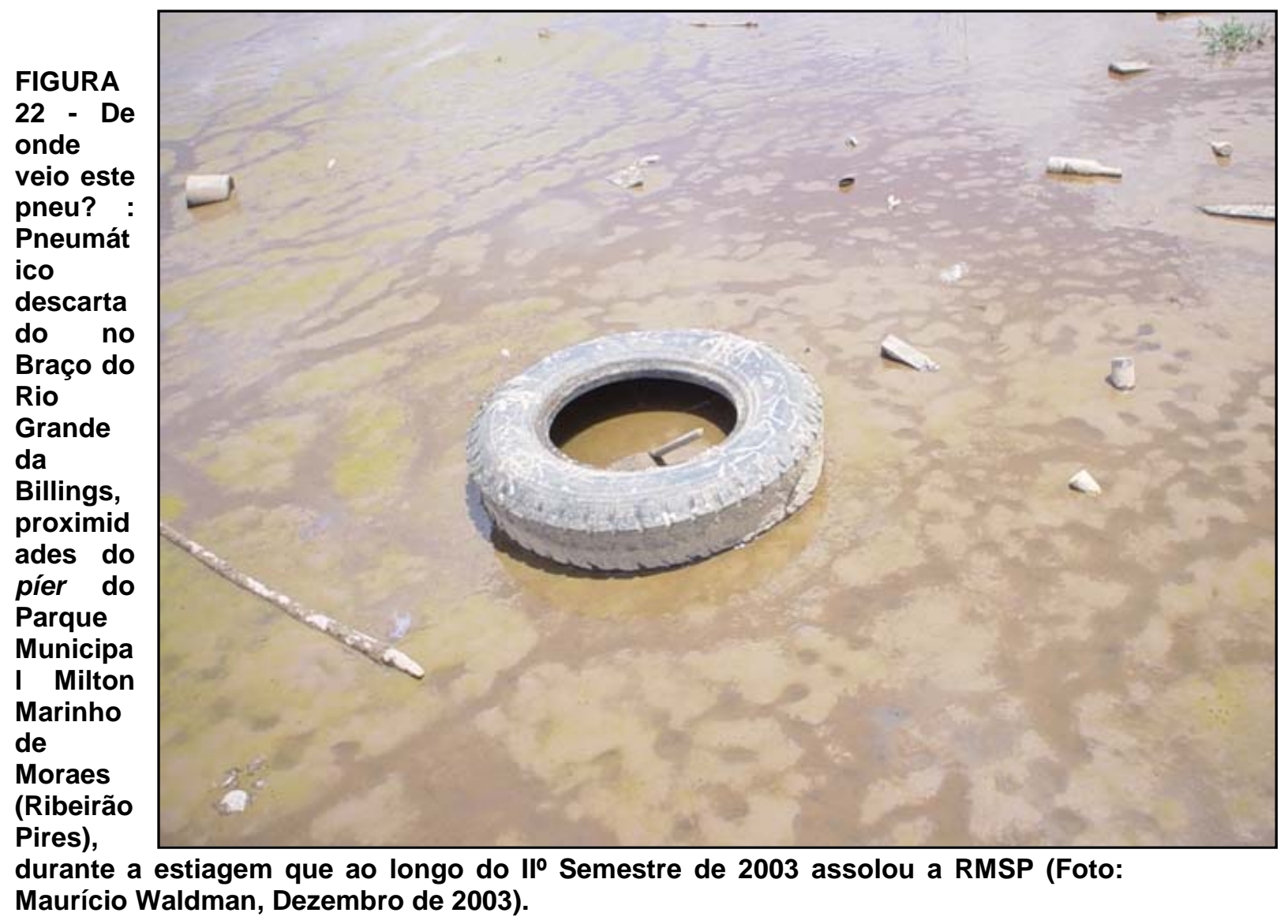


contrariamente ao mundo tradicional, os materiais são largamente industrializados, consistindo de aglomerados cada vez mais artificiais. Por esta razão, pura e simplesmente possuem um tempo de permanência no ambiente muito mais amplo, resistindo à reintegração no meio natural.

Respaldar esta afirmação não ofereceria qualquer dificuldade. De acordo com dados coletados de amplo leque de literatura específica a respeito dos resíduos sólidos, sabe-se que a degradação do papel no ambiente requereria pelo mínimo de 6 meses; as pontas de cigarro, de 1 a 2 anos; a goma de mascar, 5 anos; as embalagens tetrapak (vulgarmente conhecida como longa vida), cerca de 5 anos; quanto às latas de ferro, sua reincorporação ao ambiente solicitaria entre 10 e 30 anos; as latas de alumínio, entre 100 e 500 anos; as pilhas, entre 100 e 500 anos; os sacos plásticos, entre 10 e 20 anos; o plástico duro, entre 400 e 500 anos; as garrafas plásticas, aproximadamente 100 anos; finalmente, a espuma de nylon e o vidro, demandariam lapsos indeterminados de tempo.

Recorde-se que a simples presença física dos materiais descartados no ambiente, além de oferecerem degrabilidade dificultosa e constituírem agentes de contaminação, promovem diversos outros distúrbios. Por exemplo, o entupimento dos bueiros e das canaletas de drenagem por sacos e garrafas plásticas têm sido apontados como um dos mais persistentes motivos das enchentes nas grandes cidades do mundo. Esta afirmação poderia estar dirigida ao próprio Brasil. No país, são produzidas 210 mil toneladas anuais de plástico filme, montante que representou $9,7 \%$ de todo o lixo do país em 2003. Abandonados indistintamente no meio urbano, esses sacos plásticos, quando emaranhados na rede de drenagem urbana, impedem o escoamento das águas pluviais constituindo notório fator complicador para a questão das inundações (passim TRIGUEIRO 2003).

Face ao exposto, não há rigorosamente qualquer administração urbana que não tenha que se defrontar com a questão da destinação do lixo. Embora o Brasil possa apresentar números até mesmo modestos na comparação com outros países, estes ainda assim seriam impressionantes. No país, são jogados no lixo 62 milhões de copinhos de café por dia. Quanto ao papel branco usado anualmente, este seria suficiente para circundar a Terra 48 vezes pela linha do 
Equador e, somando-se outros tipos de papéis, poderíamos ir e voltar da Terra a Lua 25 vezes por ano. Os brasileiros igualmente descartam 4.980 toneladas de lenços e 15.000 toneladas de guardanapos de papel todos os anos. E, esta relação poderia ser enriquecida de vários outros números estarrecedores, uma relação aparentemente infindável (Cf LEGASPE, 1996:157).

No Brasil, o ato de descartar resíduos implica na geração de 130 mil toneladas de lixo domiciliar por dia. Isto é, seriam 47,5 milhões de toneladas anuais, em grande parte aguardando destinação adequada. Recorde-se que apenas $60 \%$ dos resíduos urbanos do Brasil são coletados, quase sempre nas zonas comerciais e residenciais de maior poder aquisitivo. $O$ resto permanece nas vias públicas, terrenos baldios, encostas, córregos e rios. Outro dado preocupante é que mesmo coletando o lixo, 88\% dos 5.507 municípios brasileiros, descartamno de modo inadequado. Geralmente os resíduos terminam dispostos a céu aberto ou em aterros ditos "controlados", situação que implica em óbvios impactos ambientais, dentre estes a contaminação dos lençóis freáticos e de solos agricultáveis pelos efluentes originários da degradação do lixo. Por fim, ressalvese que somente 451 municípios brasileiros, ou seja, $8,11 \%$ do total, desenvolvem programas de reciclagem (Cf GRIMBERG, 2002).

Outra questão são os encargos econômicos decorrentes do gerenciamento do lixo, um custo nada desprezível especialmente quando muitos países defrontam-se com carências em áreas essenciais quanto à saúde, educação e investimentos em infra-estrutura. No caso brasileiro, "os serviços de limpeza absorvem de 7 a 15\% dos recursos de um orçamento municipal, dos quais cerca de 50 a 70\% são destinados para a coleta e ao transporte do lixo" (CEMPRE, 2000:45/46). A coleta de resíduos possui rebatimentos para diversos outros setores da economia. No Brasil, assim como em muitos outros países, os serviços de coleta de lixo constituem o mercado preferencial de veículos pesados. Basicamente a cada quatro anos a frota de coleta de lixo do país é reposta com veículos novos (REMAI, 1991).

Por fim, como não enfocar este aspecto, a lógica da geração de resíduos termina por deslocar os efeitos perversos do seu descarte para as áreas 
periféricas das cidades, exatamente as que são habitadas pelos "de baixo". Neste sentido, um interessante estudo desenvolvido nos anos noventa pelo California Waste Management Board (Conselho de Administração de Rejeitos da Califórnia) apontou as comunidades pobres, mais abertas ou suscetíveis às promessas de benefícios econômicos, excluídas e formadas por trabalhadores pouco qualificados, como de menor oposição ao locally undesirable land-use (uso localmente indesejável do solo). Não haveria como desmentir, os lixões, aterros, incineradores e "áreas de desova" possuem localização preferencial no entorno urbano, espaço de vida dos excluídos assim como de produção de água doce.

Neste sentido, a questão do lixo, ao afetar das mais diversas formas o dinamismo social e ambiental dos humanos, o espaço habitado na quase totalidade dos elementos que o constitui, dificilmente poderia ser esquecida num debate que, como este, está voltado para os recursos hídricos. Detalhar e precisar melhor este foco torna-se, pois, um passo que se soma aos que já foram feitos até estas linhas.

\section{2. Água e lixo: Uma I nterface Perpétua}

Foi elaborada nos parágrafos anteriores uma breve exposição sobre o lixo, alinhavando dados sobre seu perfil volumétrico e gravimétrico, gastos relacionados com a sua destinação final, o complexo rol de substâncias nele incorporados e os distúrbios promovidos no ambiente de vida dos humanos. Além destes pontos, importaria ressalvar a articulação mantida entre resíduos sólidos e recursos hídricos. De um ponto de vista eminentemente geográfico, dissociar os dois temas somente poderia causar estranheza, em especial se lembrado que espacialmente ambos interagem entre si.

Por sinal, um relevante papel caberia à intersecção da temática dos recursos hídricos - além da condizente com os resíduos sólidos - com a da matriz energética. Formando um trinômio solidamente articulado entre si, esta tríade é 
indissociável de qualquer estudo envolvendo qualquer um destes temas, em vista dos aspectos relacionados com cada um deles condicionar obrigatoriamente comentários sobre os demais. Não há e não haverá jamais qualquer debate sério sobre recursos hídricos, resíduos sólidos e matriz energética habilitado a dispensar esta intersecção temática (Vide Fig. 23).

Nesta interface, a problemática urbana reclamaria destaque. Afinal, o meio urbano refere-se a uma forma de organização do espaço identificada, mais do que qualquer outra, com a modernidade e o mundo inaugurado pela economia de

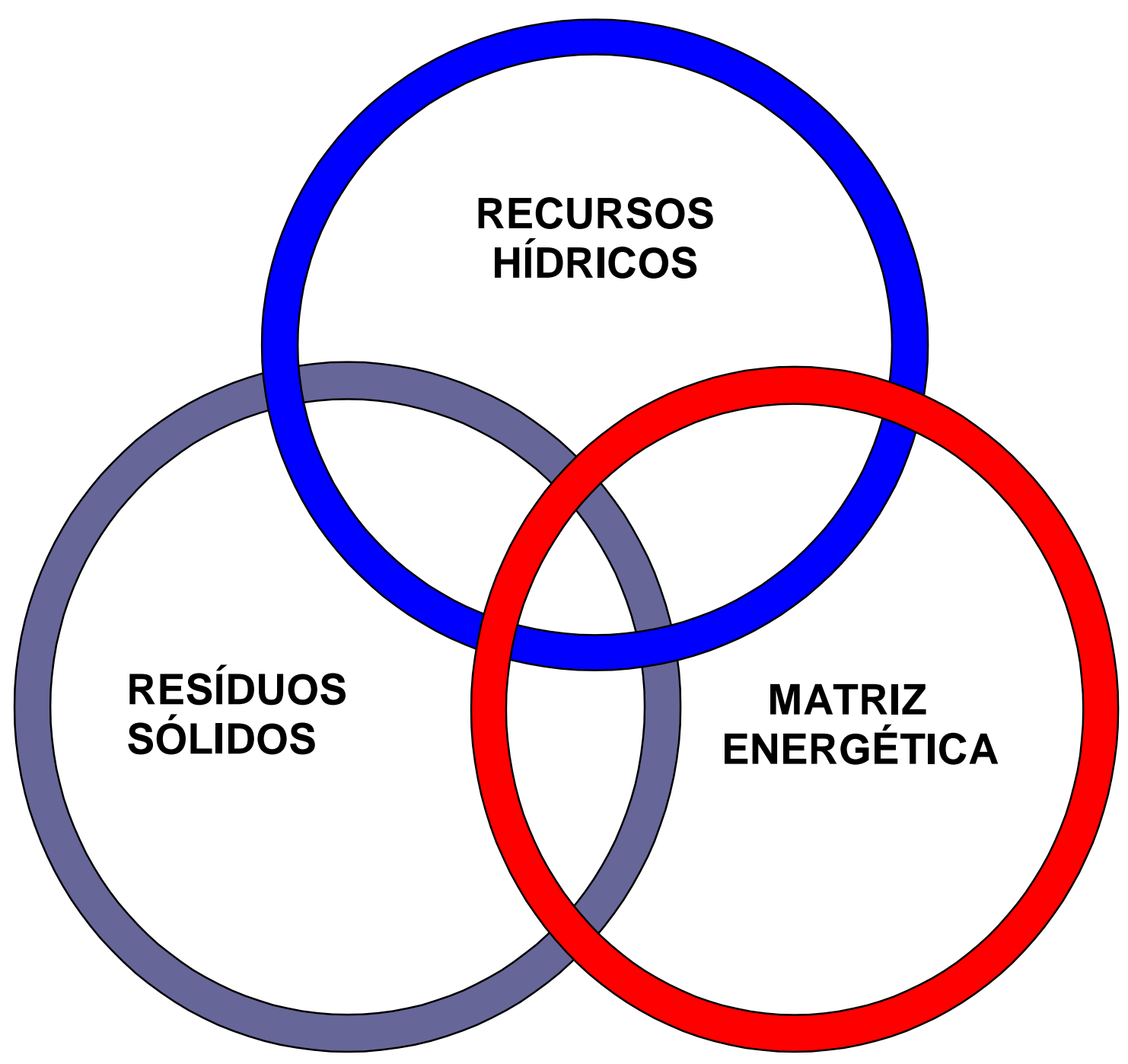


FIGURA 23 - Esquema da Tríade Temática: Uma proposição gráfica (Cf Waldman, 2003a e 2005) 
mercado. A cidade, exercendo o papel de pólo vital da produção e da circulação de mercadorias, coerentemente avoca para si o essencial do nódulo que emaranha recursos hídricos, matriz energética e resíduos sólidos ${ }^{62}$. Ademais, auferindo primazia enquanto máxima emanação de um estilo de vida considerado matriz do uso perdulário dos recursos naturais, o meio urbano é o palco por excelência da geração de vasta quantidade de resíduos.

O vulto conquistado pelos espaços urbanos, derivando na alteração de paisagens naturais inteiras, agora ocupadas por construções, fábricas e obras de infra-estrutura, resulta necessariamente numa seqüência de eventos nos quais o lixo repetidamente se conjuga com a questão das águas doces. Decididamente, as estratégias de gerenciamento dos resíduos sólidos possuem vínculo umbilical com a preservação da qualidade dos recursos hídricos que abastecem as próprias concentrações urbanas, não podendo, em hipótese alguma, dela ser desvinculada.

Ressalve-se que a questão dos resíduos sólidos urbanos tem sido apontada como uma das que poderão, sem que exista nesta afirmação qualquer alarmismo, comprometer seriamente o abastecimento de água potável no meio urbano brasileiro, um verdadeiro paradoxo, pois o território brasileiro é detentor das mais pródigas reservas de água doce do mundo. A urgência da adoção de ações para o lixo estaria somada com esforços que vem sendo desenvolvidos no sentido de preservar os recursos hídricos e manter sua qualidade. A este respeito, reconhece um conceituado manual sobre gerenciamento dos resíduos sólidos:

Num futuro não muito distante, será possível defrontar-se com sérios problemas de disponibilidade de água potável e de elevação dos custos para sua adução e tratamento, sendo plausível estimar que, se nada for feito, em 10 anos, o desabastecimento poderá atingir grandes centros urbanos, como São Paulo, Recife, Rio de Janeiro, Belo Horizonte e a maioria das áreas metropolitanas do país, em função da poluição e da queda de produção de mananciais e conflitos do uso múltiplo não planejado: irrigação, lazer, navegação, esgoto, etc (CEMPRE, 2000:8).

62 A concretude desses vínculos reflete-se nas criações culturais, como na filmografia. Por exemplo, o curta-metragem "Ilha das Flores" (Jorge Furtado, 1989), sintomaticamente localiza um lixão numa ilha, cercado por um corpo aquático. 
De resto, dado que se tem presenciado o aprofundamento da crise de abastecimento de água potável, isto nos induz a trabalhar com um leque de variáveis mais amplo possível. Decerto, a sociedade brasileira está postada diante de um problema ambiental de primeira grandeza, cuja gravidade se acentua em razão da sua débil percepção pelo imaginário social. Isto quer dizer que:

Grande parte das cidades brasileiras ainda não chega ao estágio de se preocupar com a poluição dos esgotos pluviais, já que o esgoto cloacal é ainda o problema maior (...) O lixo, conjugado com a produção de sedimentos e com a lavagem das ruas, exige procedimentos de combate criativos com custos razoáveis para se evitar que, no início do período chuvoso, a qualidade dos cursos d'água seja ainda mais deteriorada. Esse processo de poluição ocorre, principalmente, na macrodrenagem das cidades. Infelizmente, os grandes investimentos hoje existentes nos programas de recuperação ambiental das metrópoles brasileiras estão ainda no estágio de reduzir somente a carga do cloacal (TUCCI, HESPANHOL e NETTO, 2001:48).

Por esta razão, o meio urbano, ao explicitar forte interpenetração das discussões do abastecimento de água potável e do saneamento básico com a questão da drenagem urbana e das enchentes e destas, por sua vez, com a dos resíduos sólidos e da energia, ensejaria a adoção de um planejamento integrado, preocupado simultaneamente com estes setores essenciais do funcionamento do "moderno sistema de engenharia". Esta noção, é óbvio, deve buscar respaldo em um modelo conceitual apto a trabalhar com tais inter-relações, debate que embora persistente, é em linhas gerais, ainda incipiente (Ver a respeito, PITTON, 2003:44/46).

Uma outra ordem de considerações, cujo palco privilegiado também é a cidade, decorre do universo da produção econômica, particularmente a industrial. Com efeito, a relação siamesa mantida pelos resíduos sólidos com a questão dos recursos hídricos, manifesta-se no ajuizado pelo qual toda sorte de bens produzidos materializa, direta ou indiretamente, um certo input hídrico. Esta demanda pelo líquido apresenta-se ao longo de todo o processo produtivo, e ademais, no suprimento energético, cujo pressuposto é, quase sempre, a água. 
A relevância da água pode ser conferida tomando por base a chamada Análise do Ciclo de Vida dos produtos, ou simplesmente ACV. Constituindo ferramenta conceitual por intermédio da qual o processo de produção dos materiais ou atividades é analisado por completo, a ACV analisa a extração e o processamento de matérias-primas; sua fabricação; o transporte e a distribuição; consumo ou utilização dos produtos; e por fim, sua reutilização, manutenção, reciclagem e disposição final (SETAC, 1993). No Brasil, os princípios e as estruturas, assim como requisitos metodológicos para a condução de estudos de ACV são fornecidos pela NBR ISO 14040. Detalhes adicionais relativos aos métodos estão referendados por normas complementares, tais como a ISO 14041, ISO 14042 e ISO 14043, todos se relacionando às diversas fases da ACV.

A ACV documentaria a "história" de um produto, envolvendo todas as etapas que conduziram ao seu surgimento, desde a fase de obtenção das matérias primas até sua transformação em lixo ou resíduo (Vide gráfico 1). Este prisma é de fundamental importância para a compreensão e a minimização dos impactos ambientais baseados na análise do inventário produtivo. Na perspectiva da engenharia industrial,

...o mais importante efeito da aplicação do ACV é a minimização da magnitude da poluição causada por um determinado processo. A conservação de matérias primas não renováveis, como as fontes de energia, podem ser também o objetivo de uma avaliação, assim como a conservação de sistemas ecológicos em áreas sujeitas a um balanço de suprimentos delicado, como regiões onde a água é escassa. A produção de resíduos representa perda de reservas e resulta em degradação do meio ambiente (RIBEIRO, GIANETTI e ALMEIDA, 2005).

Com base nestes princípios, quando, por exemplo, são realizadas pesquisas sobre os impactos ambientais dos automóveis (geralmente restritas aos índices de poluição ocasionados pelo funcionamento dos veículos), a ACV procura identificar os efeitos causados pelo processo de sua fabricação, incluindo a demanda por água, energia utilizada, matérias primas, a produção dos seus diversos componentes (peças dos motores, válvulas, vidros, borrachas, plásticos, pneus, etc) e finalmente, a forma como ocorre a destinação final dos seus resíduos (Fig. 
24). Por conseguinte, a ACV traça uma documentação ambiental dos produtos, literalmente "do berço à cova", ou considerando-se o aproveitamento do produto após sua utilização, do "berço ao berço" (Vide RIBEIRO, GIANETTI e ALMEIDA, 2005).

Com base nesta premissa, é patente que em praticamente todas as etapas da produção está presente uma demanda por recursos hídricos. É o que ocorre no primeiro estágio (extração de recursos naturais), visando obter a matéria

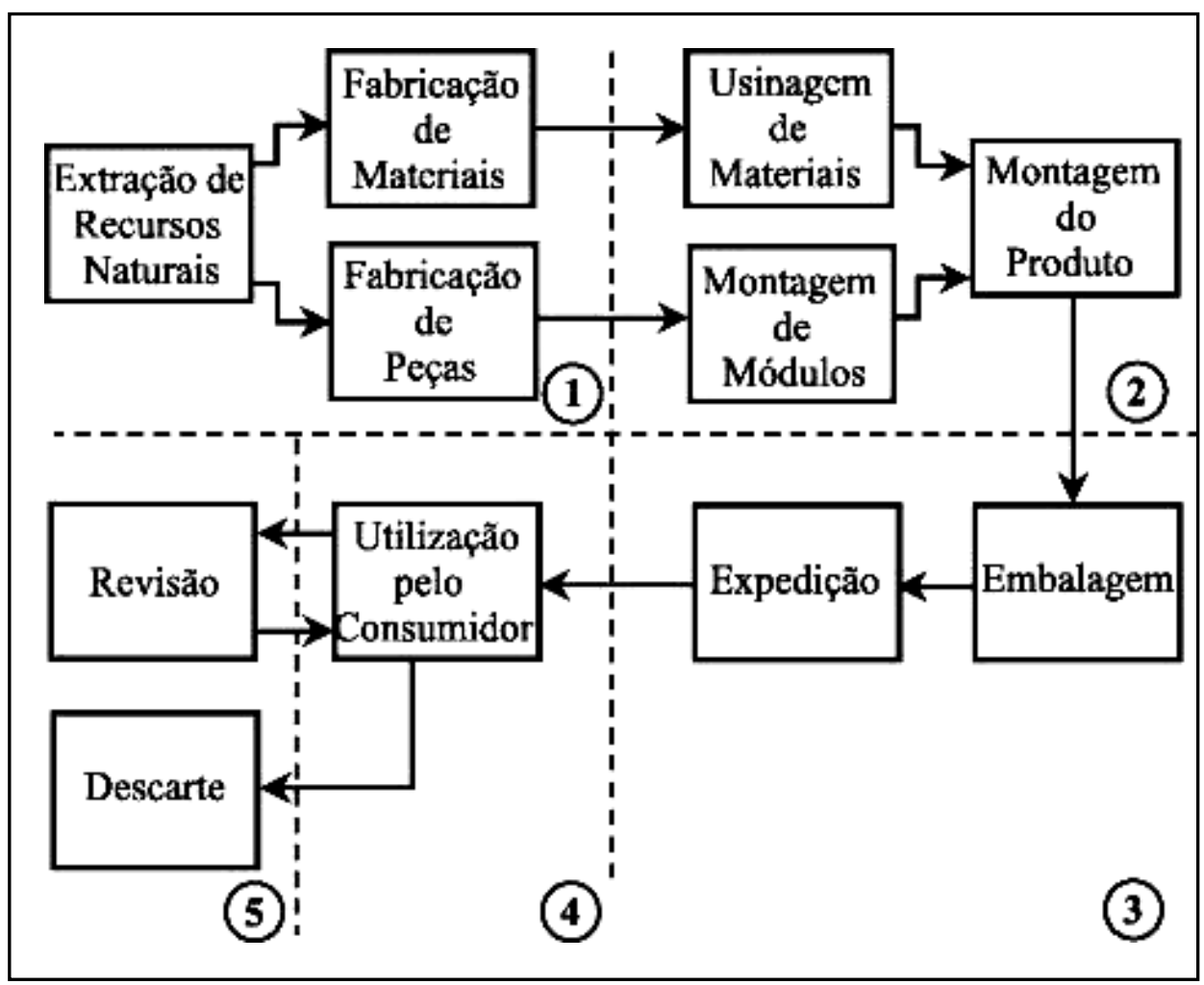

GRÁFICO 1 - Atividades nos cinco estágios de ciclo de vida de um produto (adaptado de GRAEDEL, T. E.I ALLENBY, B. R., in Industrial 
Ecology. New Jersey/USA, Prentice Hall, 1995:412, in RIBEIRO GIANNETI ALMEIDA, 2001). 


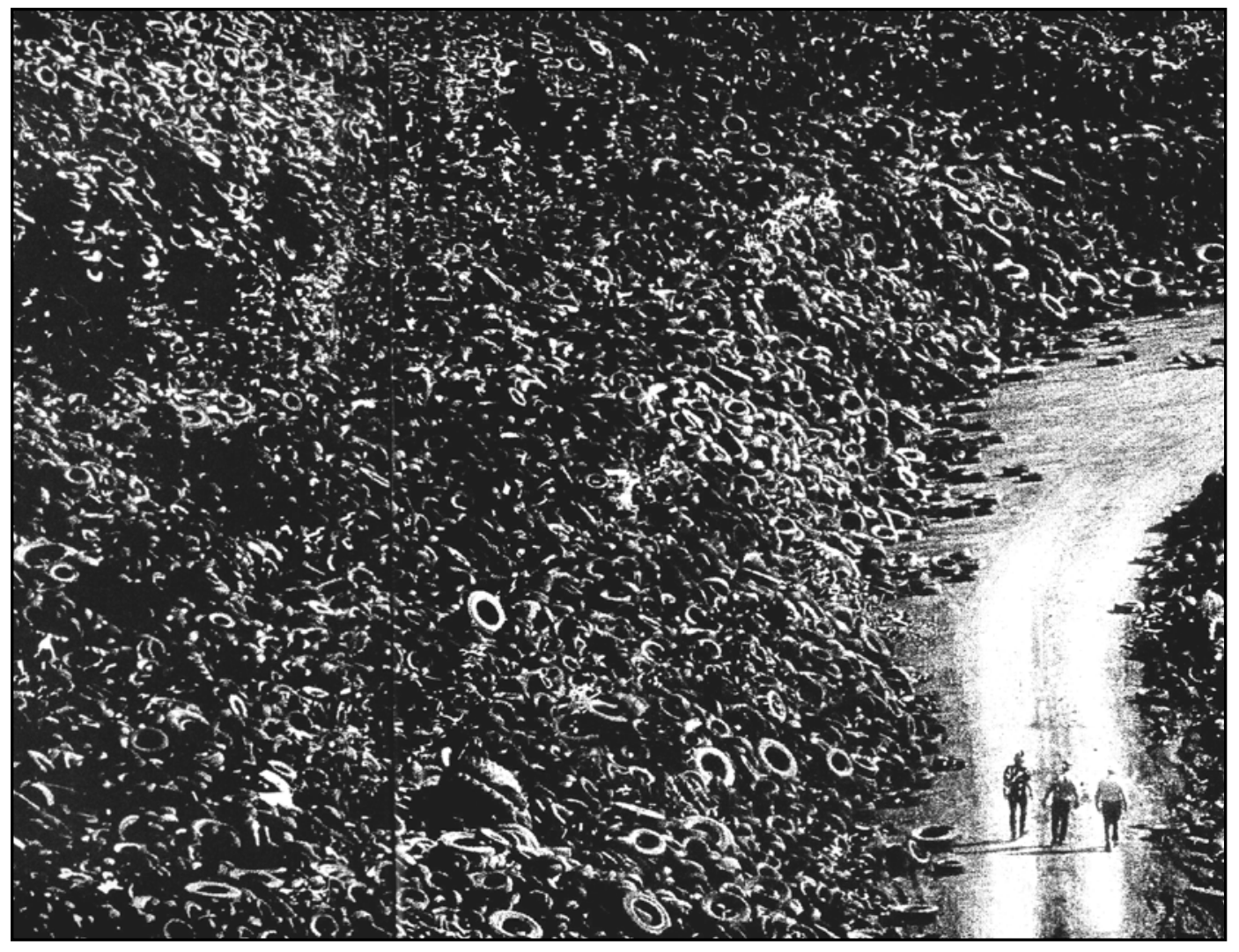

FIGURA 24 - Depósito de pneus usados nos EUA: um dia estes pneus foram água (Fonte: DIAS, 2002a: 56/57) 
prima. No estágio seguinte, usinagem e montagem dos produtos, novamente a água estaria presente. No terceiro estágio, o embalamento e o transporte atuam como consumidores diretos ou indiretos de água. As duas últimas etapas, a saber, as referentes ao consumo e à utilização dos produtos, assim como o descarte ou a própria reciclagem, formalizam etapas que para serem concretizadas, também apelam para o consumo de água. Em suma, a simbiose do ciclo de vida dos produtos com os recursos hídricos é de tal monta que seria impossível concebê-lo na ausência de água.

De resto, a interação com os recursos hídricos não cessa com a "morte" do produto, ou seja, quando o mesmo se torna um resíduo. No final das contas, se está tomando por base uma sociedade geradora de enorme quantidade de lixo. Assim, este contexto oferece variado elenco de interfaces com a questão da qualidade da água oferecida no meio urbano, sendo uma destas, justamente a que transparece por ocasião do descarte final. O gerenciamento dos resíduos sólidos objetivando a atenuação de impactos, requer destinação correta e confinamento seguro, compondo um "pacote" de tecnologias, procedimentos e modelos de gestão. Dentre estes, constituindo modalidades nas quais a relação com a água é mais evidente junto ao senso comum, pode-se citar a Coleta Seletiva de Lixo (CSL), os aterros, os incineradores e as usinas de compostagem.

Mas nem sempre outras formas de monitoramento dos resíduos são percebidas no alcance que possuem quanto à preservação das águas doces. Por exemplo, a varrição das ruas e a limpeza urbana em geral, interferem de modo decisivo para a manutenção dos corpos líquidos. Será em decorrência da eficácia destes serviços que os impactos provocados nas águas interiores pelas cargas difusas, serão maximizados ou atenuados. As cargas difusas têm origem nas descargas pluviais, que em função da dinâmica de escoamento da drenagem urbana, lavam superfícies contaminadas por todo tipo de resíduos, como telhados e vias públicas, reunindo enorme proporção de substâncias poluentes com origem orgânica e inorgânica, uma massa líquida que termina por afetar os mananciais voltados para o consumo humano (Cf TUCCI, HESPANHOL e NETTO, 2001:48 et seq). 
Certamente, além do lixo lançado às ruas, dos resíduos deixados para trás por falhas dos serviços de limpeza, dos dejetos humanos e animais e do vazamento de chorume dos sacos de lixo e dos caminhões de limpeza, várias outras interferências urbanas poderiam ingressar nas cargas difusas, comprometendo a qualidade das águas doces. Por exemplo, o movimento de veículos, que aumenta a quantidade de resíduos nas ruas principalmente pela desagregação do pavimento asfáltico, assim como o material particulado resultante da decantação da fumaça das fábricas e dos veículos automotores, formaria outro caudal de poluentes. Porém o lixo ainda constituiria um foco básico deste problema (Ver FIALHO, 1998:59).

Fato pouco conhecido, as cargas difusas, devido à expansão da urbanização, da industrialização e da geração cada vez maior de resíduos, têm sido responsabilizadas por um volume crescente de cargas poluidoras nos rios e reservatórios. Atualmente, estima-se que $25 \%$ da poluição dos rios urbanos tenha origem em cargas difusas, sendo que durante as cheias, "a carga poluente do pluvial pode chegar até a $80 \%$ da carga de esgoto doméstico" (TUCCl, HESPANHOL e NETTO, 2001:48). Portanto, estas não podem ser esquecidas nas estratégias de preservação dos corpos líquidos e tampouco secundarizadas pelo gerenciamento dos resíduos urbanos.

Finalmente, pode-se pautar na discussão sobre as interfaces entre os resíduos sólidos e os recursos hídricos, um trajeto que novamente associa estas duas variáveis, agora no sentido oposto, isto é, dizendo respeito aos desdobramentos do gerenciamento das águas urbanas na direção do lixo. Este seria o caso do tratamento primário dos esgotos, conjunto de processos cuja finalidade é remover os materiais insolúveis contidos nas águas servidas. Após a passagem forçada dos esgotos por grades metálicas, estas retêm grande quantidade de detritos, tais como latas, garrafas plásticas e toda sorte de objetos, enviados posteriormente para os aterros sanitários (Vide BRANCO, 1993:56).

Quanto ao lodo residual resultante da purificação das águas servidas nas Estações de Tratamento de Esgoto (ETE), este também segue para os aterros ou incineradores, e isto, em enorme quantidade. Por exemplo, de acordo com dados 
da Companhia de Saneamento Básico do Estado de São Paulo (SABESP), apenas a ETE de Barueri, na RMSP, despacha cerca de 250 toneladas de lodo todos os dias. O descarte destes volumes é, portanto um ponto nevrálgico. Sem contar que a disposição final do lodo chega a perfazer $60 \%$ do custo operacional de toda a planta de purificação, o grande volume de material contribui para abreviar a vida útil dos aterros sanitários, já sobrecarregados pelos RSD. Inexoravelmente, a expansão do esgotamento sanitário no Brasil irá induzir grande ampliação dos volumes encaminhados aos aterros. Mais uma vez estampando a indissociabilidade existente entre o temário da água e o do lixo, a carência de espaços nos aterros tem sustentado denúncias persistentes de disposição irregular do lodo residual, inclusive em áreas de mananciais.

Uma forma de superar este problema seria a aplicação bruta do lodo (também definido como "biosólido"), na agricultura. Afinal, embora o lodo não constitua um suprimento completo, sua composição apresenta todos os macronutrientes necessários ao desenvolvimento das plantas. Procurando reforçar o rendimento das colheitas, os agricultores de Jundiaí e de Franca (SP), autorizam o despejo de praticamente $100 \%$ do lodo obtido das ETE regionais nos seus cultivos. Mas, existem problemas. O lodo apresenta elevado porcentual de metais pesados e elevada incidência de patógenos, neste último caso, um claro reflexo das condições sanitárias vigentes no país. A deposição do lodo pode provocar queda da biodiversidade dos solos e por fim, contaminar os lençóis freáticos e outros reservatórios subterrâneos.

Em resumo, muitos são os elos que unem reciprocamente a água e o lixo, e ambos, com a vida urbana moderna. Taxativamente, a preservação da água dependerá diretamente do que vier a ser estabelecido enquanto estratégia de gerenciamento do lixo (SEMA, 1998). E, justamente esta somatória de problemas sugere uma radiografia mais aprofundada dos resíduos sólidos, pré-condição inerente à identificação do relacionamento desta questão com a dos recursos hídricos.

Como se verá adiante, discriminar e identificar impactos relaciona-se diretamente com uma clara identificação dos resíduos, das formas de descarte 
utilizadas e de tratamento do lixo, questionamentos que ocupam posição central quando o tema de debate é a água.

Enfocar o entrelaçamento de ambas questões interessaria, pois por lançar uma luz mais forte quanto à complexidade de problemas que norteiam o gerenciamento das águas doces na atualidade, assim como as potencialidades de um gerenciamento ótimo dos resíduos sólidos.

\subsection{Classi fi CaÇÃo e Desti naÇÃo dos Resíduos Sólidos}

Consideração praticamente ignorada pelo senso comum, a terminologia lixo, dado reportar a uma variada gama de substâncias, é em si mesma genérica, e, portanto, pouco consistente de um ponto de vista técnico e teórico. Além disso, na linguagem corrente lixo é regularmente utilizado como sinônimo de resíduo, situação que ensejaria recordar a existência de algumas diferenciações sutis. Certamente um arrazoado de senso comum justificaria a adoção de uma ou de outra terminologia, consoante o momento e a intenção da nossa fala.

Mas, isto não seria impeditivo de se buscar maior precisão para ambos os termos. Semanticamente, pode-se certificar que lixo seria todo o material inútil, todo material descartado posto em lugar público, tudo aquilo que "se joga fora", "não presta", ao qual se agrega longas catilinárias devotadas à sua nocividade. Quanto à palavra resíduo, esta designaria as "sobras" no processo produtivo, geralmente de origem industrial. Assinale-se também que estes dois termos podem ser tratados com base em outras acepções, consoante a visão institucional ou de acordo com o seu significado econômico (Cf CALDERONI, 2003:49).

De acordo com a Norma Brasileira Registrada (NBR) 10.004 da ABNT, os resíduos sólidos seriam aqueles que se apresentam "no estado sólido, resultante das atividades da comunidade de origem: industrial, doméstica, hospitalar, 
comercial, de serviços de varrição e agrícola" (citada em SCHALCH, LEITE e GOMES, 1990:150). Também ficariam incluídos nesta definição

...os lodos provenientes de sistemas de tratamento de água, aqueles gerados em equipamentos e instalações de controle da poluição, bem como determinados líquidos cujas partículas tornem inviáveis o lançamento na rede pública de esgotos ou corpos d'água, ou exijam para isso soluções técnicas e economicamente inviáveis em face à melhor tecnologia disponível (idem).

Nesta formulação técnica, como em muitas outras, o termo resíduo (embora não excluindo de todo o uso da expressão lixo), é amplamente utilizado, sendo usual na maioria das publicações científicas. Existem, é evidente, uma série de motivos que justificam uma certa opção preferencial pelo termo resíduo no lugar de lixo. Porém, dado que a intenção neste momento é discutir a classificação dos resíduos, seria suficiente manter por enquanto esta indicação prévia, entendida como patamar para desdobramentos que serão costurados com maior detalhamento mais adiante.

Assim, as "sobras" da civilização moderna, contrariando o senso comum, constituem um conjunto heterogêneo de materiais e substâncias, admitindo uma classificação em várias categorias básicas quando é adotado um crivo preocupado com a identificação da fonte geradora. Tendo por foco especialmente o meio urbano, os especialistas distinguem: Resíduos ou Materiais Inertes, Resíduos Especiais, Resíduos Industriais, Resíduos Comerciais e, os Resíduos Sólidos Domiciliares.

Os Resíduos Inertes correspondem fundamentalmente ao entulho oriundo da construção civil. Os inertes, normalmente compreendidos como um estorvo, podem ser de grande utilidade para a recomposição paisagística e recuperação de áreas como pedreiras abandonadas e regiões com solo pouco compactado, que deste modo podem ser viabilizadas como parques, áreas de lazer e outros equipamentos públicos. Sendo menos impactante que os demais resíduos, a sugestão dos técnicos prescreve o encaminhamento do entulho para aterros destinados exclusivamente para este tipo de resíduo. 
Quanto aos Resíduos Especiais, estes são formados por alimentos e medicamentos com validade vencida, sobras de matadouros, materiais originários de clínicas veterinárias, produtos químicos corrosivos, tóxicos e inflamáveis, assim como pelo chamado lixo hospitalar. Este último atualmente denominado de RSS Resíduos de Serviços de Saúde. A mudança da denominação justificou-se pelo fato de vários tipos de estabelecimentos gerarem resíduos com características similares aos dos hospitais, caso das farmácias, clínicas veterinárias e outras instalações assemelhadas (Ver a respeito, MOREL, 1991). A partir de Dezembro de 1987 a nomenclatura Resíduos de Serviços de Saúde foi adotada pela Associação Brasileira de Normas Técnicas (ABNT), estando firmada por normas da referida associação (NBR 12.807, com validade a partir de 01.04.1993).

Os Resíduos Industriais são gerados pela transformação das matérias primas por parte da indústria. Particularmente, os resíduos resultantes da indústria química e petrolífera integram algumas substâncias que mais tem preocupado as autoridades e os ambientalistas. Por conseguinte, estes resíduos sugerem um controle rigoroso. Farta literatura de cunho técnico justifica seu encaminhamento para incineradores ou aterros específicos (os aterros industriais), em conformidade com a tipologia dos impactos passíveis de serem desencadeados no meio ambiente.

Recorde-se que um dos maiores acidentes ambientais da história, o de Minamata, no Japão (1956), foi provocado pelo lançamento de resíduos industriais em corpos líquidos. Este acidente teve origem no despejo de águas residuárias contendo mercúrio por parte de uma indústria, provocando a contaminação de peixes e outros alimentos marinhos, que "consumidos pela população, deram origem, durante anos seguidos, a uma doença incurável, deformante, e de terríveis características, que ficou conhecida como Mal de Minamata" (SCHALCH, LEITE e GOMES, 1990:149).

O Resíduo Comercial é composto essencialmente por papéis da área administrativa e pelo papelão resultante do descarte das embalagens. Portanto, este tipo de resíduo seria em tese menos influenciado por fatores externos (Ver a respeito, FIALHO, 1998:56/57). A intensa informatização dos setores 
administrativos tem favorecido a geração de índices significativos do chamado "lixo digital" e dos seus sucedâneos, tais como cartuchos de impressoras, CDs, disquetes avariados e diversos tipos de plásticos, que passaram a participar em grau crescente na composição deste tipo de lixo.

Por último temos os Resíduos Sólidos Domiciliares (RSD). Estes correspondem à parte mais volumosa do lixo produzido pelo meio urbano, referindo-se a um dos nexos centrais da análise que se pretende desenvolver. $\mathrm{Na}$ composição dos RSD está presente uma elevada proporção de matéria orgânica, proveniente dos restos de alimentos, serviços de jardinagem e os detritos resultantes da varredura de parques e logradouros públicos, incluindo folhas, galhos e troncos. Simultaneamente, os RSD incluem substâncias inorgânicas, caso dos vidros, papéis, plásticos e metais.

A composição heterogênea dos resíduos sólidos domiciliares inspirou, junto à literatura especializada, a identificação de duas categorias básicas dos RSD, a saber: a fração inorgânica, seca ou ainda reciclável e a fração orgânica, também conhecida como úmida ou molhada. Além destas duas, há ainda os rejeitos. Sinteticamente, estas categorias podem ser descritas da forma como segue:

- Fração inorgânica, seca ou reciclável: Esta categoria é composta pelos metais, caso do cobre, do aço e do alumínio (na forma de cabos elétricos descartados, embalagens, latas vazias de alimentos, de refrigerantes e bebidas em geral, etc); vidros (frascos, garrafas, sobras, cacos e fragmentos de oficinas); papel e papelão (das modalidades mais variadas); e pelos plásticos (dos mais diversos tipos). Acredita-se que este conjunto de materiais represente aproximadamente $20 \%$ do total dos RSD.

- Fração orgânica, úmida ou molhada: Esta categoria é formada pela matéria orgânica presente nos RSD. Este seria o caso dos restos de comida, de poda de jardim, talos, cascas, palha, grãos recusados, filtro 
de papel para café e assim por diante. No Brasil, estima-se que a fração úmida represente entre $50 \%$ e $60 \%$ do peso do lixo.

- Rejeitos: Esta categoria inclui substâncias não pertencentes a nenhuma das duas frações anteriores. Nesta estão presentes o papel higiênico, papel de fax, fraldas descartáveis, absorventes higiênicos, jornais e revistas sujos de gordura, isopor, celofane, cerâmicas, espelhos, cristais quebrados, fotografias, cinzas, tocos de cigarro, etc. Estima-se que no Brasil, os rejeitos representem cerca de $30 \%$ do peso total do lixo. A definição de rejeito solicita muita cautela, repudiando conotações genéricas e aleatórias. Com o avanço das técnicas de reciclagem, materiais anteriormente desprezados tornamse dignos das atenções da indústria.

Este é o caso da embalagem longa vida, também chamada de tetrapak, cuja participação no montante dos resíduos descartados tem crescido ano a ano. Até os anos 80, esta embalagem era considerada não-reciclável. Entretanto constitui atualmente uma fonte requisitada de plástico, alumínio e de papéis reciclados:

...o princípio de reciclagem deste tipo de embalagem consiste na hidratação das mesmas, em equipamento apropriado, ocorrendo a separação das fibras celulósicas, do plástico com alumínio. As fibras celulósicas recuperadas são utilizadas na fabricação de papel e o resíduo composto por plástico com o alumínio é usado na fabricação de peças plásticas (CEMPRE, 2000:136).

No cômputo geral do lixo, o portentoso volume dos RSD incitou o surgimento de diversas propostas de gerenciamento, existindo, sem dúvida alguma, um acúmulo de discussão considerável sobre este assunto. Relativamente a estes aspectos, nosso esforço seria sumarizar as principais formas de gestão existentes, todas com óbvia repercussão teórica e concreta quanto ao meio urbano e os recursos hídricos. Nesta linha de compreensão, quanto à destinação final dos 
RSD poderíamos mencionar as usinas de compostagem, os incineradores e os aterros.

Nas usinas de compostagem, a fração úmida do lixo é transformada em composto orgânico. O processo de transformação de resíduos orgânicos em composto é muito antigo, constituindo uma prática tradicional em muitas sociedades agrícolas em todo o mundo. O composto orgânico, definido pelo linguajar comum como "adubo", é acima de tudo um revitalizador ou um condicionador dos solos. Na realidade, o composto é assim classificado

...pelo fato de sua matéria orgânica humificada estar em maior proporção e que corresponde a cerca de 40 a $70 \%$. No entanto, além do efeito condicionador ou melhorador do solo, o composto é também classificado como um fertilizante de baixa concentração em nutrientes, razão pela qual, são sempre empregadas doses elevadas, geralmente acima de 10 toneladas por hectare (SCHALCH, LEITE e GOMES, 1990:87).

A qualidade do composto produzido nestas usinas possui relação direta com o rigor da segregação dos materiais inorgânicos da matéria orgânica. Fato óbvio, a presença maior ou menor de detritos inorgânicos, procedentes da fração seca repercute na qualidade final do produto compostado. É importante recordar que bem orientada e monitorada, a compostagem pode ser implantada nos quintais das residências, jardins públicos, em hortas comunitárias, e em equipamentos urbanos, promovendo sensível melhora dos cultivos e jardins (Ver a respeito GRIMBERG, 2002).

A implantação dos incineradores tem sido proposta pelas mais diversas indicações técnicas, exaltando particularmente a redução do peso e do volume dos resíduos como seus principais benefícios. Mais recentemente, uma nova geração de incineradores opera com base no reaproveitamento energético, isto é, utiliza-se a energia liberada pela queima dos materiais para a produção de vapor e de eletricidade. O processamento de materiais de alto risco, caso em particular dos resíduos especiais, tem sido costumeiramente endereçada para as fornalhas 
dos incineradores ${ }^{63}$. Quanto às cinzas finais resultantes da queima, consideradas inertes e inócuas, estas são encaminhadas para os aterros.

A incineração tem sido culpabilizada pela emissão de componentes tóxicos presentes nas cinzas e por emissões de furanos e dioxinas, substâncias consideradas altamente tóxicas e lesivas à saúde e ao meio ambiente. Obviamente, a população residente no entorno destas instalações são particularmente agraciadas com estas emissões. Há também que ser mencionada a desvalorização imobiliária, a insatisfação dos habitantes das redondezas, os odores, a poluição visual, o elevado custo destes equipamentos (pagos com os impostos dos contribuintes) e a destruição em larga escala de muitos materiais reaproveitáveis. Por fim, last but definitely not least, a contaminação dos recursos hídricos por conta das emissões gasosas e das cargas difusas que alcançam espaços situados à jusante dos incineradores. Não admira que as regras estejam cada vez mais rigorosas no que tange a construção e operação dos incineradores (Ver SCHALCH, LEITE e GOMES, 1990:1 e CALDERONI, 2003:133/134).

Os impactos acarretados pela incineração têm motivado diversas críticas por parte da comunidade ambientalista e da área técnica, ambas de longa data e subsidiadas por razoável compêndio de dados (GREENPEACE, 1991). Por sinal, no contexto da própria comunidade médica não há, in totum, consenso no sentido de aprovar a operação dos incineradores para o conjunto do lixo hospitalar. A incineração seria uma alternativa satisfatória, "embora não necessariamente um ótimo meio de destruição para todos os resíduos clínicos" (NABHAN, 1986:2). Existem experiências que mesmo eivadas por acirrados debates, contestam que a incineração constitua opção única e exclusiva. Em Vitória (ES), durante a gestão do prefeito Victor Buaiz (1989-1992), médico de profissão, a administração municipal desta cidade encetou uma programação radical que excluía a utilização de incineradores para a destinação do lixo hospitalar, uma iniciativa que mesmo

\footnotetext{
${ }^{63}$ A respeito, consultar SCHALCH, ANDRADE, e GAUSZER, 1995, assim como SCHALCH, LEITE e GOMES, 1990:212 e seguintes.
} 
cercada de polêmicas (Fig. 25), estava subsidiada em variado leque de considerações médico-sanitárias ${ }^{64}$.

No Brasil, nos contextos nos quais as cidades dispõem de serviços de coleta, os aterros constituem a modalidade de gestão mais utilizada. Os aterros constituem uma derivação da prática ancestral de enterrar resíduos, constante em inúmeras tradições culturais e religiosas na maioria dos povos do mundo ${ }^{65}$. Diferenciados em comuns, controlados ou sanitários, os aterros, na dependência da sua especificidade, inserem desdobramentos técnicos, sociais e ambientais muito diferentes entre si. Destes três tipos, o mais encontrado nas cidades brasileiras são os aterros comuns, também denominados de sumidouros, lixeiras, vazadouros, ou como é mais freqüente, de lixões.

Caberia, no entanto advertir que na fala popular toda instalação ou área destinada ao gerenciamento dos resíduos termina impropriamente rotulada como lixão, um verdadeiro estigma que recai sobre equipamentos como incineradores, aterros sanitários, usinas de compostagem ou mesmo containers de recicláveis. Este equívoco é infelizmente reforçado pelos jornais, e pelo noticiário de rádio e da televisão, que usualmente também empregam esta terminologia de modo totalmente improcedente, uma confusão deve ser evitada a todo custo (Vide CALDERONI, 2003:118).

Muito prejudiciais ao meio ambiente e à população urbana, os aterros comuns correspondem ao simples encaminhamento de resíduos, independentemente da sua classificação, para áreas que não foram merecedoras de nenhum estudo prévio do ponto de vista geotécnico, procedimento este que se desenvolve ignorando medidas de acompanhamento, quaisquer que sejam. Como confirma a própria definição da ABNT, o "lixão" consiste apenas na descarga de resíduos a céu aberto, isenta de qualquer cuidado técnico, sanitário ou ambiental

\footnotetext{
${ }^{64}$ Observe-se que "a maior parte dos resíduos produzidos em um hospital não oferece maiores perigos que os associados aos resíduos municipais comuns" (MONREAL, 1992:2). Ademais, as opções pela reutilização e reciclagem não podem ser esquecidas (Ver entre outros, KARG JR, 1991 e SALOMÃO et alli, 2004).
} 


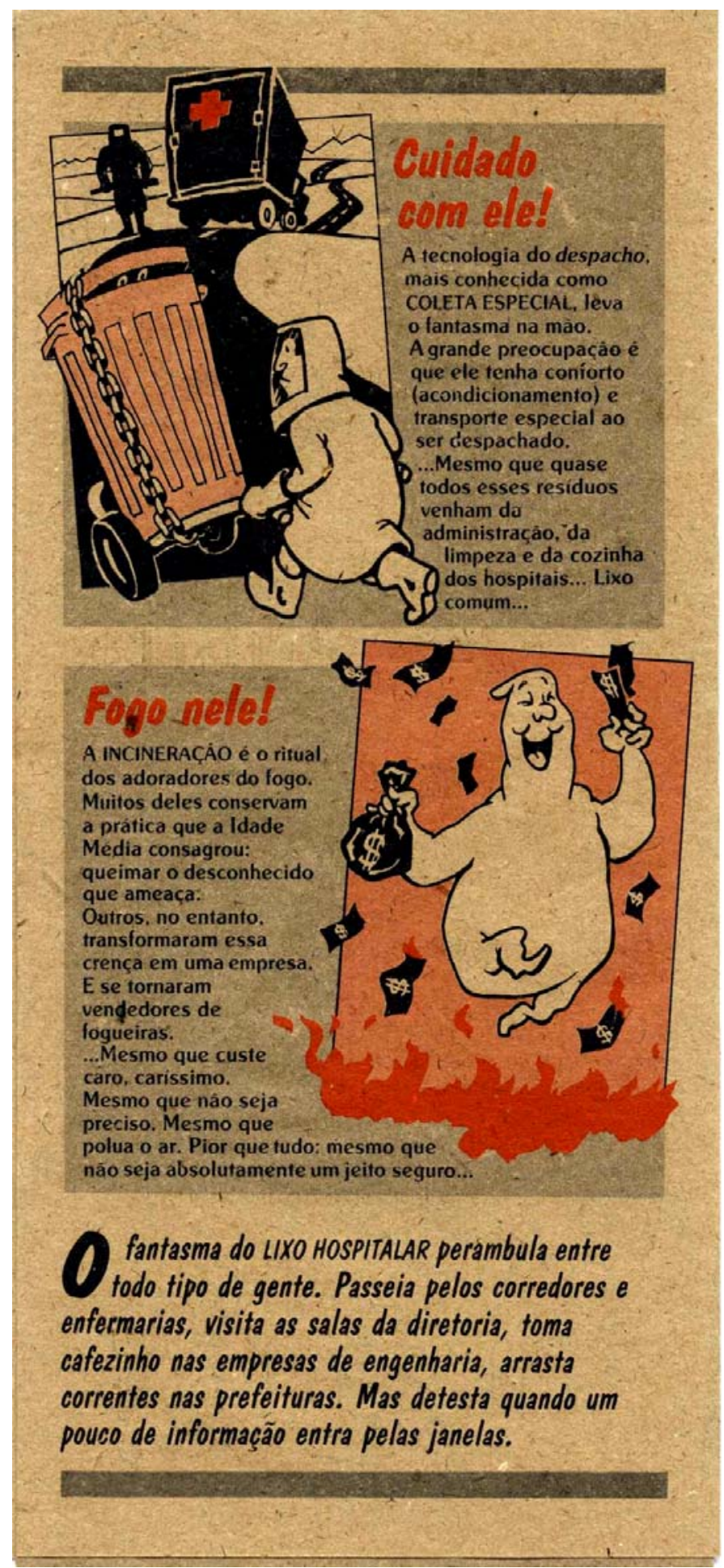

FIGURA 25 - O Fantasma da Incineração, Mito ou Realidade? : Foi com este enfoque que a campanha

${ }^{65}$ Podemos ler no Antigo Testamento: "Fora do acampamento, terás lugar onde te possas retirar para as necessidades. Tu levarás no equipamento uma pá para fazer as necessidades. Antes de voltar, cobrirás os excrementos" (Deuteronômio 23: 13-14). 
de esclarecimento datada de 1991, promovida Prefeitura Municipal de Vitória (ES) durante a gestão de Victor Buaiz (PT), trabalhou a questão do lixo hospitalar junto à sociedade civil. $O$ folheto reproduzido acima foi um dos materiais utilizados na campanha (Fonte: Secretaria do Meio Ambiente da Prefeitura Municipal de Vitória, 1991). 
(Vide NBR-1073/89). Há estimativas que apontam para a existência de 12.000 lixões a céu aberto espalhados pelo país (JURAS, 2000:4).

O geógrafo Pompeu Figueiredo de CARVALHO destaca a utilização dominante dos chamados "lixões", "promovidos e permitidos pelas administrações municipais, além dos depósitos ditos clandestinos, às vezes acusados pela ineficácia dos serviços de coleta" (2003:29). Indiscutivelmente, estes espaços constituem origem de nefasta série de impactos negativos para a sociedade e o meio ambiente na maioria dos municípios brasileiros: "muitos destes lixões estão em áreas alagadiças ou nas fronteiras d'água. É comum o uso de nascentes, ampliadas em vagas recessivas de erosão, causadas pela urbanização, como solução para os entulhos" (idem, 2003:29).

Estes problemas não constituem exclusividade dos "lixões", estando também presentes nos chamados aterros controlados. Considerados uma "versão melhorada" da prática anterior, a diferença é que o lixo recebe uma cobertura diária de material inerte, geralmente entulho ou solo retirado das proximidades. Mas, esta medida não estanca o vazamento do chorume, nem do metano. Da mesma forma que nos aterros comuns, o chorume infiltra-se no solo ou então, escoa diretamente para os corpos líquidos. Outra consideração cabível é a questão das emissões de metano, gerado pela decomposição dos resíduos. Gás inflamável e passível - quando em concentração entre 5 e 15\% no ar - de combustão espontânea, o metano constitui um poderoso agente do efeito estufa, cerca de vinte vezes mais potente que o $\mathrm{CO}^{2}$. Em resumo, os lixões e os aterros controlados, não dão conta de nenhum dos problemas ambientais gerados pelo lixo.

Os aterros sanitários, mesmo não constituindo a solução ideal, configuram um encaminhamento bem mais adequado que os dois anteriores. Fundamentados em critérios de engenharia e contando com amplo cabedal de pré-condições técnicas, ao menos em princípio nos aterros sanitários os resíduos permanecem confinados de modo seguro, assegurando-se a proteção do meio ambiente. Ao final de sua vida útil, estando estabilizados os processos de decomposição da matéria orgânica e finalizada a acomodação das camadas de terra e dos 
recalques, as áreas destinadas aos aterros podem atender outros usos, recepcionando equipamentos urbanos. Recorde-se que a implantação dos aterros sanitários requer a realização prévia de Estudos de Impacto Ambiental (EIA), objetivando avaliar as características geotécnicas da área, prevendo igualmente a proteção do subsolo e o controle das emissões do gás metano e do chorume (A respeito da drenagem de gases e percolados, vide SCHALCH, LEITE e GOMES, 1990:81/85 e CEMPRE, 2000:284/285).

É importante refletir que os aterros, por mais bem administrados que sejam, fazem parte de um pacote de medidas, não excluindo de modo algum utilização de outras tecnologias ou métodos de disposição final. Para as grandes cidades,

...é necessário, não mais apenas um aterro sanitário bem planejado, bem projetado e bem localizado. Não se pode prescindir da coleta seletiva para aumentar a vida útil dos aterros. É necessário também incorporar as usinas de tratamento e beneficiamento de lixo, incluindo os diversos componentes, destacando a compostagem orgânica e a reciclagem dos entulhos, em grande parte oriundos da construção civil. Somente assim os cursos d'água poderão deixar de ser repositório do lixo urbano (CARVALHO, 2003:29).

Por fim, advirta-se que apesar do rigor técnico sugerido pelo modelo, os aterros sanitários incorporam diversos questionamentos, como a utilização de vastas áreas de terreno, além de implicarem em investimentos consideráveis para enterrar matéria prima, um contra-senso evidente. Englobados, numa perspectiva geológica como "depósitos tecnogênicos construídos", os aterros podem apresentar situações de acidentes potenciais como escorregamentos, recalques, trincamentos e rupturas (Vide PELOGGIA, 1998:129/136). Por fim, que este equipamento, estando sujeito à falhas operacionais, pode também redundar em vários outros acidentes impactos ambientais, como 0 transbordamento do chorume, sua infiltração no solo e escapamento de gases.

Restaria, por conta do que foi colocado, reservar comentários mais substanciosos para a questão da otimização, parcimônia e do reaproveitamento dos materiais. Este discernimento nos conduz diretamente à discussão da Coleta 
Seletiva de Lixo, prática advogada como possível solução para a questão dos resíduos sólidos.

A problematização desta forma de gestão, uma proposta inserida num debate bem mais amplo, é que estará em debate a partir dos próximos parágrafos.

\subsection{RePensando os Resíduos Sóli dos Domi Cili AReS}

O volume de lixo gerado no mundo atual e os impactos por ele provocados no ambiente influenciaram uma série de especulações por parte dos especialistas em resíduos sólidos. Nesta senda, a própria conotação técnica do que é entendido como lixo terminou colocada sob questionamento. Conforme foi observado, o lixo incorpora amplo rol de estereotipias ${ }^{66}$ negativas, permitindo evocar nesta discussão diversas ponderações de ordem cultural, social e ambiental.

Assinale-se que em princípio, não estaria reservado ao termo lixo um sentido a priori adjetivado. Etimologicamente, a palavra tem origem na língua latina, aparentemente decorrendo de lix, significando cinza ou lixívia. A lix associa-se o verbo lixare, reportando a polir, desbastar, arrancar o excedente. Por isso, uma vez retirado o supérfluo, a questão seria definir o destino do resíduo, isto é, do lixo. A partir desta noção, paulatinamente lixo passou a estar ligado ao universo semântico de sujeira, daquilo que não presta e que jogamos fora. Esta noção transparece na curiosa expressão estar se lixando para algo ou alguém, própria do português do Brasil. Em outras palavras, reserva-se aos que estão em dissintonia com um dado grupo social o que não se deseja ou não faz falta a ninguém.

De qualquer modo, registros históricos revelam uma convivência não muito conflituosa de diversas sociedades do passado com o lixo. Nos séculos XV e XVI, aos tempos do filósofo Erasmo de Roterdam, as cidades européias,

\footnotetext{
${ }^{66}$ O termo estereotipia procede do grego estéreo, que significa sólido. A estereotipia corresponde ao um contexto psicológico pelo qual a repetição constante de um conceito engendra sua "solidificação", isto é, sua integração ao mundo real.
} 
...não possuindo as casas esgotos, nem existindo o serviço de lixo ou limpeza pública, as imundícies eram, à noite, atiradas nas ruas, sendo impossível dar-se um passo sem encontrar algo muito desagradável (LINS, 1967:72).

Ademais, qualquer veredicto apontando a inexistência de serviços de coleta no mundo moderno, neste incluindo as cidades européias nascidas com o advento da economia de mercado, poderia ser subscrito com certa tranqüilidade (PONTING, 1995:562/564).

Evidentemente, é possível identificar no antigo mundo tradicional várias definições desqualificantes relacionadas com os resíduos. Nesta ordem de considerações, recorde-se que a palavra hebraica para inferno, gehinom, refere-se a um antigo vale próximo de Jerusalém no qual o lixo era acumulado e queimado. Porém, isto não significa que o mundo tradicional esposasse uma visão totalizante julgando os resíduos enquanto matéria imprestável ou poluente. Aliás, a percepção do que pode ou não integrar o mundo das substâncias com as quais se admite algum tipo de convivência não se fundamenta unicamente em normas objetivas, mas fundamentalmente, em critérios de mote cultural.

Não fosse assim, não existiriam divergências quanto à proximidade socialmente permitida para com o que seria considerado nefasto ou impróprio de convívio com os humanos, uma acepção que se estende dos mais simples atos culinários até os dejetos animais e humanos. Por exemplo, assinale-se que em muitas civilizações antigas as fezes humanas eram intensamente utilizadas na agricultura $^{67}$. No extremo oriente, tal como expressamente colocado por várias visões religiosas (como o Budismo), a matéria fecal é considerada como um recurso, ao invés de um refugo, sendo freqüente sua utilização como fertilizante (Ver a respeito, WARNER, 2000:38).

Do modo como se pretende calçar esta discussão, as transformações que se processaram na forma como a sociedade contemporânea (ou ao menos parte desta) passou a perceber tanto a geração, quanto a gestão do lixo, constitui aspecto primordial. Neste plano de discussões, estas se inscrevem enquanto

${ }^{67}$ A palavra fezes não evoca significado negativo em si: ela é oriunda do latim faex, significando lama ou sedimento. 
condição sine qua non para a consolidação do substrato que pavimenta o surgimento de novos ordenamentos teóricos, impregnando o corpo conceitual e as prioridades concretas suscitadas pelo conhecimento científico para com os resíduos sólidos. Justamente esta evidência é que permite compreender o motivo de debates contumazes, como os que perpassam, por exemplo, a respeito do sentido de palavras como lixo e resíduo.

Quanto a este ponto, qualquer sinopse revelaria que no dia-a-dia, ambos os termos são utilizados indistintamente. Porém, esta atitude tem sofrido mudanças graduais. De tal sorte, embora nada obste a menção coloquial ou utilização eventual da palavra lixo, um claro elemento motivador para a opção pela terminologia resíduos sólidos reside no fato de que este termo, contrariamente à palavra lixo, exclui adjetivação negativa. No geral, considera-se que resíduos sólidos configuram uma expressão muito mais adequada para o contexto das novas estratégias de relacionamento com os bens materiais e o seu descarte, e de fato, a terminologia goza de clara preferência nos círculos de especialistas, que evitam a utilização da expressão lixo.

A conceituação de resíduos sólidos, além de preferível em função de borrar os estereótipos culturais que rondam o "lixo", é mais apropriada para assuntos como, por exemplo, a reciclagem. É bom recordar que o trato dos resíduos domésticos, em face da presença de metais, plásticos, vidros, papéis e de farta matéria orgânica, habilita a aplicação da reciclagem em larga escala. Mas não só neste caso. Vários itens dos resíduos industriais, dos resíduos inertes e mesmo de alguns que integram a categoria dos resíduos especiais, também poderiam ser reciclados. Enfim, largas proporções de matérias até poucas décadas atrás julgadas "inúteis", são agora objeto de releitura conceitual e produtiva. Nesta linha de argumentação, a cultura do lixo deveria desaparecer para ceder lugar à cultura dos resíduos sólidos, matéria prima digna de reaproveitamento (DIAS, 2002a:75).

Outro ponto importante é que as abordagens mais contemporâneas sobre a questão dos resíduos centram suas atenções muito mais na geração dos resíduos do que no lixo em si mesmo. Em outras palavras, busca-se focar a questão dos resíduos antes e não depois da lata de lixo. Desvendando singularidades técnicas, 
sociais, econômicas, políticas e culturais que levam ao descarte de materiais, tais perspectivas subsidiam estratégias de diminuição e otimização do uso dos recursos naturais, diferindo dos enfoques tradicionais, que priorizavam a questão do encaminhamento dos resíduos já gerados. Nesta ótica, a gestão dos resíduos seria sumamente uma questão de procedimento, e não de investimento.

Foi a preocupação com a diminuição da produção dos resíduos e a minimização do descarte que justificou a receptividade, a partir dos anos 80 do século passado, da proposição dos chamados três "Rs", abreviatura que corresponde em igual número de posturas iniciadas com a letra "R". Estas corresponderiam a $R$ de Reduzir, $R$ de Reutilizar e $R$ de Reciclar. Nos últimos anos, agregou-se um quarto $R$, o de Repensar, instado ao primeiro posto da seqüência. Assinale-se que os quatro "Rs" formam uma sucessão que obedece a uma hierarquia de posicionamentos, iniciando-se com a revisão do modelo de vida existente (Repensar), seguido, na ordem de disposição, dos demais procedimentos. É importante registrar que tal metodologia, embora tenha conquistado visibilidade principalmente com a atuação dos especialistas em RSD, não exclui aplicabilidade para outras classes de resíduos e tampouco, para temáticas como a água e a energia.

Das quatro atitudes citadas, a que conquistou maior notoriedade social foi indiscutivelmente a reciclagem. A reciclagem consistiria no "resultado de uma série de atividades, pela qual materiais que se tornariam lixo, ou estão no lixo, são desviados, coletados, separados e processados para serem usados como matéria-prima na manufatura de novos produtos" (CEMPRE, 2000:81). Conseqüentemente, do ponto de vista do reaproveitamento de recursos, lixo propriamente não existiria. Este seria apenas a coisa certa colocada no lugar errado. A reciclagem cabe ressaltar, tornou-se uma atividade empresarial de grande porte, mobilizando enormes recursos financeiros e dotada atualmente de uma formidável engenharia de processamento e circuitos econômicos que consolidam sua atuação, em especial nos grandes centros urbanos (Vide LEGASPE, 1996:123/160). 
A popularidade conquistada pela reciclagem é em parte resultante da intensa pregação ambientalista em favor da CSL. De fato, a recuperação de materiais descartados implica em menor ônus para o meio ambiente, economia de energia e preservação dos recursos naturais. Não seria demasiado repetir, o custo dos serviços de limpeza são altos e extremamente onerosos para a sociedade, ônus que pode ser minimizado pela própria diminuição do volume de lixo a ser retirado das ruas. Além disso, o reaproveitamento dos materiais diminui a quantidade de resíduos destinada aos aterros, aumentando sua vida útil e evitando a ocupação de novas áreas para esta finalidade, aliás, cada vez mais escassas na maioria das regiões urbanizadas (Vide CEMPRE, 2000:79/86, GRIMBERG, 2002 e CALDERONI, 2003).

Também mereceria destaque a atuação dos catadores, que ao longo das últimas décadas tornaram-se parte integrante do cenário urbano das cidades brasileiras. Os catadores, numa apreciação sintética,

...são profissionais que não tem carteira assinada, são mal reconhecidos, estão desorganizados na quase totalidade das cidades nas quais atuam e, no entanto, alimentam poderosos setores industriais com matéria-prima barata, aliviando os custos da limpeza pública com cada tonelada de materiais que retiram das ruas (WALDMAN e SCHNEIDER, 2000:124).

A categoria, conhecida com o concurso de diversas outras definições, como garrafeiro, carrinheiro, aparista e sucateiro ${ }^{68}$, mobiliza na atualidade cerca de 300.000 pessoas em todo o país. Este contingente que tem sido alavancado pela crise econômica, cujo teatro preferencial é, por definição, os grandes centros urbanos. Sua visibilidade no cenário urbano tornou-se muito expressiva na última década, resultando na formação de cooperativas e na consolidação de um movimento nacional de catadores. A catação de materiais recicláveis passou a constituir, em alguns contextos, uma das últimas alternativas disponíveis de geração de renda para a população excluída. Neste sentido, a consolidação dos movimentos de catadores não pode ser restrita enquanto evidência objetiva das 
potencialidades inerentes à reciclagem, mas igualmente, das formas que a população excluída tem encontrado para afirmar sua sobrevivência e porque não, sua identidade enquanto cidadão ${ }^{69}$.

Um aspecto bastante pertinente é que a reciclagem pressupõe, dado entrelaçar-se com as práticas do cotidiano, um vínculo real com a conservação da natureza. O exercício da reciclagem pode constituir um momento de tomada de consciência ecológica, pelo que iniciativas norteadas pela preocupação com a recuperação dos materiais inserem aspecto pedagógico indiscutível, facilmente incorporáveis nos programas de educação ambiental. Ao buscar uma finalidade ambientalmente correta em cada atitude que estiver adotando no seu cotidiano, o cidadão comum poderia tomar conhecimento de outras questões ainda mais complexas, e desta forma posicionar-se de modo mais crítico, construtivo e participante.

No entanto, o entusiasmo pela reciclagem deve ser arrefecido com uma série de reparos técnicos, sociais, econômicos e políticos. Esta recomendação corre no sentido de permitir que o papel da reciclagem em termos da conservação da natureza e do gerenciamento dos resíduos possa ser mais bem avaliado, assim como o seu lugar numa estratégia mais ampla de conservação dos recursos hídricos. Incorporar a reciclagem de modo acrítico pode suscitar vários equívocos, dos quais não se dissocia inclusive a manipulação ideológica. Como sentenciou o geógrafo Luciano LEGASPE, "não podemos cair no erro de enfocar o lixo e a indústria da reciclagem sem manipularmos o arsenal publicitário que subsidia todo o comércio atrelado à indústria" (1996:123).

Nos últimos anos, os avanços da chamada "conscientização ecológica" de setores do empresariado pouco teriam a ver com a preocupação pelo equilíbrio ambiental. Basicamente, a adoção de políticas de preservação por parte das empresas obedece tanto pressões utilitárias, da sociedade e do mercado

\footnotetext{
${ }^{68}$ Note-se que os termos, a despeito de serem tomados como sinônimos, são relacionados a atividades específicas: carrinheiro é quem retira os resíduos das ruas e das residências, sucateiro e aparista, quem armazena e vende, etc.

${ }^{69}$ A psicóloga Marina DURAN, em uma apreciação sobre os catadores, recorda que no trajeto diário destes homens pelas grandes cidades, "além de um cachorro a os acompanhar, não é raro
} 
internacional, quanto a estratégias de puro marketing. Na argumentação da socióloga e economista Raquel da Silva PEREIRA,

...as bandeiras ecológicas levantadas por empresas agregam simpatia às que se apóiam no marketing ecológico para atribuir força as suas marcas e à sua imagem institucional. No Brasil, o mercado potencial para produtos com apelo ecológico está em grande crescimento (2002:66).

Neste sentido, é preciso incitar o comentário de que a reciclagem, além de não se contrapor à dinâmica geral do sistema capitalista, pelo contrário contribui para sua reprodução em um outro patamar, agora inserida numa lógica "sustentável" e "ecológica", quando não, dando materialidade ao que algumas correntes denominam como capitalismo verde ou, eco-capitalismo. Por isso mesmo, a forte expansão da reciclagem a partir das últimas décadas do século passado nada mais expressaria, num certo sentido, do que a confirmação de um julgamento pelo qual, esta prática se prenderia de modo metafórico à uma "fantasia do eco-capitalismo" (LEGASPE, 1996).

Assim caberia primeiramente identificar o alcance e as potencialidades de aproveitamento dos materiais. Recorde-se que no geral, a reciclagem está praticamente voltada para cinco itens básicos da fração seca: vidros, papéis, plásticos, aço e alumínio. O fato de existir valorização destes componentes da fração seca decorre, em última análise, do fato destes materiais incorporarem maior valor agregado. Seria exatamente esta a nuança que capacita estes materiais a serem prioritariamente inseridos no circuito da reciclagem, uma atividade com clara expressão empresarial. A partir de uma clarividente sentença emanada pelo mundo empresarial, podemos conferir:

Deve ficar claro que a possibilidade de reciclar materiais só existe se houver demanda por produtos gerados pelo processamento destes (...) A análise do mercado de recicláveis, principalmente da região, ditará quais os produtos do lixo que poderão ser reciclados industrialmente (CEMPRE, 2000:81).

encontrar uma bandeirinha do Brasil arranjada em algum lugar da carroça junto aos objetos recolhidos" (2005:188). 
Deste modo, a fundamentação que justificaria a classificação dos RSD em fração inorgânica, orgânica e em rejeitos, das quais somente a primeira destas (a fração seca) é rubricada como reciclável, reclama alguns esclarecimentos adicionais. Particularmente, deve-se colocar em cheque a sinonímia que iguala fração seca com reciclagem, um equívoco que induz um claro reducionismo conceitual. Recorde-se de que o próprio termo reciclagem implica na retomada de um ciclo, tornando o conceito aplicável para diversos contextos. Neste particular, a fração orgânica dos RSD, ao ser constituída de substâncias que podem retornar ao meio natural através da compostagem, seria merecedora de inclusão na categoria dos recicláveis, interesse ou não esta atividade para o mercado reciclador.

Mas, o que de fato interessa ressalvar, além das críticas absolutamente cabíveis quanto aos intuitos não propriamente "ambientalistas" da indústria da reciclagem (o que não nega seus méritos em termos da minimização da geração de resíduos e de integrar uma estratégia geral de conservação da natureza), é que, na realidade, melhor do que reciclar resíduos impõe-se com maior rigor a necessidade de diminuir a geração de lixo. Não por outra razão a reciclagem é a última das quatro atitudes iniciadas com a letra "R". Basta retomar a sucessão pela qual antes de reciclar teríamos Repensar, Reduzir, Reutilizar. Somente antecedida destas três colocações é que Reciclar faria sentido.

Este na realidade constitui o aspecto fundamental para se pensar a associação dos recursos hídricos com os resíduos sólidos. Como vimos, os resíduos resultam do descarte de bens que implicaram em considerável input hídrico para serem produzidos. Além disso, impactam o meio ambiente por intermédio das cargas difusas e pelo descarte inadequado. Portanto, será através da discussão do uso racional dos recursos, aqui entendido numa ótica em que $o$ repensar está priorizado, que o debate sobre os recursos hídricos pode ser enfocado com mais clareza e intensidade.

Por isso mesmo, a fração úmida conquistaria relevo especial. Até porque, consumindo parte substancial dos recursos hídricos, dificilmente poderíamos 
conceber uma política eficiente dos recursos hídricos sem o concurso de analisála criticamente nos seus rebatimentos quanto à questão dos resíduos sólidos.

\subsection{Recursos Hídricos, Fração Orgâni Ca e Reci clagem}

Normalmente a discussão relacionada com a conservação dos recursos hídricos utiliza a imagem da torneira doméstica, da mangueira ou do chuveiro. Tais imagens, efusivamente transmitidas e retransmitidas pela mídia, induzem à conclusão de que basta fechar as torneiras para se resolver a questão da escassez da água, raciocínio este, indiscutivelmente incorreto.

Criticando esta postura, o Seminário Abastecimento de Água na MacroRegião de São Paulo: Perspectivas a Curto, Médio e Longo Prazo, promovido pela Associação Brasileira de Engenharia Sanitária e Ambiental (ABES), realizado em São Paulo (20/21-11-2003), ponderou dentre suas resoluções finais, que "além dos tradicionais apelos anuais à população para que economize (água), algo mais concreto deve ser feito" ${ }^{70}$.

Este apelo sugere pensar que existem outras formas de desperdício de água que apesar de menos "cinematográficas", nem por isso poderiam estar ausentes da reflexão a respeito do problema. Um argumento expressivo é que a agropecuária consome em média 70\% dos recursos hídricos mundiais. Portanto, avaliar a questão do desperdício de alimentos transforma-se em um dado importância capital. Já foi explicitado nos capítulos anteriores os vínculos que associam a produção de alimentos com os recursos hídricos no referente ao estágio da sua produção. Resta, pois, avaliar os impactos provocados com o seu descarte.

Refletindo primeiramente com base na informação de que os resíduos orgânicos representam, em média, algo como $60 \%$ do lixo brasileiro, a metáfora da montanha de alimentos desperdiçados seria, infelizmente, muito mais do que

\footnotetext{
${ }^{70}$ ABES Informa, edição de Novembro/Dezembro de 2003, página 10.
} 
mera figura de linguagem. Nesta perspectiva, atente-se preliminarmente para os números a seguir, coletados do artigo O Desperdício em Números, publicado no Boletim do CEMPRE ${ }^{71}$ - Compromisso Empresarial para a Reciclagem:

- O Ministério da Agricultura do Brasil estima que cerca de 14 bilhões de toneladas de alimentos são perdidos anualmente.

- Cálculos do Instituto Brasileiro de Análise Sócio-econômica (IBASE), demonstram que o brasileiro desperdiça uma verdadeira fortuna em frutas, verduras, legumes e outros alimentos perecíveis. Percentualmente, as laranjas registram perda de $10 \%$ a $15 \%$; hortaliças e pimentões 30\%; grãos, 31\%; arroz, 21\%; carne de frango, 25\%; tubérculos, 15,8\%; leite, 75\%;

- No caso das bananas, contando com a perda na estocagem e na exposição para a venda, o varejista oferece $1,66 \mathrm{~kg}$ para cada quilo vendido, que somado à perda de $20 \%$ na produção, responde pelo incrível desperdício de quase $60 \%$ da produção;

- Outros $20 \%$ de milho, soja e feijão estragam por erros na operação das máquinas agrícolas nos armazéns. Verifica-se o apodrecimento dos grãos devido ao excesso de umidade e por estarem acondicionados em sacos e outras embalagens impróprias;

- Por falta de informação, donas de casa descartam $20 \%$ de certos alimentos, como cascas e folhas, de alto poder nutritivo;

- As embalagens mal projetadas são responsáveis por $30 \%$ das indenizações de seguros no transporte rodoviário;

\footnotetext{
${ }^{71}$ Edição no 39, Maio/Junho de 1998, página 3.
} 
- O brasileiro deixa no restaurante $20 \%$ da comida que pede;

Estas estatísticas estonteantes são ombreadas pela averiguação de que o Brasil desperdiça cerca de 14 milhões de toneladas de alimentos por ano. Isto num país no qual 44 milhões de pessoas vivem abaixo da linha de pobreza e onde uma em cada quatro crianças é vulnerável à fome (GRIMBERG, 2002). De forma inequívoca, o tema do desperdício de alimentos torna-se uma questão de interesse obrigatório para o conjunto da sociedade brasileira, seus governantes, seus partidos políticos, seus cientistas e para os homens do povo em geral.

Os efeitos do descarte inadequado dos resíduos domésticos tornam-se ampliados quando se sabe que estes, no geral, não encontram destinação tecnicamente correta, sendo na maior parte dos casos despejados no curso dos rios, lagos e córregos, ou então, seguindo para os lixões ou para os aterros ditos controlados. Conseqüentemente, o gigantesco volume de alimentos descartados transforma-se em um elemento adicional no ciclo de impactos que atingem os recursos hídricos. Grande parte desta imensa massa de matéria orgânica, sendo disposta inadequadamente no ambiente e entrando em decomposição, provoca a proliferação de vetores de inúmeras doenças, tais como ratos, baratas, moscas e outros insetos.

Pior ainda, a degradação da fração orgânica do lixo constitui uma prodigiosa fonte geradora de chorume, fluído também designado como sumeiro, chumeiro, calda negra, líquido percolado. O chorume constituiria, ao lado do plutônio e da dioxina, uma das substâncias mais nocivas para o meio ambiente. Resultante da decomposição da fração úmida e agregando variados elementos biologicamente comprometedores dos equilíbrios ambientais, este efluente é um líquido escuro, ácido, com alta concentração de matéria orgânica, possuindo reduzida biodegradabilidade e elevada DBO, aproximadamente de 30 a 100 vezes maior do que a do esgoto. Para completar, a calda negra é rica em metais pesados ${ }^{72}$.

O estudo da gênese e dos efeitos do chorume tem suscitado muitas tentativas de enquadramento conceitual. Nos últimos anos, a literatura científica 
tem utilizado o termo "lixiviado" para referir-se a este efluente. Transitando em inúmeros seminários e debates relacionados com a questão dos resíduos sólidos, a nova terminologia tem por pretensão uma configuração etimológica mais científica dos que os termos precedentes, ou seja, calda negra, chorume e percolado. No caso, o termo proposto ressalta o processo de "lavagem" dos resíduos depositados nos aterros, pois o líquido inclui variado leque de substâncias, todas originárias dos processos de circulação dos líquidos na massa de resíduos, incorporando contribuições da fração orgânica e da inorgânica.

Mas, seja qual for a denominação que se venha a utilizar, o chorume é, em suma, uma substância perigosamente poluidora, sendo responsabilizada pela contaminação de vastas extensões de solo, tornando-os estéreis e inúteis para a agricultura. Outro alvo notório deste efluente tem sido os corpos líquidos. A imprensa tem divulgado ocorrências repetidas de reservatórios de água potável transformados na foz de fluxos da calda negra, com graves conseqüências para o abastecimento. Outra informação refere-se à sua infiltração, atingindo as águas subterrâneas e comprometendo sua qualidade (Vide OLIVEIRA e PASCAL, 2004). Esta seria, aliás, uma das grandes ameaças que podem afetar o aqüífero Guarani ou Mercosul. Ao que tudo indica, este reservatório foi contaminado em vários pontos pela carga de chorume, afetando um patrimônio de indiscutível importância para o conjunto do país e para a nacionalidade (Vide UNPP/BR, 2000 e também MISLEH, 2005).

Pode se ver assim que a questão da produção de alimentos e dos recursos hídricos se entrelaça (e como podemos notar, de modo perverso em muitas ocasiões), com a do gerenciamento dos resíduos sólidos. É o que ocorre em especial nos grandes centros urbanos, concretamente responsáveis pela geração da fração mais significativa de resíduos. Evidentemente existem diversas indicações visando minimizar ou solucionar o problema da fração orgânica do lixo. Incluindo toda sorte de substâncias como restos de alimentos e materiais orgânicos em geral, não seria por falta de alternativas que os problemas da fração úmida do lixo domiciliar poderiam ser pelo menos atenuados.

72 Informações técnicas mais minuciosas sobre o chorume estão disponíveis in CEMPRE 
Além de medidas visando melhorar o aproveitamento dos alimentos, revendo hábitos e valores culturais quanto às verduras, talos, sementes, cascas de frutas e de ovos, todos capacitados a serem plenamente utilizados e garantindo uma alimentação, inclusive, mais saudável e nutritiva, alternativas bastante conhecidas reportariam às técnicas de compostagem. Processos ditos domésticos ou mesmo artesanais, capacitados a transformar a fração orgânica dos RSD em um recompositor de solos, podem ser lembrados mais uma vez. Estando ao alcance do cidadão comum e de qualquer funcionário de limpeza, estes métodos podem ser aplicados em espaços como parques, canteiros e outros recantos arborizados ou ajardinados, requerendo basicamente capacitação e muito pouco (ou nada) do numerário público.

As usinas de compostagem (Fig. 26), constituem outra opção freqüentemente lembrada para solucionar o problema da fração orgânica dos resíduos sólidos. Estas instalações nada mais são do que uma tradução moderna de práticas ancestrais presentes nas concepções agrícolas mais longínquas, e nem por isso, menos eficientes. Para ser transformado em composto, o RSD é previamente triado em esteiras móveis, de modo a separar os materiais da fração seca (posteriormente vendidos para as indústrias de reciclagem), dos resíduos orgânicos. O material orgânico é a seguir colocado em biodigestores, nos quais por meio da ação dos microrganismos, obtém-se o composto orgânico, cuja utilização é muito difundida no meio rural (Ver a respeito, SCHALCH, LEITE e GOMES, 1990:87/121).

Todavia, nem sempre o produto obtido é de boa qualidade. O próprio fato dos resíduos serem encaminhados sem prévia separação para as usinas faz com que nem sempre a seleção seja eficiente. Assim, o composto pode apresentar fragmentos como cacos de vidro, metais, plásticos e pequenos objetos de todo o tipo. Além disso, pode ocorrer a presença de metais pesados e resíduos contaminados, devido ao descarte direto frascos de remédios, lâmpadas fluorescentes e de pilhas no lixo doméstico, procedimentos acintosamente inadequados que solicitam formas específicas de tratamento e de destinação final 
(Vide Fig. 27). Um complicador adicional pode advir do gerenciamento administrativo das usinas. Constituindo uma instalação de cunho verdadeiramente

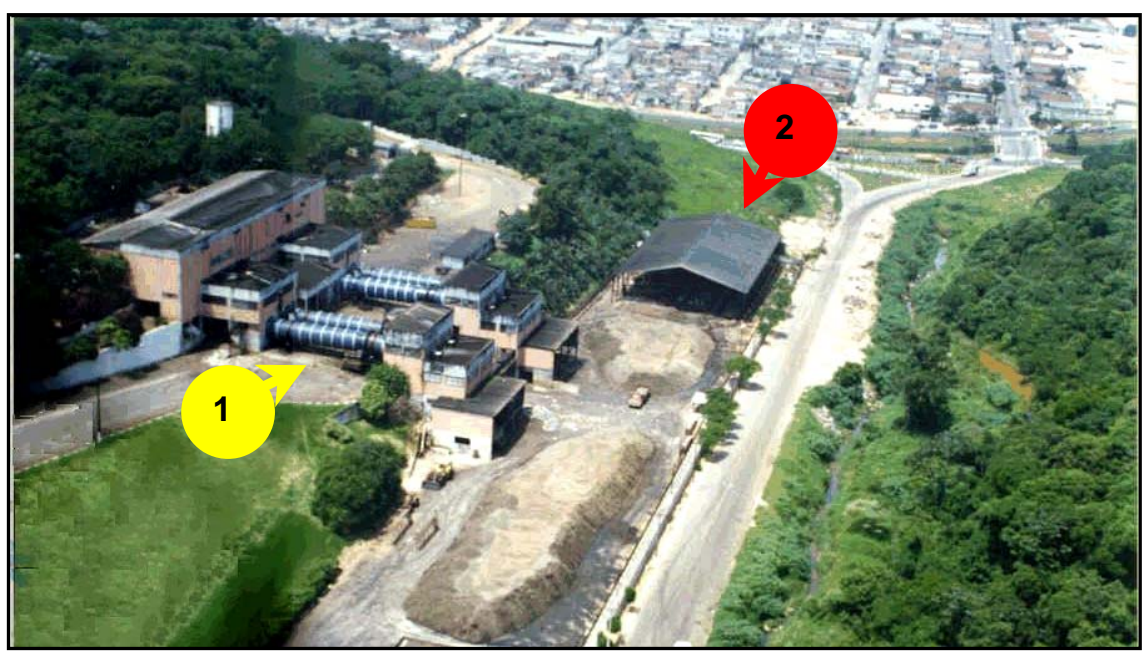

FIGURA 26 - Vista da Usina de Compostagem de São Mateus (São Paulo): localizada no interior de uma área de preservação ambiental na zona leste da capital paulista (a APA da Mata do Carmo), a instalação foi desativada na gestão Marta Suplicy (2001/2004), e atualmente a área abriga um projeto de educação ambiental. (Foto: Hemeroteca do LIMPURB, organizada por Dan Moche Schneider, LIMPURB, 2000).

Item 1) Biodigestores rotativos modelo Dano, desenvolvido nos anos cinqüenta. Este sistema opera com base em cilindros levemente inclinados de rotação lenta, no interior dos quais a fração úmida é introduzida.

Item 2) Galpão de cura do material retirado dos biodigestores, onde o composto é estabilizado. 


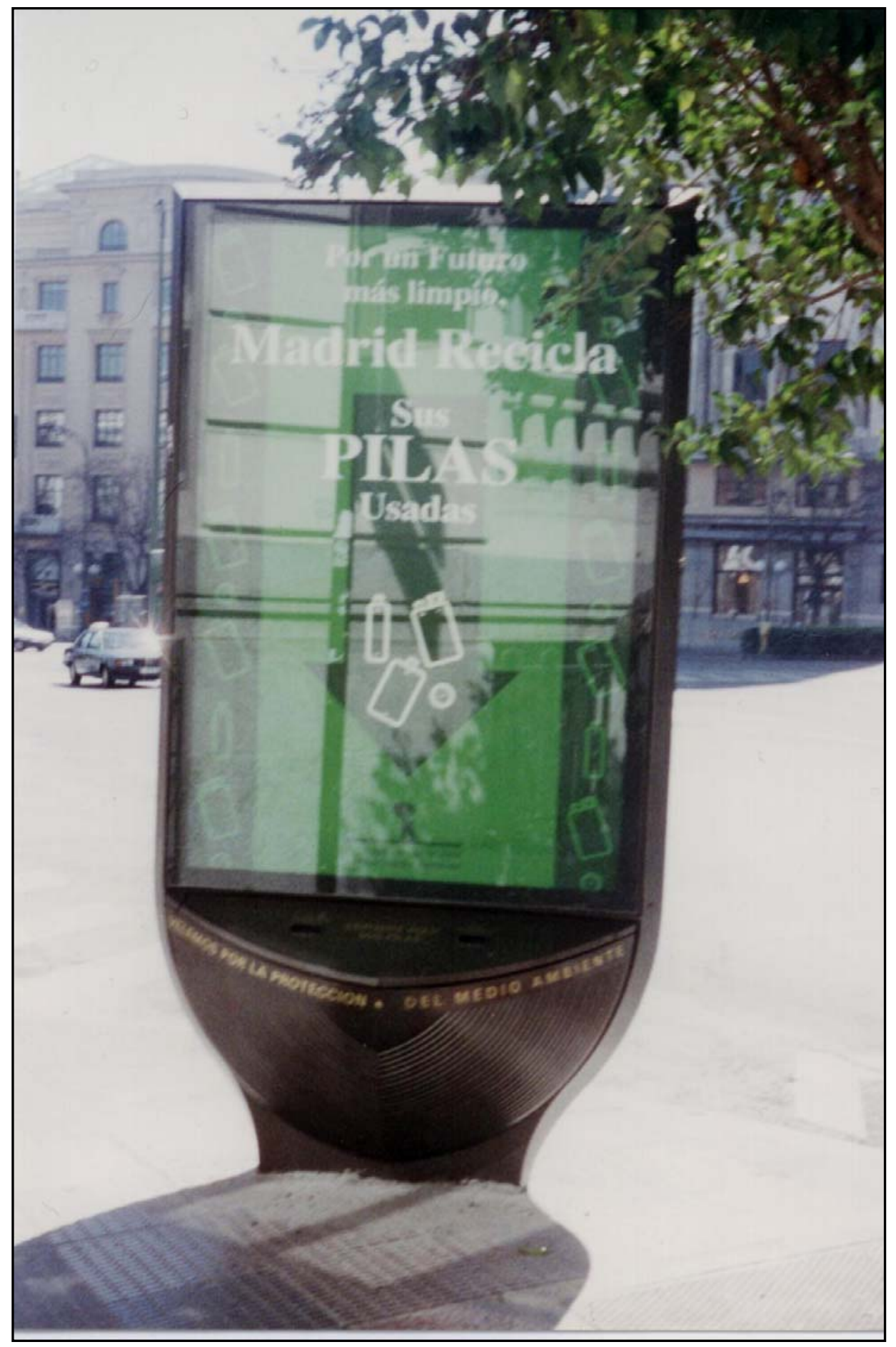

FIGURA 27 - Coletor de pilhas usadas em Madri: Visando diminuir o impacto dos metais pesados contidos nas pilhas nos recursos hídricos e ao ambiente em geral, a municipalidade de Madri plotou containers para coleta de pilhas como os da foto, dispostos por toda a área central da capital espanhola (Foto: Maurício Waldman, Abril de 1995). 
industrial, a capacitação gerencial e a qualificação do corpo técnico, lado a lado com manutenção freqüente do equipamento obviamente faz a diferença em quanto às características do composto obtido.

$\mathrm{Na}$ ausência das usinas de compostagem, uma outra solução residiria no encaminhamento dos resíduos para os aterros sanitários. Foi observado anteriormente, os aterros sanitários constituem uma instalação voltada para a disposição final dos RSD no solo, processo este fundamentado em critérios de engenharia e normas operacionais específicas, permitindo uma confinação em tese segura em termos de controle da poluição ambiental e proteção ao meio ambiente. Ao menos em princípio, num aterro sanitário o chorume é contido por um sistema de impermeabilização e coletado por um sistema de drenagem e encaminhado para lagoas de estabilização, evitando a contaminação do solo e dos lençóis freáticos (Fig. 28). Além do monitoramento dos efluentes líquidos (o chorume), também se pratica o acompanhamento da emissão dos efluentes gasosos (metano).

No entanto a realidade é, em muitas situações, infelizmente outra. Os aterros solicitam gerenciamento técnico sério, competente e contínuo, pré-condições que não necessariamente possuem solução de continuidade na vida política e administrativa brasileira ${ }^{73}$. O problema fica agravado pela própria dificuldade de monitorar a continua proliferação do lixiviado. Assim, a migração do chorume para fora do aterro, afetando águas superficiais e subterrâneas por conta do mau gerenciamento é necessariamente uma possibilidade real, problema que pode se verificar inclusive nos aterros tecnicamente bem gerenciados. Além disso, não se deve esquecer que os aterros mantêm a geração de metano e chorume por várias décadas após o esgotamento da sua capacidade, período no qual demandam cuidadoso acompanhamento.

Evidentemente, quanto maior a dimensão do aterro, tanto mais ampliado será o problema. A título de exemplo, o aterro São João, considerado de grande porte,

${ }^{73}$ Relativamente à situação dos aterros no Estado de São Paulo, vide Inventário dos Resíduos Sólidos 2002 (CETESB, 2002). 
localizado na capital paulista e ainda em operação ${ }^{74}$, gera 13 litros de chorume por segundo. Embora constitua uma emissão aparentemente

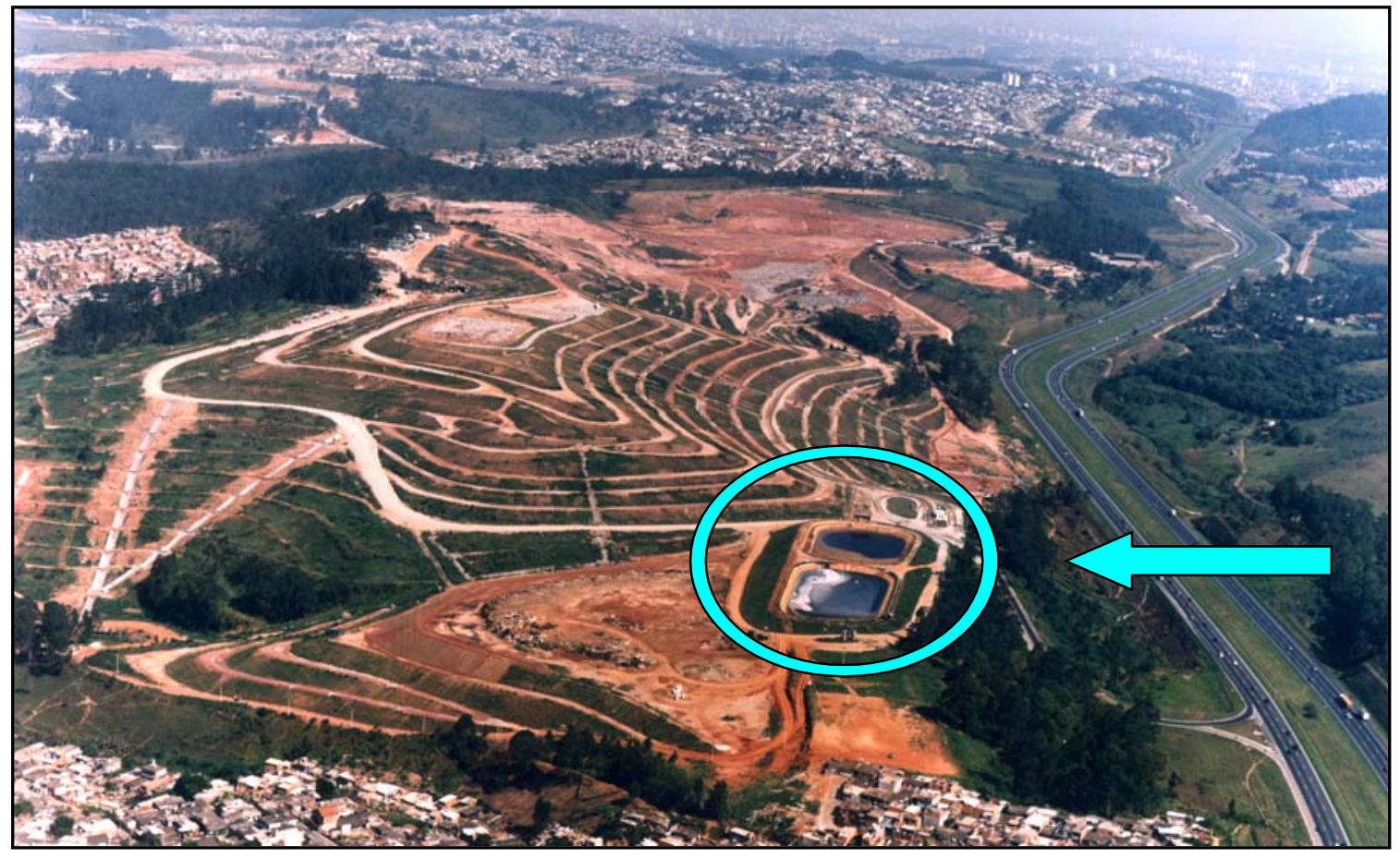

FIGURA 28 - O Aterro Bandeirantes (São Paulo): A foto registra uma vista aérea do Aterro Bandeirantes, na capital paulista, destacando no círculo azul as "lagoas canadenses", que recebem o chorume drenado da elevação à esquerda do sítio, formada por milhares de toneladas compactadas de lixo urbano (Foto: Imagens Históricas da Limpeza Pública, Dan Moche Schneider, LIMPURB, 2000).

${ }^{74}$ O Aterro São João entrou em operação em Dezembro de 1992. Sua área total é $456.000 \mathrm{~m}^{2}$ (45,60 ha), dispondo $200.000 \mathrm{~m}^{2}$ (20,00 ha) de área útil (CALDERONI, 2003:126, Ver também SANTOS, GRISELDIS e BITAR, 1995). 
insignificante, este volume significa 780 litros por minuto, 46.800 litros por hora e 1.123.200 litros por dia, algo como a capacidade de 11.230 caixas d'água por dia de percolado. E este, é apenas um dos inúmeros grandes aterros sanitários em funcionamento ou em processo de estabilização na região da RMSP.

Certamente existem questões ainda mais problemáticas, caso dos lixões, que constituem um notório expediente para a disposição final do lixo em quase $90 \%$ dos municípios brasileiros. Nestes locais, a matéria orgânica, como se viu, resultante de um extraordinário input de recursos hídricos captados do ambiente natural, tem como resultado final sua transformação em chorume. No que poderia compor um quadro orquestrado por uma sinfonia trágica, poucos poderiam em algum momento advogar a origem do percolado na captação de água de um regato límpido ou em uma tranqüila fonte campestre. Emblematicamente, o chorume parece simbolizar uma sucessão de maus tratos destinados à água, que se transforma assim no retrato da sociedade que o criou.

Nesta ordem de preocupações, as alternativas materializadas nas usinas de compostagem e nos aterros sanitários constituem paliativos e formas de atenuar o problema dos resíduos sólidos, mas não de resolvê-lo. Esta solução existirá unicamente com a implantação de uma sociedade praticante do respeito aos recursos naturais e do repúdio ao desperdício, premissas para cuja consecução deve concorrer, por sua vez, revisão das prioridades do sistema produtivo e a justiça social. Por conseguinte, a adoção do serviço de CSL certamente representa um paliativo importante, e ao lado desta, também a compostagem dos resíduos orgânicos.

Porém, certo também é que ambas não constituem a solução definitiva do problema. Conforme foi ressalvado em um outro momento deste texto, a verdadeira chave para solucionar o problema representado pelas verdadeiras montanhas de lixo é justamente não criá-las. E, para isto, é preciso, antes de tudo, Repensar o nosso padrão de vida, Reduzindo a nossa geração de Lixo e Reutilizar tudo o que for possível. 
Eis, com toda certeza, um modo de efetivamente pensar a questão dos recursos hídricos e, quiçá em futuro próximo, de aplicar uma gestão efetivamente poupadora de recursos hídricos.

\subsection{ReCURSOS HídRI COS, FraÇão I nORgÂNI CA e ReCI CLAGEM}

Neste trabalho, avalia-se que o lixo é acima de tudo um produto caro, ambientalmente oneroso e altamente impactante na ótica dos recursos hídricos. Adiante, procurar-se-á evidenciar os vínculos que associam a temática dos recursos hídricos à dos resíduos sólidos urbanos, enfatizando, no caso, no componente inorgânico ou seco do lixo urbano.

Apesar de raramente avaliados de modo articulado, caberia observar que as problemáticas dos recursos hídricos e da fração seca dos RSD compartilham interfaces inseparáveis nos mais diversos ângulos. É justamente esta visão de conjunto, consorciando ambas questões, que evidencia um quadro de comprometimentos ambientais muito mais profundo do que o explicitado quando as temáticas são analisadas em separado.

No referente ao reino das ações concretas, a proposição neste trabalho é que uma visão mais abrangente poderá atuar como um dado adicional para repaginar posturas e procedimentos, sinalizando para as possíveis soluções ou pelo menos, para a minimização dos problemas a serem enfrentados quanto ao binômio água e lixo. E, no caso brasileiro, a importância desta discussão poderia ser evidenciada pela própria participação da fração seca no conjunto dos RSD.

Respaldando esta observação, sabe-se que apesar de escassas, falhas e conflitantes, as estatísticas indicam que a fração inorgânica do lixo urbano corresponde a algo entre $20 \%$ e $30 \%$ do total dos resíduos domiciliares urbanos coletados no Brasil, porcentagem esta que aumenta ano a ano. O fenômeno se explica pela consolidação dos processos urbanos, matriz de novos hábitos de consumo, juntamente com os quais se afirmam as práticas contemporâneas de 
embalamento e distribuição. Conseqüentemente, a importância deste componente na massa total dos resíduos sólidos domiciliares gradativamente se amplia, alavancando a atuação de um setor voltado exclusivamente para a reciclagem dos materiais nele encontrados.

Paralelamente aos claros avanços da indústria recicladora, a argumentação relativa aos ganhos ambientais é recorrente na comunicação institucional difundida pelas empresas atuantes no setor. Indo direto ao ponto, é claro que esta informação procede. Sem contar a poupança das matérias primas, constata-se a redução da poluição, economia de energia (esta última vinculada intimamente com a água) e uma efetiva conservação dos recursos hídricos. Afinal, como revela a $A C V$, todas as etapas da produção envolvem um consumo de recursos hídricos e mesmo a "morte" do produto não significa o fim do seu relacionamento com a água. Nesta linha de raciocínio, seria possível apontar importantes benefícios ambientais.

Para começar temos a diminuição de um volumoso montante de materiais artificiais dispostos em um ambiente no qual dantes praticamente inexistiam, muitas vezes com óbvias implicações para com a preservação das águas. Exemplificando, para o caso do plástico os dados disponíveis informam que sua produção passou de 6 milhões de toneladas em 1960 (nos primórdios da introdução deste produto), para 27 milhões em 1970, 53 milhões em 1980, 93 milhões em 1990 e alcançando em 1994, a cifra de 110 milhões de toneladas (Cf CALDERONI, 2003:225). Confrontados com estes números e com a resistência que este material apresenta em termos da sua degradação no ambiente, não haveria como discordar que a reciclagem é bem vinda e inclusive, reclamada pelo mundo moderno. Isto, sem contar um inventário bem provido de dados significativos.

Com base em dados amealhados por um pool de empresas associadas à entidade CEMPRE (Compromisso Empresarial pela Reciclagem), como a ABAL (Associação Brasileira do Alumínio), ABIVIDRO (Associação Técnica Brasileira das Indústrias Automáticas de Vidro), ABEPET (Associação Brasileira dos Fabricantes de Embalagem de PET), BRACELPA (Associação Brasileira de 
Celulose e Papel), PLASTIVIDA (Instituto Sócio-Ambiental do Plástico), PROLATA (Programa de Valorização da Embalagem Metálica) e empresas recicladoras ${ }^{75}$, poderíamos destacar:

- Quando o aço é produzido inteiramente a partir da sucata, a economia de energia chega a $70 \%$ do que se gasta com a produção a base do minério de origem. Além disso, há uma redução da poluição do ar (menos $85 \%$ ) e do consumo de água (menos 76\%). São eliminados, ainda, todos os impactos decorrentes da atividade de mineração, que afetam a atmosfera, o solo e as bacias hidrográficas;

- O papel é feito tradicionalmente de fibras de vegetais. Para se produzir uma tonelada de papel, gastam-se quase 100 mil litros de água tratada, muita energia e mais de 50 árvores adultas. Quando se aproveita o papel já usado, os gastos são extremamente reduzidos: 2.000 litros de água tratada, economia de 50 a $80 \%$ de energia e o corte de 20 a 30 árvores adultas a menos. Além do mais, há uma sensível redução de materiais poluentes (gases e efluentes líquidos). Nas grandes cidades, recorde-se que quase $25 \%$ dos resíduos da fração seca é constituído por papel;

- O papel jornal produzido a partir das aparas requer $25 \%$ a $60 \%$ menos energia elétrica que a necessária para obter papel da polpa da madeira. O papel feito com material reciclado reduz em $74 \%$ os poluentes liberados no ar e em $35 \%$ os que são despejados na água, além de reduzir a necessidade de derrubar árvores;

- Na reciclagem do vidro é possível economizar, aproximadamente, 70\% de energia incorporada ao produto original e pelo menos 50\% de água.

\footnotetext{
${ }^{75}$ Informação presente na publicação Cempre Informa nº 59 (Setembro/Outubro de 2001).
} 
Os efeitos diretamente benéficos para as águas doces seriam de importância ponderável. Pari passu com os dados expostos, a reciclagem proporciona visível economia dos volumes de água consumidos no processo produtivo. No caso das latas de aço e do papel, a quantificação dos valores associados à redução do consumo de água indicam respectivamente $4 \mathrm{~m}^{3} /$ tonelada para a lata de aço e $29,2 \mathrm{~m}^{3} /$ tonelada para o papel. Portanto, temos num plano consuntivo exemplos concretos de economia de recursos hídricos. Esta economia de água no processo produtivo, "deve-se ao fato de que a produção a partir de recicláveis requer menos água do que a produção de matérias-primas virgens" (CALDERONI, 2003:88 e 266).

Por outro lado, a reciclagem, ao subtrair resíduos das ruas e das lixeiras, abriu uma nova frente permitindo a adoção de novas tecnologias e de novos negócios. Tudo isso tem concorrido, por exemplo, para alavancar a reciclagem dos plásticos, incentivando maior requisição deste material nos circuitos dos recicláveis e é óbvio, do PET em especial. No caso da indústria têxtil, as garrafas de polietileno tereftalato (comumente conhecidas como garrafas PET), tem encontrado uma promissora perspectiva com a utilização da fibra do PET descartado como componente da trama de tecido novo. Paralelamente à recuperação de matéria prima, as indústrias obtêm um ganho secundário em razão das roupas produzidas com fio reciclado possuírem um certo apelo "ecológico", devidamente explorado por um marketing especializado.

No Brasil, também se faz notar esta tendência. No ano 2000, o índice de reciclagem de garrafas PET foi $24,8 \%$, posicionando o país entre os que mais reaproveitam este material em todo o mundo (estatística da Associação Brasileira dos Fabricantes de Embalagens PET - ABEPET). Também no ano 2000, o país reciclou 67 mil toneladas do produto, ou seja, cerca de 1,5 bilhão de garrafas. Apesar de fazer a reciclagem de PET somente desde 1994, "o índice brasileiro é maior que o de países do Primeiro Mundo que já realizam a atividade há 20 anos, como os Estados Unidos e Japão, que reciclaram 23\% e 22\% de suas garrafas PET no ano passado" (ESCOBAR, 2000). 
A reciclagem do alumínio, ao se tratar de atividade na qual o Brasil desponta com a maior porcentagem mundial, ensejaria alguns comentários adicionais. Incentivada por campanhas promovidas pelas recicladoras, as latas deste material, encaminhadas através de centros de triagem ou provenientes do paciente trabalho dos catadores, são, sem dúvida alguma, o reciclável mais valioso, com preço cinco vezes superior ao plástico, o segundo em valor. A coleta de latas de alumínio oferece remuneração vantajosa decorrente do seu valor agregado, e não sem motivo, a latinha é considerada como "o ouro dos catadores". Em 2003, o Brasil se tornou campeão mundial em reciclagem de latas de alumínio pelo terceiro ano consecutivo, com $89 \%$ das embalagens recolhidas (Ver CALDERONI, 2003:179 e CORDIOLI, 2005).

Certamente, existiria no bojo destes dados uma miríade de motivos suficientes para celebrar os índices de aproveitamento dos recicláveis. Alicerçada com base neste cenário, a expansão da reciclagem tem sido exibida com certo triunfalismo, fazendo uso de um discurso que freqüentemente busca apoio nas teses do desenvolvimento sustentável. Aparentemente, a reciclagem resolveria de uma vez por todas os efeitos deletérios da industrialização e o mundo moderno poderia enfim encontrar tranqüilidade para manter seus hábitos de consumo a vontade.

No entanto, esta percepção deve ser balanceada com dados objetivos, aqueles que permitem entender que, grosso modo, este elenco de conquistas é acima de tudo condizente com a finalidade de assegurar a perpetuação de um modelo capitalista de gestão da economia. Recorde-se que o capitalismo se acoplou, no trajeto que percorreu desde seu surgimento no final da Idade Média até a globalização, a muitas situações diferentes. No bojo destes contextos, a prática capitalista foi adquirindo novas feições, respondendo aos painéis históricos que se apresentavam. No entanto, apesar de ininterruptamente se metamorfosear com o novo, sua linha mestra permaneceu intocada desde o princípio. Nossa indicação é que antes de ser condicionado pela crise ambiental, é o sistema econômico que desta se apropriou em proveito da sua reprodução sócio-espacial. 
Tome-se agora, por exemplo, o caso do alumínio. Material estratégico no mundo moderno, sua fabricação é comandada pelo chamado "Cartel das Seis Irmãs", composto pela Alcoa, Alusuisse, Reynolds ${ }^{76}$, Kaiser, Pechiney e Alcan. Este grupo de indústrias é quem dá a última palavra quanto à localização geográfica de qualquer fábrica de alumínio. Seguramente, este ramo da metalurgia constitui um dos mais poderosos monopólios hoje existentes no mundo. Conseqüentemente, não seria de se admirar que a reciclagem deste material também materialize um segmento altamente monopolizado. Exemplificando essa propensão concentradora, no Brasil a LATASA $^{77}$ é a única fabricante de latas de alumínio e única compradora desta sucata, sendo, portanto, um misto de monopólio e de monopsônio (Ver a respeito, CALDERONI, 2003:177/188).

Este é um relato dentre muitos outros evidenciando que a reciclagem simplesmente não está em contradição com as diretrizes maiores do sistema econômico. Historicamente, a reciclagem passa a se expandir quando deixa de ser possível manter o processo predatório anterior, questionado por modelos "ambientalmente mais contemporâneos". A escassez de recursos, também um resultado do triunfo da moderna economia de mercado, passa a justificar a recuperação dos resíduos, inclusive enquanto estratégia para realimentar o fluxo da economia. Atada à lógica do mercado, a indústria da reciclagem passa a instrumentalizar e a se nutrir das mesmas dinâmicas que perpassam pelo sistema.

Assim, a captação dos recicláveis tem se expandido através da arregimentação de desempregados e da população de rua e não como resultado de mudanças comportamentais. Muito mais do que pelo esperado sucesso dos programas de educação ambiental, é pela salvaguarda de sobrevivência mínima que o exército de catadores das cidades brasileiras se anima a retirar das ruas tudo que possa ser imediatamente comercializado no ponto de captação mais próximo. Esta argüição encontra respaldo em pesquisa do IBGE que expõe o

\footnotetext{
${ }^{76}$ Em Junho de 2004 foi anunciada a fusão entre a ALCOA e a Reynolds (Vide CAVALCANTI, 2005)

77 Esta empresa resultou de uma associação, datada de 1990, entre o Banco Bradesco, J.P.Morgan e a Reynolds Metals Co, sendo que a participação desta última foi repassada para a ALCOA.
} 
contraste entre os índices de reciclagem e os serviços de coleta seletiva de lixo. Enquanto que, por exemplo, 89\% das latas de alumínio são recicladas, apenas $1,9 \%$ do lixo é coletado de forma seletiva ${ }^{78}$. Estes dados comprovam a enorme capacidade do capitalismo exercer sua hegemonia convocando numeroso contingente de excluídos do mercado formal de trabalho para o papel de captadores.

Nesta lógica, fica bastante claro que não é devido aos progressos da "conscientização ecológica" que a reciclagem avança. As inflexões da "economia desregulamentada" orientam bem mais a estruturação deste ramo empresarial do que a preocupação com a conservação dos recursos naturais. Ipso facto, a escala de incorporação deste procedimento pelo sistema econômico no seu sentido mais amplo tem avançado homeopaticamente. Um dado comprobatório desta afirmação é que, de acordo com dados do IBGE referentes ao ano de 2002, somente 451 dos 5.507 municípios brasileiros desenvolvem programas de reciclagem. Isto é, $8,11 \%$ do total (GRIMBERG, 2002).

Outro dado é que a adoção da reciclagem, ao ser assimilada de modo gradativo (até porque atendendo aos mecanismos de reprodução do capital estes tendem, sobremaneira, a incidir nos segmentos capitalizados da economia), garante primazia para os setores mais avançados da economia, não sugerindo reais mudanças estruturais no modelo de depredação dos recursos naturais e neste contexto, tampouco dos hídricos. Não por outra razão senão pelo fato de que ocorrendo sua incorporação no conjunto do aparato produtivo, estes "ganhos de produtividade" terminam anulados pela expansão do próprio sistema de produção de mercadorias. Por conseguinte, um número ainda maior de empresas utilizando "métodos racionais", termina por tensionar a utilização dos recursos numa escala ainda mais ampliada do que antes os recursos existentes.

Foi discutido nos parágrafos anteriores que, a equação que articula os recursos hídricos aos resíduos sólidos, tem na revisão das metas e das prioridades do padrão civilizatório em vigor uma evidência que se explicita por si mesma. Em conformidade com esta nuança, iniciativas como as da reciclagem

\footnotetext{
${ }^{78}$ Cf Manchetes Socioambientais, edição de 05-11-2004.
} 
terminariam por configurar-se como um paliativo, porém, não se capacitando para a solução efetiva do problema. Ademais, a esta assertiva deve-se agregar uma outra adicional, ressalvando que a reciclagem da fração seca igualmente não esgota a questão da utilização da utilização racional dos recursos hídricos.

O que realmente está colocado é o primeiro dos quatro "Rs" anteriormente discutidos: Repensar. Por extensão, impõe-se a necessidade de se repensar o modo de vida característico da Modernidade. Esta questão envolveria a necessidade de revisão conceitual da relação mantida entre a sociedade humana moderna e a natureza, bem como das formas culturais de concepção existentes a respeito do meio ambiente ${ }^{79}$, capacitando-nos a um entendimento mais completo dos problemas e por extensão, das suas soluções.

Repensar significa menos embalagens na distribuição das mercadorias; significa a utilização de quantidades menores de alumínio; significa menor utilização de petróleo na produção de energia e menor consumo na distribuição; significa menor desperdício por parte de cidadãos conscientes das potencialidades inerentes à sua atitude individual; significa consumo responsável; significa menor consumismo, uma vida de simplicidade voluntária atendo-se ao que de fato é essencial e importante para o futuro da sociedade humana; significa enfim uma vida comunitária, com cidadãos integrados no contexto do seu espaço de vida imediato e com o meio social no seio do qual vivem e reproduzem as suas esperanças.

E isto pelo simples motivo de que repensar, ao significar menos lixo, significa mais água para todos.

\footnotetext{
${ }^{79}$ A respeito, sublinhou o antropólogo Georges BALANDIER, "Toda sociedade possui uma teoria de Natureza que Ihe é própria, que se expressa em suas configurações intelectuais, senão igualmente em complexos de símbolos, de instrumentos e de práticas" (1988:194).
} 


\section{CAPÍTULO 8}

\section{A GEOGRAFI A DA SEDE}

\section{1. Água: Natureza, Soci edade e Escassez}

O contexto atualmente vivido pela humanidade é rico de novas perspectivas, descortinando aspectos aos quais amplos segmentos sociais dispensavam, mesmo em tempos recentes, pouca ou nenhuma atenção. Quem nos séculos passados ousaria pontuar questões como a oferta decrescente de solo agrícola, de madeira, de pescado e de outros recursos naturais? No entanto, hoje são usuais os comentários a respeito das perdas de biodiversidade, desequilíbrios climáticos globais, refugiados ambientais e vários outros assuntos que não freqüentavam, nem mesmo em sonhos ou em delírios, a imaginação dos ancestrais.

Seria inevitável incluir nesta longa série de problemáticas contundentes as relacionadas com o acesso aos recursos hídricos. Afinal, esta questão constitui justamente um dos tópicos centrais desta tese de doutorado. Certamente, em função de várias pontuações explicitamente colocadas em diversos momentos ao longo deste texto, os fatos relacionados com o modo de funcionamento dos sistemas de engenharia (Cf SANTOS, 1978a e 1988), se destacariam de modo relevante nesta discussão. Sentença esposada pelos mais diversos cientistas sociais, as contradições mantidas pela humanidade com o meio natural não podem, em nenhum momento, serem desvinculadas das contradições que os humanos sustentam entre si.

Conseqüentemente, na modelagem do espaço geográfico, nos arranjos dados aos elementos naturais encontrados pelo homem diferentemente dispersos no meio ambiente, encontra-se o espelhamento das relações sociais mantidas 
pelos homens entre si, e destes, com o meio natural. Neste processo a natureza original ou primeira, é transformada em uma natureza segunda, artificial, criada pelo homem. Constituindo considerações indissociáveis da obra dos fundadores do materialismo histórico - Karl Marx e Friedrich Engels - as estas nem os marxistas não geógrafos, nem os geógrafos marxistas se dispuseram a granjear a merecida atenção (SANTOS, 1978a: 201).

A despeito disto, esta perspectiva configura um soberbo quadro conceitual capacitado a compreender a forma como a desigual repartição dos recursos naturais no espaço geográfico terminou instrumentalizada para formar, reafirmar e dar continuidade às mais diversas dessimetrias de poder. A partir deste momento seria, pois o caso de se vincular os dados referentes ao modo pelo qual as sociedades humanas têm processado sua reprodução social com os relacionados com a distribuição espacial das águas doces no nosso Planeta. A desigual repartição das águas doces ao redor do mundo constitui aspecto merecedor de inúmeras pontuações. Não por outra razão senão pelo fato da água se apresentar enquanto dado de magna importância, visto constituir, pela primeira vez na história humana, em item marcante das preocupações globais.

Na seqüência, uma primeira ponderação quanto à oferta natural dos recursos hídricos, é que esta, ao ser reconhecidamente irregular, engendraria por si mesma disparidades relativamente ao atendimento das demandas humanas. No final das contas, quem desconhece que os rios siberianos descarregam enorme volume de água nos mares gélidos do Ártico, lado a lado com a impressionante demografia da Ásia Oriental? Ou ainda, materializando outra situação bastante representativa, que o sistema fluvial formado pelos rios Ganges e Brahmaputra, ambos correspondendo a $1 \%$ da superfície do mundo, abrigam nos seus vales, não menos do que $10 \%$ do total da humanidade?

Num mundo em que o acesso à água confunde-se cada vez mais com a lógica do poder, unicamente esta nuança justificaria a intenção em identificar tanto as nações que concentram recursos hídricos quanto àquelas nas quais este é escasso. Parâmetros técnicos e quantitativos, amplamente aceitos, seriam cabíveis enquanto ferramentas para identificar variada gama de situações. Estes 
discriminam como muito ricos os países que, segundo seu potencial e uso dos recursos hídricos, apresentam índices superiores a $100.000 \mathrm{~m}^{3}$ de água doce/habitante/ano. Quanto aos países ricos, estes seriam os situados na faixa de disponibilidade entre 10.000 até $100.000 \mathrm{~m}^{3} /$ habitante/ano. Em ordem decrescente poderíamos mencionar países com potencial suficiente, entre 2.000/10.000 $\mathrm{m}^{3} / \mathrm{habitante/ano}$; regular, entre 1.000/2.000 m³/habitante/ano; pobre, entre $500 \mathrm{e}$ $1.000 \mathrm{~m} 3 /$ habitante/ano; e muito pobre, com potencial inferior a 500 m³/habitante/ano (Vide a respeito REBOUÇAS, 2002a:15).

Estes patamares permitiriam enfocar, em termos de abundância de água, um afortunado conjunto de países. Um grupo de nações muito ricas em recursos hídricos seria composto pela Guiana Francesa, Islândia, República Cooperativa da Guiana, Suriname, Gabão e a Papua-Nova Guiné. Na listagem dos países ricos, estariam presentes, entre outros, os "dois Congos" ${ }^{80}$, Angola, as Ilhas Salomão, a Venezuela, Colômbia, Brasil, Bangladesh, Camerun, Bolívia, Tchade, Vietnã, Mali, Suécia, Finlândia e Indonésia. Estas nações, poderiam estar integrando um bloco de países potencialmente provedores de água (Ver gráfico 2). É de se notar quase todos os países mencionados são tropicais e integram o grupo das nações periféricas; três dos seis países melhor agraciados localizam-se na Bacia Amazônica; outra singularidade é que quatro nações latino-americanas - dentre as quais o Brasil - figuram na lista dos países ricos em água doce (MARTINS, 2003).

Entretanto, uma vez que vários dos países citados possuem área e população pouco significativas na escala mundial, nada sugere que sejam necessariamente detentores de grandes provisões hídricas. A título de exemplo, o Gabão, a Guiana Francesa e a Islândia, embora consistindo de países formados por territórios drenados por uma vigorosa trama de rios e córregos, perfazem territórios e populações de pequena expressão. Estes países somam áreas diminutas (respectivamente $267.667 \mathrm{~km}^{2}, 91.000 \mathrm{~km}^{2}$ e $103.000 \mathrm{~km}^{2}$ ), concentram população absoluta muito modesta (1.208.435, 172.905 e 279.000 habitantes) e apresentam baixa população relativa (4,5, 2,7 e 1,9 hab/km²). Para completar, o contingente demográfico está concentrado numa fração mínima do espaço 
geográfico (a orla marítima, e nesta, basicamente as capitais), fazendo sentido, portanto, anotar que são largamente despovoados.

Por isso mesmo, apesar de disporem de significativo excedente hídrico per capita, do ponto de vista absoluto a importância destes países quanto aos recursos hídricos globais não seria em nada comparável aos "gigantes hídricos". Na realidade, o grupo de países com maior concentração de recursos hídricos

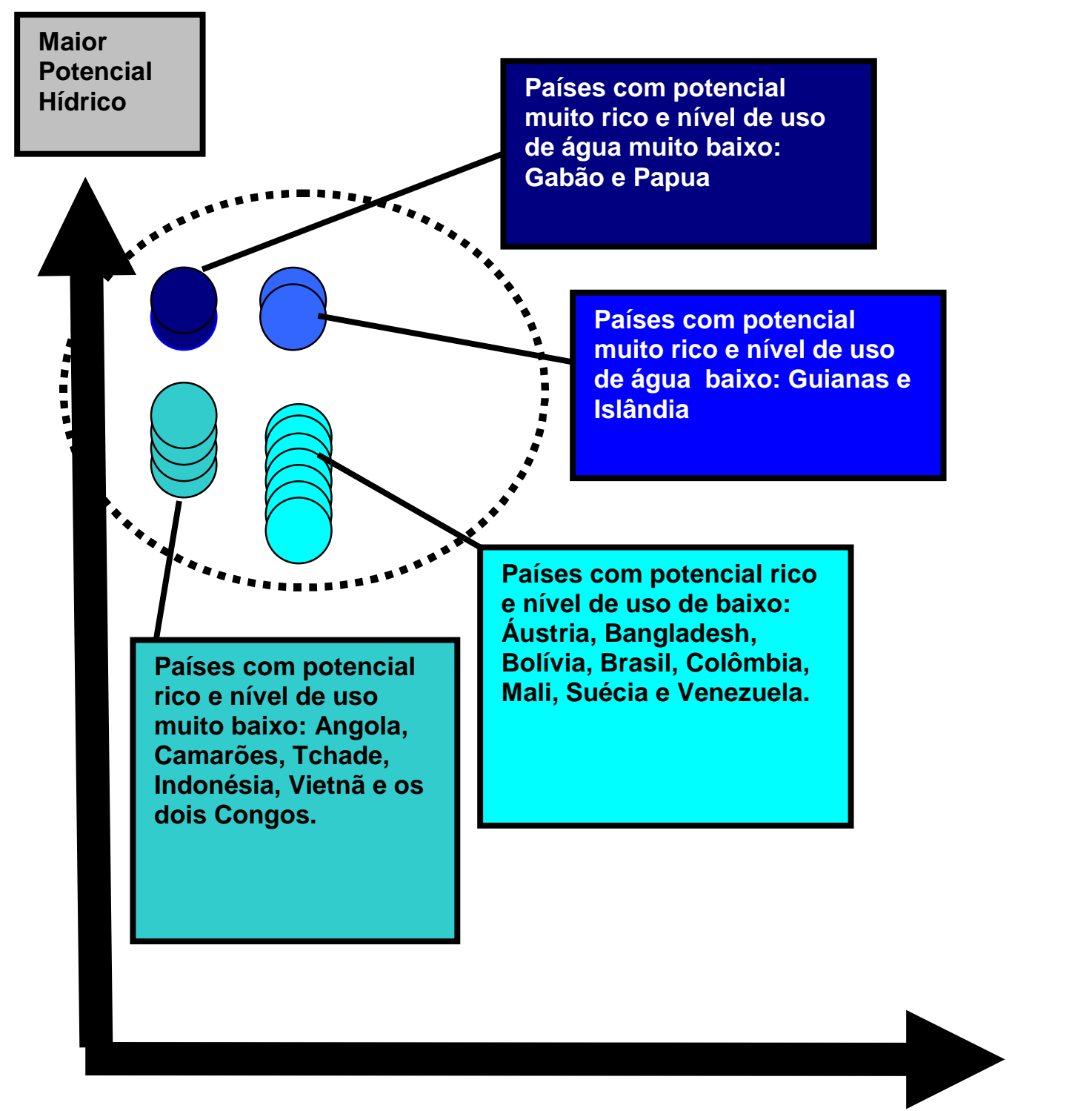

80 Estes são a República Democrática do Congo (ex-Zaire, no passado uma colônia belga) e a República Popular do Congo (anteriormente uma possessão francesa). 
Maior Nível de Uso

GRÁFICO 2 - Países Potencialmente Provedores de Água Doce (Fonte: adaptado de Margart, J., Repartition des ressources et des utilisations d'eau dans lê monde: Disparités Présents et Futures, La Houille Blanche, n², pp. 40-51, 1998). 
reúne nações com vastos territórios e abundante rede hidrográfica, formando o que tem sido denominado como "G6 da água". Este bloco, integrado pelo Brasil, Estado Unidos, Canadá, China, Índia e Federação Russa, reuniria, de acordo com o eminente hidrólogo russo Igor SHIKLOMANOV (1999), algo como $40 \%$ do escoamento da água de superfície de todo o mundo. Além dos países citados, interessaria também consignar um adendo reparador, endereçado à República Democrática do Congo. Apesar da mídia insistir na existência de um "G6", este último país, juntamente com os seis primeiros, ao ser abundantemente irrigado pela bacia do rio Zaire ${ }^{81}$, poderia mais corretamente, respaldar a identificação um G7 da água.

Quanto ao quinhão brasileiro no montante total dos recursos hídricos mundiais, além da cifra de 12\% (REBOUÇAS, 2002a:29), praticamente um consenso no meio acadêmico, poderíamos citar outras avaliações. Fala-se em 8\% (cifra mais difundida na década passada, eventualmente utilizada), 11\% (TUCCI, HESPANHOL e NETTO, 2001:42), e ainda 13\% (MARTINS, 2003). De qualquer modo, nenhum destes registros contesta o fato do país ser o maior detentor de recursos hídricos na escala mundial. Francamente, em se tratando de 8, 11, 12 ou 13\% da água mundial, está se referindo, em qualquer uma dessas circunstâncias, a um volume gigantesco do líquido. Por fim, esclareça-se que a porcentagem de 17\%, eventualmente atribuída ao Brasil em alguns textos, refere-se à somatória da vazão produzida no território brasileiro com aquela que escoa dos países vizinhos no território brasileiro, dita particularmente verdadeira no tocante à Bacia Amazônica (Vide TUCCI, HESPANHOL e NETTO, 2001:34 e 42).

Note-se que o Brasil é o único país pertencente ao G7 da água que se encontra em situação favorável em termos de disponibilidade hídrica. Nos Estados Unidos, as solicitações da sua economia e do seu estilo de vida, a despeito do gigantismo dos seus recursos, fazem com que se avizinhe grave carência de água doce já no início deste século. O Canadá certamente dispõe de muita água

${ }^{81}$ O Zaire também é conhecido, para além de muitas outras denominações regionais, como Rio Congo. Entretanto, recorde-se que este último topônimo insere uma sinonímia com a etnia bakongo, que habita apenas o trecho final deste rio. Assim, Zaire seria uma denominação não marcada por etnicismo e, portanto, mais abrangente em função de sua generalidade. 
congelada. Mas, já foi comentado, a mineração deste estoque contribuiria diretamente com o efeito estufa, comprometendo ainda mais o equilíbrio da biosfera terrestre. O mesmo pode ser dito para a Federação Russa. De resto, tanto o Canadá quanto a Rússia, nações com significativos parques industriais, apresentam elevados níveis de poluição dos seus rios e lagos, tendo ainda de dar conta das suas crescentes demandas internas ${ }^{82}$.

Relativamente à China, a Índia e a R.P. do Congo, países do Terceiro Mundo, o cenário também seria adverso. Na China e na Índia, seus recursos hídricos tem sido comprometidos pelo esgotamento deficiente, pelos efluentes resultantes de uma industrialização desenfreada e pelo próprio gigantismo das suas populações, respectivamente a primeira e a segunda posição no ranking da demografia mundial. Finalmente, a República Democrática do Congo tem se caracterizado pela intermitente turbulência política e seu quadro sanitário deixaria pelo mínimo, muito a desejar. Portanto, em termos do G7 da água, o Brasil seria uma nação propensa a ocupar um papel de ponta no comércio internacional de água doce, de um modo que dificilmente encontraria competidores (MARTINS, 2003).

Todavia, a escassez de água não se restringe às nações citadas. Paralelamente aos países cujos recursos, embora vastos, foram tornados insuficientes, pode-se localizar no extremo oposto do ranking da disponibilidade, identificar nações muito pobres em recursos hídricos. Estados insulares como Cabo Verde, Malta, Maldivas, Bahamas, Chipre e Cingapura estariam incluídos nesta relação. Nestas nações, as condições naturais somadas à pequena extensão e à citada condição de insularidade, explicam a exigüidade da rede hidrográfica e o baixo potencial de captação das águas pluviais, justificando de algum modo uma escassez de recursos hídricos. No entanto, deve-se, vis-à-vis,

82 No caso canadense, recentes declarações das autoridades norte-americanas propondo a construção de aquedutos para abastecer os Estados Unidos têm motivado vívida contrariedade entre os agricultores e da população urbana do Canadá, temerosos de serem vitimados com a falta de água em razão da exportação de água doce. 
agregar notórias injunções de ordem social e econômica ${ }^{83}$. Recorde-se que apesar de países como Nauru e Vanuatu (na Oceania), recorrerem à captação das precipitações pluviométricas para manter seu suprimento de água, estas são passíveis de serem afetadas pelas mudanças climáticas. Portanto, não seria desmotivado profetizar que em futuro próximo muitas outras ilhas e arquipélagos ingressarão na lista dos territórios assolados pela sede.

As regiões áridas e semi-áridas formam outro conjunto crítico. Estas áreas configuram um quadro natural dificultoso ao qual se agrega, em muitos casos, uma notável contabilidade de problemas geopolíticos. No Oriente Médio, um exaustivo elenco de contradições opõe países, etnias e classes sociais relativamente ao acesso às águas doces, uma rivalidade que põe a nu a origem etimológica desta palavra, procedente do latim rivus, que justamente significa rio. Exemplificando, dos onze países mais pobres de água do mundo, sete constituem nações árabes: Kuwait, Qatar, Arábia Saudita, Líbia, Bahrain, Jordânia e Emirados Árabes Unidos. A Faixa de Gaza, território árabe sob ocupação israelense, é outro cenário dramático de escassez de água. Tais países e territórios integram uma região estratégica, o Machrek $^{84}$, conhecida pela sua turbulência política, um cenário com toda certeza agravado pelo stress hídrico (Vide REBOUÇAS, 2002a:19).

Na Ásia Ocidental, não o abundante petróleo, mas sim a água escassa é o recurso estratégico por excelência. É possível imaginar um Oriente Médio sem petróleo. Porém sem água, esta região (como qualquer outra), simplesmente deixaria de existir. É por esta razão que a questão dos recursos hídricos não pode em nenhum momento ser marginalizada da avaliação dos problemas geopolíticos regionais. Insistir numa ótica exclusivamente política, econômica ou cultural, além de irrealista seria ineficaz na compreensão de diversas situações críticas.

\footnotetext{
${ }^{83}$ Exemplificando, a cidade de Cingapura representa um modelo clássico de urbe devoradora e recursos hídricos; A crise de abastecimento de Chipre, das Maldivas e das Bahamas se explica em grande parte pelo fluxo turístico, cujo consumo de água é garantido, sendo praticamente intocável.

${ }^{84}$ Trata-se de um topônimo de origem árabe significando "Ilha de Oriente", sendo empregado para designar as regiões que a geografia ocidental reconhece como "Oriente Médio". O Machrek, no imaginário espacial árabe, contrapõe-se ao Magreb, ou "llha de Ocidente", correspondendo aos atuais Marrocos, Argélia e Tunísia.
} 
Basicamente em razão de que explicitamente muitos dos conflitos do Machrek reportarem à questão do acesso à água.

Significativamente, um relatório do governo dos Estados Unidos, datado dos anos 80 , alertava que dentre dez áreas nas quais poderiam ser previstos conflitos relacionados com a escassez de água, metade localizava-se no Oriente Médio. Nesta parte do mundo, quinze países competem com sofreguidão pelas águas de vazão cada vez menor dos rios Tigre, Eufrates, Nilo e do Jordão. Por sinal, em 1975 o Iraque e a Síria já estiveram próximos de uma guerra por conta da barragem de Al-Thawrah, construída por este último país no seu trecho do Eufrates. Nem mesmo as copiosas águas do Nilo constituem uma fonte de estabilidade regional. Quando o governo etíope anunciou planos de represamento dos afluentes do Nilo, no distante planalto abissínio, o então presidente Anwar Sadat do Egito, nação definida no passado pelo historiador grego Heródoto como "uma dádiva do Nilo", a luz do fato do seu país depender das águas tépidas deste rio, ameaçou em 1979 com uma declaração de guerra.

Neste contexto, um dos conflitos mais espicaçados pela posse dos recursos hídricos tem sido protagonizado pela Turquia, que, aliás, constitui o único Estadomembro da Organização do Tratado do Atlântico Norte (OTAN) situado no Oriente Médio. Este país tem levado adiante o Projeto Grande Anatólia, um notório foco de instabilidade regional por apropriar-se dos recursos hídricos da mesopotâmia, região que concentra os raros, porém dos mais extensos e volumosos caudais d'água do crescente fértil. Tal mega-projeto turco consiste no represamento a montante, isto é, junto às cabeceiras do Rio Eufrates, de imensas quantidades de água, portanto subtraindo a vazão natural rio abaixo, isto é, a jusante. Como não poderia deixar de ser, este plano foi interpretado pelos vizinhos meridionais (Síria e Iraque), como uma ameaça aos seus interesses vitais, visto sua implantação implicar na diminuição do suprimento de água para os dois países (Vide ELLIOTT, 1998:223, VILLIERS, 2002:295/310).

Entretanto, nenhuma destas situações, conflitantes ou potencialmente geradoras de conflitos, repercute de modo tão intenso em nível da política regional e internacional quanto às contendas que opõem Israel e os países árabes. Para 
além das contradições políticas, territoriais, religiosas e de identidade nacional, que grosso modo são reconhecidamente "mais fotogênicas", estão implicitamente colocadas várias disputas relacionadas com a apropriação dos recursos hídricos. Reproduzindo um comentário sintético a este respeito,

...modernamente o conflito mais grave da água é vivenciado por israelenses e palestinos, cujos mananciais disponíveis dependem de acordos entre Jordânia, Síria, Líbano, Egito e Arábia Saudita (REBOUÇAS, 2002a:19).

Há com toda certeza um quadro natural pouco favorável marcando a geografia dos países atualmente em conflito. Aliás, poucas regiões do mundo possuem relatos tão incisivos sobre a falta de água quanto esta, a começar pelo que pode ser conferido no próprio Antigo Testamento e num repetitivo leque de informações produzidas pelas culturas locais nos últimos 30 séculos. Relatos antropológicos documentam a quase imemorial luta das tribos do deserto pela posse dos oásis e dos escassos poços de água. Os documentos cuneiformes procedentes das chancelarias da antiga Suméria assinalam, por sua vez, diversos conflitos entre as cidades da região pela água do Tigre e do Eufrates. Cidades como Meca e Reinos como Sabá, dependiam da rigorosa administração de recursos hídricos parcos, quando muito. Caberia enfim mencionar que uma das áreas mais rigorosamente tórridas do mundo, o deserto do Rub-Al-Kali (que significa "recanto seco" em árabe), situa-se na península arábica, num autêntico "cul-de-sac" do Machrek.

É possível também subsidiar estas observações com base em outras referências, dentre estas a sugestiva comparação entre Israel e o semi-árido nordestino, região que no mais das vezes, integra o imaginário nacional relacionado com a falta de água. Relembre-se que nos anos 70 do século passado, quando a agricultura irrigada israelense tinha conquistado a mídia mundial mediante a tonitruante apresentação dos sucessos repetidos das suas colheitas, assinalou um conterrâneo nosso, o geógrafo Manuel Correia de ANDRADE, relativamente à escassez de água neste país: 
Convém salientar, para dar uma idéia do déficit de umidade, que no sertão brasileiro, em Cabaceiras, na Paraíba, o município mais seco do país, chove $259 \mathrm{~mm}$ por ano, dez vezes a quantidade de chuvas que caem em certas áreas de Israel (1977:68, grifo nosso).

Como que confirmando a perspicaz observação do geógrafo pernambucano, tal ponderação reaparece de modo emblemático numa célebre declaração realizada pelo político israelense David Ben Gurion em um encontro público travado com a comunidade judaica de São Paulo por ocasião de um tour realizado em 1969 por diversos países da América Latina. Consta que inquirido pelo presidente brasileiro a respeito de um presente que o Brasil país poderia fornecer ao Estado de Israel, o visitante teria respondido sem pestanejar: "Por favor, me presenteiem com um rio, qualquer um, pode ser um destes que eu vi pelo caminho...".

Evidentemente, na impossibilidade de receber um rio de presente, Israel, adotou, obrigatoriamente, padrões de indiscutível eficiência na gestão dos recursos hídricos localizados nos territórios sob sua administração direta, um know-how disputado no mercado internacional de tecnologias de aproveitamento da água (Cf DAR e HERMONI, 2005). A magnificência técnica que caracteriza a agricultura de Israel é um dado merecidamente recordado nas avaliações sobre o uso inteligente da água nesta árida nação (REBOUÇAS, 2004:96). Recorde-se que este país

...pratica irrigação numa faixa do seu território onde a pluviometria média é de apenas $200 \mathrm{~mm} / \mathrm{ano}$, logrando alta produtividade agrícola com a aplicação de uma taxa de irrigação da ordem de $6.000 \mathrm{~m}^{3} / \mathrm{ha} / \mathrm{ano}$. Esta taxa situa-se entre 12.000 e $20.000 \mathrm{~m}^{3} / \mathrm{ha} / \mathrm{ano}$ em outras regiões do mundo, relativamente mais favorecidas em termos de disponibilidades de água e clima (REBOUÇAS, 2002a:19).

No entanto, sem desmerecer a proverbial competência israelense na gestão das águas doces presentes no seu território, esta simplesmente seria insuficiente para o atendimento das necessidades do seu sistema produtivo e consumo individual. Com base neste fato objetivo, tal lacuna terminou induzindo o Estado de Israel a uma política premeditada de apropriação de recursos hídricos alheios 
ao seu domínio direto. Esta observação diz respeito de forma cabal à requisição das águas doces extraídas dos territórios ocupados da Cisjordânia (West Bank) e de Gaza (Gaza Strip), assim como da região do Golan, todos constituindo áreas em litígio com os povos vizinhos (Fig. 29). Apenas deste modo Israel tem logrado assegurar à sua população um índice de consumo de água em média cinco vezes superior ao dos países dos arredores, uma situação ímpar em todo o Levante (Vide ELLIOTT, 1998:224).

No caso do território ocupado da Cisjordânia, a conflituosa questão da apropriação dos recursos hídricos explicita-se, por exemplo, através da proibição imposta pela ocupação israelense quanto à abertura de novos poços por parte da população civil palestina e pelo veto ao acesso desta às águas do rio Jordão. Ao mesmo tempo, os assentamentos israelenses ilegalmente instalados nestas regiões dispõem de acesso irrestrito à água, em flagrante contraste com a indigência hídrica da população palestina. De acordo com o Banco Mundial, com base em dados disponíveis no ano 2000, 90\% da água da Cisjordânia é apropriada pelos israelenses, enquanto que os palestinos dispõem dos $10 \%$ restantes. As águas dos aqüíferos da Cisjordânia fornecem atualmente cerca de

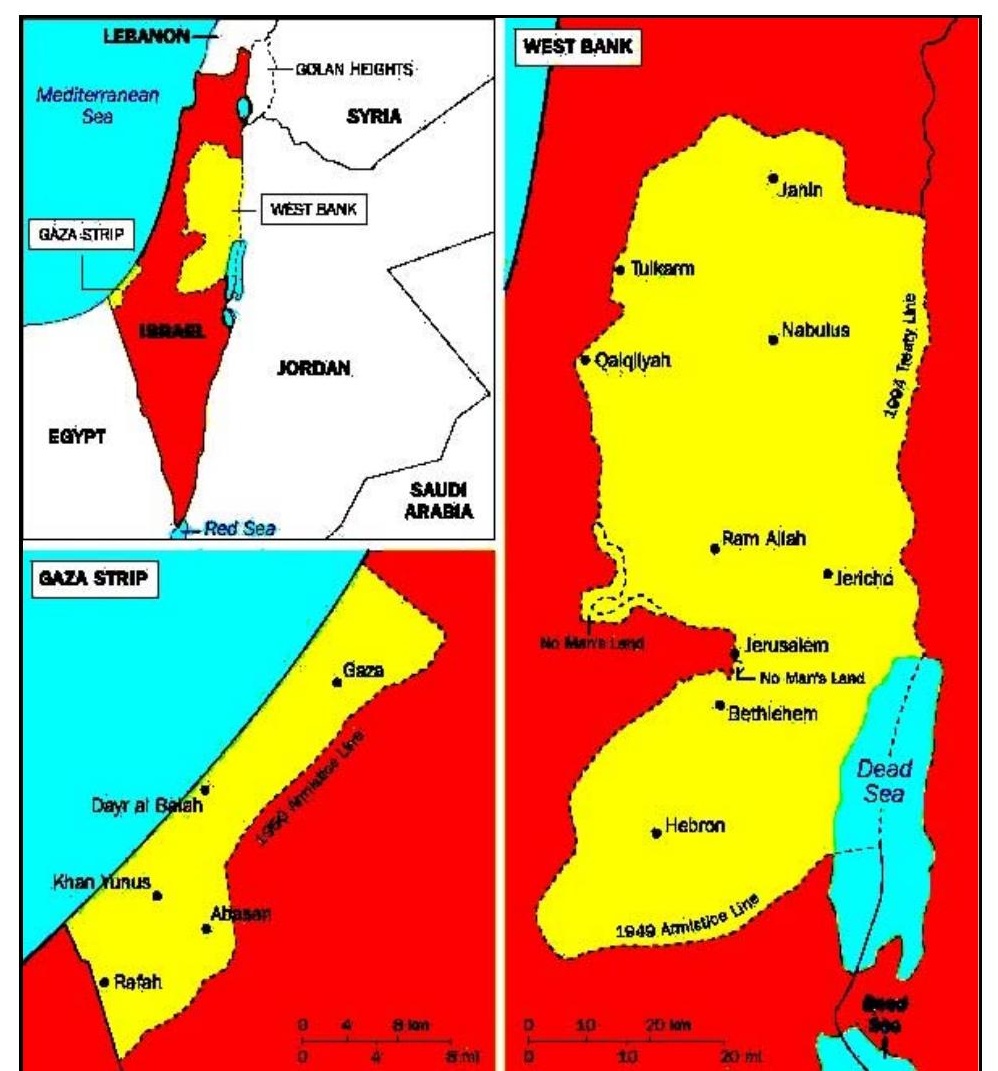


FIGURA 29 - Mapa de Israel, Cisjordânia (West Bank ou Margem Ocidental) e a Faixa de Gaza (Fonte: Mapa USAID). 
$25 \%$ do total consumido pelos israelenses, cujo ritmo de retiradas, ao extrapolar a capacidade natural, está conduzindo ao esvaziamento irrefreável destes reservatórios.

Em Gaza, a situação é ainda mais crítica. Neste pequeno enclave com 365 $\mathrm{km}^{2}$ sobrevivem cerca de 1,1 milhão de palestinos (estimativa de 2002), elevada proporção dos quais habitando campos de refugiados. A Faixa de Gaza é uma das regiões mais densamente povoadas do mundo: aproximadamente $2.000 \mathrm{hab} / \mathrm{km}^{2}$. Em Gaza, o nível de salinidade e o precário sistema de evacuação dos efluentes domésticos tornam a água dos lençóis subterrâneos crescentemente imprópria para o consumo. Constata-se paralelamente um aumento da salinidade, decorrente da exaustão dos aqüíferos, pois a retirada excessiva de água favoreceu intrusão salina provocada pela infiltração das águas salgadas do Mediterrâneo. Em 1996, um relatório elaborado pelo Banco Mundial assinala que Gaza constitui o mais inquietante de todos os casos de stress hídrico registrados ao redor do mundo.

Para esta situação, contribuiu diretamente o impacto dos assentamentos implantados por Israel na região após a Guerra dos Seis Dias (Junho de 1967). Um estudo elaborado pela Fundação Americana para a Paz no Oriente Próximo, datado de julho de 1998 e divulgado por entidades palestinas e israelenses, relaciona a escassez à apropriação de terras pelas colônias ilegais e outras áreas sob controle militar direto de Israel. Tais instalações estão associadas ao confisco da água, desviada para sustentar projetos de colonização, sendo diretamente responsáveis pelo comprometimento do abastecimento da população local. Em 2005, acredita-se que 40\% da população de Gaza não disponha de água segura para suas necessidades diárias.

Em Gaza, até o momento em que Israel encetou em Setembro de 2005 a "Operação Desenjagamento", os habitantes dos 24 assentamentos ilegais instalados nesse território perfaziam $0,6 \%$ da população total. Ao mesmo tempo, esta minoria controlava $25 \%$ das terras agricultáveis, garantindo-lhes um índice 699 vezes maior de acesso à terra do que os habitantes dos campos de refugiados, seus vizinhos diretos. Ademais, este grupo consumia $47 \%$ dos 
recursos hídricos da região. O fim do contrôle direto exercido por Israel na Faixa de Gaza, pouco alterou este cenário de escassez. A retirada dos colonos não implicou numa alteração da política israelense de gestão de recursos hídricos palestinos, até porque as autoridades israelenses não renunciaram ao usufruto dos recursos hídricos locais e são omissas quanto à transferência da sua titularidade para a administração palestina.

Relativamente ao planalto do Golan, o que está em jogo é o controle dos mananciais setentrionais que abastecem o rio Jordão, por sinal compartilhado por um grupo de países conhecidos pela aridez e pelas dificuldades quanto ao acesso à água. Suas nascentes, situadas nos cumes nevados da Síria e do Líbano, originam um curso permanente de água, algo muito raro numa região perpassada pela escassez de recursos hídricos, daí o interesse israelense em manter a posse destas cobiçadas colinas. Esta região, tomada aos sírios pelos israelenses durante a Guerra dos Seis Dias e mantidas após a Guerra do Dia do Perdão (ou do Yom Kipur, em 1973), é uma área que reúne, ao lado dos seus atributos geofísicos, uma cabal significação estratégica (Fig. 30).

Assinale-se que o rio Jordão, nanico para os padrões brasileiros (apenas 322 quilômetros de extensão), constitui-se, no entanto, no mais importante curso d'água da região ocidental do Oriente Médio (Fig. 31). O grau de contradições inseridos nesta disputa fica evidente quando tomamos conhecimento de que este curso de água é um rio internacional. Nada menos do que cinco entidades nacionais existentes ou em formação relacionam-se com o Jordão: Líbano, Síria, Israel, Jordânia e a ANP (Autoridade Nacional Palestina). Do ponto de vista ambiental, é do adequado aproveitamento das águas do Jordão que depende o equilíbrio hidrológico da área por ele drenada. Esta assertiva condiz, entre outros aspectos, com a questão do ressecamento do Mar Morto (situado na charneira fronteiriça na qual confluem os territórios de Israel, Jordânia e da Palestina), cuja retração resulta da diminuição do caudal do Jordão. Lamentavelmente, em face da água deste rio corresponder atualmente a apenas $1 / 8$ do volume registrado cinco décadas atrás, o tenebroso cenário pelo qual o Mar Morto pode estar extirpado dos mapas do mundo constitui muito mais do que uma premonição. 
Mesmo crivado por toda sorte de contradições, um dado preocupante é que o Oriente Médio não constitui a única região do mundo a vivenciar problemas sérios vinculados com os recursos hídricos. Em função da degradação ambiental, territórios anteriormente brindados com ampla oferta do líquido ressentem-se hoje da escassez de água. Fenômenos como as mudanças climáticas estariam promovendo impactos múltiplos, todos diretamente relacionados com a redução

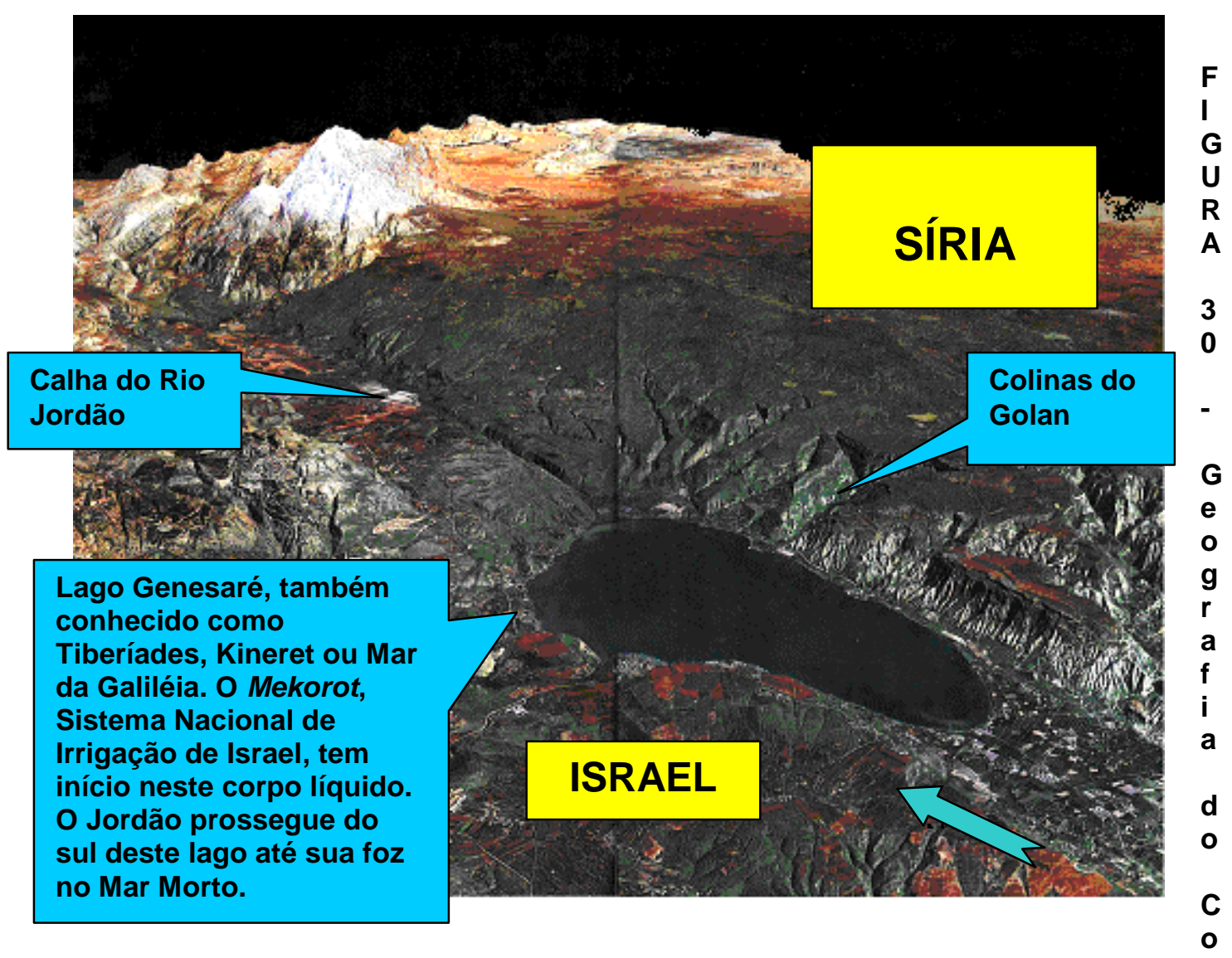

nflito: A imagem de satélite de alta resolução acima foi exagerada três vezes no sentido vertical. Ela evidencia os principais aspectos geofísicos da região do Golan, da Galiléia, sul do Líbano e do curso superior do Jordão. A montanha nevada a noroeste é o Monte Hermon, ponto culminante da área (3.018 m). As colinas do Golan, situadas a Leste, estão a cavaleiro do Vale do Jordão e do norte de Israel, uma das mais regiões mais cultivadas deste país. O Mar da Galiléia fornece cerca de $30 \%$ da água consumida pelos israelenses, tornando seus arredores de grande importância estratégica para 
Israel (Fonte: National Geography, Junho de 2000, pp. 104/105. A seta indica a direção norte). 


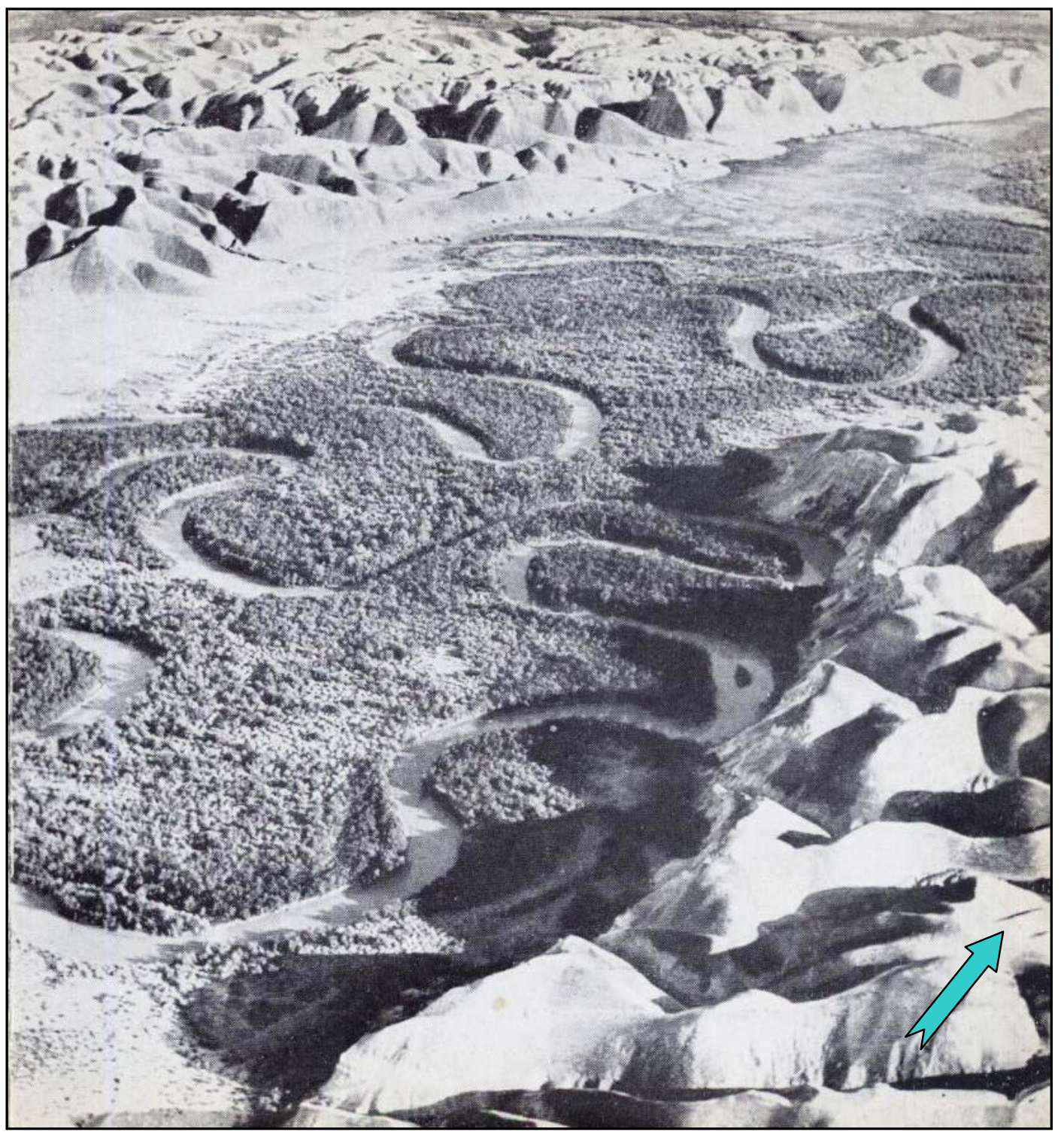

FIGURA 31 - Meandros do Rio Jordão: A foto registra o trecho final do Jordão, pouco antes deste desaguar no Mar Morto. Os inúmeros meandros que serpenteiam ao longo da calha fluvial resultam da ação das águas do rio. Tratando-se de uma calha formada por sedimentos recentes (Cenozóico), o terreno oferece baixa resistência aos dinamismos hidrológicos do rio, que desenha deste modo um trajeto errático. A Oeste do vale está o deserto da Judéia e a Leste, o deserto de Moab. Ambos contrastam com a vegetação luxuriante que ocupa a calha central do vale deste rio (Fonte: Israel, Die Goldenen Bücher, 1969, página 81. A seta indica a direção norte). 
dos estoques das águas doces. Dentre estes, poderíamos citar a desertificação, o comprometimento da vazão das bacias hidrográficas e lacustres e a elevação do nível dos mares.

Neste último caso, análises produzidas nas últimas oito décadas demonstram elevação média do nível dos oceanos na ordem de 1,2 mm/ano. O fenômeno relaciona-se com o fato das massas oceânicas estarem incorporando a cada ano $430 \mathrm{~km}^{3}$ de água proveniente dos continentes. Ao mesmo tempo em que ocorre aumento do nível dos mares, estes provocam diminuição ainda maior da área das terras emersas e conseqüentemente, variações da quantidade e qualidade dos recursos hídricos nas regiões litorâneas (NEGRET, 1982:35).

Além do Machrek, tensões relacionadas com os direitos sobre os recursos hídricos podem ser identificados nas Bacias dos rios Mekong (compartilhada entre o Laos, Burma ${ }^{85}$, China, Tailândia, Vietnã e Camboja), da Prata (irrigando o Brasil, Bolívia, Uruguai, Paraguai e Argentina) e do rio Lauca (atravessando a Bolívia e o Chile). A hostilidade entre a Índia e a Bangladesh tem sido exacerbada pela disputa em torno das águas do Ganges, o mesmo ocorrendo entre os países banhados pelo Danúbio. E estes constituem apenas alguns dos conflitos que oposto os países que usufruem bacias hidrográficas comuns.

$\mathrm{Na}$ realidade, o compartilhamento da água constitui atualmente um problema difundido na escala internacional. Nada menos do que 155 dos maiores sistemas hidrográficos do mundo estão divididos entre duas nações e, além disso, 59 estão divididos entre três a doze países. Por exemplo, no continente africano o rio Níger, percorre dez países; os rios Nilo e o Zaire banham outros nove; o Zambeze, oito; quanto ao Volta, são seis países. Quase $40 \%$ da população do mundo habita bacias hidrográficas multinacionais (Cf ELLIOTT, 1998:223).

Ressalve-se que a pressão exercida sobre os estoques naturais das águas doces decorrente, por um lado, das demandas incessantes pelo líquido por parte das residências, indústria e agricultura e de outro, pela contaminação em larga

\footnotetext{
${ }^{85}$ Burma passou a ser conhecida como Mianmar por decisão unilateral dos governantes militares deste país a partir de junho de 1989. Ressalve-se que além do movimento de oposição ao regime amplos setores de opinião não reconhecem a validade desta decisão e continuam a se referir ao seu país como Burma.
} 
escala das reservas hídricas, tem crescido de tal forma que a própria questão da destinação - ou não - de recursos hídricos para os ecossistemas naturais já entrou na pauta das especulações técnicas e das proposições de planejamento ambiental (SELBORNE, 2002:48). Não haveria como deixar de registrar as nascentes controvérsias opondo medidas de proteção à vida selvagem (inclusive as ameaçadas de extinção), com as requisições de agricultura, conflitos nos quais a produção de alimentos entra em rota de colisão com uma jurisprudência hídrica voltada para a conservação do meio natural (Vide BARLOW e CLARKE, 2003:79).

Nesta conjuntura, os ecossistemas listados como prioritários numa estratégia de aproveitamento dos recursos hídricos seriam aqueles que, reconhecidamente, são considerados indispensáveis para o abastecimento humano, desempenhando marcante relevante papel para o atendimento das necessidades humanas. Nesta situação se inscreveriam os ecossistemas concentradores de umidade que concorrem para a perpetuação dos mananciais de água potável, cuja localização nas proximidades das áreas de concentração urbana valorizaria sua manutenção. Sendo assim, se justificaria uma perturbadora indagação sobre o futuro dos demais sistemas naturais que, num contexto de escassez crescente de água, os tornariam "supérfluos", e, por conseguinte, fadados à eliminação.

De qualquer modo, quaisquer que sejam os contextos enfocados, o rol de problemas relacionados com os recursos hídricos reclamaria alguma concisão quando ao nódulo central que induz e reproduz este instigante elenco de prognósticos, todos firmados, em maior ou menor grau, na situação de stress e/ou de escassez de água. Novamente, pode-se resgatar o primado pelo qual a crise dos recursos hídricos da atualidade é um fato largamente subsidiado por uma contextualização histórica e social, na qual os fatores naturais, mesmo contribuindo para sua eclosão, não podem de modo algum ser isoladamente responsabilizado enquanto fator desencadeador desta crise.

Há que ser repetidamente pautado que o mundo atual caracteriza-se por diferenças sociais sem paralelo em toda a história da Humanidade. Basta lembrar que os cinco países mais ricos somam $86 \%$ do consumo de todos os bens produzidos no mundo. E, estes contrastes que não cessam de se aprofundar. A 
ponderação é evidente quando avaliamos dados do Programa das Nações Unidas para o Desenvolvimento (PNUD). No ano de 2002, estes enunciavam que a quinta parte mais rica da população mundial consome $45 \%$ de toda a carne e do pescado, enquanto que a quinta parte mais pobre, apenas $5 \%$. Para outros suprimentos, estes dados seriam respectivamente: $84 \%$ e 1,1\% para o papel; $74 \%$ e 1,5\% para as linhas telefônicas; $87 \%$ contra menos de $1 \%$ de toda a frota mundial de veículos; $58 \%$ contrapostos a menos de $4 \%$ quanto à energia.

Os dados expostos balizam uma crítica de mão dupla. Ela estaria endereçada para os setores de opinião que alertam para uma "crise hídrica" exposta de modo alheio ao substrato social, assim como para os que responsabilizam mecanicamente a "explosão demográfica" como causa primordial de todos os males do mundo contemporâneo, um argumento que encoraja a transformação do Terceiro Mundo em culpado sine qua non pela escassez de água doce. Um argumento em contrário é que não se pode negligenciar o fato de que os países do Norte, graças aos seus hábitos referendados em um estilo de vida dito "afluente", constituem não só consumidores de bens como igualmente de recursos hídricos.

Certificar esta situação não oferece quaisquer dificuldades de monta. Basta prestar atenção para o que segue:

Os norte-americanos usam $1.280 \mathrm{~m}^{3}$ de água por pessoa todos os anos; os europeus usam 694; os asiáticos usam 535; os sul-americanos usam 311; e os africanos usam 186. Embora o europeu comum use apenas a metade da água utilizada por um norte-americano comum, seus níveis de consumo ainda são altos se comparados aos níveis de cidadãos de países nãoindustrializados (BARLOW e CLARKE, 2003:68).

Por conseguinte, o mais provocativo dos cenários relacionados com a água, está direcionado para a questão do abastecimento dos países europeus, do Japão e dos Estados Unidos, que se aproximam a passos de gigante da situação de stress hídrico. Conforme já foi colocado, este grupo de países, detentores de gigantescos parques industriais e notoriamente esbanjadores de recursos, estarão se defrontando em futuro próximo com a premência de solucionar a "sua" questão 
dos recursos hídricos. Promotores do modelo de desenvolvimento que é o maior responsável pela crise dos recursos hídricos que hoje se vive, estas nações vêemse, pois às voltas com um dilema que retorna ao seu espaço de origem carregado de um radicalizado leque de contradições, daí o recorrente apelo teledirigido e da mídia em geral insistindo na "dramaticidade" desta crise.

A despeito do stress hídrico já ter atingido a muitas décadas a população da periferia pobre dos grandes centros urbanos, apenas quando esta crise acode os centros do poder global, sua presença se impõe junto ao imaginário mundial (VIANA, 2005). De um ponto de vista geoeconômico e geopolítico (ou quem sabe, destas duas referências simultaneamente), esta situação suscita a indagação relacionada com os possíveis cenários existentes quanto aos termos colocados para estes países satisfazerem suas necessidades de água doce. Lado a lado com prognósticos otimistas, prevendo um comércio de água beneficiando provedores e compradores do líquido, pode-se também registrar a possibilidade de conflitos, cenário este que se materializou historicamente em diversos contextos nos quais se acendeu o interesse por recursos considerados indispensáveis.

De resto, mesmo existindo concordância com o fato de que a água se transforme em um bem de mercado, como estará garantido o abastecimento daqueles segmentos sociais colocados à margem e excluídos de participação real na economia? Decerto, há que ser pensado que a escassez estará atingindo (e ainda mais duramente), as populações do Terceiro Mundo, habitantes de países que em muitos casos serão justamente os solicitados para atender as demandas dos países centrais. Para completar, quem contestaria a afirmação de que o comércio de água doce estará prioritariamente assegurando o abastecimento daqueles setores que, no Norte e no Sul do Planeta, dispõem de dinheiro para pagar pelo acesso a ele?

Esta somatória de problemas nos conduz inevitavelmente a destacar a questão das reservas brasileiras de água. Uma reconhecida avaliação, amplamente aceita, estabelece que o Brasil seria detentor, no interior da sua moldura territorial, de $12 \%$ da água superficial do planeta (REBOUÇAS, 
2002a:29). Este montante é significativo não só do ponto de vista quantitativo como do qualitativo. Numa situação verdadeiramente ímpar no mundo atual, está comprovada a existência no território brasileiro de imensos corpos líquidos altamente competitivos em termos de pureza, passíveis de serem integrados à pauta do comércio exterior.

Somente este fato justificaria a importância da problemática dos recursos hídricos para o conjunto da sociedade brasileira, constituindo motivo adicional para que esta preocupação seja discutida com maior rigor e detalhamentos possíveis, enfocando com acuidade os aspectos econômicos, sociais e políticos desta questão.

E, começando pelos que rondam o Planeta como um todo, cujos reflexos, cedo ou tarde, estarão influenciando pareceres em todos os níveis sobre a destinação a ser proposta aos recursos hídricos localizados sob jurisdição brasileira.

\subsection{A EXAUSTÃo dOS RECURSOS HídRI COS}

A opinião pública se acostumou a conceber o petróleo, assim como os metais, enquanto itens pertencentes à pauta dos recursos estratégicos. Mais recentemente, a biodiversidade também passou a integrar o elenco de insumos considerados insubstituíveis. No entanto, o que o imaginário social ainda não se deu conta é que a água igualmente possa estar se transformando - se é que tal fato já não ocorreu - em um outro recurso estratégico.

Isto porque em razão de sua escassez crescente, a água, recurso natural renovável, mas não inesgotável, tem se tornado um bem disputado, constituindose na atualidade como um fator de estabilidade social interna e da balança de poder na arena internacional. A água tornou-se claramente um recurso sobre o qual incidem com força cada vez maior as atenções do poder. Deste modo, a 
disputa por esta substância tem se tornou fonte de toda sorte de antagonismos, em curso ou potenciais (Fig. 32).

É o que se pode inferir a partir do clarividente comentário do geógrafo francês Claude RAFFESTIN:

Foi-se o tempo em que a água era considerada um bem livre. Ela só o era, aliás - e a economia política que nos desculpe - onde era superabundante em relação às necessidades (...). De fato, no passado as sociedades que elaboravam 'políticas da água' estavam localizadas em zonas de fraca precipitação e de temperatura média elevada, como no Egito, na Mesopotâmia, em certas regiões da China, etc. Hoje, por causa da utilização e do consumo aumentados pelo crescimento demográfico e econômico, todos os países se confrontam com problemas relacionados com a água a água, como qualquer outro recurso, é motivo para relações de poder e de conflitos (1993:231).

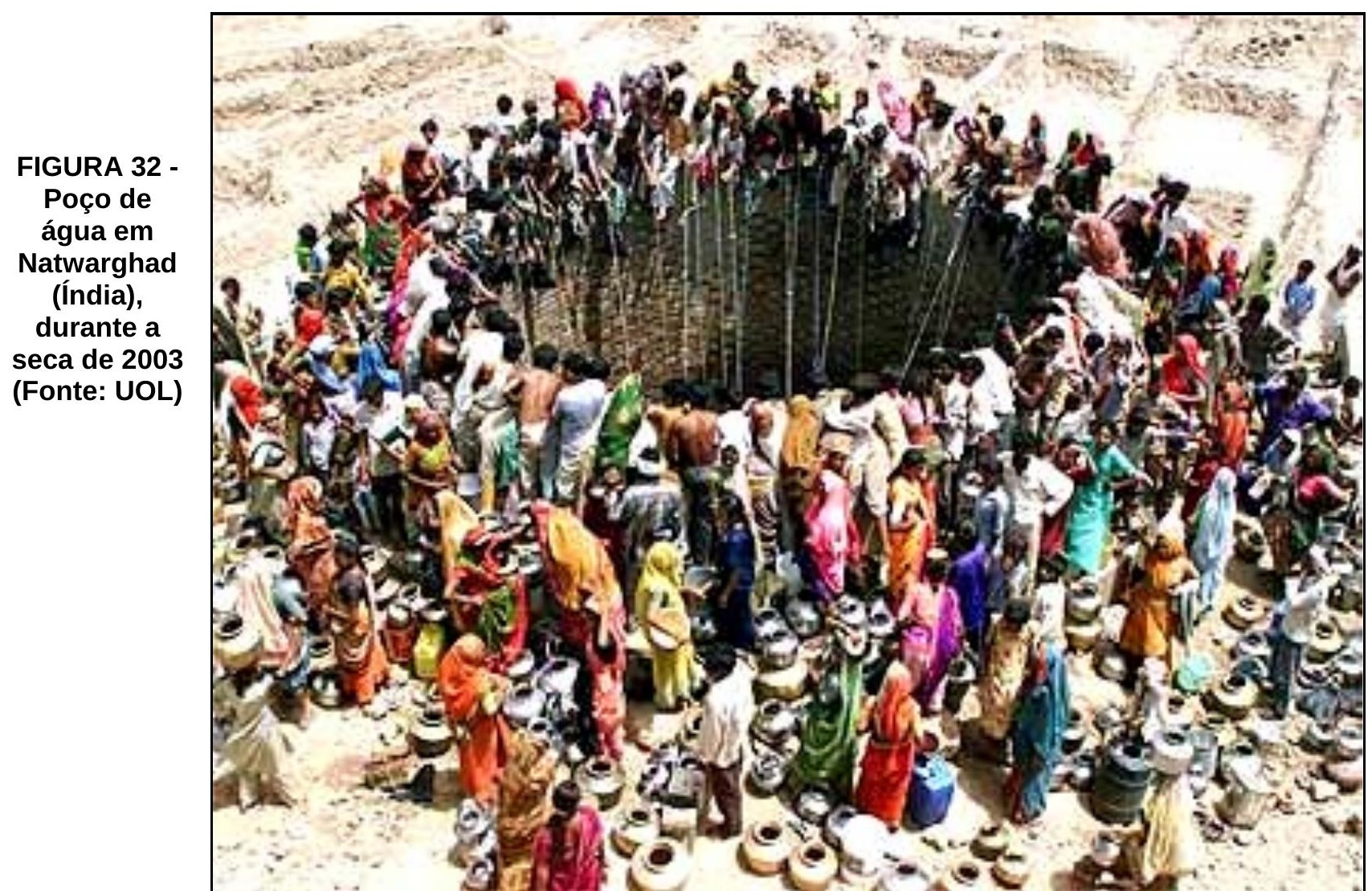


Os sinais de uma crise hídrica inédita na história humana estão por toda parte. Um claro indício de que o precioso líquido escasseou, é o surgimento de um negócio internacional de águas doces. No final do século $X X$, a água potável passou a integrar a pauta de importações de países tão diferentes quanto Chipre, Cingapura, Kuwait, Japão, Israel e os Emirados Árabes Unidos. Outro dado é que a partir dos finais do século $X X$ cresceu vertiginosamente o comércio citadino de água potável. Fato simplesmente impensável décadas atrás, os galões utilizados para distribuir este líquido tornaram-se verdadeiros ícones urbanos, inseparáveis do cotidiano das grandes cidades do mundo.

O século XX assistiu à degradação de vales fluviais inteiros, devido ao comprometimento da vazão natural em face da destruição do meio ambiente, da retirada excessiva de água para a lavoura, das atividades industriais e do consumo residencial. Este seria o caso do rio Colorado (Estados Unidos/México). Este curso d'água, que no passado chegou a ser referido como "Nilo americano", está praticamente secando. Ao alcançar sua foz, no golfo da Califórnia, grande parte do caudal (90\%) foi desviada para a agricultura e para atender as cidades do trecho norte-americano. Deste modo, a questão do uso das águas desta bacia hidrográfica, paralelamente às considerações de mote ambiental, tem motivado toda sorte de incidentes entre os Estados Unidos e o México (VILLIERS, 2002:311/319).

Outro exemplo dramático seria o rio Amarelo (ou Hoang-Ho), na China. Outrora correndo vigorosamente através das planícies de $l o e s s^{86}$ do Norte deste país e constituindo uma das bases do surgimento da soberba civilização chinesa, o rio Amarelo está morrendo. Sabe-se que desde 1985 seu curso tem secado todos os anos, e o período em que permanece sem água tem gradativamente se estendido. Em 1996, o rio ficou seco por 133 dias. Em 1997, um ano especialmente castigado pela seca, este rio deixou de atingir o mar durante exatos 226 dias (VILLIERS, 2002:363). Embora fato desalentador, este nefasto acontecimento não constitui caso único. Pelo contrário, integra vasto elenco de

\footnotetext{
${ }^{86}$ Depósito eólico composto de frações finas, acumuladas marginalmente às regiões desérticas, propiciando a formação de terrenos de alta fertilidade.
} 
agressões que tem destruído os mais diversos corpos líquidos tanto na China quanto no Planeta como um todo.

Indiscutivelmente as alterações impostas ao fluxo dos grandes vales fluviais declinaram em soberbos desastres ambientais, e isto, numa escala nunca vista. Dois destes exemplos seriam os rios Amu-Darya e Syr-Daria, que banham os países da antiga Ásia central soviética. No caso destes cursos d'água, os desequilíbrios hidrológicos provocados foram de tal monta que conduziram à virtual destruição do Mar de Aral. Outrora formando um gigantesco lago salgado localizado na confluência das fronteiras do Cazaquistão e do Uzbequistão, o Aral está em rápido processo de desaparição. O desmatamento da vegetação nativa e o uso intensivo do solo provocaram assoreamento acelerado. O processo agravou-se, em obediência a planos qüinqüenais esboçados pela antiga burocracia da ex-URSS, estipulando o desvio das águas dos rios Amu e Sir-Darya para a cultura mecanizada de algodão.

O Mar de Aral deixou assim de receber o essencial da contribuição hídrica que mantinha o seu nível. Perdendo metade do seu volume de água nos últimos trinta anos, as margens do Aral chegaram a recuar $80 \mathrm{~km}$. A navegação interior ficou impedida e a pesca, que sustentava a produção de caviar ( $10 \%$ da produção da ex-URSS), foi praticamente eliminada. A salinidade da água multiplicou-se por três e nas áreas correspondentes ao antigo leito marinho, os ventos passaram a carregar uma poeira salina carregada de pesticidas para até $500 \mathrm{~km}$ de distância, gerando novos desertos. Desastres semelhantes estão previstos para outros corpos líquidos salgados, como o já mencionado caso do Mar Morto, cujas margens tem registrado visível retrocesso nos últimos anos ${ }^{87}$.

Outro problema sério é o destino das massas líquidas formadas pelos lagos. Embora cobrindo uma área 12 vezes menor do que a calha dos rios, estes corpos líquidos acumulam um volume aproximadamente 35 vezes maior de água do que o fluxo pluvial (cf SHIKLOMANOV, 1999). Estas regiões lacustres, caso dos

\footnotetext{
${ }^{87}$ Com o objetivo de salvar o Mar Morto da agonia, em 2005 Israel e Jordânia iniciaram estudos de viabilidade de um ambicioso projeto de transposição das águas do Mar Vermelho para o Mar Morto, consistindo na construção de um canal que além de repor o nível da lâmina de água deste lago salgado, abasteceria usinas de dessalinização, uma iniciativa que beneficiaria também os palestinos (Ver AMBROSIO, 2005).
} 
Grandes Lagos da América do Norte e do Lago Baikal, na Sibéria oriental, tem sido insistentemente citadas como afetadas pela poluição, muitas vezes de modo irreversível. Assinale-se o vulto dos ambientes citados, concentrando no primeiro caso $27 \%$ da água das regiões lacustres de todo o mundo e $25 \%$, no segundo (Vide VILLIERS, 2002:57). Por fim, além dos esgotos e dos efluentes industriais, as deposições ácidas também colaboram com o seu quinhão na destruição destes corpos líquidos em todas as regiões industrializadas.

Quanto aos aqüíferos, sabe-se que os mesmos estão sendo explotados num ritmo muito superior à recarga natural, disto resultando seu esvaziamento. Recorde-se que a água subterrânea possui um tempo de renovação em média muito dilatado: segundo várias estimativas, em torno de 1.400 anos (Vide SHIKLOMANOV, 1999). Levando em consideração esta informação, salienta o especialista indiano Payal SAMPAT:

...à medida que nossa dependência da água subterrânea aumenta, a disponibilidade deste recurso se torna mais limitada. Em quase todos os continentes, muitos dos principais aqüíferos estão sendo exauridos com uma rapidez maior do que sua taxa natural de recarga (2000:12).

Entre outros casos conhecidos, pode-se citar o projeto de explotação do aqǘf́re da Núbia, uma obra do governo da Líbia por este batizada como "Grande Rio Construído pelo Homem" e executado quando todas as fontes convencionais litorâneas deste país tinham sido irreversivelmente esgotadas. Serpenteando ao longo de mais de 1.800 quilômetros de tubulações através do Saara, este aqueduto, a "Oitava Maravilha do Mundo" (tal como este projeto é emulado pela propaganda oficial), conduz água extraída de mais de mil poços da árida província saariana do Fezzan e da região de Kufra para o sedento litoral setentrional deste país (Vide Fig. 33). Esta água, por sinal, está sendo bombeada de um lençol subterrâneo que se estende por vários países, e assim, tem provocado reações na opinião pública das nações vizinhas.

Polêmicas à parte, em favor deste projeto existiriam os depoimentos de que o mesmo afugentou o fantasma das "torneiras secas", oferecendo tranqüilidade à 
população deste árido país norte-africano. Além disso, o projeto tem sustentado a implantação de sistemas de agricultura irrigada e inclusive, de bombeamento de águas servidas para assegurar o provimento futuro dos aqüíferos litorâneos situados na Cirenaica e na Tripolitânia. No entanto, a exploração das águas desses reservatórios saarianos está sendo operada sem qualquer preocupação quanto ao fato deste estoque suportar não mais do que algumas décadas de prospecção, ao menos no ritmo pelo qual suas águas tem sido retiradas. E, após

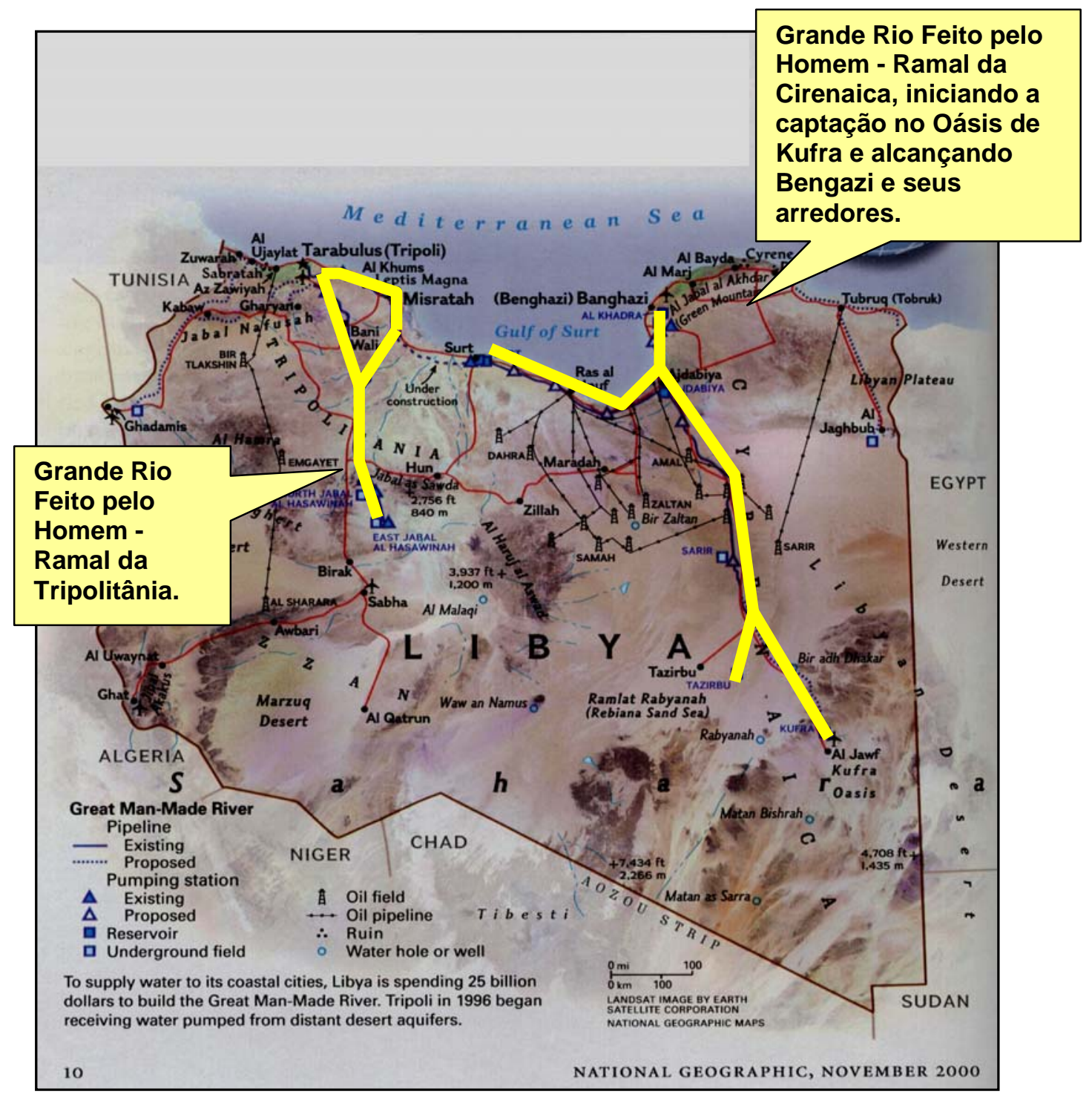


FIGURA 33 - Mapa do Sistema Grande Rio Feito pelo Homem: A Líbia é um país eminentemente desértico, integrando a Grande Diagonal Árida. É coberto em mais de $90 \%$ da sua extensão pelo Saara. Visando garantir suprimento de água para os cultivos e para as cidades costeiras, o governo líbio investiu 25 bilhões de dólares no projeto Grande Rio Feito pelo Homem. Iniciado em 1984, o sistema agora fornece água subterrânea dos aqüíferos do centro do deserto para as regiões litorâneas. $O$ trajeto dos dutos está destacado neste mapa através de linhas amarelas (Fonte: National Geography, exemplar de novembro de 2000 , página 10 , escala aproximada 1:7.900.000). 
o esgotamento do aqüífero da Núbia, onde os líbios poderão encontrar água? E os países ao redor, caso reivindiquem sua proporção de águas do aqüífero, como será possível indenizá-los?

Em linhas gerais, o drama do esvaziamento dos lençóis subterrâneos constitui um evento cujo remate, como no caso do aqüífero Ogallala, nos Estados Unidos, é ilustrativo das repercussões negativas para as sociedades humanas. $O$ esgotamento destas águas subterrâneas, que abastecem 1/5 de toda agricultura irrigada deste país, e respondem pelo funcionamento de uma província agrícola de primeira grandeza, pode conduzir a cenários muito preocupantes. Parte significativa da exportação americana de grãos é proveniente dos estados do Ogallala, bem como metade da carne produzida neste país. Por sinal, o bombeamento indiscriminado destas águas subterrâneas fez as profundidades dos poços baixarem de 30 metros, quatro décadas atrás, para mais de 100 metros nos dias de hoje (REBOUÇAS, 2004:91). Se, como tem sido intensamente prognosticado,

...a crise de água da China forçá-la a procurar o mercado mundial em busca de grãos, e se esse aumento de demanda vier quando o aqüífero de Ogallala estiver exaurido ou o bombeamento da água tiver se tornado caro demais, isso poderá gerar uma crise global de alimentos (VILLIERS, 2002:227).

Face ao exposto, posicionar-se pela preservação das águas doces está colocado na ordem do dia. Neste sentido, é importante assinalar que mesmo configurando um estoque reduzido, a fração formada pelas águas categorizadas como superficiais pela literatura especializada (quais sejam, as encontradas nos rios, lagos, oásis e demais afloramentos que ocorrem na superfície do solo), representa um suprimento colossal. Em tese, este estoque permitiria abastecer toda a população mundial, que adentrou o novo milênio com seis bilhões de pessoas. Restaria, pois indagar, o porque da sede existir no mundo e principalmente as razões que a tem acentuado.

Evidentemente, a opressão das minorias étnicas, a repressão dos povos nãorepresentados e a desigualdade social contribuem para explicar o consumo 
desigual da água, e igualmente, dificuldade e facilidades colocadas para seu aceso. Em muitos países do Terceiro Mundo, enquanto que as elites urbanas podem adquirir água mineral, fazem perfurações à vontade ou usufruem o acesso aos sistemas públicos de abastecimento de água, as camadas pobres da população se vêem obrigadas a apelar para vendedores particulares (CMMAD, 1988:283). Esta água, distribuída através de caminhões pipas, além de pouco confiável quanto a potabilidade, chega a alcançar dez a doze vezes o preço pago pelas residências conectadas à rede oficial, tendo ainda que coletá-la em baldes e armazená-la de modo geralmente precário.

Em outras situações o privilégio de obter água articula-se explosivamente com diferenças étnicas e raciais. Na República da África do Sul, fazendeiros brancos de origem bôer ${ }^{88}$ apropriaram-se do essencial da água, comprometendo o abastecimento domiciliar de imensas massas rurais formadas por negros autóctones, cujos territórios ancestrais Ihes foram, por sinal, ilegitimamente usurpados (Vide ELLIOTT, 1998:228). Um levantamento sobejamente conhecido indica que neste país, 600 mil fazendeiros brancos monopolizam $60 \%$ da água destinada à irrigação, enquanto 15 milhões de sul-africanos negros vegetam em meio à profunda indigência hidrológica (BARLOW e CLARKE, 2003:71). Neste contexto, tal como em muitos outros, não propriamente a natureza, mas antes a natureza dos sistemas sociais parece estar condenando os humanos às agruras da sede.

Fato que se impõe por si mesmo, o próprio dinamismo do processo urbano inerente à modernidade, ao qual se associam inúmeras dessimetrias sociais, políticas e econômicas, apresenta sua quota de responsabilidades, tornando insuficiente uma oferta pré-existente de água. É o que a história do ancestral Vale do México pode revelar, cujo destaque era o então lago Texcoco (ou "Lago da Lua", conforme tradução da língua materna dos antigos astecas). Antes abrigando numa das suas ilhas a capital asteca, a cidade de Tenochtitlán, a região formada

\footnotetext{
${ }^{88}$ Bôer ou africâner é a denominação dada aos descendentes de europeus que se instalaram na província do Cabo, na atual República Sul-Africana, durante a colonização holandesa. No século $\mathrm{XX}$, constituíram o esteio do finado regime do apartheid.
} 
por este notável corpo líquido $\left(7.800 \mathrm{~km}^{2}\right)$, o principal do planalto de Anahuac ${ }^{89}$, jamais registrou qualquer carência de recursos hídricos. Aliás, os mitos fundadores dos astecas se prontificam em esclarecer o papel deste esplêndido afloramento de água e dos veios que contribuíam para o estabelecimento desta civilização singular (Vide Fig. 34).

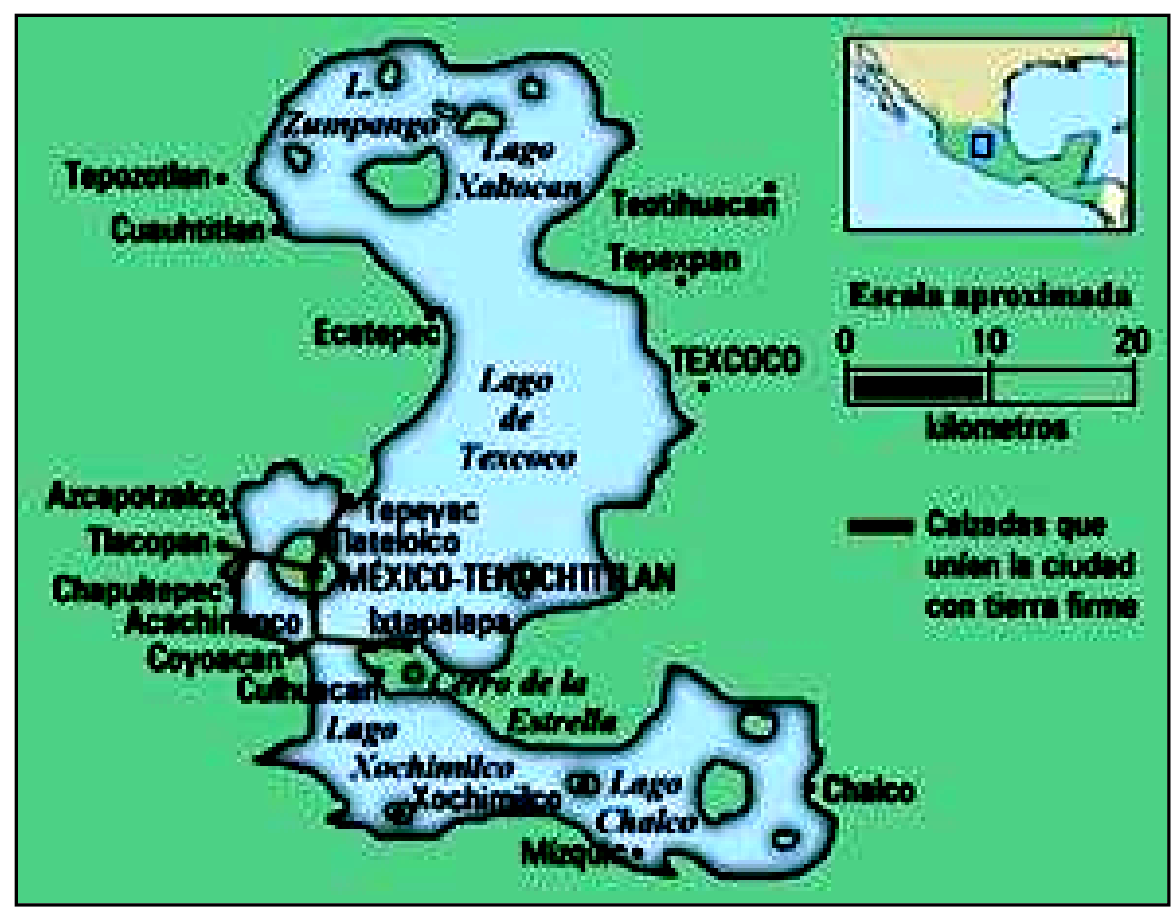

FIGURA 34 - Mapa do Lago Texcoco antes da Conquista Espanhola (Fonte: <http://ind.ntou.edu.tw/ b0232/Spirulina.files/image004.jpg>, acesso: 03-05-2005)

${ }^{89}$ Anahuac na língua nahuatl, falada pelo povo asteca, significa "próximo da água". 
O conglomerado urbano pré-colombiano do vale do México tinha por núcleo central Tenochtitlán, dotada de esplêndida arquitetura. Sua população alcançava 100.000 habitantes no século XVI, o dobro de qualquer localidade européia no mesmo período. Magnetizando todas as localidades postadas nas margens do Texcoco, a capital asteca era servida por sofisticado sistema de suprimento de água, com fontanários, tanques, bicas e reservatórios cuidadosamente construídos ao longo da urbe. Constituía um verdadeiro paraíso de jardins e hortas flutuantes, responsáveis pelo abastecimento da numerosa população indígena. Relatos pré-colombianos, além das crônicas do período colonial castelhano, ressaltam a abundância dos recursos hídricos existentes nessa região. É significativo que o vale tenha sido posteriormente batizado, em razão da prodigalidade dos seus lagos e canais, como "Veneza do Novo Mundo".

Entretanto, a atual Cidade do México (Fig. 35), a quinta maior concentração urbana da atualidade, implantada sobre as ruínas do antigo assentamento indígena e em áreas aterradas do que anteriormente formava o corpo líquido do lago, constitui uma metrópole conhecida por notórios problemas quanto ao abastecimento de água. A mancha urbana formada pela Cidade do México, uma macrocefalia urbana de primeira ordem que exerce o papel de núcleo da formação espacial mexicana, constitui o teatro por excelência de um dos mais graves exemplos de crise no abastecimento de água potável. O problema reporta ao dinamismo descontrolado desta megalópole, somado a um longo elenco de agressões ambientais, pelo qual as fontes locais de recursos hídricos foram conduzidas ao esgotamento.

Indiscutivelmente o ponto de partida desta situação foi a dominação dos colonialistas europeus. Quase imediatamente à vitória de Fernão Cortez sobre o Império Asteca (1521), os espanhóis encetaram a demolição de todas as grandes construções e a destruição dos diques, recorrendo para isso ao trabalho escravo dos seus novos súditos indígenas. A cobertura vegetal das redondezas do vale também foi eliminada. A pretensão dos conquistadores era que a Cidade do México, capital da província da Nova Espanha se assemelhasse o máximo possível de uma grande cidade espanhola, e nunca de Veneza. 
A progressiva expansão da Cidade do México terminou transformando-a num sorvedouro de recursos hídricos de um vasto entorno. Para abastecer a cidade, mananciais distantes 300 km de distância passaram a serem reclamados

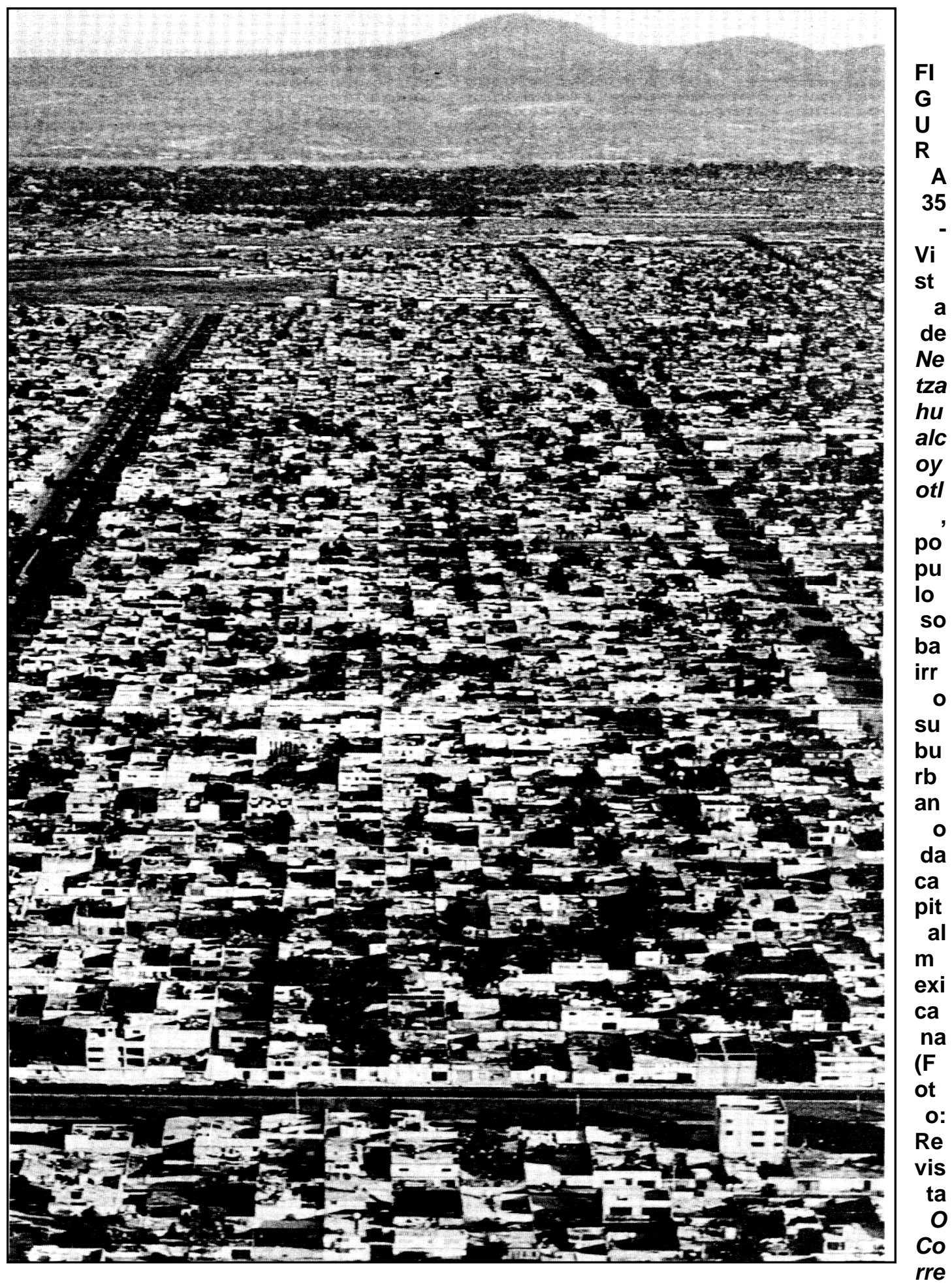


io da UNESCO, março de $\left.1985, \mathrm{n}^{\circ} 3, \mathrm{pp} .25\right)$. 
para satisfazê-la. Com a mesma finalidade, poços cujas profundidades atingem mais de 1.900 metros foram perfurados e ainda assim, não cessam de competir em ultrapassar esta marca. Basicamente, a cidade depende em 70\% destes aqüíferos, cujas águas estão sendo retiradas em um ritmo até $80 \%$ superior às suas taxas de recarga. Simultaneamente, a metrópole vivencia graves problemas de estabilidade do terreno por conta das sucessivas drenagens inadequadas do Lago Texcoco, implicando em recalques do solo que afetam áreas inteiras do sítio urbano. A Cidade do México está literalmente ficando sem água (Fig. 36). Para complicar, nada permite antever solução para o problema (Vide UNESCO, 1984; BARLOW e CLARKE, 2003:21/22).

Além da cidade do México, muitas outras metrópoles periféricas, dentre as quais se pode citar Djakarta (Indonésia), Mumbai (Índia), Bangcoc (Tailândia), Daca (Bangladesh), Kolkata (Índia), Cairo (Egito), Fortaleza (Brasil), Lagos (Nigéria), Damasco (Síria), Pequim (China) e Adis Abeba (Abissínia), apresentam quadros preocupantes quanto à disponibilidade de água, situação também motivada pela malversação dos recursos hídricos existentes. Os distúrbios que sacudiram a cidades como Delhi em 1993 (Índia), são ilustrativos do caráter explosivo que a questão do abastecimento de água potável insere. Em várias destas cidades, parte significativa da população conta apenas com água de má qualidade para suas necessidades, caracterizando gravíssimas condições sanitárias.

Recorde-se que em razão do despejo de esgotos in natura no curso dos rios, muitos reservatórios plenamente habilitados ao atendimento das demandas de diversas grandes cidades, foram transformados em simples depositários de efluentes de todo tipo. A degradação das reservas urbanas de águas doces, intensamente afetadas do ponto de vista ambiental em face do reforço de nutrientes oriundos do lançamento indiscriminado de esgotos, se explicitaria por intermédio da turbidez, da emanação de maus odores, da lama fecal e da eutrofização destes corpos líquidos. Espetáculo mais "fotogênico", o aumento do florescimento de algas e de outras plantas aquáticas está diretamente relacionado com o material orgânico presente nos esgotos domésticos (Vide Fig. 37). Este 
processo, asfixiando peixes e moluscos, afeta tanto o abastecimento de água para as atividades econômicas, quanto o próprio consumo humano.

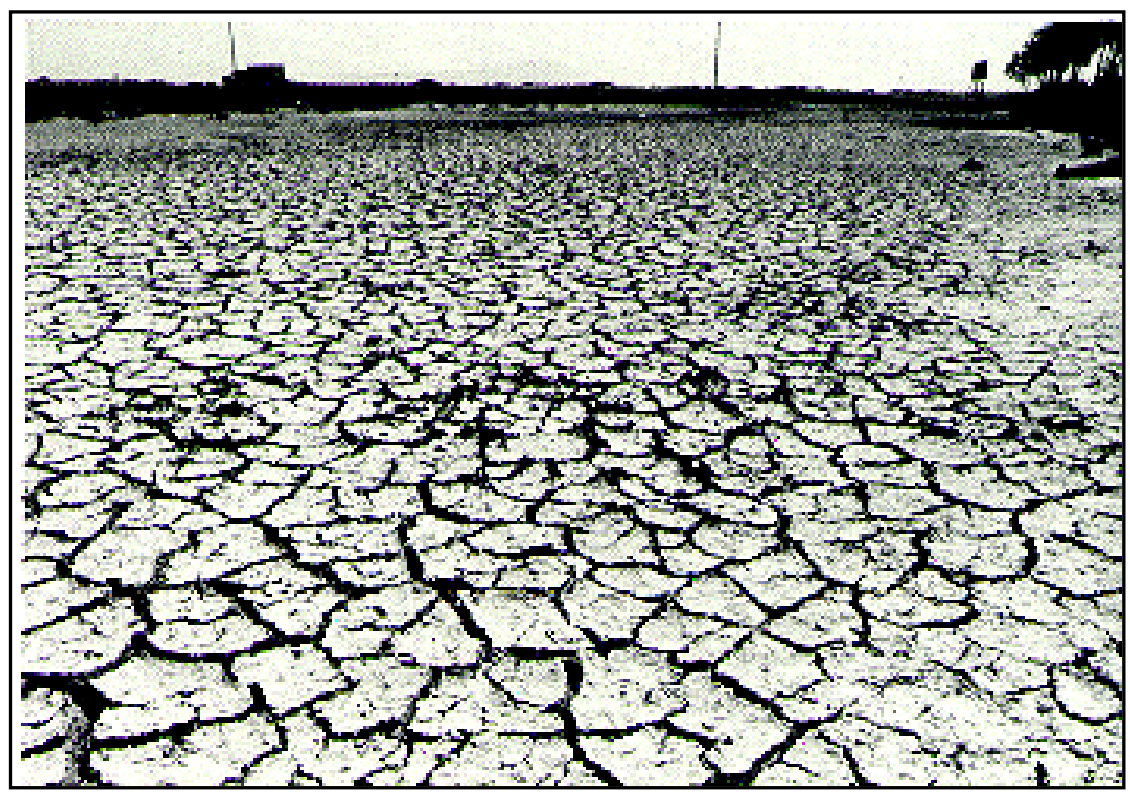

FIGURA 36 - Trecho gretado do antigo lago Texcoco hoje (Fonte: <http://www.sagan-gea.org/hojared_AGUA/paginasl TEXCOC07.JPG> acesso em 11-03-2005) 


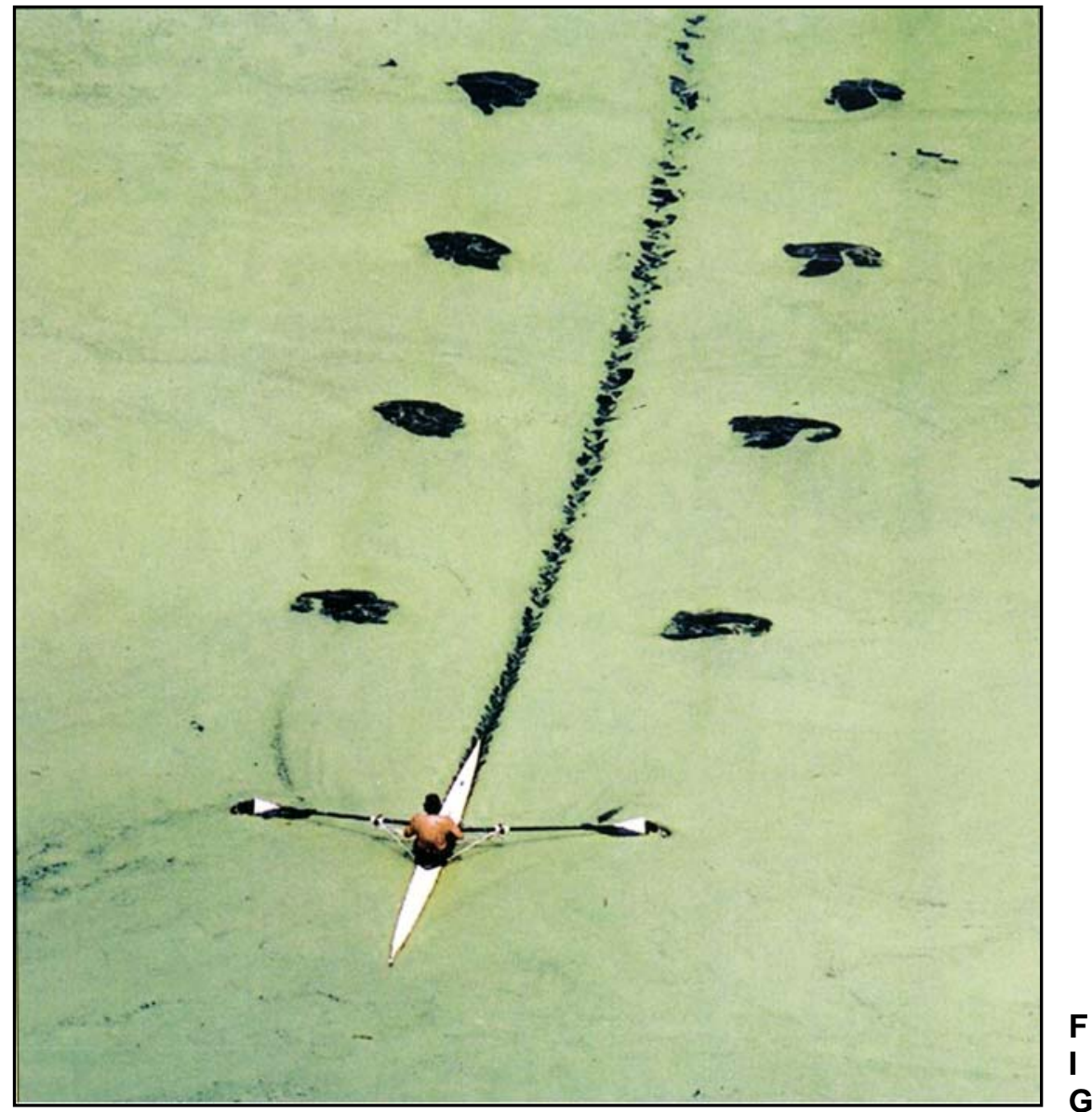

URA 37 - A eutrofização das águas: Por conta de fatores ambientais como o reforço de nutrientes juntamente com 0 aumento da temperatura da água, tem ocorrido um aumento crescente de florescimento de algas em todo o mundo, asfixiando peixes, moluscos e outras espécies. Durante a seca do verão de 1999, a lentilha d'água floresceu num ritmo milhares de vezes acima do normal nas águas lentas do Rio Schuylkill, na Pensilvânia (EUA), ocupando por completo a superfície da água. A planta nutriu-se dos despejos das estações de tratamento de esgotos, e sua proliferação, afetou o abastecimento das cidades da região (Foto: Revista World Watch, Volume 14, n 1, 2001, Contra Capa). 
Neste sentido, é fundamental registrar diversas questões políticas associadas, em vários contextos, com a depredação destes reservatórios. Exemplificando, a Região Metropolitana de São Paulo, mesmo dispondo de magníficos lagos artificiais, como as represas Billings e Guarapiranga, adota o impopular sistema de rodízio como resultado da poluição, assoreamento e comprometimento das águas destes lagos artificiais, fato para o qual contribuem a implantação de loteamentos clandestinos articulados com esquemas de clientelismo e de favoritismo político. Outras importantes regiões provedoras de água da RMSP, incluindo a bacia do Alto Tietê e do Sistema Cantareira, mesmo considerando-se a gravidade da situação vivida pela região metropolitana, também não reservam qualquer otimismo quanto à sua preservação.

Por sinal as cidades seriam num determinado ponto de vista, vetor da das agruras da sede. Os impactos decorrentes das edificações urbanas e do asfaltamento, obras que se generalizaram com a expansão do modo de vida ocidental, desempenham notável papel desagregador dos equilíbrios hidrológicos. Pesquisas empreendidas pelo famoso hidrólogo eslovaco Michal Kravcik nos anos 90 , confirmam que a impermeabilização do solo tem atuado como poderoso fator de rarefação dos recursos hídricos. O campo de estudos deste pesquisador foi seu próprio país de origem. A Eslováquia é um país da Europa central com 49.000 $\mathrm{km}^{2}$, sendo pouco maior que o Espírito Santo $\left(45.733 \mathrm{~km}^{2}\right)$. Sua população, da ordem de 5.400.000 habitantes, urbanizou-se rapidamente nas últimas décadas em resposta aos planos de desenvolvimento levados adiante pelos governos da antiga Tchecoslováquia.

As dimensões relativamente pequenas deste país, assim como sua industrialização e urbanização recentes, datadas do final da $\|^{a}$ Guerra Mundial, possibilitaram estudos de fundo sobre a questão dos recursos hídricos. Através de uma avaliação detalhada do território do seu país, uma das conclusões de Michal Kravcik é cada metro de asfalto provoca perdas anuais entre 200 e 300 litros de água. Matematicamente, chegou-se ao resultado pelo qual anualmente a Eslováquia perde de modo irreversível o equivalente a $1 \%$ das águas da sua rede fluvial. Outra conseqüência das intervenções antropogênicas seria a alteração do 
índice de chuvas. Acredita-se que na Eslováquia as precipitações pluviométricas tenham diminuído, nos últimos 50 anos, em torno de $35 \%$.

A explicação é que a água, ao invés de se infiltrar ou impregnar reservas de umidade como o solo, campos, pântanos, bosques e florestas, passa a escoar diretamente para os rios e destes, para as massas oceânicas. As obras humanas, eliminando etapas como a transpiração, induzem a retirada de enormes volumes de água do ciclo hidrológico, ao mesmo tempo em que conduzindo mais água para os oceanos, avolumam as perdas do líquido em razão da elevação do nível dos mares. A aceleração do índice de crescimento urbano em todo o mundo, tenderá a acentuar o fenômeno, diminuindo assim a quantidade real de água fresca disponível no Planeta. Nas projeções de Kravcik, o ciclo hidrológico terrestre como um todo poderá estar irremediavelmente comprometido nos próximos cem anos.

Convivendo com este cenário perpassado por nuanças das mais ameaçadoras, a apresentação de soluções rubricadas como "técnicas" se prontificariam em ofertar alguma esperança. É, justamente esta a razão que termina por granjeá-las com certa popularidade nos mais diversos meios dedicados a pensar a questão dos recursos hídricos. Poderíamos, sem dúvida alguma, registrar as possibilidades incontestes de programas de otimização dos recursos hídricos. Dentre estes, os que prescrevem a implantação de "calçadas verdes" (construídas com blocos vazados permitindo a infiltração da água), a reservação da massa líquida resultante das precipitações pluviométricas ${ }^{90}$ e das águas servidas urbanas classificadas como "cinzas"11, para usos considerados não-potáveis.

Neste quesito poder-se-ia incluir o esgotamento sanitário, assim como a lavagem de calçadas e dos quintais das residências, funções para as quais o recurso da água tratada, clorada e fluorada constituiria notória aplicação de

\footnotetext{
90 No estado do Rio de Janeiro, a Lei 4.248 (16-12-2003) instituiu o Programa de Captação de Águas Pluviais, visando oferecer treinamento aos habitantes das cidades para a coletar as águas das chuvas. Na cidade do Rio de Janeiro, o Decreto 23.940 (30-01-2004), tornou obrigatória nos casos previstos, a adoção de reservatórios que permitam o retardo do escoamento das águas pluviais para a rede de drenagem, objetivando também o reuso para finalidades não potáveis.
} 
esbanjamento despropositado. Também seria possível postular a substituição dos sistemas usuais de expulsão dos efluentes residenciais em favor dos baseados em descargas reduzidas, hidrologicamente mais eficientes e ambientalmente mais adequadas. No caso dos Estados Unidos, a simples aplicação de legislação datada de 1994 impondo maior eficiência nas instalações sanitárias reduziu em até $70 \%$ a quantidade de água consumida em milhões de banheiros norteamericanos (Vide BARLOW e CLARKE, 2003:277).

Entretanto, como não poderia deixar de ser, caberia evidenciar quanto à difusão das proposições técnicas o peso dos contextos historicamente situados. A última palavra quanto à incorporação de novas metodologias de gerenciamento dos recursos naturais, inclusive aquelas habilitadas a contribuir para com a preservação da qualidade das águas voltadas para o abastecimento das grandes cidades, cabe a injunções de ordem social, política e econômica, muitas vezes em exata oposição à conservação dos recursos hídricos. Tal panorama certamente nos reservaria cenários pouco atraentes. No que constituiria reapresentação de uma sentença histórica e sociológica por demais conhecida e repetida, o pendor do modelo de utilização dos recursos hídricos poderá apelar - e até o último momento quanto a ele isto for possível - para uma pulsão perdulária.

Nesta ordem de argumentações, seria conveniente recordar célebre diagnóstico lavrado pelo filósofo Karl Marx, segundo o qual:

Nunca uma ordem social desaparece antes de todas as forças produtivas, que nela tem lugar, tenham se desenvolvido; e nunca, novas e poderosas relações de produção surgem antes das condições materiais de existência tenham se esgotado no útero da velha sociedade (in Uma Contribuição à Crítica da Economia Política, citado em COLLINSON, 2004:192).

Porém, na hipótese desta citação se reapresentar novamente junto ao panorama histórico concreto, quais novas relações de produção poderiam ter lugar em um mundo exaurido da sua água?

\footnotetext{
${ }^{91}$ As águas cinzas corresponderiam neste contexto à água de banho e da lavagem de roupa, não se confundindo com as Gray Water Flow, isto é, as águas subterrâneas.
} 


\section{3. Água, Globalização e Neoliberali smo}

O conjunto de prédicas arroladas permitiria considerar que, indiscutivelmente, temos presenciado o desenrolar de uma era marcada pelo pipocar de espicaçadas atribulações. Hoje, mais do que em qualquer outra época precedente, o mundo assiste à erupção dos mais diversos conflitos, dentre os quais figuram sistematicamente, aqueles relacionados com a água.

Seria, pois cabível aprofundar esta discussão nos termos pelos quais as disputas centradas pelo controle dos recursos hídricos terminaram por encontrar fundamentação em conceitos preocupados com seu enquadramento enquanto recurso econômico. Lado a lado com a afirmação deste novo paradigma para os recursos hídricos, a consagrada fórmula subentendendo a água enquanto um direito passou a ser crescentemente erodida. Quando muito, esta compreensão foi substituída por uma locução de alcance bem menor, entendendo-a enquanto uma necessidade.

Neste momento pode-se recorrer à aferição do geógrafo Claude RAFFESTIN pela qual um recurso seria por definição produto de uma relação e, desse ponto de vista, não existiriam recursos naturais, mas apenas matérias naturais (1993:225). Por conseguinte, qualquer matéria natural - categoria que obviamente incluiria a água - seria passível de se tornar um recurso em função de uma determinada contextualização histórica e social. Evidentemente, dado que "toda relação com a matéria é uma relação de poder, que se inscreve no campo político por intermédio do modo de produção" (RAFFESTIN, idem), não haveria como este dinamismo deixar de se respaldar numa arquitetura de poder, subordinando a utilização do recurso ao seu gosto.

Tais enunciados destacam todo um conjunto de fatores que transformaram a questão dos recursos hídricos num debate central na sociedade contemporânea, vicejando na esteira da chamada globalização, e, articulada no interior desta, com a doutrina neoliberal. Referindo-nos ou não a este processo enquanto 
privatização, precificação ou tarifação da água, a transformação da água em mercadoria traz em seu bojo uma série de seqüelas. Perceptível no horizonte social no qual está integrada a maioria absoluta da humanidade, este movimento conduzirá a existência dos humanos às mais duras provas. Conseqüentemente, os fatos inerentes à totalidade social, política e econômica abrigada junto à globalização não permitiriam, de modo algum, que estes fossem desconsiderados. Tampouco, no tocante a uma tomada de posição por parte de todos que, de uma forma ou de outra, constituem partícipes da sociedade contemporânea.

Obviamente, este chamamento reclama a voz da massa de excluídos que se agigantou com o concurso da globalização. Como se sabe, no bojo da modernidade vasta maioria dos humanos tem sido instada a participar não como coadjuvante ativo, mas sim, enquanto atores sociais nela desigualmente integrados, uma "universalização perversa" que se recompõe dia-a-dia mediante exegeses cada vez mais radicalizadas (passim SANTOS, 1978a). Paralelamente aos dolos que tem caracterizado o dia-a-dia de imensos grupos populacionais, numa escala que se estende da falta de moradia e do desemprego, incorporando a fome e a violência urbana, agora estes mesmos segmentos constituem alvo predileto das agruras da crise hídrica mundial.

Fosse improcedente tal reflexão, não haveria como alinhavar que $26 \%$ da população do Planeta hoje vive sob condições de stress hídrico, grande parte desta no Terceiro Mundo; que, de acordo com a ONU antes de 2025, 47\% da população global serão formados por cidadãos de baixa renda acometidos pela falta de água; que nas megalópoles, atualmente características dos países do Sul, $50 \%$ da população não tem acesso a suprimentos confiáveis de água; que por fim, antes de 2030 mais da metade da população habitante das metrópoles da periferia será moradora de favelas, carente de acesso aos serviços de abastecimento e saneamento básico (MAUDE e CLARKE, 2003:67).

Seria lícito refletir que a amplitude da exclusão social nos dias atuais induziria obrigatoriamente a apresentação de formulações que permitissem discernir a origem da problemática. Daí o caráter imperioso de categorias como a da globalização, quase sempre analisada conjuntamente com a do neoliberalismo. 
Numa conceituação sintética, esta última nomenclatura seria correlata às proposições do capitalismo dito "liberalizado", liberto das amarras do "corporativismo" e dos obstáculos colocados por uma intervenção julgada "excessiva" por parte do aparato estatal. Marcando especialmente as últimas décadas do século $X X$, esta linha de interpretação se opõe a uma série de experiências de índole social-democrática que sugeriam a possibilidade de um "capitalismo com rosto humano", assim como a muitas outras esposando propostas de cunho progressista, democrático, e/ou nacionalista.

De um ponto de vista político, o neoliberalismo corresponde a uma conjuntura na qual setores conservadores do mundo ocidental costuraram um projeto que ao invés de incluir medidas sociais como forma de arrefecer a pressão dos movimentos populares e do Leste Europeu pautaram, pelo contrário, uma conduta assentada no que o capitalismo teria de mais seminal. Sem dúvida alguma, o neoliberalismo acompanhou, no plano das idéias econômicas, o recrudescimento dos embates com o antigo bloco soviético, revigorando a atmosfera da "guerra fria" surgida com o término da II ${ }^{\mathrm{a}}$ Guerra Mundial. Marcadamente, a difusão da doutrina neoliberal ocorreu em sintonia com a da globalização, com ela se confundindo das mais diversas formas (Cf OLIVEIRA, 1992:12/19, SANTOS, 2000).

Desde então, a totalidade dos teóricos neoliberais tem destacado a "competição", "integração" e "privatização" enquanto tópicos inegociáveis da condução eficiente da economia e da sociedade modernas. Além destas palavraschave, outra expressão que tipifica o vocabulário globalizado seria a "desregulamentação", jargão conotado pelos "ajustes estruturais" cujo eixo estaria firmado não nas necessidades sociais, mas sim nas reclamadas pelas ambições das grandes corporações multinacionais (GEORGE, 1997). O neoliberalismo ingressou no vocabulário contemporâneo especialmente a partir dos anos 80 do século passado, quando secundado pelo triunfo das administrações Ronald Reagan nos Estados Unidos (1981/1989) e de Margareth Thatcher, no Reino Unido (1979/199), passou a gozar de indisputada popularidade no discurso dos economistas (passim BOITO JÚNIOR, 1999). 
Descartando quaisquer arroubos reformistas, a interpretação neoliberal do oikos-nomos postula uma sociedade regrada pelo mercado total, um novo "reino iluminado" no qual o exercício do consumo realizado por indivíduos colocados à completa disposição dos dinamismos de mercado, constituiria o ápice da liberdade individual e porque não afirmar, do próprio progresso social. Deste modo, em oposição às leituras que, direta ou indiretamente, prescreviam alguma implicação social na forma de reprodução das sociedades regidas pela economia de mercado, o modo de organização do capitalismo sob a égide neoliberal diverge daquele que caracterizou diversos contextos na história do ocidente. No neoliberalismo, o capitalismo está compelido a dar vazão ao que nele existiria de mais peculiar e característico, apresentando-se como uma weltanschaung que se instituiu por todas as interfaces do mundo contemporâneo (Cf SANTOS, 2000).

No que interessaria diretamente aos ditames da nossa discussão, as políticas públicas que pautaram durante o século passado o gerenciamento dos recursos hídricos terminaram questionadas nos mais diversos aspectos por esta nova ideologia hegemônica, que propõe agora uma releitura cujo estofo, é uma reinterpretação radicalizada das relações que perpassam pelo meio ambiente e pelo mercado. Dotadas das mais sérias conseqüências para a questão do acesso às águas doces, seus ditames estratégicos realçam a suposta competência do mercado em solucionar o problema da escassez:

Se nos anos 70 a crise ambiental alertou para a necessidade de frear o crescimento diante da iminência do colapso ecológico (Meadows et ali.), agora o discurso neoliberal afirma que não existe contradição entre ambiente e crescimento. Os mecanismos de mercado se convertem no meio mais certo e eficaz de internalizar as condições ecológicas e os valores ambientais no processo de crescimento econômico. Nesta perspectiva, os problemas ecológicos não surgem como resultado da acumulação de capital. Para a proposta neoliberal teríamos que atribuir direitos de propriedade e preços aos bens e serviços da natureza para que as clarividentes leis do mercado se encarreguem de ajustar os desequilíbrios ecológicos e as diferenças sociais, a fim de alcançar um desenvolvimento sustentável com equidade e justiça (LEFF, 2004:22, grifo nosso). 
Como se vê, a intenção é "desobrigar" o mercado. Deste modo, a humanidade passou a defrontar-se com um capitalismo "desinibido", "livre de amarras", que procura aplicar com denodo suas teses mais incisivas, sendo este precisamente o significado mais pungente da globalização. Um fator essencial que explica a difusão do neoliberalismo reside no fim do Leste Europeu. Desde a queda do Muro de Berlin (1989), episódio que assinala a desintegração do antigo mundo socialista europeu, a economia de mercado, agora campeando sozinha no mundo, se desnuda por inteiro, abandonando todos os impedimentos quanto ao que entende como "livre curso da economia". Destas considerações decorre a própria contemporaneidade do neoliberalismo, ideário que passou a campear junto à intelligentsia econômica a partir dos finais do século passado, ofertando às políticas de privatização um notável impulso tipo "bola-de-neve" (Ver a respeito CHESNAIS, 1996:23 e GEORGE, 1997).

Evidentemente, como todo fenômeno localizado no tempo e no espaço, recorde-se que a globalização não se explicita de um modo homogêneo e tampouco, que os resultados da ofensiva neoliberal sejam idênticos em todo o mundo. Por sinal, a "globalização" incorpora uma diversidade de matizes e desqualificar seus diferentes avatares poderia conduzir inúmeros equívocos conceituais e políticos (passim BOITO JÚNIOR, 1999). Ainda assim, em razão da forte identificação do termo "globalização" com o discurso político neoliberal, este configuraria, no olhar crítico de muitos pesquisadores, como um conceito legitimador da estratégia internacional do capitalismo, solicitando, pois alguma cautela na sua utilização. Ao ser considerada "incômoda", não seria de todo surpreendente que a expressão "mundialização do capital" tenha sido pautada para substituir, numa visão crítica, o que temos denominado como "globalização" (Ver CHESNAIS, 1996:13/25).

Outra consideração importante é que paralelamente o ideário neoliberal demonstrou enorme capacidade de tirar proveito da crise ambiental de modo a alavancar a mercantilização da água. Recorde-se que os recursos hídricos foram crescentemente colocados a distancia dos humanos através do processo de artificialização da natureza, pelo qual, uma vez comprometidos em quantidade e 
em qualidade, terminaram incorporados ao universo das commodities $^{92}$, embasando o mercado emergente de água doce.

Cumpriria assinalar que este processo em nada se distancia das observações registradas anteriormente referentes à lógica pela qual o capitalismo, visando transformar em mercadoria recursos dantes magnanimamente ofertados pela natureza, é induzido a implementar sua destruição estrutural, pelo qual estes são num segundo momento, depois de tornados escassos, oferecidos exatamente àqueles que dantes dele usufruíam sem a intermediação do mercado.

E, é inserida nesta lógica que a água passou a ser reivindicada, sem que nesta colocação esteja presente qualquer arroubo de linguagem, como o "ouro azul do século XXI" (passim BARLOW e CLARKE, 2003). Mais ainda, como um alvo prioritário das novas formas de afirmação do sistema capitalista.

\section{4. Água: Um Direito a SER AsSEgurado}

Mas nesse contexto, o diferencial é que as conceituações tradicionais, ao questionarem as novas diretrizes de apropriação da água, constituem justificado ponto de referência. Tratando-se de uma substância de importância excepcional, enaltecida desde tempos imemoriais no imaginário cultural da totalidade das sociedades tradicionais, o acesso à água constitui nota comum, repetidamente reiterada, de um direito inalienável tanto para as comunidades humanas quanto para as formas de vida que coabitam a Terra juntamente com o homem (Ver BARLOW e CLARKE, 2003:250).

Esta relevância, aclamada pela totalidade das concepções filosóficas, éticas e religiosas do mundo da tradição, tem por justificativa o fato concreto de que não existe possibilidade da vida se fazer presente independentemente deste líquido. A água, uma vez essencial ao funcionamento da sociedade, constituiria recurso

92 O jargão econômico reconhece como commodities produtos in natura, oriundos da agro-pecuária ou da extração mineral, que podem ser estocados por certo tempo sem perda sensível de 
comum passível de usufruto a todo e qualquer membro de uma coletividade humana, sendo esta, uma condição imprescindível para a continuidade das relações sociais e culturais que perpassam pelo tempo e pelo espaço.

A releitura deste padrão de relacionamento com a água, configurando uma linha de ruptura inédita na história humana, foi certamente tonificada pela crescente escassez do líquido. O grau de ineditismo que ronda as polêmicas centradas nos recursos hídricos transparece na gradativa materialização dos seus contornos em paralelo com a agudização da crise do acesso às águas doces. Tal caráter de novidade é perceptível, por exemplo, quando lemos mais atentamente o relatório Limites do Crescimento. Este documento, confeccionado pelo Clube de Roma em Abril de 1968, configurou um momento excepcional quanto à tomada de consciência da crise ecológica, tendo tomado por base a investigação de cinco grandes tendências de interesse global: o ritmo acelerado de industrialização; o rápido crescimento demográfico; a desnutrição generalizada; o esgotamento dos recursos naturais não-renováveis; e a deterioração ambiental.

Mas, apesar da profundidade e do alcance de suas avaliações, o texto deste documento dedica à questão dos recursos hídricos não mais que algumas menções esparsas, sequer sinalizando para a possibilidade de uma crise na escala que hoje observamos. Deste modo, a despeito de ter sido elaborado a pouco menos de quatro décadas atrás (a saber, num lapso de tempo que historicamente poderíamos considerar como sendo "ontem"), o famoso relatório Limites do Crescimento, do mesmo modo que muitos outros confeccionados neste mesmo período, ignora solenemente qualquer prognóstico mais detalhado a respeito do esgotamento das águas doces, assunto cuja proeminência nos dias de hoje é incontestável.

Obviamente, esta lacuna ocorre em razão de um contexto histórico específico, no qual a sugestão de que a água pudesse faltar era simplesmente impensável, assim como revela o quanto, nas últimas décadas, a deterioração do meio ambiente se aprofundou. Na realidade, quem poderia supor, nos anos 60 do século $X X$, um quadro tão desolador da oferta de água de boa qualidade, 
acompanhado de toda sorte de impactos ambientais, da morte de grandes rios e da destruição em larga escala dos sistemas aquáticos? Quem consideraria a sério a possibilidade de a sede se alastrar e se transformar num problema de escala global? E as dramáticas estatísticas relacionadas com a exclusão hídrica, quem esboçaria tal cenário?

Ao lado destas considerações, podemos agregar outras, identificando as implicações políticas e a repercussão da crise dos recursos hídricos no tocante às relações internacionais. $\mathrm{Na}$ atualidade, os recursos hídricos constituem elemento estratégico e item inseparável da soberania dos povos. Fato em si mesmo emblemático, a primeira vez em que um caso relacionado ao meio ambiente foi arbitrado pelo Tribunal de Haia dizia respeito à água. Tratou-se de uma contenda datada de 1988 opondo a Hungria e a Eslováquia em razão do represamento do rio Danúbio através da barragem Gabcikovo-Nagymaros. Este megaprojeto hidrelétrico foi objeto de vívidas polêmicas, origem de um conflito que até o presente momento, continua sem solução a vista (Vide VILLIERS, 2002:244/254 e também BARLOW e CLARKE, 2003:89 e 239).

A depredação dos recursos hídricos, implicando a diminuição dos montantes disponíveis, determinou uma importância maior para os estoques remanescentes, acirrando ainda mais as disputas pelo líquido. Escassa, a água tem-se revelado motivo de fortes antagonismos, os quais que podem conquistar um caráter belicoso ao terem por alvo mananciais cuja distribuição, já desigual no meio natural, foi acentuada pela devastação do meio ambiente. Não por acaso, a imprensa tem-se manifestado repetidamente quanto às guerras da água, explicitando um papel inédito do recurso na organização geopolítica mundial.

Tal possibilidade transparece em uma sentença do cientista político norteamericano Daniel Deudney: "As deficiências globais e a degradação dos recursos naturais, juntamente com a distribuição desigual destas matérias-primas, podem conduzir a rivalidades nacionais e, evidentemente, à guerra" (citado in ELLIOTT, 1998:220). Foi nesta exata perspectiva que Warren Christopher, Secretário de Estado dos EUA na gestão Bill Clinton entre 1993/1997, afirmou serem "os temas 
vinculados aos recursos naturais extremamente importantes para obter estabilidade política e econômica" (citado in OHLSSON, 1998).

Evidentemente, é possível argumentar que o controle de recursos para propósitos estratégicos tem sido de longa data associado com as mais diversas esferas de poder. Dado constituírem um subsídio essencial para assegurar o predomínio político, a intenção permanente do poder é zelar e impedir que recursos de interesse estejam ao alcance de um adversário em potencial. 0 especialista alemão em ecopolítica, o professor Lothar Brock, pondera que, ao longo da história, a utilização dos recursos naturais tem significado lutas entre entidades sociais, voltadas para o acesso e distribuição destes mesmos recursos (ELLIOTT, 1998:221). Por conseguinte, a luta pelos recursos naturais seria tão antiga quanto a humanidade (RAFFESTIN, 1993:252).

Todavia, embora os recursos naturais tenham desempenhado desde passado mais remoto importante papel na definição do equilíbrio de poder e inclusive tendo cumprido o papel de casus belli em inúmeras conflagrações, estes jamais detiveram, nos tempos de outrora, a complexidade e a importância da água. Basicamente porque a água é, acima de tudo, uma fonte de vida, de continuidade da existência humana e biológica em geral, sendo, portanto essencial, fundamental e insubstituível. Não é a toa que o Tratado de Água Doce do Fórum Global da Conferência Eco-92, considera que o usufruto da água potável "se constitui num direito fundamental à qualidade de vida" (1992:2). O reconhecimento da disponibilidade e do acesso eqüitativo à água potável enquanto uma prioridade foi, deste modo, patente nas políticas públicas de abastecimento, endossando esta diretriz de modo praticamente universal.

No entanto, o neoliberalismo propõe uma nova e radical interpretação destas máximas. Em um contexto timbrado pela hegemonia do mercado, o objetivo declarado passou a ser o de colocar a água sob a égide da iniciativa privada, e preferencialmente, das grandes empresas. Esta intenção está bem clara numa conhecida declaração de Rebecca Mark, uma alta executiva da Azurix, empresa subsidiária da Enron, nos anos 90: "Não descansarei até que a água de todo mundo esteja privatizada". Nesta ótica, o prioritário passa a ser interpretar a água 
como uma mercadoria, em detrimento de qualquer outra consideração. A privatização dos serviços públicos relacionados à água (captação, purificação, distribuição, conservação e tratamento) passou a ser identificada como uma forma de implementar uma "gestão racional dos recursos hídricos". Em tese, através da lei da oferta e da procura, assim como em razão de metodologias mais avançadas de controle e gestão, tal modelo asseguraria a redução do desperdício, da poluição e da contaminação.

De fato, muito tempo se passou desde o momento em que o economista David RICARDO, um dos pais da economia clássica, ousava em pleno século XIX espontaneamente considerar que "a água e o ar são grandemente úteis; são de fato, indispensáveis à existência, embora, em circunstâncias comuns, nada se possa obter em troca deles" (1979:259, grifo nosso). Seguramente, a alteração abrupta da forma como o acesso à água tem sido estipulado, constitui elemento motivador de contestações de ordem ética. Eis como Lord Selbourne, presidente da Subcomissão sobre Ética da Água Doce da COMEST ${ }^{93}$ - World Commission on the Ethics of Scientific Knowledge and Technology (isto é, Comissão Mundial de Ética do Conhecimento Científico e Tecnológico), pondera a respeito:

O reconhecimento de que a água é um bem econômico, manifestado agora em muitas declarações e na política dos principais provedores de doações e empréstimos, tem gerado um debate político intenso e muitos temores, revelando valores culturais fundamentalmente diferentes com respeito à água. Alguns reclamam que promover a noção da água como um bem comercializável distrai a percepção do público da realidade de que a água é um bem comum, e do sentido de responsabilidade e dever compartilhados. Em outras palavras, há implicações éticas profundas na percepção de que somos, com relação à água, cidadãos e não simples consumidores. Ver a água como um bem comum põe em foco essa sua característica, enquanto a questão da propriedade pública ou privada acentua a posição de consumidor (SELBORNE, 2002:59, grifo nosso).

Mas, na ótica neoliberal, considerações de ordem ética terminam secundarizadas por perspectivas consideradas "práticas". Nesta ótica, o

\footnotetext{
${ }^{93}$ A COMEST é um departamento criado em 1997 para assessorar o programa em defesa da ética do conhecimento científico e tecnológico da UNESCO.
} 
entendimento da água como um bem econômico é defendido, por exemplo, como a única maneira de eliminar a escassez. Isto porque comercializar água acatando as regras da livre concorrência permitiria a eliminação de conflitos cuja origem seria justamente a persistência de legislações e condutas incompatíveis com uma "utilização sustentável", ao mesmo tempo em que faria vigorar uma "remuneração justa" pelos serviços. Nesta perspectiva, o gerenciamento público dos recursos hídricos, mormente quando movido por preocupações sociais, apenas poderia ser considerado inadequado e ineficaz.

Conviria, então, transferir a administração dos recursos hídricos para empresas privadas, principalmente segundo o modelo francês de gestão delegada, para que a sociedade pudesse desfrutar de um abastecimento eficiente e afinado com a realidade de mercado. Esta diretriz está perfeitamente alinhada com a estratégia de privatização dos serviços públicos de gás, eletricidade, transportes, telecomunicações, coleta de lixo e correios em voga no mundo globalizado. Evidentemente, a privatização exclui a consideração da água como um direito, pois tal formulação, postulando obrigações e restrições, torna-se prejudicial para a "liberdade dos investidores". Por isso mesmo, a defesa do conceito da água como mercadoria tem sido a tônica constante, repetida com devoção apaixonada nos fóruns patrocinados pelos órgãos financeiros internacionais, governos do hemisfério norte e grandes empresas.

Nesse contexto, cabe recordar que a criação em 1994 do World Water Forum (Conselho Mundial da Água) contou com o apoio de diversos governos dos países centrais (entre outros a França, Holanda e Canadá), de um poderoso bloco de empresas com interesses comerciais no setor e por fim, do Banco Mundial (World Bank), este último em conjunto com diversos departamentos da Organização das Nações Unidas (ONU). Estes seriam: a UNESCO, o PNUD (Programa das Nações Unidas para o Desenvolvimento), o PNUMA (Programa das Nações Unidas para o Meio Ambiente), a FAO (Organização das Nações Unidas para a Agricultura e a Alimentação) e a OMS (Organização Mundial de Saúde).

Coerentemente, o Banco Mundial tem sido um dos principais promotores da entidade. Em 1996 o World Water Forum atribuiu a si mesmo a prerrogativa de 
definir uma visão global de longo prazo sobre a água, sendo seu objetivo explícito a formulação de propostas visando a uma política mundial re recursos hídricos tendo por base o novo credo mercantil das águas, ita est, sua "comoditização". Nas palavras de Maurice Strong, secretário-geral da Eco-92 e conselheiro do World Water Forum,

...a chave para a água é a economia de mercado (...) A água barata subsidia a ineficiência. E já existem subsídios perversos demais: o erário público está sendo usado para propósitos antipúblicos (citado in VILLIERS, 2002:412).

Esta disputa em torno da consolidação da água enquanto uma mercadoria tem sido evidente nos mais diversos eventos internacionais relacionados com os recursos hídricos. Dentre estes, poderíamos destacar os Fóruns Mundiais da Água de Marrakech (Marrocos, 1997), de Haia (Holanda, 2000) e de Kioto (Japão, 2003), neste último caso também tendo por palco as cidades de Osaka e Shiga. Outro importante evento foi a Conferência de Água Doce de Bonn (Alemanha, 2001). Recorde-se que a Cúpula Mundial para o Desenvolvimento Sustentável, ocorrida em Johanesburgo (África do Sul, 2002), embora voltada para amplo temário ambiental, teve nos recursos hídricos um destaque indiscutível. O mesmo pode ser afirmado quanto à Quarta Conferência da Organização Mundial do Comércio de Doha (Emirados Árabes Unidos, 2001).

Neste sentido, a atuação do World Water Forum nos encontros internacionais não tem deixado dúvidas quanto à sua predisposição em reforçar, em âmbito mundial, a privatização da água. Patrick McCully, especialista da Internacional Rivers Network, uma ONG voltada para a atuação em áreas degradadas nos cursos fluviais, reservou palavras muito duras para esta organização. No seu parecer, o Conselho Mundial da Água não passaria de "um grupo lobista, constituído por construtoras, financiadores de barragens e corporações interessadas no tratamento, distribuição de água e saneamento" (SACCHETTA, 2003). 
Buscando reforçar a ofensiva em prol da privatização, o Banco Mundial também apoiou a criação, em 1996, da Global Water Partnership (GWP), Parceria Mundial pela Água, cujo mandato seria favorecer a aproximação entre as autoridades públicas e os investidores privados. Sintomaticamente, o GWP é presidido pelo vice-presidente para investimentos do Banco Mundial e o faturamento dos seus 67 membros empresariais soma parte expressiva do Produto Interno Bruto (PIB) mundial. Entre as metas do GWP está a expansão do modelo das Parcerias Público-Privada (PPP) e o fortalecimento do International Centre for Settlement of Investiment Disputes (ou ICSID, Centro Internacional para Resolução de Disputas e de Investimentos), um tribunal de arbitragem internacional.

Ao lado da batalha pelos corações e mentes e do controle das esferas de decisão, as grandes empresas têm rapidamente implantado seu controle sobre os recursos hídricos. A escalada da privatização da água avançou em todos os continentes, numa progressão galopante. A década passada evidenciou o surgimento e o crescimento de um fenômeno novo: a companhia internacional de água, hoje formando uma soberba listagem de grandes empresas (Tabela 4). A súbita aparição destes novos conglomerados na economia mundial constitui a mais pura comprovação de que a magnitude dos negócios é gigantesca. Do petróleo dependem os proprietários de automóveis, das indústrias e as plantas energéticas. Porém da água, não há quem dela não dependa.

Por isso acredita-se que as receitas anuais da indústria da água tenham chegado em poucos anos a aproximadamente $40 \%$ das rendas do setor petrolífero e que estas, já seriam $1 / 3$ maiores do que as do rico setor farmacêutico. De acordo com estimativas do Banco Mundial o mercado mundial de água realizou em 1998 um giro de aproximadamente US\$ 800 bilhões, projeção posteriormente elevada para US\$ um trilhão (REBRIP, 2004:3). E, certamente este mercado irá crescer ainda mais, pois as empresas de abastecimento de água atendem na atualidade em torno de $10 \%$ da população mundial, percentual que tem crescido ano após ano. 
As novas multinacionais da água, possuidoras de forte projeção no ranking dos grandes negócios, expressam através do vulto dos seus lucros o fato indiscutível de que o comércio de água tem-se confirmado como uma empreitada de grande futuro. No caso de nos determos na atuação das grandes empresas em sua totalidade, poderemos observar que estas estão presentes em praticamente todo o Planeta (Vide Tabela 5). Em suma, a água constitui um excelente negócio. Corporificado em um pequeno número de empresas, o mercado da água já nasce, sob o império da globalização neoliberal, fortemente marcado pela presença de oligopólios, atuando nos setores de água potável, água engarrafada, tratamento de água e de bebidas gaseificadas. Contudo, note- 
TABELA 4

AS MULTINACIONAIS DA ÁGUA

Vivendi

Suez

RWE-Thames River

Saur-Bouygues

Bechtel-United Utilities

Severn Trent

Anglian Water

Kelda Group

American Works Company
(França)

(França)

(Alemanha)

(França)

(EUA/Reino Unido)

(Reino Unido)

(Reino Unido)

(Reino Unido)

(Alemanha)

(Fonte: MAUDE e CLARKE, 2003:128/129, REBRIP, 2004:3) 
TABELA 5

ATUAÇÃO DAS MULTINACIONAIS DA ÁGUA POR BLOCOS REGIONAIS

EUROPA: RWE-THAMES WATER, ONDEO(*), VIVENDI, AgBaR(**), SAUR;

África Do NoRTe/ORIENTE MÉdIO: ONDEO, VIVENDI, SAUR;

ÁfrICA NEGRA: VIVENDI, ONDEO, RWE-THAMES WATER, SAUR;

AMÉRICA DO NORTE: VIVENDI, UNITED WATER, ONDEO, AQUARION, AMERICAN WATER(***);

AmÉRICA LATINA: ONDEO, AMERICAN WATER, VIVENDI, SAUR, AgBaR, AWG;

Asia: AWg, ONDEO, RWE-THAMES WATER, VIVENDI;

OCEANIA: ONDEO, VIVENDI;

(Fonte: THE WATER PAGE, MAUDE e CLARK, 2003:128 et seq)

(*) Denominação dada à divisão de água da Suez.

(**) AGBAR é uma companhia espanhola: Águas de Barcelona S.A.

${ }^{(* * *)}$ Denominação dada à divisão de água da RWE-Thames River em operação no continente americano. 
se que os interesses destas grandes empresas não são coincidentes, podendo implicar os mais diversos conflitos. De acordo com o economista italiano Ricardo PETRELLA, cada um dos setores hegemônicos no mercado dos recursos hídricos, água potável, engarrafada, bebidas gaseificadas, tratamento de esgotos,

...tem no momento seus protagonistas, suas especialidades, seus mercados, seus conflitos. A água potável das torneiras, por exemplo, tem Vivendi, Suez-Lyonnaise des Eaux, Thames Water, Biwater, SaurBouygues e suas filiais. A água mineral engarrafada tem, sobretudo, a Nestlé e a Danone, respectivamente $\mathrm{n}^{0} 1$ e $\mathrm{n}^{0} 2$ mundiais, em muito superiores aos outros engarrafadores. Estes últimos, além da Coca-Cola e da Pepsi-Cola, tornaram-se concorrentes das empresas de tratamento d'água graças ao desenvolvimento e comercialização (mesmo nas empresas e residências), de uma água dita de síntese, purificada, apresentada como mais sadia que a das torneiras (2003).

Com base em fontes de índole diversa, sabe-se que em 2000 a receita das duas maiores corporações de água, as empresas francesas Vivendi (antiga Générale des Eaux) e Suez (ex-Suez-Lyonnaise des Eaux), apontavam respectivamente para lucros atingindo as fabulosas somas de US\$12 e US\$ 9 bilhões, renda resultante do controle de $70 \%$ que estas companhias exercem sobre o novo mercado de água doce ao redor do mundo. Esta rápida supremacia conquistada pela Vivendi e pela Suez no mercado mundial decorre da larga experiência destas empresas enquanto prestadoras de serviço no setor do fornecimento de água potável no seu país de origem. Com efeito, a privatização da água foi levada adiante na França pelo Imperador Napoleão III já em meados do século XIX.

Estas duas empresas, consideradas a "General Motors" e a "Ford Motor Company" do mercado de água, reunindo grande experiência a partir do trato no mercado doméstico, capacitaram-se para o passo seguinte, qual seja, a busca pela hegemonia no mercado mundial de fornecimento de água. Paralelamente a essas "empresas veteranas", outros conglomerados empresariais, como a gigante alemã de energia, a famosa RWE (Rheinisch-Westfälisches Elektrizitätswerk Aktiengesellschaft, fundada em 1898) tem conquistado progressão constante no mercado de água doce. Em 1990 a RWE adquiriu a Thames Water, do Reino 
Unido, formando a RWE-Thames Water, com planos para projetar sua influência para muitos outros países. A Vivendi, a Suez e a RWE figuram entre as cem maiores empresas do mundo, atuando em dezenas de países em todos os continentes. A RWE opera atualmente em 46 países, a Vivendi em 90 e a SuezLyonnaise em 130.

Todavia, o rápido sucesso das novas corporações da água não pode ser explicado unicamente pelo histórico de atuação, competência administrativa ou experiência comercial. Para tanto, concorreu o inestimável apoio materializado nas grandes instituições financeiras internacionais. A estratégica de mercantilização da água tem sido subsidiada de vários modos pelos chamados Structural Adjustment Programs (SAP), Programas de Ajustes Estruturais, estabelecidos pelo Fundo Monetário Internacional (FMI) e pelo Banco Mundial. Estes programas são tradicionalmente baseados em eliminação de subsídios, anulação das barreiras protecionistas, corte de investimentos públicos destinados para a educação e saúde, flexibilização dos direitos trabalhistas e, evidentemente, na imposição da privatização.

Contudo, esta pauta foi ampliada ao longo dos últimos anos com a inclusão de cláusulas claramente comprometidas com a mercantilização dos recursos hídricos. Os acordos comerciais firmados pela Organização Mundial do Comércio (OMC) buscam, por exemplo, impulsionar a privatização dos serviços de água exigindo que estes sejam abertos ao comércio e à competição por parte das empresas privadas, proposição que também aparece como exigência do Banco Mundial e do FMI para a contratação de empréstimos internacionais. Assim sendo, "uma folheada em históricos de dívida de 40 países com o FMl durante 2000 mostra que 12 deles tiveram como imposição pelo Fundo o aumento nos preços e a privatização da água" (KALILI, 2004).

Somando-se ao respaldo internacional, a mercantilização da água tem sido apoiada por diversos governos dos países periféricos alinhados com a política neoliberal, nações cujas sociedades possuem, na maioria dos casos, escasso poder de mobilização. Este pormenor justifica que o avanço da privatização esteja ocorrendo com maior velocidade nos países do Terceiro Mundo (Vide Tabela 6). 
$\mathrm{Na}$ argumentação de muitos críticos, este direcionamento transpareceria não só na "flexibilização" das normatizações referentes aos recursos hídricos, mas também, em nome do "Estado mínimo", ao expediente de "sucateamento" dos serviços públicos. Esta prática consistiria em conduzir premeditadamente as empresas públicas a uma situação de não-operacionalidade, em razão da

TABELA 6

A ESCALADA DA PRIVATIZAÇÃO DO ABASTECIMENTO DE ÁGUA E SANEAMENTO 1997- 2010 (previsão)

Região

Europa Ocidental

Europa Central e Oriental

América do Norte

América Latina

África

Ásia
\% privatizada em 1997

20

4

5

4

3

1
\% privatizada em 2010

35

20

15

60

33

20

(Fonte: THE WATER PAGE) 
diminuição ou ausência de investimentos. Uma vez tornados inoperantes, estes serviços seriam, então, a pretexto de implantar métodos modernos e eficientes de gestão, transferidos para a iniciativa privada.

No Brasil, particularmente no decorrer das duas gestões presidenciais de Fernando Henrique Cardoso (1995/1999 e 1999/2002), desenvolveu-se claramente uma orientação no sentido de privatizar dos serviços de água. Esta tendência transparece, por exemplo, na Lei de n. ${ }^{0} 9.433$ (08/01/1997), que institui a Política Nacional de Recursos Hídricos (PNRH), cria o Sistema Nacional de Gerenciamento de Recursos Hídricos (SNGRH) e regulamenta o inciso XIX do artigo 21 da Constituição Federal. Tal legislação, embora considerando a água como um "bem de domínio público" (art. $1^{\circ}, \mathrm{I}$ ), e que em caso de escassez, cabe priorizar "a pessoa humana e os animais" (art. $1^{\circ}$, III), inova ao compreender que a água seria igualmente "dotada de valor econômico" (art. 1º, II).

A implantação desta normatização foi impulsionada com o respaldo das agências internacionais de financiamento. Dados do Banco Mundial para o período 1995-2000 mostram que a maior parte dos empréstimos efetuados para o Brasil concentraram-se nos setores de água, saneamento e obras contra enchentes. No biênio 1999-2000, quando a educação recebeu financiamento de US\$ 1 bilhão, estes alcançaram a vultosa soma de US\$ 6 bilhões. Os resultados desta política são evidentes: hoje, cerca de 58 municípios (dentre os quais Manaus, Campo Grande e Limeira) têm seus serviços de abastecimento controlados pela iniciativa privada.

Esta linha de conduta não sofreu alteração na gestão do presidente Luís Inácio Lula da Silva (2002-), que claramente deu continuidade a esta política. $\mathrm{Na}$ nova administração, a Parceria Público-Privado, uma peça central do mecanismo de privatização, tem sido defendida como forma de ampliar investimentos nos serviços de água e saneamento. Esta estratégia tem seguidamente recebido apoio de setores empresarias com interesse neste setor da economia. A PPP do saneamento já desperta o interesse de grandes grupos privados, entre eles as 
construtoras Andrade Gutierrez e Odebrecht, assim como a empresa de saneamento Degremont, ligada a Suez Ambiental ${ }^{94}$.

A posição do governo federal quanto a esta questão não admitira qualquer imprecisão. Por exemplo, ela está claramente exposta na entrevista concedida ao jornal O Estado de S. Paulo pelo secretário de Saneamento Ambiental do Ministério das Cidades, Abelardo de Oliveira Filho, que inclusive se posicionando de modo contrário ao colocado na campanha eleitoral de 2002, foi enfático ao destacar que "é importante a participação do setor privado (...) não há divergências quanto a isso" (OTTA, 2004).

Todavia, os resultados das privatizações têm contrastado com a apologia que tem caracterizado sua difusão. Um exemplo paradigmático é o de Cochabamba, na Bolívia. Nesta cidade, a terceira maior deste país, os serviços públicos de água foram privatizados por conta da aplicação dos Programas de Ajuste Estrutural. Coube à multinacional Bechel, através da subsidiária Águas del Tunari, aplicar a "versão hídrica" do receituário neoliberal em Cochabamba. O resultado da aplicação da "gestão racional dos recursos hídricos" logo se fizeram sentir. Em Cochabamba, a elevação das tarifas de água foi de 100\% a 200\% entre dezembro de 1999 e janeiro de 2000, chegando a consumir 80\% da renda familiar.

No que constituiu a primeira grande mobilização popular do século $X X I$, a população foi às ruas em protestos generalizados, inconformada com a majoração promovida pelos novos administradores da água da cidade (Fig. 38). A "Guerra da Água", tal como prontamente passou a ser denominada pela imprensa mundial, logrou colocar um ponto final nesta experiência de privatização, revendo o processo e restabelecendo o controle público sobre a água. Embora os resultados deste enfrentamento ainda aguardem o encaminhamento de pendências jurídicas, o levante de Cochabamba correspondeu inequivocamente a uma afirmação da água enquanto direito, e não mercadoria (LOBINA, 2000).

Há também, em termos das novas metodologias de fornecimento, resultados decepcionantes do atendimento aos consumidores, dentre estas o sistema prépago de água. No Brasil, há pelo menos três companhias testando este sistema: a

\footnotetext{
${ }^{94}$ Nota divulgada na versão eletrônica do jornal Valor Econômico, edição de 22/4/2004,
} 
SABESP (SP), a SANEATINS (TO) e a SANEAGO (GO). Este sistema funciona do mesmo modo que para a telefonia celular, sendo o acesso á água facultado na proporção dos créditos adquiridos, e cortado uma vez comprovada a insolvência do consumidor. $\mathrm{Na}$ ótica dos seus defensores, este sistema permitiria melhor controle do consumo, monitoramento da rede, como a detecção imediata de

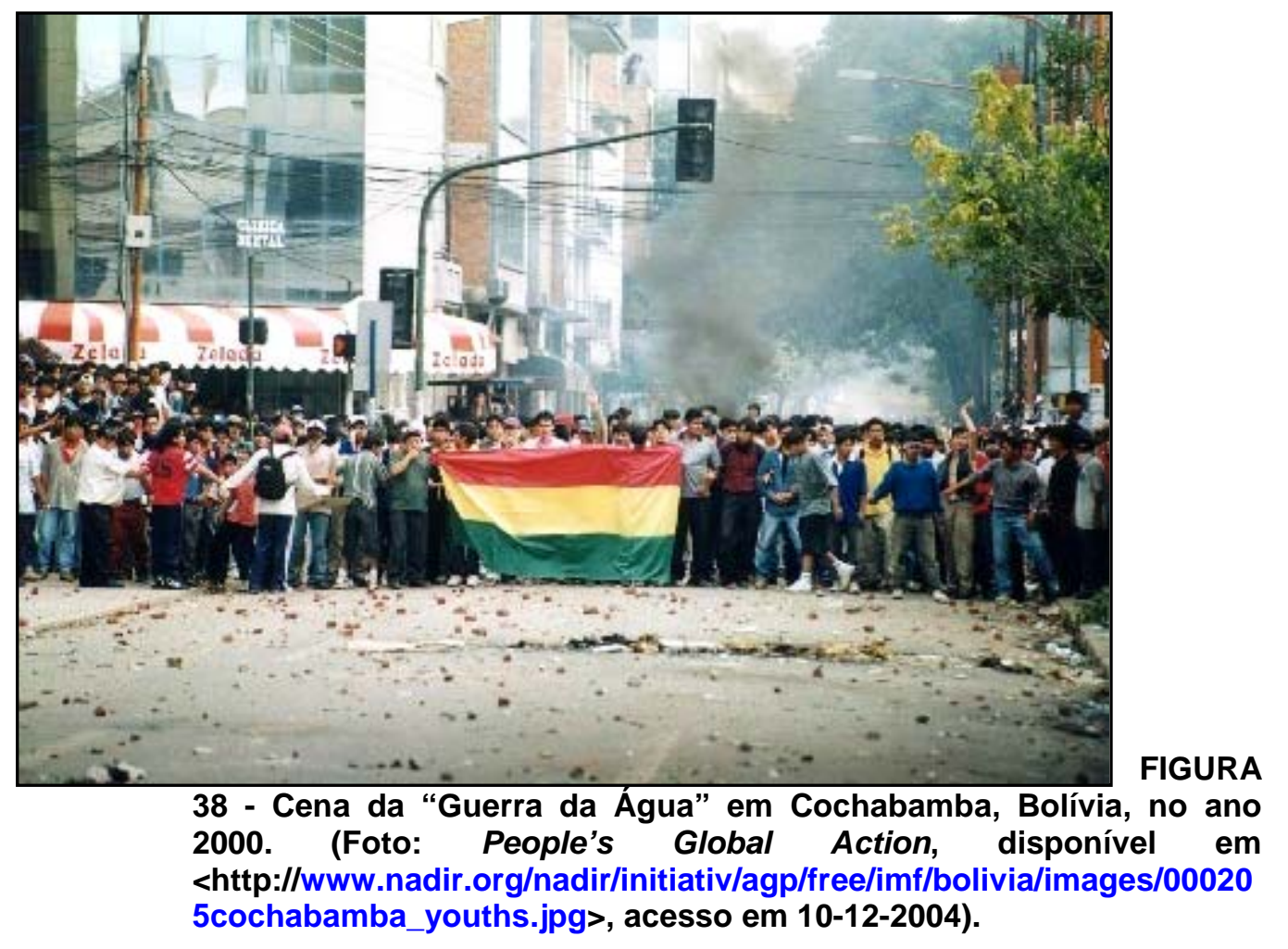


vazamentos. Assim, graças à melhor utilização e controle mais rígido do fornecimento, a medida repercutiria positivamente na distribuição e preservação das águas doces.

Claramente, o sistema pré-pago se insere na ótica da eficiência e da remuneração por serviços prestados presentes nas estratégias e no discurso neoliberal, e, portanto, tem sido implantado pelas empresas de fornecimento de água e apoiado pelo Banco Mundial. Outro aspecto importante é que o lucro das empresas de água também é pré-assegurado, uma vez que o fornecimento de água somente é liberado mediante pagamento prévio. Deste modo, o problema da inadimplência encontra uma "solução" definitiva na implantação de uma política que tem sido vinculada ao que tem sido classificado como exclusão hídrica ou apartheid hidrológico, dela decorrendo sérios impactos sociais e sanitários.

O mais interessante é notar que o sistema pré-pago enfrentou sua primeira grande oposição não em um país do Sul, mas sim no refinado e tecnologicamente avançado Reino Unido. Em razão de inúmeros problemas, dentre os quais a ampliação dos casos de disenteria e de problemas de saúde relacionados com o corte de fornecimento de água, o governo britânico decidiu em 1998 banir o sistema pré-pago do país. Com base neste fato, restaria, pois, indagar sobre as perspectivas sanitárias pouco animadoras que o sistema pré-pago poderia engendrar em países com padrão de vida inferior (ou mesmo muito inferior) aos vigentes na Grã-Bretanha. Considere-se também que a própria excelência do produto oferecido pelas empresas privadas não as posiciona necessariamente como prestadoras de serviços de qualidade.

Por exemplo, as águas minerais obtiveram expressiva projeção econômica pela presumível segurança oferecida pelo produto, permitindo a vertiginosa expansão do mercado de água engarrafada. No que seria indicativo das potencialidades deste mercado, nos anos 70 , o volume anual mundial de água engarrafada foi de aproximadamente um bilhão de litros. Antes do final desta década, eram 2,5 bilhões de litros. No final dos anos 80 , a produção atingia 7,5 bilhões de litros e no ano 200, foram 84 bilhões de litros. No entanto, um documento da FAO informa que a água engarrafada não possui qualidade melhor 
do que a oferecida pelas torneiras, até porque, em muitos países, estas águas estão sujeitas a análises e padrões menos rigorosos do que os aplicados aos sistemas tradicionais de abastecimento (Vide BARLOW e CLARKE, 2003:170/172).

Isto, sem contar os impactos provocados pelo modelo de distribuição de água engarrafada, dentre os quais aqueles que envolvem a produção de plástico. O uso de vasilhames plásticos tem se expandido com base numa sinergia de fatores, dentre os quais podemos contar a influência da indústria petroquímica, razões de ordem prática (como o peso menor e a maior resistência à tração mecânica e ao rompimento por conta da queda dos recipientes) e inclusive, o vínculo da matéria plástica com o imaginário moderno, reforçado por insistentes campanhas de marketing (Vide Fig. 39). Assim, em 2001 o uso de garrafas plásticas implicou a produção de 1,5 milhão de toneladas de plástico, envolvendo consideráveis conseqüências para o meio ambiente, tanto por conta da produção das mesmas, quanto pelo descarte inadequado dos vasilhames (RAMOS, 2004:14).

Um outro ângulo da questão é o fato de muitas empresas alterarem a composição química original de fontes colocadas sob sua jurisdição. Particularmente, o contencioso opondo desde os anos 90 a sociedade civil e a multinacional Nestlé em São Lourenço (MG) revela as implicações da mercantilização da água. Em 1992 a Nestlé adquiriu o controle mundial da empresa Perrier Vittel, incluindo nesse espólio a concessão da exploração comercial das fontes do Parque das Águas de São Lourenço. A cidade de São Lourenço, que integra pólo turístico do Circuito das Águas do sul de Minas Gerais, tem sua economia intimamente vinculada às águas minerais, conhecidas desde 1826 e afamadas pelo seu indiscutível valor medicinal. A Nestlé, agora senhora do Parque das Águas da cidade, perfurou em 1996 um novo poço com o intuito de fabricar a água de marca Pure Life (isto é, Vida Pura).

Nesse processo, a água mineral (que por definição, trata-se de um bem natural raro e nobre), é desmineralizada e artificialmente enriquecida de sais, acatando uma fórmula aplicada nos diversos países nas quais essa marca é 
fabricada. Este líquido, na realidade um produto, constitui uma espécie de ersatz wasser (ou seja, num sucedâneo da água natural). A desmineralização é combatida por diversos pesquisadores, repudiada pelos ambientalistas e criticada por especialistas, que observam nessa prática somente um capítulo adicional do processo de estandardização inerente à economia de mercado. Para completar,

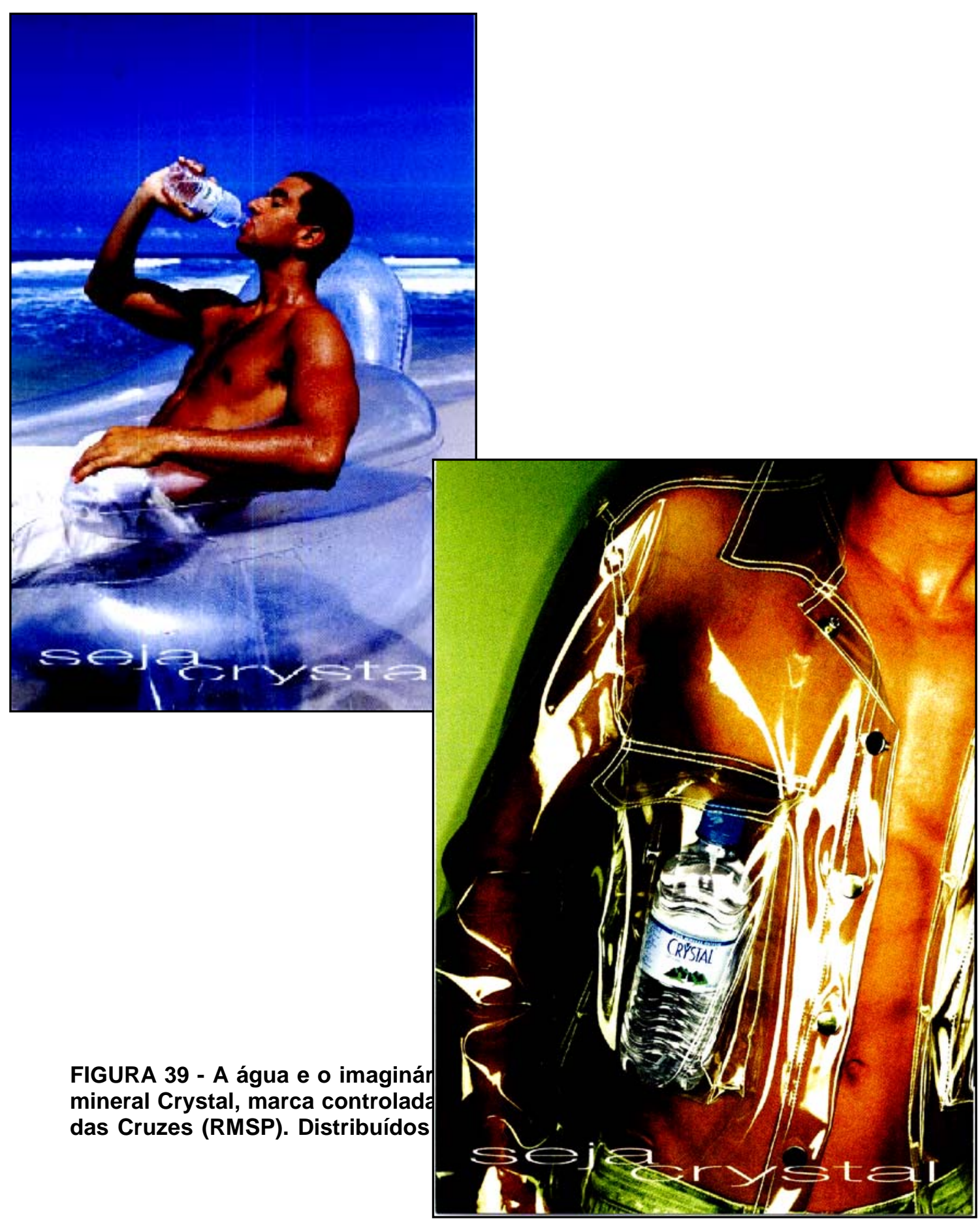


da capital paulista, estas peças publicitárias vinculam natureza, sensualidade e o consumo de água engarrafada com as embalagens PET. 
este processo não é permitido por lei. Mesmo assim, a Nestlé continuou a fabricar a Pure Life. Além desta polêmica jurídica, a empresa, visando a atender seus objetivos comerciais, intensificou o ritmo de bombeamento das fontes comprometendo os lençóis subterrâneos, provocando em 2002 a desaparição da fonte magnesiana e induzindo o recalque do terreno da área da concessão (Vide VILLELA, 2005).

Estes impactos ambientais, extremamente sérios, motivaram a mobilização dos cidadãos na defesa do Parque das Águas de São Lourenço, impetrando ações judiciais apoiadas pelos ambientalistas locais contra a multinacional. No que evidencia as limitações do Estado mínimo frente ao poder econômico das grandes empresas, esta mobilização, mesmo angariando respaldo legal, apoios no próprio país de origem da Nestlé (a Suíça), e farta visibilidade na mídia européia (contrastando com o cauteloso silêncio da grande imprensa nacional durante este episódio), terminou frustrada por manobras burocráticas e pela influência da poderosa multinacional. Bastou a companhia anunciar o fechamento da sua unidade para que as autoridades estaduais e federais corressem em seu socorro. Em Minas Gerais, foi prontamente concedida à Nestlé uma licença corretiva permitindo o funcionamento de sua fábrica e, em nível federal, o Departamento Nacional de Produção Mineral (DNPM) anunciou a publicação de nova portaria autorizando a desmineralização "parcial" das águas minerais.

Todo esse elenco de procedimentos, realizados a revelia da lei, foram metodicamente analisados pela Curadoria do meio ambiente de São Lourenço. Na ação civil pública instruída em Dezembro de 2001 pelo promotor de Justiça e curador do Meio Ambiente da cidade, Dr. Pedro Paulo Barreiros Aina, estão registrados, dentre outros agravos, os que seguem: a perfuração do poço foi ilegal, já que não houve autorização do DNPM; o DNPM constatou a irregularidade e não tomou nenhuma atitude; a comunidade vem sendo ameaçada pela degradação ambiental promovida pela Nestlé, que pode afetar suas atividades sociais e econômicas, que giram em torno do turismo e das águas; a produção da Pure Life configura uso irracional de recurso ambiental raro e limitado por parte de uma empresa cujo único interesse é o lucro. 
No que explicita a força como o neoliberalismo se enraizou no nosso país e no que pese a consistência da argumentação legal, este histórico de agressões aos recursos hídricos inaugurado pela Nestlé nos anos noventa, em plena gestão FHC, tem se prolongado sem alterações na administração do presidente Luís Inácio Lula da Silva.

Assim sendo, como evidencia o transcorrer deste episódio, seria lícito questionar a eficácia "dos marcos regulatórios" que muitos advogam enquanto uma "modalidade contemporânea" habilitada a "controlar" a atuação das grandes empresas no mundo globalizado. Se o que se tem à disposição é um Estado tão dócil aos grandes interesses, qual seria no final das contas a contrapartida colocada à disposição da sociedade?

\subsection{Desafios da Geopolítica da Sede}

O que foi exposto até agora ensejaria pontuar diversos reparos quanto ao polêmico modelo de gestão neoliberal dos recursos hídricos. Este, além de suscitar dos mais inquietantes cenários para o mundo globalizado, poderia inserir proclamações dirigidas para uma outra compreensão de mundo. Assim, se torna possível encadear diversificada coletânea de ponderações relacionadas ao tema, dentre as quais:

1. Há que ser registrado que a escassez e a demanda crescente por recursos hídricos é potencialmente indutora de uma perspectiva geopolítica cujo anseio máximo buscaria, no limite, o controle da totalidade das águas doces mundiais. Em vista deste processo estar tendencialmente assentado na escassez da substância, esse poderia rapidamente transmutar-se numa autêntica geopolítica da sede, inspirando uma cartilha política cujo enunciado básico seria o poder azul, isto é, uma dominação sustentada a partir do controle dos ambientes aquáticos. 
Conforme foi sugerido, a questão dos recursos hídricos explicita, em termos do que ela representa para os interesses dominantes, a forma pela qual algumas "preocupações ecológicas" terminam por se tornar "mais globais" do que outras. Contemporaneamente, o que se tem testemunhado não seria um "global" assimilado enquanto um termo meramente geográfico apropriado para descrever "uma crescente interdependência ambiental", tal como é freqüentemente veiculado pelo discurso de tradição reformista. Mais do que isso, ele constitui um termo político, que de acordo com a ambientalista indiana Vandana Shiva, garantiria para o Norte um novo espaço político para controlar o Sul, criando dessa forma uma base moral para o "imperialismo verde" (ELLIOTT, 1998:251/252).

Por isso, os espaços agraciados por águas doces poderão constituir alvo de cobiça direta por parte dos países centrais. Neste panorama, o fato de existirem grandes conglomerados baseados no comércio das águas azuis seria, em si mesmo, um pressuposto para sua concretização, com desdobramentos materializados na intervenção militar estrangeira e guerras desencadeadas pela posse do líquido. Como adverte o cientista político Armando BOITO JÚNIOR: "Cada Estado imperialista toma os interesses das suas empresas multinacionais como referência básica para a definição de sua política internacional" (1999:35).

2. No que diria respeito ao Brasil e diversos países sul-americanos, seria inescapável mencionar que a região detém várias pré-condições para ser alçada à condição de uma área de interesse prioritário em um mundo assodado pela sede, a começar pela presença do imenso estoque hídrico da Amazônia. Este contexto instigaria pensar uma visão geoestratégica habilitada a discernir, por exemplo, formas de relacionamento a serem estabelecidas por nações como a Bolívia, Venezuela, Colômbia e o Brasil, que simultaneamente usufruem a condição serem países amazônicos e co-possessores deste vasto reservatório de águas doces. E isto, com certa premência. 
No passado, o presidente Theodore Roosevelt (1858-1919), um dos próceres do ethos estadunidense ${ }^{95}$, entendendo que os EUA estavam predestinados a assumir a balança de poder do globo, inaugurou, com base nas concepções geopolíticas do almirante Alfred Tayer Mahan, a chamada política do big stick (isto é, do grande porrete). Seu objetivo confesso era o fortalecimento de regimes alinhados com o hegemonismo norte-americano, obtido por intermédio de ações intervencionistas, especialmente no teatro caribenho. Muito longe de ter desaparecido, esta lógica reaparece num diversificado mostruário de predicações geopolíticas nas quais a nota comum tem sido a "integração" da América Latina sob a égide dos EUA (Vide MELLO, 1999:113/114).

Conforme difusamente noticiado, desde os anos 90 do século passado os Estados Unidos têm realizado intervenções diretas na América do Sul a título de combater a insurgência armada e o narcotráfico. A presença militar deste país foi acompanhada pela criação de bases militares no Equador, na Colômbia e no Peru (PETRAS, 2002:33). Mais recentemente, sinais insistentes apontam para o interesse da administração George W. Bush em manter guarnição militar no Paraguai, país estratégico relativamente à Bacia da Prata e ao Aqüífero Guarani. Assim, a percepção de uma movimentação militar (inclusive por contar com antecedentes históricos), seria bem mais consistente do que um mero devaneio da imprensa politicamente engajada ${ }^{96}$.

Além disso, a lógica das relações internacionais do mundo atual permite obter acesso aos recursos hídricos prescindindo de opções manu militari. A proposta da Free Trade Area of the Americas (FTAA) ou Área de Livre Comércio das Américas (ALCA), constituiria um excelente atalho para alcançar este objetivo. Alicerçada na doutrina neoliberal, a ALCA é um tratado que propõe, a título de

\footnotetext{
${ }^{95}$ Não sem razão, o munumento nacional de Mount Rushmore (Dakota do Sul), dispõe Roosevelt ombro a ombro com três outros grandes "ícones" da americanidade: George Washington, Thomas Jefferson e Abraham Lincoln.

${ }_{96}$ Ao lado da moderação necessária para evitar pressuposições fantasistas, é óbvio que geoestratégicamente existem duas formas clássicas para dominar bacias hidrográficas: seria pelo controle das cabeceiras ou da foz. É o que sugere a localização de bases dos EUA nos países andinos e a pretensão por Alcântara (Maranhão). Quanto ao Paraguai, as especulações se acentuaram com a visita do secretário de defesa dos EUA Donald Rumsfeld a Assunção em Agosto de 2005 (Manchetes Socioambientais, edição de 13-09-2005).
} 
enfrentar a concorrência européia e asiática, a desregulamentação e flexibilização comercial e financeira entre a maior potencia econômica, bancária, cultural, mediática, científica, tecnológica e militar do continente, os EUA, e seus vizinhos latino-americanos, do Rio Grande até a Terra do Fogo (Ver entre outros, COGGIOLA, 2005).

$\mathrm{Na}$ voz dos seus críticos, a criação da ALCA não implicaria em qualquer "integração", com exceção da voltada para catapultar os interesses econômicos dominantes. Neste sentido, o acordo intensificaria a mercantilização da natureza, submetendo a biodiversidade, os recursos minerais e os acervos hídricos às leis do mercado e aos interesses das transnacionais. Particularmente para ao quesito água, a aproximação dos Estados Unidos da condição de stress hídrico tem motivado, por exemplo, a discussão de diversos mega-empreendimentos já antevendo a viabilização do transporte de maciços volumes do líquido. Como argutamente registraram Maude BARLOW e Tony CLARKE, existem nada menos que cinco grandes projetos de canais transoceânicos em andamento pretendendo cortar o istmo centro-americano para consolidar a infra-estrutura voltada para o novo - e promissor - comércio mundial de água doce (2003:164/167).

Em suma, a titularidade da exploração dos estoques de água doce, transformados em um recurso estratégico de capital importância, descartaria tal preocupação enquanto uma simples fabulação de uma imprensa xenófoba. Pelo contrário, trata-se de um tema a ser discutido com toda seriedade e atenção possível. A mesma que os grandes interesses econômicos tem dedicado a esta questão.

3. O avanço da mercantilização da água respaldaria o questionamento de relevantes interfaces conceituais. Uma destas reportaria ao próprio significado que o neoliberalismo impingiu para a "esfera do econômico", referendada por este enquanto parâmetro exclusivo de gerenciamento da totalidade da sociedade humana. Porém, contrariamente a este primado, vigoraram no passado dos humanos múltiplas interpretações aplicadas à economia, constituindo uma 
inverdade e uma imprecisão histórica, antropológica e sociológica restringi-la às implicações construídas no bojo do mundo ocidental.

Do mesmo modo do que em muitas outras polêmicas, o resgate dos sentidos que outrora perpassavam pelo imaginário social contribui para lançar uma nova luz sobre os significados que terminaram esposados pelo mundo contemporâneo. Revisitando as sociedades tradicionais toma-se conhecimento de que a economia se irmanava com outras finalidades, por intermédio das quais esta era entendida enquanto uma ferramenta voltada para satisfazer as pessoas e fortalecer os vínculos da antiga Gemeinschaft, jamais a si mesma. No mundo da tradição, "em vez da economia estar embutida nas relações sociais, são as relações sociais que estão embutidas no sistema econômico" (POLANYI, 2000:77).

Deste modo, pensar uma sociedade postada no comando da economia, invertendo o padrão que tem guiado a experiência econômica do mundo ocidental - qual seja, o da economia enquanto elemento magnetizador da sociedade - incita repensar as premissas colocadas para a economia. Sobejamente, o "espelhamento invertido" do mundo moderno inspira refletir sobre o vínculo solene da economia com a dimensão cultural e o aproveitamento dos recursos naturais, uma articulação que não tem propriamente constituído uma prioridade no império da modernidade (Ver a respeito CARVALHO, 1978).

Conseqüentemente, a economia deveria incorporar uma ótica diferente da que hoje governa a sociedade humana, promovendo a participação, a inclusão e o equilíbrio ambiental, estendidos ao conjunto dos participantes do mundo globalizado. Como foi sintetizado pelo geógrafo Claude RAFFESTIN:

Em outros termos, coloca-se o problema fundamental da repartição das coisas entre os seres humanos. Ou todo mundo recebe a mesma quantidade de bens e de serviços e então se trata de uma 'eco-nomia' no sentido etimológico, ou então se estabelece um conjunto de critérios que determinam aqui a abundância, e ali a rarefação. Então, não se trata mais de uma economia, mas de uma política cujas finalidades não são a expressão de uma necessidade endógena que implica a permanência de uma estrutura, mas a expressão de uma vontade exógena que determina as finalidades das partes da estrutura que se devem manter (1993:34). 
4. Evidentemente, uma releitura da economia implicaria em ampliar o universo de questionamentos. Extrapolando o campo da economia, percebe-se que grande maioria das instituições existentes - como poderia ser esclarecido através do contato com qualquer bibliografia básica voltada para a questão ambiental - não foi desenhada para ocupar-se dos dilemas básicos da escassez ecológica. Esta admoestação sugere que o Estado passe a ser repensado nesta perspectiva, sob pena de não se dar conta da problemática ambiental (GUIMARÃES, 1991:123). Ademais, seria inerente a esta proposição que a intervenção estatal passe a ser configurada numa direção exatamente oposta aos defensores do "Estado mínimo", isto porque a questão ambiental reclama um Estado forte e não fraco (Cf ELLIOTT, 1998:250). No caso da água, esta é uma condição necessária para se garantir que o recurso possa tornar-se, na lei e na prática, um patrimônio comum da sociedade, controlado por uma gestão pública.

O reforço do papel do Estado não pode ser dissociado do fortalecimento real da representação da sociedade. Equívoco comum a muitas abordagens é entender que a existência pura e simples de "canais de participação" constitui em si mesma um "instrumento de democratização das decisões". Muitas vezes, os compromissos em prol de instituições baseadas na soberania cooperativa reforçam processos políticos por meio dos quais os interesses privilegiados de poucos se tornam mais bem representados do que os interesses democráticos da maioria.

As instituições internacionais e os processos de gerenciamento ambiental, não são nesta perspectiva democráticas, a despeito da participação - alguns sugerem a cooptação - das ONG. Mais ainda, o gerenciamento ambiental continua, numa perspectiva crítica, a representar uma coalizão regimes ricos e poderosos, suas corporações e seus esquemas bélicos. Portanto, um dos direcionamentos das instituições estatocêntricas tem sido deslocar o debate ambiental relativamente às soluções da crise ambiental fora das mãos daqueles que são mais diretamente afetados por ela, uma realidade que solicita revisão urgente (ELLIOTT, 1998:251). 
5. Finalizando, recorde-se que a própria globalização não é um fenômeno irreversível, sendo possíveis outras possibilidades. O momento ora vivido é uma das vias abertas pela história, mas não constitui, em absoluto, o único caminho a ser trilhado. Esta ressalva importa em razão de nada poder impedir que surjam mais adiante fórmulas que recrudesçam ainda mais os agravantes sociais e ambientais que caracterizam a sociedade contemporânea, quanto outras que façam retroagir o processo de degradação.

Caberia ao movimento vivo da sociedade descortinar alternativas ao que se tem presenciado e quem sabe, substituir este panorama por um outro, afeito às necessidades da imensa maioria da humanidade. Refletindo sobre a possibilidade de novas expectativas, asseverou François CHESNAIS:

Destacar que seriam 'irreversíveis' a hipertrofia financeira e todo o seu séqüito de desgraça é cair num molde muito suspeito de determinismo histórico. No sentido mais forte, seria atribuir a processos sociais, produtos da atividade humana, caráter análogo ao das evoluções biológicas. Para certos autores, apelar para a idéia de 'irreversibilidade', muitas vezes junto com um chamado ao 'realismo', sempre foi como justificar a ordem estabelecida ('a ordem natural das coisas'). Para outros, essa idéia traduz uma submissão resignada diante de relações econômicas e políticas das quais não parece fácil livrar-se, quando parece não haver saídas ou alternativas claras (1998:32).

Porém, contrariando o senso conformista, nada implicaria na compreensão de que a resistência ao modelo neoliberal foi extinta ou que a sociedade contemporânea caminha na repetição sincopada do adágio neoliberal. Pelo contrário, em todo o mundo são notados movimentos antiglobalização, atraindo adeptos, simpatizantes e militantes que se empenham em denunciar e conter o avanço das suas diretrizes. Uma expressão deste inconformismo é o Fórum Social Mundial (FSM), que em 2005 efetivou seu quinto encontro.

Proposto inicialmente como uma contraposição ao Fórum Econômico Mundial que se reúne na cidade de Davos (Suíça), o FSM é um evento mundial organizado pelos movimentos sociais com objetivo de discutir temas relevantes e alternativas para as questões centrais da atualidade. Significativamente, os recursos hídricos tem sido um dos temas que tem despertado maior interesse nas oficinas e grupos 
de discussão do FSM. E indicativo não menos importante, os óbices quanto à privatização e a defesa do direito de acesso à água tem transparecido como um verdadeiro consenso em todos estes encontros (Fig. 40).

Claramente a água constitui um motivo privilegiado para a mudança, em especial porque apenas este líquido vital pode nos fazer observar de modo radical que a sede de lucros não poderá levar o mundo a nenhuma outra situação que não a da mercantilização da própria morte.

Assim, mais do que nunca, é preciso não só repensar o mundo na ótica da solidariedade, de uma outra mundialização, que consolide o caminho da comunhão dos bens ofertados pela natureza, como também agir para que a mudança ocorra, o quanto antes, melhor (Ver SANTOS, 2000 e MORIN, 2002).

Que se busque assim na satisfação da sede, o caminho privilegiado para honrar os mais sublimes sonhos, anseios e esperanças! 


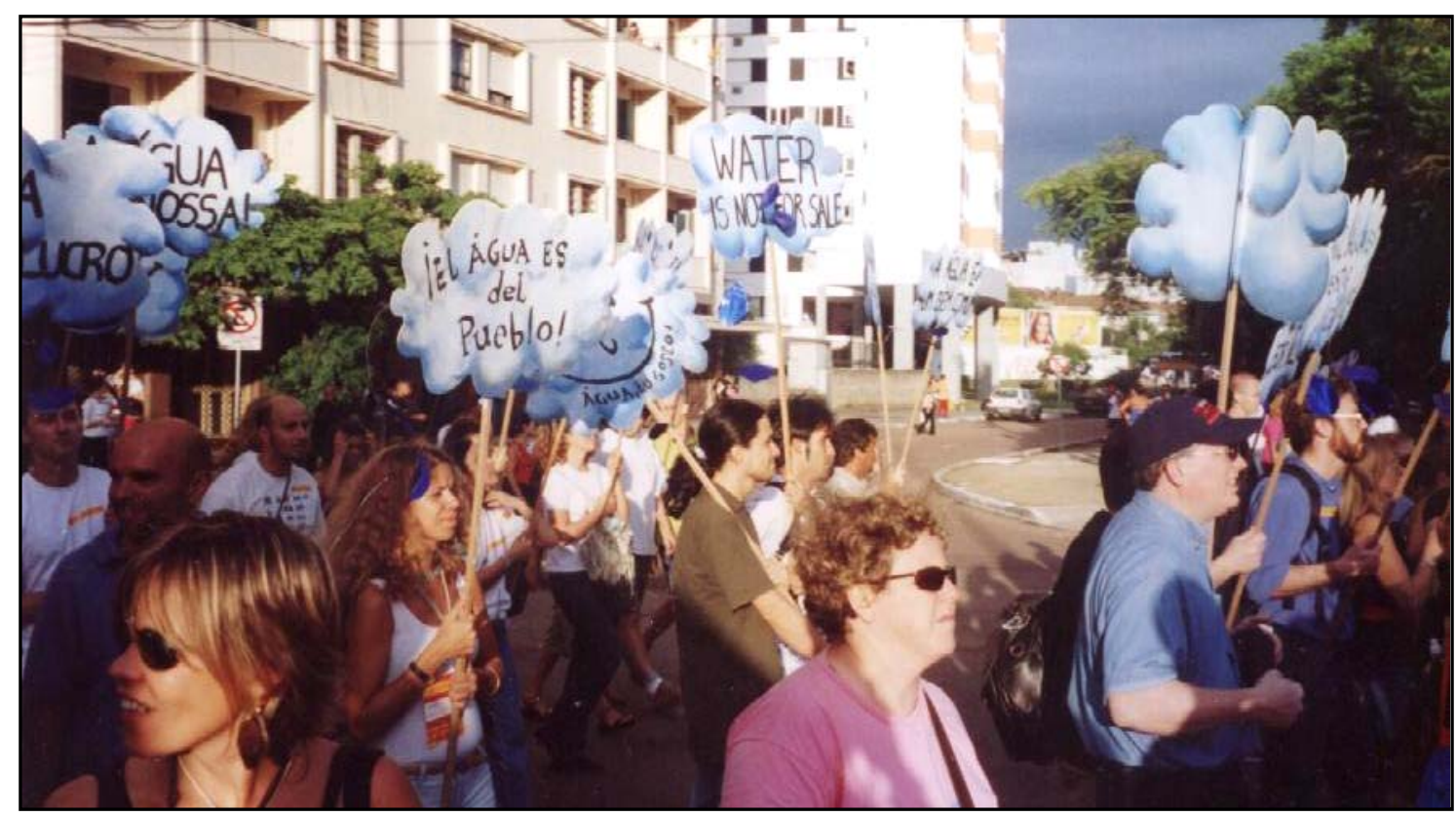

FIGURA 40 - Manifestação contra a privatização da água: Protesto realizado durante o Fórum Social Mundial de Porto Alegre, em 2003 (Foto: Lica Sisla). 